| แसा 
ANNA HELENA DE ASSIS MEIRELLES VILLELA

\section{EXPOGRAFIA NA 27a. BIENAL DE SÃO PAULO}

DISSERTACCÃO DE MESTRADO APRESENTADA A FACULDADE DE ARQUITETURA E URBANISMO DA UNIVERSIDADE DE SÃO PAULO PARA OBTENÇÃO DO TíTULO DE MESTRE EM ARQUITETURA E URBANISMO

ÁREA DE CONCENTRAÇÃO: PROJETO, ESPAÇO E CULTURA

ORIENTADORA: PROFA. DRA. FERNANDA FERNANDES DA SILVA

EXEMPLAR REVISADO E ALTERADO EM RELAÇÃO À VERSÃO ORIGINAL, SOB RESPONSABILIDADE DA AUTORA E ANUÊNCIA DA ORIENTADORA.

A versão original, em formato digital, ficará arquivada na Biblioteca da Faculdade. São Paulo, 10 de junho de 2019

SÃO PAULO 
Autorizo a reprodução e divulgação total ou parcial deste trabalho, por qualquer meio convencional ou eletrônico, para fins de estudo e pesquisa, desde que citada a fonte. email: ah@metropole.arq.br.

Imagens da capa e aberturas dos capítulos: registros da 27a. Bienal de São Paulo Fotos: Juan Guerra. Fonte: Arquivo Wanda Svevo.

Projeto gráfico: Cassia Buitoni

Revisão de texto: Diana de Abreu Dobránszky

Catalogação na Publicação

Serviço Técnico de Biblioteca

Faculdade de Arquitetura e Urbanismo da Universidade de São Paulo

Villela, Anna Helena de Assis Meirelles

Expografia na 27 Bienal de São Paulo / Anna Helena de Assis Meirelles

Villela; orientadora Fernanda Fernandes da Silva. - São Paulo, 2018.

$272 p$

Dissertação (Mestrado) - Faculdade de Arquitetura e Urbanismo da Universidade de São Paulo. Área de concentração: Projeto, Espaço e Cultura.

1. Bienais de Arte. 2. Exposição de Arte. 3. Arte. I. Silva, Fernanda Fernandes da, orient. II. Título.

Elaborada eletronicamente através do formulário disponível em: < http://www.fau.usp.br/fichacatalografica/> 
À Fernanda Fernandes pela orientação precisa, entusiasmada e acolhedora.

À Mirtes Marins de Oliveira pela leitura cuidadosa e comentários da banca de qualificação e pelo preciso material bibliográfico compartilhado.

Ao Agnaldo Farias pela contribuição na banca de qualificação e por me acolher no grupo de estudos.

À Marta Bogéa por ter me convidado para entrar no universo das exposições em 2004 e por todas as colaborações e parcerias que se seguiram. Pela entrevista concedida e por muitas conversas e trocas generosas.

À Ana Paula Pontes pelas conversas, apoio e parceria.

À Maria Julia Herklotz minha parceira de muitos projetos e expografias.

À Diana de Abreu Dobránszky que fez uma revisão de texto cuidadosa e fundamental.

À Cassia Buitoni pela primorosa diagramação, essencial para a compreensão dessa dissertação tão visual.

Ao arquivo Wanda Svevo por disponibilizar material de consulta, à Ana Paula Marques e Khadyg Fares.
Ao Guilherme Wisnik e colegas do grupo de estudos pelas conversas e discussões.

Aos Amigos Mariana Vaz, Vanessa Ferrari, Paula Santoro, Paula Zasnicoff, Alexandre Brasil, Carolina Bueno, Milton Braga, Mirella Marino, Cezar Shundi, Tatiana Machado, Paulo Mattos, Carlos Livieres, Paula Fonseca e Sabrina Lapyda pelos momentos fundamentais de descontração.

À Mara Nogueira pela disponibilidade e carinho no cotidiano. Aos meus pais, irmãos e à Sui pelo apoio constante.

Ao Silvio pelo incentivo, pelas diversas leituras que foram mais que imprescindíveis para a existência desse trabalho e por compartilhar comigo o mais importante da vida.

À Joana e Dora por existirem e alegrarem minha vida. 
À Dora, Joana e Silvio 
Essa dissertação tem como foco de investigação expografias de exposições de arte contemporânea. Elege como estudo de caso a 27a. Bienal de São Paulo cujo tema foi Como viver Junto (2006). O estudo se dá a partir da análise crítica das relações interdisciplinares, que constituem a exposição: arte, curadoria, arquitetura pré-existente e expografia.

A escolha da 27a. Bienal se justifica pelo caráter experimental da mostra que implementou diversas mudanças no modelo institucional estabelecido até então. Estas transformações ampliaram o papel dos curadores e por consequência alteraram a relação com o projeto expográfico, que passou a ter um caráter mais autoral.

O estudo se inicia com a contextualização da mostra, com uma retomada histórica da Bienal de São Paulo até 2006, análise espacial do Pavilhão Ciccillo Matarazzo e avaliação do legado da 27a. Bienal para as expografias das mostras subsequentes. Faz uma análise da inserção da proposta curatorial da 27a. Bienal no circuito global das exposições internacionais. Finaliza com a leitura crítica da mostra a partir da reconstituição de um percurso pela exposição, apontando como se deram as relações interdisciplinares entre narrativa curatorial, projeto expográfico e obras de arte no Pavilhão Ciccillo Matarazzo.

Palavras chave: expografia, exposição, arte contemporânea, 27a. Bienal de São Paulo, curadoria, Pavilhão Ciccillo Matarazzo.
This dissertation focuses on the investigation of the exhibition design of contemporary art exhibitions. Elects as a case study the 27th Bienal de São Paulo whose theme was How to Live Together (2006). The study is based on a critical analysis of the interdisciplinary relationships that constitute the exhibition: art, curatorship, preexisting architecture and exhibition design.

The choice of the 27th Biennial is justified by the experimental character of the exhibition that implemented several changes in the institutional model established until then. These transformations amplified the role of the curators and consequently altered the relation with the exhibition design, that became more authorial.

The study begins with the contextualisation of the exhibition, with a historical resumption of the São Paulo Biennial until 2006, spatial analysis of the Ciccillo Matarazzo Pavilion and evaluation of the legacy of the 27th Bienal for the exhibitions of the subsequent shows. It analyzes the insertion of the curatorial proposal of the 27th Bienal in the global circuit of international shows. It finishes with the review of the exhibition with the reconstitution of a tour through the show, pointing out how the interdisciplinary relations happened between curatorial narrative, design exhibition project and works of art in the Pavilion Ciccillo Matarazzo.

Keywords: exhibition design, exhibition, contemporary art, 27th Bienal de São Paulo, curatorship, Ciccillo Matarazzo Pavilion. 


\section{SUMÁRIO}

\section{INTRODUÇÃO}

\section{CAPÍTULO 1: O CONTEXTO DA 27a. BIENAL DE SÃO PAULO}

19 1.1. BREVE HISTÓRICO DA BIENAL DE SÃO PAULO E SUAS EXPOGRAFIAS (1951-2006)

57 1.2. A SEDE DA BIENAL DE SÃO PAULO: PAVILHÃO CICCILLO MATARAZZO

57 1.2.1. De Pavilhão das Indústrias a Pavilhão Ciccillo Matarazzo

62 1.2.2. O Pavilhão hoje

65 1.3. LEITURAS DO PAVILHÃO A PARTIR DAS BIENAIS APÓS 2006

68 1.3.1. A 28a. Bienal

73 1.3.2. A 29a. Bienal

77 1.3.3. A 31a. Bienal

85 CAPÍTULO 2: O CONCEITO CURATORIAL E O PARTIDO EXPOGRÁFICO

87 2.1. A 27a. BIENAL E O SISTEMA GLOBAL DAS ARTES

89 2.1.1. Como Viver Junto e a crítica a globalização

99 2.1.2. Fim das Representações Nacionais

102 2.1.3. Curadoria Coletiva

104 2.1.4. Bienal além da exposição

112 2.1.5. Residências artísticas

113 2.1.6. A 24a. Bienal como referência

124 2.1.7. O legado da 27a. Bienal

127 2.2. PROJETO EXPOGRÁFICO E CURATORIAL

127 2.2.1. O partido do projeto expográfico

$130 \quad$ 2.2.2. A narrativa curatorial 
137 3.1. PAVIMENTO TÉRREO: A RELAÇÃO CURADORIA E EXPOGRAFIA E A INSERÇÃO DAS OBRAS DE ARTE CONTEMPORÂNEA

137 3.1.1. O acesso da exposição

147 3.1.2. O percurso pelo térreo

157 3.2. PRIMEIRO PAVIMENTO: A RELAÇÃO ARQUITETURA E EXPOGRAFIA EM DIÁLOGO COM A CURADORIA 3.3. SEGUNDO PAVIMENTO: A PRESENÇA DO PROJETO EXPOGRÁFICO

169 3.3.1. O primeiro setor

179 3.3.2. O segundo setor

185 3.4. TERCEIRO PAVIMENTO: COMO VIVER JUNTO

193 3.5. PRAÇA BROODTHAERS E ÁREA CLIMATIZADA: UM DIÁLOGO VERTICAL E HORIZONTAL

194 3.5.1. A Praça Broodthaers

205 3.5.2. Área Climatizada

216 3.6. ANÁLISE GRÁFICA DA EXPOGRAFIA

CONSIDERAÇÕES FINAIS

BIBLIOGRAFIA

\section{ANEXOS}

244 ANEXO 1: ENTREVISTA COM MARTA BOGÉA

259 ANEXO 2: DOCUMENTO DA FUNDAÇÃO BIENAL

260 ANEXO 3: LISTA DE OBRAS UTILIZADA PELA EXPOGRAFIA DA 27a. BIENAL 


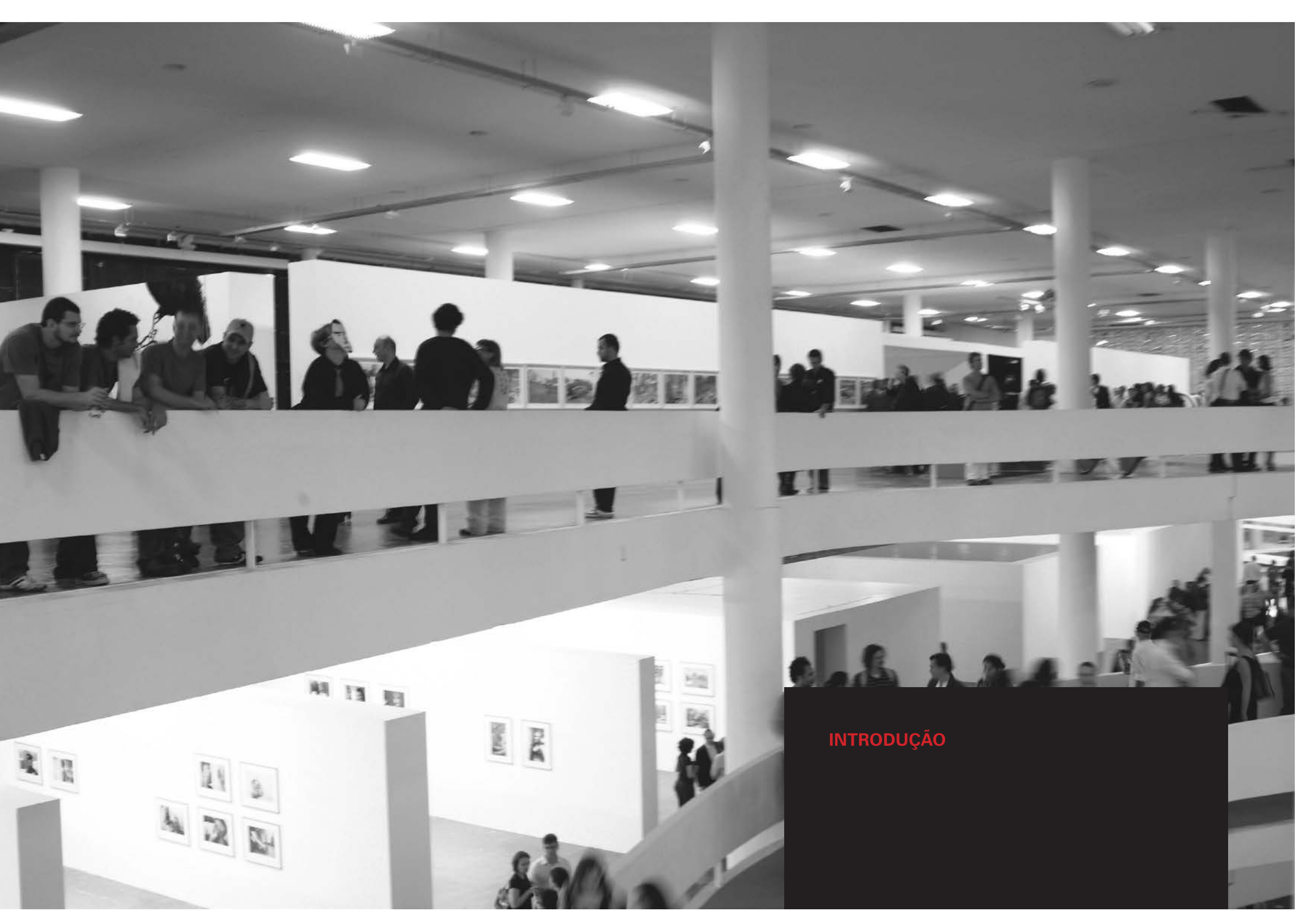


As exposições tornaram-se o meio pelo qual a maior parte da arte se torna conhecida. [...] As exposições são o principal local de intercâmbio na economia política da arte, onde a significação é construída, mantida e ocasionalmente desconstruída. Parte espetáculo, parte evento sócio-histórico [...], exposições [...] estabelecem e administram os significados culturais da arte (GREENBERG; FERGUNSON; NAIRNE, I997, p.2)

As exposições de arte contemporânea se constituem a partir de narrativas construídas por uma equipe curatorial e das relações entre as obras selecionadas e o espaço onde são instaladas. Todas essas conjunções são delimitadas pela arquitetura pré-existente do edifício onde se dá a mostra e pelo projeto expográfico proposto. Esse trabalho pretende analisar as relações interdisciplinares entre expografia, curadoria, arquitetura e arte contemporânea a partir do estudo de caso da 27a. Bienal de São Paulo.

A expografia é um campo de atuação da arquitetura que vem se difundindo; no entanto, são poucas as análises sobre o

I Tradução da autora. Texto original: "Exhibitions became the medium though which most art becomes known. [...] Exhibitions are the primary site of Exchange in the political economy of art, where signification is constructed, maintained and occasionally deconstructed. Part spectacle, part socio-historic event, part structuring device, exhibitions [...] establish and administer the cultural meanings of art". papel do arquiteto nas exposições contemporâneas e de como esta atuação é um elemento fundamental para a constituição das mostras. As publicações sobre essas exposições temporárias, embora sejam foco de grande investimento pelos curadores, ficam restritas à proposta curatorial e às obras de arte. São raros os textos críticos ${ }^{2}$ sobre a arquitetura e a expografia. Entretanto, é através delas que se configuram as mostras.

Essa pesquisa surgiu a partir de questionamentos elaborados dentro do percurso profissional da autora — que participou de diversos projetos de expografia para mostras temporárias e de longa duração, dentre elas as 27a., 28a. e 3ra. Bienais.

A Bienal de São Paulo é a segunda mais antiga exposição do gênero do mundo e é considerada um dos principais eventos de arte contemporânea internacional, junto da Bienal de Veneza e da Documenta de Kassel. ${ }^{3}$ Embora tenha, desde o princípio, contado com arquitetos nas montagens da mostra, os catálogos das Bienais de São Paulo passaram a incluir continuamente o projeto expográfico apenas a partir da 29a. Bienal, ${ }^{4}$ com textos elaborados pelos arquitetos sobre o partido do projeto e a

2 Na pesquisa realizada a revista Afterall se destacou como uma publicação monográfica que analisa exposições paradigmática em todas as suas camadas: contexto sociocultural; relações com o espaço e entre obras, estratégias de display e narrativa curatorial. Tradução da autora.

3 A Bienal de São Paulo teve sua primeira edição em I951, a Documenta em I955 e a Bienal de Veneza em I895.

4 Antes de 20I0, a I6a. Bienal (I98I) fez a publicação das plantas no catálogo da mostra. 
apresentação de plantas. Mesmo assim, as informações ainda são insuficientes para reconstituir as relações entre as obras e para a compreensão de como o discurso curatorial se realizou no espaço. No caso da Bienal, o Pavilhão Ciccillo Maratazzo (ou Pavilhão da Bienal) é um elemento importante, e as obras de arte muitas vezes criam interfaces com sua arquitetura.

O que se observa na realização dessas mostras é que sempre há uma distância entre o conceito inicial curatorial e a sua realização. Os registros têm sido parciais, representando mais a intensão teórica do projeto do que sua efetiva concretização.

Essa dissertação elege como eixo principal de investigação as expografias das exposições de arte contemporânea. Tendo como objeto a análise, especificamente, a 27a. Bienal de São Paulo, realizada em 2006, com curadoria geral de Lisette Lagnado, cujo tema foi Como viver junto. A intenção é discutir as relações que se processam entre expografia, curadoria, espaço arquitetônico — no caso, o Pavilhão Ciccillo Matarazzo, projeto do arquiteto Oscar Niemeyer_—, e arte contemporânea, considerados como os quatro pilares que sustentam a exposição.

A 27a. Bienal possuiu um caráter experimental e implementou uma série de transformações na estrutura da Bienal de São Paulo5 e, por consequência, no modelo de curadoria.

5 A Bienal de São Paulo se mantinha até 2006 vinculada ao modelo geopolítico da Bienal de Veneza, com as representações nacionais, no qual os países eram responsáveis pela seleção e envio das obras de arte.
Tais mudanças ratificaram a inserção da Bienal de São Paulo no circuito global das artes nos anos 2000. As principais propostas foram em sua maioria mantidas nas edições subsequentes: ausência de representações nacionais; curadoria coletiva; investimento no projeto educativo; residências artísticas; expansão da Bienal para além do pavilhão, inserindo obras no parque e pela cidade; e ampliação da abrangência da mostra com seminários e catálogos críticos. O fim das representações nacionais consolidou o papel do curador geral, assegurando um novo modelo de curadoria agregado a plataformas discursivas.

O eixo conceitual da mostra foi construído a partir dos textos e proposições de Hélio Oiticica, trazendo uma proposta de revisão crítica da história da arte contemporânea. Com base no tema apresentado, essa edição da Bienal criticou a globalização e a sociedade do espetáculo. Essa abordagem a colocou em sintonia com as principais exposições internacionais da época.

A curadoria discursiva consolidou sobretudo a possibilidade de um diálogo fértil com o projeto expográfico. Onde o arquiteto concebe o projeto de forma autoral, tendo como premissa o conceito curatorial. Em um trabalho estreito com os curadores, passou a influenciar a disposição e a relação entre obras, tornando a arquitetura um instrumento para a concretização da narrativa curatorial. Para uma situação de implantação de uma exposição em um edifício de características 
singulares como o Pavilhão da Bienal, o projeto expográfico tem a responsabilidade de estabelecer o diálogo entre as diversas equipes que trabalham na construção da exposição. O projeto deve contemplar, além do conceito curatorial, uma boa circulação, a visibilidade das obras, e a relação entre elas.
A dissertação foi estruturada em três capítulos. O primeiro capítulo, O contexto da 2Ja. Bienal de São Paulo, tem como objetivo dar subsídios à compreensão das transformações propostas na 27a. Bienal, do ponto de vista curatorial e expográfico. O capítulo se inicia com um breve histórico das Bienais de São Paulo até 2006 que tem como intuito tratar da relação da Bienal com a sua sede, e demonstrar que o surgimento do curador tem como uma de suas consequências a transformação do papel dos arquitetos. Cruzando o histórico da Bienal de São Paulo e da análise dos projetos museográficos/expográficos, pode-se entender quando o projeto de arquitetura ganha um papel autoral e propõe uma construção de uma narrativa no espaço expositivo. Este momento coincide com o surgimento da figura do curador-geral, na i6a. Bienal (1981), cargo ocupado por Walter Zanini - essa foi a primeira vez que se propõe o rompimento da setorização das representações nacionais através da organização da mostra por analogia de linguagens.

Os projetos expográficos das Bienais são intervenções temporárias no Pavilhão Ciccillo Matarazzo, edifício moderno paradigmático de Oscar Niemeyer. O histórico e a leitura espacial do pavilhão tornam-se, portanto, elementos essenciais para a análise crítica das expografias.

O capítulo fecha com a análise dos diálogos estabelecidos por expografias com a pavilhão após a 27a. Bienal. O projeto de Marta Bogéa para a essa edição teve como uma das 
principais características uma leitura apurada do edifício, alterando a lógica de acesso da mostra, modulando a circulação dos visitantes, e reforçando relação com parque. Todas essas inovações reverberaram nas Bienais que se sucederam.

O segundo capítulo, $A$ construção do projeto curatorial e expográfico na 2Ja. Bienal, estuda os eixos conceituais do projeto curatorial e como se deu a sua relação com a concepção do partido expográfico. O capítulo faz uma contextualização da mostra no sistema global das artes a partir da análise dos principais pontos de transformação no modelo da Bienal de São Paulo realizada pelo projeto curatorial da 27a. Bienal. Traça um paralelo de suas propostas com situações semelhantes em outras mostras internacionais, como a roa. e a ira. Documenta de Kassel (1997, 2002), a za. Bienal de Havana (I989), a 6a. Manifesta (2006) e a 24a. Bienal de São Paulo (1998). O estudo do projeto curatorial foi um elemento central para a compreensão da seleção de obras, a organização dos núcleos e a concepção da narrativa. O fechamento do capítulo se dá com a apresentação das diretrizes da narrativa curatorial, da relação conceitual da expografia com a curadoria, e da definição do partido expográfico com base nos fluxos e do sistema expositivo.

O terceiro capítulo, Interlocução da expografia, curadoria, arte contemporânea e a arquitetura na 2Ja. Bienal, faz uma imersão no estudo de caso da 27a. Bienal e uma análise de como se dão as relações entre proposta expográfica, projeto curatorial, a arquitetura do pavilhão e as obras de arte contemporânea comissionadas inseridas no contexto da mostra. Estas são as questões centrais dessa dissertação. A análise foi feita por meio da reconstituição de um percurso pela mostra, lançando luz sobre as relações interdisciplinares e evidenciando a narrativa curatorial e sua inserção no espaço. O capítulo foi dividido por setores do edifício que configuraram núcleos curatoriais. O método de análise se deu pela leitura do espaço do pavilhão, pela avaliação da expografia proposta, pelos diálogos estabelecidos na inserção das obras de arte com a expografia e arquitetura, pela relação entre obras de arte e pela constituição da narrativa curatorial. As plantas, esquemas e imagens desenvolvidos para essa pesquisa foram ferramentas essenciais para a reconstrução da narrativa da 27a. Bienal e para a compreensão de como se efetivaram as relações no espaço.

Evidencia-se, assim, a importância da relação entre os profissionais envolvidos. Da mesma forma que demonstra o difícil diálogo entre as propostas, que estabelecem relações conflituosas as quais, por momentos, ressaltam o conceito da mostra e, por outros, o prejudicam. 
Este capítulo se inicia com uma retomada histórica das Bienais de São Paulo e suas expografias. O recorte para a análise se deu pelas transformações da estrutura organizacional da instituição e pela importância que os curadores ganharam como figuras centrais que transformaram ao longo dos anos o caráter das mostras e de suas expografias.

A segunda parte contempla o histórico do Pavilhão Ciccillo Matarazzo, sede da Fundação Bienal: um importante edifício da arquitetura moderna brasileira que foi projetado para receber as exposições das indústrias e passou a receber mostras de arte. E apresenta uma análise de seu projeto, construção e das condições atuais de uso do edifício.

A terceira parte de capítulo faz uma breve análise de como as expografias, após a consolidação de uma nova estrutura institucional e da consolidação de um novo modelo de curadoria (após a 27a. Bienal), tiraram partido do pavilhão e possibilitaram novas leituras do edifício a partir das mostras. 


\subsection{BREVE HISTÓRICO DA BIENAL DE SÃO PAULO E SUAS EXPOGRAFIAS (1951-2006)}

A primeira Bienal de São Paulo ocorreu em I951. ${ }^{\text {C Considerada }}$ um dos principais eventos de arte contemporânea internacional, junto da Bienal de Veneza e da Documenta de Kassel, foi criada a partir do desejo de Francisco Matarazzo Sobrinho, ${ }^{2}$ ou Ciccillo Matarazzo, presidente do recém-inaugurado Museu de Arte Moderna de São Paulo, ${ }^{3}$ de realizar uma grande mostra internacional, seguindo o modelo da Bienal de Veneza. ${ }^{4}$ Esta mostra foi concebida pelo MAM e montada em

I A Bienal de Veneza, modelo para a Bienal de São Paulo, foi inaugurada em I895.

2 Francisco Matarazzo Sobrinho (I898-1977) foi um industrial e grande incentivador das artes plásticas. Fundou, em 1948, o Museu de Arte Moderna de São Paulo (MAM SP), inaugurado em I949, e em I95I a Bienal Internacional de Arte de São Paulo, que presidiu até a sua morte.

3 O Museu de Arte Moderna de São Paulo (MAM SP) foi inaugurado em I948, sem uma sede definida. Estavam a frente do museu Matarazzo Sobrinho e sua esposa, Yolanda Penteado, que mantinham contato direto com Nelson Rockefeller e com o Museum of Modern Art de Nova York (MoMA), que contribuiu com doações de obras de arte para fundação de museus de arte moderna no Brasil. Em I949, o MAM inaugura sua primeira sede no edifício dos Diários Associados-Assis Chateaubriand cedeu o espaço após solicitação do casal Matarazzo. No edifício, na rua Sete de abril, também funcionava o MASP, fundado em 1949 .

4 A Bienal de Veneza convida os países a participar e estes são responsáveis pela escolha dos artistas e pela construção de seus pavilhões. Há também um terreno cedido pela prefeitura de São Paulo, a Esplanada do Trianon na avenida Paulista, onde hoje se localiza hoje o Museu de Arte de São Paulo Assis Chateaubriand (MASP). Um pavilhão temporário foi projetado por Luís Saia ${ }^{6}$ e Eduardo Kneese de Mello e a museografia foi desenvolvida por Jacob Ruchti. ' É importante destacar o fato de que a

uma premiação de artistas. A Bienal de Veneza tem um número restrito de pavilhões por uma limitação de espaço do Jardim, e por isso restringe os países que podem participar com seus próprios pavilhões. A primeira vez que houve um pavilhão africano na Bienal de Veneza foi na 52a. Bienal, em 2007. O Pavilhão Central, nos Jardins, no entanto, também recebe artistas convidados pela curadoria, que não representam países. Os países que não tem pavilhões nos Jardins também se apresentam no Arsenal, e muitos artistas que não se apresentam como representação nacional têm exposições espalhadas por toda a cidade de Veneza.

5 O local, neste momento, seria destinado à futura sede do MAM e da Bienal. Em I952, ocorre um concurso para o Palácio das Artes, que seria a sede do MAM e da Bienal, no terreno da Esplanada do Trianon. O vencedor do concurso foi o arquiteto Affonso Eduardo Reidy, mas o terreno foi disputado pelo MASP e o projeto não foi realizado (NASCIMENTO, 20I7).

6 Luís Saia (I9II-I975) era arquiteto formado pela escola politécnica da USP e fez parte do Instituto do Patrimônio Histórico e Artístico Nacional (IPHAN).

7 Jacob Ruchti (1917-1974) era um arquiteto nascido na Suíça, formado pelo Mackenzie (São Paulo) em I940; fez parte da equipe que fez o projeto do Instituto de Arquitetos do Brasil de São Paulo (IAB-SP) entre outros projetos modernos. 
Bienal teve um projeto museográfico desde sua primeira edição e em estreita relação com os arquitetos modernos.

A Bienal de São Paulo veio ampliar os horizontes da arte brasileira. Criada literalmente nos moldes da Bienal de Veneza, seu primeiro resultado foi romper o círculo fechado em que desenrolavam se as atividades artísticas no Brasil tirando-as de isolamento provinciano. Ela proporcionou um encontro internacional na nossa terra, ao facultar aos artistas e público brasileiro o contato direto com o que se fazia de mais novo e de audacioso no mundo (PEDROSA, I970 apud FARIAS, 200I, p.73).

Em 1953, a 2a. Bienal abre os festejos do IV centenário de São Paulo, ocupando o Pavilhão das Nações e Pavilhão dos Estados no Parque Ibirapuera ${ }^{8}$ com 28 mil metros quadrados de exposição (AMARANTE, I989). Essa mostra foi um grande sucesso e é considerada, atualmente, a mais importante mostra de arte moderna de todos os tempos (FARIAS, 200I). Contou com Guernica, ' de Pablo Picasso, como o grande destaque da

8 O Parque Ibirapuera foi projetado em 1954 por Oscar Niemeyer, Zenon Lotufo, Hélio Uchôa e Eduardo Kneese de Mello para a comemoração do IV centenário da cidade de são Paulo. Contava com diversos edifícios para exposições: Pavilhão das Nações, Pavilhão dos Estados, Pavilhão das Indústrias e Palácio das Artes.

9 Atualmente, a Guernica não pode deixar o Museo Nacional Centro de Arte Reina Sofía de Madri por questões de segurança e conservação.
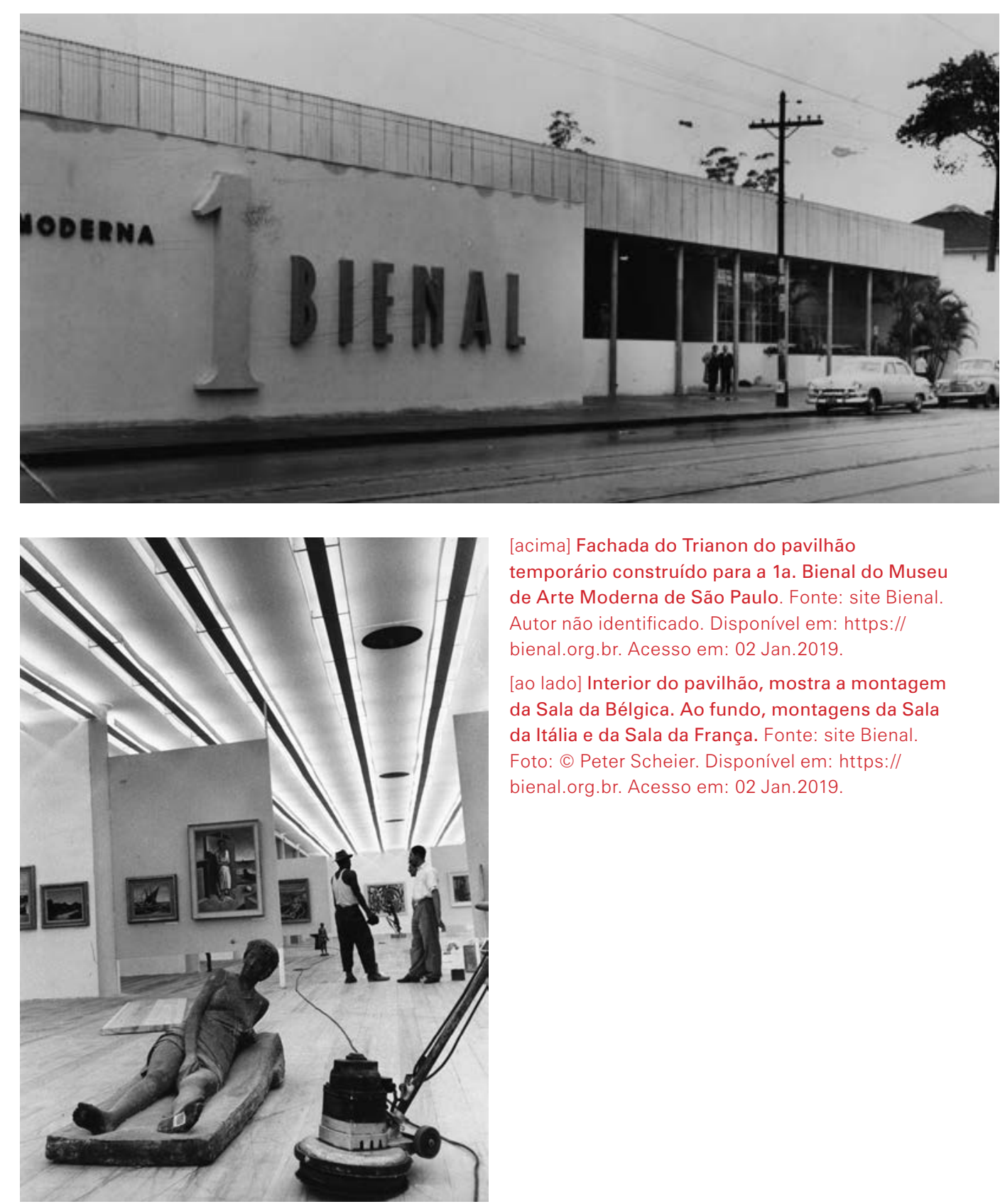

[acima] Fachada do Trianon do pavilhão temporário construído para a 1a. Bienal do Museu de Arte Moderna de São Paulo. Fonte: site Bienal. Autor não identificado. Disponível em: https:// bienal.org.br. Acesso em: 02 Jan.2019. [ao lado] Interior do pavilhão, mostra a montagem da Sala da Bélgica. Ao fundo, montagens da Sala da Itália e da Sala da França. Fonte: site Bienal. Foto: @ Peter Scheier. Disponível em: https:// bienal.org.br. Acesso em: 02 Jan.2019. 
[à esq. no topo] Sede da 2a. Bienal, o Palácio das Nações. Fonte: site Bienal. Autor não identificado. Disponível em: https://bienal.org.br. Acesso em: 02 Jan.2019.

[à esq. embaixo] Francisco Matarazzo Sobrinho e Juscelino Kubitschek visitam a obra de Pablo Picasso, Guernica na 2a. Bienal de São Paulo. Fonte: site Bienal. Autor não identificado. Disponível em: https://bienal.org.br. Acesso em: 02 Jan.2019.

[à dir.] 2a. Bienal: vista geral. Fonte: site Bienal.

Autor não identificado. Disponível em: https://bienal.org.br.
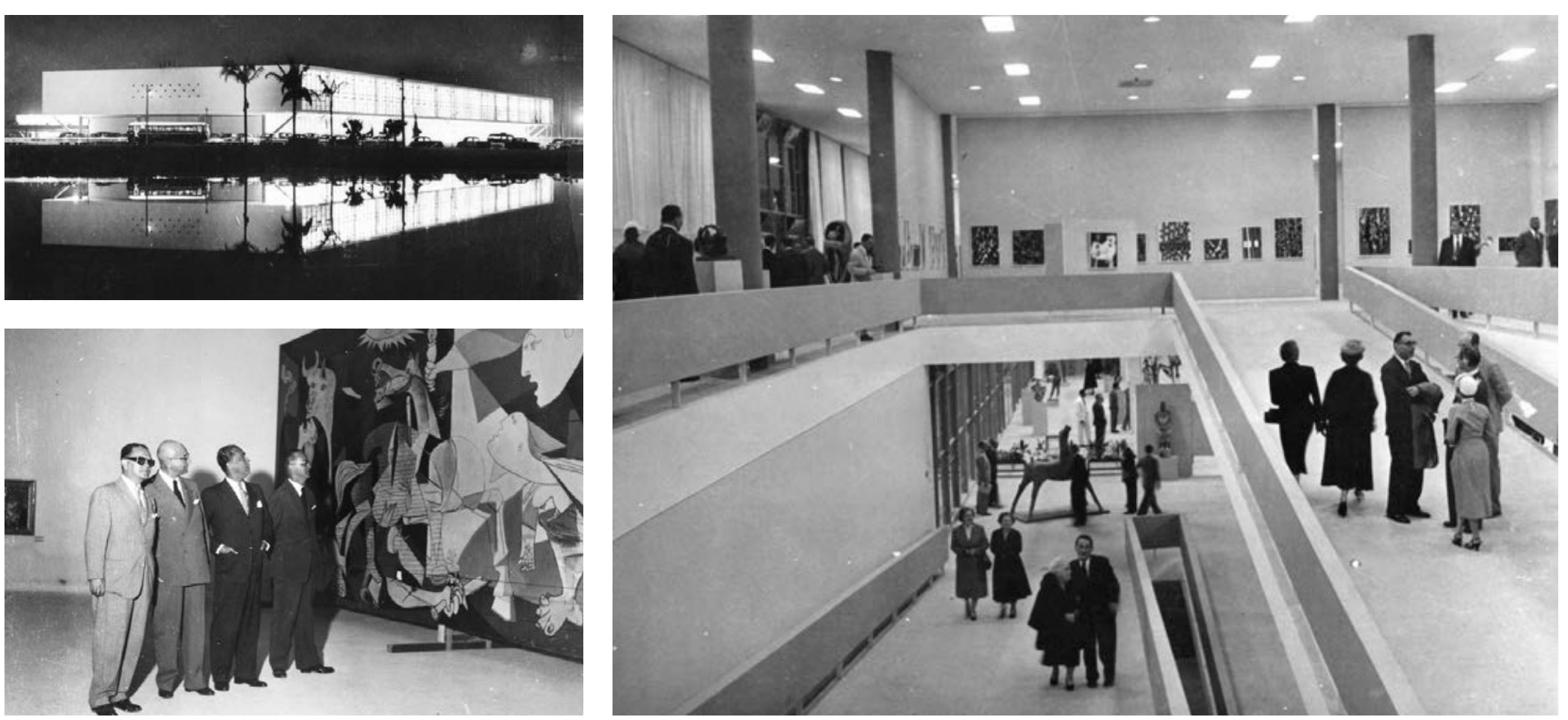
mostra e mais 74 obras do artista. Havia salas especiais de Paul Klee, Piet Mondrian, Alexander Calder, Edvard Munch entre outros. A representação francesa trouxe obras cubistas com os principais artistas do movimento, a italiana trouxe uma sala com obras do futurismo e a inglesa uma sala com Henri Moore, que recebeu o prêmio de escultura na mostra (FARIAS, 200I).

Em 1957, a 4a. Bienal é transferida para o Pavilhão das Indústrias, também dentro do Parque Ibirapuera, projetado para abrigar exposições e feiras das indústrias. O edifício com planta livre de grande dimensão (250x50 metros), estrutura independente e caráter monumental foi projetado para suportar grandes cargas. Possui um montacarga de grandes dimensões e um sistema elétrico superdimensionado para época. Toda esta infraestrutura construída para a exposição de grandes máquinas se mostrou adequada ao novo uso expositivo, acima de tudo por sua flexibilidade, e acabou se tornando a sede definitiva da Bienal e sua principal identidade, como descreve Agnaldo Farias:

O talento de Niemeyer, sua capacidade de fundir os pressupostos barrocos com o modernismo arquitetônico traduziu-se num monumental paralelepípedo envidraçado, com uma das faces dotada de texturas cambiantes, efeito dos para sóis móveis. Em seu interior, apoiado em enormes colunas de formato orgânico, um conjunto de rampas dava acesso aos andares superiores, sublinhado por um vazio que atravessa os
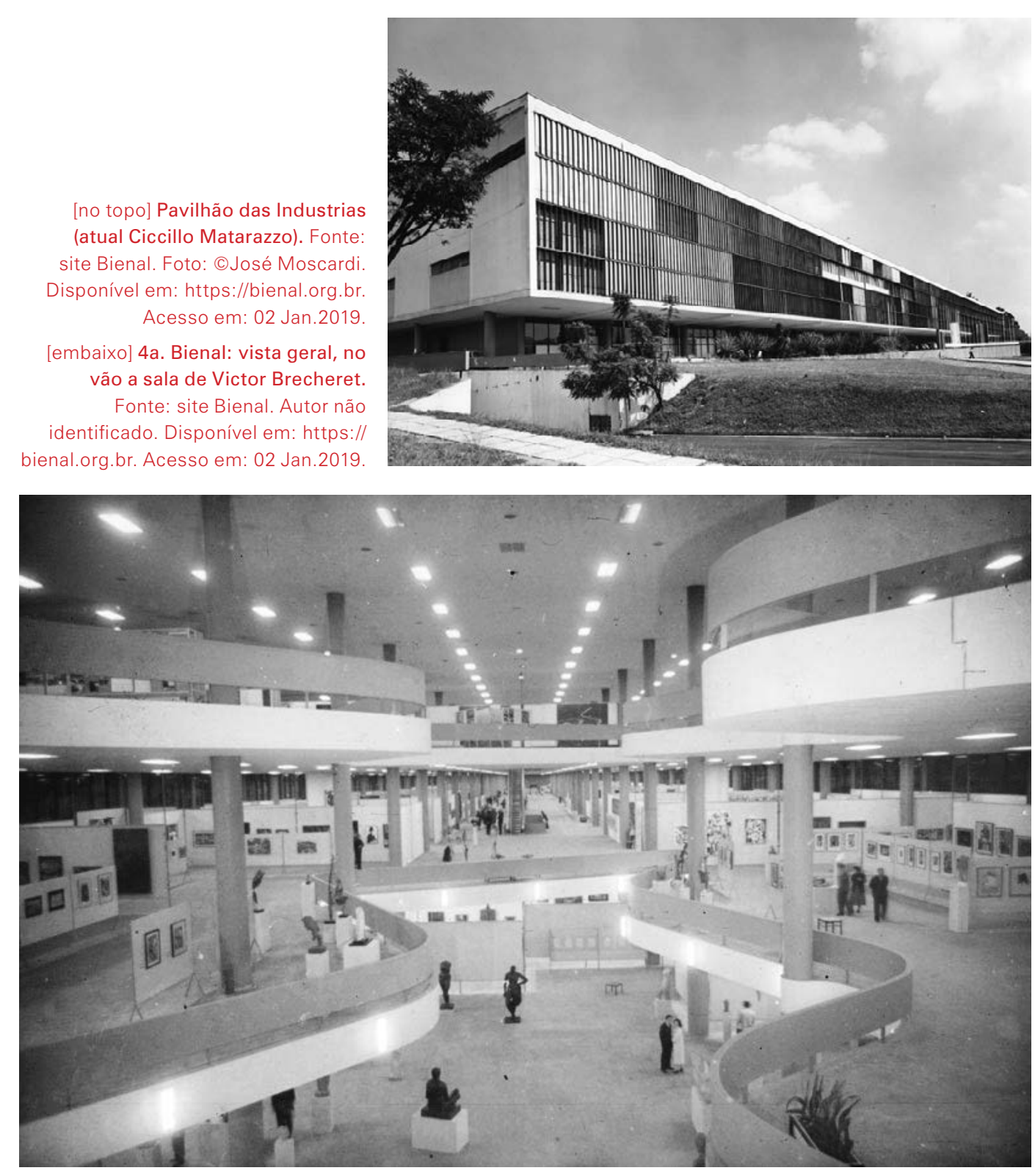

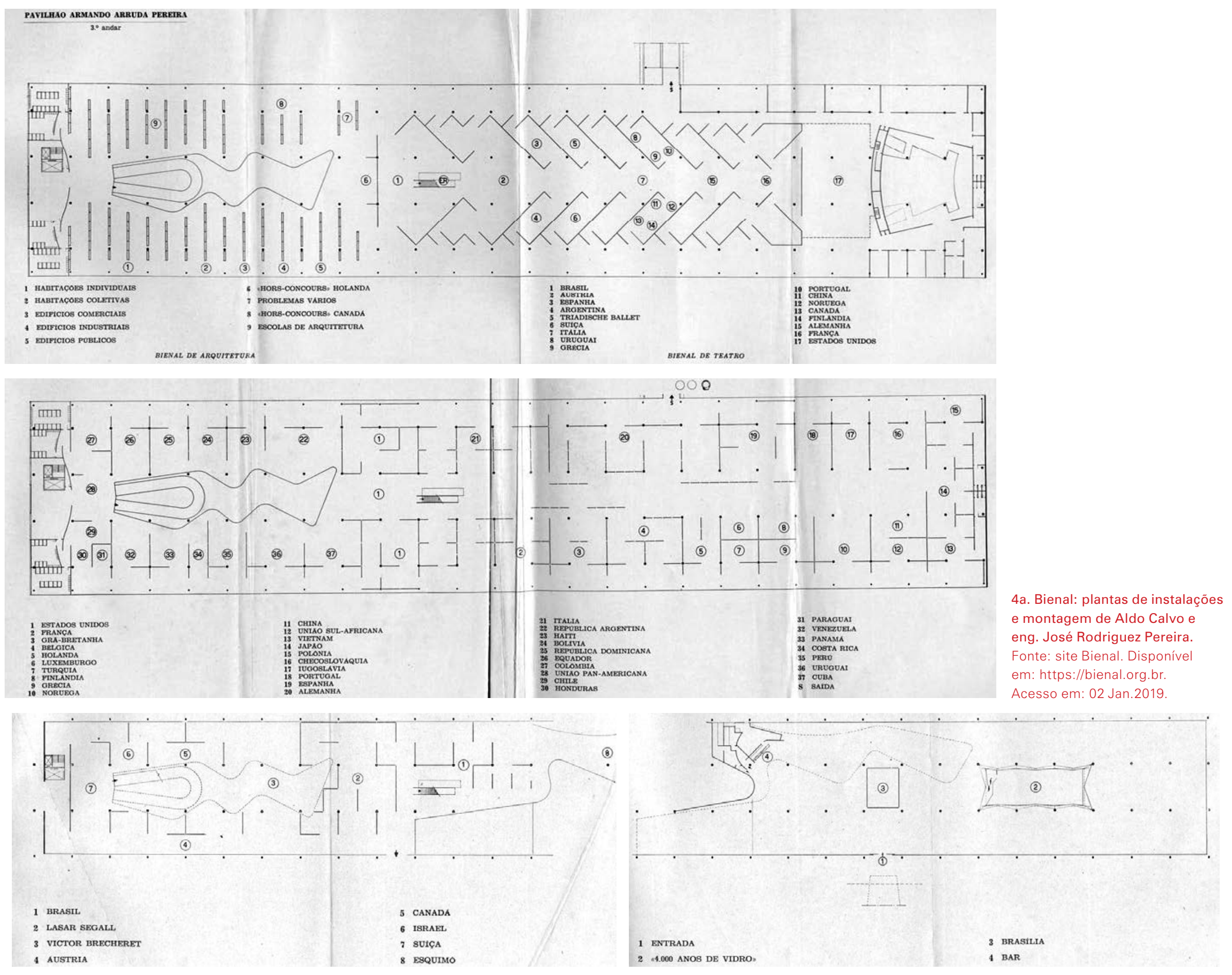
três andares, um imenso oco de bordas irregulares, que conferia uma imprevista sensualidade a edificação. A nova casa da Bienal revelar-se-ia um de seus signos mais marcantes (FARIAS, 200I, p.96).

Nesse mesmo ano, ocorreu um incêndio ${ }^{\mathrm{I}}$ no edifício dos Diários Associados, de Assis Chateaubriand, na rua Sete de abril, ${ }^{\text {II }}$ que abrigava a primeira sede do MAM e do MASP.

Sem sede, em $195^{8}$ o MAM mudou-se para o Parque Ibirapuera: primeiro no Palácio das Artes (hoje chamada Oca), depois passou a ocupar uma parte do terceiro andar do Pavilhão das Indústrias. Em I962, foi criada a Fundação Bienal de São Paulo—separando a exposição do MAM — que passou a ser a responsável pela organização das Bienais, tendo como presidente Matarazzo Sobrinho. A 7a. Bienal (I963) foi a primeira desvinculada do MAM São Paulo ${ }^{\text {I2 }}$ (ALAMBERT; CANHÊTE, 2004).

Io O incêndio se iniciou na Cinemateca Brasileira que ocupava o mesmo edifício.

II O edifício Guilherme Guinle [projeto Jacques Pilon (I905-I962)], na rua 7 de abril, onde já funcionava o jornal Diários Associados. O Masp ocupa metade do segundo andar $\left(\mathrm{I} .00 \mathrm{~m}^{2}\right)$. O proprietário do jornal era Francisco de Assis Chateaubriand (I892-1968), mecenas do MASP (NASCIMENTO, 20I7).

I2 Neste momento, a Bienal se separou definitivamente do MAM a partir de um projeto de lei que tornava a Bienal uma instituição pública viabilizando o recebimento de verbas públicas federais e estaduais - até então contava apenas com verba municipal (ALAMBERT; CANHÊTE, 2004).
A separação do MAM levou a Bienal a se reestruturar. O Diretor Artístico, ${ }^{13}$ que era o cargo logo abaixo de Matarazzo Sobrinho, foi substituído pela Assessoria de Artes Plásticas, constituída por um grupo de críticos nomeados pelo presidente da Bienal. A Bienal manteve sua toada de sucesso até a 9a. edição (1967), quando é evidente o impacto da ditadura militar no país, instalada em I964. ${ }^{\mathrm{I} 4} \mathrm{~A}$ exposição teve obras censuradas e na Ioa. Bienal (I969), com o endurecimento da ditadura após o AI-5, houve um boicote internacional, liderado pelo crítico de arte Mário Pedrosa, ${ }^{15}$ que estava exilado na Europa. A i2a. Bienal (i973) foi organizada pelo Conselho de

I3 Lourival Gomes Machado (I e VI Bienal), Sérgio Milliet (II, III e IV Bienal) e Mário Pedrosa (IV Bienal).

I4 A ditadura militar no Brasil foi o regime instaurado em I de abril de I964 e que durou até I5 de março de 1985 , sob comando de sucessivos governos militares. De caráter autoritário e nacionalista, teve início com o golpe militar que derrubou o governo de João Goulart, o então presidente democraticamente eleito. O regime pôs em prática vários Atos Institucionais, culminando com o Ato Institucional Número Cinco (AI-5) de I968, que vigorou por dez anos. A Constituição de 1946 foi substituída pela Constituição de 1967 e, ao mesmo tempo, o Congresso Nacional foi dissolvido, liberdades civis foram suprimidas e foi criado um código de processo penal militar que permitia que o Exército brasileiro e a Polícia Militar pudessem prender e encarcerar pessoas consideradas suspeitas, além de impossibilitar qualquer revisão judicial.

I5 Mário Pedrosa (1900-I98I) foi crítico de arte e ativista político. Em suas atividades como crítico de arte, destaca-se como diretor do Museu de Arte Moderna de São Paulo, colaborando na criação do Museu de Arte do Rio de Janeiro, com papel destacado no surgimento do movimento concretista. Foi curador da II Bienal Internacional de Arte de São Paulo (I953) e secretário geral da IV Bienal Internacional de Arte de São Paulo (1957). Foi membro do júri de várias bienais de artes plásticas em todo mundo. Disponível em: $<$ https:// pt.wikipedia.org/wiki/M\%C3\%Aırio_Pedrosa>. Acessado em: I fev. 2019. 
[no topo] 9a. Bienal: Sala Especial: Ambiente USA - 1957/67, com a obra Marilyn de James Gill. À esquerda, intervenção do público frente ao contexto político da época. Fonte: site Bienal. Autor não identificado. Disponível em: https://bienal.org.br. Acesso em: 02 Jan.2019.

[embaixol 10a. Bienal: $A$ Bolha de Marcelo Nitsche instalada no térreo, na mostra que ficou conhecida como Bienal do boicote. Fonte: site Bienal. Disponível em: https://bienal.org.br. Acesso em: 02 Jan.2019.
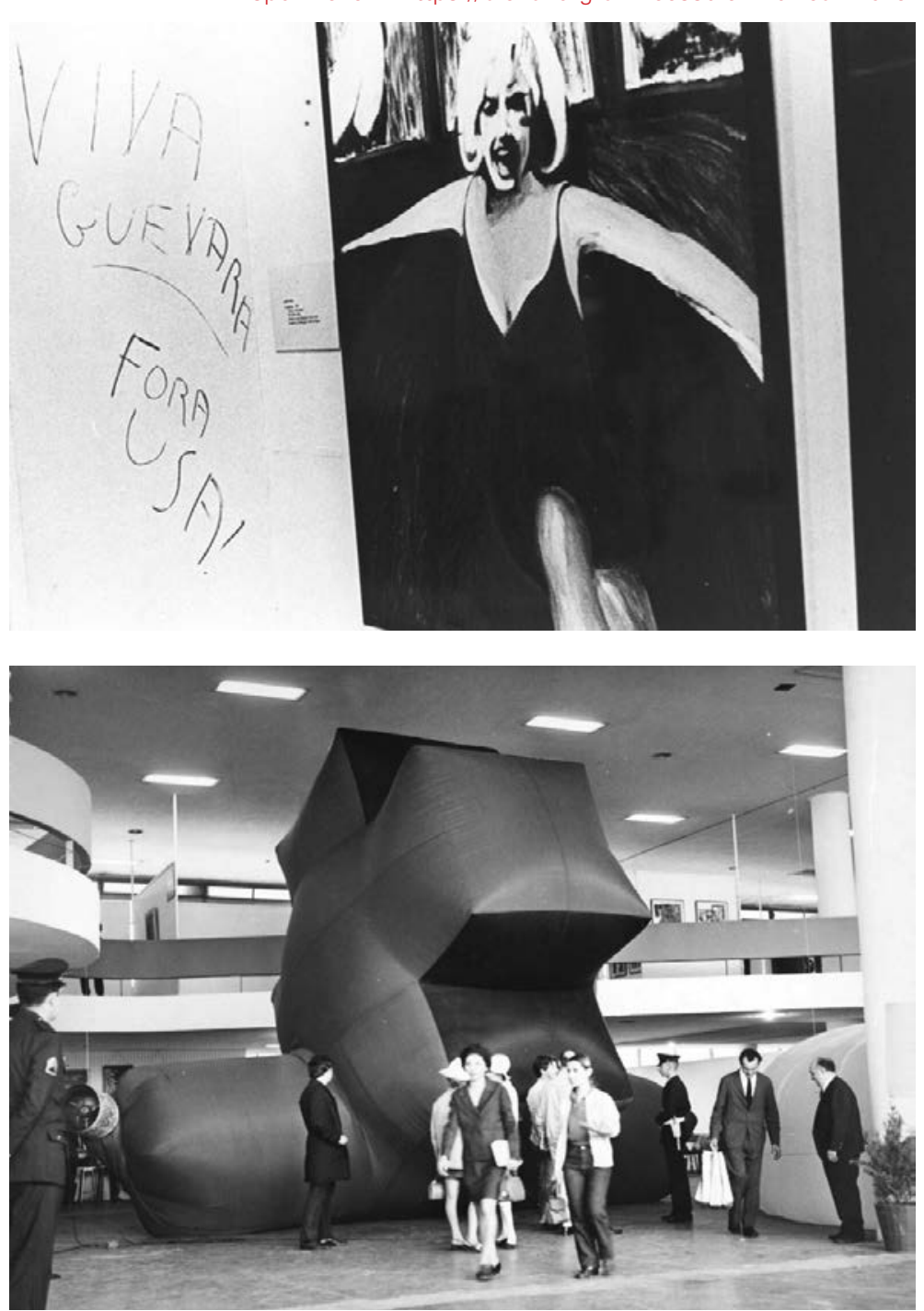

Arte e Cultura (CAC), criado para substituir a Assessoria de Artes Plásticas e que contava com Matarazzo Sobrinho entre seus membros (ALAMBERT; CANHÊTE, 2004).

Em I975, Matarazzo Sobrinho deixou a presidência da Bienal e, sem seu mecenas, a iza. Bienal passou por uma crise financeira, com risco de não acontecer. Diante desta situação Matarazzo Sobrinho voltou ao cargo, viabilizou a inauguração da exposição e renunciou em seguida (Idem, 2004).

A XIV Bienal de São Paulo ${ }^{16}$ foi a primeira realizada após o falecimento de Ciccillo Matarazzo. Coincidentemente foi a primeira a romper com uma das características mais marcantes do evento: deixar aos países convidados a decisão de escolher com quais artistas se fariam representar. Este modelo inspirado na Bienal de Veneza era o responsável por transformar cada edição do evento num conjunto em que as partes não se juntavam [...] Mas não é caso de supor que o Conselho de Arte Cultura ousasse mexer nessa clausula do estatuto da Bienal, até porque para bem e para o mal ele sempre foi um aspecto distintivo do evento, que sempre se orgulhou de apresentar o mais

I6 As Bienais da ra. até a I 4a. edição mantinham o modelo de Veneza em que cada País era responsável pela escolha de seu representante e por seu financiamento. Como consequência, o espaço dessa Bienais era dividido por países, com uma divisão geopolítica do espaço. 
vasto e inclusivo painel de arte contemporânea do mundo (FARIAS, 200I, p.36)

A partir deste momento, os países passaram a obedecer a um critério de seleção dos artistas, cujas obras deveriam se relacionar com os temas propostos.

Foi apenas na i6a. Bienal (1981) que surgiu a figura do curador geral, naquela edição a cargo de Walter Zanini, que, junto com o CAC, realizou uma série de transformações na estrutura da mostra. Ocorreu também o fim do boicote. ${ }^{17}$ Foram criados três núcleos e a setorização foi feita pelos pavimentos do pavilhão. As obras foram organizadas por analogia de linguagem ou por seu suporte. ${ }^{18}$ Essa proposta curatorial transformou completamente o espaço expográfico, que antes era constituído prioritariamente por salas ou setores por nação, permitindo uma construção espacial que criasse percursos e narrativas a partir da proposta curatorial. Não por coincidência, essa mostra foi a primeira a publicar o projeto de montagem no catálogo, cuja a autoria foi de Jorge Aristides de Souza Carvajal.

17 A partir de 1978 com a revogação do AI-5 e em I979 com a lei da anistia, iniciou-se um processo de redemocratização e a reforma partidária, que pôs fim ao bipartidarismo.

I8 No entanto, muitas obras enviadas pelas representações nacionais não se relacionavam com os núcleos propostos e criou-se um quarto núcleo para artistas divergentes. 16a. Bienal: vista do vão central. Fonte: site Bienal. Foto: ( Agencia Estado. Disponível em: https://bienal.org.br. Acesso em: 02 Jan.2019.

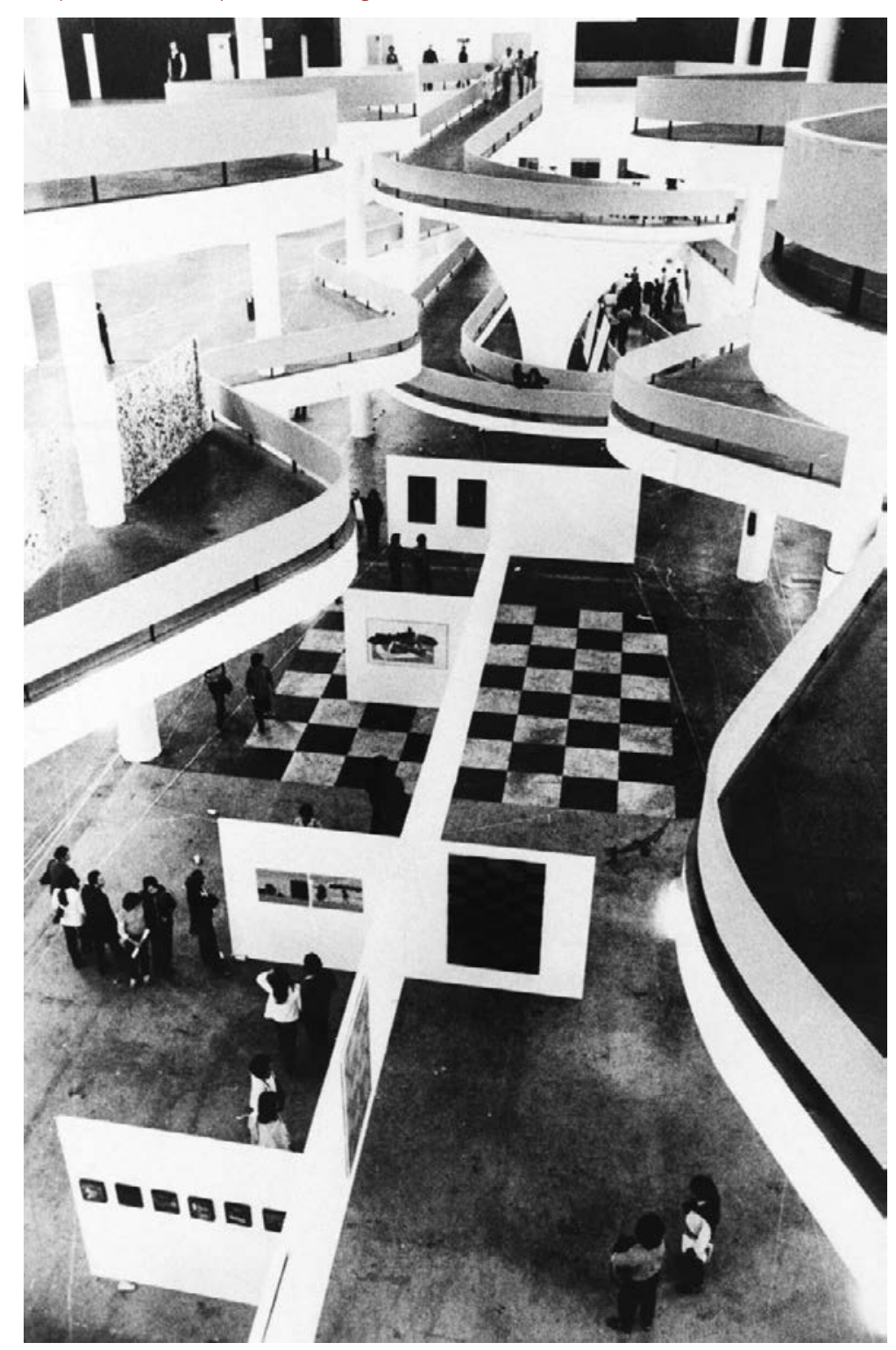




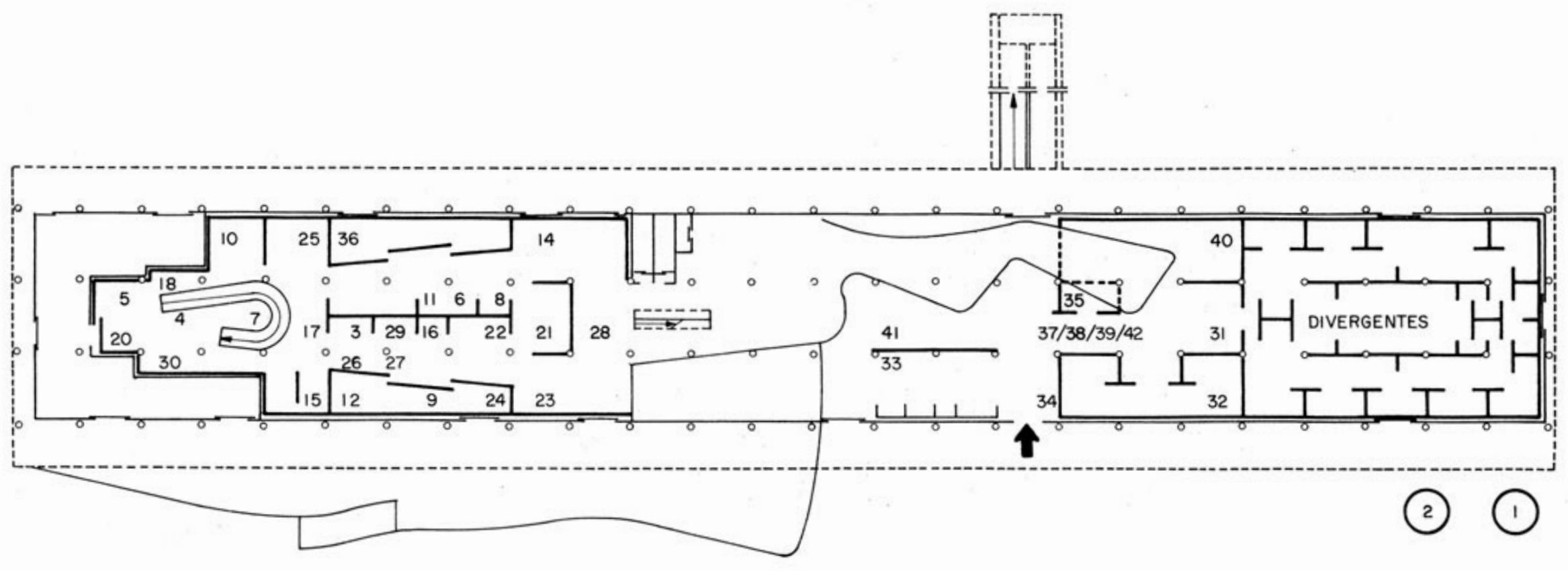

\section{PLANTA do TÉRREO E MEZANINO}

\begin{tabular}{|c|}
\hline $\begin{array}{l}\text { 1. Modiano, Sara } \\
\text { 2. Uribe. Alberto }\end{array}$ \\
\hline NÜCLEO I Vetor B1 \\
\hline $\begin{array}{l}\text { 3. Barbatre, François } \\
\text { 4. Barelier, André } \\
\text { 5. Barthélémy, Gerard } \\
\text { 6. Bassan, Nessin } \\
\text { 7. Cho, Sung-Mook } \\
\text { 8. Chol, Sang-Chul } \\
\text { 9. Cobo. Chema } \\
\text { 10. De Marziani, Hugo } \\
\text { 1. Dorrego. Rolando } \\
\text { 12. Franco. Carlos } \\
\text { 13. Gailiani, Omar } \\
\text { 14. Granato, Ivald } \\
\text { 15. Guimarăes, José de } \\
\text { 16. Han, Man-Y Young } \\
\text { 17. Han, Un-Sung } \\
\text { 18. Kang. Kunk-Jin } \\
\text { 19. Mainolfi. Luigi }\end{array}$ \\
\hline
\end{tabular}

20. Mazzei, Ana Maria
21. M. C. Van Scherpenberg-Katie
22. Migliorisi, Ricardo
23. Pascual, Jose Luiz
24. Perez Villalta, Guillermo
25. Pinheiro, Jorge
26. Piruca, Franco
27. Salvo
28. Testoni
29. Vargas, Patricia
30. Zerpa, Carlos
Núcleo II
31. Burri, Alberto
32. Delvaux, , Paul
33. Grupo Gorgona
34. Grupo Oho
35. Guccione, Piero
36. Guston, Philip
37. Guttuso. Renato
38. Kounellis, Janis
39. Mariani, Carlo M.
40. Pfahler, Georg Karl

41. Svoboda, Josef
42. Turcato, Giulio
Artistas Divergentes
43. Aguilar Ponce
44. Barrios, Cesar
45. Barrios, Molses
46. Baik, Kum-Nam
47. Batista, Domingo
48. Bido, Candido
49. Biscardi, Campos
50. Brunovsky, Albin
51. Cabrera, Vitico
52. Casterán, Jorge
53. Cepeda, Ender
54. Choi, Boong-Hyun
55. Choi, Wook-Kyung
56. Chon, Joon
57. Court, Francisco Javier
58. Dabova
59. Dobkowski, Jan
60. Dueñas, Olga
61. Galdos Rivas, Enrique

62. Ghenea, Silvia
63. González, Julio
64. Guiliermo, Erwin
65. Halas
66. Herrebarria, Adriano
67. Hloznik, Vincent
68. Javier Cabrera, Raul
69. Jávor, Piroska
70. Kim, Chung-Jung
71. Kim, Joung-Soo
72. Kim, Sang.Ku
73. Krebs. Ella
74. Lara, Clever
75. Lechev
76. Martincek, Martin
77. Martino, Federico
78. Morel. Marcel
79. Mytaras, Dimitris
80. Niño, C.
81. Panayatov
82. Panayatova
83. Park, Ki-Ok
84. Peña, A.
85. Piscoya, Herman

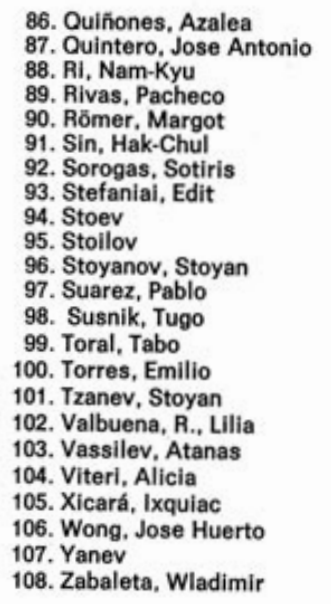




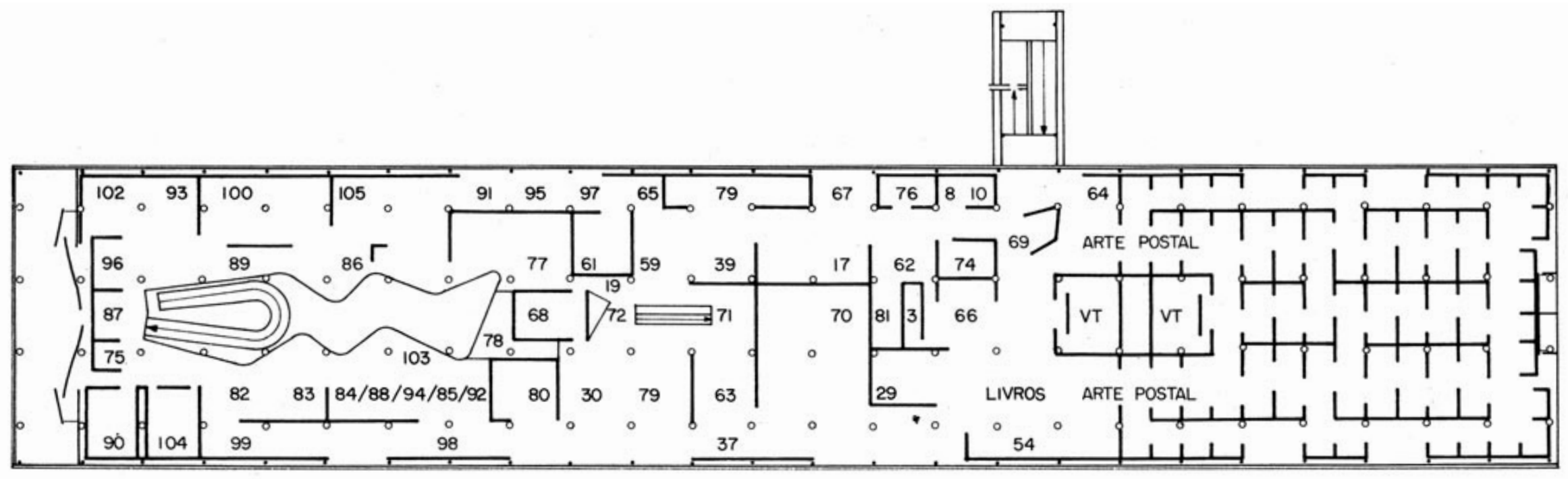

\section{PLANTA DO SEGUNDO ANDAR}

\section{NUCLEO I Vetor A1}

1. Abramovic/Ulay

2. Ars Natura

4. Bagnoli, Marco

5. Bufill, Juan

7. Gadé, Julia

8. Galeta, Ivan Ladislav

9. Huerga, Manuel

11. Ivekovic, Sanja

12. Pujol Carles

13. Trbuljak, Goran

14. Todosijevic, Ras

5. Zulueta, Ivan

NÚCLEO I Vetor A2

16. Ackling, Roger

17. Alexanco
18. Barcelo Migue

18. Barcelo, M

20. Breakwell, Ia

21. Bustamante, Meris

22. Chaimowicz, Marc Camille
23. Coen, Lavista, Serrano

24. Crumplin, Colin

26. Estrada, Enrique

27. Finlay, Ian Hamilton

28. Fulton, Hamish

29. Gette, Paul-Armand

31. Guerrero, Mauricio

32. Hamilton, Richard

33. Hellion/Hendrix

34. Hilliard, John

36. Kurtycz, Marcos

37. Krasnianski, Bernardo

38. Lara, Magali

39. Le Gac

40. Long, Richard

42. Marin, Manuel

43. McKever, Ian

44. Nash, David
45. Nicolson, Annabel

46. Nissen, Brian

47. Nissen, Brian

48. Onwin, Glen
49. Peyote y la Compañia
50. Phillips, Tom

51. Posada, Antonio

53. Santiago

54. Taller de Experimentación Gráfica

55. Tremlett, David

56. Valencia, Ruben

57. Wakely, Shelagh

58. Zavala, Manuel

59. Zervou, Cristina
6ush

NÚCLEO I Vetor A3

61. Bec, Louis

62. Bouteas, Yannis

63. Broniatowski

65. Castles, John

66. Chira, Alexandro

67. Fischer, Hervé

68. Freitas, Yole de
69. Geiger, Anna Bell

70. Gillbert \& George

71. Guerrero, Myrna

72. Hernandez, Gilda
73. Machado, Ivens

74. Martinis, Dalibor

76. Muntadas

77. Plaza, Julio

78. Rojas, Miguel Angel

79. Siña, Alejandro

80. Stone, William

81. Tunga

NÚCLEO I Vetor B1

82. Boero, Renata

83. Ceccobelli, Bruno

84. De Maria, Nicola

85. Dessi, Gianni

87. Fasfan, Aaime

88. Fortuna, Pietro

89. Fukuoka, Michio

90. Gross, Carmela

91. Jurkiewcz

92. Lurakami, Nino

94. Piffero, Luca Mari

95. Sapija, Andrezy

\author{
96. Schendel, Mira \\ Schieferdecker, Jürgen \\ 99. Sena, António \\ 100. Sued, Eduardo \\ 101. Sezwczyk
}

NÚCLEO I Vetor B2

03. Bijelic, Milivo]

104. Fajardo, Carlos

\section{Exposiçăo ARTE POSTAL}

\section{Centro de Video-Arte}

\section{Livros de Artistas}

Artistas do Vetor A1 cujos números nâo constam da planta estáo incluí-

Artistas do Vetor A2 cujos números năo constam da planta estão inclufi-
dos no espaço de Livros de Artistas. 


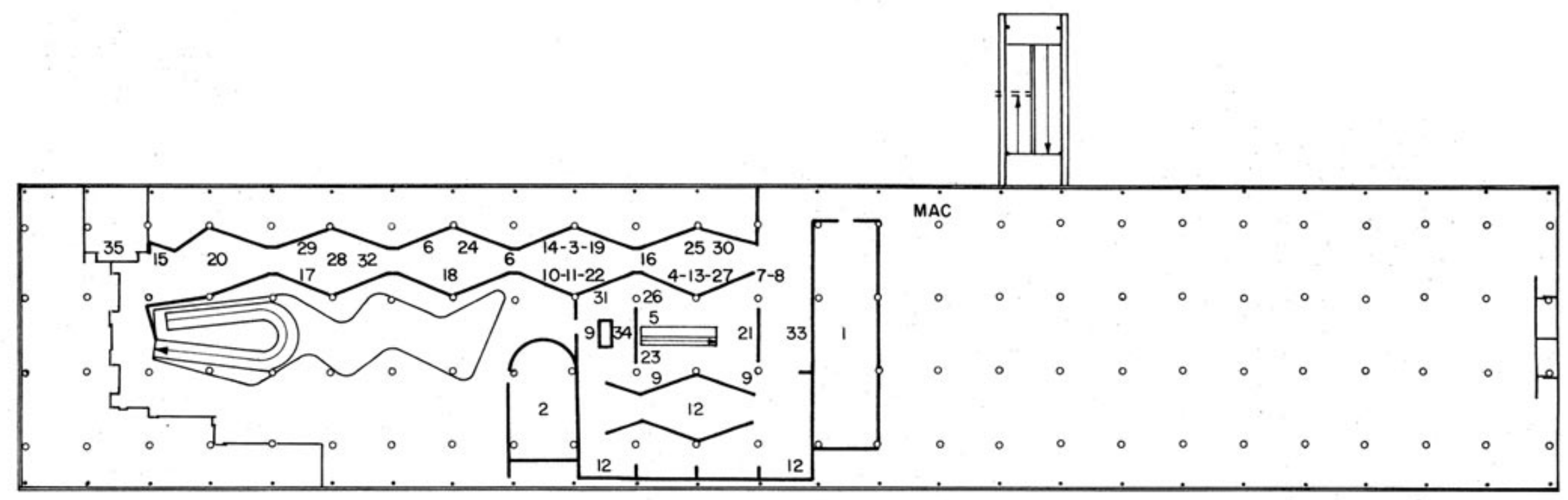

PLANTA DO TERCEIRO ANDAR

NÚCLEO III

1. Exposiçăo MUSsICA E DANÇA

2. CINEMA

Exposiçăo ARTE INCOMUM

3. Adelina

$\begin{array}{ll}\text { 4. Albino } & \text { 13. Farid } \\ \text { 5. Aloise } & \text { 14. Fernando } \\ \text { 6. Antônio Poteiro } & \text { 15. Gill, Madge } \\ \text { 7. António Sérgio } & \text { 16. G. T. O. } \\ \text { 8. Aurora } & \text { 17. Hauser, Johann } \\ \text { 9. Carles-Tolrá, Ignacio } & \text { 18. Heil, Eil } \\ \text { 10. Carlos } & \text { 19. Isaac } \\ \text { 1. Emygdio } & \text { 20. Jaime } \\ \text { 12. Facteur Cheval } & \end{array}$

5. Aloîse

7. António Sérgio

2. Facteur Cheva
21. Müller. Heinrich Anton

22. Octávio Ignácio

23. Periphimous, A. G.

24. Raphael

25. Santos, Gabriel dos

26. Schärer, Hans

28. Tatin, Rober
29. Tschirtner, Oswald

30. Volanhuk, Jakim

31. Walla, August

33. Woblfli, Adolf

34. Zemánková, Anna

35. SALA DE CONFERENCIAS 
Até a Iรa. Bienal, as exposições faziam uso de dois sistemas expositivos: um autoportante, com painéis baixos e outro vinculado à estrutura do pavilhão; o segundo era composto por painéis com estrutura tubular metálica que seguia a modulação estrutural do pavilhão e utilizava os pilares como travamento. ${ }^{19} \mathrm{O}$ montante vertical vencia o pé direito do pavilhão (piso teto) e resultava em uma estrutura muito delgada com fechamento apenas na altura necessária para a instalação das obras de arte, soltando-os visualmente do piso e do forro e conferindo leveza à museografia. Esse sistema expositivo tinha uma estrutura muito similar ao sistema modular desenvolvido em 1949 por Lina Bo Bardi no MASP para mostras didáticas. ${ }^{\circ}$ Com a curadoria de Walter Zanini, ${ }^{21}$ que alterou o sistema de organização da mostra por nação e transformou a expografia, esse sistema foi revisto e, então, surgem painéis com caráter de parede, sem estrutura aparente e chegando até o chão.

I9 O sistema se fixava nos pilares por braçadeiras, garantindo o travamento da estrutura metálica.

20 SCHINCARIOL, Zuleica apud Pesquisa de pós-doutorado de Ana Paula Nascimento.

2I Walter Zanini (I925-2013) foi um historiador, crítico de arte e curador brasileiro, diretor do Museu de Arte Contemporânea da Universidade de São Paulo, entre 1963 e 1978, e constituiu as bases conceituais e curatoriais do primeiro museu universitário do Brasil dedicado à arte contemporânea. Foi curador das ı6a. e ı 7 a. edições da Bienal Internacional de Arte de São Paulo. [no topo] 16a. Bienal: montagem da dupla de artistas britânicos Gilbert \& George. Fonte: site Bienal. Foto: (c) José Roberto Cecato. Disponível em: https://bienal.org.br. Acesso em: 02 Jan.2019.

[embaixo] 16a. Bienal: Segmento de Arte Postal.

Fonte: site Bienal. Foto: ๔ José Roberto Cecato. Disponível

em: https://bienal.org.br. Acesso em: 02 Jan.2019.
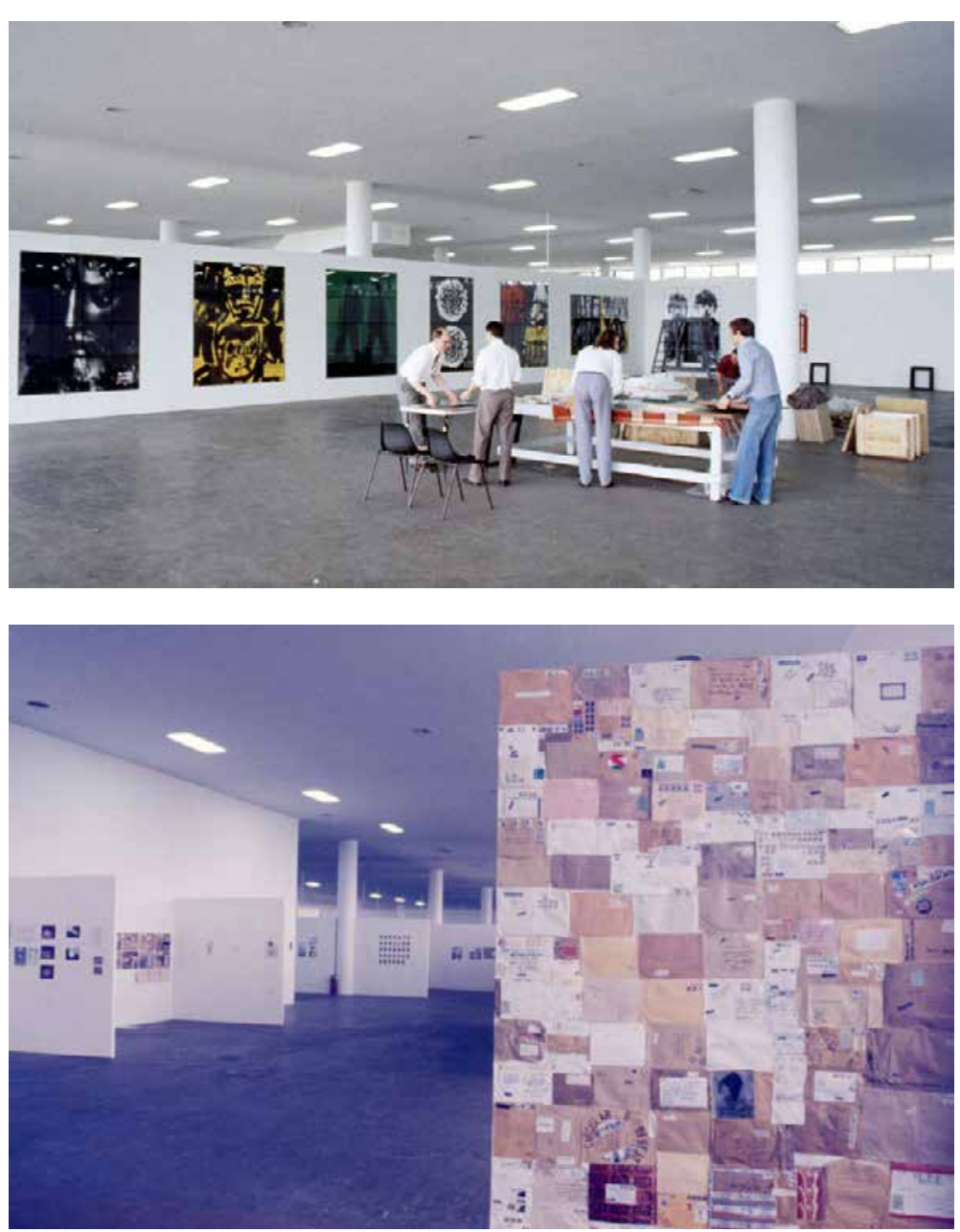
[no topo] 6a. Bienal de São Paulo: vista do sistema expositivo. Montagem da Sala Especial dedicada ao artista brasileiro Danilo di Prete. Fonte: site Bienal. Foto: ( $)$ Athayde de Barros. Disponível em: https://bienal.org.br. Acesso em: 02 Jan.2019

[embaixo] 12a. Bienal: Sala Geral da Coréia. Pode-se observar o sistema expositivo utilizado anteriormente. Fonte: site Bienal. Autor não identificado. Disponível em: https://bienal.org.br.
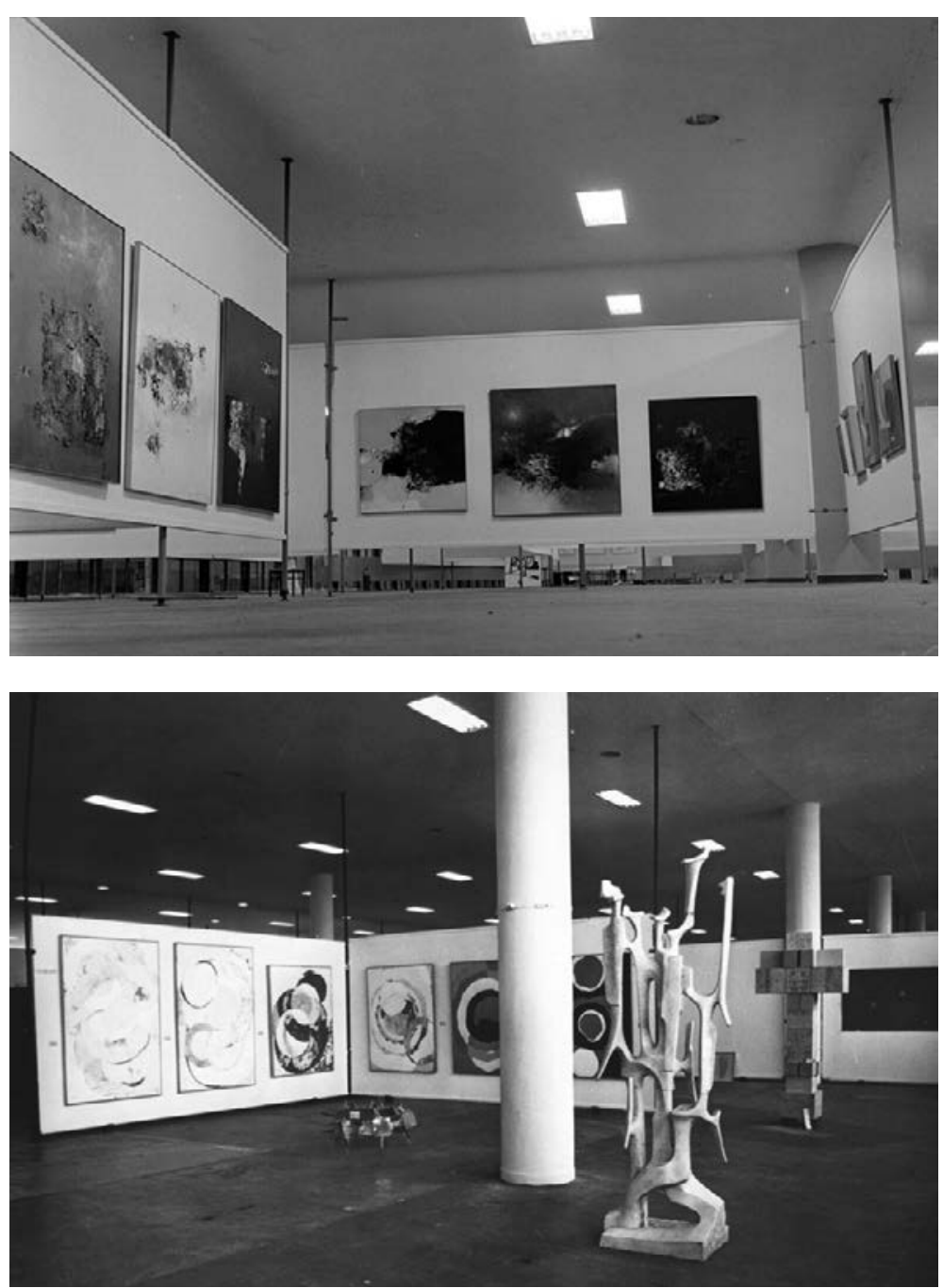

As Bienais subsequentes mantiveram o curador geral ${ }^{22}$ e o sistema de organização implementado com sucesso por Zanini. A ı8a. e a I9a. Bienais tiveram como curadora geral Sheila Leiner, ${ }^{23}$ dando início ao período dos curadores-autores, segundo Alambert e Canhête (2004. p.I73): “[...] a ideologia da autoria curatorial vinha sendo esboçada desde as bienais do início da década, sob direção de Walter Zanini, concretizando-se e atingindo um verdadeiro estatuto teórico com a nova curadora, Sheila Leirner”.

A I8a. Bienal (1985) foi marcada pelo retorno à pintura a partir do neoexpressionismo alemão, ${ }^{24}$ que se tornou um fenômeno global com obras de grandes dimensões. O pavilhão foi ocupado por um grande número de telas as quais Leirner e Haron Cohen, arquiteto responsável pela expografia, responderam com uma proposta radical. A curadora imaginou expor as telas como um anel de Moebius, uma superfície sem fim. Dentro dos limites possíveis, Cohen concretizou a proposta

22 A r6a. e a I7a. Bienais tiveram como curador geral Walter Zanini e a I8a. e a I9a. Bienais tiveram como curadora geral Sheila Leirner.

23 Sheila Leirner (São Paulo, I948) é uma curadora, jornalista e crítica de arte brasileira.

24 Modalidade artística resgatada a partir da década de 1980, foi fortemente influenciado pelo expressionismo, simbolismo e surrealismo e trouxe de volta a pintura e a escultura, com suas representações críticas, emocionais e subjetivas. A primeira geração era composta de artistas de Berlim e Düsseldorf, nascidos antes ou durante a Segunda Guerra Mundial: Georg Baselitz, Markus Lüpertz, Sigmar Polke, Gerhard Richter, A. R. Penck, Jörg Immendorff, Anselm Kiefer. 
com a implantação de três imensos corredores lineares e paralelos. As obras de cinquenta artistas foram expostas em dois painéis com cinco metros de altura e cem metros de comprimento, dispostas lado a lado com um afastamento entre obras de menos de trinta centímetros. O arranjo foi nomeado pela curadora de a Grande Tela. O espaço foi pensado para dar um caráter de procissão ritualística ao percurso. As áreas ao redor da Grande Tela eram chamadas pela curadora de naves laterais e o conjunto central com as pinturas de templo. Essa Bienal é um exemplo importante de como uma decisão curatorial levou a uma expografia contundente, abrindo um espaço para um caráter experimental e propositivo da relação curadoria-expografia (MATOS, 2009, P.25I). A proposta gerou muita polêmica uma vez que dificultava a leitura individualizada das obras. O crítico alemão Jürgen Harten retirou sua equipe de organização e obras da Bienal por não aceitar a montagem, artistas consagrados como Jiř́ Dokoupil (I954, Alemanha) e Enzo Cucchi (1949, Itália) se queixaram da vizinhança de suas obras com trabalhos imaturos de jovens artistas (FARIAS; 200I). Para o crítico argentino Jorge Glusberg, essa foi a última grande exposição internacional neoexpressionista; a Grande Tela teve "a função de um anti-museu ou anti-galeria, com objetivo crítico de ilustrar o momento da história da arte” (AMARANTE, I989, p.328). [no topo] 18a. Bienal: vista do vão central com performance de Jonathan Borofsky. Fonte: site Bienal. Autor não identificado. Disponível em: https://bienal.org.br. Acesso em: 02 Jan.2019.

[embaixo] 18a. Bienal: a grande Tela de Sheila Leirner e Haron Cohen. Fonte: site Bienal. Autor não identificado. Disponível em: https://bienal.org.br. Acesso em: 02 Jan.2019.
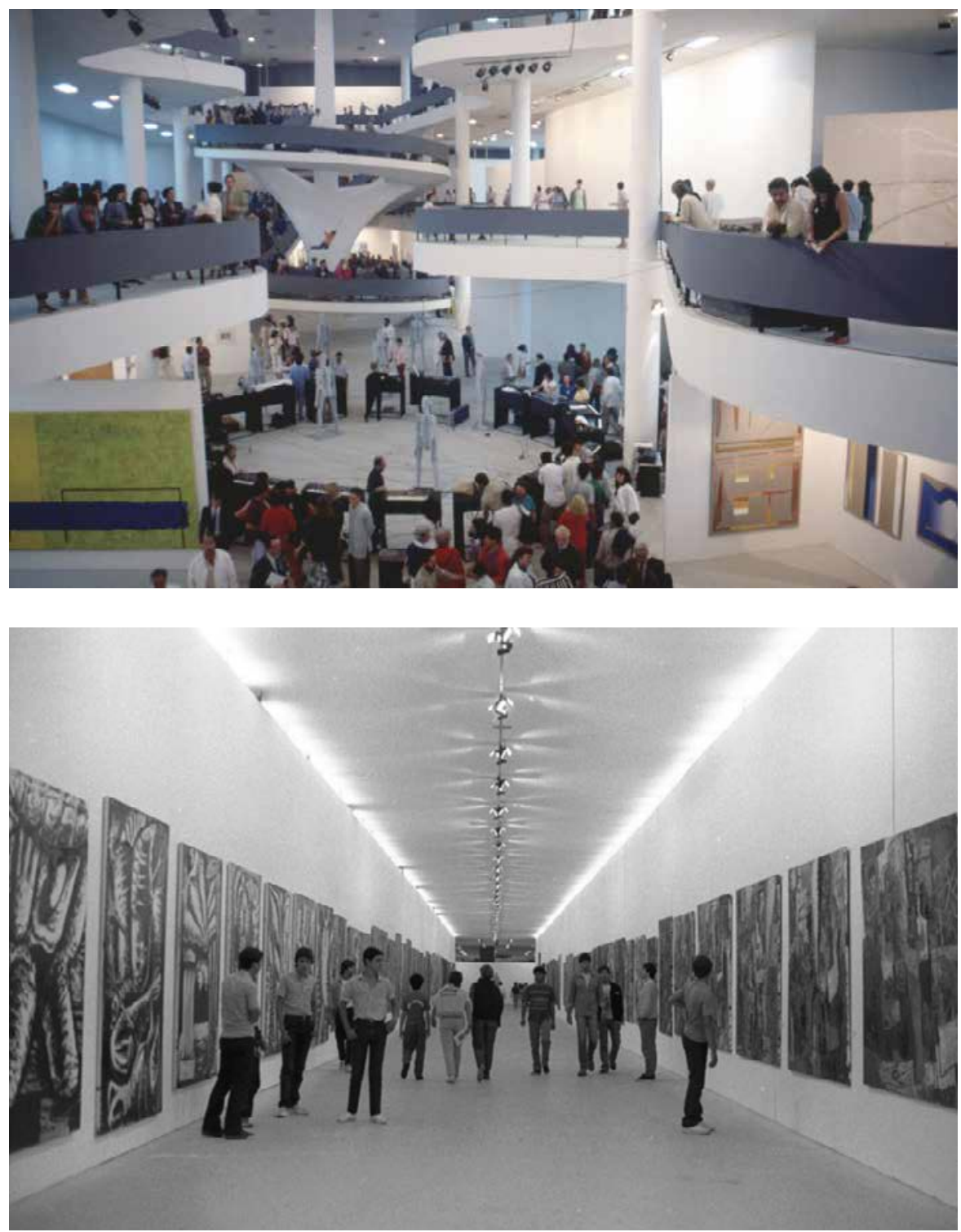
PLANTA DO TÉRREO E 1.: ANDAR

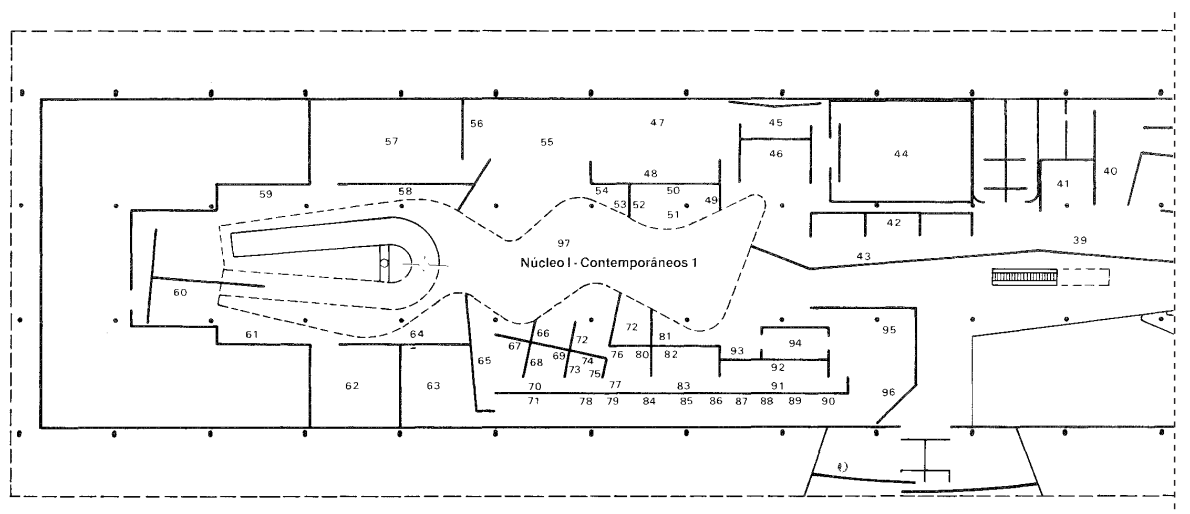

\begin{tabular}{|c|}
\hline 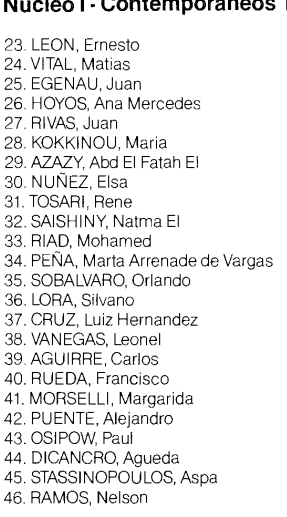 \\
\hline
\end{tabular}
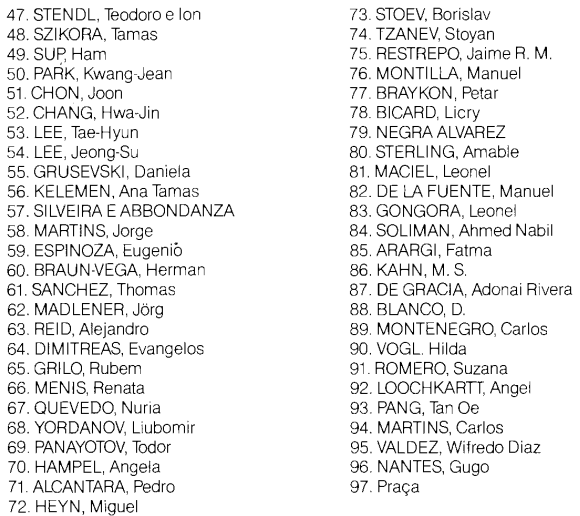

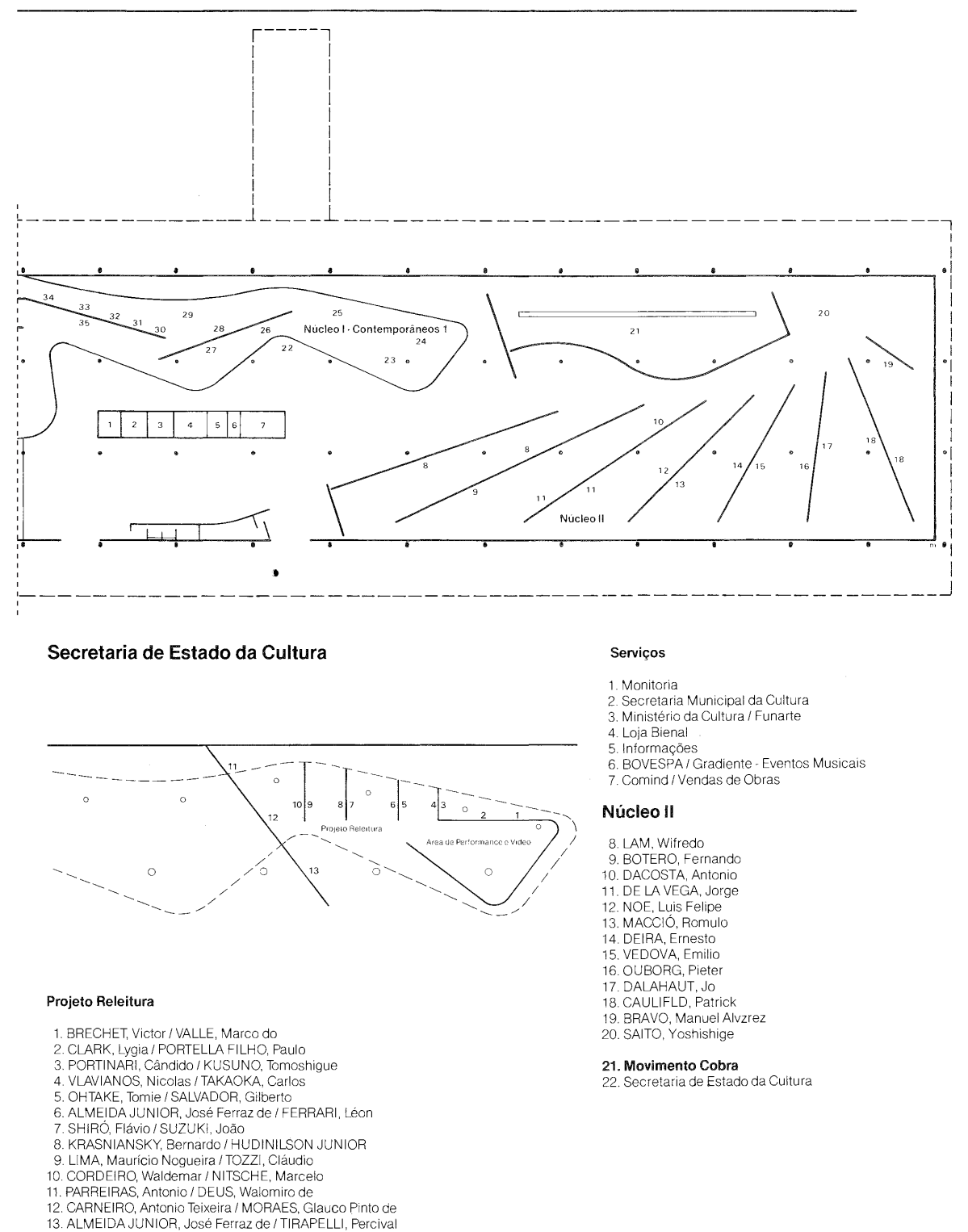


18a. Bienal: projeto de arquitetura e montagem de Haron Cohen e Felippe Crescenti. Fonte: Arquivo Wanda Svevo.
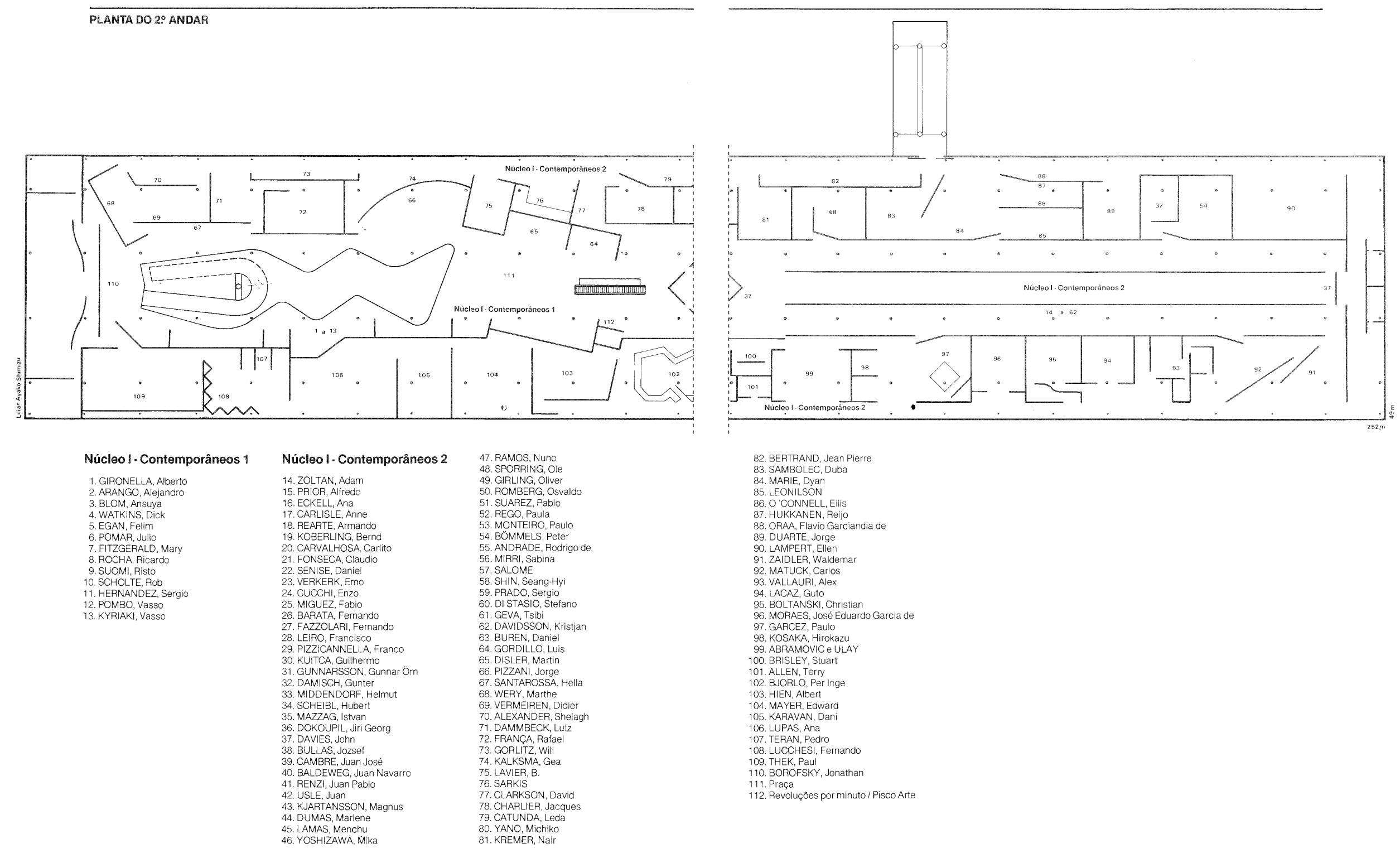

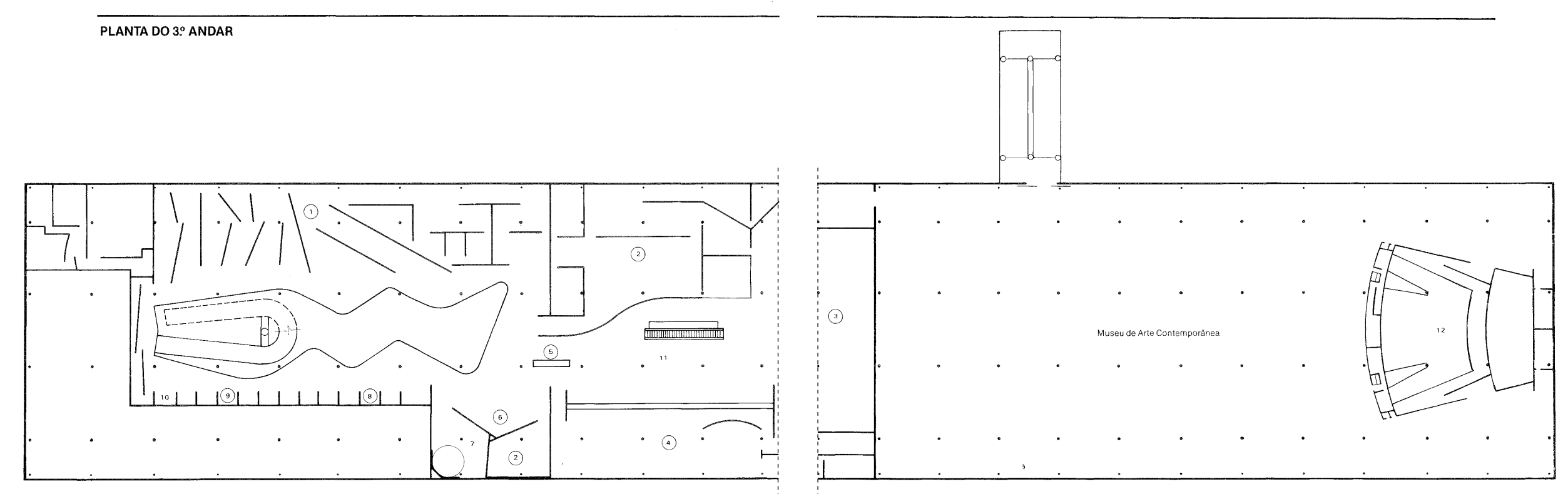

Exposiçōes Especiais e Grupos

1. Expressionismo no Brasil: Heranças e Afinidades

2. Entre a aiencia ea Ficcáo

5 Video Arte na Reṕ́blica Federal da Alen

6 V Video Arte: Uma Comunicaçąa Criativa

7. Waka Tjopu

9. Xilogravuras Contem borâneas na Literatura de Corde

10. Litografias do Atellề Vienense
11 Praca

12. Auduitório 
$\mathrm{Na}$ 2oa. Bienal alterou-se novamente a estrutura da mostra: foi criado um triunvirato para a curadoria, a proposta de Zanini de analogia de linguagens foi abandonada, e houve um retorno às salas nacionais e à premiação que havia sido abandonada desde a I 5 a. edição (FARIAS, 200I, p.I86). Essa transformação se revela na expografia, na qual se vê a volta de uma compartimentação do pavilhão em inúmeras salas para atender a demanda de uma sala por nação, no lugar das propostas em diálogo com o discurso curatorial. [embaixo] 20a. Bienal: vista do vão central com a instalação Lightning with stags in its glare (1958-87), de Joseph Beuys. Fonte: site Bienal. Foto@Agência Estado. Disponível em: https://bienal.org.br. Acesso em: 02 Jan.2019.

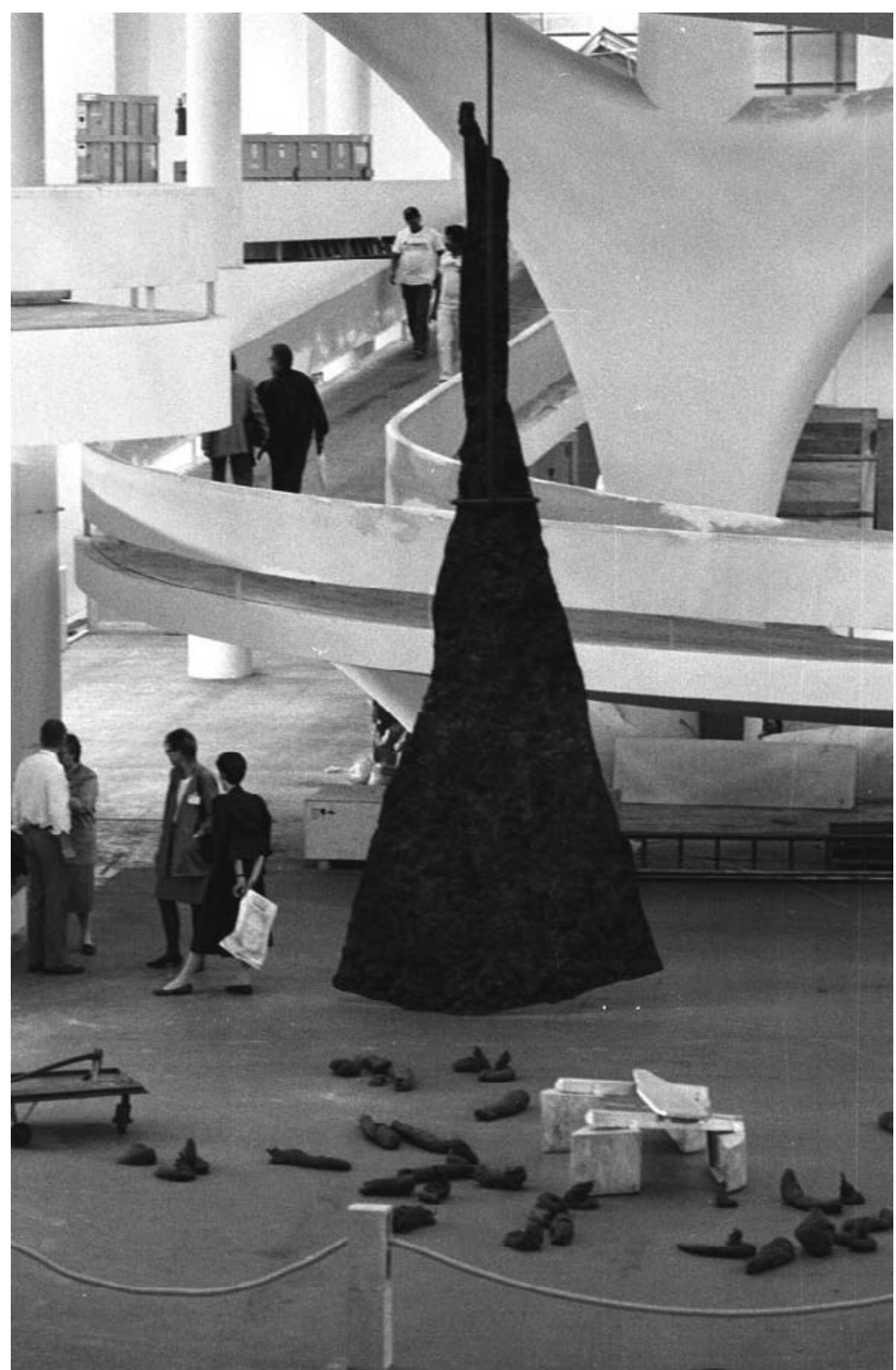




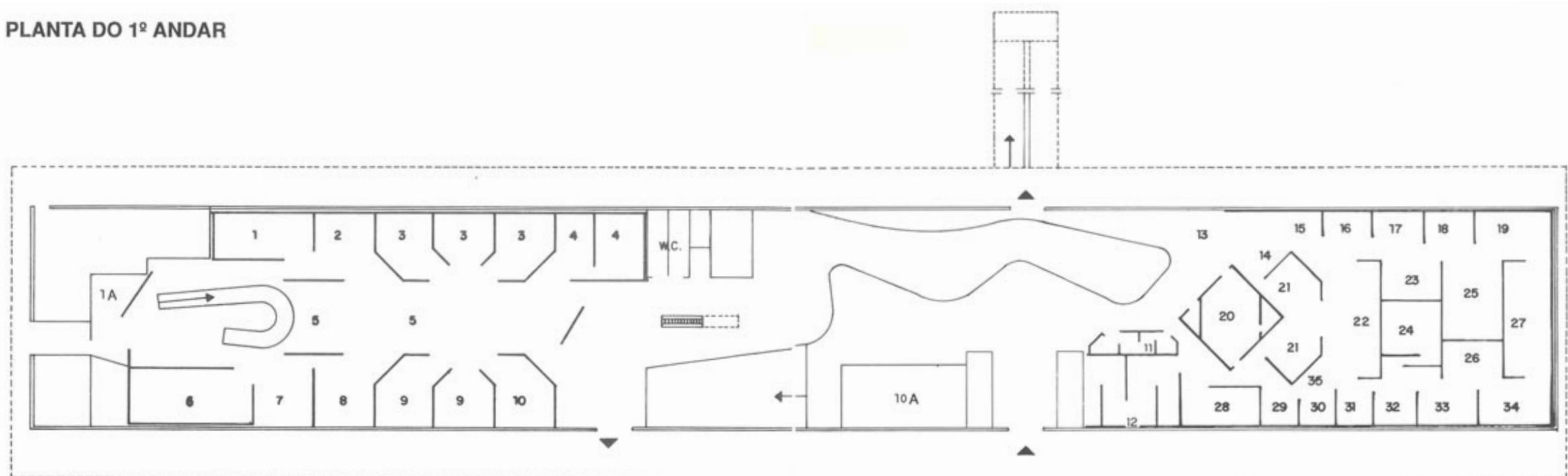

\section{EXPOSIÇĂO INTERNACIONAL}
01. VENEZUELA
01a. ROMÊNIA
02. ÁUSTRIA
03. BÉLGICA
05. REPÚBLICA FEDERAL. DA
5. REPUBLICA
6. COLÓMBIA
07. DINAMARCA
08. CORÉIA DO SUL
09. PORTUG
10. ITALIA EDDY NOVARRO

\section{EVENTOS ESPECIAIS}

11. AS BIENAIS DOS ANOS 50

12. HUMOR EM CUBA

13. BONECOES, CARAS

CARETAS

14. HILDE WEBER

15. SALA DE MEMORA
16. FLAVIO IMPÉRIO

17. FLÁVIO DE CARVALHO

18. LASAR SEGALL

19. ALDO CALVO

20. A CIDADE MUDA - AUDITÓRIO

21. ROBERT WILSON

22. DANIELA THOMAS

24.

25. J.C. SERRONI

26. SIRON FRANCO

27. NECESSIDADE DE NARRAR
28. ARTE EM JORNAL

9. JOSÉ ANTONIO DA SILVA

30. MARIA BONOMI

31. TOMIE OHTAKE

35. BORIS BUCAN 


\section{PLANTA DO $2^{\circ}$ ANDAR}
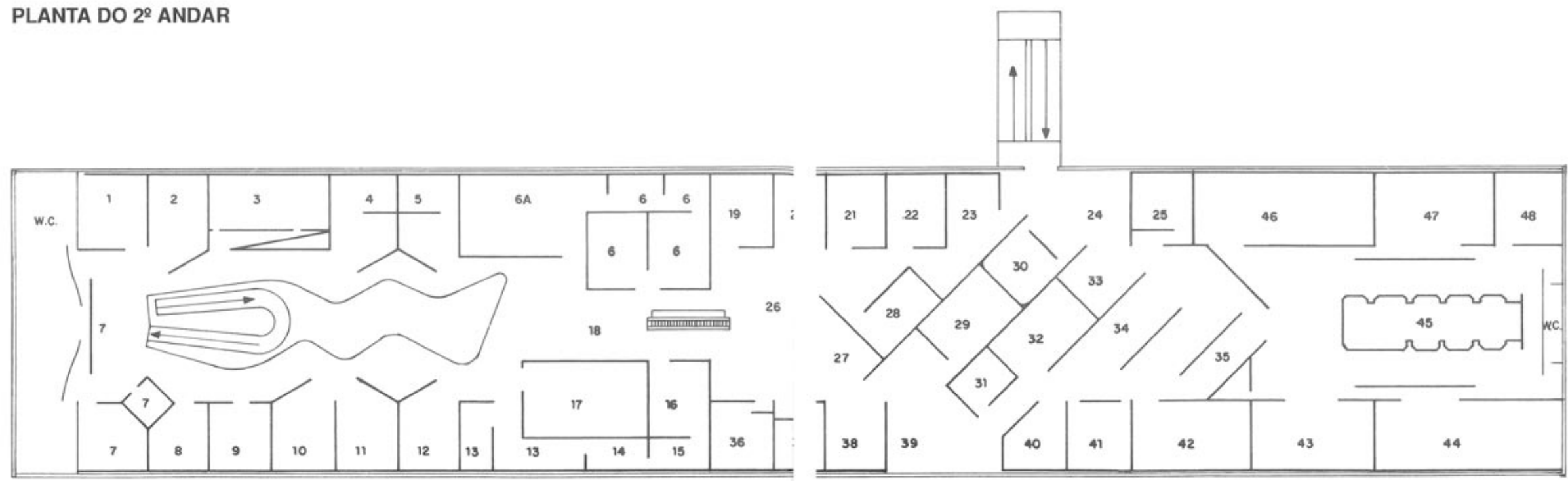

\section{EXPOSICĀO INTERNACIONAL}
01. URUGUAI
02. REPÚBLICA DEMOCRÁTICA
03. ALEMA
04. PERA
05. FINLÅNDIA
06. FRANCA
06. YVES KLEIN - SALA
06a. YVES KLEIN - SALA
ESPECIAL INTERNACIONAL
07. GRA-BRETANHA
08. MÉXICO
09. ISRAEL
10. LUXEMBURGO
11. BULGÁRIA
12. ARGENTINA
13. ARGENTINA
15. INDIA
16. PORTO RICO
17. CANADÁ
17. CANADA
18. JAPĀO
BRASIL.

\author{
19. NUNO RAMOS \\ 20. ANNA BELLA GEIGER \\ 21. FÁBIO MIGUEZ \\ 22. JAC LEIRNER
23. HILTON BERREDO
24. CILDO MEIRELES \\ 25. FLÁVIA RIBEIRO \\ 26. AMILCAR DE CASTRO \\ 28. JOSÉ RESENDE \\ 29. DANIEL SENISE \\ 31. CARMELA GROSS \\ 3. MARCOS COELHO BENJAMIM \\ 34. MARCO DO VALLE \\ 35. ESTER GRINSPUN \\ 36. CARLOS VERGARA \\ 37. EMARD SUED \\ 39. EMMANUEL NASSAR
}

40. ANÉSIA PACHECO E. CHAVES

41. MONICA SARTO

SALAS ESPECIAIS NACIONAIS
43. ARQUITETURA
44. ABSTRACCAO - "EFEITO
BIENAL"-1954-63

45. VICTOR BRECHERET

EVENTOS ESPECIAIS

\section{STUDIO INTERNACIONAL}

DE ELETROGRAFIA

48. FRACTAL ART 
PLANTA DO 3 N ANDAR

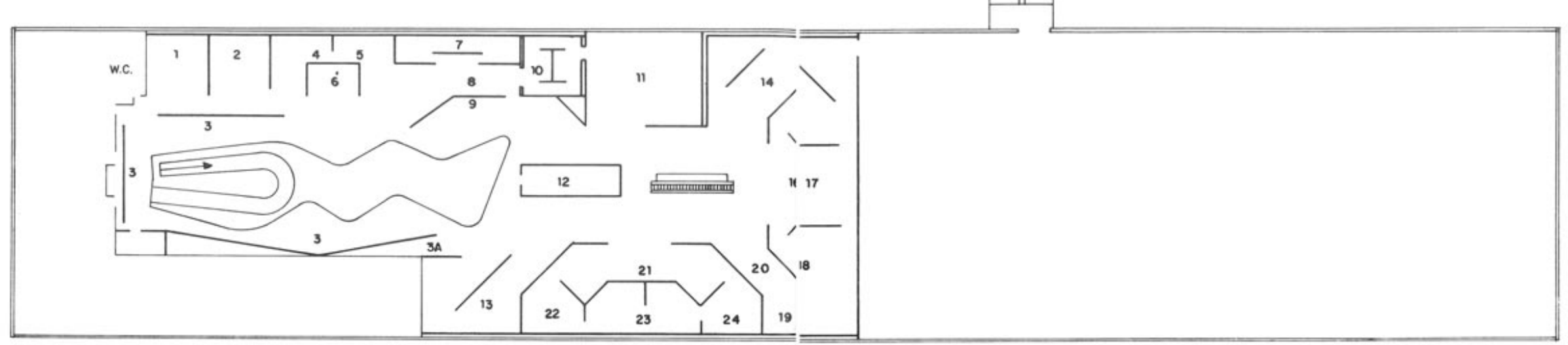

EXPOSIÇÃO INTERNACIONAL SALAS ESPECIAIS
01. GRÉCIA
02. EQUADO
03. CHILE
03a. VIDEO - CAPELA SISTINA
04. GUATEMALA
06. REPÚBLICA DESAN
MARINO NTERNACIONAIS
14. OSWALVO GUAYASAMIN
15. ALFREDO HLITO
16. FRANK STELLA
18. MARIA HELENA VIEIRA DA
18. MILVA
19. ALANBELCHER
07. SUIÇA
08. EGITO
09.
10. HOLANDA
11. E.U.A.
21. RICHARD HAMILTON
22. DAVID HOCKNEY
23. NEIL WILLIAMS
24. DALE CHIHULY
13. POLÓNIA 
A 22a. Bienal (1994) e a 23a. Bienais (1996), ambas com a curadoria geral de Nelson Aguilar, tiveram a premiação extinta. As propostas curatoriais foram: A ruptura com o suporte e $A$ desmaterialização da arte no final do milênio, respectivamente. Edemar Cid Ferreira ${ }^{25}$ havia assumido a presidência da Fundação Bienal e tinha como diretriz internacionalizar a mostra e transformá-la em um grande evento. Para atingir esse objetivo convidaram o maior número possível de países e houve um investimento no núcleo histórico para atrair o público. Segundo Vinicius Spricigo (2009), em 1994 se inicia um processo de inserção da Bienal de São Paulo no sistema global das artes que se dá a partir da aceitação no cenário internacional de que construímos uma história diferente, uma modernidade latino-americana com suas peculiaridade pós-colonialista e sob a influência do imperialismo norte-americano.

$\mathrm{Na}$ 22a. Bienal foram organizadas salas especiais para os artistas brasileiros Hélio Oiticica, Lygia Clark e Mira Schendel, afirmando a qualidade de sua produção e equiparando-os com prestigiados artistas internacionais, decisão que resultou em um

25 Edemar Cid Ferreira (1943), economista e banqueiro brasileiro, cuja falência fraudulenta de seu banco foi decretada em 20 de setembro de 2005 . Em I993, assumiu a presidência da Fundação Bienal. Em 1994 esteve à frente da realização da 22a. Bienal e, em I996, da 23a. Bienal de São Paulo, ainda hoje considerada histórica por especialistas. Em 1997, deixou a presidência da Fundação Bienal para preparar a exposição comemorativa Brasil 500 anos, que ocorreu em $2000 \mathrm{e}$ ocupou 60 mil metros quadrados e a maioria dos prédios do Ibirapuera. Fundou a Associação Brasil 500 Anos, completamente separada da Fundação Bienal, tanto física como financeiramente. Verbete disponível em: <https://pt.wikipedia.org/wiki/Edemar_Cid_Ferreira>. Acessado em: 2 jan. 2019. reverberação internacional da arte contemporânea brasileira. ${ }^{26}$ O projeto expográfico dessa mostra ficou a cargo de Ronald Cavaliere, arquiteto da Fundação Bienal. Na configuração espacial não houve uma mudança em relação às propostas anteriores; apesar da transformação curatorial, manteve-se o loteamento do espaço. Segundo Farias (200I), houve um congestionamento de obras e, para abrigá-las, foram feitas uma grande quantidade de salas que lotaram o pavilhão, o que chegou a comprometer a leitura da mostra. Cada uma das setenta nações pôde convidar três artistas, ${ }^{27}$ e cada artista ocupou uma sala.

26 "De fato, logo após o final da XXII Bienal, os jornais noticiavam que I67 obras de dezesseis artistas brasileiros, entre eles Hélio Oiticica, Tunga, Nuno Ramos, Leonilson, Waltércio Caldas, Daniel Senise e Mira Schendel estariam em onze galerias de Nova York sob o título de Art from Brazil in New York. A ideia teria surgido de três galeristas nova-iorquinos, Mary Sabbatino, Lori Ledis e Robert Flam, que visitaram a Bienal paulistana e ficaram impressionados com as obras que viram. 'Nos reunimos e resolvemos montar um "braço da Bienal” em Nova York', disse Sabbatino. A iniciativa contou com patrocínio de sete empresas brasileiras e do Ministério das Relações Exteriores, cuja a informação seria 'fazer uma reatualização da imagem do Brasil' " (ALAMBERT; CANHÊTE, 2004, p.I9I).

27 Foram 239 artistas no total. 

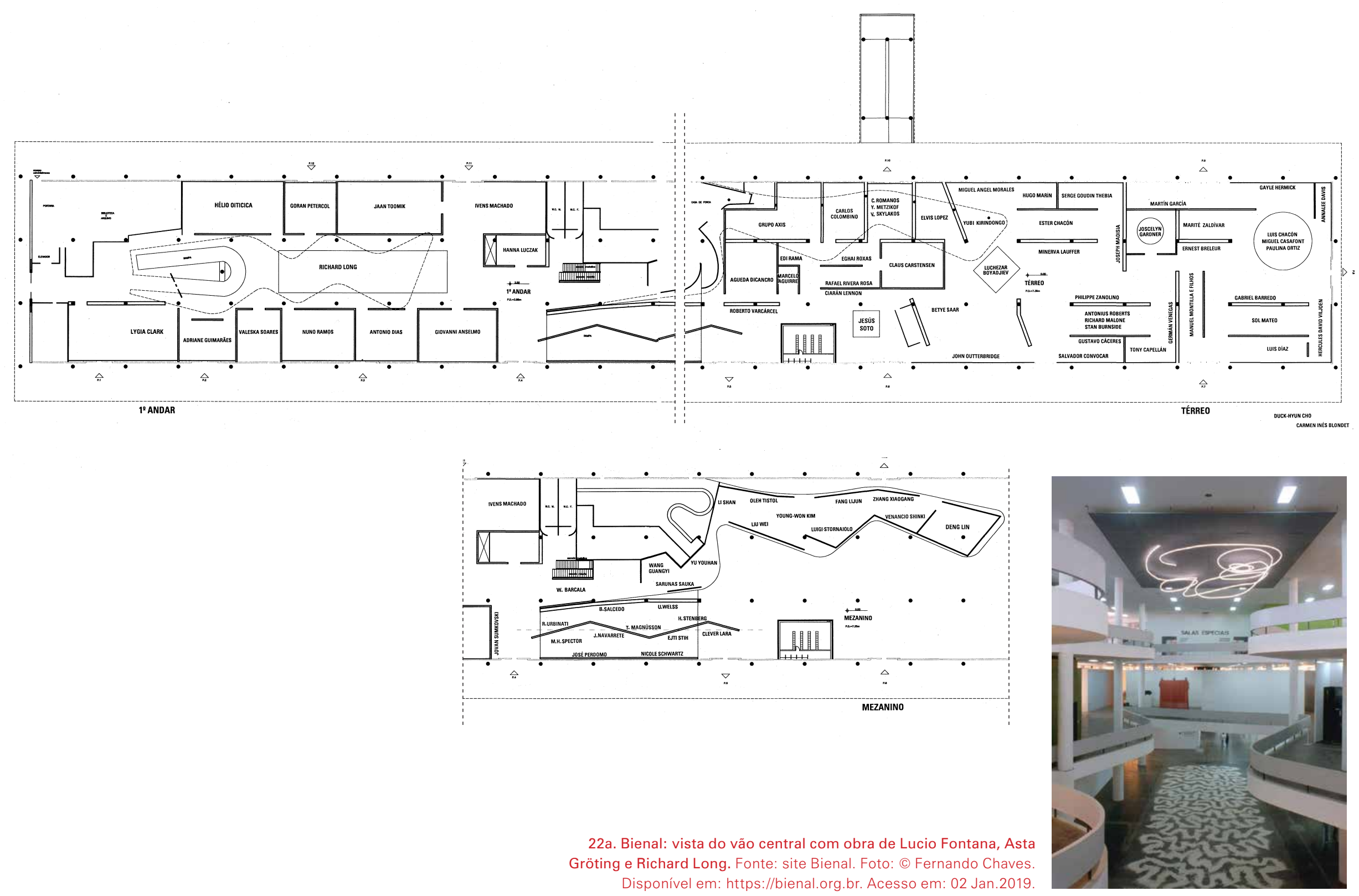

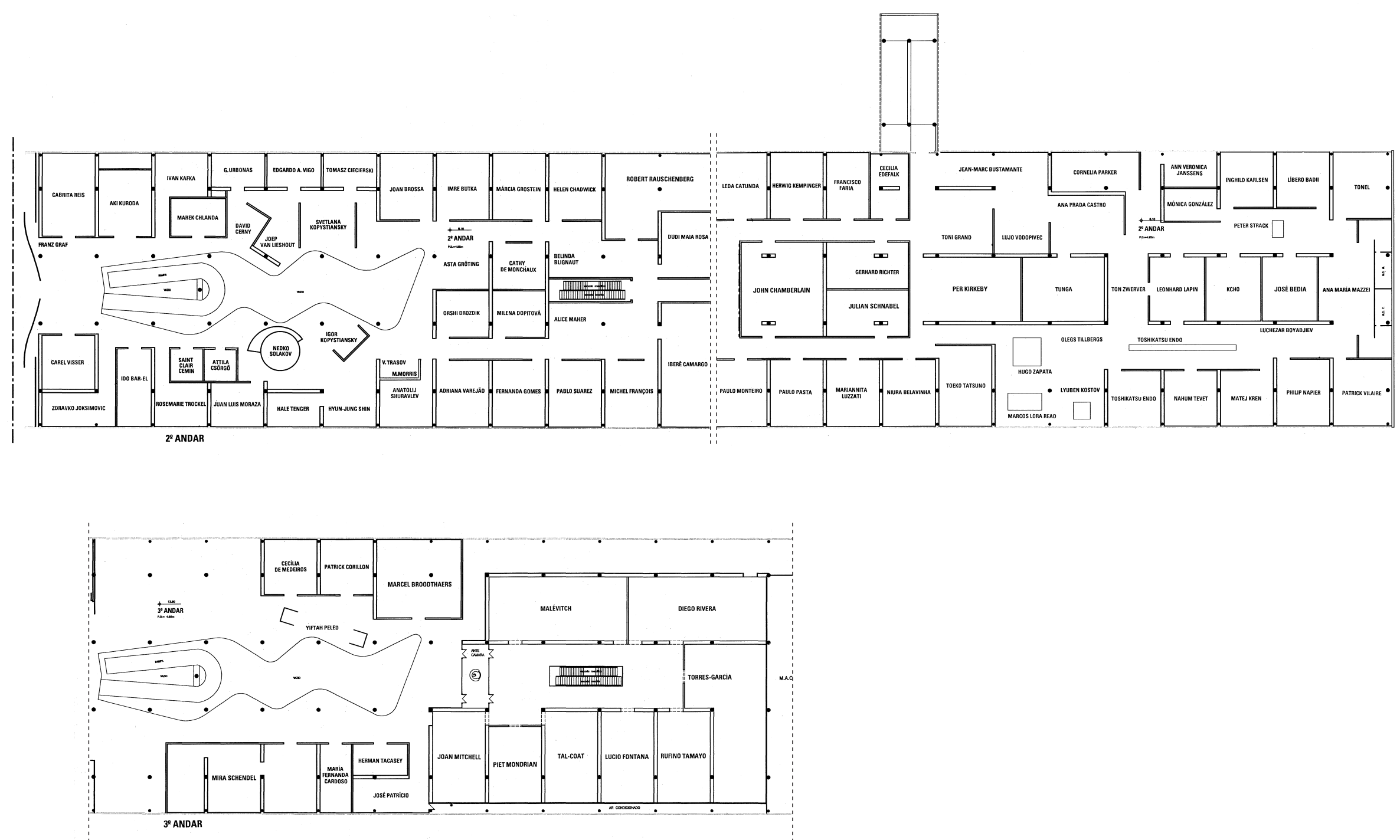
23a. Bienal: vista do Vão central com obra de Anish Kapoor e Tomie Othake. Fonte: site Bienal. Foto: (c) Fernando Chaves. Disponível em: https://bienal.org.br. Acesso em: 02 Jan.2019

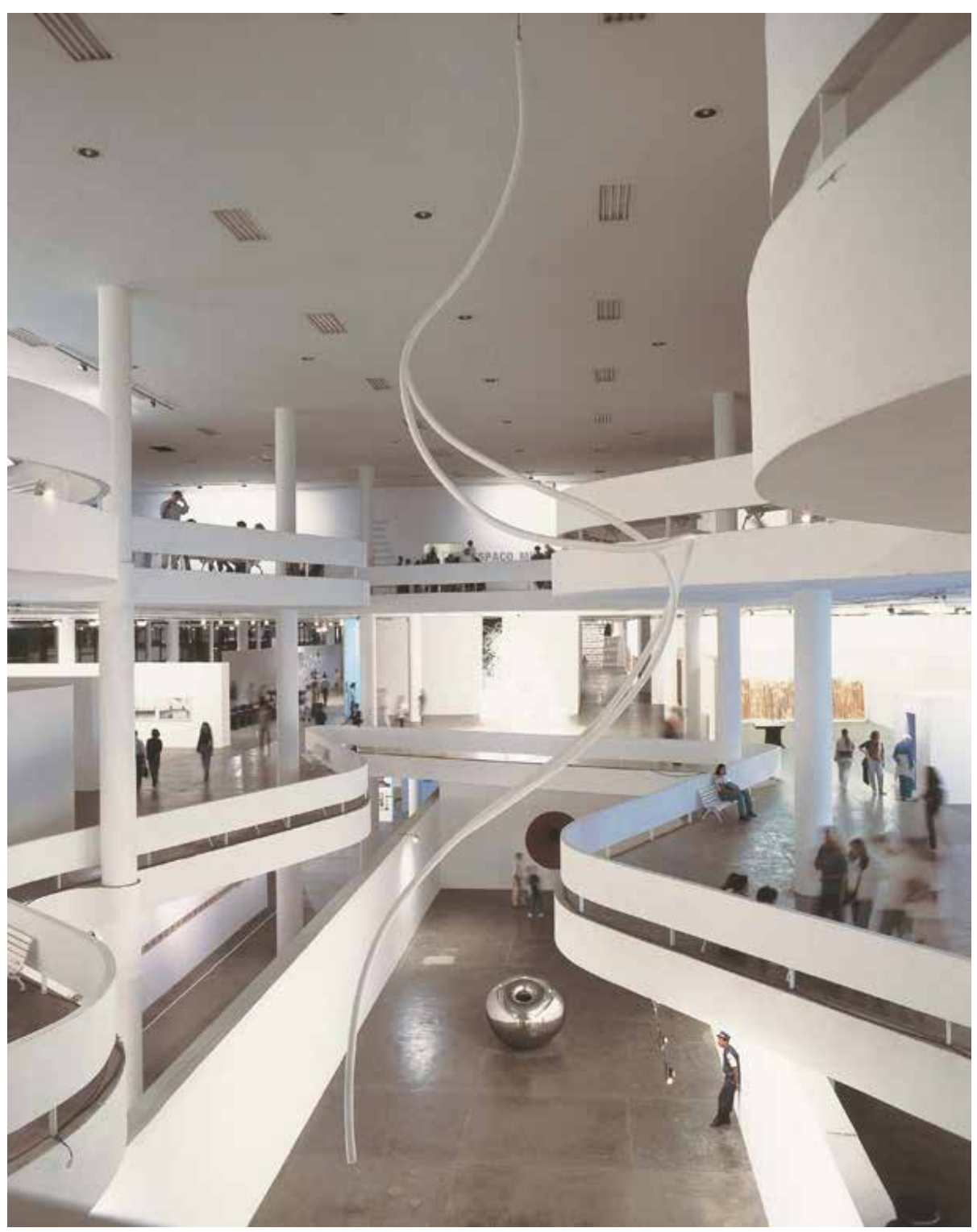

A 23a. Bienal retomou o debate da desmaterialização da arte no final do milênio ${ }^{28}$ ao se apropriar do título de um dos primeiros textos críticos sobre a arte conceitual, escrito por Lucy R. Lippard e publicado em i968. A proposta curatorial questionava a ausência de artistas brasileiros na genealogia da arte conceitual no artigo da norte-americana. Aguilar posicionou artistas brasileiros como Cildo Meirelles, Antonio Manuel e Artur Barrio entre outros como referencias importantes da arte conceitual na mostra (SPRICIGO, 2009). O projeto expográfico de Paulo Mendes da Rocha ${ }^{29}$ para a 23a. Bienal foi um salto qualitativo, valorizou a relação da expografia com o pavilhão e acabou com a sua excessiva compartimentação..$^{30} \mathrm{Na}$ proposta, os painéis ficavam em sua maioria soltos e não se fechavam em salas, o que resultou em um espaço fluido e possibilitou diversos percursos em diálogo com a proposta curatorial.

28 "A desmaterialização da arte", dos críticos de arte norte-americanos Lucy R. Lippard e John Chandler, foi originalmente publicado na revista Art International, n.I2, fevereiro de 1968, p.31-36. Tradução de Fernanda Pequeno e Marina P. Menezes de Andrade disponível em: https://www.ppgav.eba.ufrj.br/wp-content/uploads/2013/I2/ae25_lucy.pdf. Acessado em: or fev. 20I9.

29 Paulo Mendes da Rocha (1928) um dos principais arquitetos paulistas do século XX. Foi responsável pela expográfia da 23a. Bienal e 24a. Bienal.

30 Para evitar o adensamento excessivo os artistas foram limitados a um por nação. 


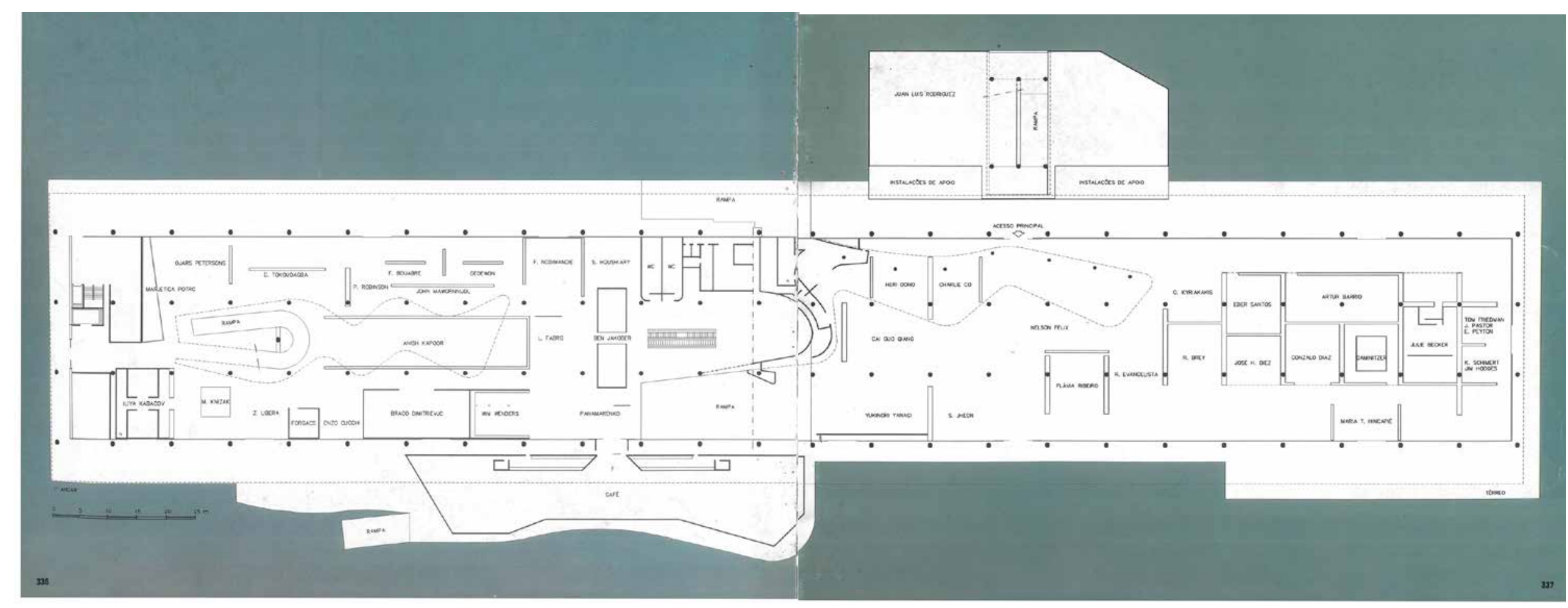



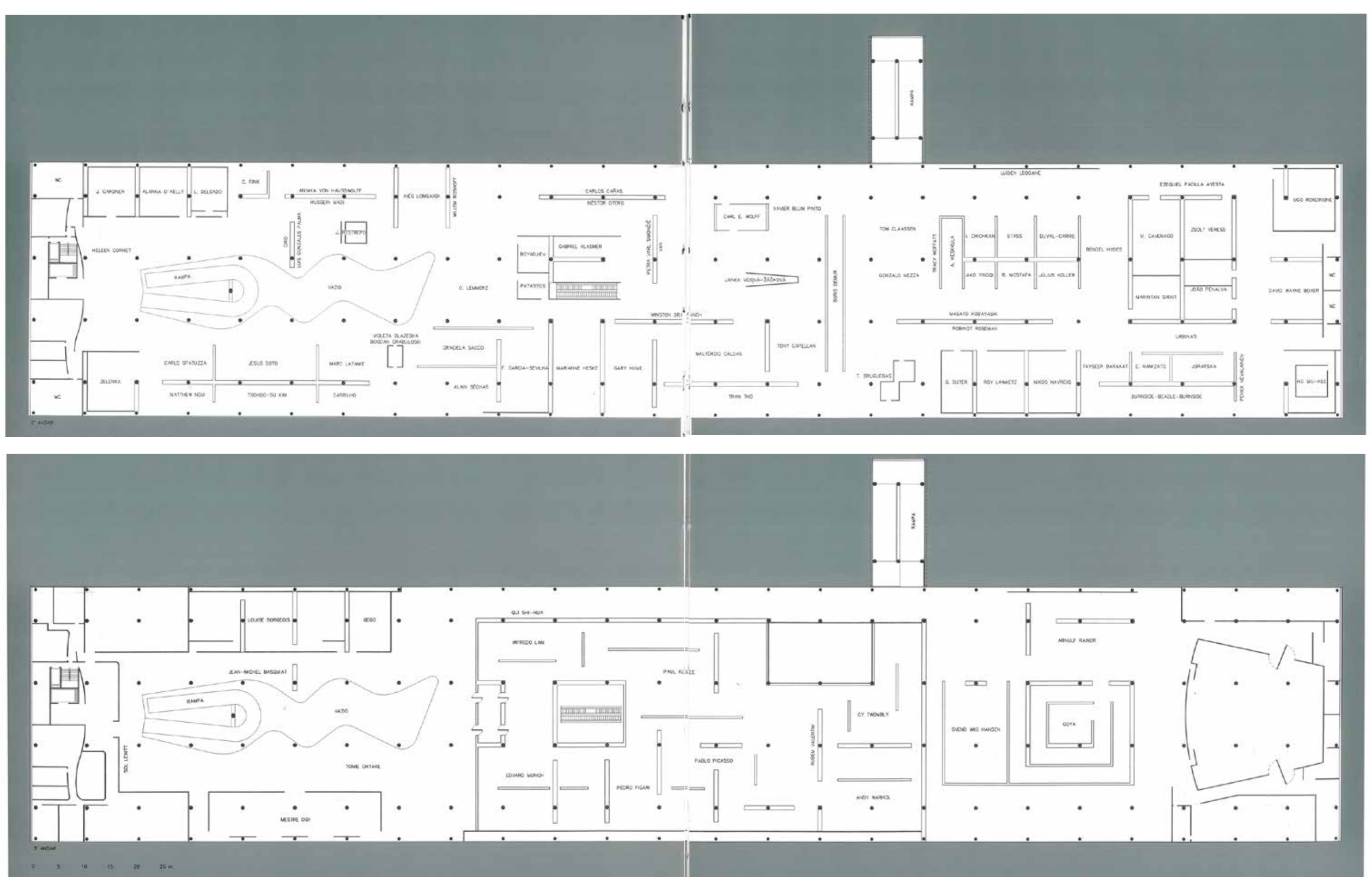
Com curadoria geral Paulo Herkenhoff, a 24a. Bienal (1998) foi um grande sucesso de público e crítica. O projeto curatorial abordou o conceito de antropofagia e propôs uma reconstrução da história da arte a partir de uma nova perspectiva. A mostra “foi considerada por grande parte do público e da crítica especializada como a melhor exposição entre todas de seu gênero" ${ }^{\text {I }}$ (FARIAS, 200I, p.254). A museografia, mais uma vez projetada por Paulo Mendes da Rocha, buscou estabelecer visualmente as relações entre as obras reforçando a diretriz curatorial de criar contaminações e dissolver as demarcações geopolíticas, reduzindo o número

3I Essa Bienal consta como uma das melhores exposições internacionais do mundo nos compêndios de exposições internacionais Biennials and Beyond - Exhibitions that made art history, de Bruce Altshuler, e está no livro Show Time - The 50 most influential exhibitions of contemporary art, de Jens Hoffmann, na categoria "Biennial Years" (anos de bienal) e ainda é a única exposição brasileira a ter um livro da série Exhibition Histories, da Afterall Books (CYPRIANO, 20I4). de salas fechadas. Houve um esforço no sentido de evitar salas e valorizar as relações entre obras, pavilhão e a cidade de São Paulo. Apesar da manutenção das representações nacionais, Herkenhoff e a equipe de curadores conseguiu, por meio de um intenso trabalho diplomático, desfazer o caráter casuístico de seleção reiterando a importância do conceito de antropofagia, indicando nomes e restringindo uma obra por país. Essa Bienal se tornou uma referência fundamental para a elaboração curatorial da 27a. Bienal_essa relação será aprofundada no capítulo 2. Herkenhoff não aceitou fazer a 25a. Bienal já que naquele momento era usual o curador fazer duas mostras seguidas. Ivo Mesquita foi o curador indicado para fazer a mostra subsequente.

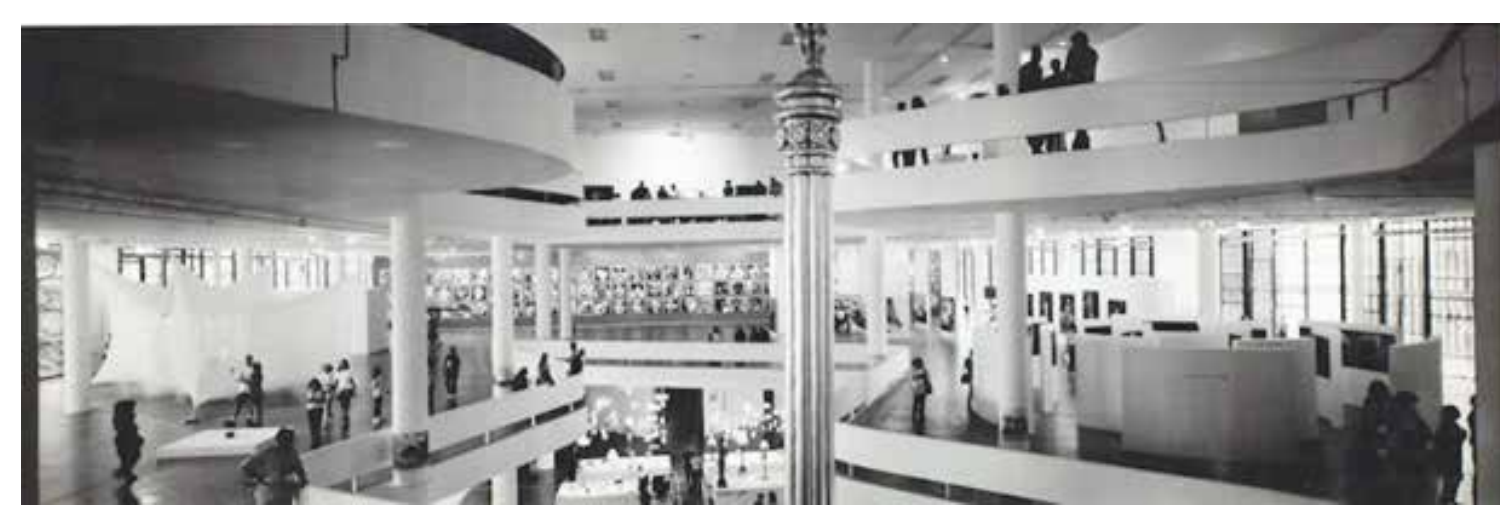

[pág. ao lado] 24a. Bienal: projeto de arquitetura de Paulo Mendes da Rocha. [no topo] Térreo e 10. pavimento.

[ao centro] 2o. Pavimento. [embaixo] Terceiro pavimento.

Fonte: Arquivo Wanda Svevo.

[nesta pág.] 24a. Bienal: vista geral da mostra.

Fonte: site Bienal. Foto: ( ) Autor Gal Oppido.

Disponível em: https://bienal.org.br. Acesso em: 02 Jan.2019 

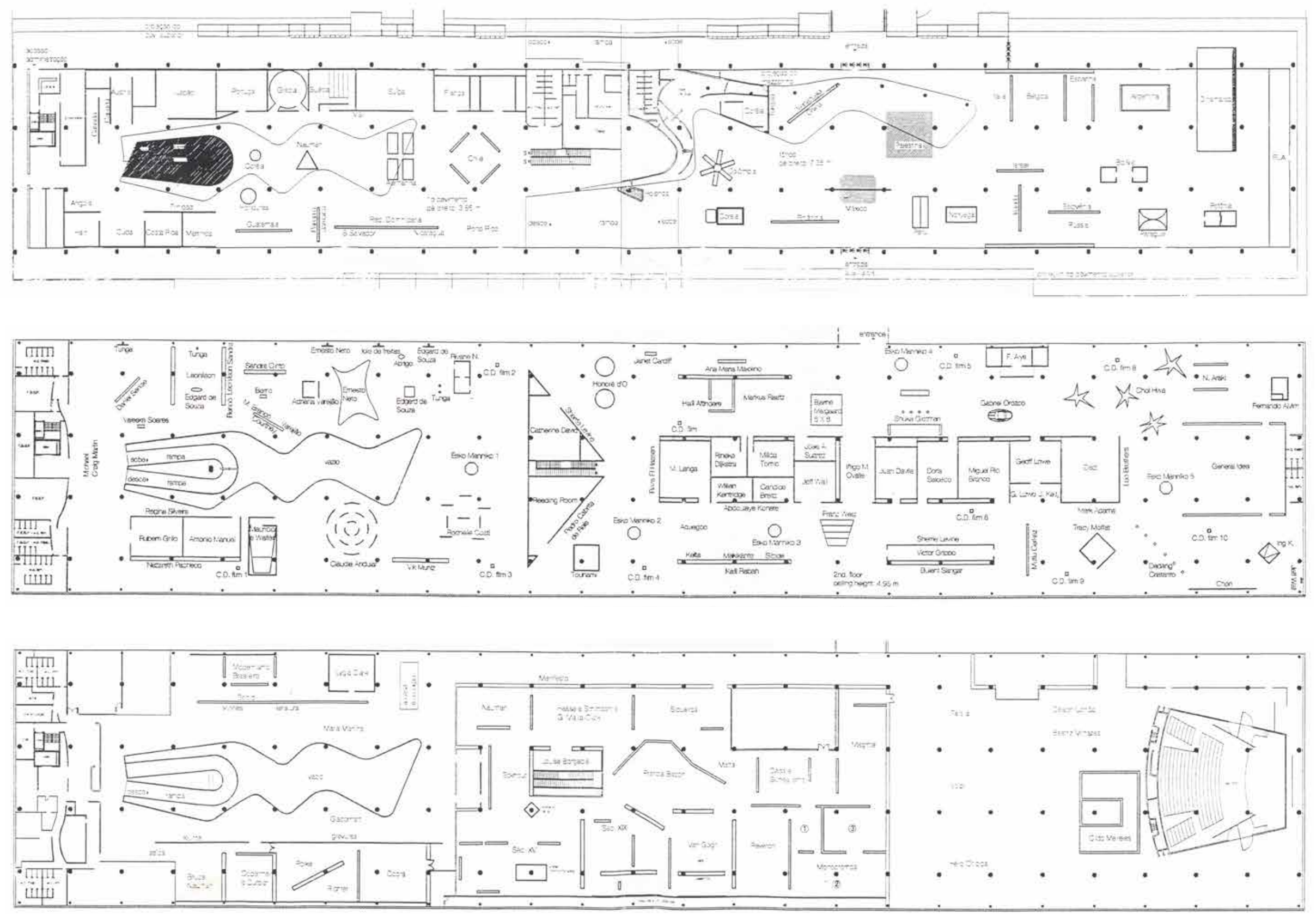
A 25 a. Bienal, que deveria ter acontecido em 2000, acabou sendo adiada por dois anos devido à Mostra do Redescobrimento: Brasil 500 anos, realizada por Cid Ferreira, que abrangeu quase todos os espaços do Parque Ibirapuera (Pavilhões da Bienal e Pinacoteca, Museus do Folclore e da Aeronáutica). A mostra, de caráter monumental, ocupou 6omil metros quadrados e drenou toda a verba para o evento. Alegou-se, assim, a inviabilidade de organizar os dois eventos simultaneamente. Mesquita, contrariado pela situação imposta, renunciou ao cargo de curador da 25 a. Bienal (CYPRIANO, 20I6).

Diante desta conjuntura, a Fundação indicou pela primeira vez um estrangeiro como curador geral, o alemão Alfons Hug. A Bienal retomou o forte caráter das representações nacionais que havia sido dissolvido na 24a. Bienal, com uma sala e curador responsável por nação. A curadoria do núcleo brasileiro ficou a cargo de Agnaldo Farias. Uma das obras mais emblemáticas da mostra foi o Hotel das estrelas, de Carmela Gross, que instalou um letreiro de néon com a palavra "hotel" na fachada norte do pavilhão. A obra faz uma crítica contundente ao processo de espetacularização da cultura. A museografia proposta por Mario Biselli e Artur Katchborian também retomou a relação uma sala por artista ou nação, que havia sido eliminada na edição anterior. As salas foram construídas junto aos caixilhos, no primeiro e terceiro pavimentos, interferindo na leitura das obras junto ao pavilhão, assim como sua relação com o parque.

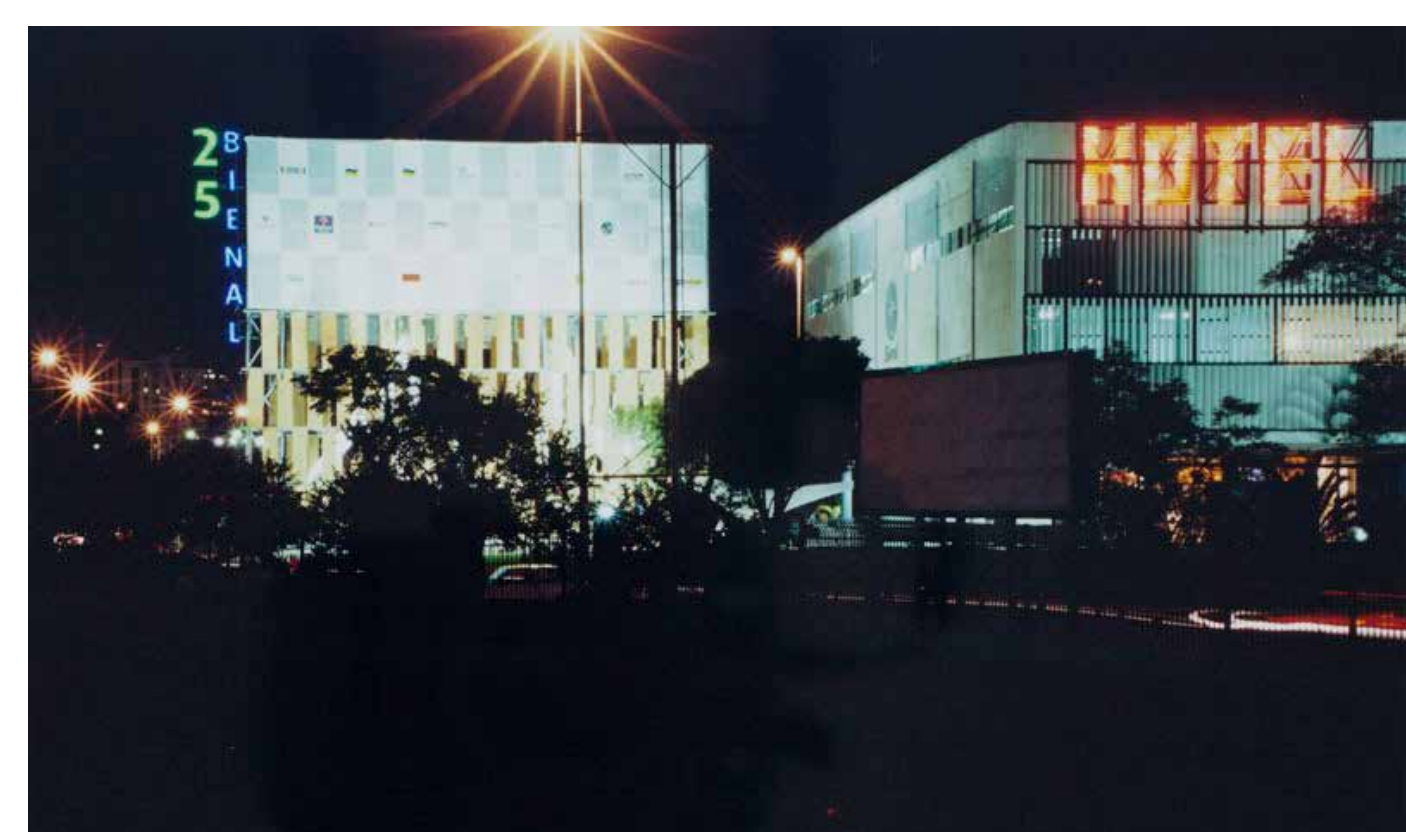

25a. Bienal: vista da obra Hotel das estrelas de Carmela Gross na fachada do Pavilhão. Fonte: site Bienal. Foto: (c) Juan Guerra. Disponível em: https://bienal.org.br. Acesso em: 02 Jan.2019. 


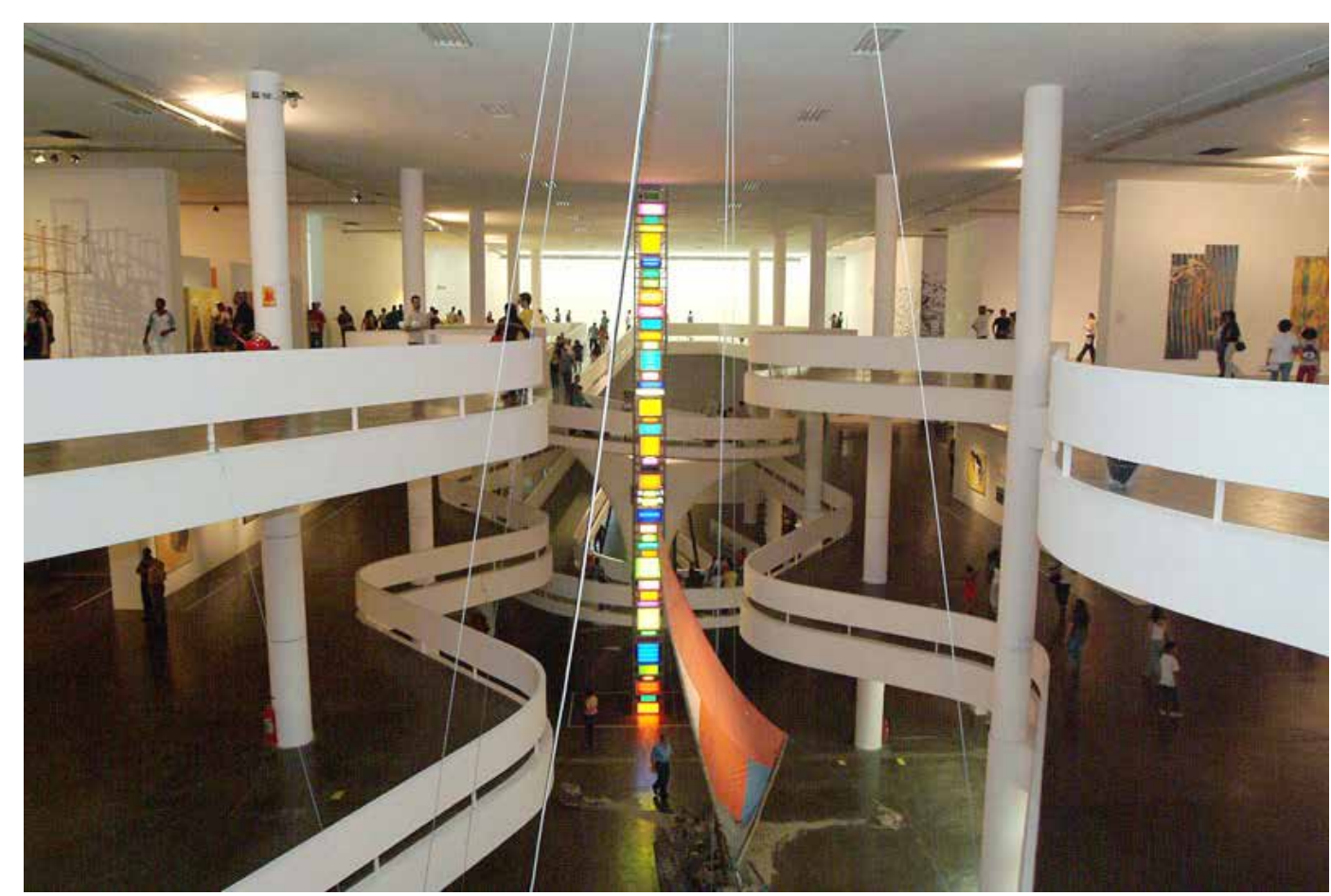

26a. Bienal: Vão central da Bienal com destaque para a obra de David Batchelor Fonte: site Bienal. Foto: (c) Juan Guerra. Disponível em: https://bienal.org.br Acesso em: 02 Jan.2019
O novo presidente da Fundação Bienal, Manoel Pires da Costa, manteve Hug à frente da 26a. Bienal, mas consciente de que precisava fazer uma grande mudança na próxima edição (CYPRIANO, 20I6).

A partir de sua demanda, um grupo de conselheiras ${ }^{32}$ encomendou propostas para a 27a. Bienal para os curadores: Lisette Lagnado, Paulo Venâncio Filho, Ana Maria Belluzzo e Lorenzo Mammì (que declinou ao convite). Para seleção do projeto curatorial foi montada uma comissão internacional com críticos de arte e curadores desvinculados da Fundação Bienal: Paulo Herkenhoff, Aracy Amaral, Manuel Borja-Villel (Macba, Espanha), João Fernandes (Fundação Serralves, Portugal) e Lynn Zelevansky, (Los Angeles County Museum, Estados Unidos) (CYPRIANO, 20I6). O projeto vencedor foi o de Lisette Lagnado, 33 denominado, naquele momento, Blocos sem fronteira.

32 Eleonora Mendes Caldeira, Elizabeth Machado, Evelyn Ioschpe e Maria Ignez Barbosa.

33 Nascida no Congo, Lagnado radicou-se no Brasil em 1974, estudou jornalismo na PUC-SP, e sua primeira curadoria foi em 1993, no MAM, com a exposição Entre o desenho e a escultura, eleita melhor do ano pela APCA. Em sua fase inicial, destaca-se ainda a catalogação da obra de Leonilson (1957-I993), que resultou na mostra São tantas as verdades (1995) junto ao livro homônimo, a primeira monografia de peso sobre o artista. Lagnado também trabalhou na sistematização dos escritos de Hélio Oiticica, que se tornou objeto de sua tese de doutorado. Curadora independente, nunca havia realizado uma Bienal, a não ser uma sala dedicada a Iberê Camargo na II Bienal do Mercosul, em 1999 (CYPRIANO, 2016, p.I60). 


\section{$25^{\circ}$ BIENAL DE SÃO PAUIO}

Salas Especiais Brasil
Cidades
Paises

\section{Térieo}

(1)

(2)

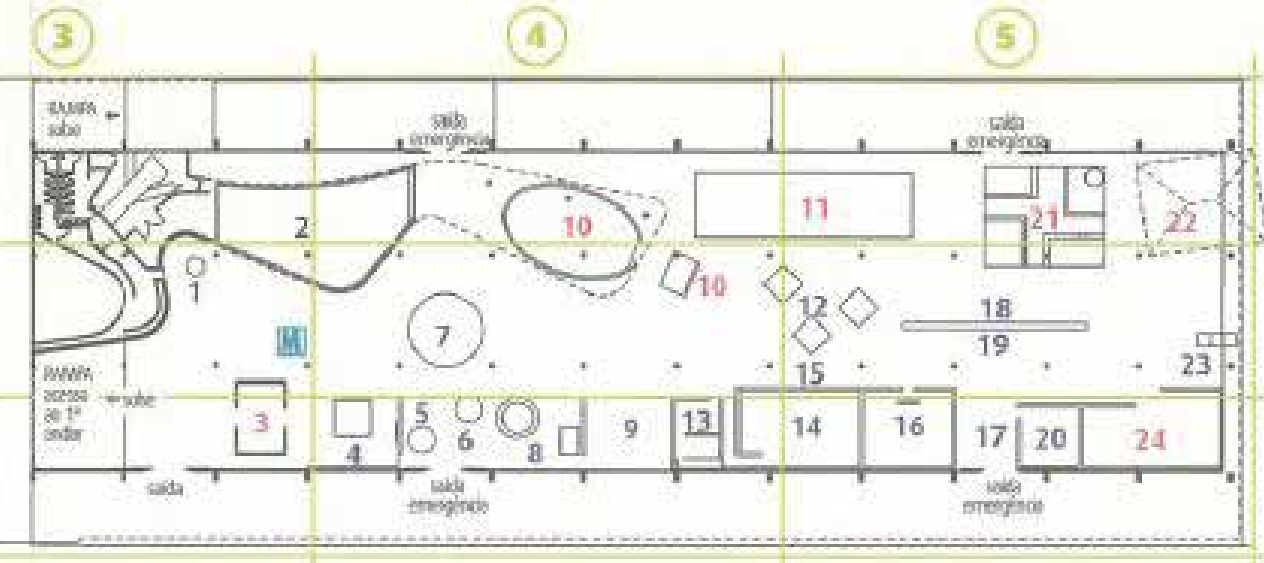

(c)

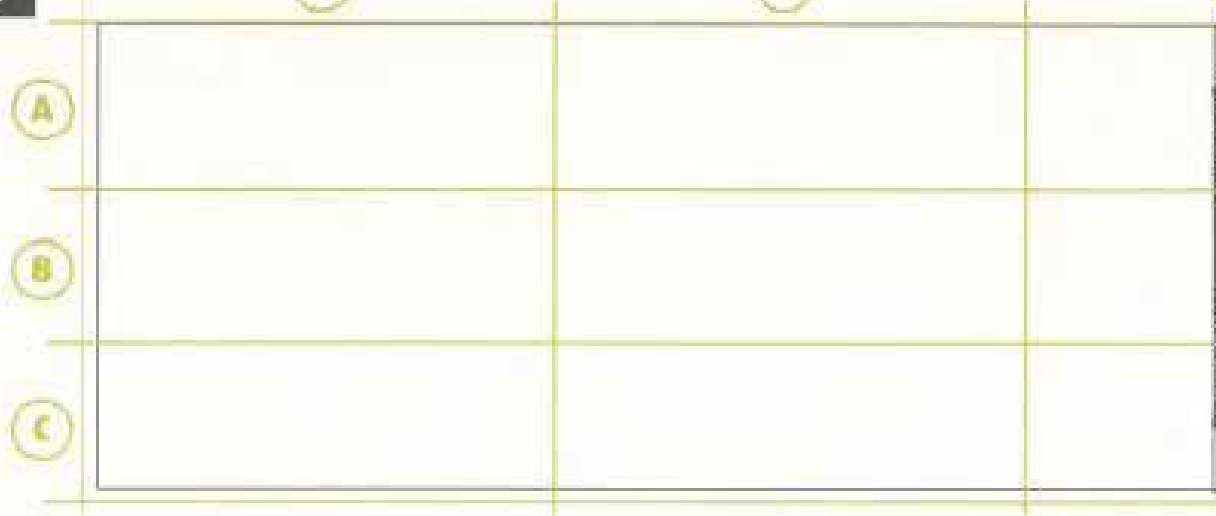

Cidades

Paises Mesa Informativa

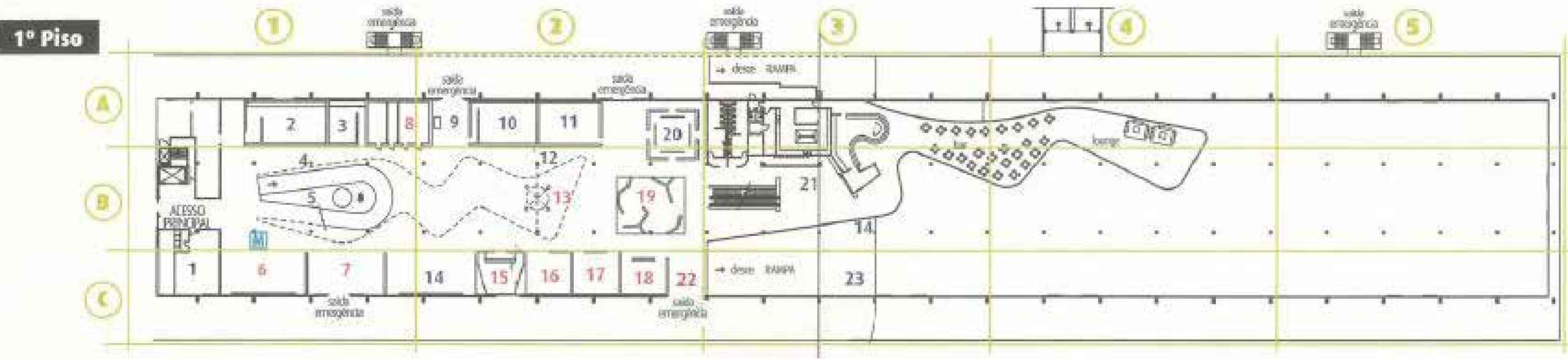




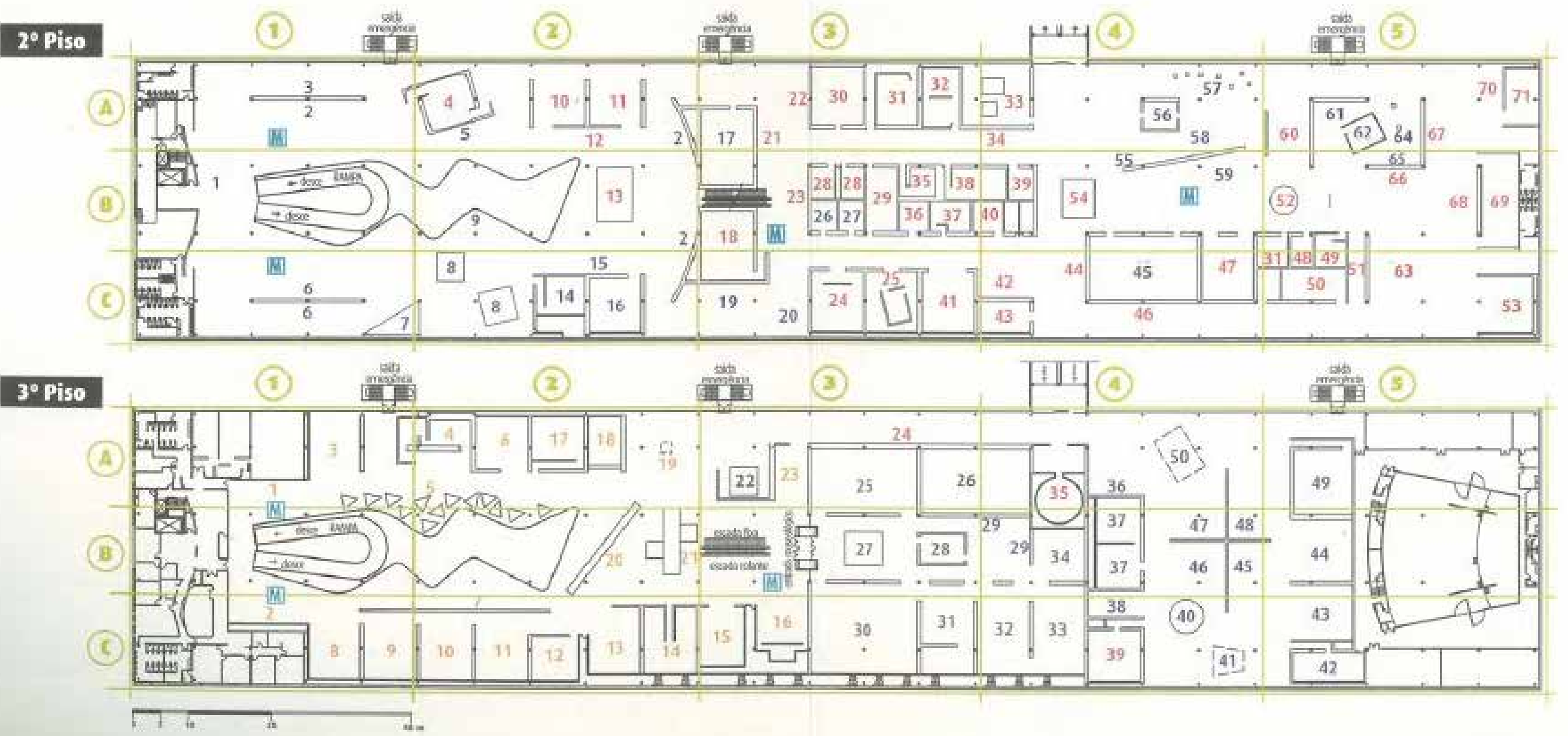




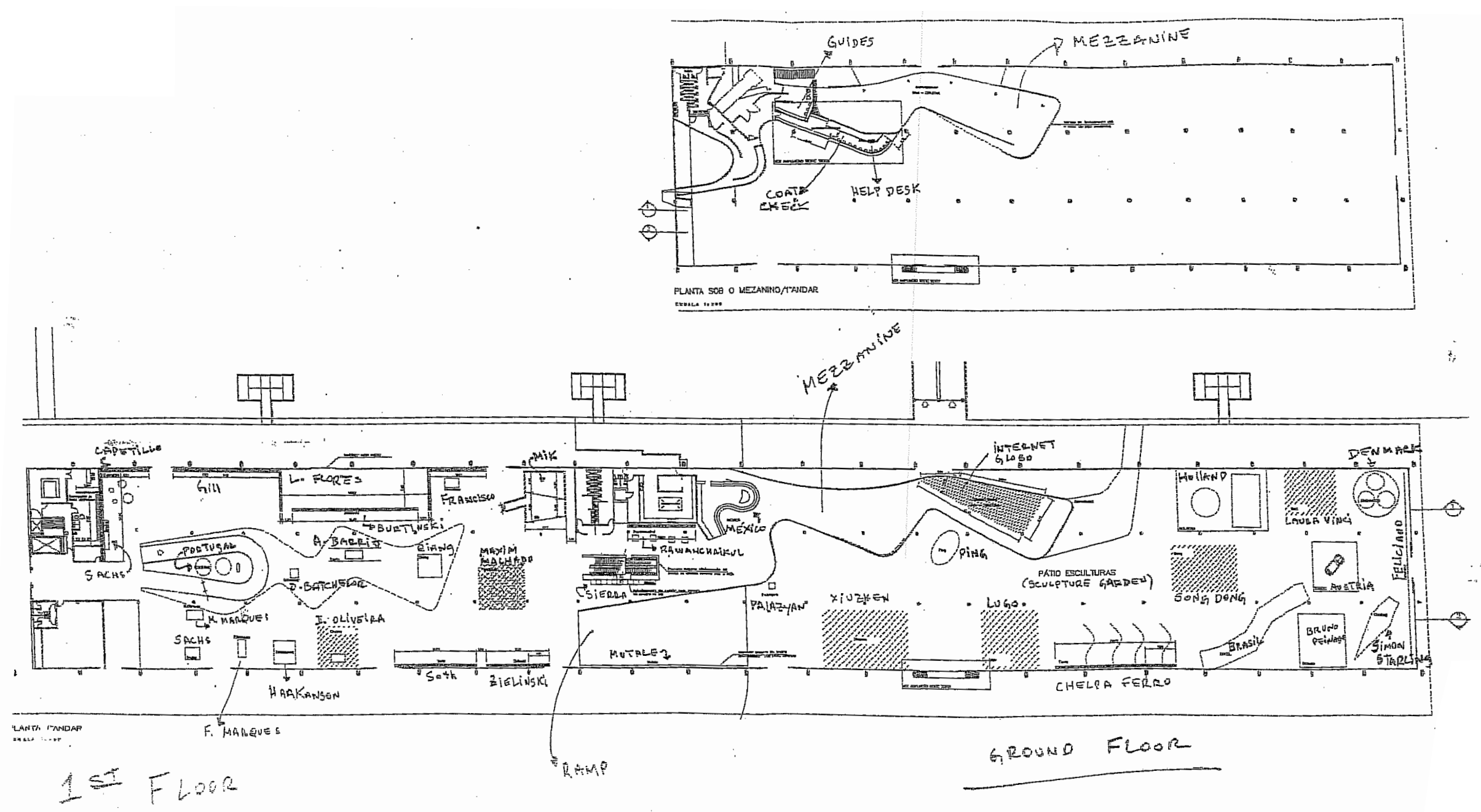




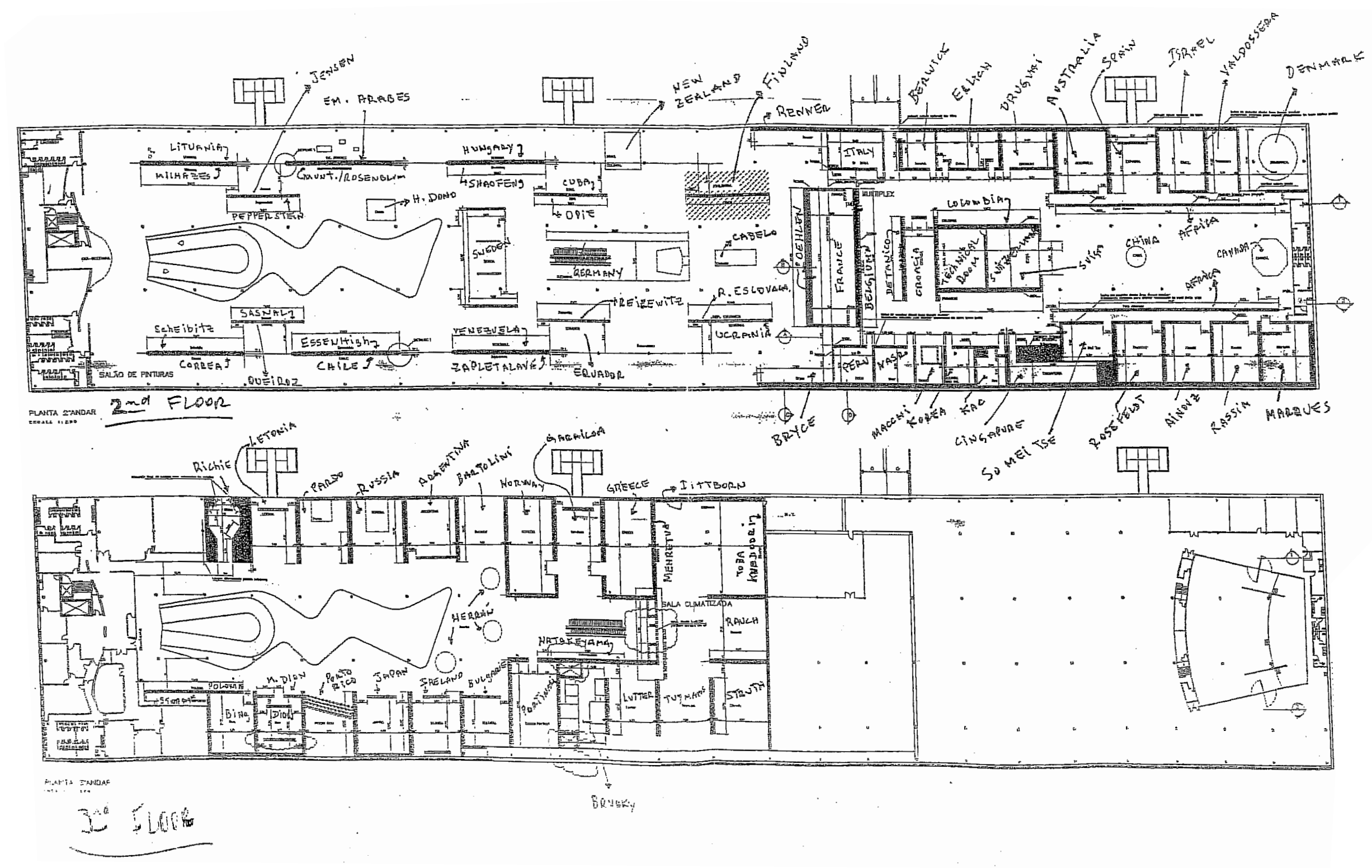


A seleção por projeto deu à curadora legitimidade para criticar a instituição e propor todas as mudanças que levaram à transformação da Bienal. A seleção do curador das Bienais anteriores se dava por meio de indicação do conselho da Bienal e, mesmo com a evidente importância desse processo, o concurso de projetos curatoriais nunca mais foi feito (Idem).

O projeto de Lagnado, posteriormente intitulado Como viver junto, tinha o eixo conceitual estruturado a partir dos textos de Hélio Oiticica e das notas e seminário Como viver junto, de Roland Barthes. (LAGNADO; PEDROSA, 2006). A proposta de abolição ${ }^{34}$ das representações nacionais estava na base conceitual do projeto, transformando a estrutura em vigor. ${ }^{35}$ Lagnado chamou uma equipe de cocuradores para compor uma curadoria coletiva: Adriano Pedrosa ${ }^{36}$, Cristina Freire ${ }^{37}$, Rosa Martínez ${ }^{38}$,

34 Termo utilizado pelos curadores da Bienal, Lisette Lagnado e Adriano Pedrosa, no catálogo da exposição (LAGNADO; PEDROSA, 2006).

35 Conforme aponta Adriano Pedrosa (2006, p.82), cocurador da mostra no catálogo da exposição "as representações nacionais estão relacionadas ao modelo das grandes exposições mundiais ou universais que remontam ao século XIX".

36 Adriano Pedrosa foi curador adjunto e editora das publicações da $24 a$. Bienal, curador do Museu de arte da Pampulha, Belo Horizonte (200I-2003), e do inSite_05, San Diego/Tijuana (2005). (LAGNADO, 2008)

37 Cristina Freire é professora e curadora do Museu de Arte Contemporânea da Universidade de São Paulo (MAC-USP). (LAGNADO, 2008).

38 Rosa Martinez (Sória-Espanha) foi historiadora de arte e curadora do Museu de Arte Moderna de Istambul até 2007. Foi curadora da Manifesta I, em
Cartaz da 27a. Bienal: Como viver junto.

Autoria: Jorge Macchi, Rodrigo Cerviño Lopez.

Fonte: site Bienal. Disponível em: https://

bienal.org.br. Acesso em: 02 Jan.2019.

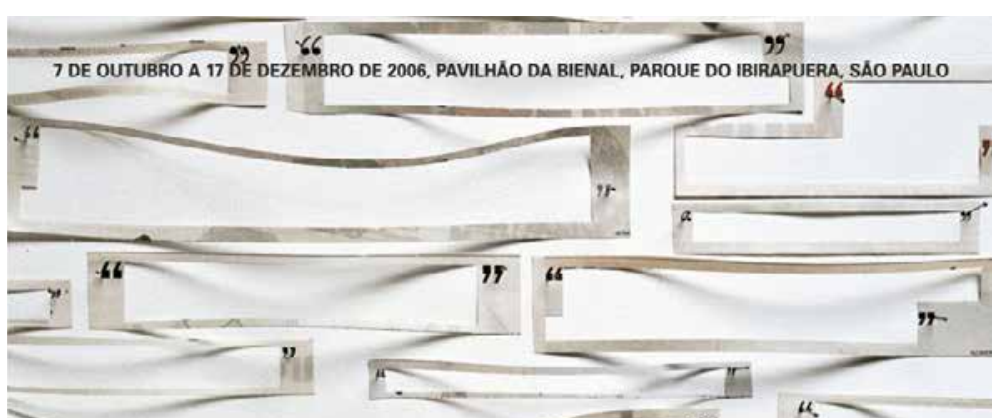

27a. BIENAL DE SÃO PAULO COMO VIVER JUNTO

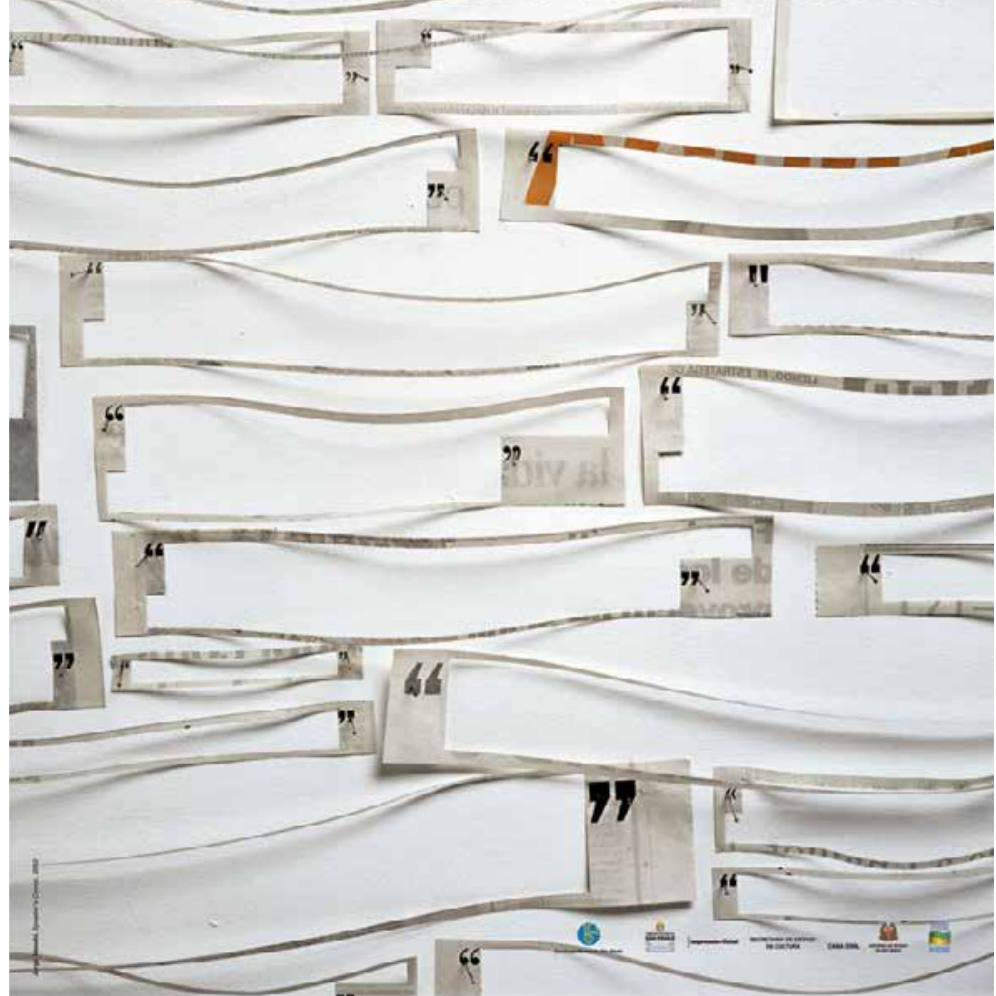


José Roca ${ }^{39}$, e o curador convidado Jochen Volz ${ }^{40}$. Como será discutido no capítulo 2, tal proposta pretendia atualizar da Bienal de São Paulo, reinserindo-a no circuito global das artes por meio de uma aproximação ao modelo intelectual da Documenta de Kassel. O fim das representações nacionais resultou em uma nova maneira de trabalhar para os curadores e passou a ser adotado como modelo para as Bienais subsequentes.

Como se pode verificar a partir desta breve retomada histórica das exposições, foi na ı6a. Bienal que, pela primeira vez, o projeto curatorial se sobrepôs à lógica compartimentada das representações nacionais. Neste momento houve uma grande transformação do caráter da mostra, que deixou de seguir o modelo das feiras internacionais e passou a construir

Roterdã (I996), da 5a. Bienal de Istambul (I997), da 3a. Bienal de Santa Fé (1999), e da ia. Bienal de Moscou. (LAGNADO, 2008).

39 José Roca (Bogotá-Colômbia) Foi responsável pelas exposições temnporárias da Biblioteca Luis Ángel Arango, em Bogotá. Foi co-curador da Trienal Poli/Gráfica de San Juan em Porto Rico (2004)

40 Jochen Volz (Braunschweig- Alemanha) foi curador do Portikus, em Frankfurt(200I-2004), foi curador do Centro de Arte Contemporânea de Inhotim(2005-20I2), Brumadinho, Minas Gerais. (LAGNADO, 2008). um discurso próprio. Esta mudança foi essencial para que a espacialidade da exposição ganhasse qualidade e novas camadas, deixando de ser um projeto de sistema construtivo e setorização. O projeto expográfico constrói a espacialização da narrativa curatorial, relações entre obras, e entre a arquitetura provisória e existente.

As Bienais com propostas curatoriais estruturadas que tiveram projetos expográficos de grande qualidade são os exemplos paradigmáticos da i8a., 23a. e 24a. Bienal. Não por coincidência as mesmas procuraram desfazer, cada uma dentro das suas limitações, a divisão geopolítica das representações nacionais.

Nas edições que mantiveram a setorização por nação, o projeto museográfico ou expográfico ${ }^{41}$ ficou limitado à organização e dimensionamento de salas no espaço e layout de obras dentro delas. Portanto, a desvinculação do modelo de Veneza teve um impacto positivo nas expografias das mostras subsequentes à 27a. Bienal. Abriu-se um caminho de construção do discurso curatorial no espaço, estabelecendo uma relação interdisciplinar entre curadoria, arquitetura e artistas que foi adotado nas mostras sequentes como um novo modelo.

4I A palavra expografia passa a ser utilizada nas fichas técnicas da Bienal a partir da 27a. Bienal. 


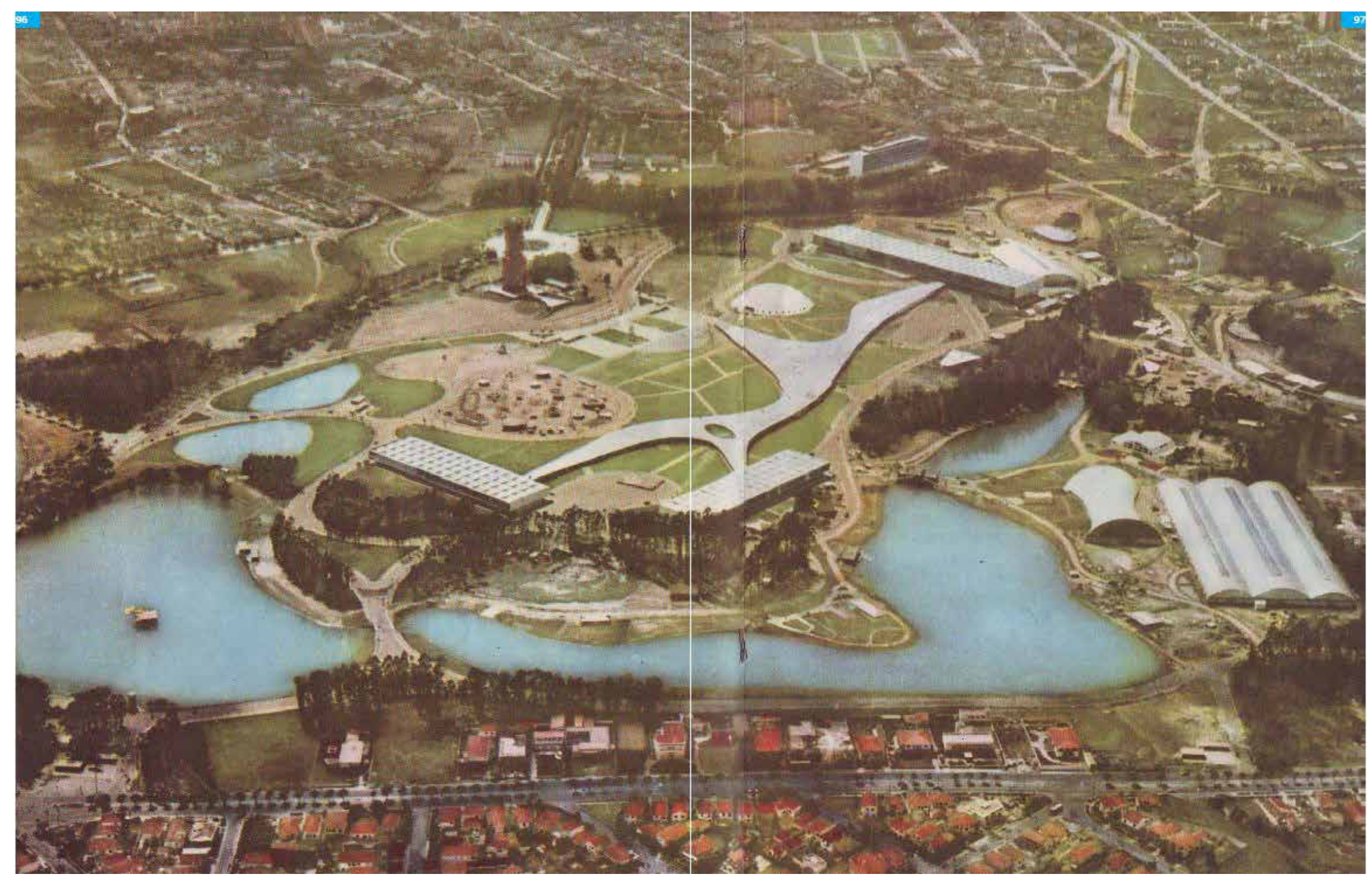

Imagem aérea do parque Ibirapuera durante do IV Centenário. Fonte MANCHETE, IV Centenário de São Paulo.

Rio de Janeiro, n. especial, 1954. Sem numeração. Foto: autor desconhecido. 


\subsubsection{De Pavilhão das Indústrias a Pavilhão Ciccillo Matarazzo}

O Pavilhão das Indústrias, ${ }^{42}$ projeto de Oscar Niemeyer e equipe, ${ }^{43}$ construído para as comemorações do IV centenário de São Paulo, é o maior edifício do conjunto do Ibirapuera e se conecta à marquise em sua extremidade sul. Mede em planta $250 \times 50$ metros e se divide nominalmente em cinco pavimentos: Térreo com pé direito duplo (7,40 metros), que tem continuidade através de uma rampa com o primeiro pavimento e com mezanino ${ }^{44}$ (pé direito de 3,95 metros); o segundo e terceiro pavimentos são duas imensas plantas livres (pé direito de 4,95 metros) e o subsolo é um auditório.

O edifício possui estrutura independente de concreto protendido ${ }^{45}$ com laje com caixão perdido e pilares com modu-

42 O nome oficial era Pavilhão das Indústrias teve seu nome alterado para Pavilhão Ciccillo Matarazzo após a sua morte em 1977.

43 Zenon Lotufo, Hélio Uchôa e Eduardo Kneese de Mello.

44 O mezanino está no mesmo nível do primeiro pavimento e avança sobre a área de pé direito duplo do térreo.

45 Sistema que aumenta o desempenho do concreto para vencer vãos de dimensões maiores. lação de dez metros no sentido longitudinal e doze metros no transversal. No térreo e primeiro pavimento há um balanço de sete metros, formando uma grande marquise contínua nas faces norte e sul do edifício - longitudinais. Nessas fachadas, os vedos são grandes cortinas de vidros com caixilhos de ferro. A fachada norte, que tem incidência solar constante, é protegida com brise vertical móvel. Nas fachadas leste e oeste, onde estão localizados os banheiros e serviços nos segundo e terceiro pavimentos, os vedos são de alvenaria com pequenas aberturas.

A rígida grelha estrutural e o prisma do volume do edifício contrastam com a qualidade de seu espaço interno. O mezanino, que avança no térreo, o vazio interno que conecta os três pavimentos, e sua rampa, que possui desenho sinuoso, dão ao edifício um caráter monumental. Soma-se a esses elementos sinuosos as diferenças de pé direito e relação com o exterior. O resultado são espaços com qualidades muito distintas, que tornam o edifício surpreendente. 
Segundo a revista Acrópole, ${ }^{46}$ foi utilizada a mais alta tecnologia disponível na época para construção do conjunto. ${ }^{47} \mathrm{~A}$ matéria apresenta detalhes dos reforços e soluções estruturais utilizados, inclusive com foto das ferragens; descreve a dificuldade de execução da cobertura em alumínio com baixa declividade e indica que este pavilhão é o único do conjunto do parque que tem elevador, um imenso monta-carga e ainda recebeu escadas rolantes para atender ao grande fluxo de público.

$\mathrm{O}$ projeto do Pavilhão das Indústrias, publicado nas revistas Módulo n.66, Acrópole, Revista Brasil Arquitetura Contemporânea e no livro Arquitetura Moderna do Brasil, de Henrique Mindlin, entre outras publicações da época, mostra que metade do pavimento térreo (seis módulos estruturais) seriam uma grande área de pilotis aberta, com o trecho que corresponde ao mezanino (também seis módulos estruturais) fechado com caixilhos. As portas de acesso ficariam no eixo de acesso da marquise e no centro dos pilotis, que funcionaria como uma grande área de acolhimento ou foyer. O projeto

46 "Este esbelto pavilhão levantado no parque de Ibirapuera, no recinto destinado as comemorações do IV centenário de São Paulo será destinado a exposição permanente das industrias nacionais. Excelente em suas linhas arquitetônicas, constitui mais uma expressão da magnifica e moderna arquitetura brasileira. Em sua construção foram empregados todos os métodos modernos da engenharia brasileira, tanto manuais como mecanizados, e graças a estes métodos e ao programa aplicado pelos construtores foi possível apresentar ao público, apesar do curto prazo disponível para uma obra desta categoria” (Acrópole, n.193· P.54).

47 O cálculo estrutural foi feito pelo engenheiro Joaquim Cardozo.

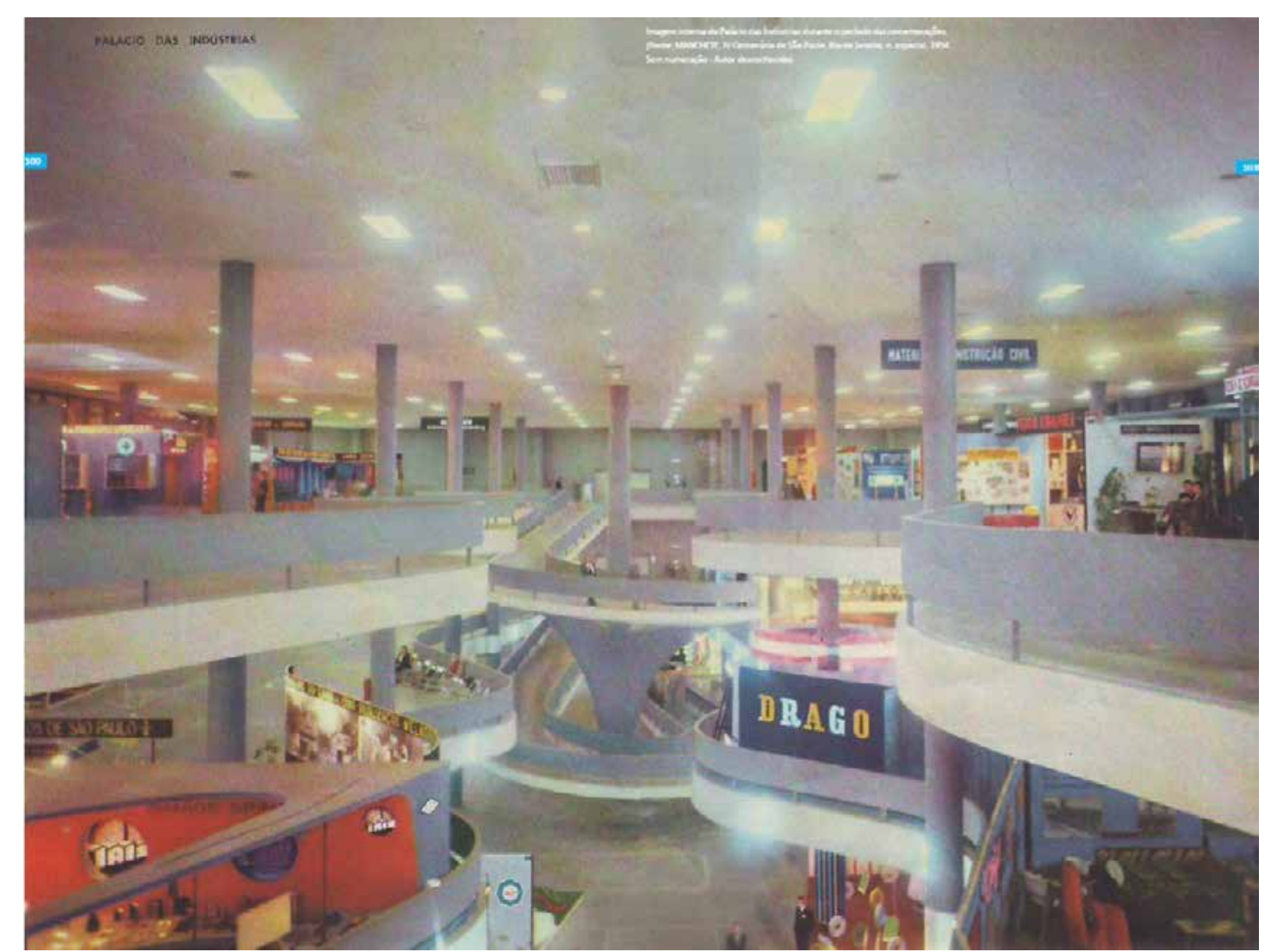

Palácio das industrias no período das comemorações do IV Centenário. Fonte: MANCHETE, IV Centenário de São Paulo. Rio de Janeiro, n. especial, 1954. Sem numeração. Autor desconhecido. 

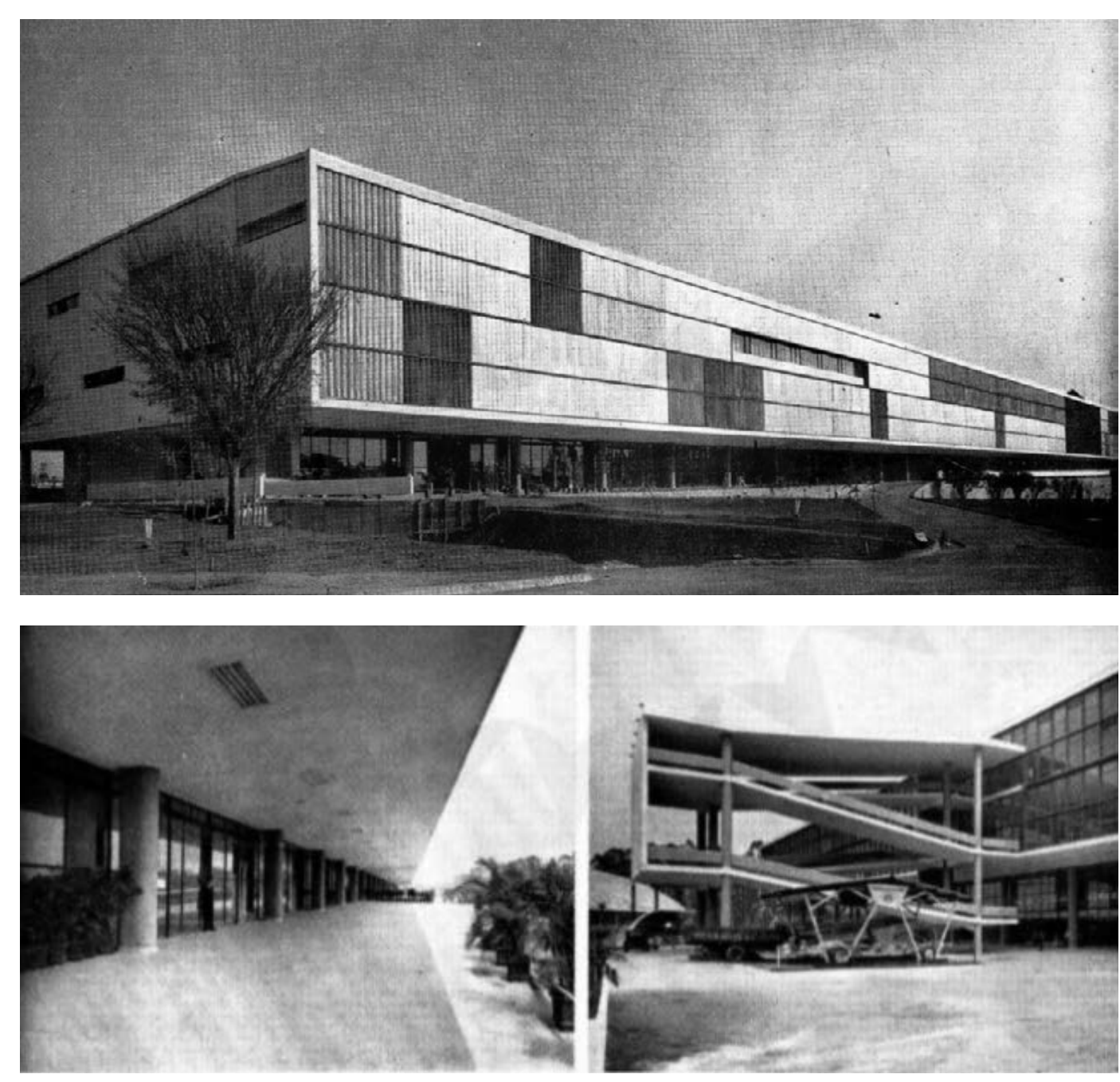

[no topo] Vista da fachada norte do Pavilhão das Indústrias em 1954. Acrópole, ano 16, n.193, 1954, p.53.

Fonte: http://www.acropole.fau.usp.br/edicao/193

[embaixo] Vista do balanço fachada norte e fachada sul e rampas externas do Pavilhão das Indústrias, 1954. Acrópole, ano 16, n.193 1954, p.53. Fonte: http://www.acropole.fau.usp.br/edicao/193 do pavilhão foi alterado durante a construção e toda a área do térreo foi fechada com caixilhos. Outra mudança que se pode observar é a ausência do vazio que conectava visualmente o fundo do segundo com o terceiro pavimento.

O conteúdo da revista Módulo descreve e critica as alterações sempre no sentido de aumentar área útil, em detrimento da qualidade dos espaços, nos projetos dos pavilhões (fato que não ocorreu apenas no Oavilhão das Indústrias):

Também nos Pavilhões se pode observar outro detalhe demonstrativo da incompreensão dos que fizeram responsáveis pela construção do Parque Ibirapuera. Ali, igualmente, havia sido projetados espaços abertos, na parte inferior, para livre circulação dos visitantes - e sempre com o objetivo de proporcionar-lhes maior amplitude de perspectiva. Sob a alegação de necessidade de aproveitamento de espaço, baixaram-se os vidros-que só deveriam cobrir a parte superior da construção. Em favor do utilitarismo que não se justifica, mutilaram também esses prédios (Módulo n.66, p.20).

O fechamento do pavimento térreo com caixilhos transformou a volumetria projetada, que no projeto possuía a leveza de prima apoiado sobre pilotis e transformou-se um volume que chega ao piso. Para além da questão formal, pode-se 

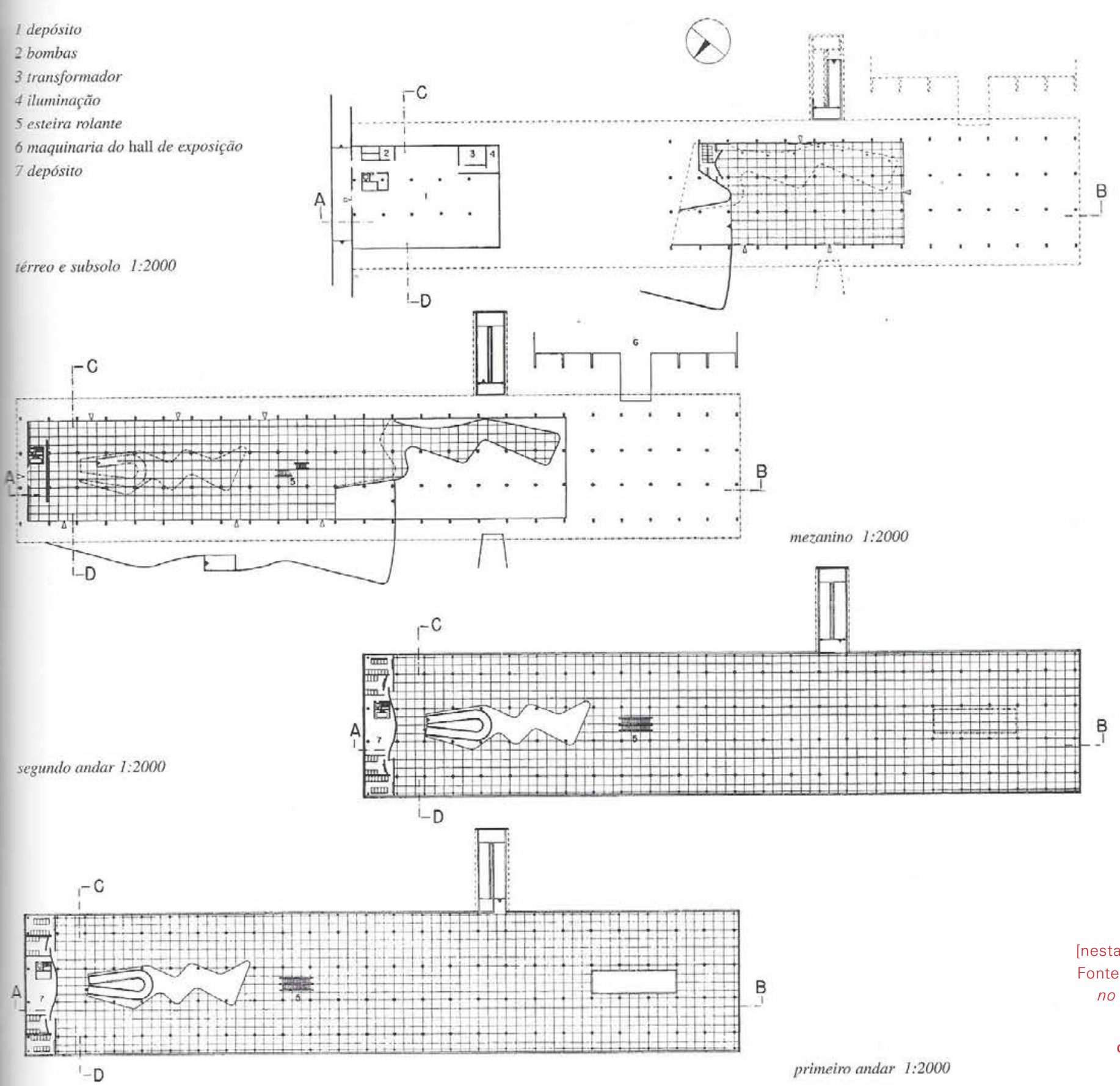
no Brasil, p.186. Colibris. Rio de Janeiro, 1956.

[pág. ao lado] Plantas atuais e originais da construção do Pavilhão Ciccillo Matarazzo. Fonte: acervo da autora. 


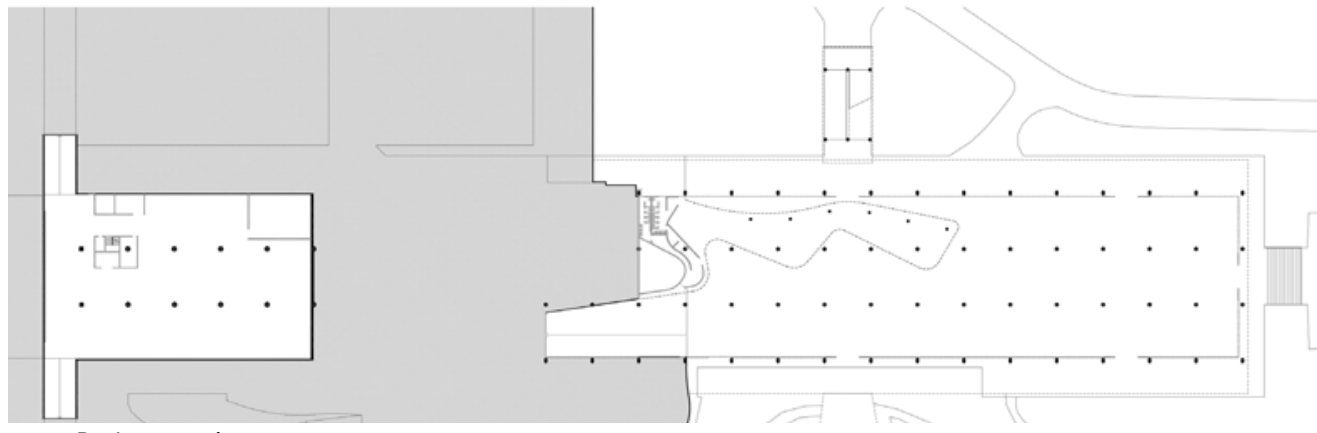

Pavimento térreo

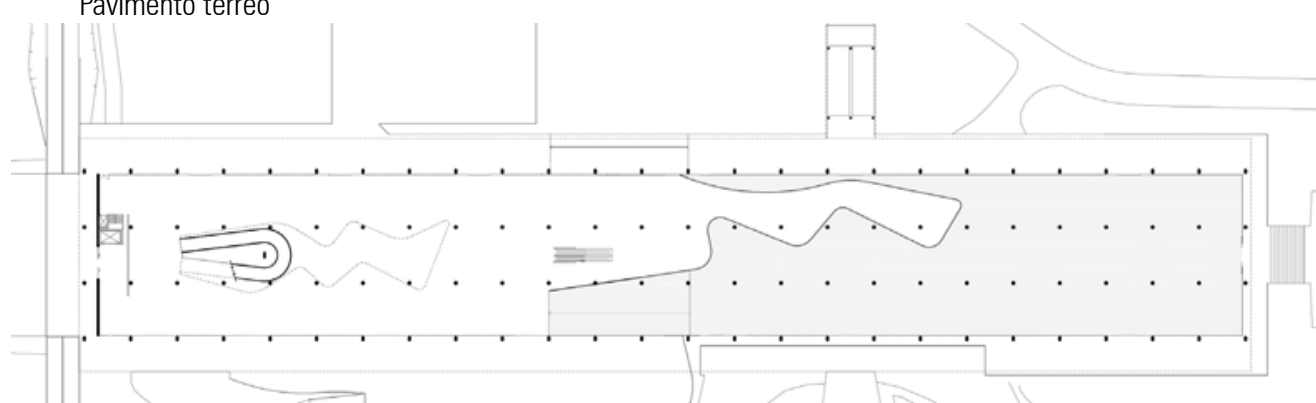

Primeiro pavimento
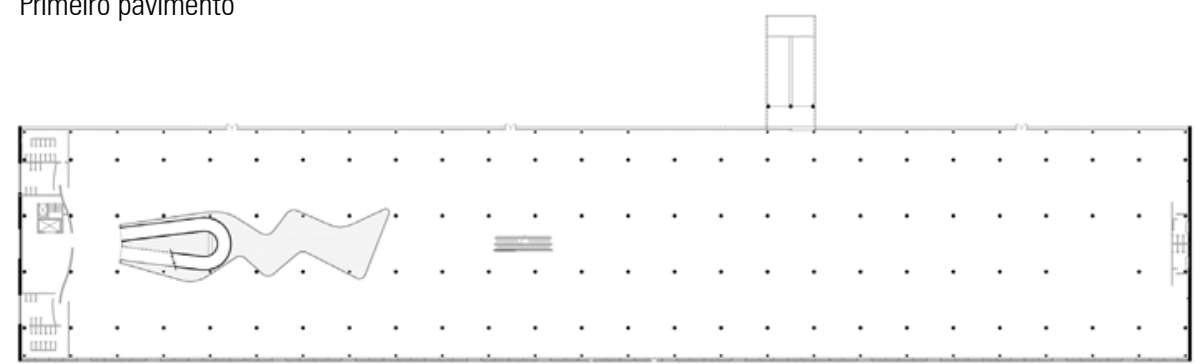

Segundo pavimento

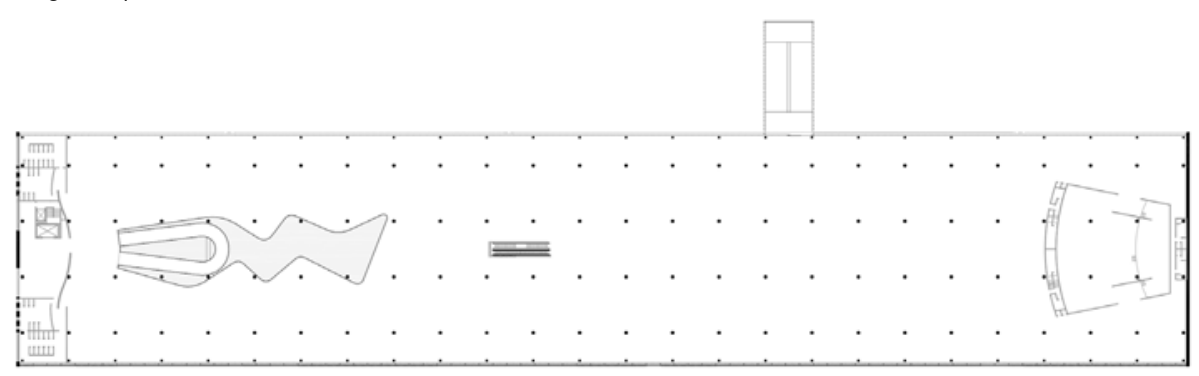

Terceiro pavimento

$\stackrel{5}{5}^{10} \underbrace{20}$

Plantas originais de construção do Pavilhão Ciccillo Matarazzo

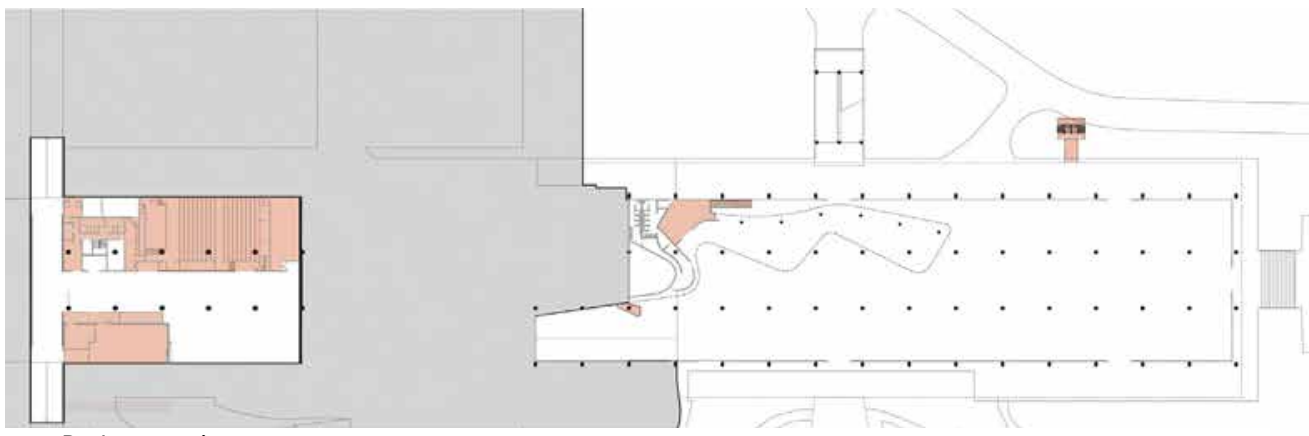

Pavimento térreo

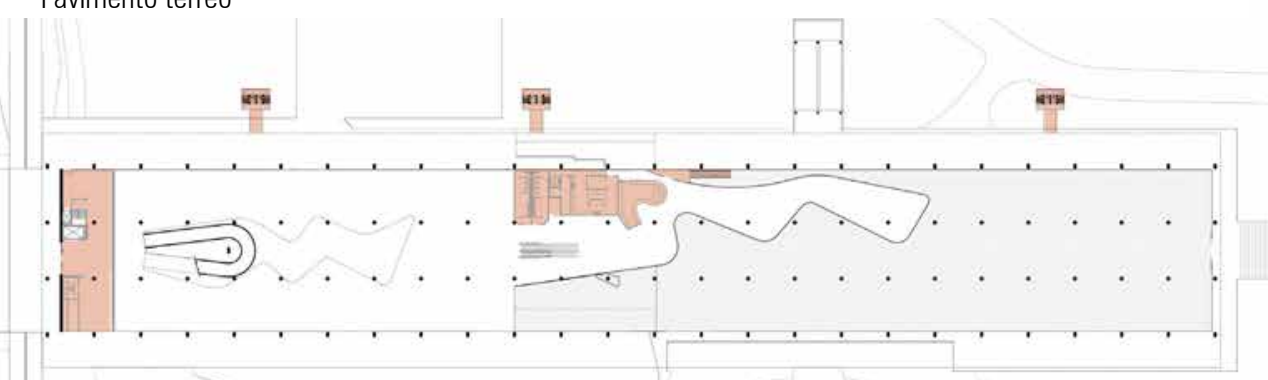

Primeiro pavimento

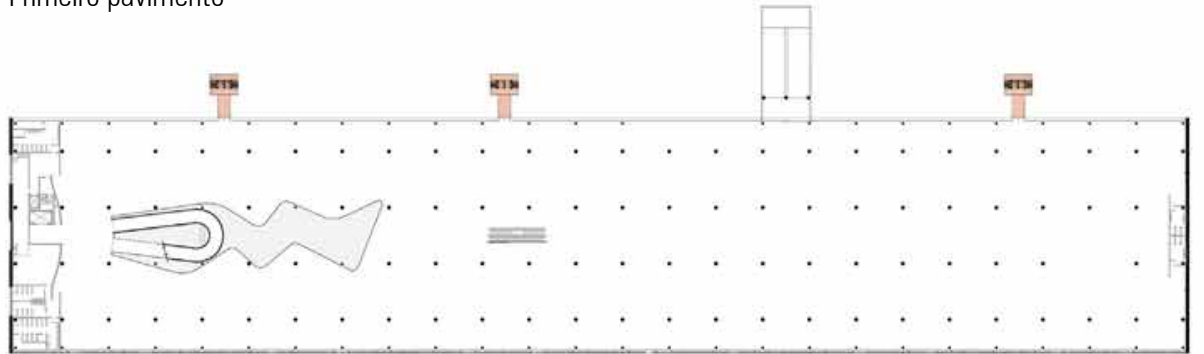

Segundo pavimento

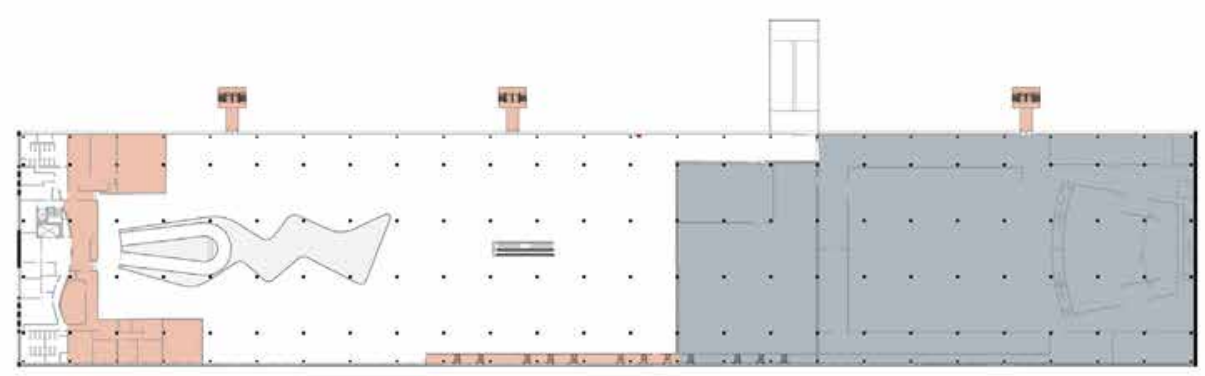

Terceiro pavimento

$\square$ áreas administrativas e serviços ocupadas pela Fundação Bienal a partir de1967 $\square$ áreas do MAC-USP desde de 1965

Plantas atuais do Pavilhão Ciccillo Matarazzo 
dizer que o pavilhão ganhou um grande salão de pé direito duplo, mas a solução gerou um problema na circulação. $O$ grande fluxo de público que vem pela marquise fez com que o principal acesso se mantivesse ali no meio do pavimento, o que antes teria um caráter de foyer se tornou área expositiva. Em um edifício que se caracteriza pelo seu grande comprimento longitudinal e cujo programa é expositivo, a circulação se divide logo na entrada gerando um problema: para direita o salão do térreo e para esquerda os demais pavimentos.

A circulação vertical de público no pavilhão se dá por três pontos: a rampa monumental do vão próxima à fachada oeste do edifício, uma escada rolante que fica quase no centro, ao lado do vazio, e as rampas externas que ficam no eixo da marquise e que atendem a parte leste do prédio.

A rampa monumental, mais do que circulação, é um elemento essencial na leitura do edifício. Suas curvas contrastam como rigor do edifício e reafirmam a linguagem de Niemeyer. O vão no qual ela se insere cria um espaço vertical que rompe com o sentido longitudinal, reforçado pelo imenso comprimento do pavilhão. As rampas são sem dúvida a principal circulação do pavilhão, tornando a circulação vertical em um percurso onde se desvela todo o espaço, de onde se pode ver todos os pavimentos. As escadas rolantes, que tem sentido oposto ao das rampas, faz uma conexão rápida entre os pavimentos.

\subsubsection{O Pavilhão hoje}

O Pavilhão da Bienal de São Paulo é indissociável da mostra, sua imagem é a principal referência da Bienal. A arte e a Bienal se transformaram muito ao longo de mais de seis décadas e as 29 Bienais que ocorreram no Pavilhão, desde de 1957 , evidenciam a sua grande flexibilidade. O edifício possui características que conferem aptidão para receber diferentes tipos de expressão artística: a planta livre com estrutura independente, as grandes lajes e vãos entre pilares, as diferenças de pé-direito que criam volumetrias muito diversas, o vazio monumental da rampa. Fica a cargo dos projetos expográficos construir os sistemas expositivos para receber essas diferentes expressões de arte e estabelecer diálogo com o pavilhão, que tem sempre uma presença muito forte nas exposições.

O pavilhão que nos anos 1950 havia sido superdimensionado em sua infraestrutura, hoje está aquém das exigências técnicas para uma exposição de arte contemporânea de grande escala: não possui climatização (há uma grande amplitude térmica dentro do edifício), não há controle de luminosidade, o caixilho de ferro não é estanque, as lajes vibram muito, não há um sistema elétrico que atenda a grande demanda das obras, não há uma sistema estrutural auxiliar para fixação das obras e equipamentos, há problemas com o atendimento de acessibilidade universal. 
O edifício passou por uma série de adaptações ao longo das décadas e todas foram tratadas de forma isolada como se fossem independentes. As intervenções acabaram causando grande impacto: as instalações elétricas em eletrocalhas no forro criaram uma rede que interfere na leitura contínua do forro, prumadas de circulação vertical e novas saídas de emergência que criaram uma grande interferência na fachada sul e instalação de hidrantes para atender às normas dos bombeiros. ${ }^{4}$ Parte do terceiro pavimento recebeu a instalação de ar condicionado para viabilizar o recebimento de obras de arte com exigências de conservação. As máquinas foram instaladas junto à fachada norte, criando uma grande área técnica fechada por painéis piso-teto que bloqueiam os caixilhos.

Além disso, a área ocupada pela Fundação Bienal e a instalação do Arquivo Histórico Wanda Svevo ${ }^{49}$ também cresceu. A partir da i6a. Bienal, já se pode observar a grande

48 Essas escadas foram construídas de forma provisória, com andaimes e permanecem ali.

49 "Concebido em 1955 por Wanda Svevo, então Secretária Geral do MAM-SP, para dar apoio à realização das Bienais, o Arquivo Bienal partiu da missão de se tornar um centro de referência em arte no século 20. Tombado em I993 pelo Condephaat como bem cultural de interesse histórico, devido ao conteúdo de seu acervo, o arquivo está operando pelo tratamento integrado de sua documentação. Os critérios adotados para sua organização têm como fundamento a história da Fundação Bienal de São Paulo e dos eventos realizados por ela, destacando sua origem, processo de produção e as atividades que exerce" (Disponível em: <http://www.bienal.org.br/arquivo>. Acessado em: I fev. 20I9. área ocupada por setores administrativos no terceiro pavimento, que foi crescendo pouco a pouco contornando a área ao lado do vão da rampa e interferindo em uma das principais características do pavilhão, que é a relação visual do vão com a transparência do parque. O segundo pavimento foi o único a ser mantido em sua amplitude, sem o fechamento com áreas administrativas ou serviços.

O edifício está tombado por órgãos públicos de preservação de patrimônio cultural, ${ }^{\circ}$ no entanto nunca foi pensado um projeto global de restauro e conservação, e as intervenções tem caráter provisório e precário. ${ }^{\text {I }}$

Para cada exposição, além do sistema expositivo, toda a infraestrutura de suporte é construída com caráter provisório: são aplicados películas nos vidros, instaladas cortinas, passa-se uma rede elétrica paralela, toda a rede para iluminação é refeita para receber um projeto luminotécnico específico, ${ }^{52}$ são montadas estruturas auxiliares para o suporte das instalações de arte. ${ }^{33}$

50 CONDEPHAAT Resolução I de 25/0I/1992 — Tombamento junto com o conjunto de edifícios do Parque Ibirapuera, que foi também tombado pelo IPHAN em 2018.

5I Houve um projeto de ampliação feito por Oscar Niemeyer em 1994 que não foi aprovado pelo CONDEPHAAT e, consequentemente, abandonado.

52 As luminárias existentes não atendem às demandas contemporâneas.

53 A Fundação Bienal não permite que nada seja fixado diretamente nas lajes ou pilares, as estruturas auxiliares são fixadas dentro do caixão perdido da laje com a retirada das caixas de luminárias embutidas. 
Além do uso para a exposição da Bienal, que ocorre por três meses a cada dois anos, o pavilhão é alugado sistematicamente para receber as mais diversas feiras e eventos, e cada um deles ${ }^{54}$ traz consigo toda a infraestrutura necessária. Fica evidente a necessidade de que se pense em um projeto de restauro, modernização e de infraestrutura para exposições que diminua o investimento de instalações provisórias.

54 Eventos como: Fashion Week; feiras de educação; SP-Arte; Era dos Games; Wine Weekend; Travelweek São Paulo etc. 


\subsection{LEITURAS DO PAVILHÃO A PARTIR DAS BIENAIS APÓS 2006}

As Bienais de São Paulo sempre tiveram interlocução com projetos de arquitetura, desde sua primeira edição em que se construiu um pavilhão temporário. Após a mudança para o Pavilhão das Indústrias, a possibilidade de intervenção nessa obra singular de Oscar Niemeyer trouxe aos arquitetos das Bienais um grande desafio. Como dialogar com este edifício que é uma obra de referência e se impõe de forma contundente?

As mudanças estruturais da Bienal, que foi progressivamente se afastando do modelo de Veneza e suas representações nacionais a partir de I98I, e a transformação do papel do curador, que passa a atuar no campo prático da crítica, ${ }^{55}$ propondo plataformas discursivas, levaram ao aumento de complexidade dos projetos das Bienais, tanto do ponto de vista curatorial como do expográfico. A análise que se segue aborda uma seleção de expografias que estabeleceram diálogos com a arquitetura do pavilhão após a consolidação deste novo modelo de mostra a partir de $2006 .^{56}$

55 LAGNADO, Lisette. Marcelina I.p.I2

56 A 24a. Bienal apesar de não ter transformado formalmente a estrutura da Fundação Bienal, possuía um modelo de curadoria que trabalha com conceito
A análise da 27a. Bienal será aprofundada no capítulo 3 desse trabalho, mas cabe aqui lançar luz sobre o acesso dessa exposição que reverberou para as mostras que se sucederam. A arquiteta Marta Bogéa, ${ }^{7}$ responsável pelo projeto da 27 a. Bienal, propôs pela primeira vez o acesso da exposição por uma praça de acolhimento na extremidade oeste do pavilhão. As diferentes possibilidades de acesso e circulação haviam sido exploradas nas mostras anteriores: acesso pela marquise, pela praça das bandeiras (primeiro pavimento), pela fachada oeste (frente para avenida Pedro Álvares Cabral), fachada leste e também pela rampa externa, proporcionando uma entrada pelo terceiro pavimento. A proposta de Bogéa surgiu a partir da análise da circulação do pavilhão, quando se constatou que havia uma contradição no acesso usual pela marquise, que cindia o edifício. Essa leitura foi confirmada após uma pesquisa acerca do projeto original do pavilhão, que previa no térreo uma área de pilotis. Esse acesso conferiu ao público

e sem representações nacionais, mas foi um caso isolado. A 25a. e 26a. Bienal voltaram a divisão geopolítica.

57 Marta Bogéa é arquiteta e foi autora do Projeto da 27a. e da 29a. Bienal. Hoje é professora do departamento de projeto na FAU-USP. 


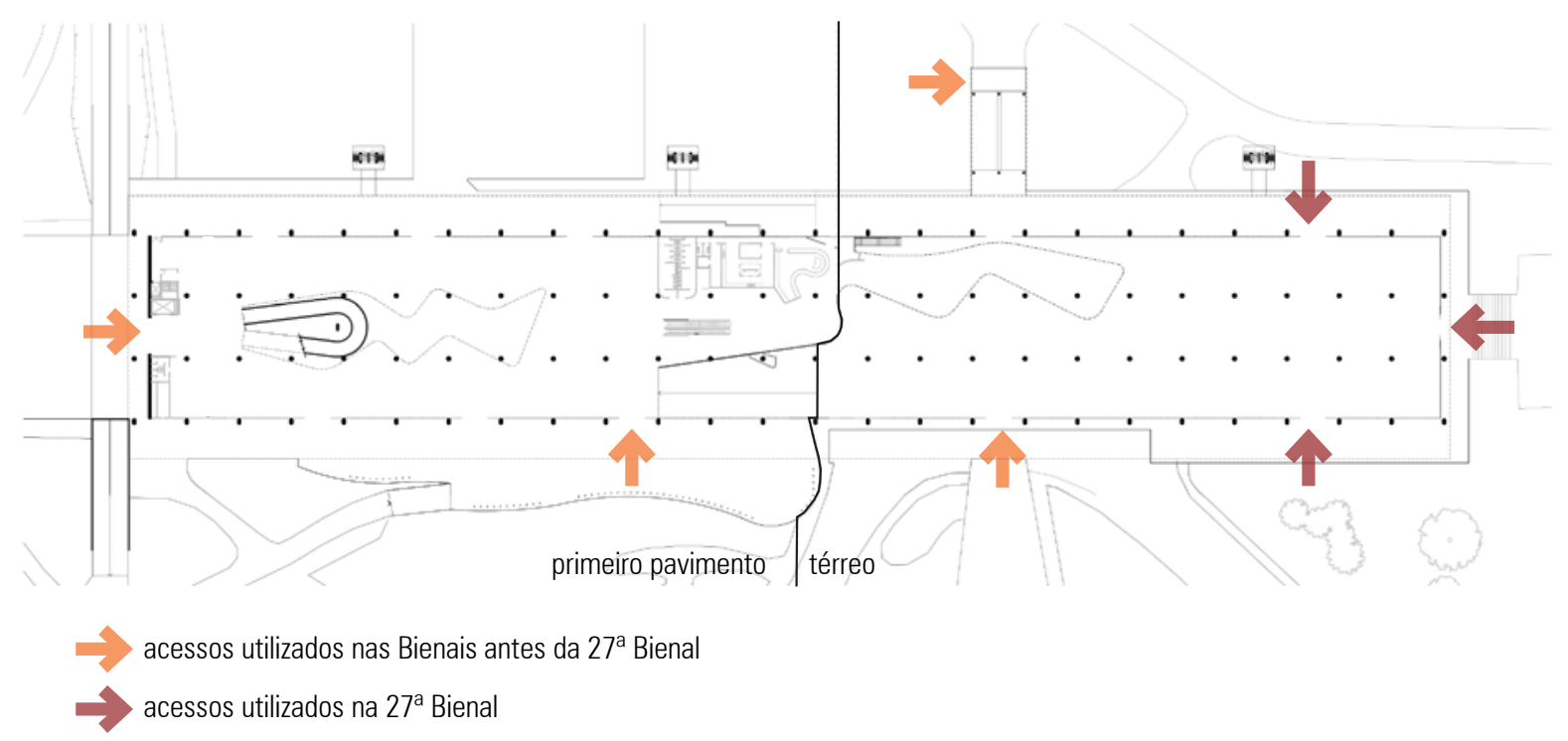

Esquema com indicação de acessos de público adotados das Bienais 
[embaixo à esquerda] Vista externa da cabeceira oeste do Pavilhão.

Fonte: Archdaily Foto: Pedro Kok. Disponível em: https://archdaily.com.br. Acesso em: 02 Jan.2019

[embaixo à direita] Vista da continuidad longitudinal do pavimento térreo. Fonte: acervo da autora. Foto: Maria Julia Herklotz.
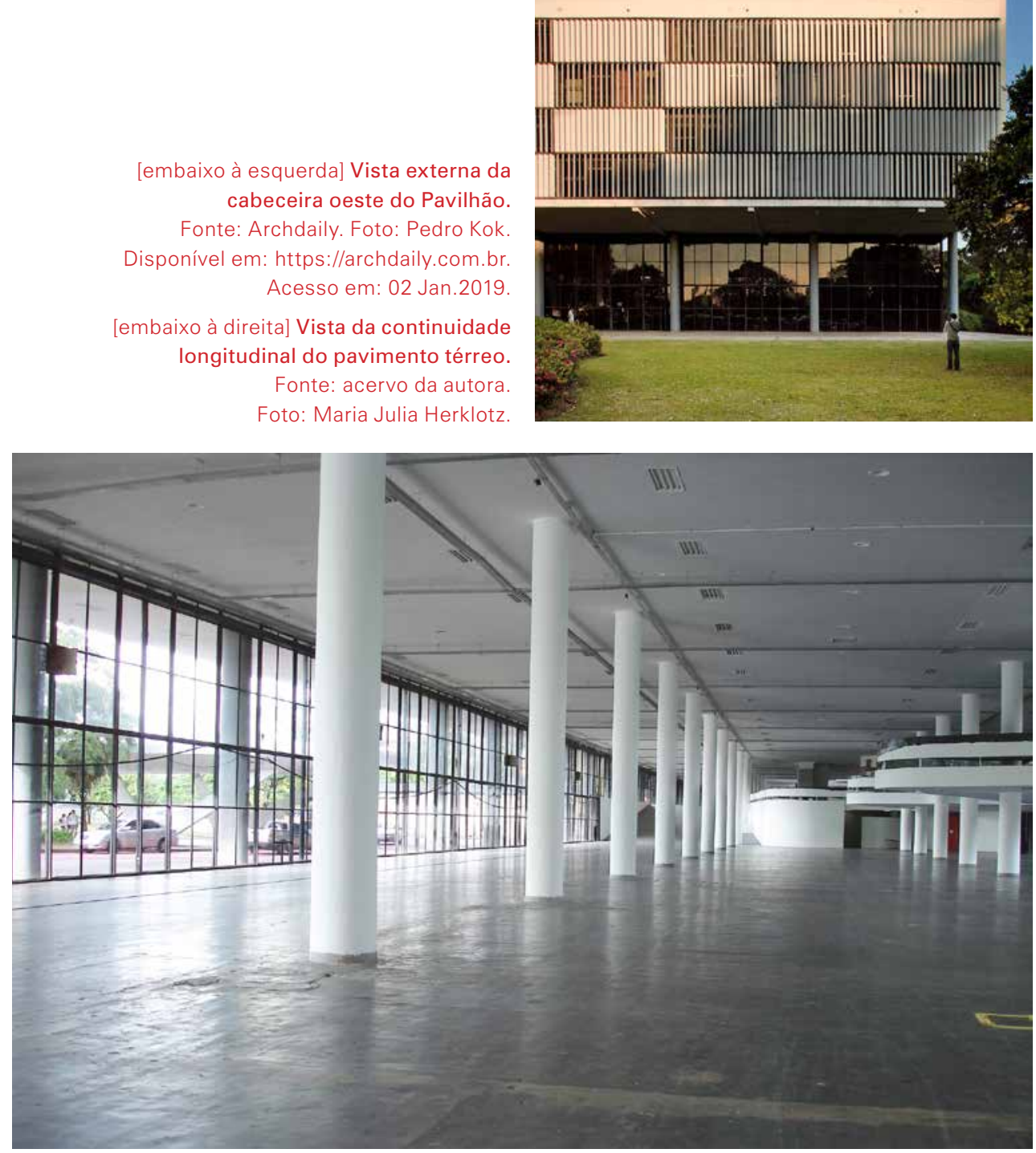

a possibilidade de fazer uma leitura da imensa profundidade do edifício, valorizando a perspectiva da cabeceira, de onde se pode ver a sua totalidade, e garantiu a premissa curatorial de um percurso continuo pela mostra.

A proposta de acesso da 27a. Bienal foi retomada e aprimorada por Bienais subsequentes:

- 28a. Bienal (2008) deixou o pavimento térreo aberto, onde ocorreram performances, e o controle de acesso da exposição se iniciava no primeiro pavimento;

- 3ıа. Bienal (20I4) criou uma praça pública no pavimento térreo com todas as portas abertas, o controle e as catracas ficavam no início da rampa do primeiro pavimento, reiterando a relação direta que esse pavimento tem como parque;

- 32a. Bienal (2016) usou o acesso pela cabeceira oeste, e o aprimorou ao suprimir catracas e detectores de metais. As áreas de apoio (guarda-volumes, educativo) foram alocados em volumes anexos, o que garantiu um acesso franco ao público diretamente à exposição, diminuindo, desta forma, a barreira entre frequentadores do parque e a exposição;

- 33a. Bienal (20ı8) abriu grande parte das portas do térreo deixando todo este pavimento como uma extensão do parque com acesso fluido do público ou passantes. 


\subsubsection{A 28a. Bienal}

A 28a. Bienal (2008) foi marcada por uma profunda crise financeira da Fundação Bienal. A mostra, que se chamou Em vivo contato, ${ }^{58}$ teve curadoria de Ivo Mesquita e ficou conhecida como a "Bienal do vazio". A proposta curatorial deixou desocupado todo o segundo pavimento do pavilhão, o único de onde se pode ter uma leitura de sua extensão e escala, simbolizando a crise institucional pela qual passava a Fundação e a exposição. Essa edição questionava, entre outras coisas, o formato da Bienal e sua manutenção no Pavilhão Ciccillo Matarazzo ${ }^{59}$. A visão do pavilhão vazio e a grandiosidade de seu espaço criou um grande impacto no público acostumado

58 Curadoria: Ivo mesquita (curador chefe) e Ana Paula Cohen (curadora adjunta). Arquitetura: Felippe Crescenti e Pedro Mendes da Rocha (autores) Anna Helena Villela e Maria Julia Herklotz (colaboradoras).

59 Ivo Mesquita (2008) trata deste tema em entrevista dada ao jornal-catálogo da mostra, intitulado 28a.B: "O princípio do projeto foi a partir da constatação de que a Bienal de São Paulo não colecionou um acervo material, mas criou memória e um museu imaginário de arte contemporânea para os brasileiros. Por outro lado, a Bienal está condenada ao edifício, que passa a ser um problema, são mais de 30 mil metros quadrados, requer uma infraestrutura muito grande. Quanto às crises institucionais, há uma série delas, mas acredito que antes de ser uma crise institucional, há uma crise vocacional: a Bienal deve saber a que veio. Em I95I estava claro. Hoje, não mais. O que ela deve fazer agora? O prédio é sede da Fundação desde I957, e ela o gerencia, digamos assim. Tem uma concessão de 99 anos dada pela prefeitura. Em 2003 , o prédio foi tombado e passou a ter regras de uso muito rígidas. Por exemplo, não é permitido furar a parede, o teto ou o chão. Para montar uma exposição de arte contemporânea é complicado".

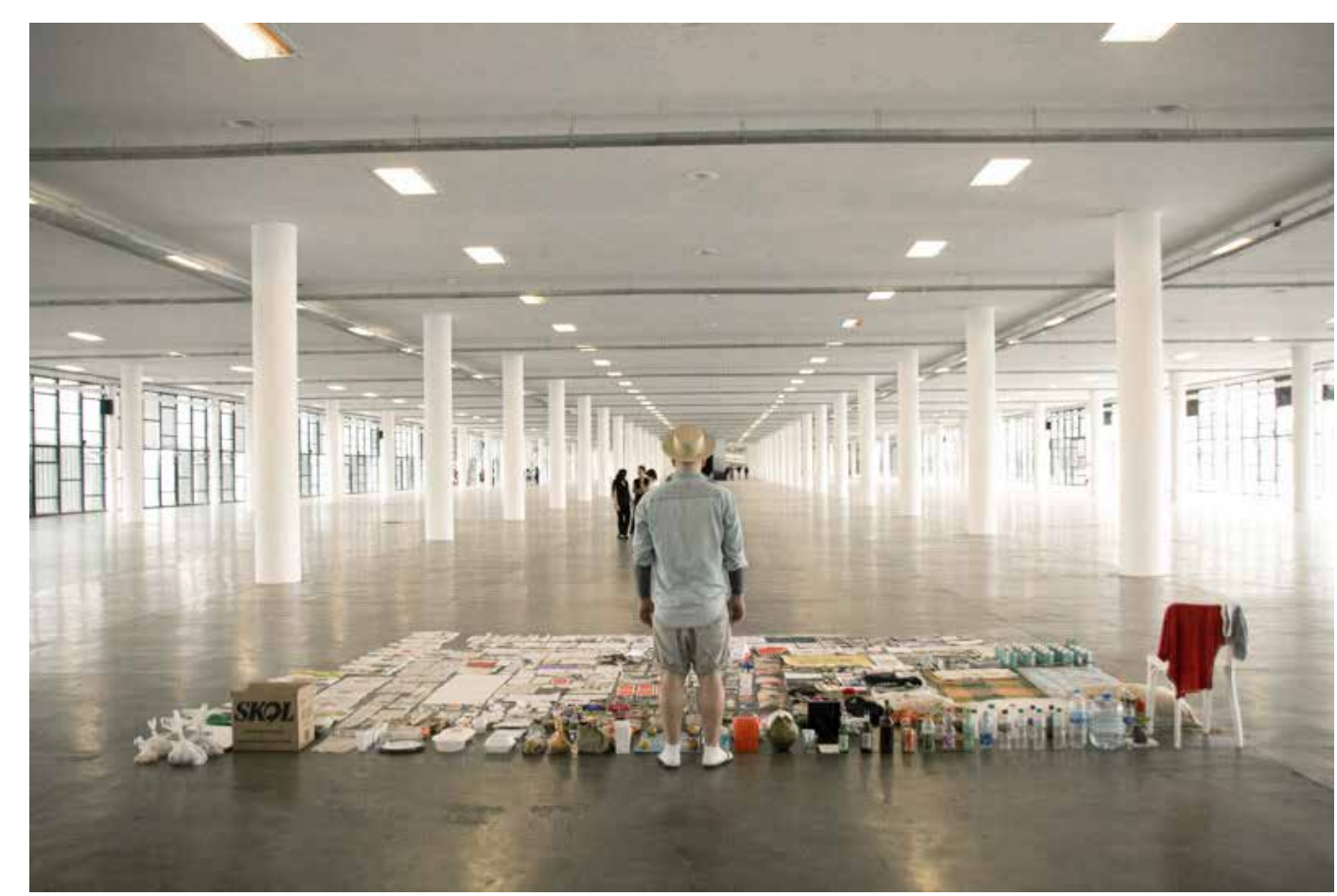

28a. Bienal de São Paulo-A Bondade de estranhos de Maurício lanês e vista do segundo pavimento vazio. Fonte: site Bienal. Foto: ๔ Amilcar Packer. Disponível em: https://bienal.org.br. Acesso em: 02 Jan.2019. 

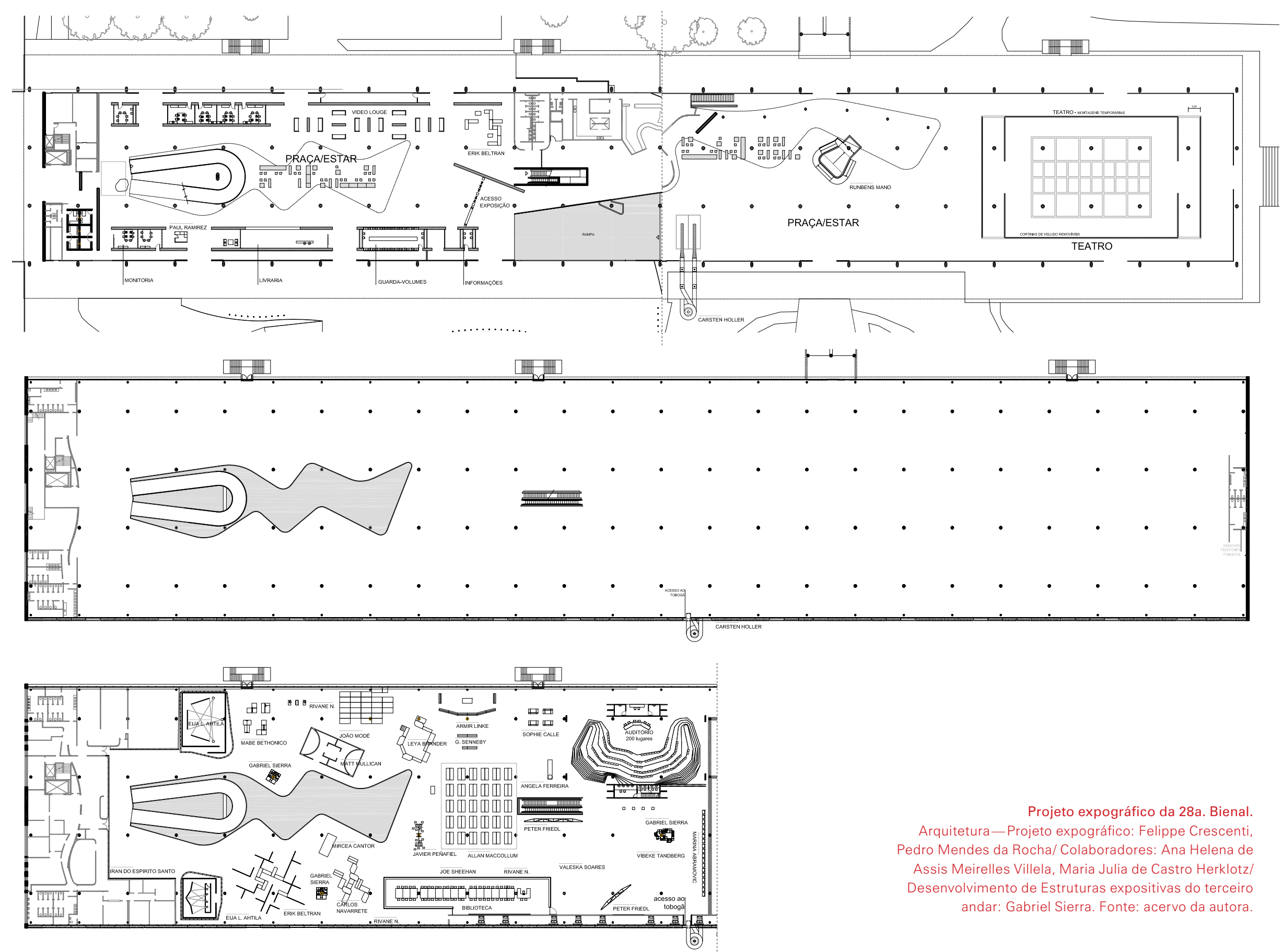

Projeto expográfico da 28a. Bienal. Arquitetura_Projeto expográfico: Felippe Crescenti, Pedro Mendes da Rocha/ Colaboradores: Ana Helena de Assis Meirelles Villela, Maria Julia de Castro Herklotz/ Desenvolvimento de Estruturas expositivas do terceiro andar: Gabriel Sierra. Fonte: acervo da autora. 
em vê-lo sempre ocupado com painéis, salas e obras. Apesar de mal recebida pela imprensa nacional, ${ }^{60}$ foi uma edição reconhecida no circuito internacional e faz parte das poucas Bienais de São Paulo citadas nos compêndios de Bienais. ${ }^{61}$

A expografia da 28a. Bienal foi dividida em dois projetos desenvolvido por equipes distintas: o sistema expositivo do terceiro pavimento foi desenvolvido pelo artista Gabriel Sierra; a biblioteca de catálogos, arena de discussão no terceiro pavimento, serviços de apoio no primeiro pavimento e área para performances no térreo ficaram a cargo de Felippe Crescenti e Pedro Mendes da Rocha. Sierra projetou suportes autoportantes em compensado aparente — um sistema expositivo inovador para Bienal_, sem a presença de painéis-paredes ou salas como divisórias entre obras. Cada obra recebeu um desenho específico desenvolvido pelo artista, em sua maioria elementos delicados que não criavam obstáculo visual ou compartimentação. Como resultado, o espaço do terceiro pavimento ficou

$60 \mathrm{Na}$ imprensa local a exposição gerou grandes polêmicas e discussões sobre as possibilidades de ser articulada uma autorreflexão, sob o comando da figura de um "curador independente", no interior das exposições de arte das instituições culturais do Brasil. As constantes crises financeiras e políticas que assolam importantes museus de arte no país e a própria Fundação Bienal dão sinais da precariedade do contexto institucional brasileiro. Temos, assim, a impressão de que uma crítica seria inviável, devido à fragilidade das instituições que promovem cultura no país (SPRICIGO, 20I0, p.I08).

6I Está citada no compêndio Biennials and Beyond_Exhibitions that made art history, de Bruce Altshuler na categoria "Bienais discursivas" e também no livro de Jens Hoffmann, Show Time - The 50 most influential exhibitions of contemporary art, na categoria "new forms".
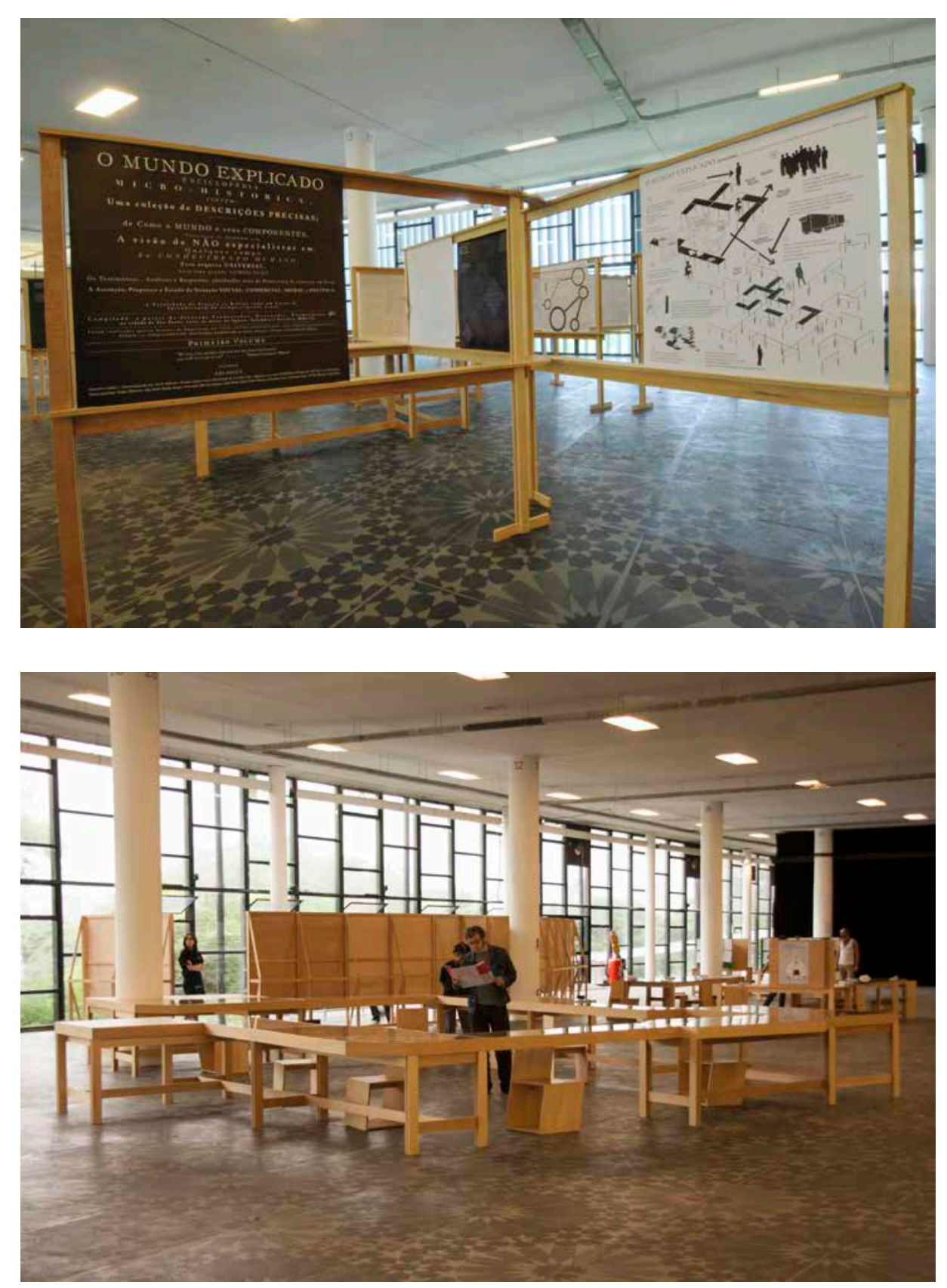

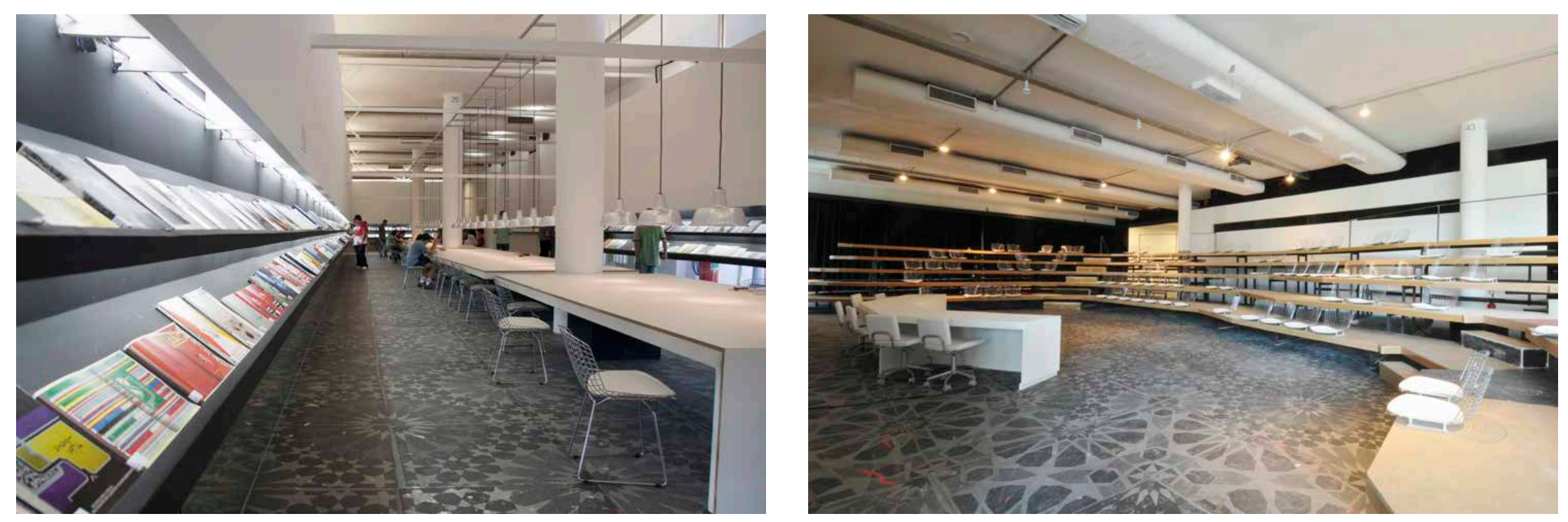

[página ao lado] 28a. Bienal: Estruturas expositivas do terceiro andar de Gabriel Sierra. Fonte: Arquivo Histórico Wanda Svevo / Fundação Bienal de São Paulo. Foto: Amilcar Packer.

[acima, à esquerda] 28a. Bienal: vista da biblioteca de catálogos no terceiro pavimento. Fonte: Arquivo Histórico Wanda Svevo /

Fundação Bienal de São Paulo. Foto: Amilcar Packer.

[acima, à direita] 28a. Bienal: vista do auditório do terceiro pavimento. Fonte: Arquivo Histórico Wanda Svevo / Fundação Bienal de São Paulo. Foto: Amilcar Packer.

[embaixo] 28a. Bienal: vista do vão central e vídeo lounge. Fonte: Arquivo Histórico Wanda Svevo / Fundação Bienal de São

Paulo. Foto: Amilcar Packer.

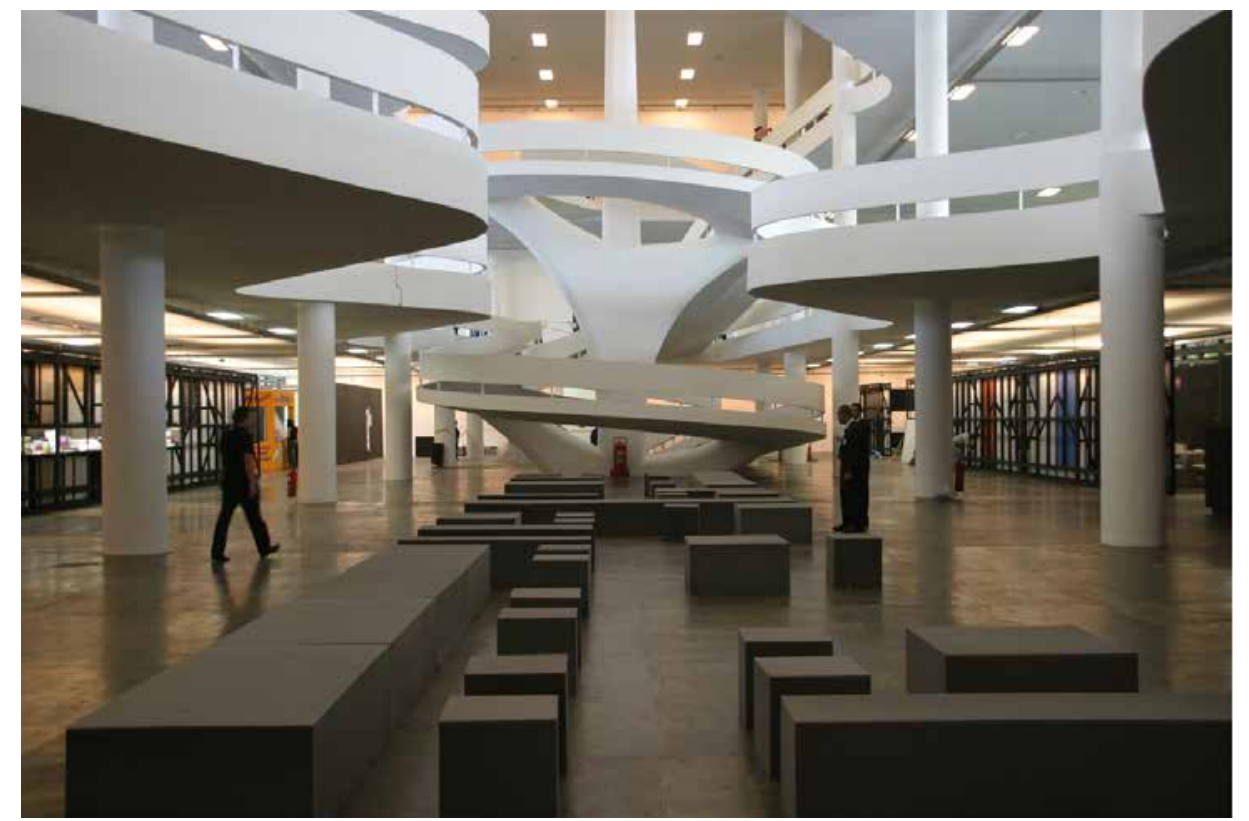


amplo e ganhou unicidade, e as obras puderam dialogar ente si, com seus suportes, com o pavilhão e com o parque.

Essa Bienal, que questionava a permanência da mostra no pavilhão, trouxe duas instalações site specific de artistas que interviram no pavilhão, transformando seu espaço: Valerio Sisters, de Carsten Höller, ${ }^{62}$ e Escalpo 5036, de Dora Longo Bahia. ${ }^{63}$

Höller instalou dois escorregadores na fachada oeste do pavilhão, criando novas conexões entre o segundo e terceiro pavimentos diretamente com o térreo. $\mathrm{O}$ artista defendeu o uso de escorregador como meio de transporte, como uma possibilidade de circulação vertical rápida. Os escorregadores instalados transformaram a lógica de circulação do pavilhão, com uma possibilidade de sair da exposição sem ter que percorrer todo o edifício, da forma tradicional imposta pela arquitetura, através da rampa, pelo vão central.

Dora Longo Bahia aplicou uma película em todo o piso do terceiro pavimento, que na 28a. Bienal concentrava grande parte das obras, transformando completamente a leitura deste espaço. O imenso tapete com motivos islâmicos cobriu todo o piso de concreto. Sob esta película havia uma base de tinta vermelha e a medida que a película superior foi se desgastando com a circulação do público, a camada vermelha foi sendo revelada.

62 Artista alemão (1961).

63 Artista brasileira (196I).

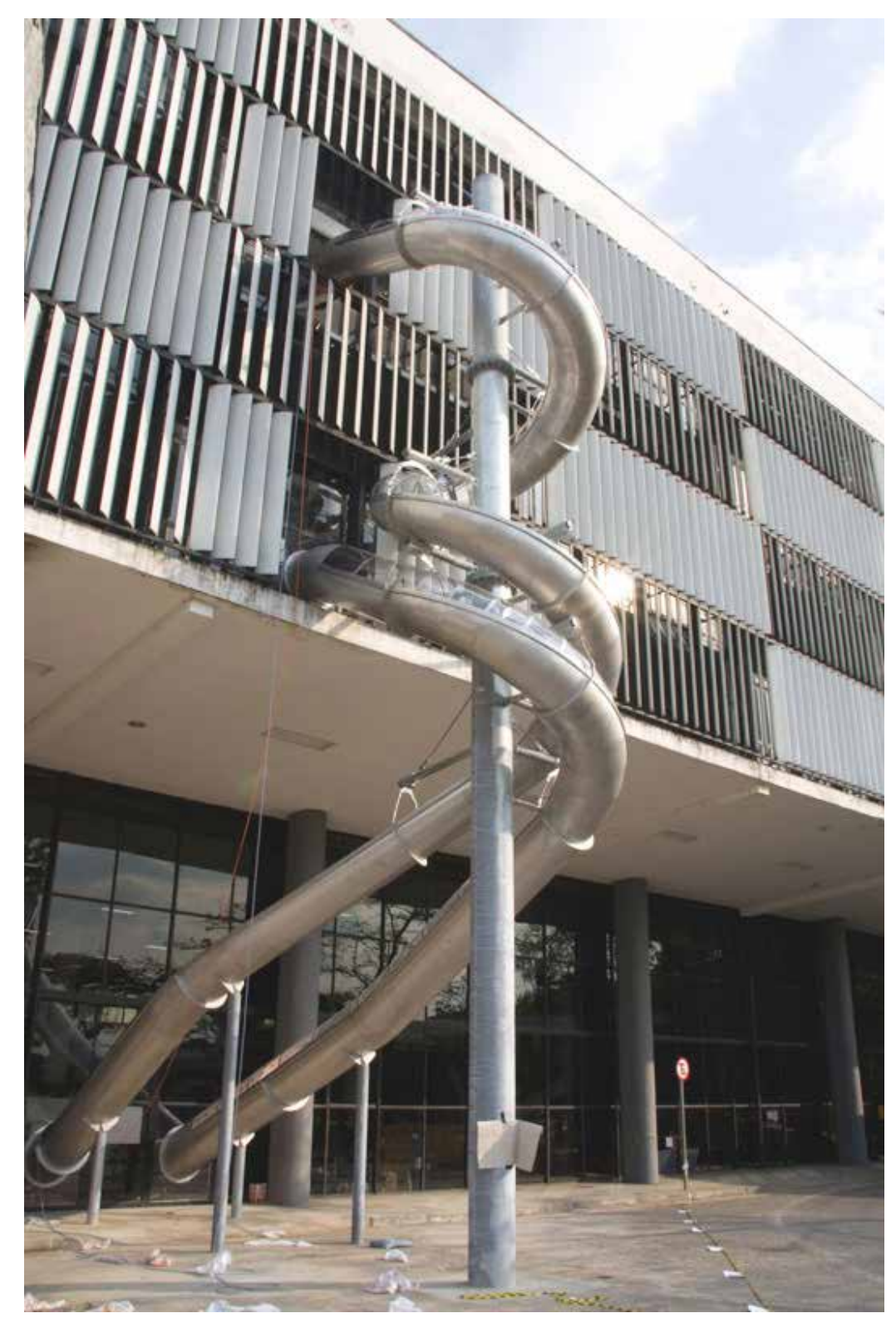

28a. Bienal: vista externa da obra Valerio Sisters de Carsten Höller. Fonte: site Bienal. Foto: Amilcar Packer. Disponível em: http://bienal.org.br/ exposicoes/28bienal/fotos/4127. Acesso em: 02 Jan.2019. 


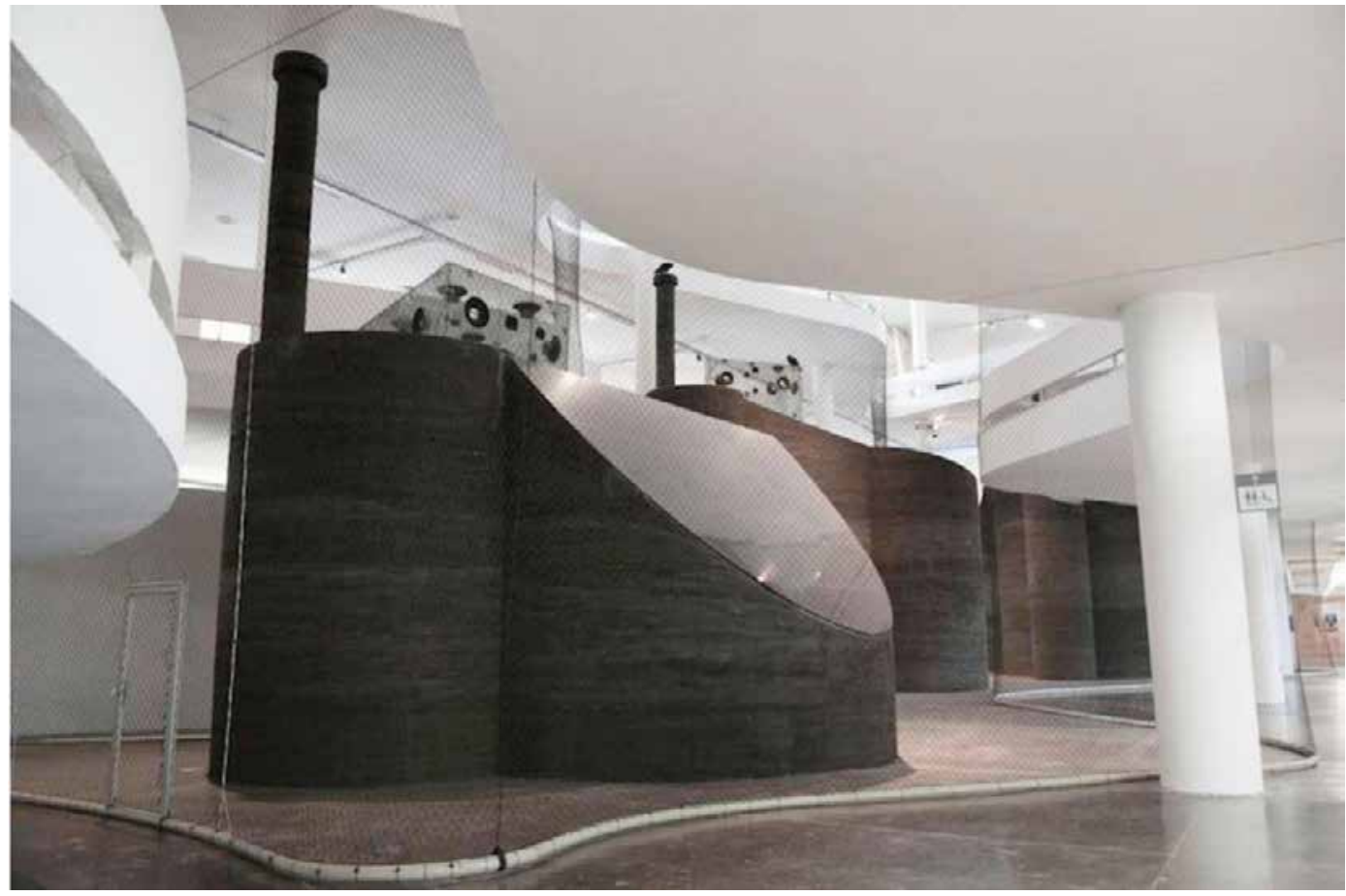

29a. Bienal: obra do vão Bandeira Branca de Nuno Ramos. Fonte: site Nuno Ramos. Foto: Nuno Ramos. Disponível em: http://www.nunoramos.com.br/portu comercio.asp?flg Lingua $=1 \&$ cod Artista $=110 \& \operatorname{cod}$ Serie $=105$. Acesso em: 02 Jan.2019.
1.3.2. A 29a. Bienal

A 29a. Bienal-Há sempre um copo de mar para um homem navegar (2010) ${ }^{64}$, com curadoria de Agnaldo Farias e Moacir dos Anjos, teve como aspecto central:

o reconhecimento do caráter ambíguo que a arte possui desde que se viu liberta de sua função de meramente representar o que já existe e é sabido. Por um lado, a arte é aquilo que, de uma maneira que lhe é própria, interrompe as coordenadas usuais da experiencia sensorial do mundo. Por outro lado, justamente por possuir essa potência de desconcerto, a arte é capaz de reconfigurar os temas e as atitudes passiveis de serem inscritas em espaços de convívio e partilha (FARIAS; ANJOS, 20I0, p.20).

Marta Bogéa retorna à expografia da mostra com uma proposta não ortogonal a partir de eixos diagonais dentro da modulação do pavilhão, criando um labirinto, ou arquipélagos, baseado no conceito da mostra, e transformou as coordenadas ortogonais usuais do pavilhão (BOGEA, 2oro, p.4I4). O

64 Curadoria: Agnaldo Farias e Moacir dos Anjos (curadores chefes), Chus Martinez, Fernando Alvim, Rina Carvajal, Sarat Maharaj, Yuko Hasegawa (cocuradores); arquitetura: Marta Bogéa (autora), Tiago Guimarães (coordenador),Laura Bigliassi e Marcus Vinicius Santos (colaboradores). 


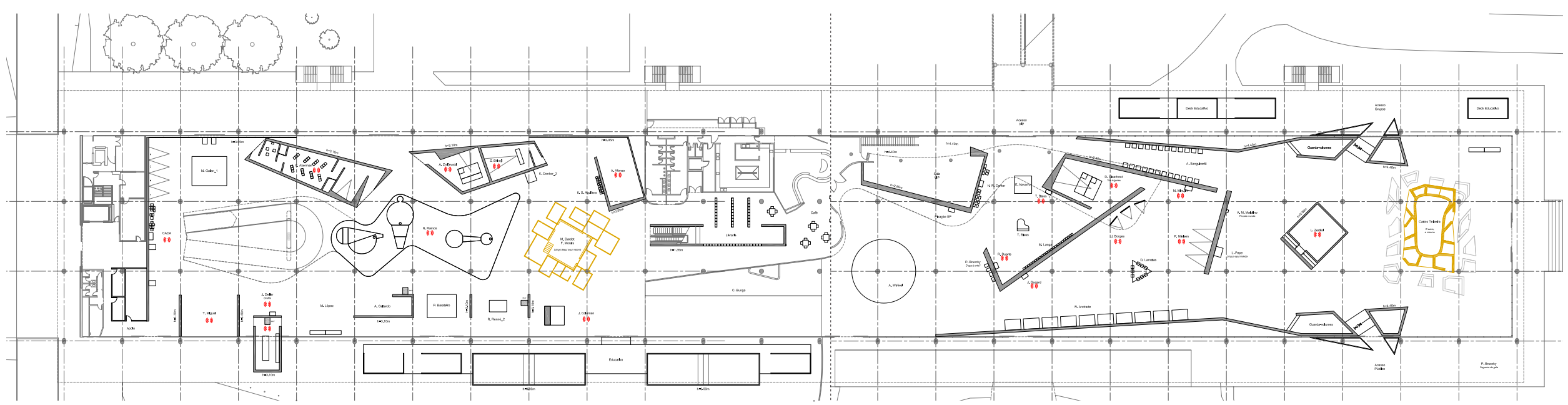

Projeto expográfico da 29a. Bienal. Arquitetura: Marta Bogéa / Colaboradores: Tiago Guimarães (coordenador); Laura Bigliassi;

Marcus Vinicius Santos. Fonte: Arquivo Wanda Svevo. 

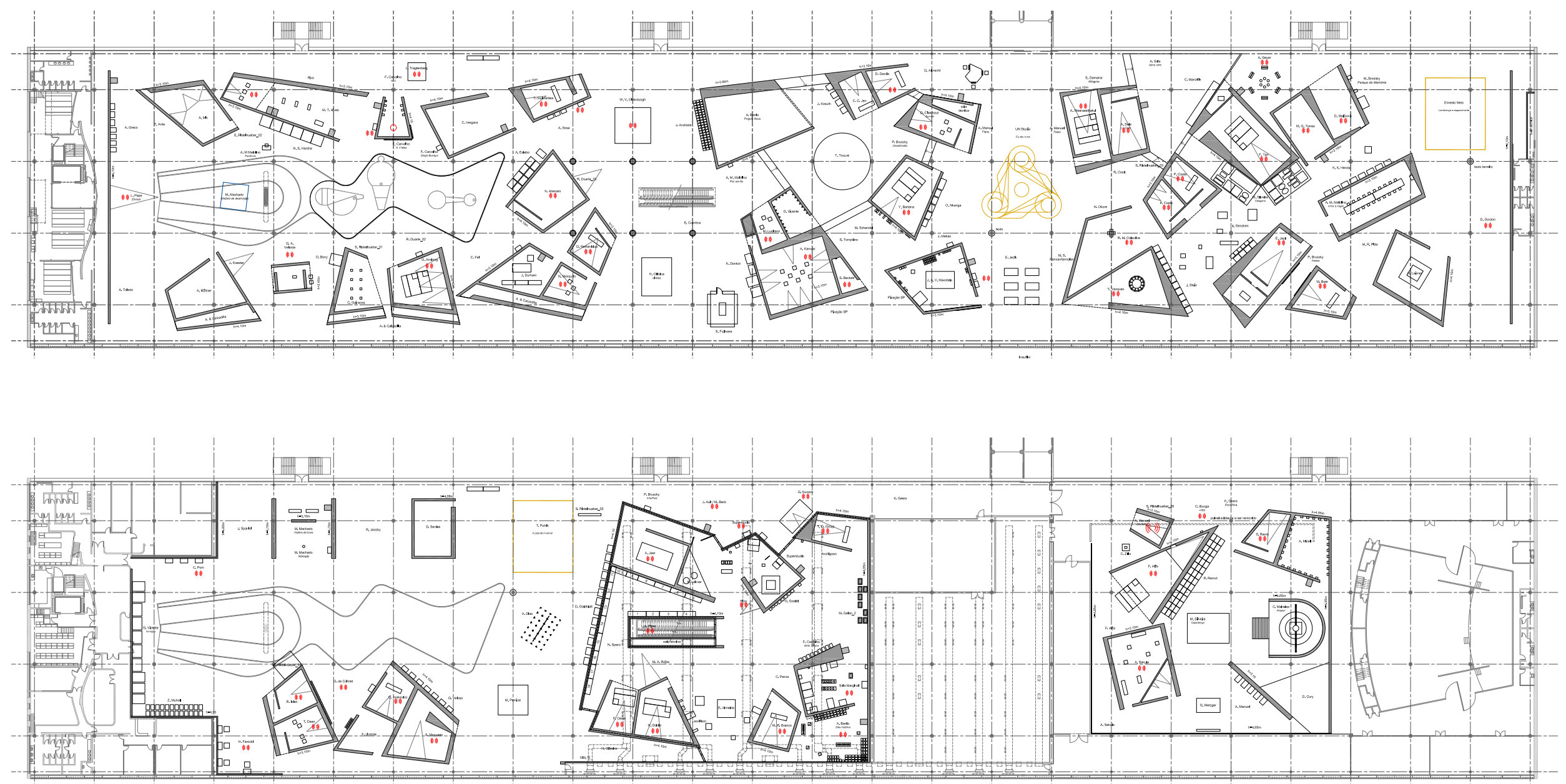
espaço resultante tem uma lógica totalmente distinta do edifício. No entanto, as divisórias e salas não tocavam o forro ou as fachadas, e a salas estavam dispostas de modo a permitir visuais de leitura do espaço do pavilhão.

Contrariando também a lógica espacial do vão central, a instalação Bandeira branca (20I0), de Nuno Ramos, preencheu o vazio monumental do pavilhão com a inserção de uma tela preta que fechou o contorno do vão, nos três pavimentos. No centro do vão, no primeiro pavimento, foram dispostas três esculturas de taipa de pilão em areia preta e caixas de vidro sonoras que tocavam fragmentos das canções Carcará $^{65}$, Bandeira branca ${ }^{66}$ e Acalanto. ${ }^{67}$ Ali conviveram, soltos nesse espaço, três urubus (FARIAS; ANJOS; 20IO, p.380).

65 Composição de João do Vale e José Candido.

66 Composição de Max Nunes e Laércio Alves.

67 Composição Dorival Caymmi. 


\subsubsection{A 31a. Bienal}

\section{selected configurations / experiential qualities}

C3

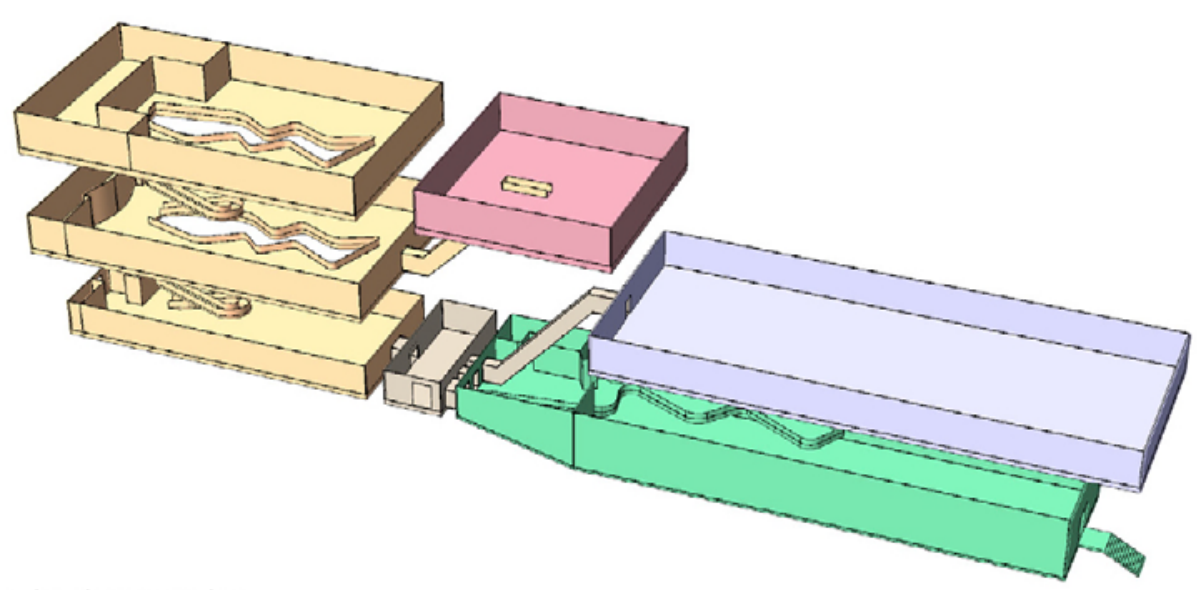

4 buildings - interior connection

a different breaking down of floor proportions. emphasis on circular movement per sector dialectical relations between the different sectors - experience of discovery and diversity of experience throughout the site
A 3ra. Bienal-Como (..) sobre coisas que não existem (2012) ${ }^{68}$ teve uma especificidade em relação às outras: uma equipe estrangeira de curadores e o arquiteto-curador israelense Oren Sagiv.

Sagiv fez uma leitura do pavilhão muito distinta da usual, interviu no edifício transformando completamente seu espaço e, desta forma, se tornou um contraponto para a expografia das Bienais. A partir de uma análise dos possíveis percursos e circulações verticais, Sagiv compreendeu de que há no edifício espaços com qualidades muito distintas, como se fossem muitos edifícios dentro de um único, e repartiu o prédio em três grandes áreas: O térreo com pé direito duplo e mezanino, o espaço que se relaciona diretamente com o vão central e o a grande laje do segundo pavimento. Somou-se a essa análise a avaliação pela equipe de curadores de que "o edifício é grande demais para abrigar uma exposição que se aglutine como uma experiência única" (SAGIV, 20I4, p.2I5).

A proposta do projeto expográfico foi a segmentação do edifício em três setores e a inversão da lógica habitual; a curadoria foi pensada a partir da expografia:

68 Curadores: Charles Esche, Galit Eilat, Nuria Enguita Mayo, Oren Saviv, Pablo Lafuente (curadores), Benjamin Seroussi e Luiza Proença (curadores associados); arquitetura: Oren Sagiv (autor), Anna Helena Villela (coordenadora), Roi Zach, Izabel Barboni, Beatriz Vicino, João Yamamoto, Liz Arakaki, Maria Julia Herklotz, Stav Dror e Vifat Zailer (colaboradores). 

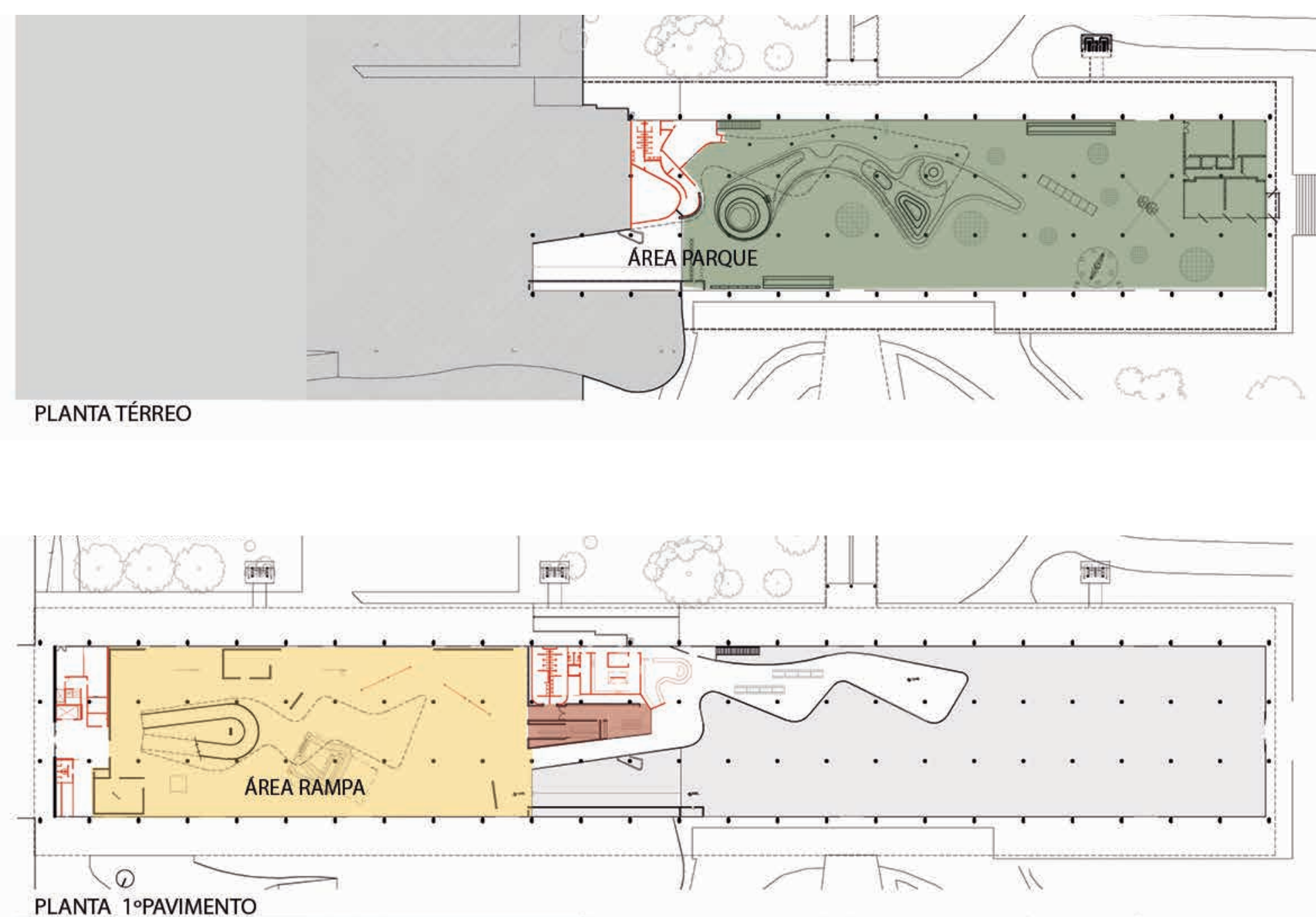


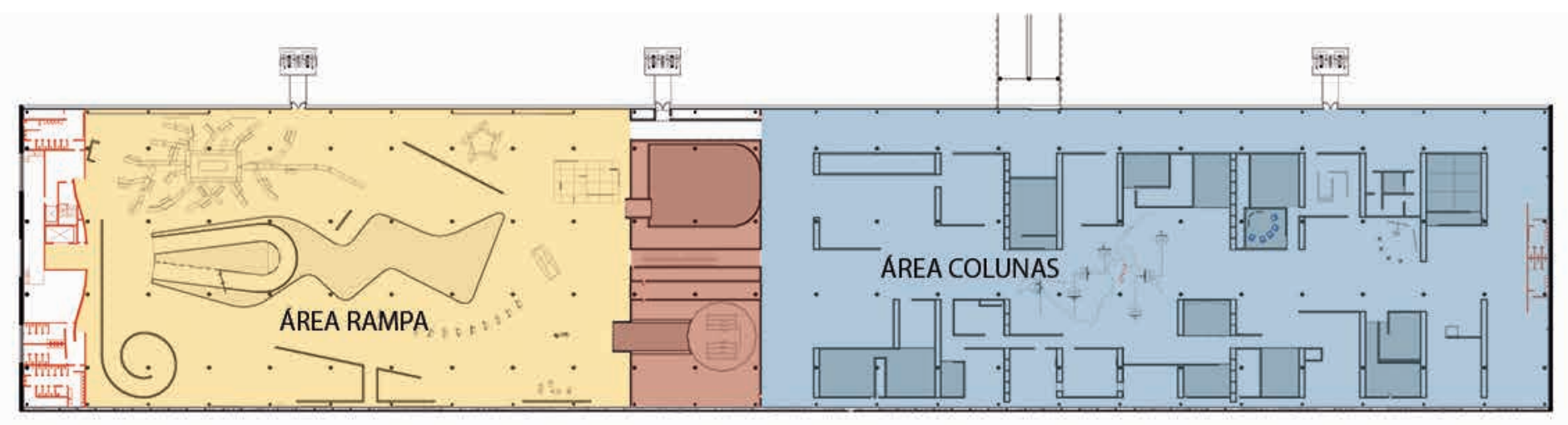

PLANTA $2^{\circ}$ PAVIMENTO

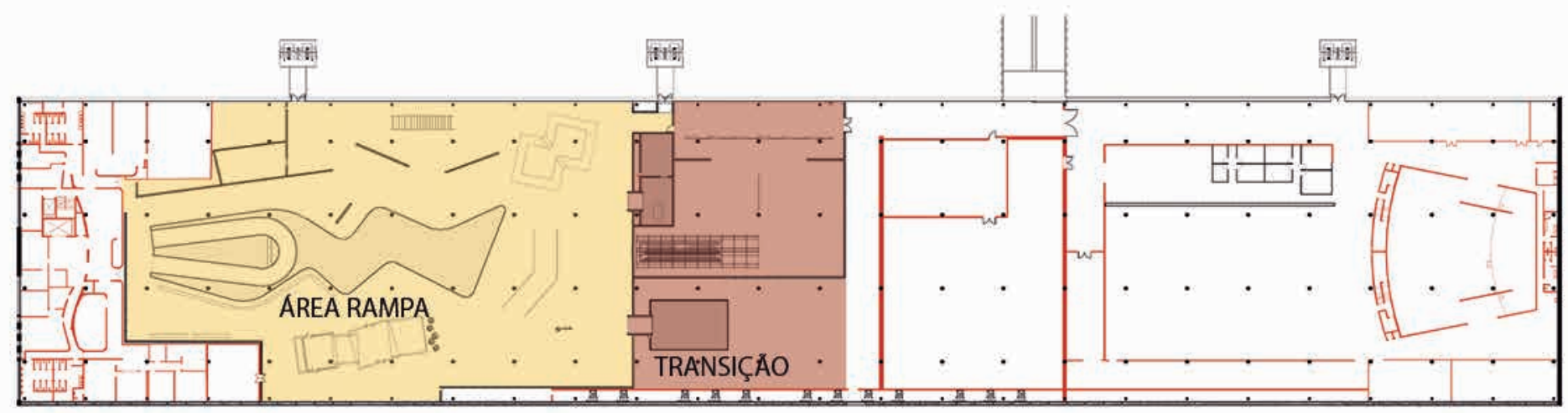

PLANTA DO $3^{\circ}$ PAVIMENTO 
- A Área Parque, que ficava no pavimento térreo, tinha como principal característica sua relação direta com o parque e o seu programa era social, um espaço de encontro entre o lugar do público e o lugar da arte. Todas as portas foram abertas no pavimento térreo, conferindo o franco acesso do público. O controle passou a ser feito no pé da rampa de acesso ao primeiro pavimento. O principal elemento desse espaço era uma grande arquibancada proposta como espaço de convívio para receber diversas atividades vinculadas à mostra ou não. Essa plataforma elevada, inserida no térreo, criava um diálogo com o nível do mezanino, colocando o público em outro ponto de vista, inusitado, em relação à arquitetura (SAGIV, 20I4, p.215);

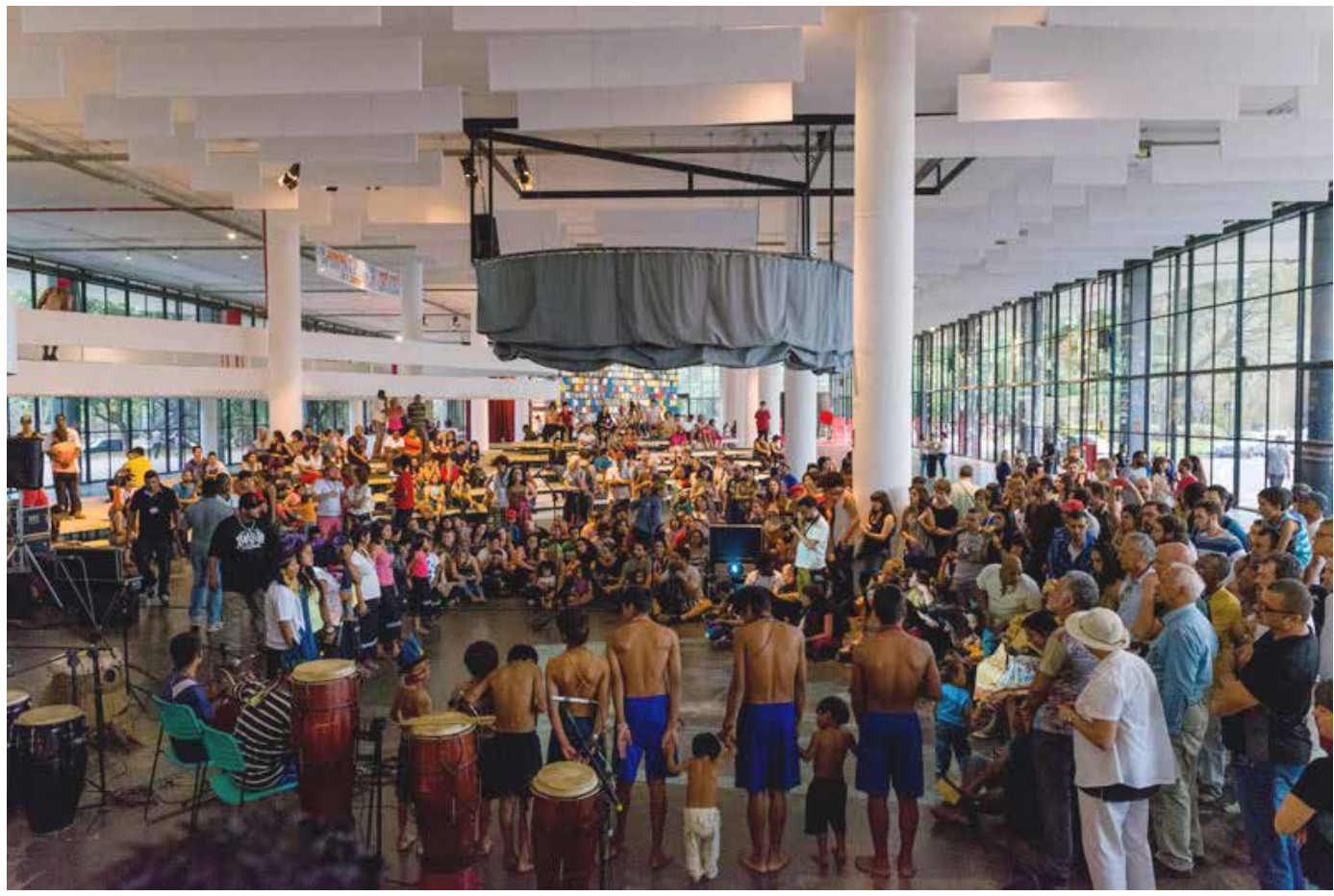

[acima] 31a. Bienal: Vista da Área Parque. Fonte: site Bienal Foto: (c) Leo Eloy / Fundação Bienal de São Paulo. Disponível em: http://bienal.org.br/ exposicoes/31 bienal/fotos/4093. Acesso em: 02 Jan.2019.

[embaixo] 31a. Bienal: Corte da ilha na Área Parque e relação com o mezanino. Fonte: MAYO; ESCHE, 2014

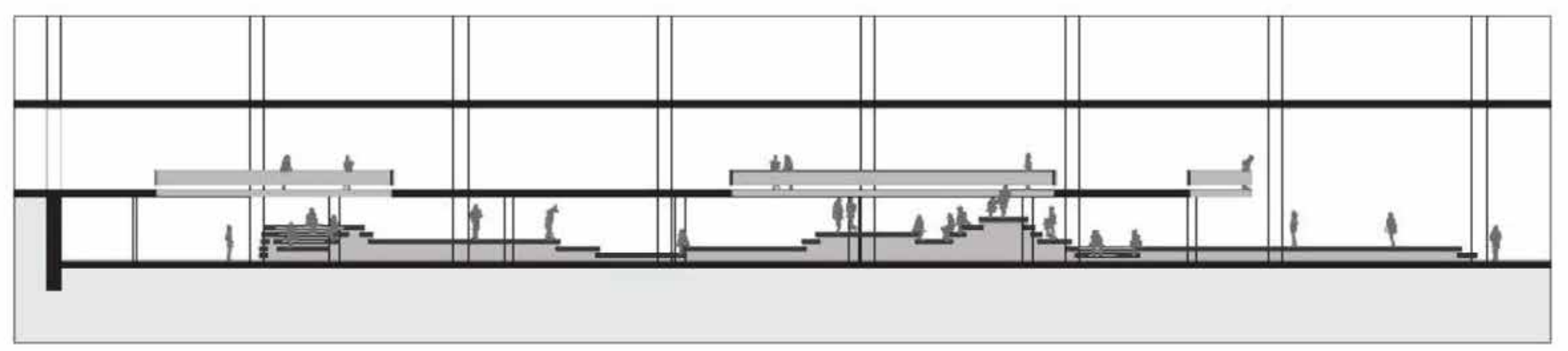




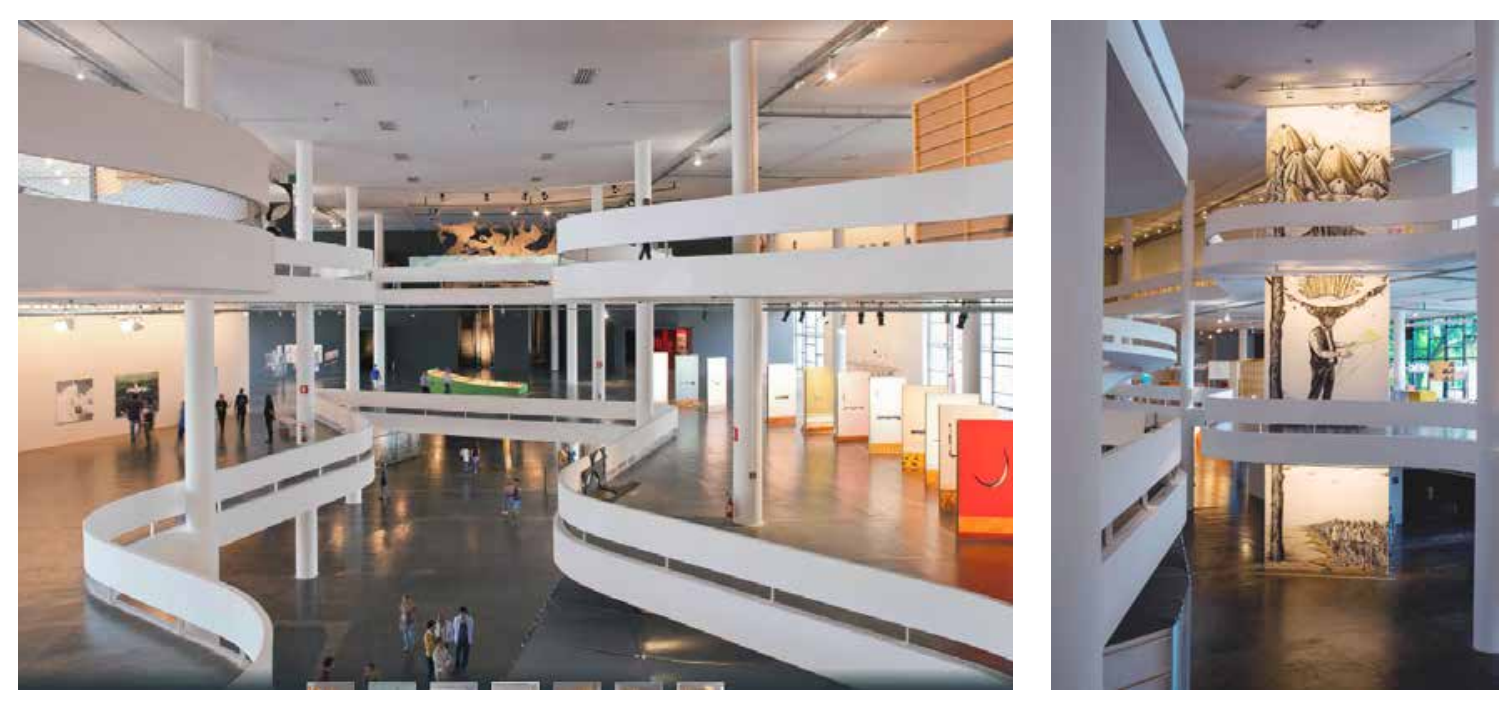

[à esq.] 31a. Bienal: vista da Área Rampa, ao fundo parede cinza que segmentou o Pavilhão. Fonte: site Bienal. Foto: @ Leo Eloy / Fundação Bienal de São Paulo. Disponível em: http://bienal.org.br/ exposicoes/31 bienal/fotos/4093. Acesso em: 02 Jan.2019.

[à dir.] 31a. Bienal: vista da Área Rampa, obra Dark Clouds of the Future de Prabhakar Pachpute. Fonte: site Bienal. Foto: (c) Leo Eloy/ Fundação Bienal de São Paulo. Disponível em: http://bienal org.br/ exposicoes/31 bienal/fotos/4093. Acesso em: 02 Jan.2019

[embaixo] 31a. Bienal: estudo das visuais da Área Rampa: 1o., 2o. e 3o. pavimentos. Fonte: MAYO; ESCHE, 2014.
- A Área Rampa, espaço adjacente ao vão central nos três pavimentos, tinha como característica a sua relação de visão vertical, visuais entre os pavimentos e a rampa. Uma grande parede piso-teto cinza escuro nos três pavimentos fazia a segregação deste setor, reiterando a verticalidade do vão. A expografia se resolveu com poucos painéis em longos planos, sempre do piso ao teto, sugerindo a continuidade dos planos entre os pavimentos. A obra de Prabhakar Pachpute, Dark Clouds of the Future, reiterava a proposta expográfica, era um único desenho em painéis com a mesma locação nos três pavimentos e que davam a sensação de continuidade vertical;
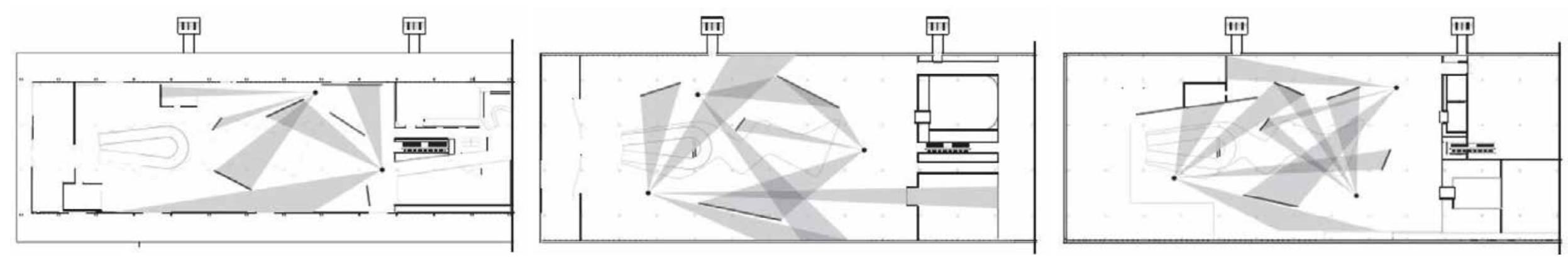
- a Área Colunas, grande laje do segundo pavimento que começa a partir da escada rolante, tinha como característica fundamental um espaço regular com uma malha de pilares ritmados. Para esse espaço foi proposta a construção de um centro escuro de clima intimista, mais próximo ao museológico, completamente distinto das outras experiências. Para orientar o percurso, neste espaço mais fragmentado por salas, foram inseridas duas linhas de painéis transversais ao pavilhão, com fechamento de tela de onde se via as fachadas do edifício e a luz natural do parque.

A proposta curatorial, cujo eixo central era a construção de uma jornada transformadora, foi pensada a partir destas três áreas com atmosferas e expografias marcadamente distintas. Desta forma, Sagiv, com seu olhar estrangeiro, transformou temporariamente o espaço do pavilhão e também e apresentou uma nova possibilidade de relação entre expografia e projeto curatorial. A sua posição de arquiteto-curador fez com que o partido da expografia estabelecesse diretrizes para a curadoria.
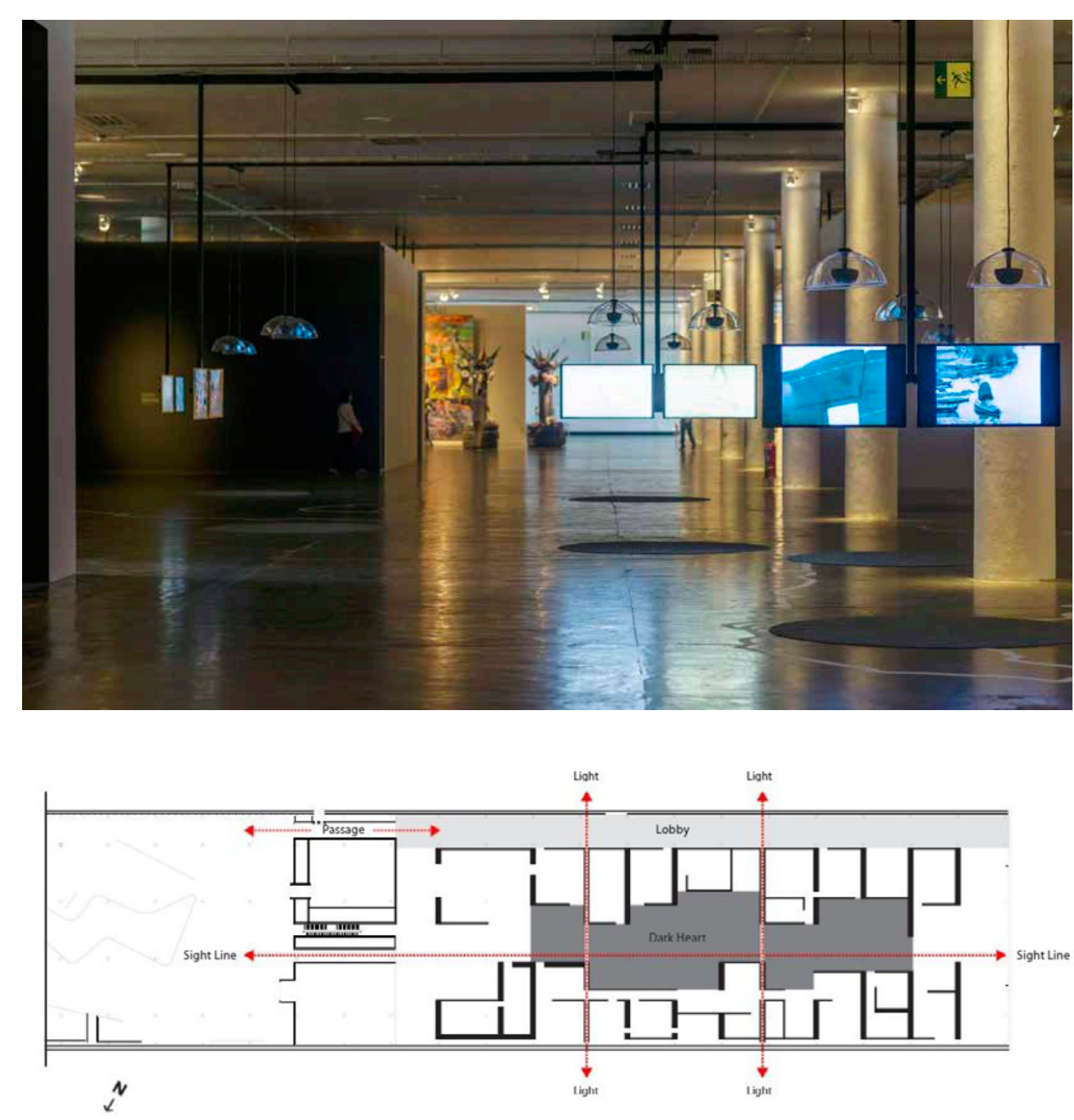

Esquema geral da área Colunas

[no topo] 31a. Bienal: vista da Área Colunas. Fonte: site Bienal. Foto: ( L Leo Eloy / Fundação Bienal de São Paulo. Disponível em: http://bienal.org.br/exposicoes/31bienal/fotos/4093. Acesso em: 02 Jan.2019.

[embaixo] 31a. Bienal: esquema da Área Colunas. Fonte: MAYO; ESCHE, 2014. 
Apesar dos seus mais de sessenta anos, o pavilhão tem se mostrado um edifício bastante flexível e adequado para receber as Bienais. Seu caráter monumental e simbólico, por um lado, e as diversas qualidades espaciais, por outro, permitem diversas formas de apropriação pelas obras de arte contemporâneas e os projetos expográficos vêm estabelecendo diálogos férteis com sua arquitetura. A cada edição da mostra o pavilhão impõe sua presença e, sem dúvida, um dos principais desafios que se impõe aos arquitetos responsáveis pelas Bienais é trazer novas propostas de ocupação em diálogo com o projeto curatorial. 


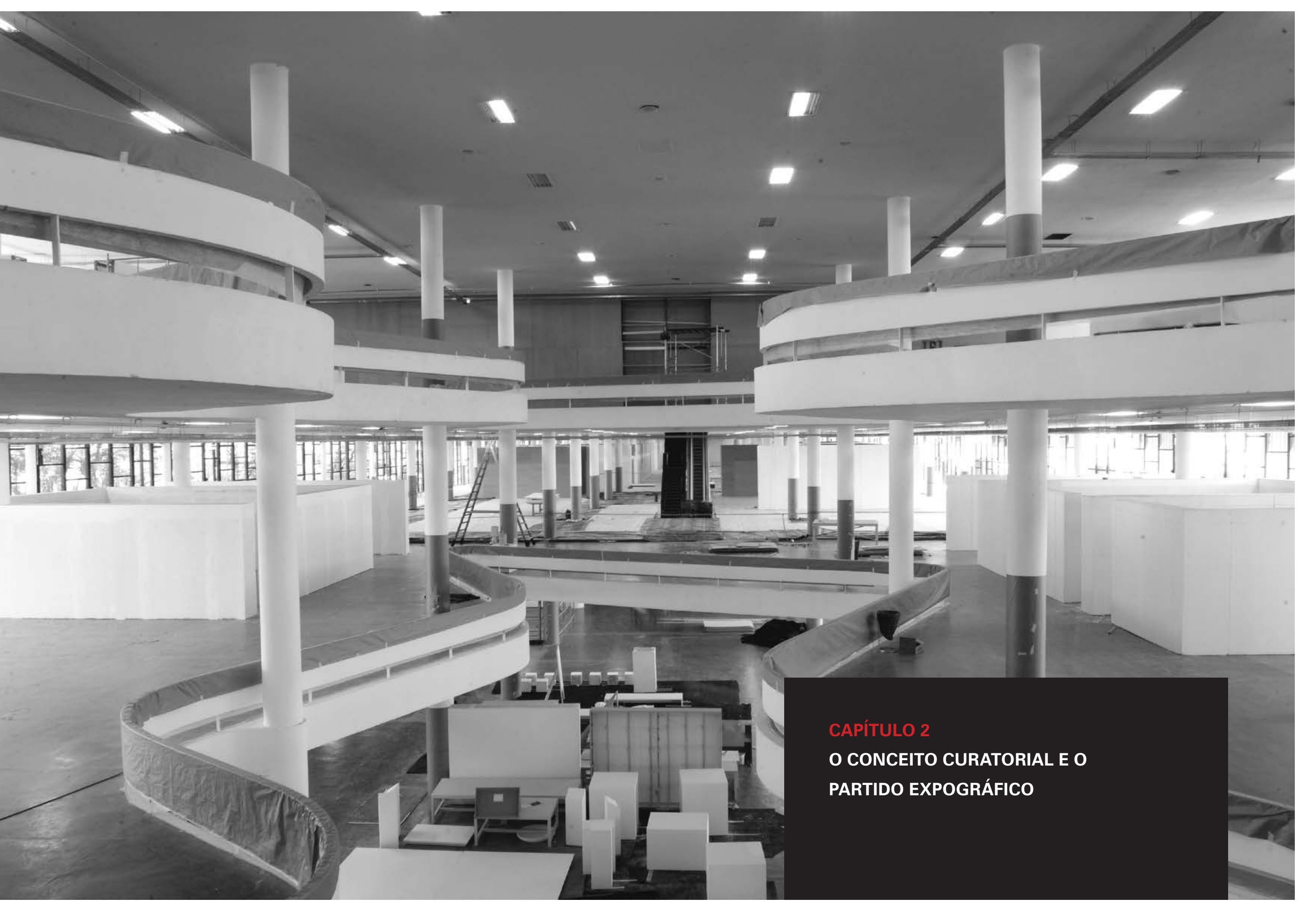


Este capítulo tem como foco a plataforma conceitual da $27 \mathrm{a}$. Bienal de São Paulo e a relação estabelecida com o partido do projeto expográfico.

A primeira parte do capítulo faz uma análise comparativa da proposta curatorial da 27a. Bienal com as principais mostras internacionais contemporâneas a ela. Avalia como as transformações na estrutura institucional e do modelo de curadoria da Bienal ocorridas em 2006 contribuíram para a inserção da Bienal de São Paulo no circuito global das artes.

A segunda parte apresenta a estrutura da narrativa curatorial, com a configuração dos núcleos e sua organização conceitual no espaço do Pavilhão. Aborda aspectos da relação entre a arquiteta Marta Bogéa e a equipe de curadores. Indica as primeiras ações do projeto expográfico em diálogo com a proposta curatorial: a definição do acesso e fluxo da exposição e proposta de sistema expositivo a partir da leitura espacial do Pavilhão Ciccillo Matarazzo. 


\subsection{A 27a. BIENAL E O SISTEMA GLOBAL DAS ARTES}

A 27a. Bienal de São Paulo, realizada em 2006, trouxe uma série de inovações para a estrutura da exposição, para o modelo institucional e para o papel do curador que foram assimiladas e mantidas nas edições subsequentes (CYPRIANO; OLIVEIRA, 20I6). Segundo o curador da 3Ia. edição (20I4), Charles Esche', é a partir dessa edição que a Bienal se torna "uma plataforma que permite a experimentação com o próprio formato" (20I4, p.56). E Vinicius Spricigo ${ }^{2}$ aponta que a grande transformação ocorrida nessa mostra não foi a mudança estrutural, mas o enfoque nas discussões acerca dos efeitos da globalização cultural e da crise da esfera pública da arte. (2009, p.24).

Para entender o contexto internacional em que se insere a 27a. Bienal e dar conta de seu impacto é preciso retomar, mesmo que brevemente, a difusão das bienais de arte pelo mundo a partir dos anos I990. Em "Cultura de bienais e

I Charles Esche foi curador da 3ra. Bienal de São Paulo, diretor do museu Van Abbemuseum na Holanda e professor de curadoria e arte contemporânea da Universidade de Artes de Londres.

2 Vinicius Spricigo é professor adjunto do Departamento de História da Arte da UNIFESP. Foi curador associado ao Fórum Permanente. a emergência do discurso curatorial globalizado", 3 Paul $\mathrm{O}^{\prime} \mathrm{Neill}$ (2OI2) define bienais como exposições de larga escala que ocorrem a um certo intervalo de tempo, apresentando um grande número de obras expostas e um alto orçamento, e que tem como meta a inserção no mercado globalizado da arte. O autor aponta uma série de transformações pelas quais as bienais passaram a partir de I989 e busca examinar como e porque se tornaram um fenômeno contemporâneo global.

Segundo Esche $^{4}$ (20II), o ano de I989 foi um dos momentos mais significativos do século 20: a queda do muro de Berlim, o fim dos governos comunistas e a invenção da internet provocaram um momento de transformação global,

3 Título original: "Biennial culture and the emergence of a globalized curatorial discourse: curating in the context of biennials and large-scale exhibitions since 1989". In: The Culture of Curating and the Curating of Culture(s). Cambridge, Londres: MIT Press, c2oI2. Tradução da autora. Paul O’Neill é um curador independente, artista e escritor. Diretor do programa de graduação de estudos curatoriais no Bard College de Nova York.

4 “Introduction: Making Art Global”. In: Rachel Weiss (ed.), Making Art Global (Part 1): The Third Havana Biennial 1989. Londres: Afterall Books (Exhibition Histories vol. 2), 20II, p.8-13. O ano de I989 é ainda citado como marco por Paul O’Neill, Francis Fukuyama, Lara Buchholz e Ulf Wuggenig, entre outros. 
cuja característica mais marcante foi a inserção de países pós-coloniais e pós-comunistas no mercado global, movimento que estabeleceu uma nova ordem cultural, além de econômica. Nesse contexto, as bienais internacionais foram umas das principais chaves de posicionamento, indicando que as cidades desses países estavam abertas para negócios.

A za. Bienal de Havana (1989) e a 24a. Bienal de São Paulo (1998) foram influências importantes na construção de uma plataforma para 27a. Bienal, cuja curadoria propôs uma perspectiva não eurocêntrica para a história da arte contemporânea.

No ano de 1989 foram inauguradas três exposições que tiveram impacto no modelo de curadoria que se difundiu pelas bienais: Les magicien de la Terre (Paris); za. Bienal de Havana e Other Story (Londres). Essa mostras rejeitaram o modelo da Bienal de Veneza com representações nacionais e trouxeram propostas de bienais com curadorias autorais e com temas em torno de questões sociopolíticas e da inserção da alteridade.

5 "While the British exhibition sought to include into the national artistic narrative the consequences of post-imperial migration, and the French show recalled the universalist aspirations of the 1789 Revolution, the Cuban project aimed to mobilise marginalised art communities from both inside and outside the USA-led West on the basis of international socialism. Each was driven by a historical narrative specific to its national context, and yet all three coincided with a moment when the course of global events was sharply and irreversibly interrupted." (ESCHE, 2OI I, p.8).
Para Esche (20II), a mudança fundamental que ocorreu após a Bienal de Havana foi nas próprias obras de arte das bienais, que passaram a ter uma relação com a política e o contexto social das cidades sedes; posteriormente estas obras ficaram conhecidas pejorativamente como "arte de bienal". As características dos trabalhos apresentados em Havana, tais como seu engajamento com a esfera local e a propensão a discursividade, tornaram-se paradigmáticas para arte contemporânea. O autor indaga a razão de haver uma arte global e se existe uma poética de tal âmbito, não baseada na realidade local, mas gerada a partir de uma rede cultural globalizada.

Este é o paradoxo que a arte enfrenta e que a bienalização da arte nos últimos vinte anos trouxe nitidamente em foco. As bienais, em seu desejo utópico, podem moldar um “bom lugar” onde a sociedade está presente e participativa ou um "não lugar" do fetichismo global de mercadorias (MOSQUERA apud ESCHE, 2OII, p.I3).

Apesar da repercussão mundial da 3a. Bienal de Havanaque institui um novo modelo de exposição global —, a grande difusão de bienais pelo mundo, bem como a ampliação da abrangência do circuito de arte internacional ocorrida a partir de I989, na Documenta de Kassel, mãe dos statements 
curatoriais, esta mudança de paradigma só ocorreu em 2002 com a XI Documenta (ESCHE, 2OII).

$\mathrm{Na}$ mesma linha, as transformações propostas para a $27 \mathrm{a}$. Bienal de São Paulo — como o fim das representações nacionais, a curadoria coletiva, a construção de uma plataforma de discussão para além da exposição (seminários, publicações e mostra de filmes) e a implementação de residências artísticas_ _ foram parte de um processo de inserção da Bienal de São Paulo no contexto internacional mais amplo do sistema global das artes, afastando-a definitivamente do modelo da Bienal de Veneza e aproximando-a da Documenta de Kassel.

\subsubsection{Como Viver Junto e a crítica a globalização}

A interrogação “como", inserida no "viver junto", invadiu a 27a. Bienal, com a guerra entre Israel e o grupo Hizbollah ("Partido de Deus"), interrompendo o ritmo de trabalho dos artistas libaneses convidados. Sem representação nacional, o continente mais difícil de ser desbravado foi a África. (LAGNADO, 2006a, p.54).

O projeto curatorial da 27a. Bienal estabeleceu um eixo conceitual estruturado a partir das notas e do seminário Como viver junto de Roland Barthes ${ }^{6}$ — que deram nome à mostra — e do repertório propositor de Hélio Oiticica ${ }^{7}$ — mesmo que suas obras não estivessem expostas nesta edição da Bienal. Segundo Lagnado, "Oiticica estava procurando reunir uma série de elementos para dar sentido a sua mais importante investida: liquidar a representação para superar o modelo de exposição" (Idem, 2006a, p.55). A proposta de Lagnado era retomar as proposições de Oiticica, mostrar seu caráter visionário ${ }^{8}$ e posicioná-lo como uma referência essencial para

6 Roland Barthes (1915-1980) foi um dos mais importantes intelectuais do século 20, semiólogo francês foi ligado ao movimento estruturalista.

7 Hélio Oiticica (1937-1980), artista carioca, é considerado um dos mais experimentais artistas do século 20. Durante os anos I950 participou dos grupos Frente e Neoconcreto. Em 1969, fez uma emblemática exposição na White Chapel Gallery em Londres. Passou grande parte dos anos I970 em Nova Iorque.

8 Termo utilizado por Lagnado ao se referir à atualidade das proposições de Oiticica. 
a arte contemporânea. Neste sentido, o projeto trazia em seu conceito a escala local e global ao trabalhar com os seminários de Barthes e destacar uma fase da obra de Oiticica pouco divulgada e valorizada no cenário artístico internacional.

[...] agora pelo viés não mais de suas obras, mas de seus escritos e de suas proposições críticas, permitiria, portanto, uma nova revisão das perspectivas eurocêntrica que foram formuladas no contexto da arte contemporânea a partir dos anos I990, principalmente aquelas em torno dos conceitos de instalação e participação do espectador (SPRICIGO, 2009, p.I54).

Por meio do tema, a exposição abordou disputas territoriais, guerras, segregação, e a impossibilidade de convívio, ou seja, tratava de questões políticas relacionadas à globalização. Para Lagnado, “É por isso que os conflitos de identidade, território e sobrevivência no mundo globalizado ganham uma tônica especial na exposição. Era uma ferida e tocamos nela. O que brota nem sempre é agradável” (LAGNADO apud BRASIL, 2006, p.35).

A expansão das bienais desde os anos 1990 apoiou uma visão do globalismo como produto inevitável do nosso tempo e o tema tem sido abordado de diversas formas nas principais mostras (O’Neill, 20I2). O’Neill cita exemplos de exposições com esse caráter que também foram referências importantes para Lagnado e sua equipe de curadores e os ajudaram a pensar a plataforma da 27a. Bienal:

- Documenta 10 (1997): a curadora Catherine David ${ }^{9}$ propõe uma visão inclusiva da história da arte mundial, na qual a heterogeneidade da estética contemporânea seria usada para prover uma multiplicidade que representa a mudança que se manifestou com o processo de globalização. David construiu a base teórica da mostra a partir dos livros The year 1967: from art objects to public thing: or variations on the conquest of space (1997), de Jean-François Chevrier, que aborda a relação entre poética e política, e objeto de arte e atividade artística nos anos I960; e o conceito de distância ativa, de Jacques Rancière, utilizado pela curadora para distinguir obras que deslocam o individuo e incitam a partilha de um espaço comum. Apesar da abordagem pós-colonialista, a curadora da mostra recebeu críticas por privilegiar artistas ocidentais no espaço expositivo e os não ocidentais no programa de eventos (SPRICIGO, 2009, p.76). No entanto, David foi uma referência importante para Lagnado. A curadora francesa foi responsável pela internacionalização de Oiticica ao colocá-lo na Documenta X e, posteriormente, realizou uma mostra

9 Catherine David (nascida em 1954) é historiadora de arte francesa, curadora e diretora de museu. David foi a primeira mulher e a primeira curadora estrangeira da Documenta X (1997), em Kassel, Alemanha. 

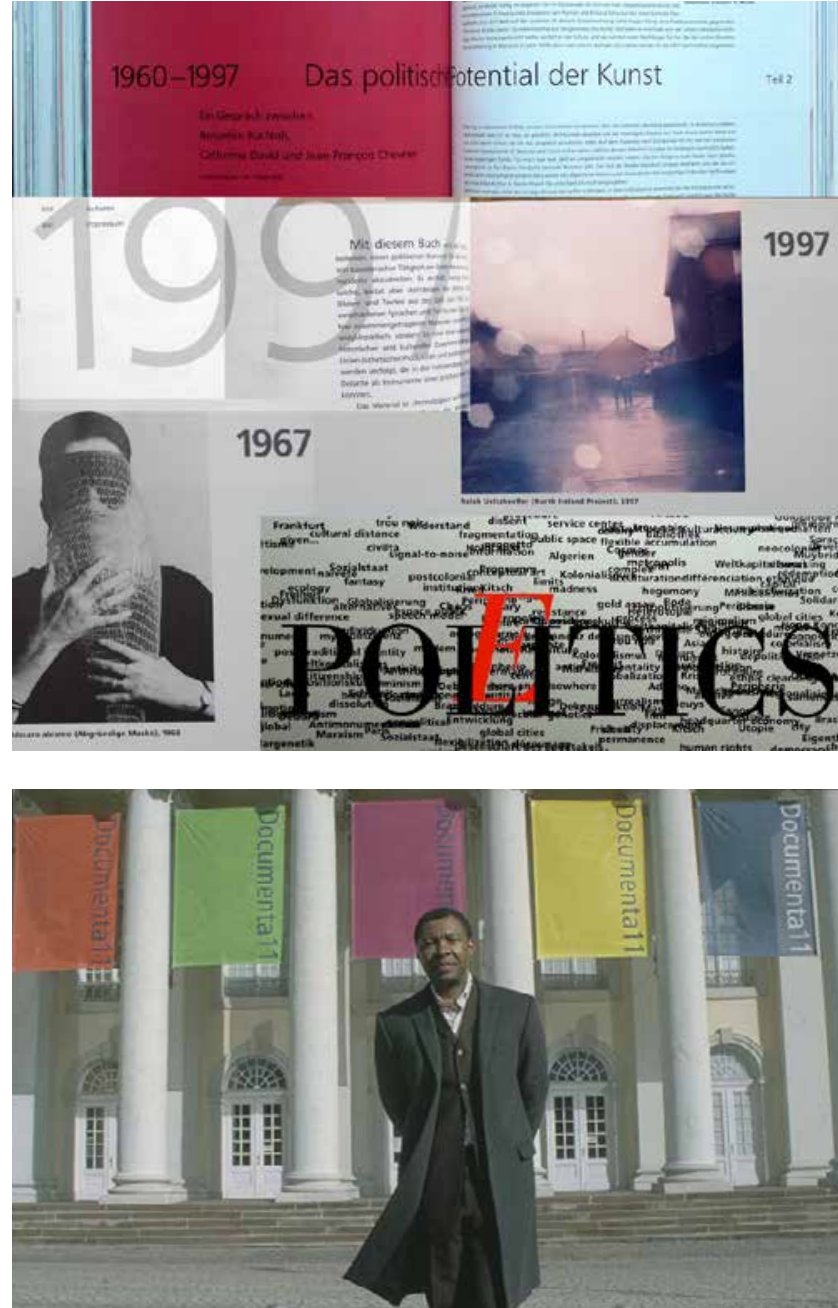

[no topo] Imagem do site da Documenta de Kassel 10 (1997). Fonte: site Documenta X. Disponível em: <https://documentax. wordpress.com/documenta-kassel-1997/>. Acesso: 02 jan. 2019. [embaixo] O diretor artístico da Documenta 11 (2002), Okwui Enwezo em frente ao Museu Fridericianum, no edificio foram instalados cinco bandeiras coloridas reprentando as cinco plataformas da mostra. Fonte: oncurating. Foto: Ryzard Kasiewic. Disponível em: <http://www.oncurating.org/issue-33-reader/post-north-documenta11-and-the-challengesof-the-global-exhibition.html\#.XCPFH1xKiUk>. Acesso: 02 jan. 2019. retrospectiva do artista. Ademais, Lagnado também adota como fonte Rancière, citando-o diversas vezes no catálogo da mostra (SPRICIGO, 2009).

- Documenta 11 (2002): o curador Okwui Enwezor ${ }^{10}$ inovou ao propor cinco plataformas que incluíam debates e exposições espalhadas em cinco cidades de quatro continentes diferentes: Viena (Áustria)/Berlim (Alemanha), Nova Délhi (Índia), Santa Lucia (Caribe), Lagos (Nigéria) e Kassel (Alemanha). A exposição de Kassel tinha como objetivo criar um espaço que mesclasse obras de arte e ideias, assim como é possível conecta fragmentos aceitando suas multiplicidades e diversidades. Essa foi a primeira Documenta a reunir artistas em uma escala global com uma postura crítica diante da história da arte eurocêntrica. Enwezor utilizou a estrutura de poder na mostra para dar voz a discursos periféricos com diferentes estratégias pós-coloniais (SPRICIGO, 2009, p.83,). O caráter das plataformas de Kassel foi revisitado pela 27a. Bienal de São Paulo, com um caráter mais local do que global, e a visão crítica acerca da história da arte também foi um dos eixos da mostra de 2006

Io Okwui Enwezor (nascido em I963) é um curador nigeriano, crítico de arte, escritor, poeta e educador, especializado em história da arte. Foi o primeiro curador não ocidental da Documenta de Kassel. 
- 50a. Bienal de Veneza (2003): com o título Sonhos e conflitos: a ditadura do observador e curadoria de Francesco Bonami, tem como tema o glomanticismo, que une "globalismo e romantismo, onde economia e informação finalmente intersecta com a complexidade da identidade individual e as emoções” (BONAMI apud O'NEILL, 20I2, p.67). A Bienal de Veneza é citada pelos curadores da 27a. Bienal de São Paulo como um modelo a ser combatido por seu caráter de feira e manutenção das divisões geopolíticas. (PEDROSA, 2006a)

- Manifesta 6 (2006) em Nicósia, Chipre: A bienal europeia com curadoria coletiva de Mai Abu ElDahab, Anton Vidokle e Florian Waldvogel tinha como proposta transformar o evento em uma escola de artes para debates e produção, procurando fugir do caráter espetacular da mostra e criar um espaço de encontro entre comunidades locais. $\mathrm{O}$ projeto não foi concluído após o cancelamento de contrato com os curadores pela Câmara Municipal. " A Manifesta consistiu um modelo para os curadores da 27a. Bienal ao adotar a curadoria coletiva e ao sugerir a dissolução do caráter espetacular das mostras internacionais de artes.

II Disponível em: <https://www.e-flux.com/announcements/41260/letter-from-former-curators-of-manifesta-6/>. Acesso em: 02 jan. 2019 .
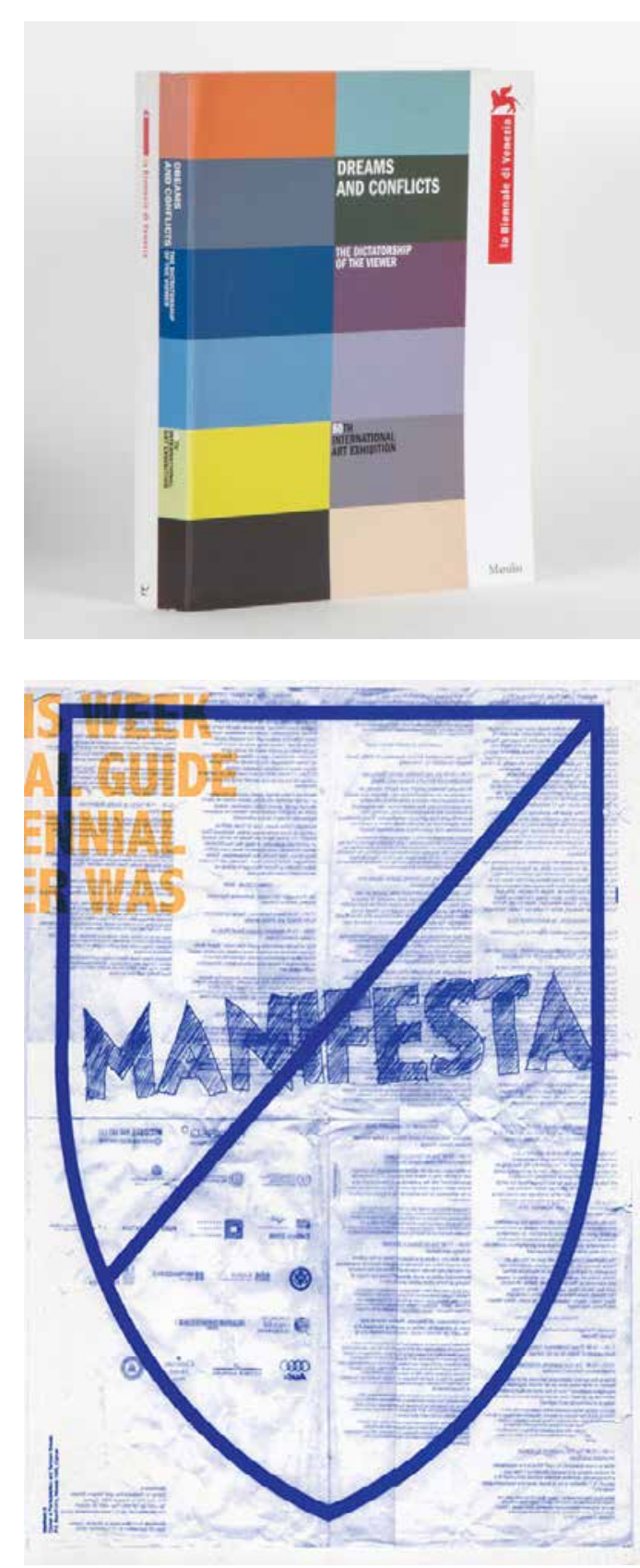

[no topo] Capa do catálogo da 50a. Biennale di Venezia (2003). Fonte: left matrix. Disponível em: <http://www. leftmatrix.com/veniceb50.html>. Acesso: 02. jan.2019.

[embaixo] Nicosia This Week. An Unofficial Guide to the Biennial that Never Was.

Esse guia alternativo para a cidade de Nicósia, Chipre, foi produzido para acompanhar Manifesta 6. Após o cancelamento abrupto da bienal em 2006, esta semana tornou-se um dos poucos registros históricos de um grande evento que nunca aconteceu. Fonte: art book. Disponível em:<http:// www.artbook.com/9789086900527. html>. Acesso 02.jan. 2019. 


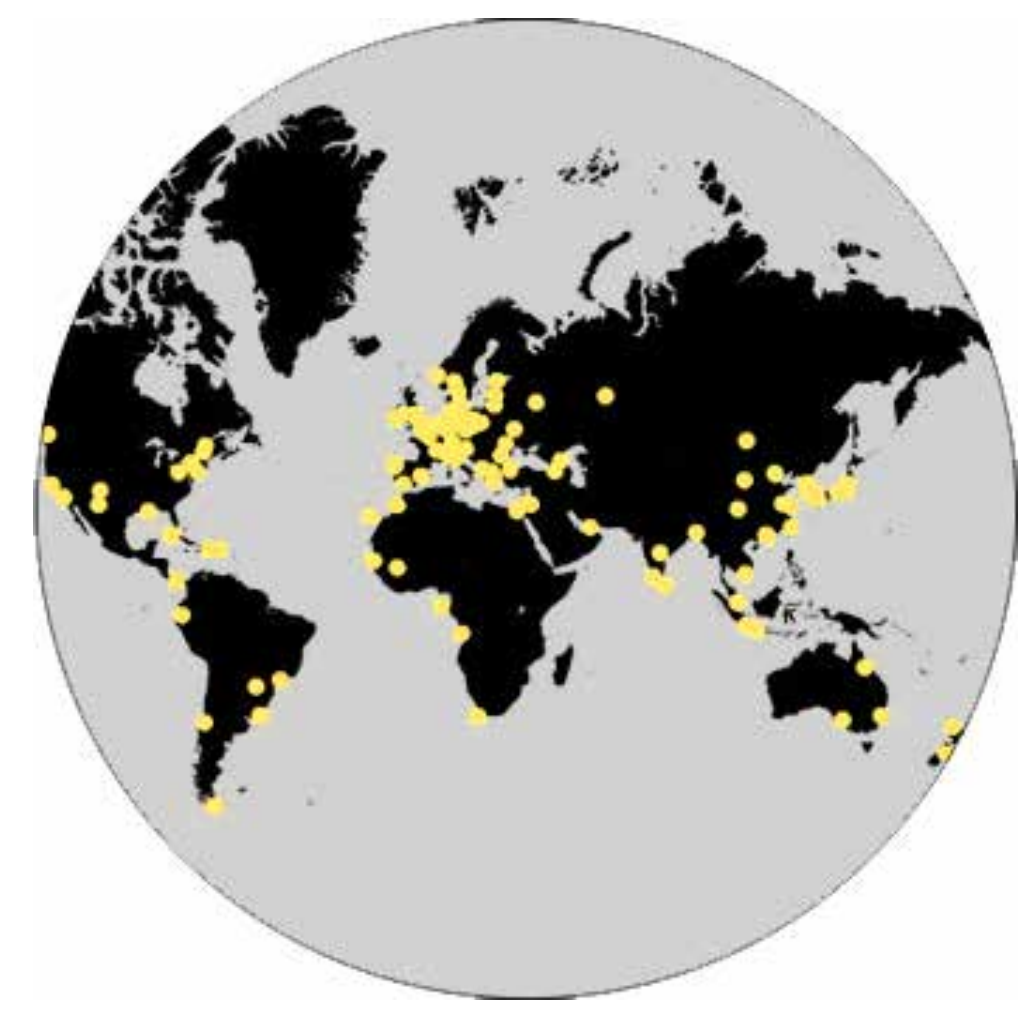

Mapa indica as cidades sedes de bienais pelo mundo em 2018 Fonte: Biennial Foundation. Disponível em: <http://www. biennialfoundation.org/home/biennial-map/>. Acesso em:02.ja.2019.
No entanto, O’Neill (2OI2) argumenta que há sempre uma contradição e/ou inconsistência nas posturas críticas à globalização dessas exposições, já que as bienais estão inseridas no hierárquico sistema global das artes e, mais do que isso, são um produto do mesmo.

A difusão de bienais, especialmente no hemisfério Sul e no Oriente, levou a uma globalização no campo da arte que, por sua vez, gerou uma extensão espacial das relações sociais: incentivou a mobilidade de artistas e curadores, o adensamento de interações sociais e a inserção de artistas não ocidentais no circuito internacional. A construção desta rede social ampliada deu argumentos à teoria que defendia a globalização cultural como um processo de inclusão e democratização cultural (Esche, 20II).

Contudo, Buchholz e Wuggening (20II) demonstram no artigo "Globalização cultura mito e realidade: o caso da arte visual contemporânea" que, apesar da aparente inclusão, o valor simbólico ${ }^{12}$ dos artistas ocidentais se manteve historicamente acima dos não ocidentais. Assim como a inserção destes no mercado global das artes não foi proporcional à difusão de bienais que ocorreu a partir dos anos I990. Segundo os autores, a interpenetração cultural não causou nenhum efeito digno de

I2 Para mais informações ver artigo de Lara Buchholz e Ulf Wuggenig, "Cultural Globalization Between Myth and Reality: The Case of the Contemporary Visual Arts", ART-E-FACT, no.4. Disponível em: <http://artefact.mi2.hr/_ ao4/lang_en/theory_buchholz_en.htm>. Acesso em: 02 jan. 2019 . 
nota na estrutura de poder. "Ainda seria o regime representacional ocidental que ditaria os modos de apropriação da arte não ocidental, seria o poder simbólico do ocidente que atribuiria à arte não ocidental o papel exótico de alteridade"I3 (Idem, 20II).

Havia uma intenção clara da curadoria da 27a. Bienal de inserção da Bienal de São Paulo na cena artística internacional por meio da construção de uma plataforma de debates sobre a arte contemporânea, a globalização cultural e a arte global, deixando de lado a aproximação por critérios formais que havia sido adotada nas edições anteriores. Consequentemente, os artistas selecionados para a mostra produziam trabalhos engajados socialmente e com forte viés político.

A exposição não foi bem recebida por grande parte dos críticos, que apontava para a ausência de obras como expressão individual, argumentando que os trabalhos apresentados tinham cunho puramente social e eram privados de caráter estético. Também acusavam que o discurso curatorial era autoritário, submetendo as obras a sua narrativa.

As críticas foram publicadas em diversos artigos em periódicos e sites especializados: "Bienong - Ou como viver junto do jeito que eu quero", de Rafael Campos Rocha (2006), que se referiu ao caráter social das obras como um

I3 Tradução da autora. Texto original: "it would be still the Western representational regime that dictates modes of appropriation of non-Western art, and it would be still the symbolic power of the West that attributes non-occidental art the role of playing its 'exotic', but nevertheless self-assuring "other”." modismo internacional, comparou-as a organizações não-governamentais (ONGs). Em seu texto "Vanguarda do tédio", o historiador e crítico de arte Jorge Coli observa que "O álibi das intenções éticas e intelectuais não conseguem substituir o interesse da criação"(COLI, 2006), e critica a curadoria autoral: "Na atual mostra, os artistas não vivem juntos; vivem debaixo: da ideia, do conceito, das determinações imperiosas" (Idem, 2006). No artigo "Na mostra, ética eclipsou a estética", Juliana Monachesi (2006) declara que a 27a. Bienal foi redundante: "Mas a monotonia não está apenas na montagem da exposição, está na escolha dos curadores de privilegiar a postura ética do artista em detrimento da experiência estética que as obras poderiam gerar". Em “Arte, terceiro setor", ${ }^{14}$ o jornalista Bernardo Carvalho (2006) reiterou a ideia de que não havia arte na mostra: “[...] como não pode eliminar o mercado na qual a própria Bienal está inserida, optou por abolir o artista e a arte, sob o espirito das ONGs, substituindo o valor da individualidade autoral pela ação comunitária e o bem comum”.

Os principais aspectos críticos levantados pelos autores poderiam ser resumidos pelas dicotomias conceito e criatividade, ética e estética, individual e coletivo, arte e mercado. Em que pese as críticas, o resultado da mostra foi coerente com seu projeto curatorial que tinha como eixo o Programa

I4 Este artigo consta no catálogo da exposição comemorativa 30x Bienal como única referência à 27 a. Bienal. 
Ambiental de Oiticica. No catálogo, há uma reprodução do documento original do subterranean tropicalia projects (1966) que se inicia pelo conceito de

Anti-arte — compreensão e razão de ser do artista não mais como um criador para a contemplação mas como um motivador para a criação — a criação como tal se completa pela participação dinâmica do espectador, agora considerado como participador" (OITICICA apud LAGNADO; PEDROSA, 2006a p.22).

Tropicália, Penetráveis PN2 e PN3, 1967 de Hélio Oiticica. Fonte: Anjos, 2012. Foto: César Oiticica Filho. Disponível em: <http://www.scielo.br/scielo php?script $=$ sci $\_$arttext\&pid $=$S1678-53202012000200022\&ln

$\mathrm{g}=$ en\&nrm=iso\&tlng =pt>. Acesso em: 02 Jan.2019.

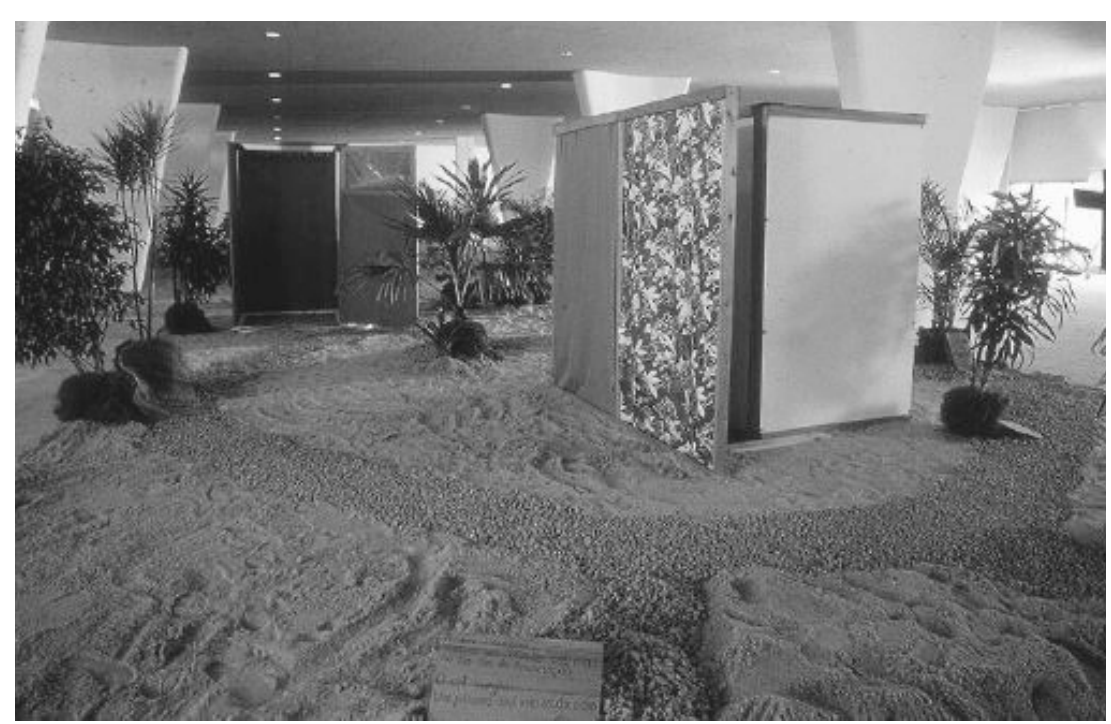

Oiticica propõe a transformação do papel do artista, que deixa de ser apenas criador e passa a ser um propositor. Segundo Favaretto, o ambiental se completa quando as estruturas são transformadas em receptáculos abertos a significação, lugares para recriação da subjetividade.

Essa abertura à participação vai exigir uma reconfiguração da concepção do artista e do trabalho de arte, incluindo o trabalho artístico na cultura, e por aí o político como intrínseco e não como uma necessidade que vem apenas de fora. Digo “apenas” porque a demanda vinha de toda parte; naquele tempo era impossível ao artista ficar imune a essa contaminação do contexto, a necessidade interna estava contaminada do externo. É por aí que a Anti-arte ambiental acaba tendo uma 
configuração muito específica com Oiticica, o que faz dela até hoje uma coisa surpreendente, no sentido em que ela pode ser entendida de muitas maneiras, embora as circunstâncias, cada situação, cada artista, cada lugar, sejam muito diversos, e a questão das relações entre o externo e o interno, entre as experimentações e o contexto social, político e cultural, continuem sendo o problema principal quando se pensa a conjunção de arte e política (FAVARETTO,2009, p.9).

Portanto, no que se refere às críticas citadas, o que estava em confronto eram diferentes concepções artísticas.

O caráter coletivo, interativo e social das obras da 27 a. Bienal estava presente na produção de diversos artistas contemporâneos de destaque no circuito internacional. Em I998, Nicolas Bourriaud ${ }^{15}$ publicou o livro Estética relacional, que teve uma grande divulgação e tornou-se uma referência no meio. A estética relacional foi formulada a partir da convivência do autor com grupos de artistas dos anos I990, entre os quais Rirkrit Tiravanija, Philippe Parreno, Liam Gillick, Pierre Huyghe e Dominique Gonzales-Foerster. Segundo Bourriaud, as obras de arte relacionais procuram estabelecer encontros em que o significado é elaborado coletivamente e

I5 Nicolas Bourriaud (França, I965) é curador e crítico de arte. Com Jérôme Sans, Bourriaud cofundou o Palais de Tokyo em Paris, onde atuou como codiretor de 1999 a 2006. estão vinculadas às contingências de seu ambiente e público, em contraponto à autonomia da arte moderna. Portanto, estabelecem uma nova relação entre arte e público: configuram uma situação em que os espectadores são levados a criar uma comunidade, ainda que temporária ou utópica; são produções coletivas que minimizam o status da autoria individual por meio de obras abertas à interação e constante transformação.

Bourriaud procurou redefinir a agenda da arte contemporânea desvinculando-a da história da arte dos anos I960. Para ele, as obras são uma resposta à mudança econômica baseada em serviços, à globalização e à internet e outras tecnologias, e por isto trazem uma mudança de atitude social. Ao invés de propostas utópicas dos anos I960, adotam propostas microtópicas, com soluções provisórias que possibilitam habitar o mundo de uma forma melhor. Para o curador, as obras relacionais, por seu caráter social e interativo, são tão politizadas quanto as da geração dos anos I960 (BISHOP, 2004).

Em 2004, Claire Bishop ${ }^{16}$ escreveu o artigo "Antagonism and relational aesthetics", ${ }^{17}$ no qual ressalta que a importância do livro Estética relacional de Bourriaud está em identificar uma tendência recente da arte contemporânea. A autora critica o fato de não haver antagonismo nas obras citadas por Bourriaud, dado

I6 Claire Bishop é historiadora de arte, crítica e professora no departamento de história da arte no CUNY Graduate Center, em Nova York.

I7 Claire Bishop. "Antagonism and relational aesthetics". October, n. IIo, fall 2004, P. 5I-80. 
essencial da democracia, o que enfraquece o caráter político das obras. Nas relações propostas pelas obras da estética relacional as pessoas se identificam umas com as outras porque elas têm algo em comum e não há conflito. Argumenta que há um longo histórico de participação do público na história da arte e que simplesmente ativar o espectador não é um ato democrático em si, porque toda a obra de arte dá o limite de atuação do público.

As tarefas que se colocam diante de nós atualmente são analisar como a arte contemporânea se dirige ao observador e avaliar a qualidade das relações com o público que ela produz: a posição do sujeito que qualquer trabalho pressupõe as noções democráticas que sustenta e como elas se manifestam na experiência do trabalho (BISHOP, 20II. p.I3I).

Bishop analisa algumas obras de Tiravanija a partir da leitura de Bourriaud, para quem ele é um artista paradigmático da estética relacional. O artista, que trabalha entre a performance e instalação, montou cozinhas coletivas e uma reprodução de seu apartamento em uma galeria, onde o público poderia cozinhar, tomar banho ou dormir. Nas suas palavras:

Suas instalações refletem a compreensão de Bourriaud de que as relações produzidas por trabalho de arte relacional são fundamentalmente harmoniosas, porque são dirigidas a uma comunidade de sujeitos com algo em comum. Esse é o motivo pelo qual os trabalhos de Tiravanija são políticos apenas no sentido mais vago, quando o que se defende é o diálogo em relação ao monólogo (a comunicação de apenas uma via igualada ao espetáculo pelos situacionistas). [...] A microtopia de Tiravanija abre mão da ideia de transformação na cultura pública e reduz seu escopo aos prazeres direcionados a um grupo privado em que uns se identificam com outros — todos frequentadores de galeria (BISHOP, 2OII, p. I23).

$\mathrm{Na}$ 27a. Bienal, a proposta de Lagnado era abordar esta produção contemporânea que emerge nos anos I990 a partir de uma perspectiva histórica, não eurocêntrica. A construção desta perspectiva na mostra se deu pela estruturação do statement curatorial a partir das proposições de Oiticica e pela inserção de artistas considerados históricos-contemporâneos: Ana Mendieta, Gordon Matta-Clark, Marcel Broodthaers e Felix Gonzalez-Torres. Para a curadora, a teoria propositiva de Oiticica foi fundamental para se pensar a interatividade nas artes; e o sentido ético-social do Programa Ambiental teve mais repercussão na arte contemporânea atual do que quando foi elaborado nos anos I960. A proposta buscava ampliar o recorte de Bourriaud e aprofundar a leitura do caráter político das obras, transcendendo a questão da interatividade (FIALHO, 2006). 
Em 2006, Claire Bishop publicou na revista Artforum o artigo "The social turn: collaboration and its discontents", no qual aborda a virada social da arte impulsionada por artistas que se afastaram da obra de arte como objeto de consumo e adotaram práticas colaborativas. Bishop questiona o abandono da estética por parte destes artistas, assim como considera necessário que os críticos deixem de avaliar sua produção por critérios éticos e passem a discuti-la e compará-la como arte, ou seja, a partir da estética. A autora argumenta que as melhores práticas colaborativas tratam da força contraditória entre a autonomia da arte e a intervenção social, na estrutura da obra e na sua recepção (2006). Em visita à 27a. Bienal, Bishop rebateu as críticas ao caráter assistencialista das obras, argumentando que a abordagem social foi uma das frentes de desenvolvimento da arte contemporânea que tomou a forma de projetos engajados socialmente e transdisciplinares. ${ }^{18}$ Sobre a reivindicação dos críticos à 27 a. Bienal pela transcendência pela arte, Bishop afirmou que:

[...] o paradigma romântico de arte transcendente foi desafiado e desmantelado por artistas ao longo de todo século 20, precisamente porque ele apresenta a arte como algo universal que se eleva acima da realidade social e política" (BISHOP, 2006a).

I8 Bishop cita o descompasso do Brasil em relação ao desenvolvimento da arte contemporânea, se referindo às $25 a$. e 26 a. Bienais, que tiveram uma abordagem conservadora voltada ao mercado.
Para Bishop, a maioria dos trabalhos da mostra tem uma lógica estética que é íntegra à suas especificidades e o fato de se sustentarem de forma bem-sucedida dentro do espaço expositivo no pavilhão também é um indicativo de seu caráter estético $^{\text {19 }}$ (idem, 2006a).

A 27a. Bienal e suas obras relacionais, portanto, estava conectada com as discussões da época e da vanguarda contemporânea. A curadoria trouxe um olhar crítico para essa produção contemporânea a partir das proposições de Oiticica, que resultou em obras consistentes na maioria dos casos. A construção do projeto curatorial da mostra procurou atualizar a Bienal de São Paulo em questões latentes do circuito internacional desde os anos 1990. A dificuldade de aceitação de obras com viés social e coletivo pela crítica brasileira revelou, em muitos casos, uma desconexão com esta produção recente e uma cisão com as discussões e críticas internacionais. No entanto, em 2006, em com a globalização cultural consolidada pensar na Bienal de São Paulo como apartada do circuito global das artes revela uma abordagem equivocada.

I9 Este é um dos pontos que a crítica aponta como problemática no que concerne artistas europeus que, em nome de um engajamento político, não enfrentam a representação do trabalho para o público. 


\subsubsection{Fim das Representações Nacionais}

A primeira novidade da 27a. Bienal de São Paulo, intitulada “Como viver junto”, é o fim do segmento tradicional das representações nacionais. Essa mudança exprime a sua atualização e o seu vigor num mundo globalizado, onde a arte rompe fronteiras e continua a propor uma leitura crítica dos acontecimentos contemporâneos (GIL ${ }^{20}, 2006$, p.54).

Segundo O’Neill, o fim das representações nacionais nas bienais internacionais passou a acontecer a partir do final dos anos 1970, quando a curadoria transcende as fronteiras geográficas e olha para a rede cultural global como sua fonte material. Exemplo paradigmático desta mudança foi a exposição Les Magiciens de la Terre (1989), que substituiu a tradicional Bienal de Paris e mudou o sistema de seleção nacional de obras para explorar as práticas artísticas da Ásia, da África e da América Latina ao lado de trabalhos contemporâneos da Europa e dos Estados Unidos. Para Esche, a za. Bienal de Havana, que prescindiu de pavilhões e representações nacionais em um país pós-comunista e latino-americano, foi paradigmática para a difusão desse novo modelo de exposição

20 Ministro da cultura de 2003 a 2008, governo Luís Inácio Lula da Silva. internacional desvinculado dos padrões estabelecidos pela Bienal de Veneza.

A Bienal de São Paulo foi criada em I95I por Francisco Matarazzo Sobrinho e tomou como referência a estrutura geopolítica da Bienal de Veneza. Esse modelo passou a ser questionado a partir de I98I, momento em que surge a figura do curador e quando a desigualdade de recursos financeiros entre os países e a seleção de obras que não condiziam com a proposta curatorial geral passou a ser problematizada. Em depoimento, Paulo Herkenhoff (2008) afirmou que procurou aproximar a 24a. edição, da qual foi curador, ao modelo intelectual da Documenta de Kassel, propondo uma Bienal estruturada em relação ao discurso curatorial, contudo sem criar alarde para que a instituição não o impedisse de se afastar do modelo geopolítico da Bienal de Veneza.

$\mathrm{Na} 27 \mathrm{a}$. Bienal, a proposta de transformação da estrutura já constava no projeto curatorial, que vinculava as diretrizes adotadas ao discurso de Hélio Oiticica. Segundo Lagnado:

Havia duas coisas que o Hélio tentava combater: a ideia de representação, e por isso acabamos com as representações nacionais, e o sentido ético na arte, de não se preocupar que as obras fossem apenas belas, mas pudessem transformar o espectador, que é o que ele chama de "desestetização" (LAGNADO apud CYPRIANO, 2005, E4). 
Para os curadores, havia uma crise de representatividade, visto que ao longo dos anos as Bienais passaram a criticar o modelo vinculado às representações nacionais, o que deixava todo o seu sistema organizacional fragilizado. O conceito de nação passou a ser questionado tanto por artistas que não queriam representar seus países, quanto por curadores que questionavam a impossibilidade de escolher um artista que representasse uma nação.

Se o primeiro passo foi abolir as chamadas representações nacionais [...] os demais passos também pertencem ao esforço determinado de conferir uma dimensão política a uma mostra tão importante para a cidade, o Brasil e mundo (LAGNADO; 2006a, p. 53).

Havia uma resistência na Fundação Bienal de se desvincular do padrão de Veneza, de modo que o concurso para a seleção de projeto curatorial realizado para 27a. Bienal finalmente legitimou esta mudança na estrutura institucional.

Segundo Pedrosa (2006), as representações nacionais estavam relacionadas às exposições universais do século I9. Naquele momento, viajar era pouco acessível e então se reunia em pavilhões nacionais arte e artefatos culturais para que o público tivesse conhecimento das produções de países distantes. Modelo que se tornou ultrapassado a medida que o turismo foi sendo democratizado. Pedrosa argumenta a favor do papel do curador neste novo modelo de mostra:

Se nem todos podem viajar para conhecer outras culturas, ao menos os curadores responsáveis por bienais podem fazê-lo e assim realizar um grande número de viagens de pesquisa para selecionar, eles mesmos, os artistas pertinentes à mostra que organizam, compondo um conjunto mais consistente e coeso (PEDROSA, 2006a, p.82).

Assim, se tornou praxe que os curadores viajassem pelo mundo para fazer a seleção de obras, o que foi nomeado por Lagnado como curador-viajante. ${ }^{21} \mathrm{O}^{\prime}$ Neill destaca que a mobilidade é um pré-requisito para a curadoria no século 2 I. Considera o aumento no número de viagens dos curadores um subproduto das bienais. Essas figuras passaram a ser nômades, capazes de propor exposições conectadas a uma rede global de conhecimento. O novo papel do curador é selecionar e expor arte internacional através de critérios subjetivos cuja questão central é inclusão da alteridade.

Curadores de bienal tendem a ser excepcionalmente bem viajados, e suas exposições conectam em um

2I Termo adotado por Lagnado no anteprojeto da 27a. Bienal de São Paulo. 
complexo conhecimento de rede global. É o curador que viaja mais, que tem o maior alcance do trabalho, quem tem o sentido mais amplo da prática, o curador cuja atividade (exposição) está mais próxima da prática e tem o maior impacto nela. ${ }^{22}$ (MEYER apud

O’NEILL, 20I2, p.73-74)

Os curadores da 27a. Bienal viajaram pelo mundo buscando por obras e artistas que contribuíssem para a narrativa proposta por eles. E houve um grande investimento em trazer artistas não ocidentais. Segundo Lagnado, essa foi a Bienal de São Paulo com a mais ampla e diversificada presença de artistas africanos.

Contudo, a intensão de reduzir a desigualdade entre a quantidade de obras de países periféricos e centrais na mostra após o fim das representações nacionais não foi atingida em sua plenitude. Após essa mudança estrutural, a verba da Bienal continuou sendo proveniente de empresas e embaixadas com interesses específicos de patrocinar o que lhes convêm. Em texto sobre a 24a. Bienal, publicado na revista Afterall, Lagnado faz uma autocrítica acerca da ausência de autonomia dos curadores com o fim das representações nacionais.

22 Tradução da autora. Texto original: “ It's curators who travel the most, who see the greatest range of work, who have the broadest sense of practice; the curators whose activity ( exhibition) is closest to practice and has the greatest impact on it".
O evento de São Paulo está em uma encruzilhada inesperada: como lidar com expectativas mais altas do sistema internacional do que do seu público local? Avaliada em termos de pedagogia crítica e análise a lacuna entre um evento e sua reflexão acadêmica, bem como entre um evento e as massas, descobrimos que a Bienal ainda tem que imprimir um padrão ético para sua estratégia curatorial que demonstra sua independência da metrópole ou de qualquer força que expresse poder. Lamentavelmente, mesmo a abolição das representações nacionais não constituiria o horizonte desejado de autonomia: hoje os imperativos do mercado ameaçam afogar contribuições, incluindo as obras mais radicais, em águas cada vez mais $\operatorname{escuras}^{23}$ (LAGNADO, 2015, p.62).

23 Tradução da autora. Texto original: "The São Paulo event is at an unexpec ted crossroads: how to cope with higher expectations from the international system than from its local audience? Assessed in terms of critical pedagogy and analyzing the gap between an event and its academic reflection, as well as between an event and the masses, we find that the Bienal has yet to imprint an ethical standard for its curatorial strategy that demonstrates its independence from the metropolis or any force that expresses power. Regrettably, even the abolishment of national representations would not constitute the desired horizon of autonomy: today market imperatives threaten to drown contributions, including the most radical works, in ever-murkier waters". 
Além do fim das representações nacionais, o tradicional núcleo histórico ${ }^{24}$ — acomodado em uma área climatizada — foi eliminado. Esse segmento já não constava na mostra anterior, com a justificativa de que os museus brasileiros estavam consolidados o suficiente para assumir o papel de fazer exposições históricas que não cabia mais a Bienal. O evento, desta forma, poderia ser discutido e elaborado pelo grupo de curadores em sua totalidade, buscando a integridade da narrativa curatorial. $\mathrm{Na}$ época, estas propostas geraram críticas favoráveis e contrarias, mas foram incorporadas pelas edições seguintes do evento e deixaram de ser questionadas.

\subsubsection{Curadoria Coletiva}

A proposta de uma curadoria coletiva já estava na carta convite do concurso da 27a. Bienal. A mudança de direcionamento em relação à edição anterior ${ }^{25}$ acompanhou a tendência no cenário mundial de bienais nas quais curadorias individuais estavam sendo substituídas por grupos de curadores, buscando uma abordagem colaborativa. As mostras com curadoria

24 No terceiro pavimento do Pavilhão da Bienal há uma área com ar-condicionado que se consolidou ao longo das mostras como núcleo museológico ou exposições especiais.

25 Com curadoria individual do alemão Alfons Hug. coletiva de maior repercussão foram a Documenta II (2002), com direção artística de Okwui Enwezor, com o apoio de um time de seis curadores, ${ }^{26}$ e que aconteceu em cinco plataformas em quatro continentes; e a Manifesta, conhecida como a bienal europeia, ${ }^{27}$ na qual curadores reconhecidos no campo das artes, sem relação direta entre si, são chamados para desenvolver em uma exposição em uma cidade estratégica da Europa com uma agenda geopolítica.

Segundo O'Neill (2OI2), Harald Szeemann ${ }^{28}$ concluiu a era de ouro dos grandes curadores na 49a. Bienal de Veneza (200I), cuja obra-chave foi The End of the 2uth Century, de Joseph Beuys. A edição posterior, a 5oa. Bienal de Veneza (2003), é considerada por O’Neill o final simbólico das grandes narrativas. O diretor artístico Francesco Bonami convidou onze curadores ${ }^{29}$ para fazer suas exposições separadamente, mas interligadas com o tema central.

Lisette Lagnado e sua equipe ${ }^{3 \circ}$ radicalizaram a proposta

26 Diretor artístico: Okwui Enwezor. Curadores: Carlos Basualdo, Susanne Ghez, Sarat Maharaj, Okwui Enwezor, Uta Meta Bauer e Octavio Zaya, Mark Nash.

27 Iniciada a partir do mercado comum Europeu.

28 Harald Szeemann (1933-2005) era curador e historiador de arte suíço. Foi curador da emblemática mostra Quando atitudes se tornam forma (1969) e iniciou a prática de curadoria independente, sem vínculo institucional.

29 Carlos Basualdo, Catherine David, Gilane Tawadros, Hou Hanru, Molly Nesbit, Hans Ulrich Obrist, Rirkrit Tiravanija, Gabriel Orozco.

30 Cocuradores: Adriano Pedrosa, Cristina Freire, José Roca e Rosa Martinez. Curador convidado: Jochen Volz. 

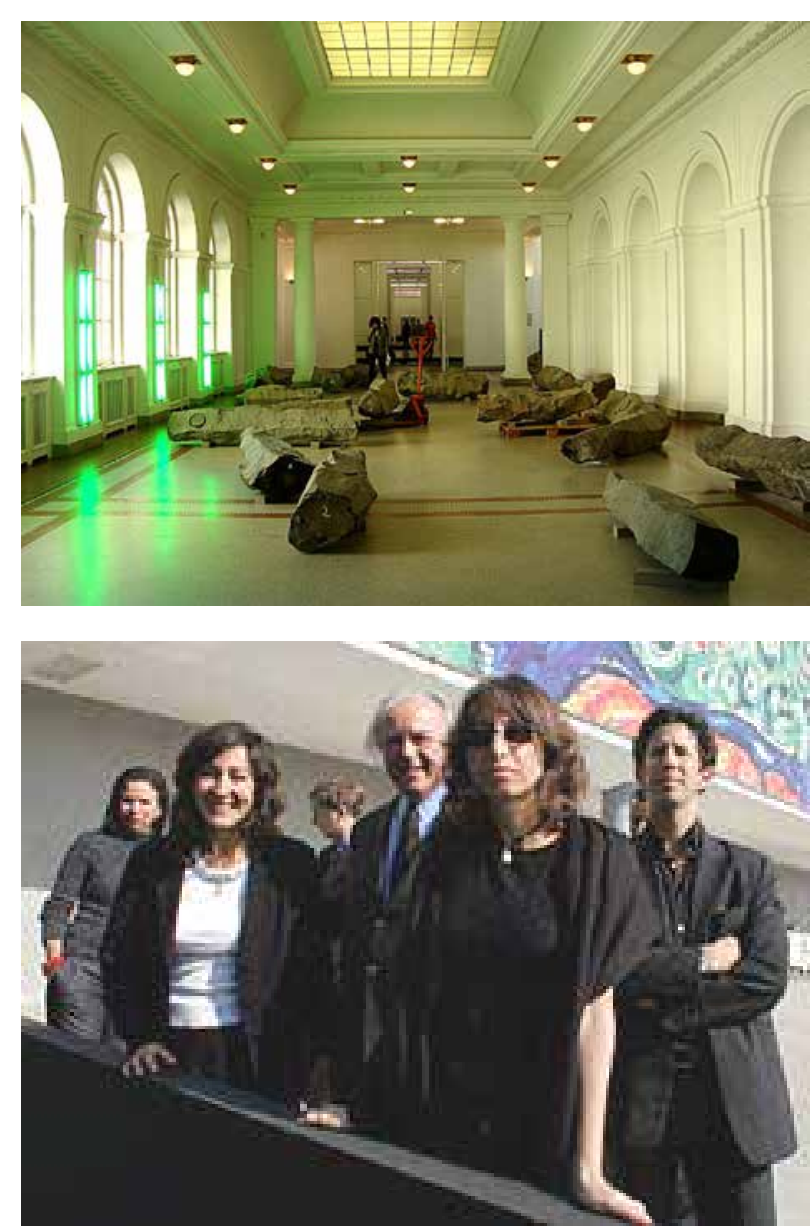

[no topo] A obra The end of the 21th Century de Joseph Beuys, exposta em Hamburger Bahnhof em Berlim (2009). Fonte: wikipedia.org. Disponível em: <http://en.wikipedia. org/wiki/The End of the Twentieth Century\#/media/

File:Berlin_museum_fur_gegenwart_Beuys.JPG.

[abaixo] A curadora geral da 27a. Bienal: Lisette Lagnado; os cocuradores: Adriano Pedrosa, Cristina Freire, José Roca e Rosa Martinez; e o curador convidado: Jochen Volz. Fonte: uol. Disponível em: https://entretenimento.uol.com.br/arte/ ultnot/2005/07/28/ult988u328.jhtm. Acesso em: 02 jan. 2019. para além do que vinha sendo feito em Kassel ou Veneza e forjaram uma nova forma de curadoria coletiva, na qual as decisões, a escolha de artistas e as discussões deveriam ser realizadas conjuntamente, com a participação de todos. Era uma proposta de trazer para a curadoria o conceito da mostra: como viver junto. Pedrosa aborda esta questão no catálogo da exposição:

Entretanto, é preciso fazer uma distinção entre curadoria em grupo e curadoria coletiva. A primeira consiste num grupo de curadores que trabalha mais ou menos de forma autônoma. [...] [N]a curadoria coletiva por outro lado, o grupo de curadores trabalha em conjunto e em discussão permanente sobre a maioria dos aspectos da mostra. Esse é o caso da Manifesta, e foi o modelo proposto por Lagnado (2006, p.84).

Embora tenha havido a defesa da curadoria coletiva na 27a. Bienal, Lagnado não abriu mão de seu papel de curadora-geral, assumindo a linha de frente nos momentos de enfrentamento seja com a Fundação Bienal, seja com os críticos. A presença do curador convidado, Jochen Volz, também revela uma contradição dentro dessa organização teoricamente sem hierarquias. Volz foi chamado para a curadoria especifica do núcleo Broodthaers a qual organizou junto com Lagnado, e teve uma participação no mostra 
distinta dos demais cocuradores. Além disso, o conceito curatorial da mostra foi construído por Lagnado baseada em sua tese de doutorado. A curadora tinha papel central tanto intelectual quanto politicamente, interferindo no equilíbrio e equidade entre curadores.

\subsubsection{Bienal além da exposição}

No final dos anos 1990, os curadores das grandes mostras internacionais passam a mobilizar o campo da investigação pública com debates, palestras, publicações, eventos e performances. Esta tendência tornou-se, de certa maneira, pré-requisito das bienais. A Documenta II é o principal exemplo dessa transformação com plataformas que consistiam em espaços de debate intelectual. Seus curadores ainda priorizaram a programação audiovisual, com a exibição de documentários contemporâneos, em detrimento dos objetos de arte, como uma maneira de evitar que a produção de artistas locais fossem fetichizada pelo mercado (O’Neill, 20I2).

Spricigo argumenta que há uma tipologia de bienal. São mostras que compartilham práticas comuns e operam de forma similar: suas obras são, em sua maioria, site specifics desenvolvidos com comunidades e em um contexto local; contemplam uma plataforma horizontal para produção de conhecimento que pode se configurar de diversas formas - com debates, seminários ou até uma escola de arte, como no caso da Manisfesta; e, finalmente, tornam-se espaços de reflexão crítica de arte e da própria exposição (2009, p. 18).

Neste sentido, a proposta curatorial da 27a. Bienal expandiu seus limites para além da exposição ao buscar um debate intelectual e fugir da efemeridade e do caráter espetacular do evento. Foram feitos seis seminários ao longo daquele ano, com temas escolhidos por cada um dos curadores como fundamentais para a preparação e discussão da mostra: Marcel, 30 (organizado pelo curador convidado Jochen Volz), uma comemoração dos trinta anos da morte de Marcel Broodthaers ${ }^{31}$, artista que direcionou sua obra para a crítica institucional aos museus; Arquitetura (organizado pelo cocurador Adriano Pedrosa), que trouxe a discussão sobre a obra de artistas fundamentais no campo da arquitetura e da arte como Gordon Matta-Clark e Dan Graham (ambos presentes na mostra); Reconstrução (organizado pela cocuradora Cristina Freire), que discutiu temas como migração, diáspora e questões de identidade e de gênero; Vida coletiva (organizado pela curadora-geral Lisette Lagnado), que trouxe as discussões de Roland Barthes e o Programa Ambiental de Hélio Oiticica para o

3I Marcel Broodthaers (1924-1976), após atuar como poeta por duas décadas, decidiu que seria artista visual em 1964. Sua obra tinha com intensão discutir a missão dos museus, o papel do artista, a relação vida e arte e sua relação comercial. 


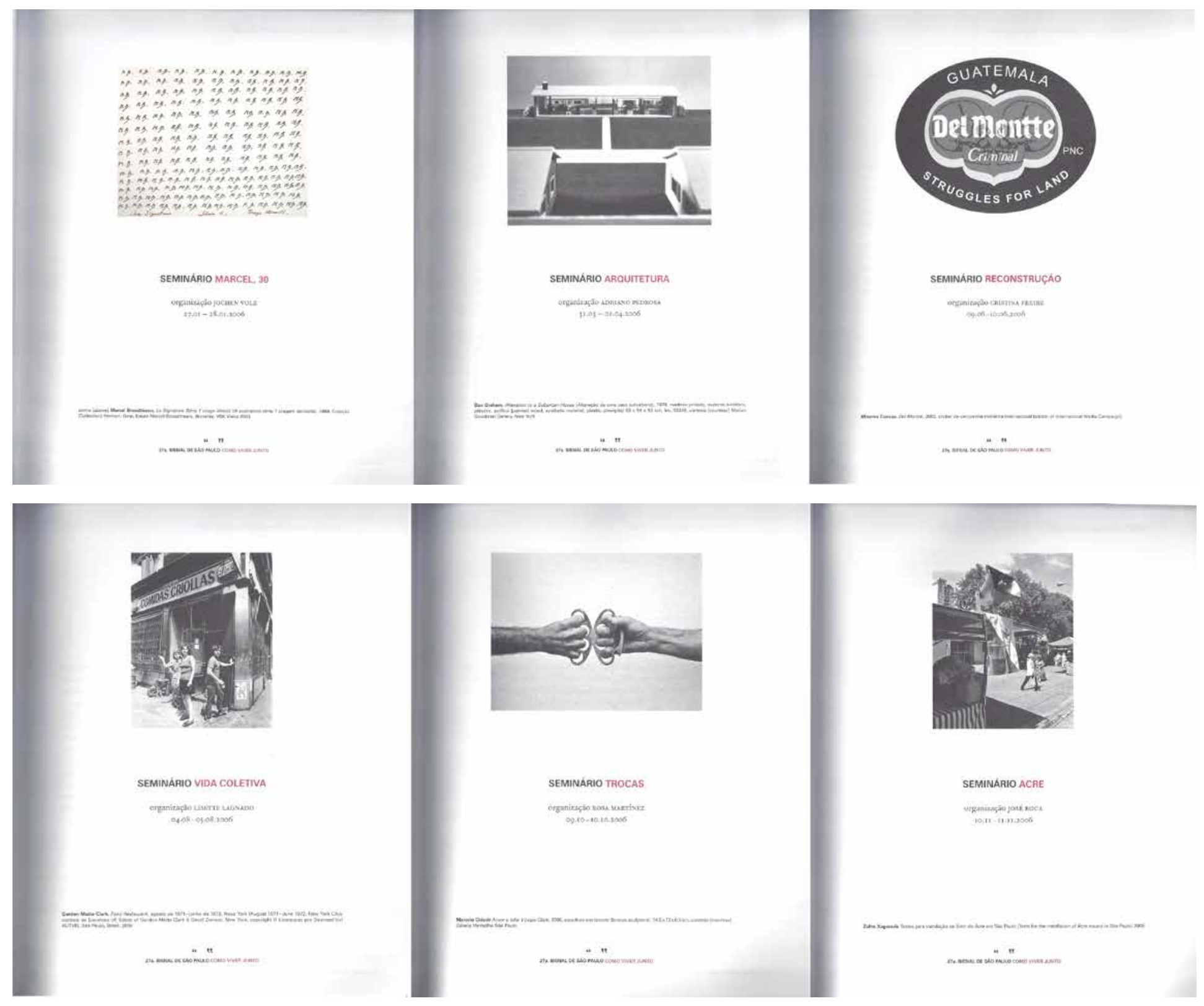

Composição com capas dos folders dos cinco seminários da 27a. Bienal. Fonte: LAGNADO, 2008. 
contexto político a artístico atual; Trocas (organizado pela cocuradora Rosa Martinez), que enfoca as ideias de transferência e intercâmbio como modos mais otimistas de organização entre as pessoas; Acre (organizado pelo cocurador Jose Roca), que abordou questões de fronteiras, direito a terra e território a partir de um olhar para o Estado do Acre.

Pedrosa indica que uma referência para fazer os seminários foram as plataformas da Documenta II (2002). "Os seminários da 27a. Bienal, entretanto, não têm a aspiração global das plataformas da Documenta e preocupam-se em estabelecer um diálogo mais próximo com o público paulistano, numa introdução aberta a crítica da exposição” (PEDROSA, 2006a, p.85). Até aquele momento, as Bienais de São Paulo faziam palestras, ou discussões pontuais; foi em 2006 que, pela primeira vez, a Bienal virou um projeto maior que a exposição.

As publicações também foram reformuladas: não foi feito apenas o catálogo, mas também um guia voltado para público leigo e uma publicação com a transcrição dos seis seminários. Como organizadores do catálogo, Lagnado e Pedrosa construíram meticulosamente uma narrativa que aprofundava as discussões da mostra. Seguindo a proposta elaborada na 24 a. Bienal por Pedrosa, ${ }^{32}$ o catálogo deixou de funcionar apenas como um registro das obras de arte e foi pensado como um

32 Adriano Pedrosa foi curador adjunto de Paulo Herkenhoff e responsável pela produção dos catálogos da 24a. Bienal. livro de teor crítico e reflexivo. A publicação contemplou textos originais do Programa Ambiental de Oiticica, verbetes de Barthes inseridos entre textos dos curadores e de diversos autores e artistas, ${ }^{33}$ e contou com obras de artistas feitas exclusivamente para o catálogo, como a de Rivane Neuenschwander, que não estava presente na mostra.

O design gráfico e sinalização da exposição foram desenvolvidos por Rodrigo Cerviño e Cassia Buitoni. A sinalização contou, além das etiquetas padrão com o título das obras, com textos descritivos de cada artista contextualizando os trabalhos expostos. Cerviño também foi autor do cartaz da mostra em parceria com o artista Jorge Macchi.

A 27a. Bienal também investiu no educativo, deixado a cargo Denise Grinspum, ${ }^{34}$ que desenvolveu um projeto de formação de educadores, outro voltado para o treinamento de professores - que incluía o fornecimento de material didático - , e um programa com o objetivo de trazer moradores da periferia para a exposição. O educativo foi pensado em

33 Além do texto dos curadores havia textos de Eliane Robert Moraes, Gianni Vattimo, León Ferrari, Milton Hatoum, Zayd Minty, Teresa Caldeira e Ali Behdad.

34 Denise Grinspum é arte educadora. Graduada em Licenciatura em Educação Artística pela FAAP (198I). Realizou o mestrado em Artes (I99I) e doutorado em Educação (2000), ambos pela Universidade de São Paulo. Foi diretora do Museu Lasar Segall de 2002 a 2008, onde implantou e coordenou a Área de Ação Educativa em (1985 a 2002). Foi a curadora do projeto educativo da 27a. Bienal de São Paulo, em 2006. 
conjunto com a curadoria desde o princípio, buscando ampliar e democratizar a mostra. O papel pedagógico está na base das funções atribuídas à Bienal de São Paulo e o trabalho do educativo foi essencial para aproximar as escolas públicas e o público em geral da arte contemporânea. O que se vê no caso da Bienal de São Paulo é que a cada edição o projeto educativo é mais fortalecido — tendência também no cenário internacional.

Essas propostas aproximaram a Bienal de São Paulo do que vinha sendo proposto nas demais bienais internacionais, cada vez mais vistas como veículos para produção de conhecimento e debate intelectual. Para Spricigo (2009), trazer para o centro do debate a globalização é o que possibilitou a inserção da Bienal no circuito internacional.

A 27a. Bienal também se expandiu para além dos limites físicos do pavilhão: havia obras de arte espalhadas nas proximidades do pavilhão e também pelo parque Ibirapuera, como Double terrain de jeu (pavillon-marquise), de Dominique Gonzalez-Foerster, que implantou falsos pilares no pavilhão e na marquise; Geometrias daninhas, de Hector Zamora, que produziu uma intervenção impedida de ser concluída no lago. ${ }^{35}$ Ainda havia obras espalhadas pela cidade, ampliando o diálogo com a metrópole em que a Bienal se insere, tais como a instalação urbana de Renata Lucas no bairro da Lapa, intitulada Matemática rápida, matemática lenta, que duplicava uma calçada e todos os elementos que a compõe, como postes, guias e árvores; as intervenções nas torres de ventilação da linha I de metrô, projetadas por Grönlund-Nisunen; a visita aos terrenos baldios de São Paulo realizada por Lara Almarcegui; a instalação de sons da Amazônia na avenida Rio Branco, por Zafos Xagoraris; e o projeto JAMAC (Jardim Miriam Arte Clube), que fez intervenções nas fachadas do Bairro Jardim Miriam. Para as visitas às obras do JAMAC, mais afastada que as demais obras fora do parque, a Bienal forneceu um ônibus que transportava o público ao bairro periférico Jardim Miriam durante o período da exposição. Além disso, ocorreu a Quinzena de Filmes, com a presença de parte significativa da programação da Bienal em duas salas de cinema da cidade.

35 A obra consistia em implantar no lago 51 octógonos de aguapés, no entanto, a administração do parque, alegando um impacto ambiental, proibiu a inserção das plantas. A obra então se restringiu às estruturas de PVC flutuando pelo parque. Hector Zamora acabou propondo um projeto na praia recanto das crianças, em São Vicente, com uma rede de boias no mar. 
Mapa do Parque do Ibirapuera com a indicação das obras externas ao pavilhão: 1.Damian Ortega; 2.Gordon Matta-Clark; 3.Dan Graham

4. Dominique Gonzalez-Foerster; 5. Marcelo Cidade.

Fonte: Arquivo Wanda Svevo.

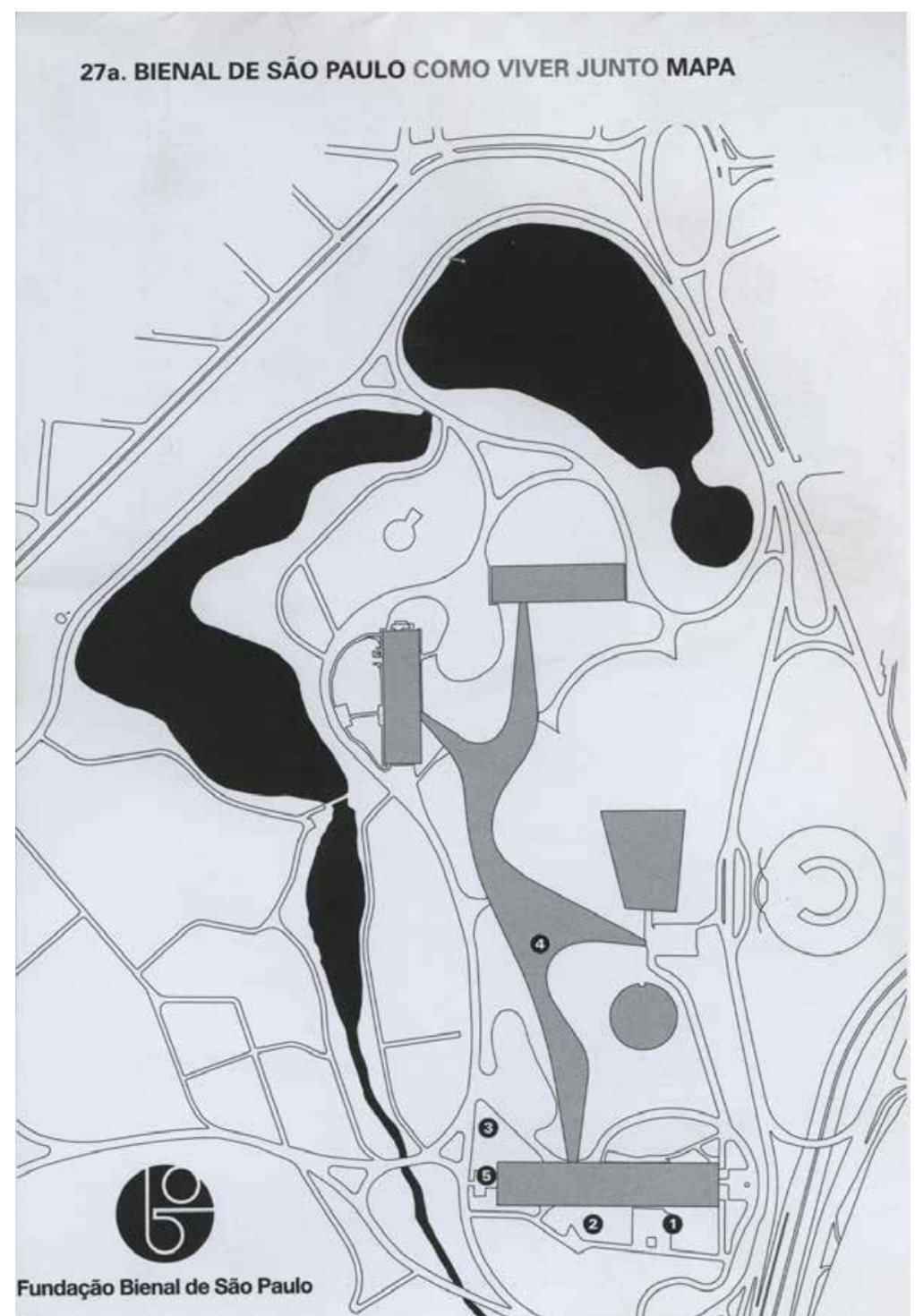

[no topo] Double terrain de jeu de Dominique Gonzalez-Foerster na marquise do Parque lbirapuera. Fonte: site Bienal. Disponível em: https://bienal org.br. Acesso em: 02 Jan.2019.

[embaixo] Geometria daninhas de Hector Zamora no lago do Parque. Fonte: Arquivo Wanda Svevo.
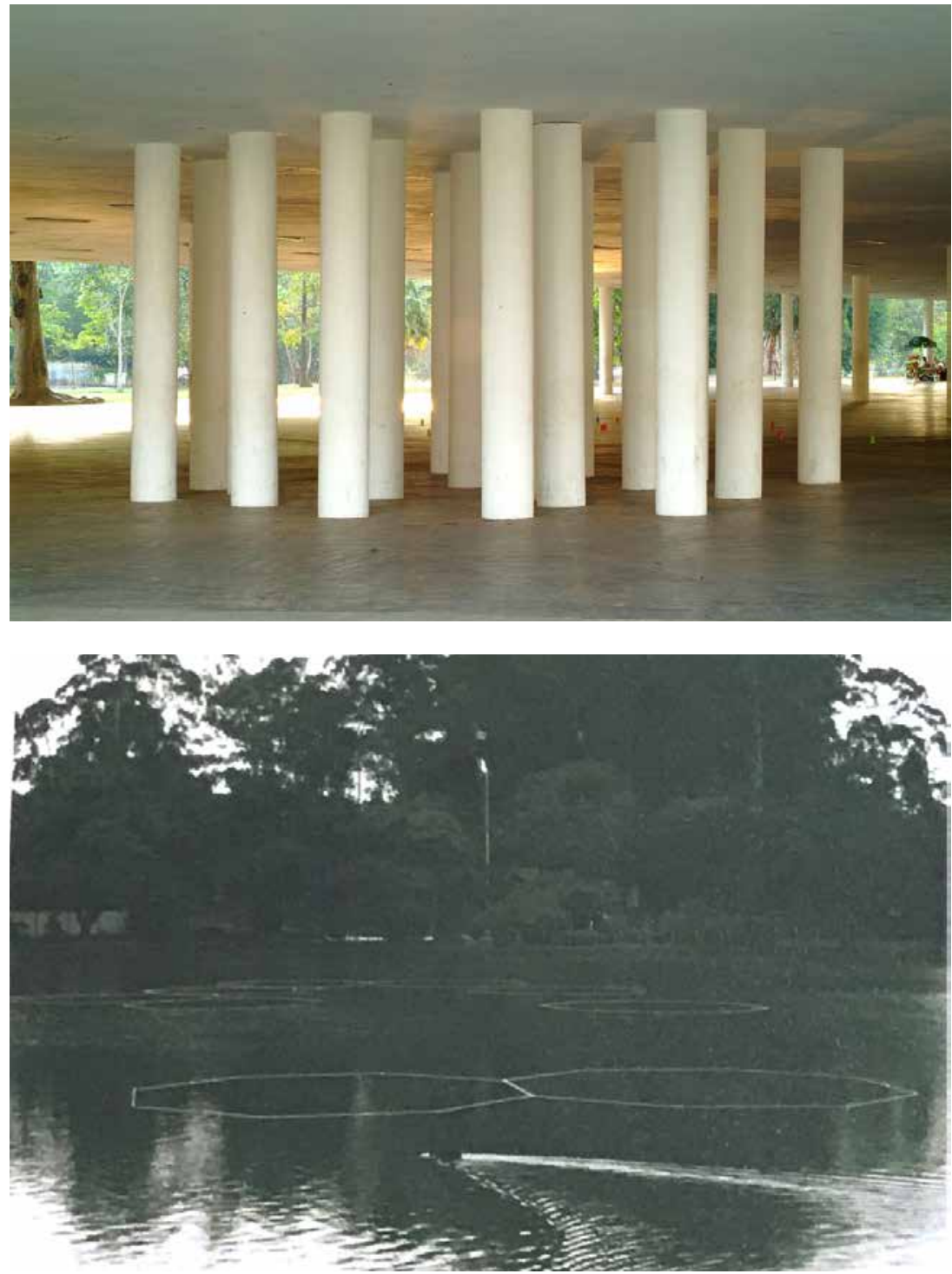
[no topo à dir.] Variations on a Theme de Grönlund e Nisunen -intervenção na linha 1 do metrô. Capa do guia produzido pelos artistas. Fonte: Arquivo Wanda Svevo.

[embaixo à esq.] Variations on a Theme: São Bento tower de Grönlund e Nisunen -intervenção na linha 1 do metrô. Fonte: site Grönlund e Nisunen

Foto: (c) Tommi Grönlund. Disponível em: http://g-n fi/2006 sao paulo.php. Acesso 15 de jan. de 2019

[embaixo à dir.] Variations on a Theme: Liberdade tower de Grönlund e Nisunen -intervenção na linha 1 do metrô. Fonte: site Grönlund e Nisunen. Foto: () Tommi Grönlund. Disponível em: http://g-n.fi/2006_sao_paulo.php Acesso 15 de jan. de 2019

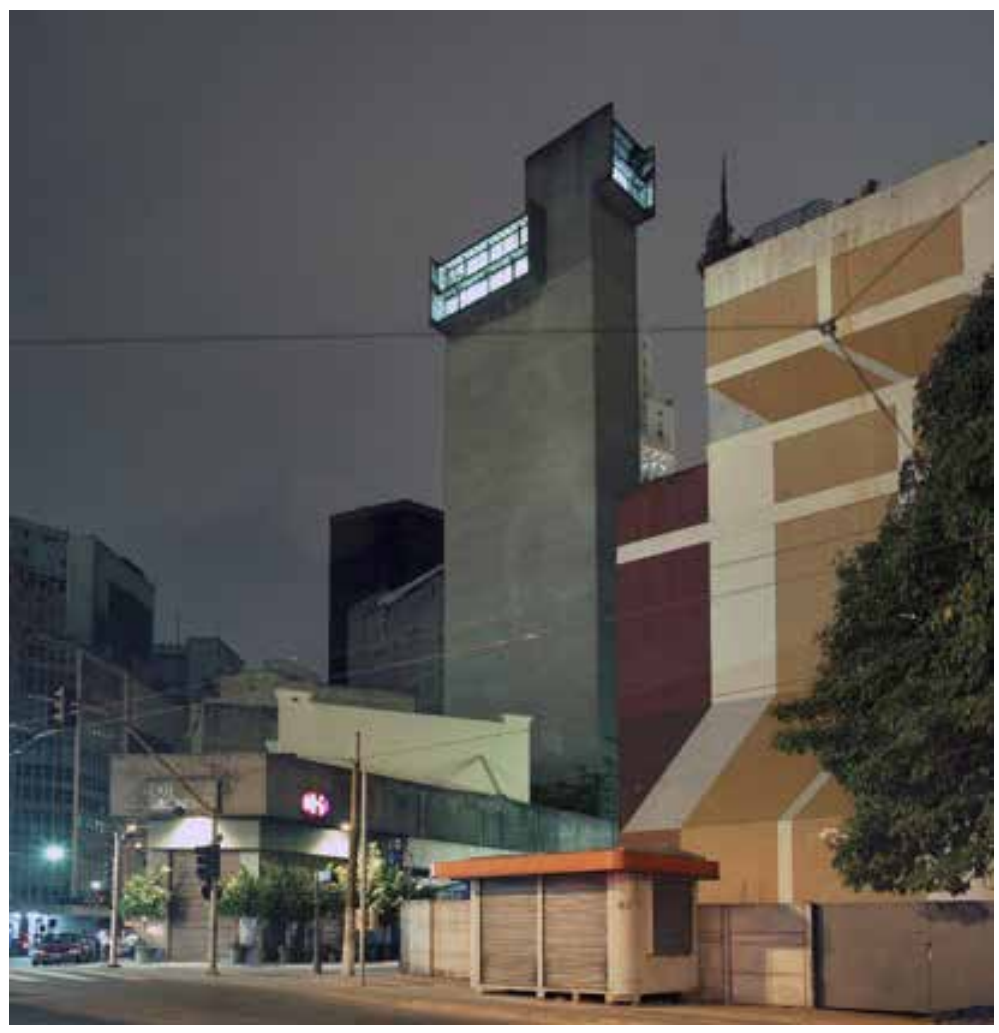

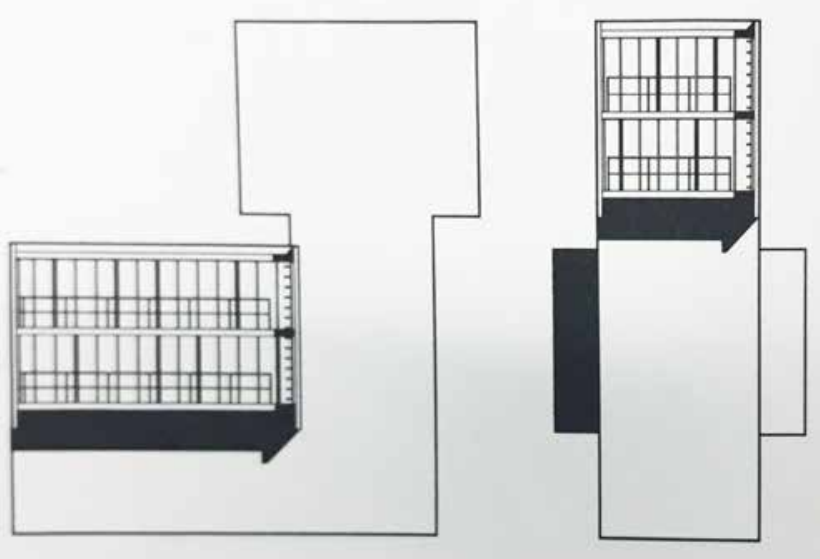

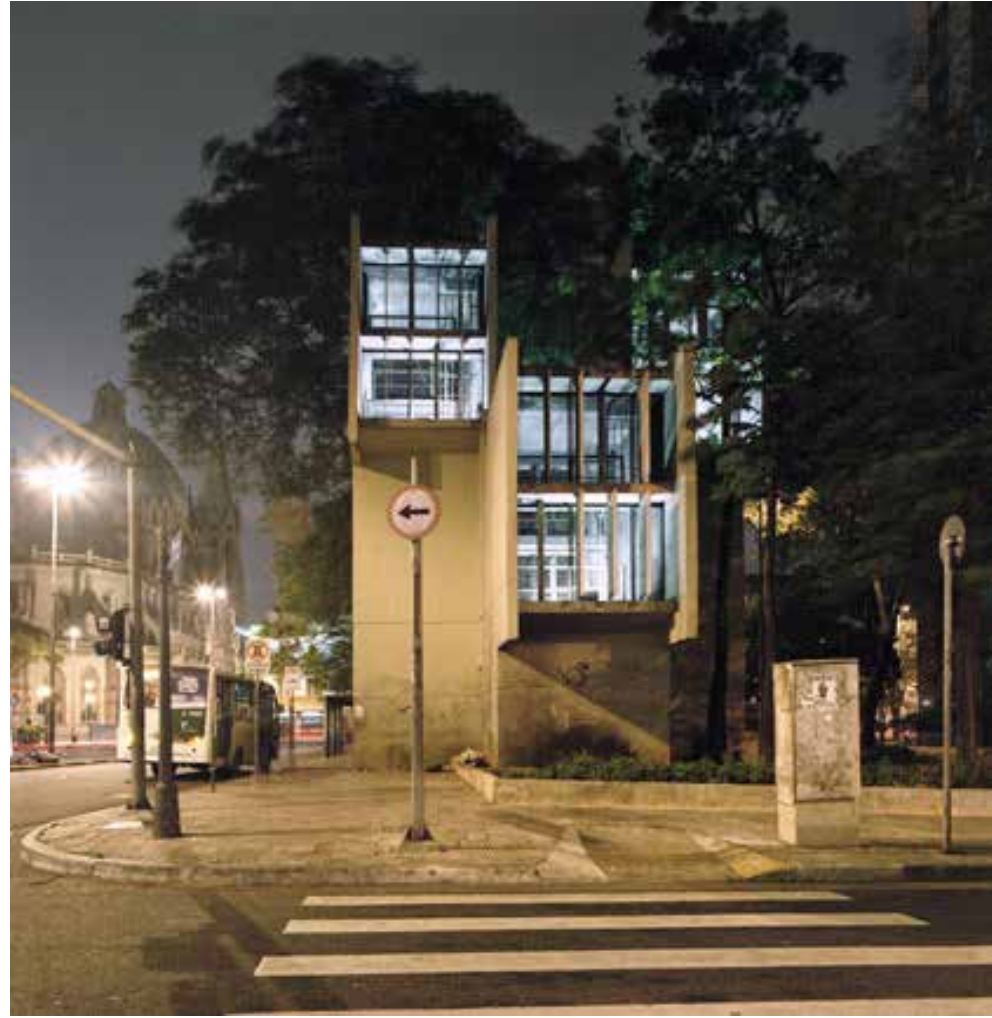

EXPOGRAFIA NA 27a. BIENAL DE SÃO PAULO 


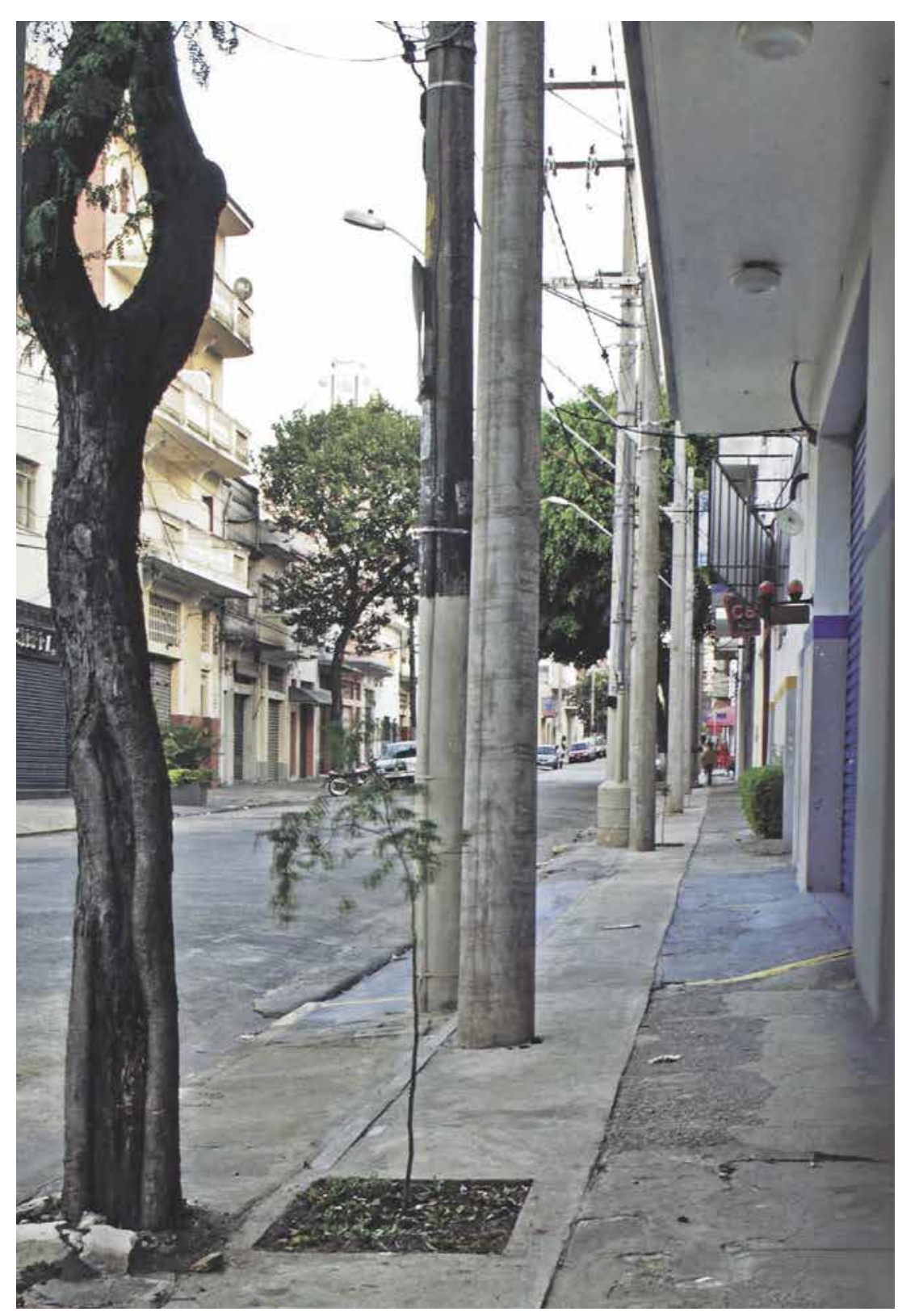

Matemática Rápida, Matemática Lenta de Renata Lucas no bairro da Lapa. Fonte: LAGNADO, PEDROSA (2006a).
GUIA DE TERRENOS BALDIOS DE SÃO PAULO

GUIDE TO THE WASTELANDS OF SÃO PAULO

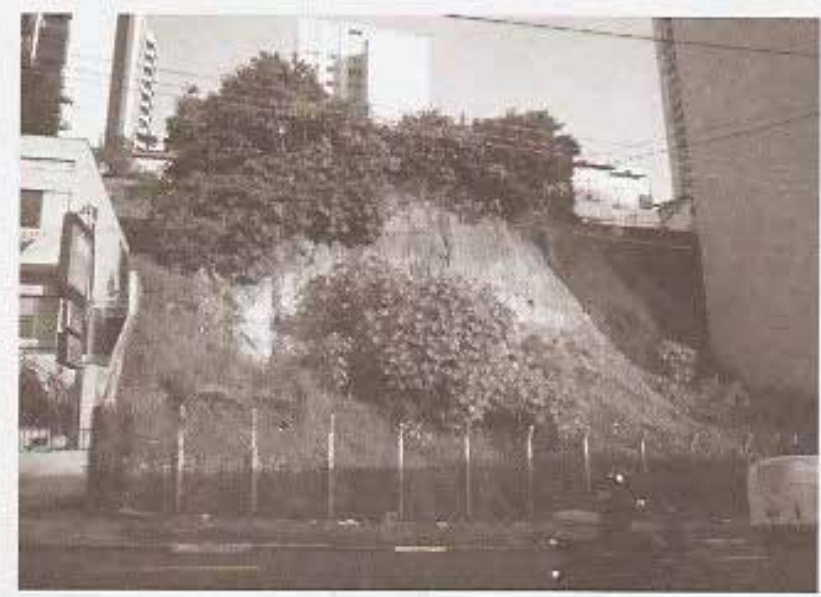

Uma seleçăo dos lugares vazios mais interessantes da cidade A setecrion of the most intoresting emply placeses in thet gat

Guia de terrenos baldios de Lara Almarcegui. Fonte: Arquivo Wanda Svevo. 


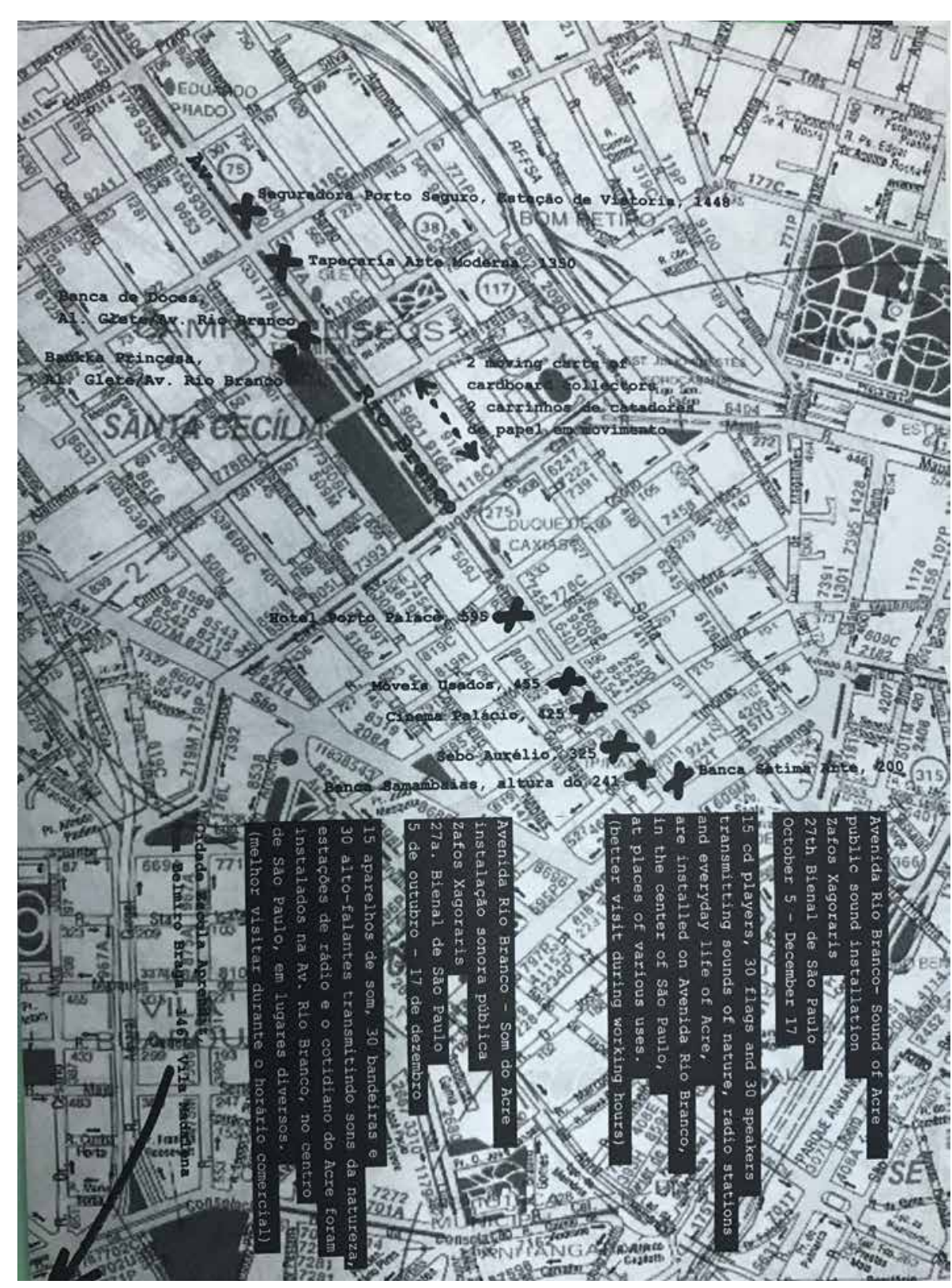

Folder da obra Sound of Acre - Avenida Rio Branco de Zafos Xagoraris. Fonte: Arquivo Wanda Svevo.

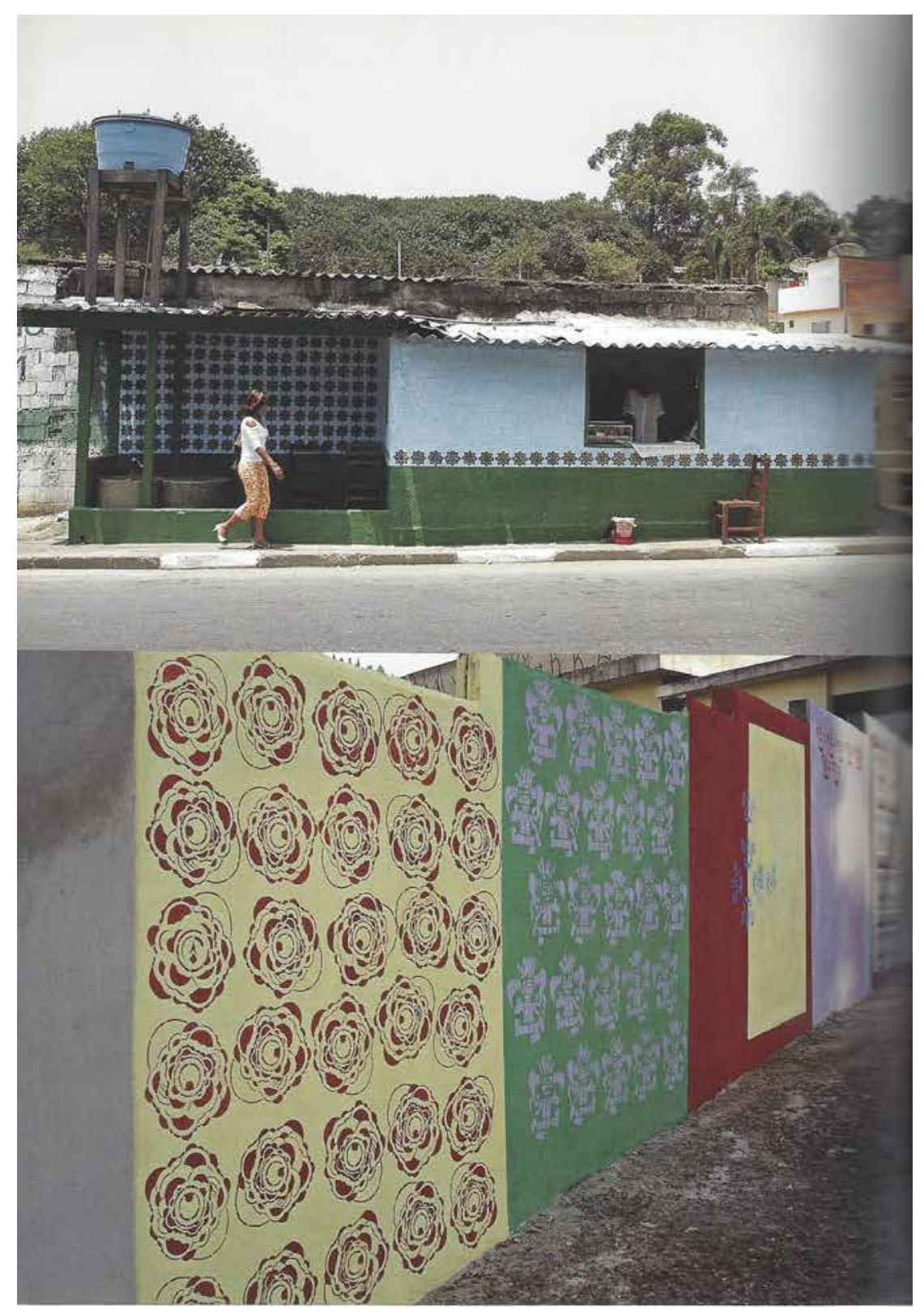

Bar da Maria e Muro do JAMAC. Fonte: LAGNADO, PEDROSA (2006a). 


\subsubsection{Residências artísticas}

A 27a. Bienal convidou dez artistas ${ }^{36}$ para fazer residências artísticas em Rio Branco, Recife e São Paulo. Esta foi outra proposta pioneira desta mostra.

Na era da exposição global [...] não se trata apenas de importar obras do estrangeiro, mas também de trazer artistas para que possam se familiarizar com o local onde a mostra é realizada e lhes oferecer oportunidade de responder à especificidade do sitio (PEDROSA, 2006a, p. 85).

No capítulo "Contexturas: sobre artistas e/ou antropólogos" do catálogo da mostra, Cristina Freire discorre sobre esta transformação do trabalho artístico contemporâneo:

As instituições e práticas artísticas não se definem mais, há algum tempo, em termos espaciais, ou seja, não se localizam num estúdio, museu ou ateliê ou galeria. Instalam-se, antes, numa rede discursiva e dirigem-se a um sujeito social marcado

36 Alberto Baraya, Marjetica Potrc e Susan Turcot, Meschac Gaba, Armando Andrade Tudela, Florian Pumhösl, Francesco Jodice, Lara Almarcegui, Minerva Cuevas e Shimabuku. pela diferença étnica, econômica, política e sexual

(FREIRE, 2006, p.IO7).

Freire argumenta que apesar do paradigma do artista como etnógrafo ter sido sistematizado por Hal Foster ${ }^{37}$ no final dos anos 1990, muitos artistas já haviam abordado esta questão em manifestos nos anos i960 e i970. O Programa Ambiental de Hélio Oiticica, de i966, é um dos precursores citados; os Parangolés ocupam este lugar entre arte/música/dança/ arquitetura que se realizam na vivência do artista e do espectador (2006):

Há uma vontade de um novo mito proporcionado aqui por esses elementos da arte (construtividade popular), há uma interferência deles no comportamento do espectador, uma interferência contínua e de longo alcance, que se poderia alcançar nos campos da psicologia, da antropologia, da sociologia, da história (OITICICA apud FREIRE, 2006, p.III).

Portanto, a abordagem antropológica das obras de arte estava contemplada no eixo do projeto curatorial da $27 \mathrm{a}$. Bienal:

37 Se refere ao texto "O artista como etnógrafo", publicado no livro O retorno do real, de Hal Foster. 
Esse é o local mais buscado (o Acre) para residências artísticas. Elas podem trazer a imagem de um Brasil exótico, mas convidamos artistas que têm a prática de deslocamento, da pesquisa antropológica (LAGNADO apud CYPRIANO; 2005b, p.E4).

As residências artísticas propostas na 27a. Bienal estavam previstas no anteprojeto curatorial e tinham como premissa o caráter inovador e a proposta de criar uma rede de relações do local com o global, nas palavras de Lagnado: "Cada cidade será escolhida de acordo com o vínculo da pesquisa [...] fazendo com que as instituições locais possam fruir da experiência do estrangeiro que vem de longe" (LAGNADO, 2005, p.7). O'Neill indica dois conceitos importantes para entender esta difusão e sustentação das bienais como modelo internacional dominante: glocal e contemporâneo. Glocal é um termo cunhado nos anos i980 que designa um ponto de intersecção entre o global e o local em uma rede de inter-relações. A política local é muito significativa para as bienais, já que dá status cultural à cidade e a insere em uma rede global. $\mathrm{O}$ formato também é eficiente para consolidar o mercado da arte internacional. O local influencia na escolha dos artistas, do tipo de arte que será exibido e a qual público irá contemplar a exposição ( $\mathrm{O}^{\prime} \mathrm{N}$ eill, 20I2). O conceito de contemporâneo é essencial para as bienais que estão sempre se reinventando e propondo novas tendências. Desta forma, os curadores são pressionados a serem cada vez mais dinâmicos, carismáticos e capazes de identificar novos artistas e obras para o conteúdo de suas exposições. As bienais promovem uma prática artística relacionada ao contexto local ou dentro da narrativa curatorial, e uma nova arte é exposta antes de ser sancionada pelo mercado da arte. Assim, cada evento aspira ser mais contemporâneo e global que os seus similares ( $\mathrm{O}^{\prime} \mathrm{Neill}$, 20I2). As residências artísticas propostas na 27a. Bienal e o grande volume de trabalhos site specific produzidos a partir da vivência dos artistas no Brasil revelam a clara intensão da curadoria de valorização do local e da inserção da mostra na rede global descrita por $\mathrm{O}^{\prime} \mathrm{Neill}$.

\subsubsection{A 24a. Bienal como referência}

A 24a. Bienal (1998) foi uma referência essencial para Lagnado e sua equipe ao montarem seu projeto curatorial. Por esse motivo, fazer uma análise crítica da relação entre as duas exposições torna-se uma ferramenta importante para aprofundar o estudo sobre a 27a. Bienal.

A mostra de 1998 teve como curador-geral Paulo Herkenhoff, como curador adjunto Adriano Pedrosa e mais uma equipe de 74 curadores, sendo considerada por muitos críticos como a mais importante Bienal de São Paulo de arte 


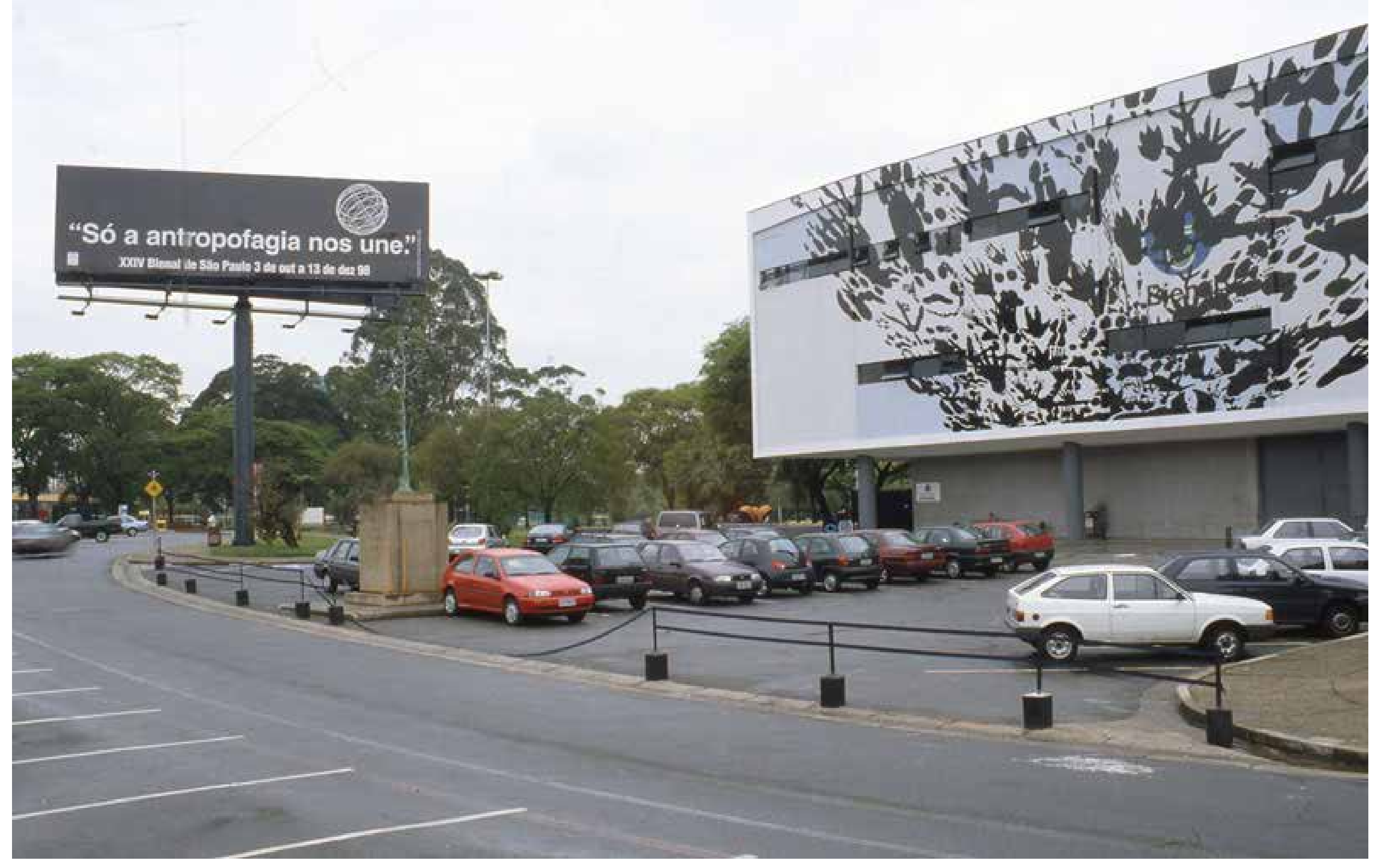

Trope/ de Regina Silveira na fachada da 24a. Bienal, participante da seção Arte Contemporânea Brasileira: Um e/entre Outro/s - Um entre Outros.

Fonte: site Bienal. Foto: Juan Guerra. Disponível em: <https://bienal.org.br.>. Acesso em: 02 Jan.2019. 
contemporânea(FARIAS, 200I). A 24a. Bienal foi estruturada a partir de três pilares: o programa educativo, os catálogos e a exposição propriamente dita. O educativo teve a curadoria de Evelyn Ioshpe e foi baseado na profundidade do olhar de Jean-François Lyotard. $3^{8}$ Os catálogos foram coordenados por Pedrosa e tinham a proposta de constituir um livro crítico, não apenas uma compilação de obras. O grande investimento no projeto educativo e nas publicações também foi eixo fundamental da 27a. Bienal. Havia em ambas exposições um questionamento acerca do papel da Bienal de São Paulo, aproximando-as de Kassel, ao propor discussões intelectuais, e afastando-as da proposta geopolítica de Veneza.

Herkenhoff optou por construir uma curadoria conceitual ao ingressar no campo prático da crítica ao invés de escolher um tema relacionado à arte, como era usual naquele momento nas Bienais de São Paulo. ${ }^{39} \mathrm{O}$ conceito escolhido foi o da Antropofagia, através da releitura de Montaigne (1553-1592) à luz de Oswald de Andrade (I890-I954), refletindo sobre o canibalismo real e cultural. A proposta era criar uma nova perspectiva pós-colonial para a história da arte, tirando o Brasil da periferia como mero reverberador das tendências ocidentais e colocando-o no centro, como um estado com maioridade cultural, capaz de contribuir e transformar a história da arte (LAGNADO,

38 Cf. A condição pós-moderna, de Jean-François Lyotard.

39 Ver capítulo I para contexto histórico.
2008). No catálogo da 27a. Bienal, Pedrosa (que fez parte da equipe das duas exposições) aponta para a relação entre ambas as Bienais por suas curadorias de caráter conceitual.

Lagnado assumiu uma postura crítica similar na 27 a. Bienal ao adotar o repertório propositor de Oiticica como conceito. Apesar do artista ter reconhecimento internacional, o Programa Ambiental e as proposições dos nos I960 e 1970 como Subterranean Tropicalia Projects ${ }^{40}$ ou Babylonests ${ }^{41}$ haviam sido, segundo a curadora, pouco divulgadas e valorizadas. Lagnado tinha como proposta se contrapor à estética relacional de Bourriaud, conforme descrito anteriormente, posicionando Oiticica como um dos precursores da arte coletiva, social e inserida na vida dos anos i990. A curadora procurou, através da Bienal, assim como Herkenhoff, inverter a hegemonia ocidental na história da arte contemporânea. Há uma proximidade entre os dois curadores no que se refere ao entendimento do papel do curador como agente crítico na construção da história da arte.

Herkenhoff conduziu um teste prático de uma teoria da arte revisitada baseada em um processo poroso de diálogo e

40 Que reúne projetos de penetráveis para área pública, desenvolvidos no início da década de 1970, quando Oiticica morou em Nova Iorque nunca desenvolvidos (ANJOS, 20I2).

4I Transformou seu apartamento em Nova York em um espaço experimental feito de ninhos, onde vivia, trabalhava e recebia amigos por tempo indeterminado (ANJOS, 20I2). 
contaminação entre trabalhos. O núcleo histórico ${ }^{42}$ era o trecho da exposição em que essa proposta ficava mais evidente. Ele foi constituído a partir do conceito de transversalidade, desconstruiu hierarquias entre gêneros, técnicas e nacionalidades e, por meio da aproximação feita pela narrativa curatorial, trouxe elementos do passado para o presente. Este conceito era vivenciado no espaço através da organização das obras em sequência, ou de como obras contemporâneas brasileiras foram inseridas ao lado de obras históricas. A curadoria da mostra construiu um diagrama da história antropofágica da arte para ilustrar as relações propostas entre artistas e que também era o mapa do núcleo histórico. A proposta fazia uma referência direta ao diagrama evolutivo de Alfred Barr, ex-diretor do Museu de Arte Moderna de Nova York (MoMa), que elaborou uma narrativa sobre a evolução das vanguardas europeias, chegando à arte abstrata norte-americana. O núcleo histórico recebeu muitas críticas no sentido de impor uma leitura às obras, mas teve um grande impacto positivo no cenário global das artes. Segundo Herkenhoff: "Como resultado da Bienal, Antropofagia é um dos primeiros conceitos constituídos na experiência cultural brasileira a ingressar na gramática internacional da arte” (2008a, p.33).

\footnotetext{
42 Houve um rompimento do papel exercido pelas exposições especiais, que ocupavam a área climatizada e a separação que havia entre obras contemporâneas e históricas
}

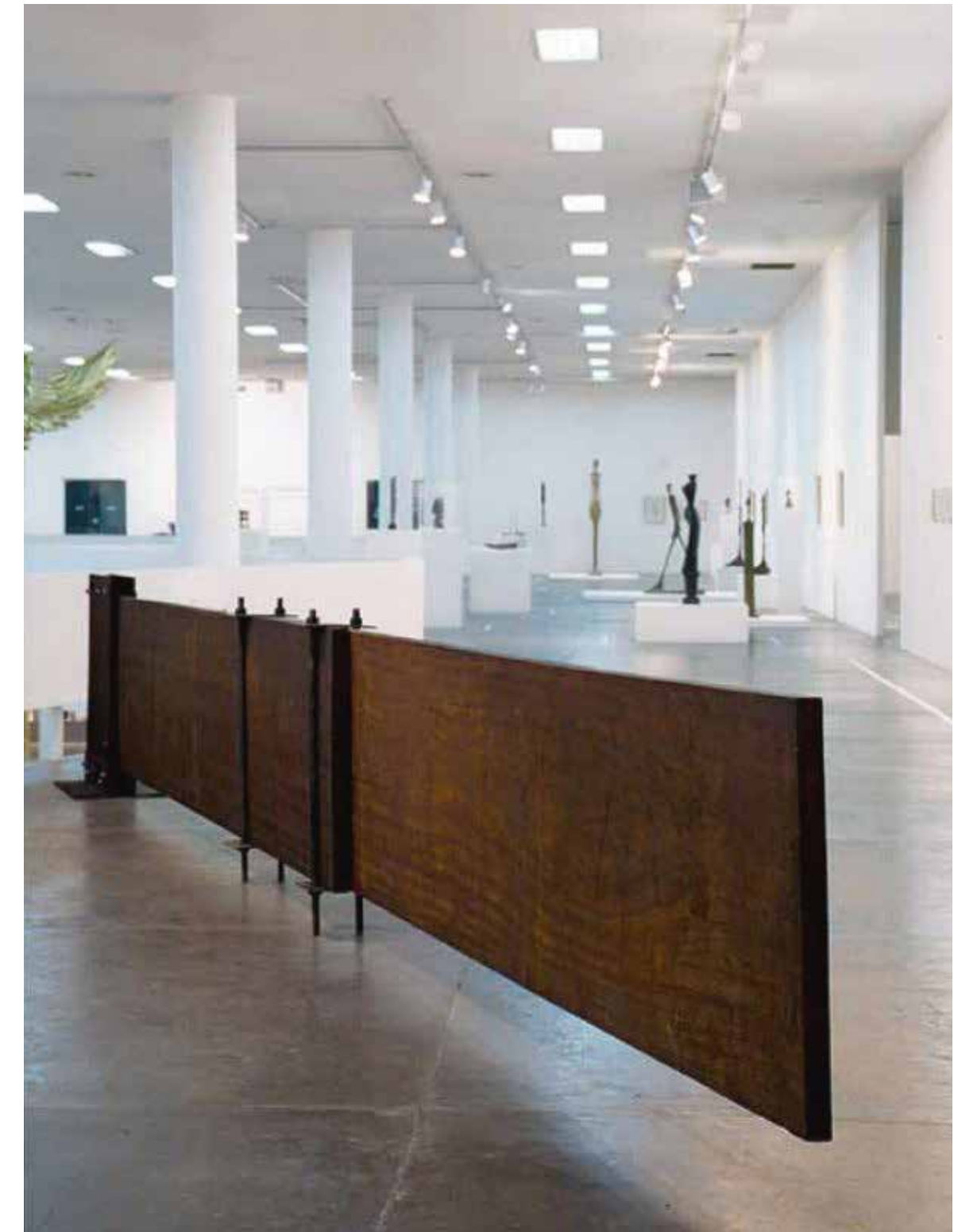

Núcleo histórico da 24a. Bienal: escultura sem título de José Resende (1970-97), ao fundo trabalhos de Alberto Giacometti. (LAGNADO; LAFUENTE, 2015). Fonte: Arquivo Wanda Svevo. Foto: Juan Guerra. 


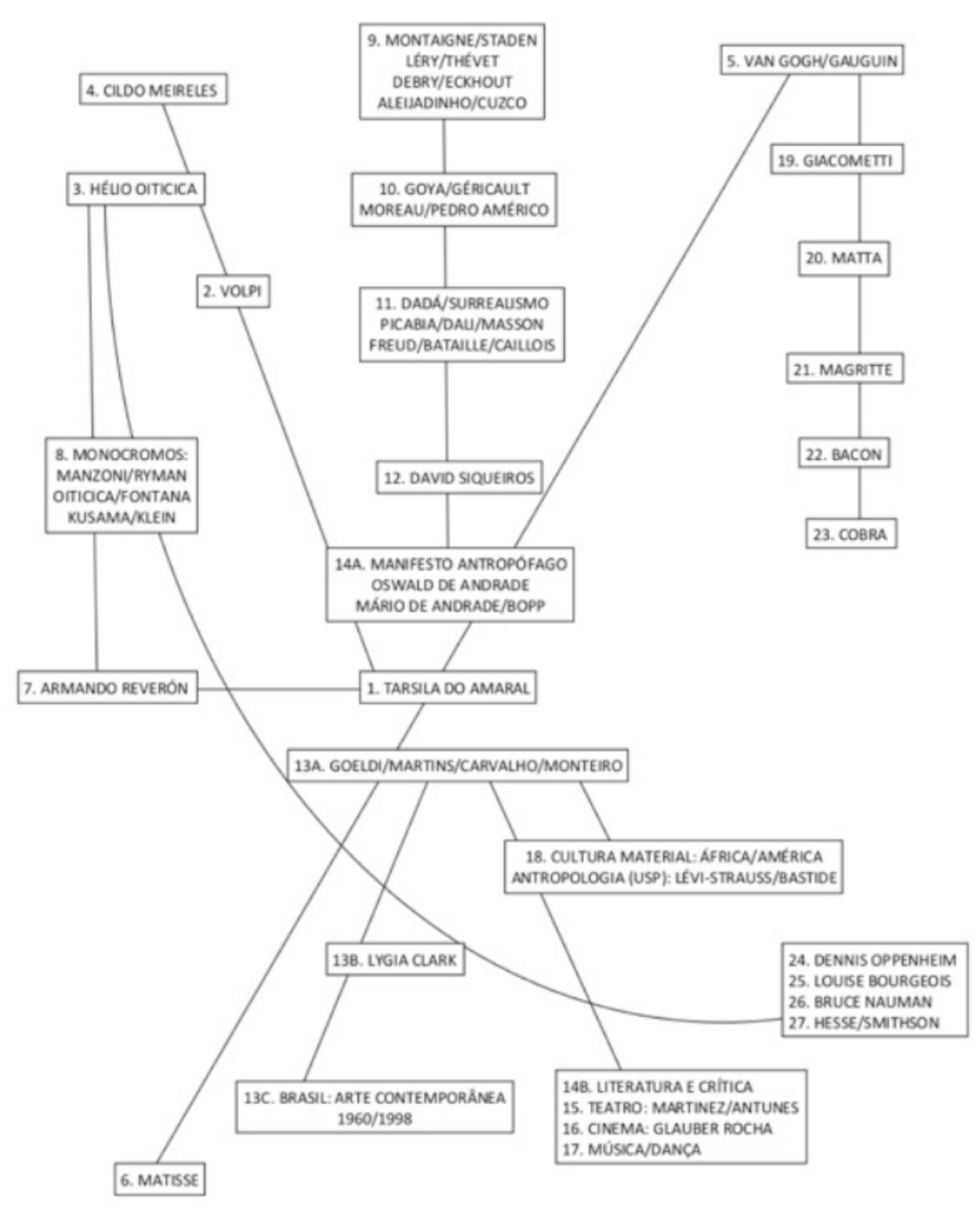

Diagrama de concepção do Núcleo histórico feito por Paulo Herkenhoff.

Fonte: palestra Mirtes Marins de Oliveira.

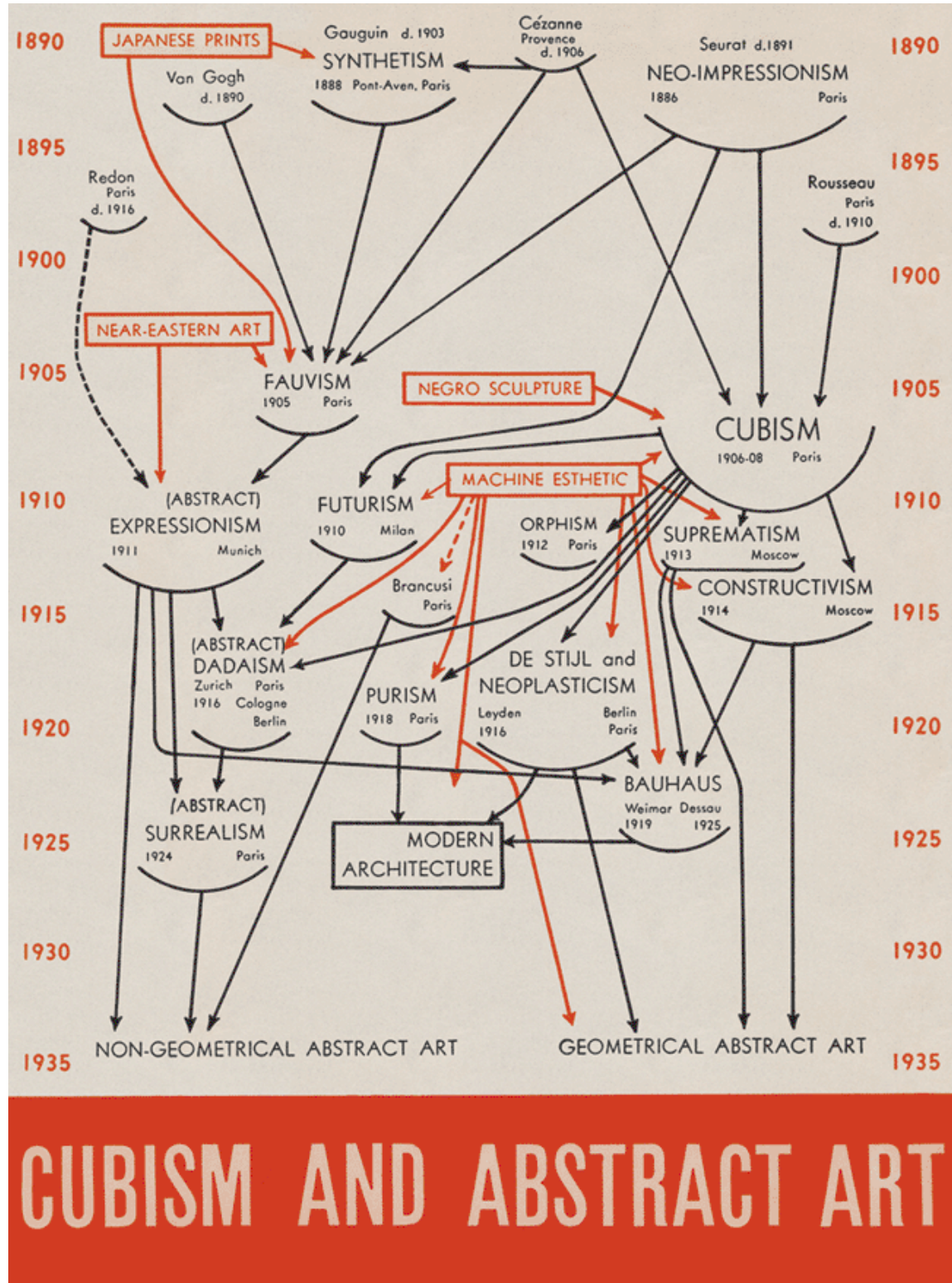

Diagrama Cubism and Abstract Art de Alfred Barr. Fonte: palestra Mirtes Marins de Oliveira. 
Lagnado se apropriou dos conceitos de contaminações e porosidade de Herkenhoff, citados pela curadora em diversas entrevistas. A proposta na 27a. Bienal também se revela de forma mais evidente na área climatizada, onde os artistas históricos-contemporâneos estavam ao lado de jovens artistas, ou em instalações site specific. A construção da exposição no espaço, no entanto, não foi tão bem-sucedida na mostra de 2006 como havia sido em 1998. As contaminações e a porosidade apenas ocorreram pontualmente.

Coube ao arquiteto Paulo Mendes da Rocha a missão de traduzir o conceito curatorial da 24 a. Bienal no espaço. A premissa inicial da curadoria era que os espaços fossem fluidos e que não houvesse painéis fechando os caixilhos. A intenção, segundo Herkenhoff (2008), era homenagear a cidade de São Paulo, integrando-a à exposição. Usou como referência para a transparência que desejava o Museu de Arte Moderna do Rio de Janeiro ${ }^{43}$ e o Museu de Arte de São Paulo (MASP). ${ }^{44} \mathrm{O}$ curador-geral ainda instruiu a todos os curadores responsáveis pelas representações nacionais que evitassem o uso de salas fechadas, possibilitando, desta forma, uma exposição mais integrada, que enfatizaria a relação obra a obra. Essa articulação tornou viável a construção

43 MAM foi inaugura do em I948 no aterro do Flamengo e foi projetado pelo arquiteto carioca de Affonso Eduardo Reidy (1909-1964).

44 O MASP foi inaugurado na avenida Paulista em I968, projeto da arquiteta ítalo-brasileira Lina Bo Bardi (I9I4-1992).

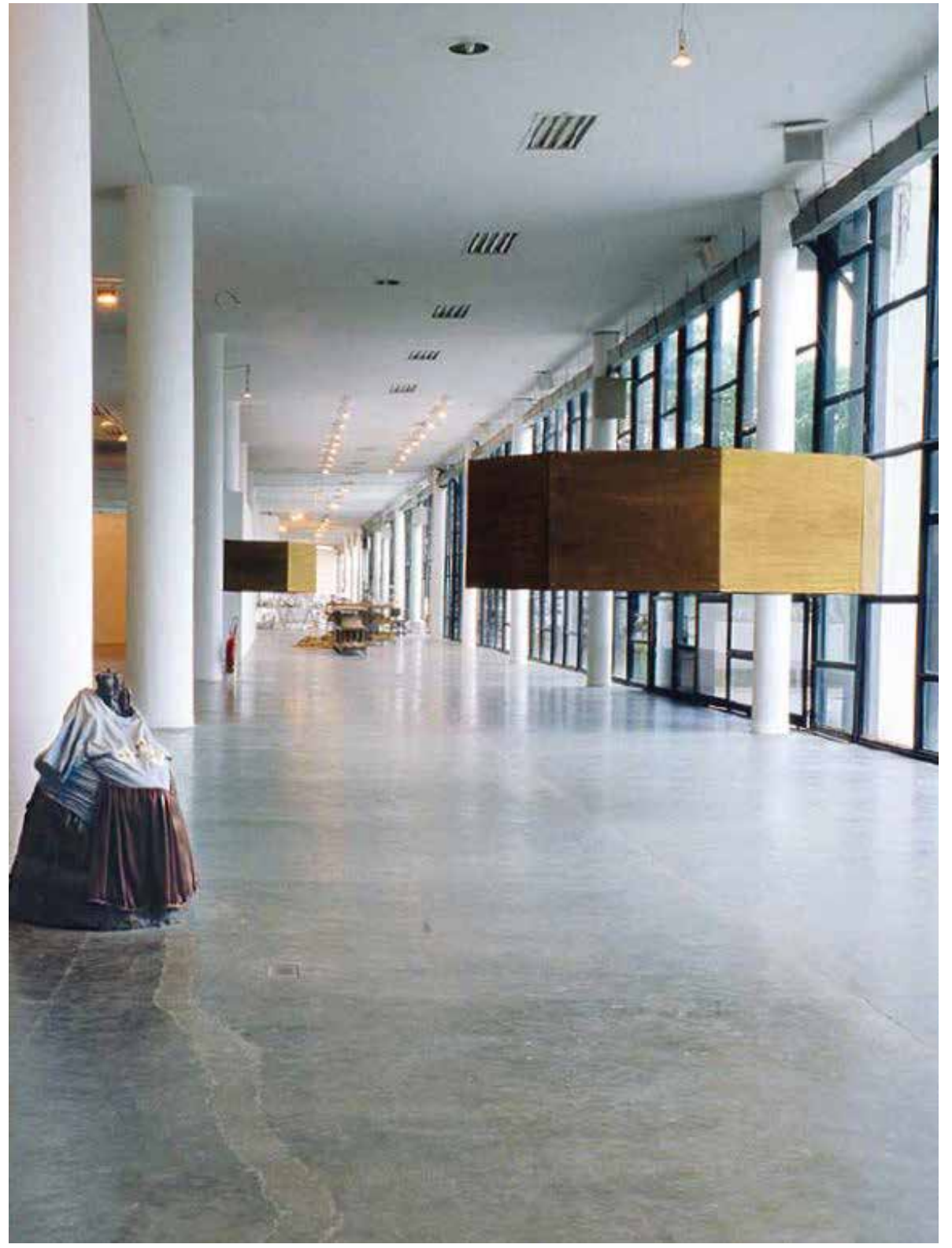

Roteiros, roteiros (...) e a relação das obras abertas para o Parque. Fonte: Arquivo Wanda Svevo. Foto: Juan Guerra. 


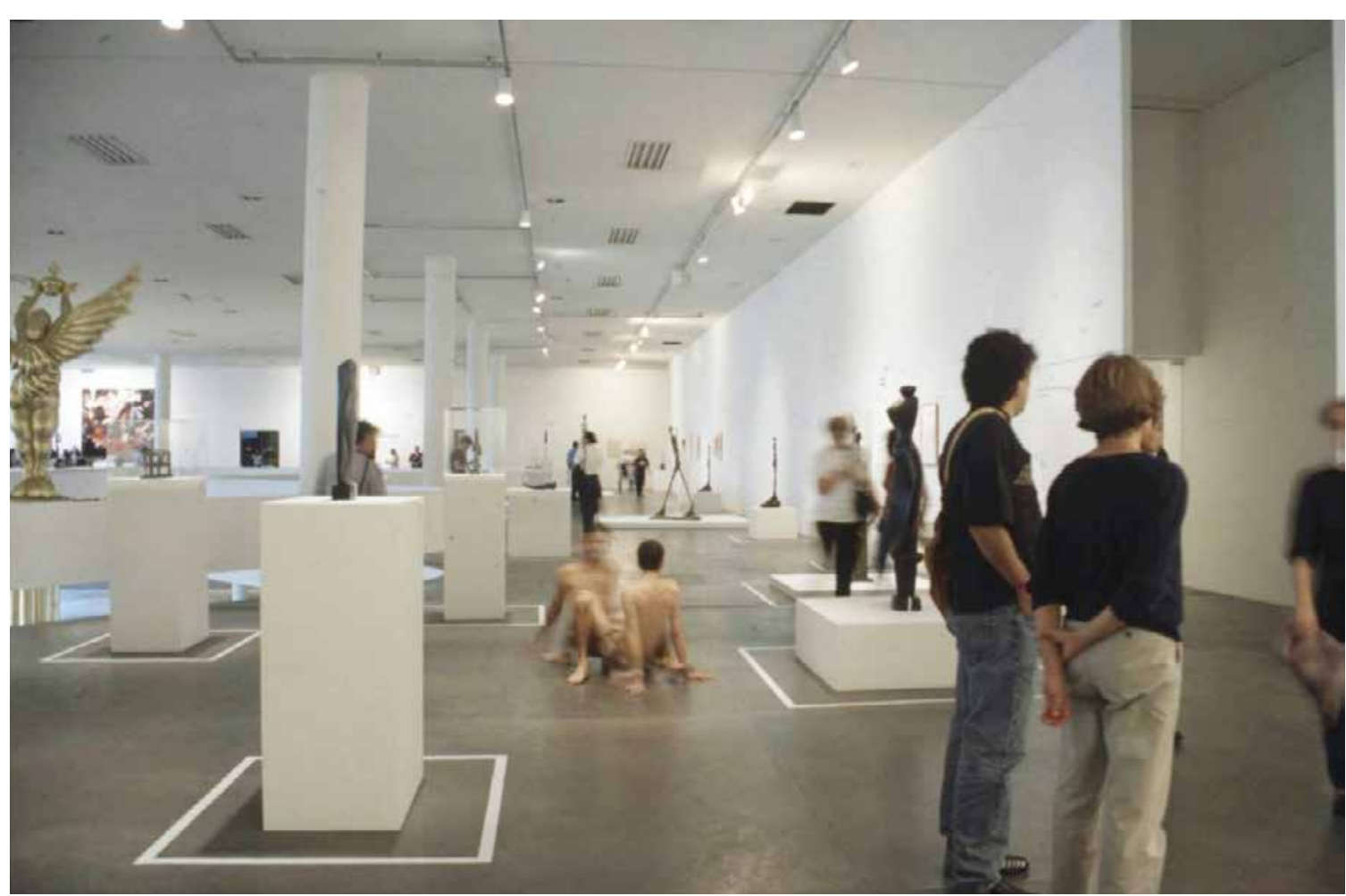

Núcleo histórico da 24a. Bienal: seção de Alberto Giacometti, à esqueda a obra do vão Encore, Encore, Encore (1997) de Choi Jeong-Hwa, no centro está a escultura performance de Laura Lima Sem título (1997-98), que percorreu toda a exposição. (LAGNADO LAFUENTE, 2015). Fonte: Arquivo Wanda Svevo. Foto: Juan Guerra. espacial da narrativa curatorial com nitidez. Nas palavras de Herhenhoff:

A maioria do nosso público vem apenas uma vez à Bienal, portanto o desafio é fazer uma exposição conceitualmente complexa e espacialmente leve. [...] Claro que entendemos necessidades específicas de salas e paredes, silêncio e isolamento, mas nós gostaríamos de limitar esses, como estamos fazendo em outros segmentos da XXIV Bienal, a instâncias quando for estritamente necessário. Em suma, gostaríamos de inverter a suposição de que uma nação $=$ um artista $=$ uma sala ${ }^{45}$ (apud LAGNADO, 2015, p.47).

A exposição tinha quatro segmentos: Um e/entre Outro/s (dedicado à arte contemporânea brasileira); "Roteiros, Roteiros, Roteiros, Roteiros, Roteiros, Roteiros, Roteiros" (dedicado à arte contemporânea internacional); núcleo histórico; e representações nacionais. Apesar da 24a. Bienal ainda estar vinculada ao modelo de Veneza, mantendo

45 Tradução da autora. Texto original: "Most of our public come just once to the Bienal, thus the challenge is tomake an exhibition which is conceptually complex and spatially light.[...] Of course we understand specific needs for rooms and walls, silence and isolation, yet we would like to limit those, as we are doing in other segments of the XXIV Bienal, to instances when it is strictly necessary. In short we would like to reverse the assumption that one nation $=$ one artist $=$ one room." 
as representações nacionais, os curadores conseguiram, através de um trabalho diplomático, dissolver a divisão geopolítica no espaço submetendo a seleção de obras ao conceito da Antropofagia, o que possibilitou a construção de uma narrativa curatorial coerente. O curador em artigo comemorativo de ro anos da 24a. Bienal, fez uma descrição dos objetivos da definição semiológica do espaço: “[...] desmontar hierarquias do espaço geral, desconstruir a centralidade e o poder da localização, situar a América Latina em diálogos estratégicos, o Brasil em contextos históricos precisos" (HERKENHOFF, 2008a, p.35).

O resultado foi uma exposição com poucas salas ${ }^{46}$ e com um espaço fluido que possibilitou a confrontamento de obras. Os conceitos de contaminação, porosidade e transversalidade se revelaram no espaço. Cada ponto de vista permitiu simultaneidade visual de diversas obras e a construção das múltiplas relações a partir da narrativa curatorial. Nas palavras de Herkenhoff (2008a, p.30):

Toda a montagem do pavilhão do Ibirapuera conspirou para um encontro: justapor a revista Cannibale (1920), de Picabia, à Revista de Antropofagia (1928),

\footnotetext{
46 Nota-se que há poucos vídeos na mostra. A presença de grande número de vídeos nas exposições contemporâneas acarreta, na maioria dos casos, em um grande número de salas fechadas.
}

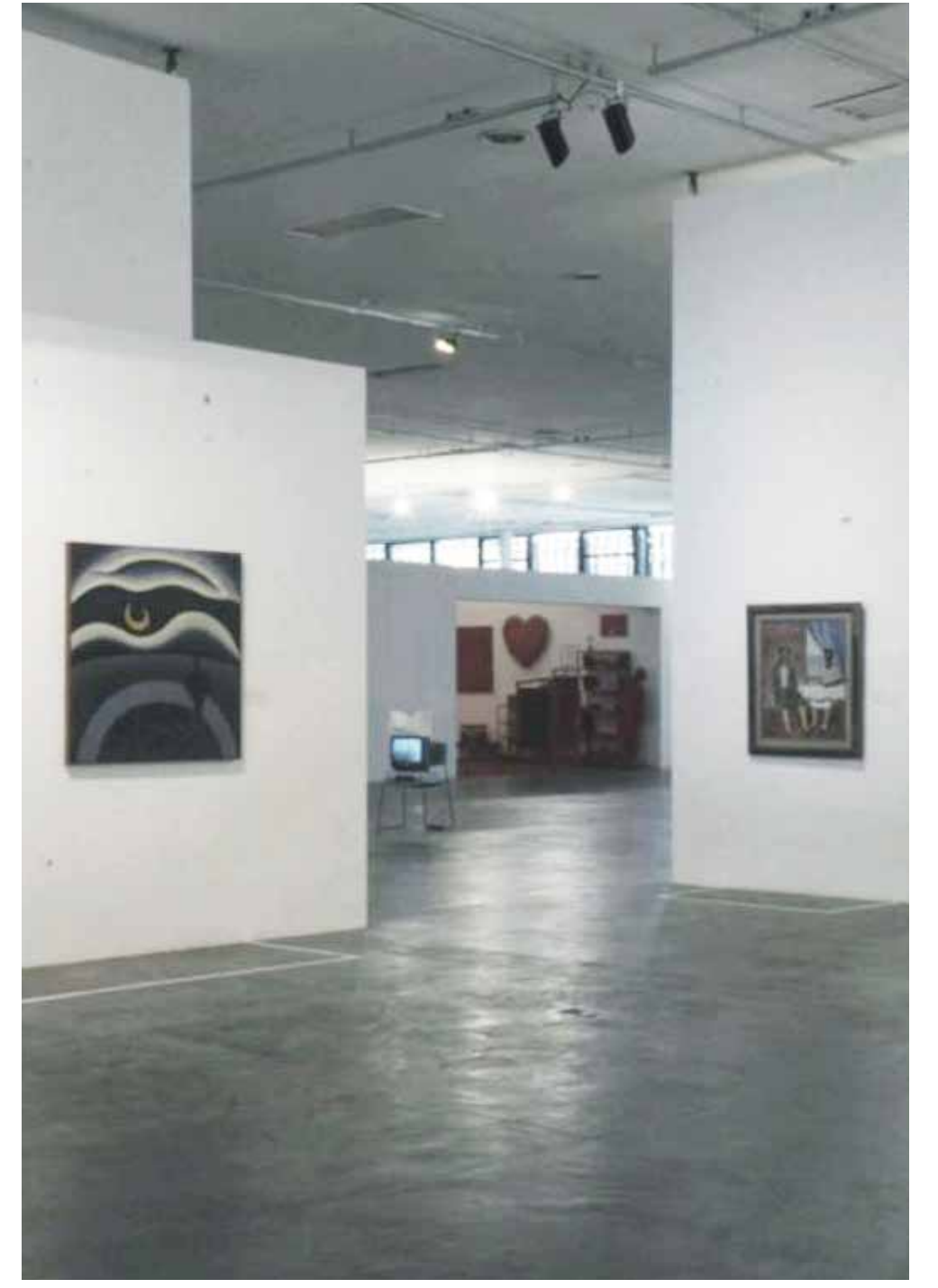

Núcleo histórico da 24a. Bienal: à esqueda obra de Tarsila do Amaral $A$ lua (1928), à direita uma das primeiras pinturas de Alfredo Volpi (1945), ao fundo a instalação Desvio para o vermelho de Cildo Meireles (1967-84) e o vídeo de Franz West. (LAGNADO; LAFUENTE, 2015). Fonte: Arquivo Wanda Svevo. Foto: Juan Guerra. 


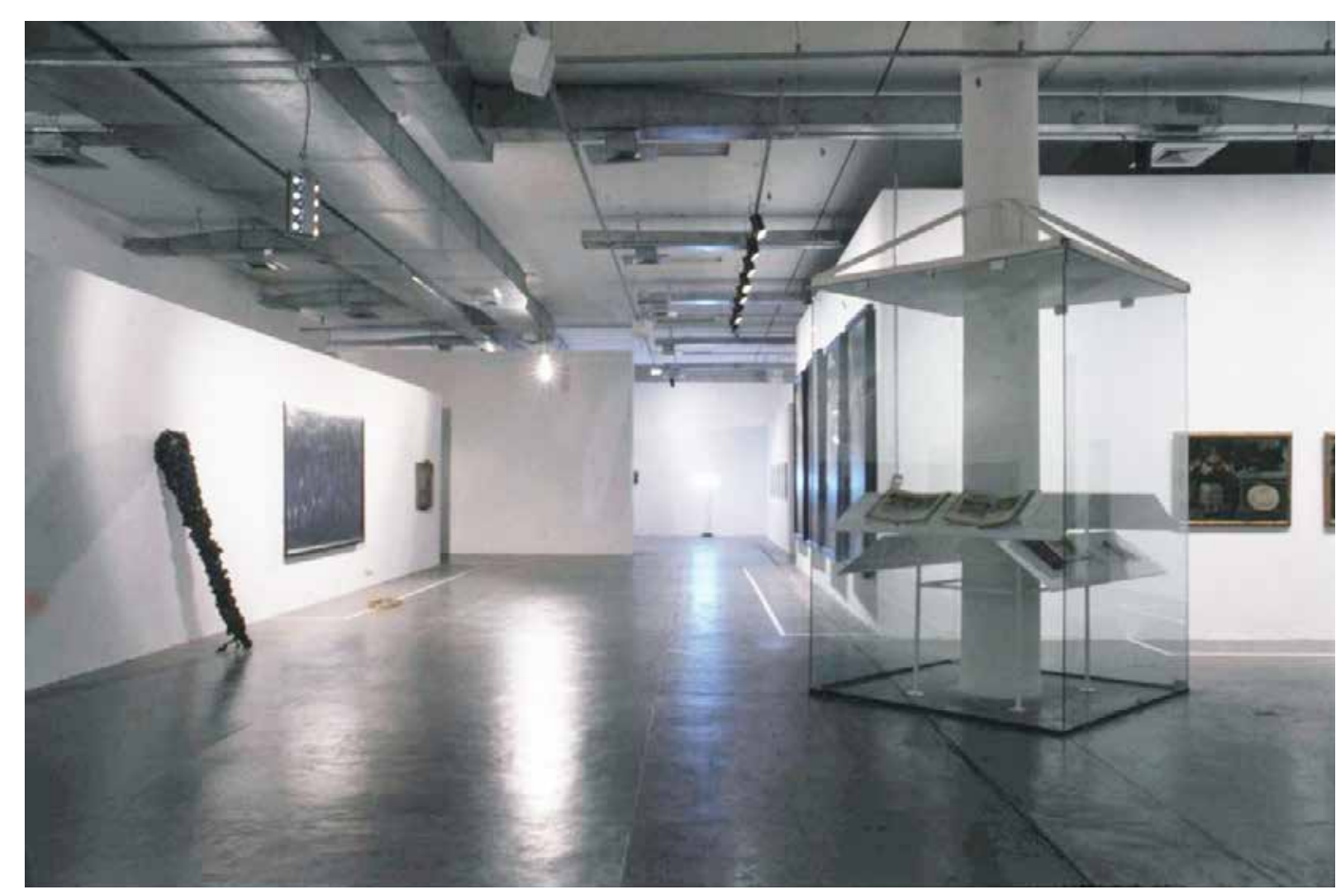

Núcleo histórico da 24a. Bienal: à direita a Dança dos Tapuyas (1641) de Eckhout ao lado de $\mathrm{TaCaPe}$ de Tunga (1986-97). Vitrine com livros, incluindo Essais (1580-95), de Michel de Montaigne e Histoire d'un voyage fait en la terre du Brésil (História de uma Viagem à Terra do Brasil, 1578), de Jean de Léry. (LAGNADO; LAFUENTE, 2015). Fonte: Arquivo Wanda Svevo. Foto: Juan Guerra. de Oswald de Andrade. Juntar as duas publicações se constituiu numa passagem da energia produtiva de um ponto a outro como processo de transformação da cultura. Esta é minha predileta entre as muitas justaposições, como confrontar o Eixo exógeno, de Tunga, com o quadro Lea e Maura (dito As gêmeas), de Guignard, uma das quais era a mãe do primeiro artista.

TaCaPe (I986-I997), de Tunga, ficou ao lado da tela Dança tarairiu (s.d.), de Albert Eckhout, na sala do século I6. De modo deliberado, estes dois atos de confronto alinhavam a obra de Tunga contra o período colonial e o Modernismo para apontar seu lugar na história da formação da arte brasileira. Seria mais óbvio situá-lo no momento barroco e nas zonas de canibalismo psíquico. Curadoria pode ser o ofício dos pequenos gestos.

Formou-se uma diagonal que atravessava o percurso dos visitantes com as exposições de Reverón, Matta e Siqueiros. Isso equivaleria dizer que não se faria o percurso da história da arte ocidental sem passar pela arte latino-americana. Já a arte brasileira, ou contaminava todo o espaço museológico (Pedro Américo, Lygia Clark, Cildo, Varejão), ou se integrava na sala dos monocromos brancos do pós-guerra (os brasileiros eram exibidos ao lado de outros latino-americanos, norte-americanos e europeus, como a herança 
de Malevitch). Essa infiltração era uma espécie de guerrilha historiográfica e afirmativa.

O display expositivo foi construído de forma a ativar o conceito de antropofagia. Uma das estratégias adotadas de contaminação no núcleo histórico, foi o uso de epigrafes e notas de rodapé a partir da inserção de obras contemporâneas brasileiras em salas históricas, aplicadas no alto do painel ou em sua base, fora do eixo do olhar, fazendo referência à escrita. Alguns exemplos dessas contaminações propostas foram: uma Trouxa ensanguentada (1970) de Artur Barrio, que entrou no rodapé ao lado da sala de Francis Bacon; na sala dedicada ao Dada e Surrealismo, sobre uma seleção de desenhos de André Masson, foi inserida a obra Sigmund de Vik Muniz (1997); na sala de Eva Hesse e Robert Smithson, foi inserida uma obra da série Droguinhas (1965-1966), de Mira Schendel, em um canto do painel.

Foram feitas inserções de textos na abertura das salas históricas, tais como Rabelais and his world de Mikhail Bakhtin, o Manifesto Antropofágico de Oswald de Andrade e Totem e tabu de Sigmund Freud. O último abriu uma seção em que todos os painéis foram pintados de preto - criando uma unidade para o conjunto a partir da cor, o curador propôs uma nova leitura das obras desta seção à luz do texto de Freud.

Apesar da defesa da porosidade e da contaminação e, mais do que isso, do conceito Como viver junto, a seleção de
Núcleo histórico da 24a. Bienal: A contaminação Droguinhas (1965-66) de Mira Schendel inserida no canto da sala de Eva Hesse e Robert Smithson. (LAGNADO; LAFUENTE, 2015). Fonte: Arquivo Wanda Svevo. Foto: Juan Guerra.

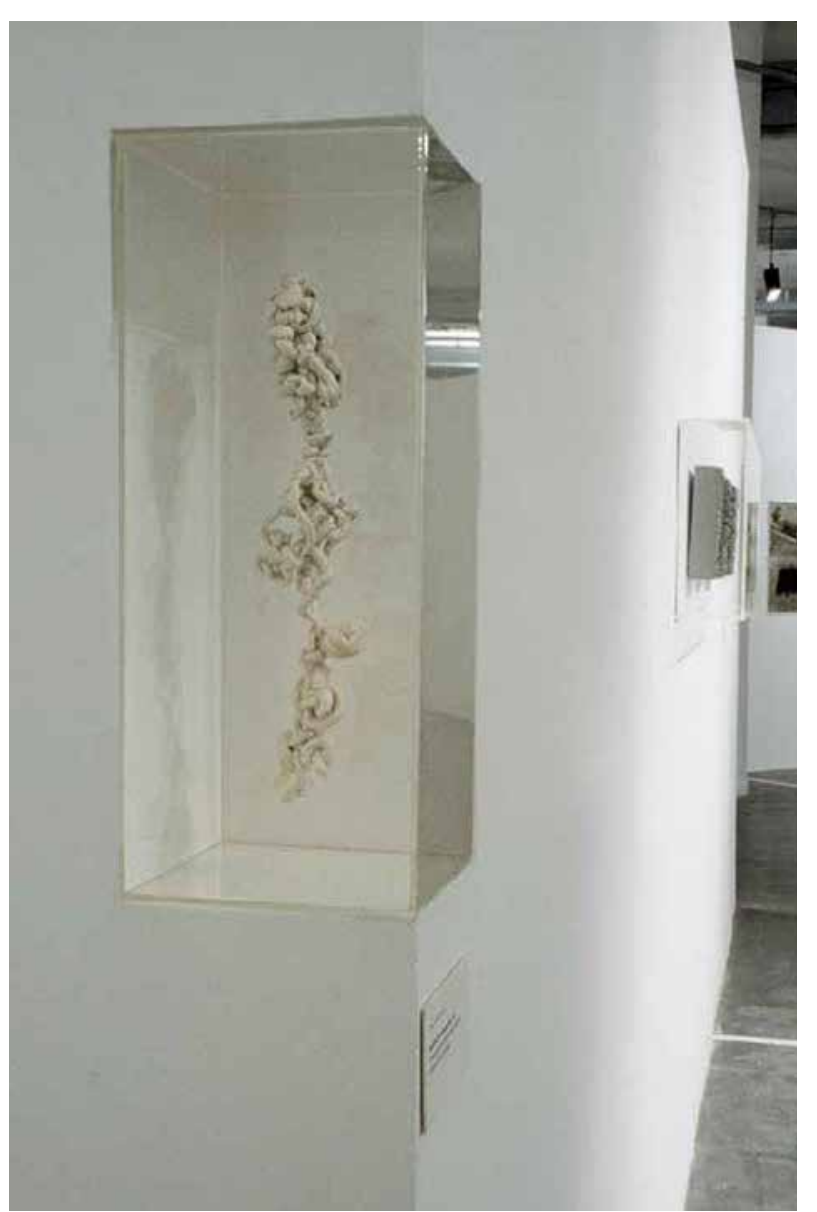


[no topo] Núcleo histórico da 24a. Bienal: Seção Totem e Tabu que foi pintada de preto ofereceu ao público um "Modo de Usar": "1. Tabu: o pai come o filho: 2 Transgressão: os filhos comem o pai e 3. Totem: sociedade come seus filhos'. À esquerda, Tiradentes esquartejado (1893) de Pedro Américo e a seção de Francis Bacon, Figura em movimento (1985). (LAGNADO: LAFUENTE, 2015).

Fonte: Arqu

[embaixo à esq.] Núcleo histórico da 24a. Bienal: A contaminação Trouxa ensaguentada de Artur Barrio na sala

de Francis Bacon. (LAGNADO: LAFUENTE, 2015).

Fonte: Arquivo Wanda Svevo. Foto: Juan Guerra.

[embaixo à dir.] Núcleo histórico da 24a. Bienal: espaço destinado a obras Dadá e Surrealismo com desenhos de André Masson, no alto do painel uma contaminação de Herkenhoff, um retrato de Sigmund Freud de Vik Muniz, Sigmund, da série Chocolate (1997). (LAGNADO; LAFUENTE,

2015). Fonte: Arquivo Wanda Svevo. Foto: Juan Guerra.
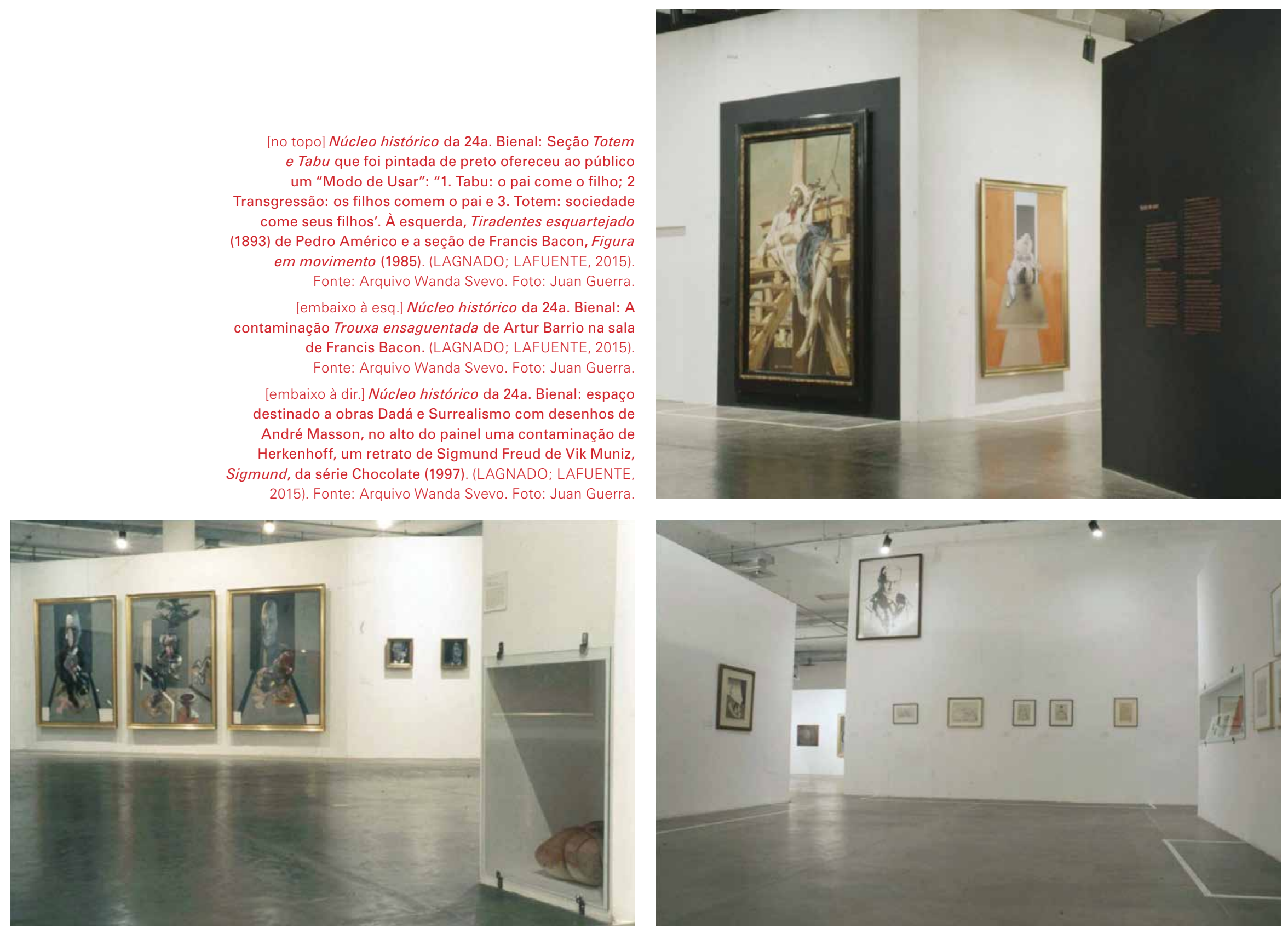
obras da 27a. Bienal pelos curadores não seguiu a premissa da 24a. Bienal de desencorajar as salas fechadas, assim como o display não foi pensado obra a obra, mas para cada artista e seu conjunto de obras. A proposta de criar um mini survey ${ }^{47}$ (uma pequena retrospectiva) de cada artista para contextualizá-lo levou à construção de muitas salas e, soma-se a isto, a presença maciça de salas de vídeo. O resultado foi o loteamento do pavilhão em um contexto em que muitas vezes a construção de uma narrativa individual se sobrepôs à força do confrontamento entre obras e à grande narrativa da mostra.

47 Termo adotado por Lagnado no anteprojeto curatorial para 27a. Bienal.

\subsubsection{O legado da 27a. Bienal}

Apesar de ter encontrado muita resistência de críticos e não ter sido reconhecida, mesmo que a posteriori, a 27a. Bienal de São Paulo trouxe uma série de inovações importantes para o modelo e para a estrutura da instituição que a realiza. Elas foram assimiladas e transformaram as edições posteriores.

Os curadores nômades da 27a. Bienal declararam usar como referência outras bienais ou exposições de grande escala, como o modelo de curadoria da Manifesta ou o modelo de plataformas da Documenta, ou seja, havia uma clara intenção de sintonia com o contexto internacional.

Se houve críticas relacionadas ao fim das representações nacionais ou pela aproximação antropológica, social e política das obras naquele momento, como mencionado anteriormente, este assunto não voltou a ser questionado nas mostras seguintes, que mantiveram a mesma abordagem. As representações nacionais não foram ainda retomadas e as Bienais mantiveram a plataforma discursiva e política. A 3 га. Bienal e 32 a. Bienal adotaram o modelo de curadoria coletiva. Os seminários, as publicações críticas, as residências artísticas e o investimento no projeto educativo se consolidaram como estratégias de aprofundamento das discussões propostas pelos curadores e para torná-las acessíveis a um público mais amplo.

A contradição é que todas as transformações realizadas no sentido de questionar a sociedade do espetáculo, se, por um 
lado, ampliaram e aprofundaram a discussão e tiraram o caráter de evento efêmero, alongando a Bienal por um ano por meio das residências artísticas e dos seminários; por outro, aproximaram a Bienal de São Paulo do sistema internacional do mundo das artes, que mantém as suas estruturas hierárquicas e prescinde da chancela do ocidente. O curador Tadeu Chiarelli fez uma dura crítica no final da mostra: "Penso que com raras exceções as últimas edições da Bienal de São Paulo vêm atuando mais como caixas de ressonância de Kassel e Veneza do que como propositoras de tendências" (apud MARIO GOIA, 2006, E4). Segundo o sociólogo e crítico de arte Pascal Gielen:

A Bienal é uma pós-instituição de trabalho imaterial e da chegada da multidão artística onde curadores, artistas, audiência, independentemente de suas sinceridades, precisam manter um certo grau de cinismo e oportunismo para atingir o hierárquico sistema global de arte (apud O’Neill, 20I2, p.66).

Na revista Afterall Cultural Anthropophagy sobre a 24a. Bienal de 2015, Lagnado faz uma análise crítica sobre as dificuldades de se fazer a curadoria de uma Bienal de São Paulo: discute o caráter contemporâneo da mostra, questão também apontada por O'Neill, que precisa sempre trazer inovações em relação às mostras antecedentes; problematiza a proposta defendida por ela na 27a. Bienal, de ampliação da mostra para além da exposição; e considera os programas paralelos como um fator de enfraquecimento da mostra em si. A curadora também aponta a dificuldade de se manter uma proposta crítica que resista ao poder econômico envolvido nas mostras internacionais. Em suas palavras:

As ferramentas analíticas necessárias para a avaliação de bienais de arte são distintas daquelas exigidas por outras exposições internacionais. Envolvem critérios extra-estéticos, tais como a relevância do tema, a sofisticação da exibição e uma consideração do caráter histórico da exposição: as bienais devem considerar o que foi conseguido (ou não) pelas edições anteriores ao dar uma conta da história no modo mais contemporâneo-uma contradição em termos. Atividades paralelas, que evoluíram para se tornarem características centrais das bienais, acrescentam ainda um conjunto de fatores complicadores. Para garantir a singularidade do evento, existe agora uma cultura geral de seminários e filmes, residências de artistas e oficinas, intervenções em escala de trabalho público, parcerias com escolas e universidades, projetos educacionais e publicações, e assim por diante. Esta tendência levou a um declínio no significado da condição sine qua non para exposições: a exposição em si. Em 
um evento após o outro, os curadores de as bienais mais ambiciosas perseguem objetivos cada vez mais elaborados, assumindo a ambígua missão de melhorar seu projeto para alcançar o nível desejado do grande evento, tendo que lutar contra sua diluição na cadeia de suprimentos do turismo cultural globalizado. Poucas iniciativas são capazes de resistir à destruição da força econômica e burocrática dessa maquinaria anti-prometeu (LAGNADO, 20I5, p. 8$). .^{8}$

48 Tradução da autora. Texto original: "The analytical tools required for appraising art biennials are distinct from those required by other international exhibitions. They involve extra-aesthetic criteria, such as the relevance of theme, the sophistication of the display and a consideration of the exhibition's historical character: biennials have to consider what has been achieved (or not) by previous editions while giving an account of history in the most contemporaneous mode - a contradiction in terms. Parallel activities, which have evolved to become central features of biennials, add a further set of complicating factors. To ensure the event's singularity, there is now a general culture of seminars and films, artists' residencies and workshops, interventions on a public-work scale, partnerships with schools and universities, educational projects and publications, and so on. This trend has led to a decline in the significance of the sine qua non condition for exhibitions: the exhibition itself. At one event after another, the curators of the more ambitious biennials pursue evermore elaborate aims, taking on the ambiguous mission of upscaling their project in order to achieve the desired major event, while having to struggle against its dilution into the supply chain of globalised cultural tourism. Few initiatives are able to withstand being ground down by the economic and bureaucratic force of this pounding anti-Promethean machinery". 


\subsection{PROJETO EXPOGRÁFICO E CURATORIAL}

\subsubsection{O partido do projeto expográfico}

A proposta de fazer uma Bienal com curadoria coletiva se expandiu para as outras disciplinas envolvidas na construção da mostra. Lagnado incluiu a arquiteta Marta Bogéa, responsável pelo projeto expográfico, e a educadora Denise Grinspum, responsável pelo projeto educativo, nas primeiras reuniões dos curadores, quando os conceitos e partidos do projeto estavam sendo discutidos. Definido pela curadora como fórum, essas reuniões deram subsídios para que Bogéa traduzisse os conceitos levantados pela equipe curatorial no espaço expositivo. ${ }^{49}$

O acompanhamento da etapa conceitual pela da equipe de arquitetura era uma prática pouco usual em projetos de expografia (BOGÉA, 20I8). Apesar de perceber o estranhamento da equipe curatorial em relação a essa abertura, Lagnado sustentou a proposta. $\mathrm{O}$ mais usual, naquele momento, seria

49 LAGNADO, Lisette. Em entrevista para Uol Entretenimento em 22/09/06. Disponível em: <https://entretenimento.uol.com.br/27bienal/entrevistas/ textos/ult4026u6.jhtm>. Acessado em: 6 jan. 2019. que o projeto expográfico começasse a ser desenvolvido após uma definição, ou ao menos um encaminhamento, do partido curatorial e da lista de obras e artistas. Essa nova abordagem permitiu que os projetos expográficos e a seleção de artistas fossem elaborados em simultaneidade, iniciando uma relação dialética desde a sua concepção.

Bogéa considerou a proposta uma boa estratégia para enfrentar um projeto expográfico com a complexidade e velocidade de uma Bienal:

Ela é uma curadora que entende que se arquitetura vem só quando os dados estão fechados, ela acaba apenas atendendo uma série de fatos com uma velocidade e uma voracidade que a escala da Bienal apresenta. Acompanhar as reuniões curatoriais, representava, sobretudo, ir tentando me aproximar da lógica conceitual e da maneira como estes curadores — um grupo muito peculiar, pois são muitos curadores - apresentava e espacializava o raciocínio de cada uma de suas escolhas, e como eles enfrentavam a poética de cada artista, mais do que as obras, 
já que naquele momento não havia nenhuma obra escolhida. Ao mesmo tempo, eu ia me aproximando e me apropriando da compreensão do edifício da Bienal (BOGÉA, 2006)

Bogéa definiu o partido inicial do projeto a partir do raciocínio de porosidade, conceito presente no projeto curatorial. A proposta trazia a ideia de um espaço contínuo de convívio permanente, de múltiplas possibilidades de percurso e permeabilidade visual tanto interna entre obras e quanto para o exterior do pavilhão. Outro elemento essencial para a concepção do projeto expográfico foi fazer uma leitura espacial do pavilhão, a qual levou a compreensão de que o seu imenso comprimento é sua principal característica e de que, portanto, o sentido longitudinal determina a leitura do espaço interno e da circulação de pessoas.

A partir desta análise, a arquiteta desenvolveu o projeto começando pela circulação e acesso à exposição. O acesso, na maioria as bienais, era realizado no eixo transversal do edifício, no meio do pavilhão, reiterando o fluxo do público que vêm pela marquise do parque Ibirapuera. Esse acesso habitual, no entanto, segregava as exposições em duas partes desconexas, além de segmentar parte do pavimento térreo-de pé direto duplo - , uma das áreas mais valorizadas do edifício (BOGÉA, 2006). Refletindo sobre as contradições geradas pelo acesso pela marquise, Bogéa retomou o projeto original do Pavilhão das Industrias..$^{50} \mathrm{~A}$ área de acolhimento que havia originalmente no projeto confirmou a hipótese de circulação da arquiteta. A primeira decisão de projeto foi, então, a de que a entrada ao pavilhão se daria através de uma praça na extremidade oeste do pavimento térreo.

Entra por lá, e não só por uma única entrada, mas por três portas, que não configuram um único acesso, mas um acesso dado por uma praça. Uma praça de chegada, de recebimento, de acolhimento, que se vale do conceito da curadoria de ser um espaço em que as fronteiras estão borradas, ou seja, onde os limites não são tão claros. Temos uma condição de convívio e continuidade em que o espaço institucional se apresenta justaposto ao espaço expositivo. Os serviços, balcões de apoio, guarda-volumes, atendimento ao público, café, livraria estão todos presentes junto das obras. Algumas vezes tão imbricadas, que a obra se confunde com a natureza dos serviços, como o barulho de fundo da Renata Lucas ou a livraria e a obra do Ateliê Bow-Wow. Estas relações vão configurar este acesso como um espaço híbrido por natureza e como uma praça em que o dentro e o fora vão estar muito mais indistintos, até se valendo de uma

50 Se refere ao livro Brazil Builds de Henrique Mindlin. No projeto do pavilhão, o caixilho era recuado, soltando a ponta do volume superior, e funcionava como um grande acolhimento. 

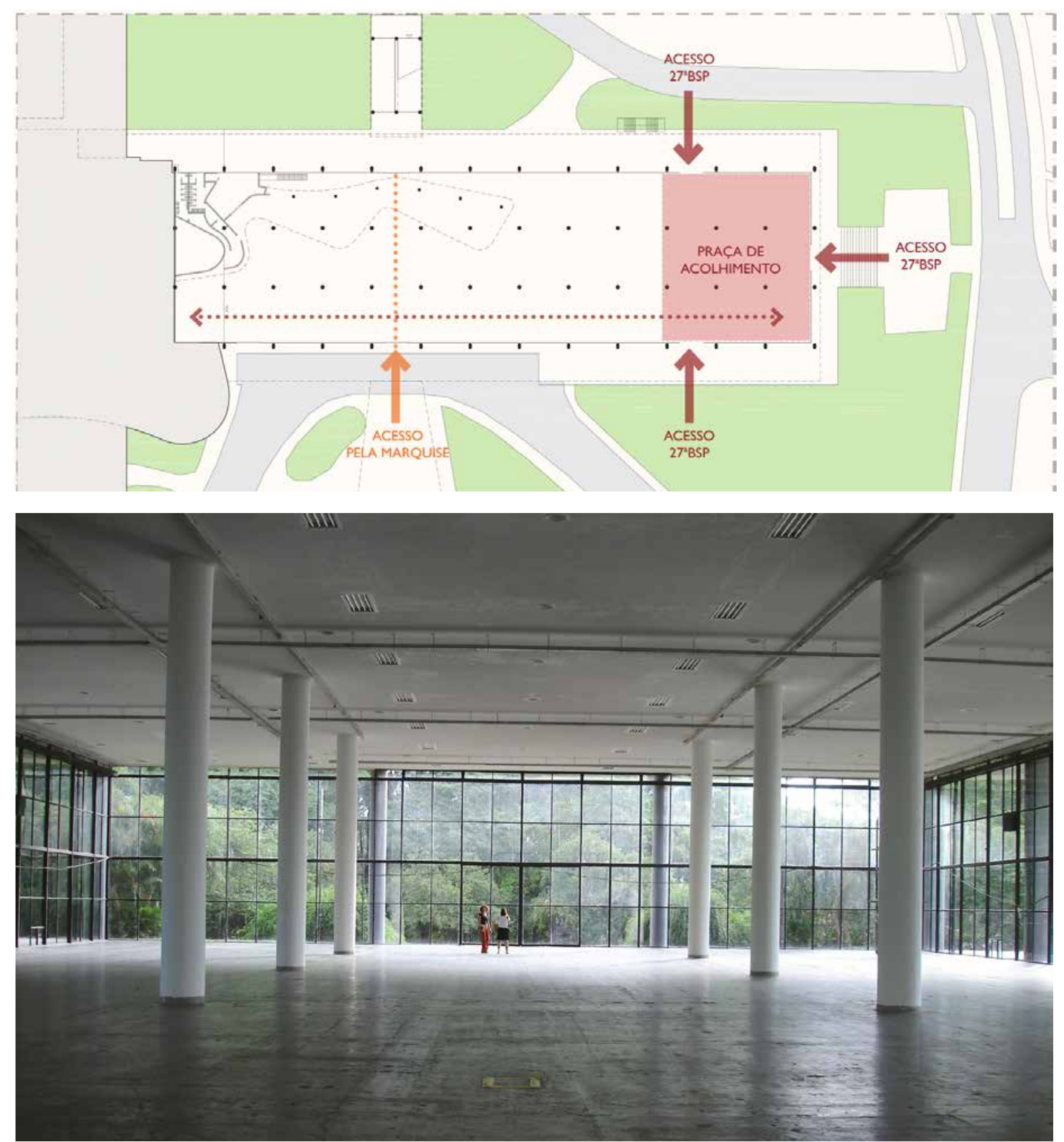
condição diferente da chegada pela marquise, em que havia uma fronteira dada pelo viário, pelos carros que interrompem a continuidade de passeio entre a marquise e a porta. Agora a entrada se dá por uma grande varanda, se quisermos entender assim (BOGÉA, 2006).

Para valorizar o caráter longitudinal do pavilhão, a circulação no segundo e terceiro pavimentos foi pensada de forma continua para permitir a leitura de sua extensão, com a exceção da área climatizada no terceiro. O projeto previa circulações ao longo dos caixilhos - garantindo que nenhuma sala fosse construída próxima à fachada - e no eixo longitudinal ao lado do vão central, que deveria ser prolongado por toda o comprimento do pavilhão.

A proposta inicial da expografia procurou dar destaque ao pavilhão, com um sistema expositivo que pudesse ser claramente diferenciado da arquitetura existente. Cada pavimento tinha um partido de projeto desenvolvido a partir da análise de sua espacialidade, o fluxo, a construção de relações visuais e as obras de arte: no térreo, os painéis reforçariam o fluxo longitudinal; no primeiro pavimento, haveria um espaço fechado, de luz controlada; no segundo e terceiro pavimentos, painéis soltos seriam implantados no sentido transversal ao pavilhão, garantindo a vista para o parque e para o interior; e as circulações deveriam ser contínuas pelo centro, alinhada com o vão, e pelas fachadas norte e sul.

\subsubsection{A narrativa curatorial}

O Programa Ambiental de Hélio Oiticica, artista morto em I980, serviu de fundamento para desenhar a plataforma conceitual da 27a. Bienal. Por ser um projeto com sentido ético-social, ele repercute hoje, mais do que quando foi elaborado, nas práticas artísticas contemporâneas. Algumas ideias como a passagem do museu para o mundo, refletem o modo como as pessoas se organizam cotidianamente na esfera social (LAGNADO, 2006e, p. I).

David Carrier (2006), em Art Museum as Narrative, define a narrativa curatorial como a organização das obras de artes no espaço. As obras são organizadas a partir de uma interpretação que leva o público a uma leitura desejada — muitas vezes diferente da concepção desenvolvida por cada artista. Carrier aponta que, embora a estrutura narrativa seja conhecida, ela costuma ser pouco explicitada, analisada e documentada, tanto com plantas quanto com depoimentos do processo de montagem.

O conceito curatorial da 27a. Bienal propôs uma reflexão sobre o Como viver junto, ou, segundo Barthes, como achar a justa distância para tornar possível a vida social e a justaposição de ritmos diferentes em um mesmo espaço físico. A mostra foi conceituada na interseção de duas linhas que marcaram a experimentação do artista Hélio Oiticica: o sentido de artista 
construtor, que está na base da experimentação neoconcreta, e o adeus ao esteticismo. Na mostra, esses pensamentos foram traduzidos em dois eixos: Projetos Construtivos e Programas para a Vida. Em um documento no arquivo da Fundação Bienal, os curadores explicitam a relação entre o repertório propositor de Oiticica e os textos de Barthes:

Chega-se a um debate difícil: quando o artista coloca a serviço do ambiente, participando da configuração da vida cotidiana, qual é a diferença residual entre arte e vida, representação e realidade? O título desta Bienal, "Como viver junto" inspirado dos cursos e seminários ministrados por Roland Barthes no College de France, apresentou-se como desdobramento de uma reflexão acerca da construção de um espaço comum, uma vez que se debruça sobre o conturbado tema da coexistência de povos, ritmos de produção, práticas cooperativas. A potência criativa estaria apta a construir uma liberdade? Como estabelecer verdadeiras trocas entra arte e sociedade? ${ }^{\text {II }}$

Vale ressaltar que ausência de obras de Oiticica foi uma importante decisão curatorial, pois o foco estava sendo

5I Documento oficial produzido pelos curadores para a Fundação Bienal, sem data, ver anexo 2. direcionado para as propostas teóricas do artista. Lagnado justifica seu intuito no catálogo da mostra alegando que os Projetos Ambientais perdem sentido quando reconstruídos:

Sem serem uma nova categoria formal, mas uma territorialização do indivíduo em áreas abertas, os Projetos Ambientais de Oiticica colocam um problema quando são reconstruídos, porque acabam negligenciando mudanças comportamentais. Se os tempos são outros, é preciso reconhecer a artificialidade de aplicar, hoje, proposições de vida inauguradas com Éden [Whitechapel, Londres, I969] (2006a, p. 57).

O projeto original de Lagnado, denominado blocos sem fronteira, era constituído de seis grupos de obras: Broodthaers (com reflexões da obra de Marcel Broodthaers), Arquitetura (sobre a relação arte e arquitetura), Reconstrução (sobre a reconstrução material e imaterial), Vida Coletiva (relacionando o vetor extraído dos cursos de Barthes e a ideia de comunidade recorrente nos Programas Ambientais de Oiticica), Trocas (lidando com a ideia de transferência e intercambio entre pessoas) e Acre (acerca das noções de floresta, território e fronteiras brasileiras). Cada um dos curadores ficou responsável por um bloco e a divisão dos artistas seguiu esse critério. O sétimo bloco seria uma mostra de filmes transversal a todos os temas. 
Os seis blocos deram origem aos seminários e o sétimo bloco foi transformado na Quinzena de Filmes, que aconteceu em uma sala de cinema, ${ }^{52}$ como uma mostra paralela à 27a. Bienal. Os seminários ocorreram ao longo do ano de 2006 e sua proposta era ser uma plataforma de discussão que daria suporte a uma compreensão mais aprofundada da 27 a. Bienal, a qual não se restringiria a uma exposição temporária. Havia uma intenção de questionar a efemeridade de um evento custoso e reverter o caráter espetacular da mostra ao proporcionar um espaço de discussão e produção intelectual ao longo de todo o ano (LAGNADO, 2006a).

O desenvolvimento do projeto curatorial e a busca por uma clareza maior na comunicação com o público levaram a uma reformulação das estratégias tradicionais. Para atingir tal objetivo, os blocos citados acima deram lugar a dois grandes eixos de reflexão, se aproximando da abordagem sem categorias de Oiticica:

- Projetos Construtivos, sobre como construir o espaço social ou o habitat; Oiticica usava o termo artista construtor, em suas palavras: "São os construtores, construtor da estrutura, da cor, do espaço e do tempo, os que acrescentam novas visões e modificam a maneira de ver e sentir, portanto os que abrem novos rumos na sensibilidade contemporânea”

52 Sala de cinema no conjunto Nacional na avenida Paulista em São Paulo-SP.
(OITICICA apud LAGNADO, 2005). Dentro deste eixo estão: Arte e Arquitetura (real e imaginária), discutidas a partir do papel que ocupam na criação de novas formas de comportamento, sobre o que faz de um espaço físico um lugar de convivência. E Reconstrução, “[...] cujo aspecto físico é evidente na reconfiguração do perfil das cidades destruídas por guerras, reais ou simbólicas e, por outro lado latente na dinâmica dos deslocamentos, transformações, diásporas e migrações" (FREIRE, 2006, p.I75).

- Programas para a Vida, sobre como colocar em prática relações comunitárias. (CYPRIANO, 2005). Este bloco da 27a. Bienal retoma reflexões de Broodthaers sobre a ficção, o suporte, a anti-teoria, a crítica da instituição, a não arte, o falso. Aborda as trocas entre artistas e não artistas, o trabalho imaterial; a discussão sobre o Acre ${ }^{53}$

53 O tema Acre surge após uma visita de Lagnado ao estado, onde entra em contato com as problemáticas locais e decide trazer o tema para trabalhar questões de fronteira, conflitos pela terra, comunidades locais. O Acre foi área de colonização espanhola mas foi povoado somente em I877, que naquela época pertencia à Bolívia, com a chegada da quase totalidade dos migrantes que, oriundos do Nordeste do Brasil, colonizaram a região para buscar a borracha que se encontrava na Floresta Amazônica. Os seringueiros, lutaram com as tropas para realizar a ocupação da região e, em ${ }_{1903}$, foram os autores da proclamação do Estado Independente do Acre. Então, a região foi ocupada militarmente pelo governo brasileiro e depois o Brasil assumiria o controle do Acre. O governo brasileiro decidiu criar o Território Federal do Acre em I904. O presidente do Brasil João Goulart elevou o Território Federal do Acre à categoria de Estado em 1962. Fonte: https://pt.wikipedia.org/wiki/Acre 
traz a problemática das fronteiras e a busca de um sistema coletivo de valores e exemplos de subsistência e produção.

A organização da narrativa curatorial no espaço foi definida a partir desses dois eixos. A proposta era a de um fluxo continuo pela exposição por meio do qual ainda seria possível perceber a presença dos blocos, mas deixando clara a intenção de não setorização:

Você entra na Bienal e vê claramente projetos de arquitetura, maquetes relacionadas ao habitat. Mais para frente, temos a questão do comportamento dentro da arquitetura, as questões sociais que surgem, as questões políticas. No terceiro andar, é mais "como viver junto" porque seria a coisa mais “Éden” do Hélio Oiticica.

Como eu não quis trabalhar com categorias, como o Hélio não trabalhava, existem momentos de respiro. Não é ton-sur-ton, eu não trabalhei com afinidades, pelo contrário, quando eu via que havia sobreposições de questões eu tentei afastar os artistas para dar autonomia para eles. Mas o caminho é sempre contaminado. É Projetos Construtivos na entrada, como construir uma África do Sul [...]. Então, claro, você não pode discutir a construção de uma nação sem falar das pessoas desta nação. Então está tudo impregnado do comportamento das pessoas. Mas o primeiro piso eu diria que discute mais o habitat, a moradia, a fronteira, a arquitetura; as questões sociais e políticas vão crescendo no segundo andar, até a utopia do terceiro andar, do "como viver junto" (LAGNADO, 2006d).

A arquiteta defende que a expografia deve ser um amparo sereno suficiente para que a obra prevaleça (2006), ou seja, o oposto de uma proposta cenográfica. Propôs que o percurso fosse editado por diferentes qualidades de luz ao longo do pavilhão. Em determinadas situações tirou partido da iluminação natural do edifício, em outros casos trabalhou exclusivamente com sistema de iluminação artificial, ou de salas escuras.

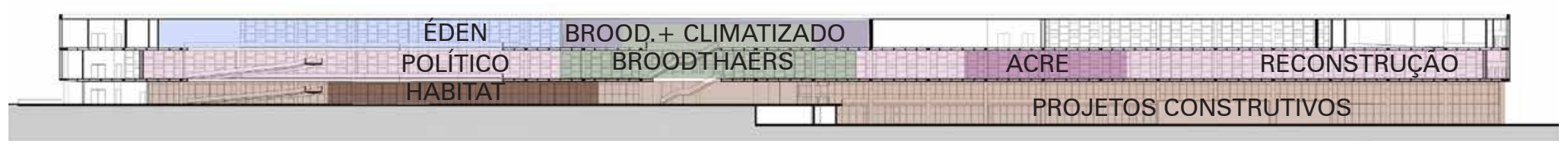

Diagrama: corte longitudinal do Pavilhão com indicação da narrativa curatorial, conforme descrição de Lagnado (2006c). Fonte: acervo da autora. 
A primeira coisa é que as pessoas se deixem levar naturalmente pelas obras, mas também se deixem levar pelo pavilhão. (Que tenham) a compreensão de que este espaço tem uma particularidade que o distingue de um museu, de um cubo branco clássico. Os artistas, até onde eu pude acompanhar, puderam não só entender, mas se encantar com isso, a ponto de dialogar o tempo inteiro com a presença do pavilhão. É a oportunidade de ver obras que poderiam estar sendo apresentadas de uma maneira muito distinta, se estivéssemos em um museu, com espaços estanques, fechados e isolados. As obras aqui neste prédio foram ativadas por um espaço de convívio mais permeável—não só entre os trabalhos apresentados, mas, sobretudo, entre as obras e o pavilhão, em particular, que se abre para a cidade e para um parque como o Ibirapuera (BOGÉA, 2006).

Conforme aponta Bogéa, o projeto curatorial da 27a. Bienal e a forte presença do pavilhão favoreceram uma grande quantidade de obras que estabeleciam diálogo com o espaço do edifício, principalmente no térreo, no primeiro e no segundo pavimentos, onde se concentraram os artistas construtivos.

A ideia de constituir um sistema expositivo mais neutro para atender a heterogeneidade da Bienal e que não se sobrepusesse às obras foi efetivado com painéis autoportantes de madeira pintados de branco. O sistema era composto por planos e volumes que não encostavam no forro ou nos caixilhos, procurando manter a transparência do parque a as longas vistas que o edifício proporciona.

Como já foi abordado anteriormente, havia a proposta dos curadores de expor mais de uma obra por $\operatorname{artista}^{54}$ e o desejo mais recorrente dos últimos de que suas obras fossem exibidas sem interferências. Essas demandas levaram à construção de muitos volumes fechados e à fragmentação do espaço. A apreensão da exposição pelo público ficou prejudicada pelo excessivo adensamento de dispositivos e obras. Apesar disso, a crítica Maria Hirszman (2006) fez uma análise positiva da expografia:

O projeto assinado por Marta Bogéa dá ao prédio de Oscar Niemeyer uma limpeza e uma visibilidade impressionantes. Um grau de enxugamento que nos permite finalmente imaginar esse espaço transformado num verdadeiro campo de experimentação artística em vez de uma sucessão de pequenas mostras individuais. Evidentemente ainda há um acúmulo de paredes, recurso necessário para conseguir exibir o grande volume de obras selecionado para a exposição, sobretudo no caso das fotografias e das videoinstalações.

54 A lista chega a Iı8 artistas, dos quais quatro estão apenas no catálogo; os outros II 4 tiveram mais de uma obra exposta na mostra. Ver lista de obras no anexo 3 . 


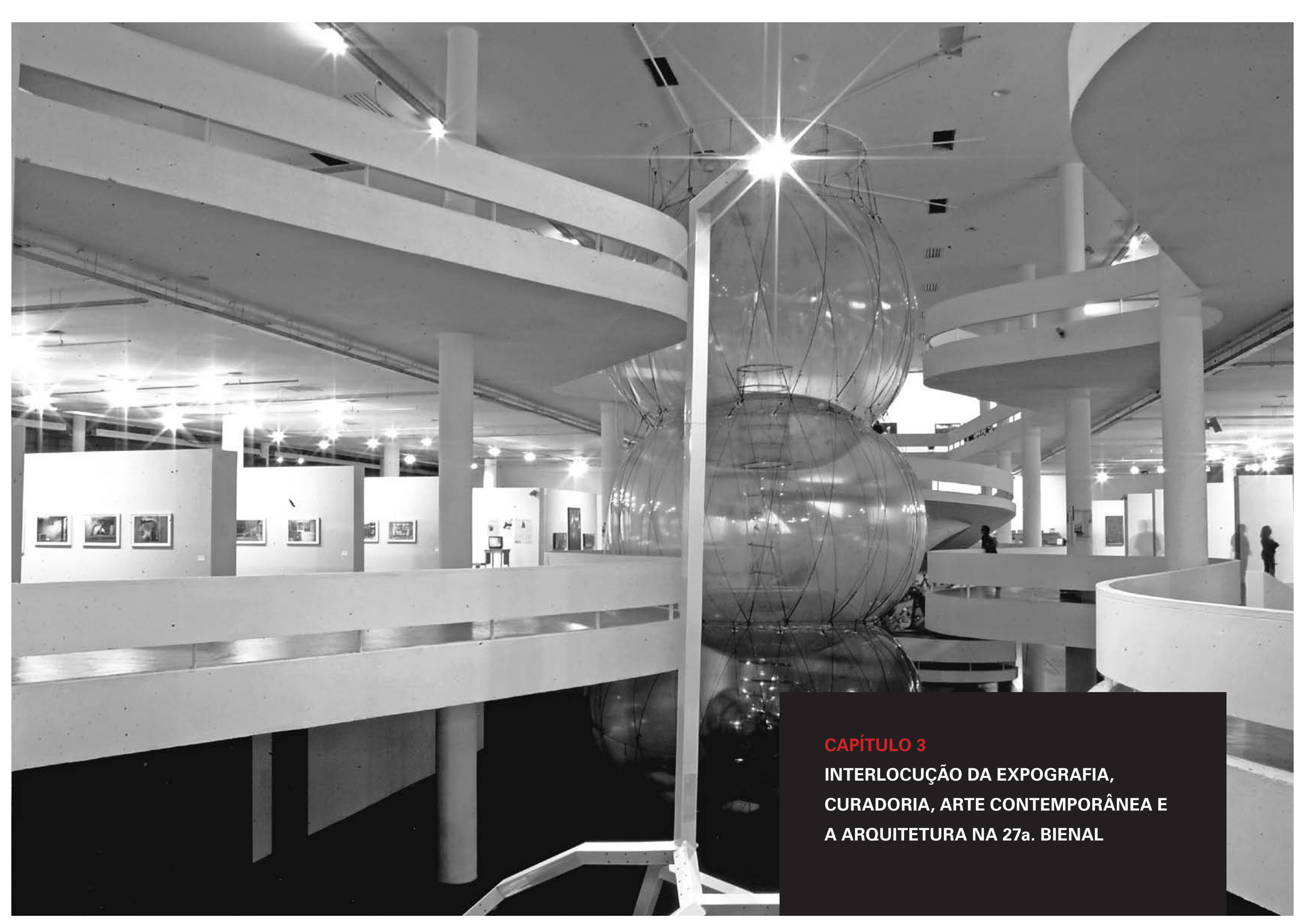


Esse capítulo estuda as relações entre os quatro eixos centrais da dissertação: expografia, arquitetura, curadoria e arte contemporânea na 27a. Bienal de São Paulo. Analisa de que forma o discurso curatorial se revelou na construção do espaço expositivo. A proposta foi fazer um percurso pela mostra que se inicia no térreo e termina na área climatizada, com dois pontos estratégicos de aprofundamento de análise: acesso e praça Broodthaers/área climatizada. 


\subsection{PAVIMENTO TÉRREO: A RELAÇÃO CURADORIA E EXPOGRAFIA E A INSERÇÃO DAS OBRAS DE ARTE CONTEMPORÂNEA}

\subsubsection{0 acesso da exposição}

Vista do acesso da mostra na inauguração para público. Fonte: Arquivo Wanda Svevo. Foto: Juan Guerra.

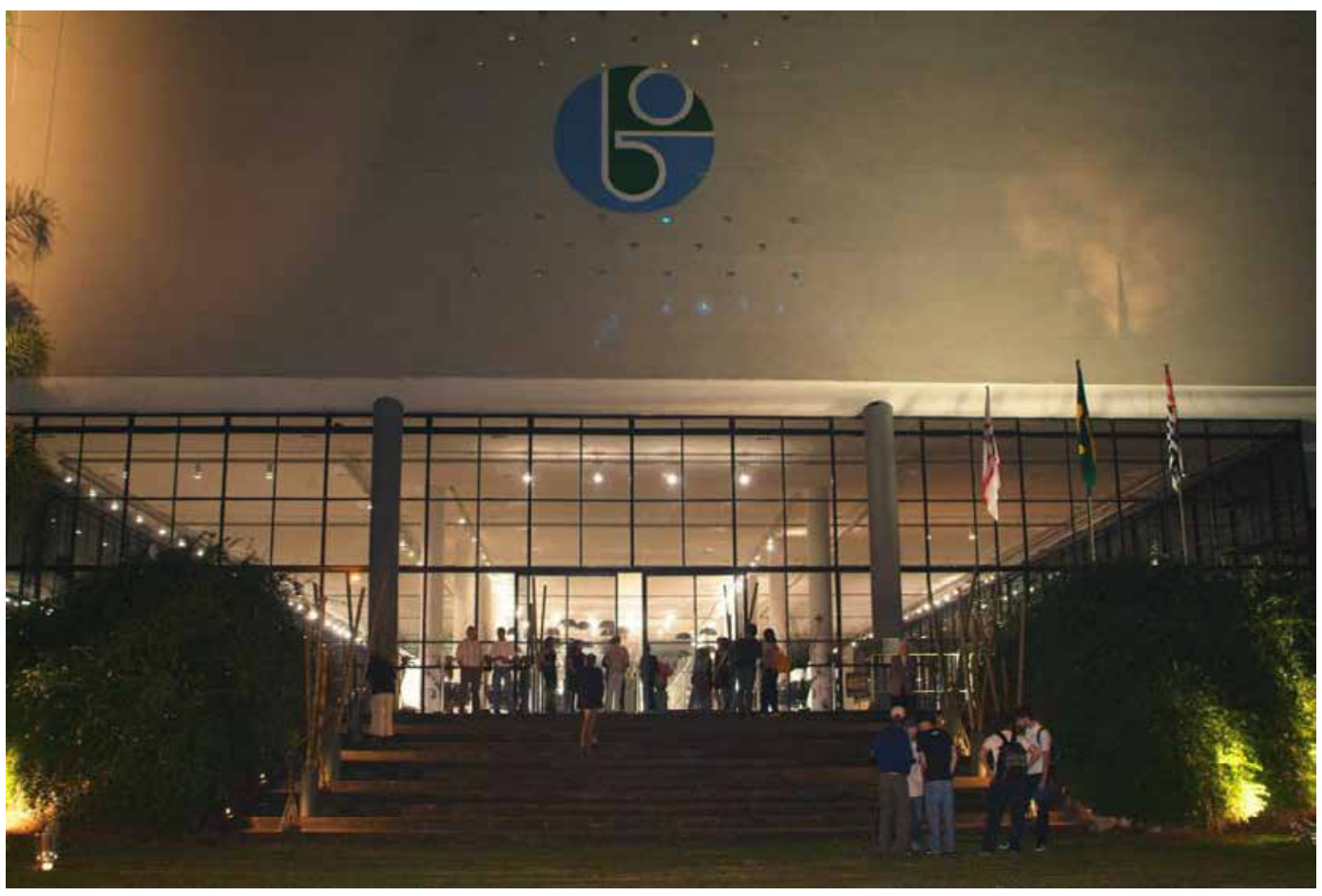

O acesso e a circulação de público são questões centrais em projetos expográficos, especialmente em um edifício de grandes dimensões como o Pavilhão Ciccillo Matarazzo. O edifício oferece muitas opções de acesso: no térreo e no primeiro pavimento existem quatorze portas que se abrem para o Parque Ibirapuera, ${ }^{1}$ e há ainda a possibilidade de acesso direto aos pavimentos superiores pela rampa externa. A circulação vertical é feita por três prumadas distribuídas pelo pavilhão: a rampa escultórica na parte leste, as escadas rolantes próximas ao centro e a rampa externa na parte oeste. Portanto, a combinação entre acessos e prumadas de circulação vertical gera diversas possibilidades de circuitos dentro do edifício.

Como as decisões sobre os fluxos da exposição estão amarradas ao conceito curatorial e à narrativa que se pretende construir, elas não podem ser pensadas apenas pelo ponto de vista da arquitetura. O projeto curatorial da 27a. Bienal,

I Seis portas em cada fachadas norte e sul e uma porta em cada cabeceira (leste e oeste). 


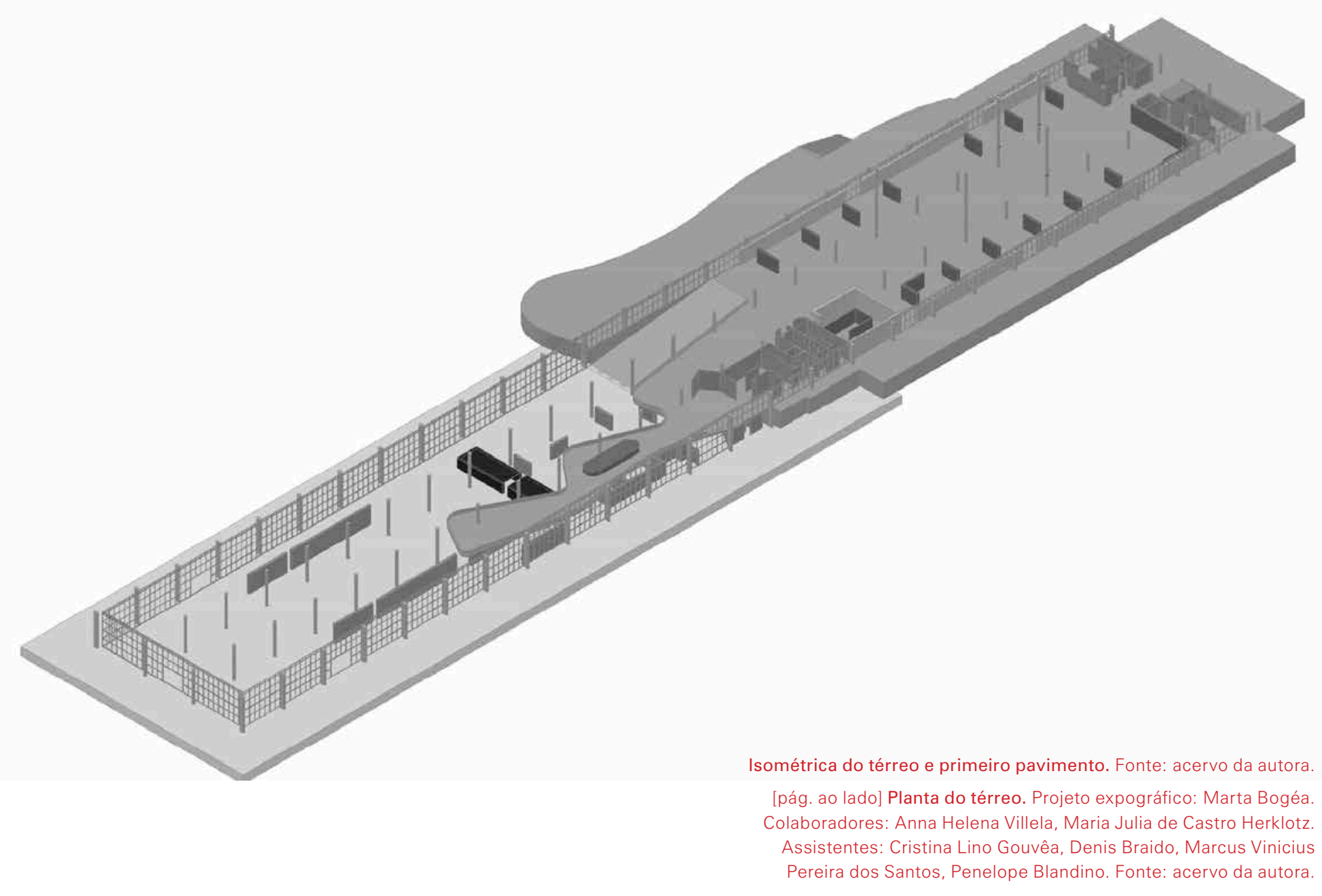


ainda na etapa conceitual, tinha como premissa uma narrativa contínua para a exposição. ${ }^{2}$ Considerando essa prerrogativa curatorial, Marta Bogéa buscou uma solução para o fluxo interrompido dentro do pavilhão, uma vez que os acessos usuais tanto pela marquise quanto pelo primeiro pavimento criavam necessariamente um rompimento no edifício em duas partes. O térreo, nas duas opções, ficava apartado do resto do pavilhão, criando um bolsão isolado.

Uma referência importante de Bogéa para definir a nova entrada foi o trabalho a obra de Rubens Mano, Vazadores $(2002)^{3}$ na 25a. Bienal cujo acesso se fez pela fachada leste (frente para Avenida Pedro Alvares Cabral). O artista propôs na fachada dos fundos (fachada oeste), na configuração de fluxo da mostra, um elemento que mimetizado à arquitetura, criava um corredor fechado com vidros basculantes, onde o público poderia descobrir uma passagem para dentro da exposição sem pagar pela entrada ${ }^{4}$. Esta obra lançou luz para esta possibilidade de acesso que não havia sido utilizada.

2 Informação fornecida por Marta Bogéa em entrevista realizada em 20I8. Ver anexo I.

3 Rubens Mano tratou da obra Vazadores em palestra realizada na Escola da Cidade. Disponível em: <http://escoladacidade.org/bau/rubens-mano-o-espaco-enquanto-imagem-projetada-2/>. Acesso em: I2 jan. 2019.

4 Até a 25 a. Bienal a entrada da mostra era cobrada, a partir da 26a. edição passa a ser gratuita.
A proposta de acesso pela cabeceira oeste, no sentido longitudinal do edifício, foi reiterada pelo estudo do projeto original do pavilhão, 5 que configurava o térreo como uma grande área de pilotis.

Como a fachada oeste não oferecia uma marquise de acolhimento, Bogéa transformou esse espaço interno do edifício em um foyer ou praça que funcionaria como uma extensão do parque, abrindo acessos pelas três fachadas na cabeceira do pavilhão e recuperando, assim, o caráter do projeto original. $\mathrm{O}$ acesso pela fachada oeste atendeu às diretrizes curatoriais e viabilizou uma circulação continua que valorizou o enorme sentido longitudinal do pavilhão.

No centro da praça de acolhimento, a curadoria implantou uma obra que representava o statement curatorial, ${ }^{6}$ com a intenção de criar um grande impacto. O público, que era convidado a entrar na exposição de maneira fluida por três grandes aberturas, foi recebido, ou melhor dizendo impedido, pela obra Security (2006) [1] de Jane Alexander (1959, Joanesburgo, África do Sul).

A colonização do continente africano recoloca em perspectiva o passado escravocrata do Brasil e, nesse

5 O estudo do projeto original do pavilhão revelou a proposta de uma grande área de pilotis no trecho oeste, que criava um espaço de acolhimento e soltava o pavilhão como um prisma.

6 Principal afirmação da curadoria. 
[no topol Vazadores, Rubens Mano, na 25a. Bienal (2002).

Fonte: uol entretenimento.

[embaixo] Security, Jane Alexander [1]. Fonte: Arquivo Wanda Svevo.

Foto: Juan Guerra.
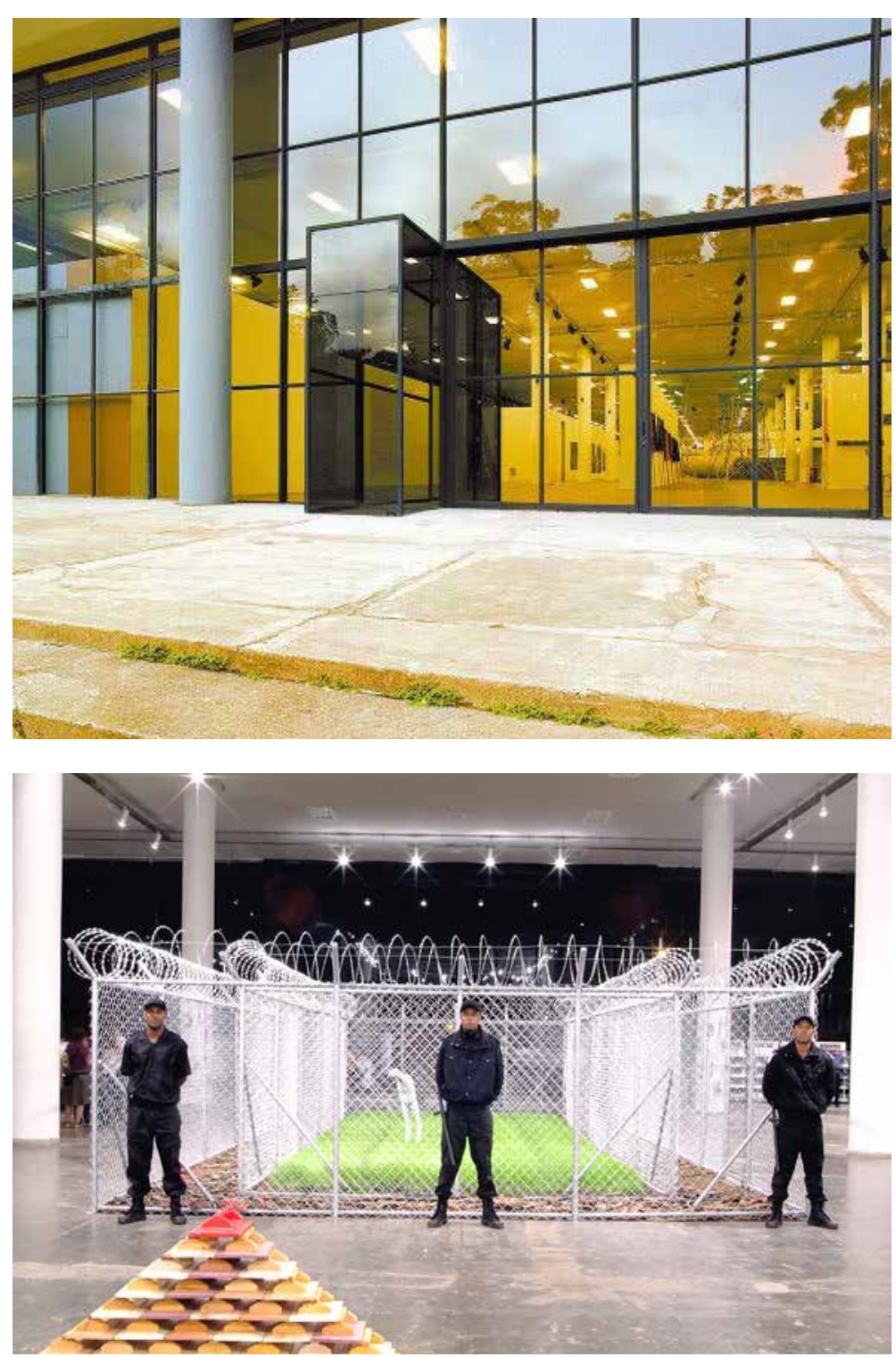

[no topo] Vista interna do acesso do acesso da 27a. Bienal.

Fonte: Arquivo Wanda Svevo. Foto: Juan Guerra.

[embaixo] Vista do pavimento térreo vazio no início da montagem da exposição. Fonte: acervo Marta Bogéa. Foto: Juan Guerra.
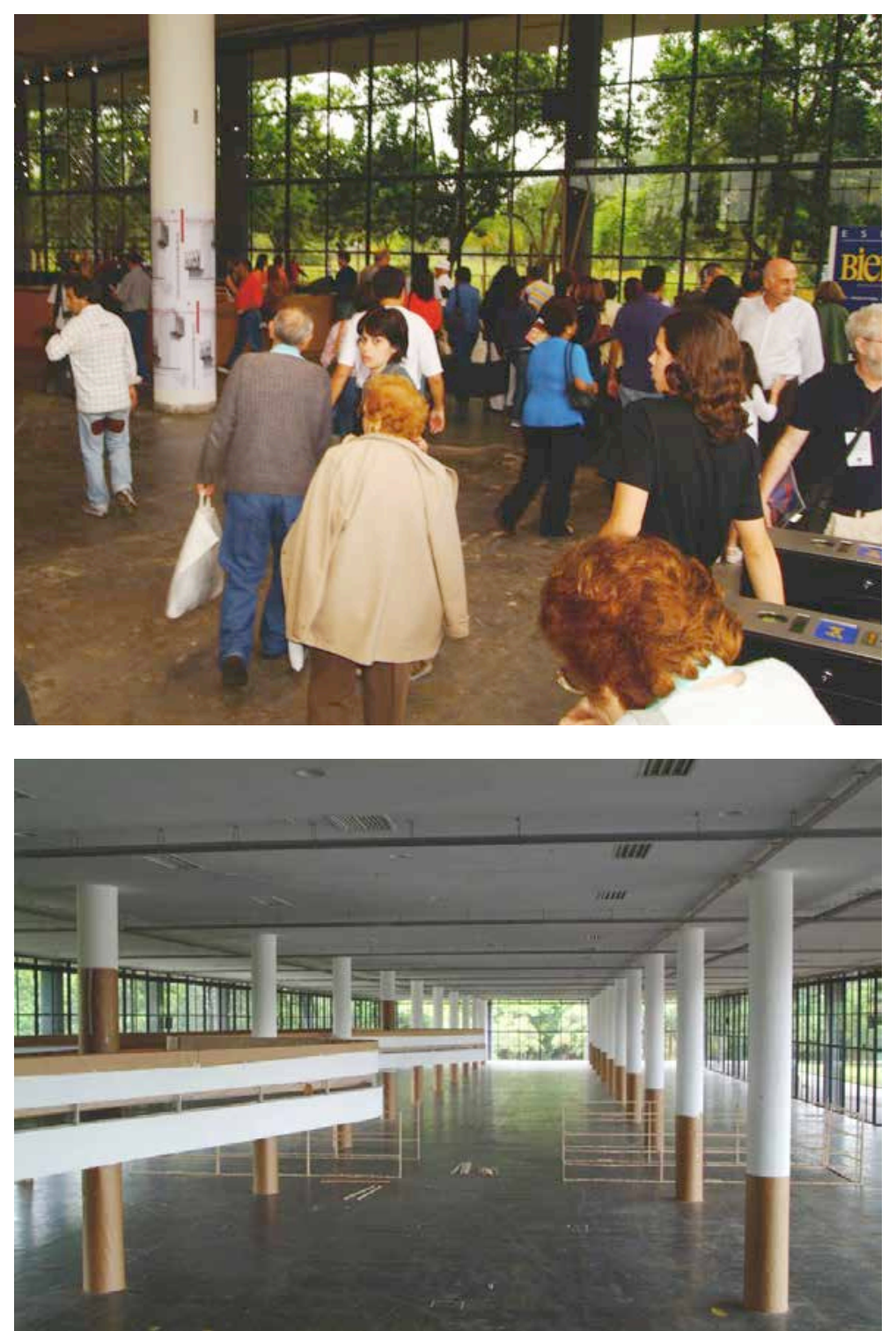
sentido, a poderosa instalação de Jane Alexander, Security, foi escolhida para fornecer o statement curatorial da mostra logo na entrada do pavilhão. O resultado desta Bienal sem as representações nacionais trouxe à tona questões relativas à diferença entre pátria e terra, nacionalidade e exílio, casa e abrigo (LAGNADO,2006a, p.53-54).

A obra dissolveu, no primeiro instante, qualquer idealização que o tema da mostra Como viver junto pudesse criar. A instalação era constituída por duas camadas de cercas de alambrado e arames farpado. O espaço entre as cercas tinha o piso forrado de armas brancas utilizadas no regime do apartheid sul-africano. No centro, um gramado com um ser híbrido com cabeça de ave, corpo que se a assemelha ao de um ser humano sem braços ou um pássaro sem asas, sem vida, solitário, prisioneiro e incomunicável. Ao redor das cercas circulavam seis seguranças afrodescentes com cassetetes, trazendo uma mensagem clara sobre a segregação e violência.

A resiliência dos preconceitos raciais e formas de discriminação; a reprodução de formas neocoloniais de dominação; a sempre crescente obsessão pela segurança e a proliferação paralela e global de fronteiras fortificadas e sistemas de vigilância são alguns dos temas dominantes do trabalho recente de Alexander ?

A decisão de colocar a obra de Alexander como abre-alas da exposição revelou como Lagnado tirou partido desse acesso, que se desejava fluido e convidativo pelo projeto expográfico, para expor a carga política da mostra, construindo uma fronteira a ser vencida pelo público.

As obras de Marepe (1970, Santo Antônio de Jesus, BA), que trabalha com a cultura popular por meio da apropriação de objetos, puderam ser vistas em simultaneidade com a instalação de Alexander: Desempoladeiras (2006) [5a], constituída por ferramentas de construção civil empilhadas que remetem à mão de obra de migrantes na construção civil de São Paulo, e Cânone (2006) [5b], construída com guarda-chuvas, empilhados e conectados por um gancho e um pêndulo, um protegendo ao outro e buscando equilíbrio - segundo o artista, uma forma de justiça (LAGNADO; PEDROSA, 2006b, p.156). A vizinhança entre a obras de Alexander e Marepe revela a construção do discurso curatorial que fez a conexão entre os contextos de segregação sul-africano e o brasileiro.

Do lado de fora do pavilhão, próximo ao acesso, foram instaladas três obras importantes para estruturar a narrativa

7 Pep Subiró. Security (Surveys from the Cape of Good Hope). Exhibition at La Centrale Électrique, Brussels. Maio de 20II. Disponível em: https://universes. art/en/magazine/articles/20II/jane-alexander/. Acesso: ०8/09/2018. 
[no topo] Vista do térreo: na frente Desempoladeiras [5a] de Marepe; ao fundo a praça de acolhimento e Security, de Jane Alexander Fonte: Arquivo Wanda Svevo. Foto: Juan Guerra.

[embaixo] Vista a partir do parque do pavilhão Homenagem a Vilanova Artigas de Dan Graham [2]. Fonte: Arquivo Wanda Svevo. Foto: Juan Guerra.
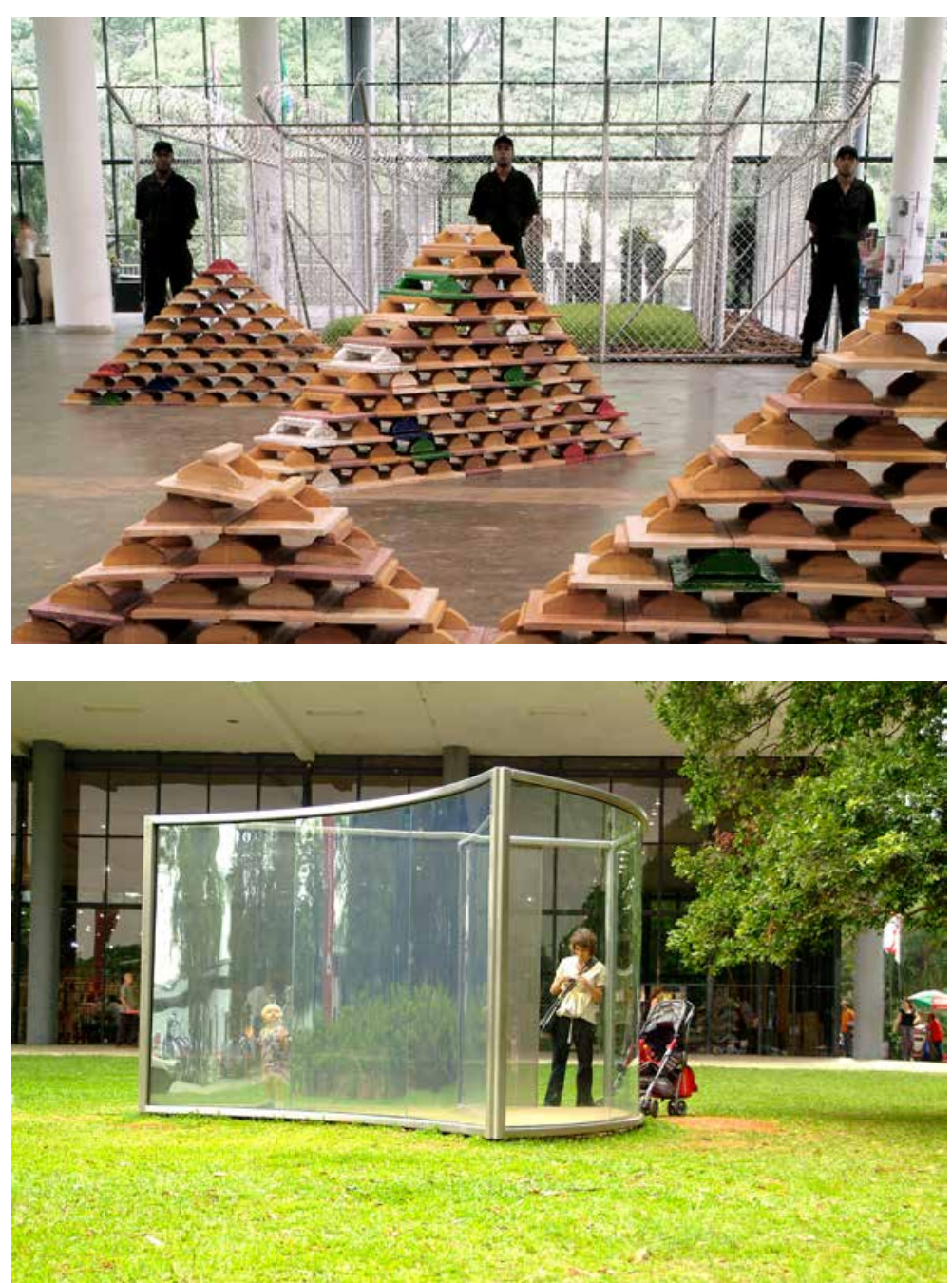

curatorial. Eram trabalhos com um forte caráter construtivo e que exerciam o papel de expandir a Bienal para o parque: Homenagem a Vilanova Artigas (2006) [2], um pavilhão de Dan Graham (I942, Urbana, Estados Unidos); Dumpster Duplex (I972/2006) [3], de Gordon Matta-Clark (I943, Nova York, Estados Unidos) e Escada parasita (2006) [4], de Marcelo Cidade (i979, São Paulo, SP).

O pavilhão de vidros curvos Homenagem a Vilanova Artigas foi instalado entre o acesso da mostra e a marquise, uma área de jardim com grama e árvores. Graham fez a opção pelo uso de curvas em sua instalação apesar de ter sido desaconselhado devido à referência obvia à Oscar Niemeyer. ${ }^{8}$ No entanto, a proposta cujo intuito era "arremedar e parodiar e depois virar tudo de cabeça para baixo" (GRAHAM, 2006 p.56) foi mantida. Segundo o artista, seu pavilhão era muito mais barroco, com distorções anamórficas e estava mais ligado ao céu e a paisagem, enquanto o de Niemeyer estava relacionado ao corpo. A ironia do artista também se evidencia ao nomear o pavilhão dentro do conjunto do Parque Ibirapuera, uma homenagem a João Batista Vilanova Artigas, ${ }^{9}$ o principal representante da escola Paulista de arquitetura moderna que, segundo a historiografia, propôs uma abordagem que diverge

8 Depoimento dado pelo artista publicado no Guia da mostra.

9 Em entrevista, Dan Graham diz que admira a obra da FAUUSP de Artigas e seu caráter comunitário e socialista, e cita a casa Kubitschek em Belo Horizonte como um exemplo de como Niemeyer trabalha bem em pequena escala. 
da de Niemeyer ${ }^{10}$. Artigas, diferente de Niemeyer incluiu na sua arquitetura a discussão sobre modos de vida. A inserção desse pavilhão entre árvores e arbustos de fato favoreceu mais a relação com a natureza do parque do que com os edifícios adjacentes para quem o vivenciou. Mas a obra pode ser vista de cima, em sua integridade, através das frestas dos brises do segundo pavimento Pavilhão da Bienal. ${ }^{\text {II }}$ Para Adriano Pedrosa, os pavilhões de Graham se inserem no conceito curatorial porque são lugares para convivência, de fruição estética e de lazer, nesse sentido é profundamente vinculado com o Crelazer de Hélio Oiticica. Beatriz Colomina, ${ }^{\mathrm{I} 2}$ no seminário Arquitetura, aponta que as instalações de Graham são espaços definidos por reflexos que tornam os pavilhões,

Io Embora Artigas e Oscar Niemeyer fossem amigos e correligionários no PCB, na história da arquitetura brasileira ele costuma ser considerado o responsável pela ruptura com a geração dos criadores de Brasília (Niemeyer e Lucio Costa), chamada por alguns de escola carioca. "Artigas passa a adotar uma técnica produtiva que espelha sua concepção de país e projeta outra imagem da identidade moderna do Brasil”, diz Renato Anelli, professor do IAU-USP. "Em relação à obra de Niemeyer, Artigas radicaliza a estrutura, tornando mais claros os processos de projeto e construção. Ele explora os espaços abertos, interpretando a questão social por meio de uma arquitetura sem barreiras, sem portas, mas não é tão tentado à forma livre e algo exibicionista da "escola carioca". Disponível em: $<$ http://revistapesquisa.fapesp. br/2015/06/16/turbilhao-artigas/>. Acesso em: II jan. 2019.

II São raros os registros fotográficos da obra, uma hipótese da ausência de registros é insatisfação declara por Graham em relação a qualidade de execução do pavilhão que prejudicou a vivência na obra.

I2 Professora de arquitetura e diretora do Programa de Medias e Modernidade da Universidade Princeton, nos Estados Unidos.
Dumpster Duplex de Gordon Matta-Clark [3]. Fonte: LAGNADO; PEDROSA, 2008.

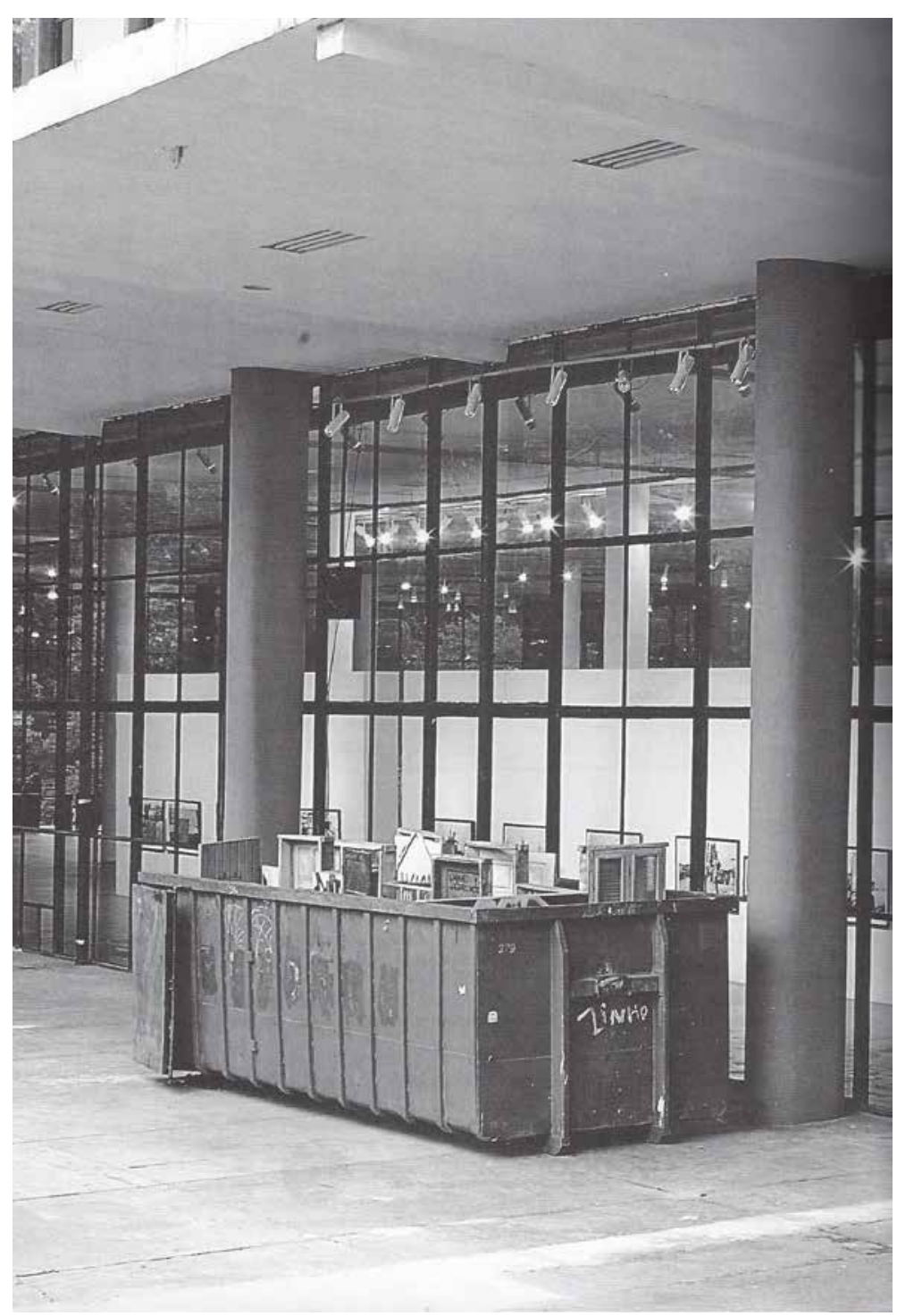


aparentemente estáticos, em espaços ativos cuja linguagem se aproxima dos meios de comunicação eletrônicos, mas sem o uso de tecnologia (COLOMINA, 2008, p.I4I).

Dumpster Duplex, ou caçamba duplex, de Gordon MattaClark foi instalada na marquise, na fachada sul ao lado do acesso. A obra, um imenso contêiner de lixo, foi moradia do artista em 1972 em Nova Iorque. A instalação chamava atenção para a situação da grande população de moradores sem teto: “[...] uma moradia descartável para as pessoas que a cidade descarta" (CRAWFORD, 2008, p.235). Os visitantes que compareciam à caçamba eram convidados a participar da performance, transeuntes que passavam pela rua, eram convidados a filmar. O material que documentou a performance gerou o filme Open House (I972).

O Open House é uma estrutura construída dentro de um contêiner industrial na cidade de Nova York entre 98th e II nd Greene Street. O contêiner foi dividido em três corredores e depois em salas menores, usando materiais descartados, como portas e peças antigas de madeira. A construção sem teto funcionava como um lugar dirigido por artistas, dançarinos e assim por diante, que ativavam a peça simplesmente movendo-se em torno de seus espaços. A chuva no dia da abertura produziu uma dança de guarda-chuva viva e colorida que adiciona um toque lúdico ao filme.
O Open House documenta esse período no início da década de 1970, quando vários artistas estavam revistando as instalações industriais abandonadas do Baixo Manhattan para novos espaços de criação, promoção e exibição como alternativas para o estúdio, o museu e a galeria (HINOJOSA, 2007, s.p.)

Este ambiente ativista do SoHo nos anos I970 em Nova Iorque foi vivenciado por Oiticica (que viveu lá de 1970 a I978) no momento em que o artista desenvolveu os Programas Ambientais, base conceitual da 27a. Bienal. Havia uma grande proximidade propositiva do ponto de vista construtivo e da ação entre os artistas. Ambos estavam desinteressados pelo trabalho dentro da estrutura oficial. Mais do que uma crítica do sistema da arte, a proposta era que o trabalho de arte se inserisse na vida coletiva (FAVARETTO, 2008, p.244). A coexistência de Matta-Clark e Oiticica nos anos I970 e a importância que Lagnado dá a ela, remete à pergunta de Roland Barthes acerca da contemporaneidade destacada pela curadora no catálogo da mostra:

Mas, em estado bruto, o Viver-Junto é também temporal, e é necessário marcar aqui esta casa: “viver ao mesmo tempo em que...", "viver no mesmo tempo em que...” = a contemporaneidade. Por exemplo, posso dizer, sem mentir, que Marx, Mallarmé, Nietzsche e 
Freud viveram vinte e sete anos juntos. Ainda mais, teria sido possível reuni-los em alguma cidade da Suíça em I876, por exemplo, e eles teriam podido-último índice do Viver-Junto — “conversar”. Freud tinha então vinte anos, Nietzsche trinta e dois, Mallarmé trinta e quatro e Marx cinquenta e seis. (Poderíamos nos perguntar qual é, agora, o mais velho). Essa fantasia da concomitância visa a alertar sobre um fenômeno muito complexo, pouco estudados, parece-me: a contemporaneidade. De quem sou contemporâneo? Com quem é que eu vivo? (BARTHES apud LAGNADO; PEDROSA, 2006a, p.I6).

Matta-Clark foi um artista essencial na construção histórica da arte relacional contemporânea realizada na mostra. A presença de sua obra no acesso da exposição constituiu uma introdução à narrativa curatorial.

$\mathrm{Na}$ fachada de acesso, Marcelo Cidade instalou Escada parasita (2006), uma pequena escada metálica sobre a empena cega do pavilhão que se assemelha às escadas externas de emergência. Nesse caso, trata-se de um elemento sem função, sem acesso, que não liga nada a lugar algum. As dimensões da escada não se relacionam com o pavilhão, nem tem a altura de um pé direito; é um corpo externo que adere à fachada do edifício, mas que não se relaciona com seu interior, abordando aqui também um tema caro ao artista: a fronteira entre o
Escada parasita de Marcelo Cidade [4]. Fonte: site Bienal. Foto: Juan Guerra.

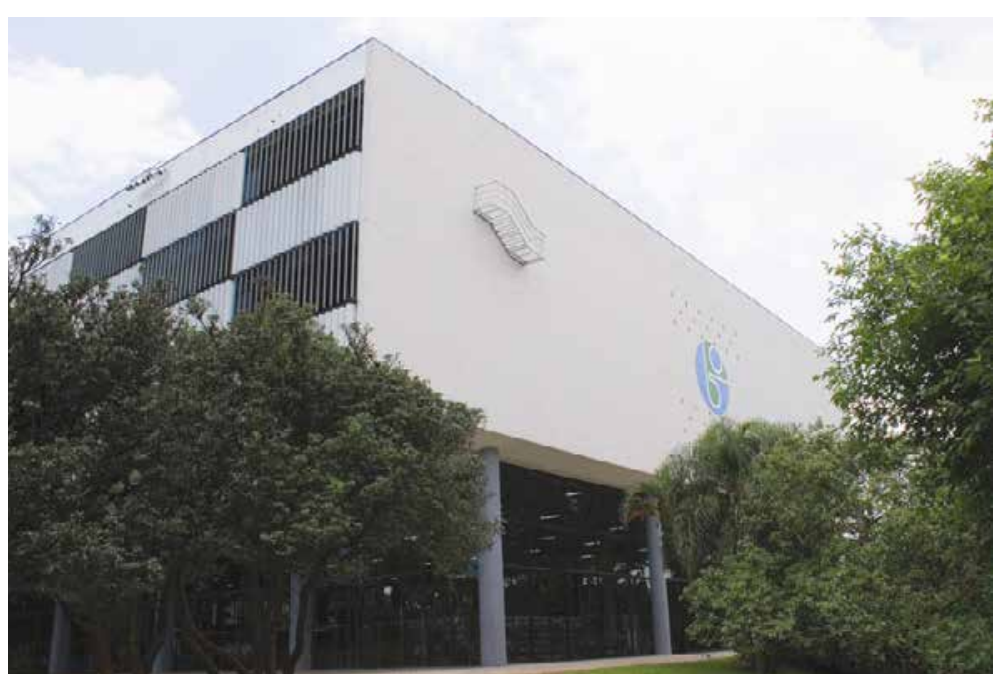


público e o privado. A obra traz uma crítica ao funcionalismo na arquitetura e, ao ser instalada na fachada do pavilhão, ${ }^{13}$ ganha um caráter ainda mais forte. O funcionalismo é um dos principais pilares da arquitetura moderna e foi duramente questionado por arquitetos e artistas pós-modernos. Nesse sentido, o Pavilhão Ciccillo Matarazzo é um importante representante da arquitetura moderna brasileira. Com plantas livres, estruturas independentes, cortinas de vidro, e brise soleil, as fachadas cegas das extremidades do edifício são os únicos lugares nos quais não há relação visual entre interior e exterior. A instalação da escada claramente subvertia a lógica funcional do pavilhão.

As obras que construíam o acesso da mostra foram criteriosamente escolhidas pela curadoria para anunciar a exposição. Segundo Pedrosa, "Matta-Clark e Graham são âncoras da 27a. Bienal” (PEDROSA, 2008, p.ro8). O caráter político e ativista da exposição ficava evidente nas obras de Alexander e de Matta-Clark; no espaço lúdico do pavilhão de Graham que se alinhava ao crelazer e à tropicália de Oiticica; e na crítica à arquitetura funcionalista de Cidade, temas que foram retomados ao longo da mostra.

I3 A obra já havia sido instalada anteriormente na Galeria Vermelho, em São Paulo, em 2006.

\subsubsection{O percurso pelo térreo}

O pavimento térreo possui como característica mais marcante sua relação direta com o parque, aspecto que o projeto expográfico procurou valorizar, deixando a luz natural e a paisagem externa estabelecerem uma forte presença na relação com as obras. Segundo a descrição de Bogéa (2006, s.p.): "O acesso inicial é um núcleo em que você vê o lado de fora e tem pouca arquitetura nova, o espaço vai se configurando pelas obras, pela própria natureza delas, tridimensionais e construtivas".

O acesso realizado pelo eixo longitudinal do pavilhão foi reiterado pelos dois principais elementos expográficos do pavimento. Duas longas linhas de painéis estabeleciam o sentido do fluxo e ocupação expográfica. Suas faces internas também deram suporte às séries de fotografias de Mauro Restiffe (1970, São José do Rio Claro, SP), Empossamento (2003) [6a] e Istambul (2003) [6b]. As fotografias de Empossamento foram feitas durante a cerimônia de posse do presidente Luiz Inácio Lula da Silva, em 2003. A arquitetura e o urbanismo modernos de Brasília apareciam como uma ruína, como se o espaço não fosse adequado a receber a multidão ou ter o uso para o qual fora designado.

O artista mostrava essa espécie de clima ruinoso não apenas por se tratar da documentação do clima de fim de festa, mas, sobretudo, pelo sutil desalinhamento da 
arquitetura de Niemeyer em relação ao próprio espaço da imagem fotográfica (CHIARELLI, 20I3, s.p.)

Segundo Restiffe, há uma relação de tensão entre Empossamento e Istambul, que se dá a partir da quebra de estereótipos: Brasília, uma cidade vazia, estava tomada por uma multidão, e Istambul, uma cidade "lotada", é mostrada desabitada (RESTIFFE, 2006).

As fotografias das cidades estabeleciam franco diálogo com as obras de Marepe, conforme citado anteriormente, que ocuparam o espaço central entre os painéis: as Desempoladeiras, que remetem à mão de obra da construção civil, e Cânone, na qual o artista construiu uma estrutura e um abrigo.

Nesse espaço central também estava uma enorme maquete urbana do Recife: Sweetness (2006) [7] de Meschac Gaba (1961, Cotonou- Benin), artista africano que mora na Holanda e que que escolheu fazer sua residência no RecifePE. O artista fez uma maquete da capital pernambucana feita com açúcar e inseriu nela edifícios símbolos de poder, como o Empire State Building, de Nova York. Utilizou o açúcar como metáfora do afeto e, simultaneamente, retomou a história da construção por escravos do Recife colonial, escravos que também trabalhavam na produção de açúcar, principal produto de exportação da colônia.

$\mathrm{Na}$ face externa dos painéis, que se abriam para o parque, as séries de fotos jornalísticas da República Democrática do
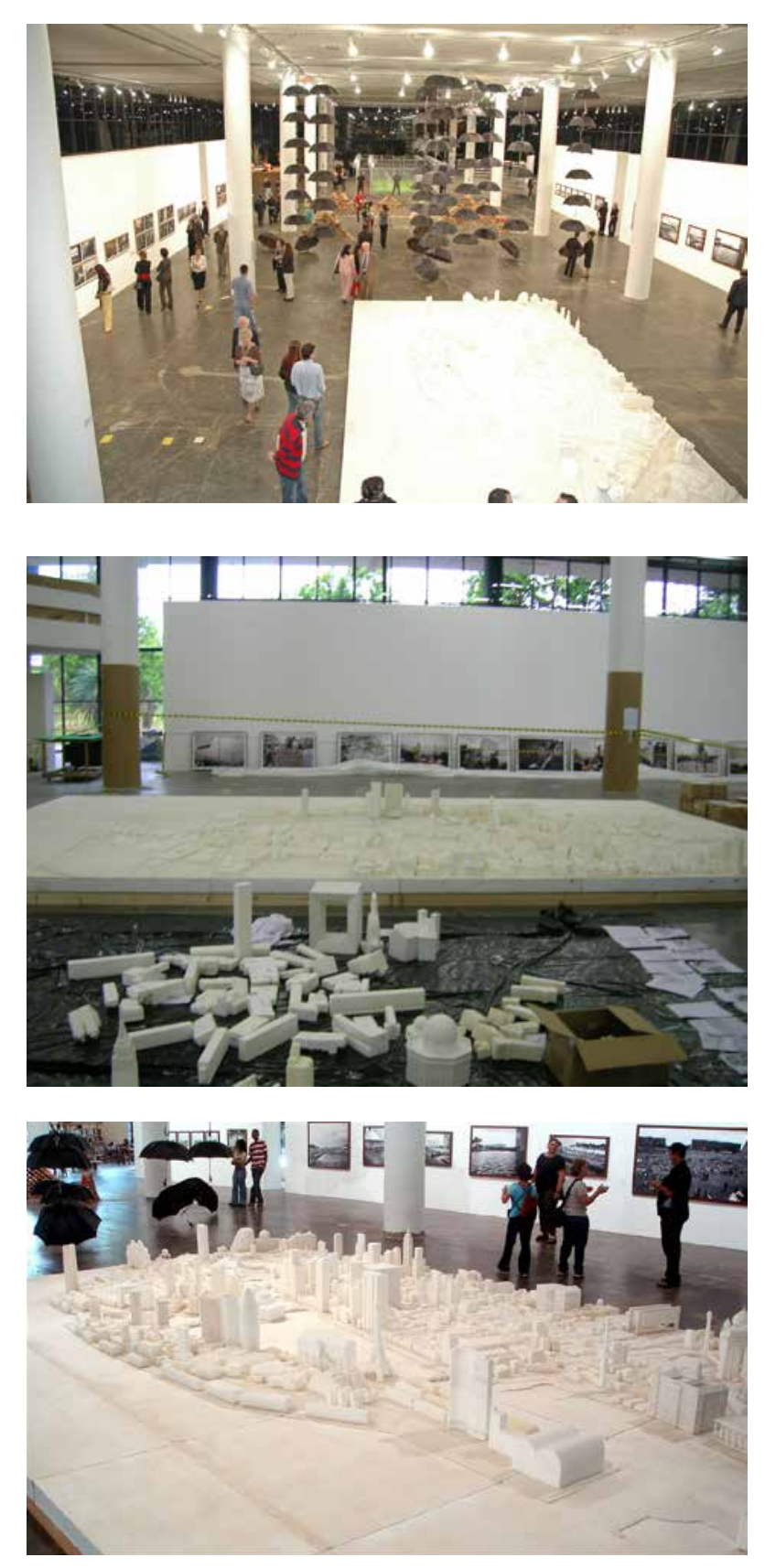

no topol Vista do térreo a parti do mezanino. Fonte: Arquivo Wanda Svevo. Foto: Juan Guerra. [ao centro] Montagem da obra Sweetness [7] de Meschac Gaba, ao fundo Empossamento [6a].

Fonte: acervo da autora.

Foto: Maria Julia Herklotz. [embaixo] Sweetness de Meschac Gaba [7]. Fonte: flickr. Disponível em: https://flickr.com. 

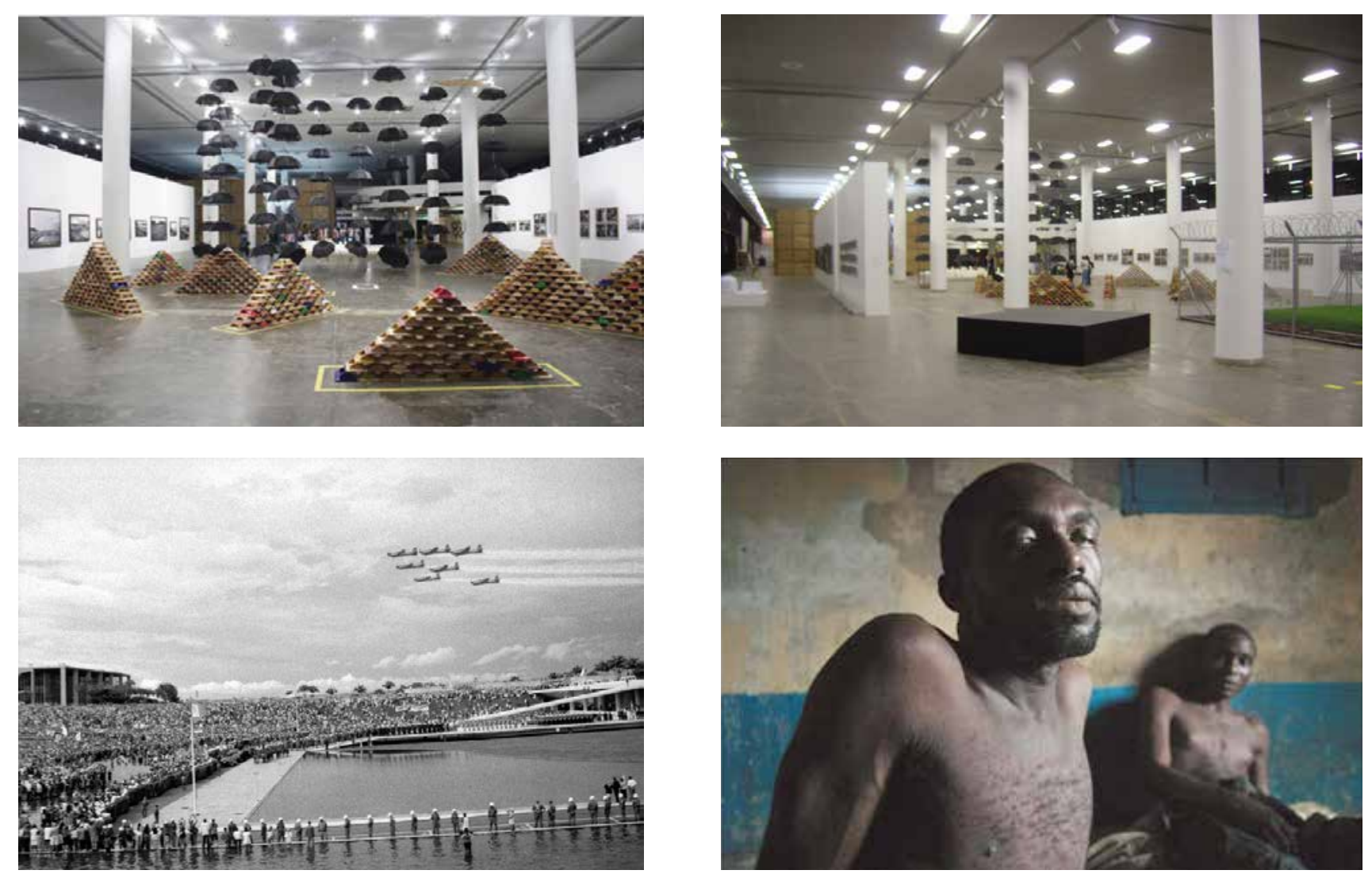

Restiffe [6a]. Fonte: acervo da autora.

[embaixo] Pyramid da série Istambul de Mauro Restiffe [6b]. Fonte: acervo da autor

Desempoladeiras [5a] Cânone [5b] do

Marepe; nas laterais os painéis com as tografias de Mauro Restiffe. Fonte: acervo Marta Bogéa. Foto: Juan Guerra.
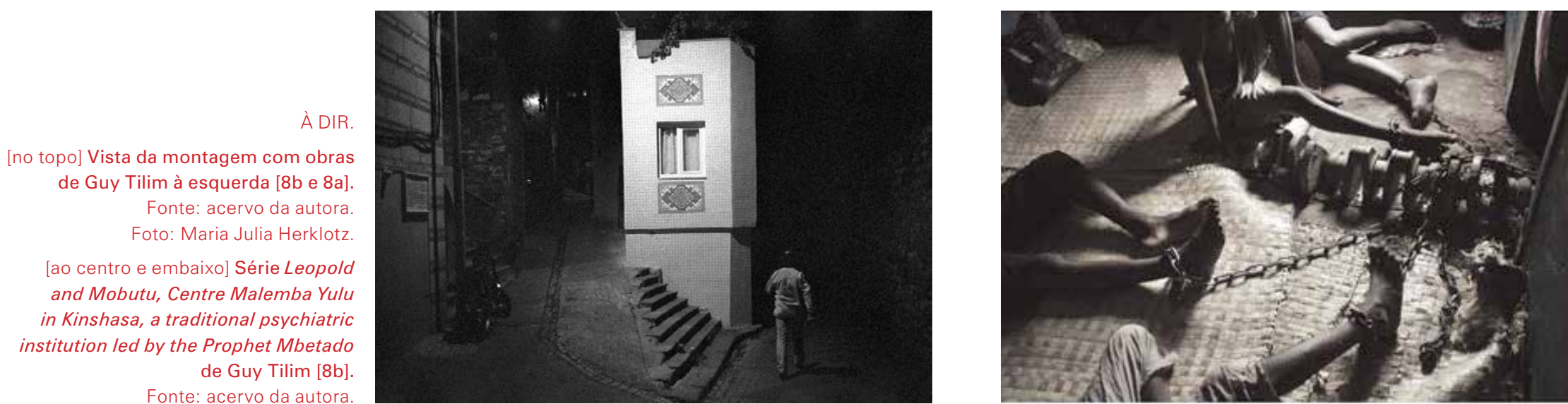
Congo, Leopold and Mobuto (I997-2004) [8b] e Democratic Republica no Congo, Kinshasa (2006) [8a], de Guy Tillim (I962, Joanesburgo, África do Sul), revelavam a violência do legado da colonização na África. Suas fotografias estabeleciam diálogos com as instalações de Alexander e Gaba pela temática da colonização europeia e pelo caráter arquitetônico e urbano com os trabalhos de Restiffe e Marepe. Todas estas obras reiteravam o caráter construtivo e abordavam o território, a colonização e a segregação. No entanto, a inserção de fotografias jornalísticas ao lado de artísticas foi alvo de crítica por Monachesi:

[...] enfileirar as fotos de Guy Tillim, que retratam a paisagem urbana de Kinshasa, capital da República Democrática do Congo, os resquícios da era colonial no país e a mobilização e ativismo durante as eleições em 2006, em frente à série de Mauro Restiffe que flagra Brasília no dia da posse de Lula, em 2003, gera confusões, podendo sugerir que ambos são fotojornalistas, o que não é fato no caso do artista brasileiro. Nestes dois exemplos, o resultado é o enfraquecimento dos trabalhos pela opção desastrada no estabelecimento de diálogos (MONASCHESI, 2006, s.p.).

Bishop também criticou a opção pelas fotografias documentais na mostra:
Há muita fotografia documental que funciona como espaço reservado para problemas políticos em países específicos, em vez de serem escolhidas como fotografias narrativa ou visualmente complexas (BISHOP, 2006a, s.p.).

Seguindo o fluxo de circulação, os painéis paralelos encaminhavam à instalação Restore Now (2006) [9] de Thomas Hirschhorn (1957, Lensburg, Suíça). O artista suíço fazia parte do mainstream das exposições internacionais e foi um dos principais destaques da mostra. Segundo Bishop, embora Hirschhorn não conste nos livros de Bourriaud é um artista que potencializa o caráter democrático e político de suas obras a partir da inclusão do antagonismo. ${ }^{14} \mathrm{O}$ artista apresenta em seus trabalhos uma relação entre arte e espectador, e se contrapõe à Estética Relacional, em suas palavras:

Eu não quero convidar ou obrigar os espectadores a interagirem como que eu faço; eu não quero ativar o público. Eu quero me doar, me engajar a tal ponto que os espectadores confrontados com o trabalho podem participar e se envolver, mas não como atores (HIRSHHORN apud BISHOP, 2OI2, p.I28).

\footnotetext{
I4 A principal crítica de Bishop à Estética Relacional é que as obras não contemplam o antagonismo, que é base da democracia, para mais informações ver capítulo 02 .
} 

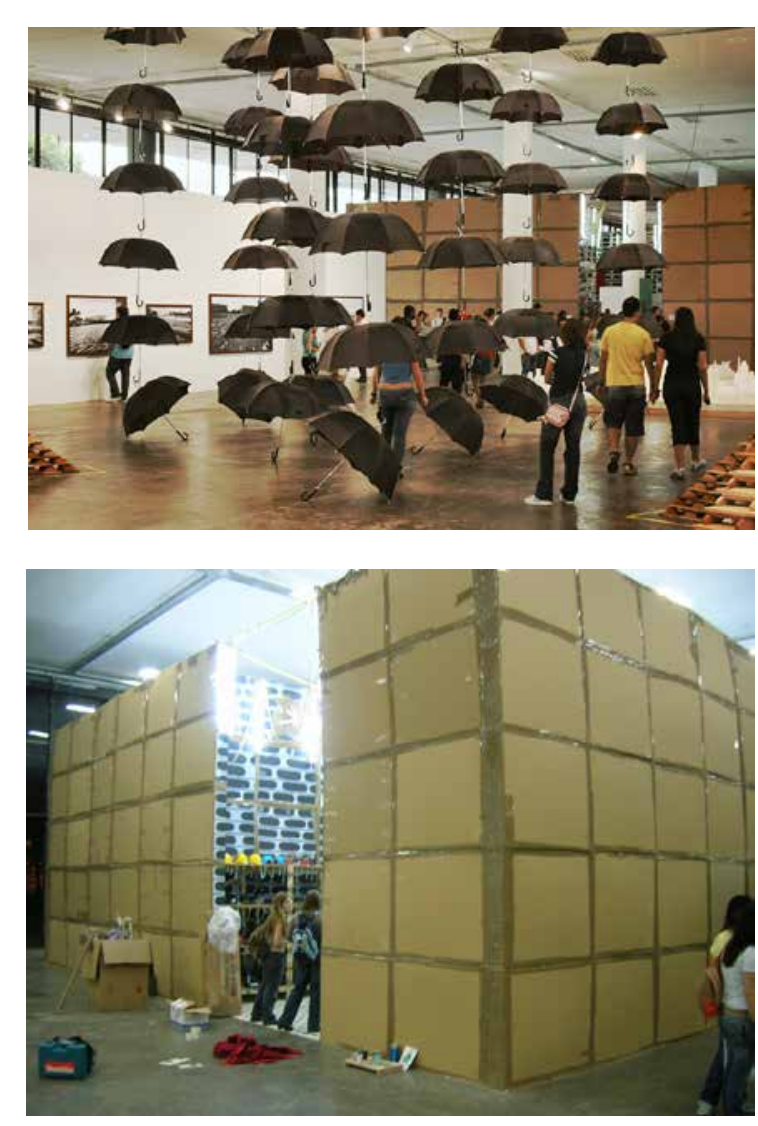

[no topo] Vista de Cânone de Marepe e ao fundo Restore Now de Hirshhorn [9]. Fonte: pixeluz. Disponível em: http://pixeluz.

blogspot.com/2006/11/cnone.html

[ao centro] Vista externa da obra Restore Now de Thomas Hirshhorn [9]. Fonte: acervo

da autora. Foto: Maria Julia Herklotz.

[embaixo] Vista interna da obra Restore Now de Thomas Hirshhorn [9]. Fonte: flickr.

Disponível em: https://flickr.com.
Ele retoma aqui a discussão acerca da autonomia da arte por duas vias: questionando as obras abertas e defendendo que o caráter político da obra se dá a partir de como ela é feita (contra o princípio de qualidade), ${ }^{15}$ ou seja, não depende de sua interação com o espectador para ser completada (BISHOP, 2006b). A sua instalação na 27a. Bienal tinha esse caráter:

Em Restore Now (2006), uma diversidade de objetos e materiais se transforma em ferramentas para uma interpretação (re)construtiva do mundo. Rejeitando as normas acadêmicas de transmissão e formatação do pensamento e interrogando sobre as possibilidades de acesso democrático ao conhecimento, Thomas Hirschhorn transforma suas ideias sociopolíticas em situações materiais no mundo. A escolha dos objetos que compõem suas obras parte de uma associação simbólica entre eles e, embora compartilhem do estatuto de objects trouvés, o seu valor e significado se tornam circunstanciais e contextuais. Por meio destes elementos e de seu acúmulo, o artista denuncia a natureza consumista da sociedade contemporânea, a manipulação dos meios de comunicação e nos lembra, por

I5 Hirshhorn se opõe a ideia de qualidade defendida por Clemenet Greenberg, Michael Fried, entre outros críticos, como critério de julgamento estético da arte moderna. 
exemplo, que os livros podem ser as novas ferramentas de intervenção no mundo. As obras de Hirschhorn são dispositivos cenográficos ativos que se apropriam do espaço numa propagação anárquica de informação visual e gráfica. Seu vocabulário é o da colagem, com utilização ostensiva da fita adesiva. Suas referências vão da Merzbau de Kurt Schwitters (I887-I948) ao engajamento de Joseph Beuys (I92 I-I986) passando pelo uso da cultura pop de Andy Warhol (I928-I987). ${ }^{16}$

A obra era um enorme volume construído em papelão autoportante, com quase cinco metros de altura, e interrompia completamente o espaço de térreo. A permeabilidade visual que se desejava a partir da praça de acesso até a rampa, o principal eixo do partido da expografia, se perdeu. Como resultado, o espaço se revelou mais uma vez contraditório. O grande eixo simétrico construído pelos painéis conduzia o fluxo para um volume excêntrico que criou um bloqueio visual e um rompimento no percurso, com uma obra que levava a uma imersão. A implantação dessa obra foi uma decisão curatorial cuja intenção era criar atrito também na configuração do espaço.

Adjacente a Restore Now, o mezanino do pavilhão conformava um espaço de qualidade muito distinta, com sua

I6 Texto explicativo da obra Restore Now no site do Instituto Inhotim, que adquiriu a obra após a 27a. Bienal. Disponível em: <http://inhotim.org.br/ inhotim/arte-contemporanea/obras/restore-now/>. Acesso em: I2 jan. 2019. sinuosidade e pé direito baixo. A proposta de ocupação dessa área foi implantar obras que precisassem de um espaço mais controlado ou intimista. A instalação-performance Novos costumes (2006) [10a], de Laura Lima (I97I, Governador Valadares, RJ), se apresentava como uma loja de roupas, um espaço comercial dentro do espaço expositivo, que disponibilizava vestes ou adornos em vinil transparente. As peças eram ativadas pelo público, que pôde desfilar com elas. Lima recusa a associação direta que se fez de sua obra com os Parangolés ${ }^{17}$ de Oiticica, argumentando que, na Novos costumes, o seu interesse está nas trocas e relações sociais, mais do que nas alterações de percepção do cotidiano. (MONACHESI, 2003). As vestes, que para a artista

17 Fruto das experiências de Hélio Oiticica (1937-1980) com a comunidade da Escola de Samba Estação Primeira da Mangueira, no Rio de Janeiro, o Parangolé é criado no fim da década de i960. Considerado por Hélio Oiticica a "totalidade-obra", é o ponto culminante de toda a experiência que realiza com a cor e o espaço. Apresenta a fusão de cores, estruturas, danças, palavras, fotografias e músicas. Estandartes, bandeiras, tendas e capas de vestir prendem-se nessas obras, elaboradas por camadas de panos coloridos, que se põem em ação na dança, fundamental para a verdadeira realização da obra: só pelo movimento é que suas estruturas se revelam. Os Parangolés ampliam a participação do público na medida em que sua ação não está mais restrita ao manuseio, como nas obras anteriores. Eles pressupõem a transformação na concepção do artista, que deixa de ser o criador de objetos para a contemplação passiva e passa a ser um incentivador da criação pelo público. Ao mesmo tempo que pressupõe uma transformação no espectador, dado que a obra só acontece com sua participação. Trata-se de deslocar a arte do âmbito intelectual e racional para a esfera da criação, da participação. Disponível em http://enciclopedia.itaucultural. org.br/termo3653/parangole. Acesso em: I2 dez. 2018. 

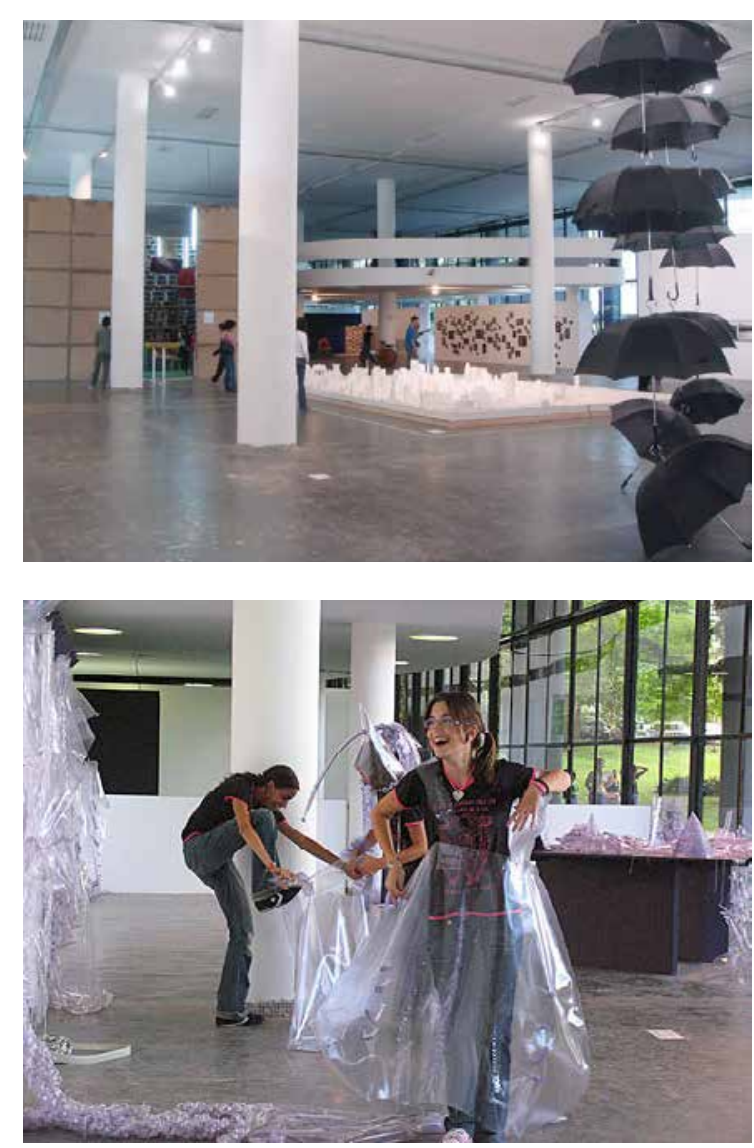

[no topo] Vista geral do térreo com o mezanino à direita. Fonte: flickr.

Disponível em: https://flickr.com.

[ao centro] Novos costumes de Laura Lima [10a]. Fonte: flickr. Disponível em:

https://flickr.com.

[embaixo] Spectre de Marwan Rechmaoui [11] sob o mezanino. Fonte: flickr. Disponível em: https://flickr.com. são adornos não usuais, transformam pessoas em seres não identificáveis; em alguns casos limitam o movimento, impõem posturas ou interligam pessoas. Esse trabalho se insere em uma pesquisa mais extensa da artista, Homens=carne, Mulher $=$ Carne, em que aproxima humanos, animais e todos os seres vivos por meio de sua condição carnal.; Ainda sob o mezanino foram instaladas: Spectre (2006) [11], de Marwan Rechmaoui (1964, Beirute, Líbano), uma maquete de um edifício modernista luxuoso dos ano i960 projetada para a cidade de Beirute que muda de caráter após a guerra civil nos anos I970 — a obra que não pôde ser finalizada devido à guerra do Líbano que se iniciou em 2006; salas de projeção com filmes de Ivan Cardoso [12a] (I952, Rio de Janeiro, RJ) realizados em parceria com Oiticica — uma ancoragem com o projeto curatorial e único momento em Oiticica se faz presente na mostra — e uma mesa de luz com os negativos desses projetos [12b]; e a projeção dupla Double Voyage (2006) [13a], de Shaun Gladwell (I972, Austrália), que trabalha com a poética do equilíbrio e traz imagens invertidas de duas pessoas com corpos em estado de transformação-um deficiente, que anda de skate em parada de mão dentro da Oca do Parque Ibirapuera, e uma dançarina transexual, que dança pole dance em um clube de striptease.

Seguindo o percurso paralelo ao mezanino está a videoinstalação enchendo.vazando (2006) [14], de Marcellvs L.(I980, Belo Horizonte, MG) composta por duas caixas 
baixas e cegas com back projection ${ }^{18}$ formando uma passagem estreita ao centro. A intenção era criar um contraponto entre a amplitude deste espaço e a passagem estreita, com vídeos dos dois lados. O filme, que mostra um barco abandonado na areia a partir do mar e se movimenta com a mudança da maré, suscita uma outra relação com a temporalidade. No contexto da exposição, insere o observador em outro ritmo e dá ao público uma sensação de vertigem, de perda de chão.

Após esta passagem há mais duas instalações de grande porte: We intended to sing the love of danger, the habit of energy and fearlessness ${ }^{19}$ [15], de Lars Ramberg (1964, Oslo, Noruega), a estrutura da casa futurística Venturo dos anos I960 projeto do arquiteto finlandês Matti Suuronen, pré-moldada em plástico, foi concebida como unidades móveis, que poderiam ser transportadas por um contêiner. A instalação procurava estabelecer relações entre a arquitetura moderna brasileira e a nórdica. A estrutura que se aproximava mais a uma ruína foi montada sobre um tapete e em frente a uma grande imagem com uma paisagem Nórdica colada no caixilho do pavilhão; e, ao fundo, a instalação Carnival (2006) [16], de Nikos Charalambidis (1967, Limassol, Grécia), que recebeu a performance de uma escola de samba na inauguração da mostra.
O trabalho de Charalambidis se apoia em suas experiências de infância, quando a invasão do exército turco o expulsou de sua casa no Norte do Chipre. Nessa peça apresentada na 27a. Bienal, ele fez uma associação das escolas de samba com a memória do carnaval em sua cidade natal.

Bishop aponta que, apesar da forte presença escultural das obras, o térreo foi um dos piores momentos da exposição: "A maior parte do piso térreo é espetáculo vazio: a instalação com guarda-chuvas de Marepe e o trabalho de Nikos Charalambidis assim como o mercado de Meschac Gaba em um piso superior são fracos conceitualmente”.

A premissa expográfica para o térreo de construir visuais na exposição valorizando o comprimento do pavilhão, não se realizou. Nesse aspecto houve uma dissidência entre as propostas arquitetônicas e as curatoriais. Para os curadores, o fluxo contínuo foi uma estratégia importante para que, a partir da inserção de obras que o rompesse, criar zonas de tensão. Reiterando na construção do espaço expositivo a dificuldade de se viver junto. Esta experiência se intensificou tanto no acesso com a obra de Alexander, como na inserção das grandes instalações de Hirshhorn e Ramberg.

\footnotetext{
I8 Sistema de projeção de uma imagem por trás de uma tela.

I9 Tradução: Tínhamos a intenção de cantar o amor pelo perigo, o hábito da energia e destemor.
} 
[no topo] Double Voyage (2006), de Shaun Gladwell [13a]. Fonte: site art gallery. Disponível em: https://www.artgallery. nsw.gov.au/collection/works/120.2014/.

[embaixo] Vista do térreo a partir do mezanino. À direita a obra de Ramberg, ao fundo os volumes pretos são da

videoinstalação enchendo vazando de Marcellvs [14]. A

cobertura na passagem entre os volumes foi construída posteriormente. Fonte: flickr. Disponível em: https://flickr.com.
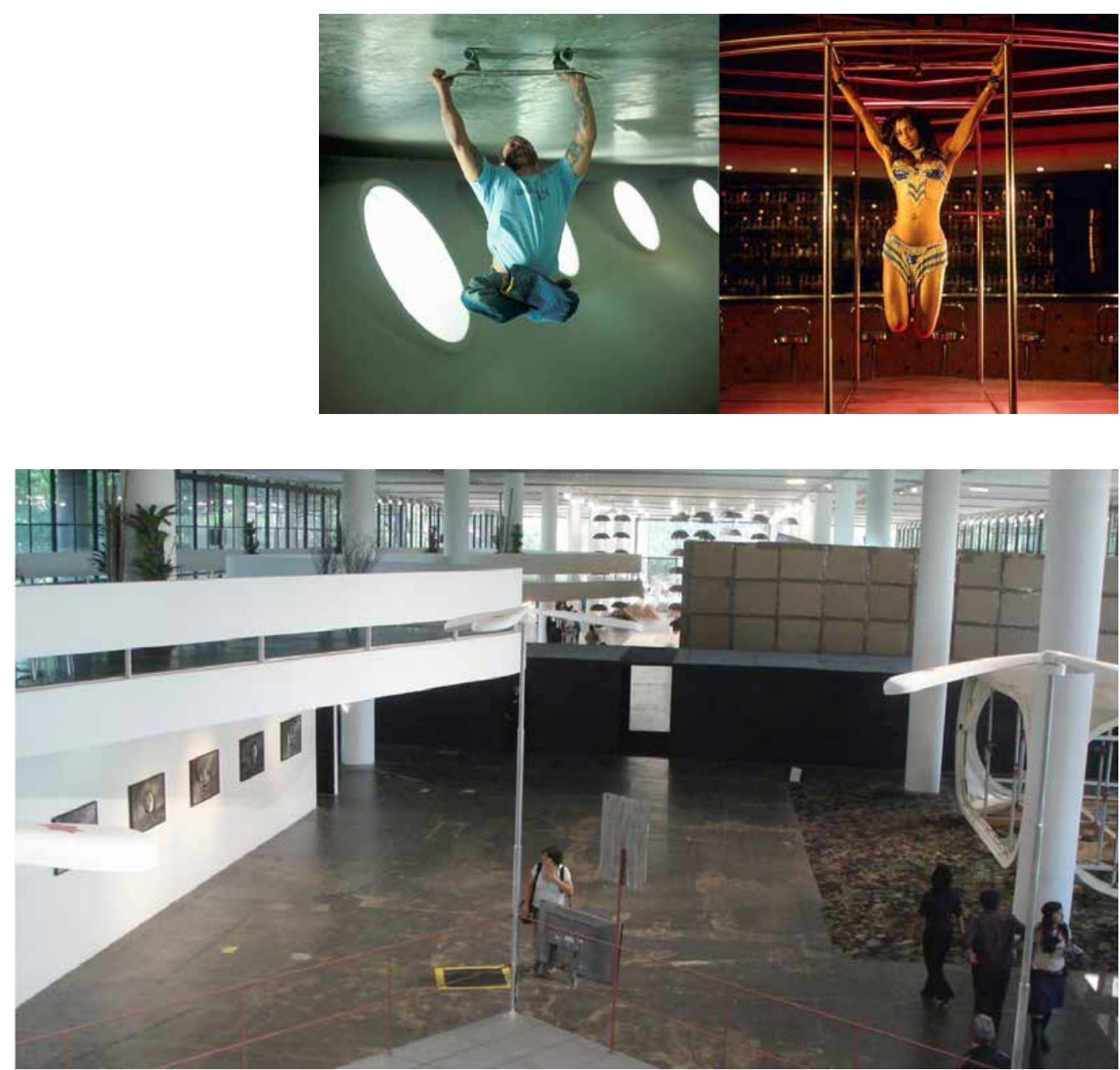

[no topo] We intended to sing the love of danger, the habit

of energy and fearlessness de Lars Ramberg [15] que

fechou os caixilhos em frente a marquise do lbirapuera.

Fonte: flickr. Disponível em: https://flickr.com.

[embaixo] Vista a partir do mezanino na inauguração

da mostra com a performance Carnival de Nikos

Charalambidis [16]. Fonte: acervo da autora. Foto:

Maria Julia Herklotz.
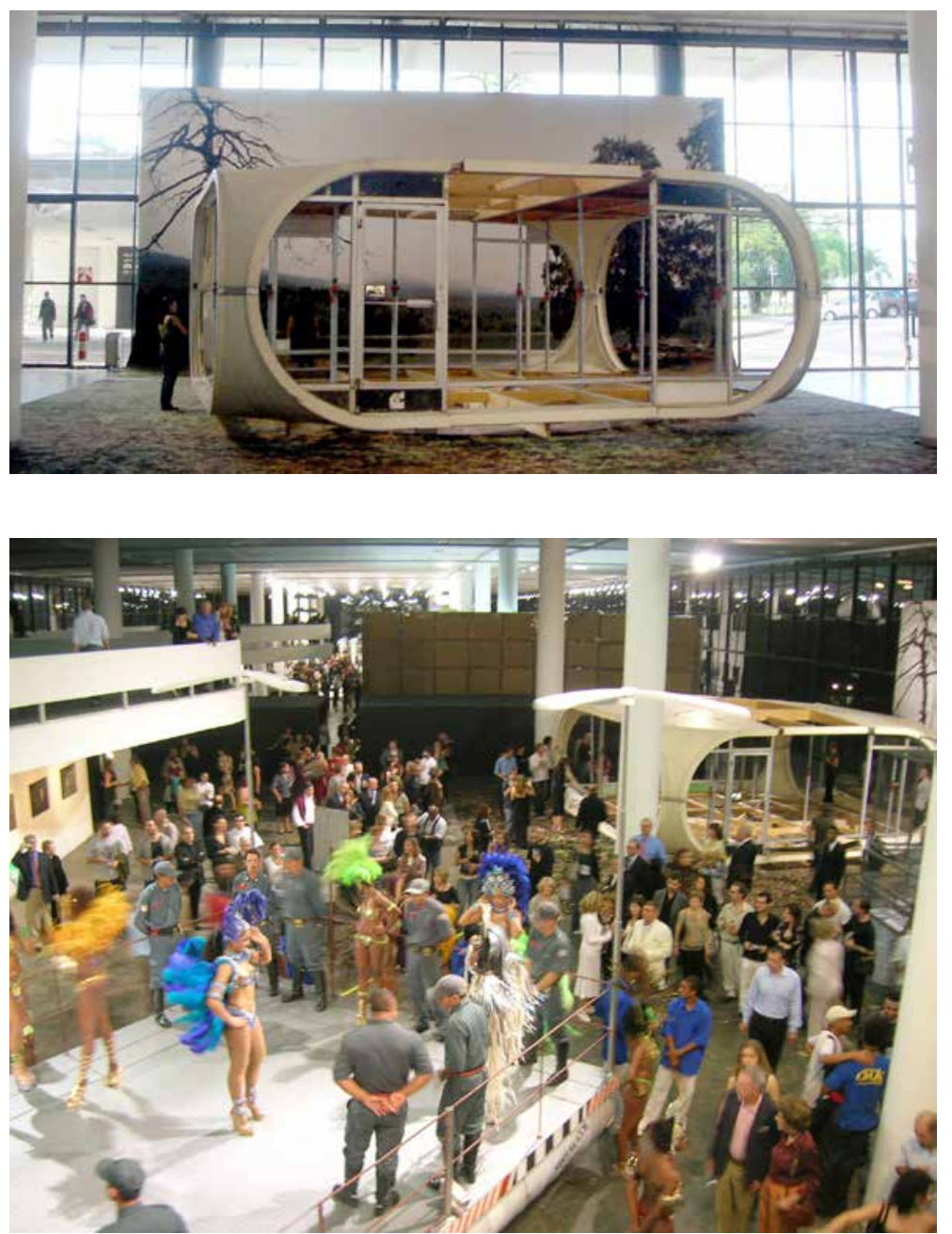


\section{Spกग}
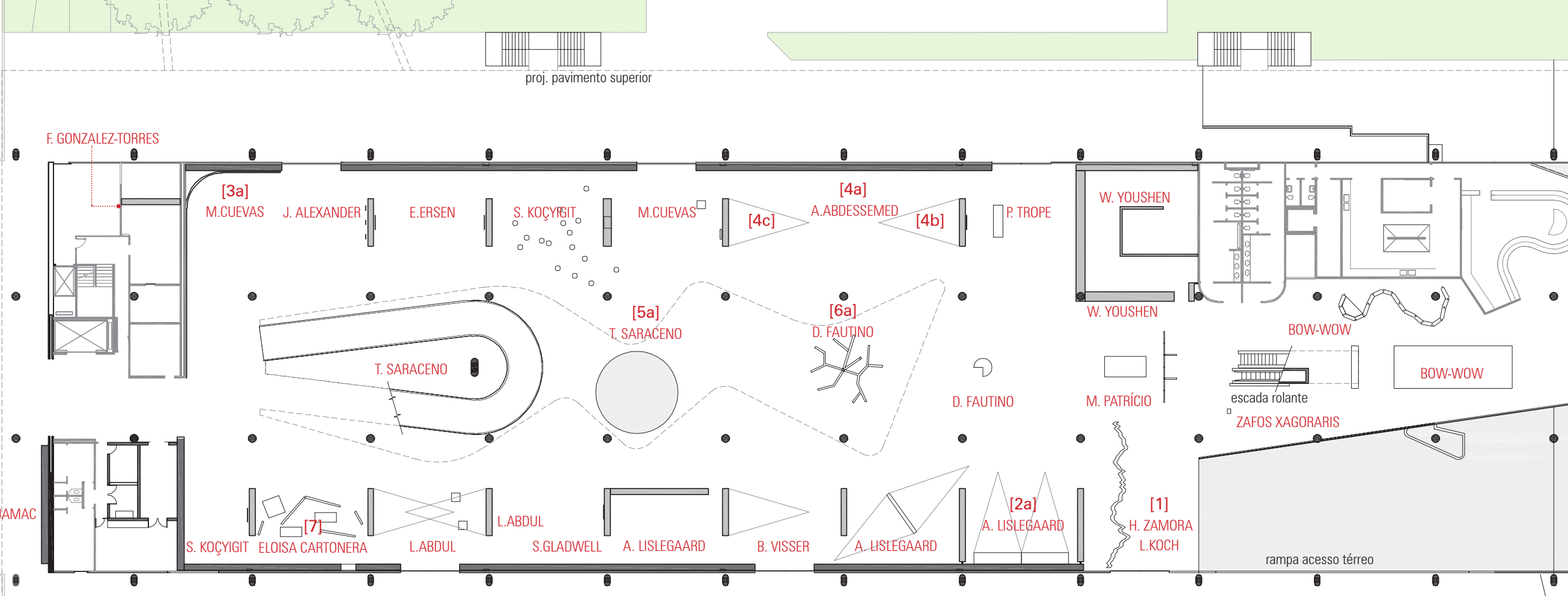

proj. pavimento superior 
O primeiro pavimento do pavilhão possui características espaciais muito distintas do térreo, apesar de haver uma continuidade dada pela rampa. É o pavimento com menor pé direto ${ }^{20}$ e sua relação com o parque é muito prejudicada em vários aspectos: a área sob a marquise da fachada sul é utilizada como estacionamento dos funcionários da Bienal; na fachada norte há a Praça das Bandeiras, que faz o acerto de nível do pavimento com a rua interna do parque; e a fachada leste é ocupada por serviços. As fachadas são recuadas, ${ }^{21} \mathrm{O}$ que faz com que o pavimento possua uma largura menor que os superiores e o vão central têm uma presença e verticalidade marcantes - usualmente é o espaço que se reserva a uma obra de grande destaque.

O projeto expográfico da 27a. Bienal propôs o fechamento das fachadas de vidro com painéis, buscando construir um espaço sem luz natural. A proposta foi criar um espaço único,

20 O térreo tem pé direito de 3,95 metros, três metros a menos que térreo e um metro a menos que o segundo e terceiro pavimentos.

2I As áreas do balanço da estrutura com vão de 5 metros ficam para fora dos caixilhos, configurando uma marquise continua nas fachadas norte e sul do edifício. no qual vídeos e instalações pudessem ficar abertos, apenas com painéis soltos transversais ao pavilhão. Essa ação da expografia demandou um trabalho intenso com artistas e curadores envolvidos, uma vez que o pedido inicial dos artistas era sempre por uma sala individual fechada. Os artistas que haviam sido destinados a este núcleo, mas que não aceitaram as condicionantes do espaço, foram realocados para outro lugar no pavilhão onde poderiam ter suas salas fechadas de acordo com suas necessidades. ${ }^{22}$ Bogéa descreve a situação da seguinte maneira:

Do outro lado do térreo [se refere ao primeiro pavimento], a paisagem interior é tão intensa que é uma bobagem a gente configurar a visada externa. Ao contrário, se deve revelar esta interioridade como o forte deste pavimento. Além disso, tem um pé direito menor, então a opção da arquitetura, amparada pela curadoria, foi fazer aquele espaço ter luz controlada. O olhar vai se dirigindo para o vão e acaba por

22 Depoimento de Marta Bogéa em entrevista realizada em 20I8 - ver anexo I. 
revelar obras que constituem este contínuo vertical, que é uma das forças deste prédio, e um espaço mais aberto, inclusive quando existem alguns vídeos (BOGÉA, 2006).

A leitura feita pela expografia se mostrou adequada ao espaço do primeiro pavimento e às demandas do núcleo de obras. O fechamento dos caixilhos da fachada sul é inevitável para que os carros não façam parte da exposição. A construção de uma série de pequenas salas neste espaço de menor profundidade levaria ao sufocamento do vão central, que foi valorizado pela proposta com a iluminação advinda dos pavimentos superiores. Essa permeabilidade visual tornou possível o diálogo entre as obras dos três pavimentos. A qualidade do espaço conferiu ao público uma circulação mais fluida, com possibilidade de ver as obras em simultaneidade, sem tornar o percurso em uma maratona exaustiva de inúmeras salas de vídeo.

No patamar da rampa que conecta o térreo e o primeiro pavimento, ${ }^{23}$ foi implantada uma grande parede irregular de elementos cerâmicos vazados Uma boa ordem [1] de Lúcia Koch (I966, Porto Alegre, RS,) e Hector Zamora (I974,

23 O que se convencionou a ser nominado como primeiro pavimento do pavilhão também está no nível do parque. Como o terreno tem um declive de aproximadamente 3 metros ao longo do pavilhão, os dois pavimentos, térreo e primeiro, estão em continuidade conectados por uma rampa.
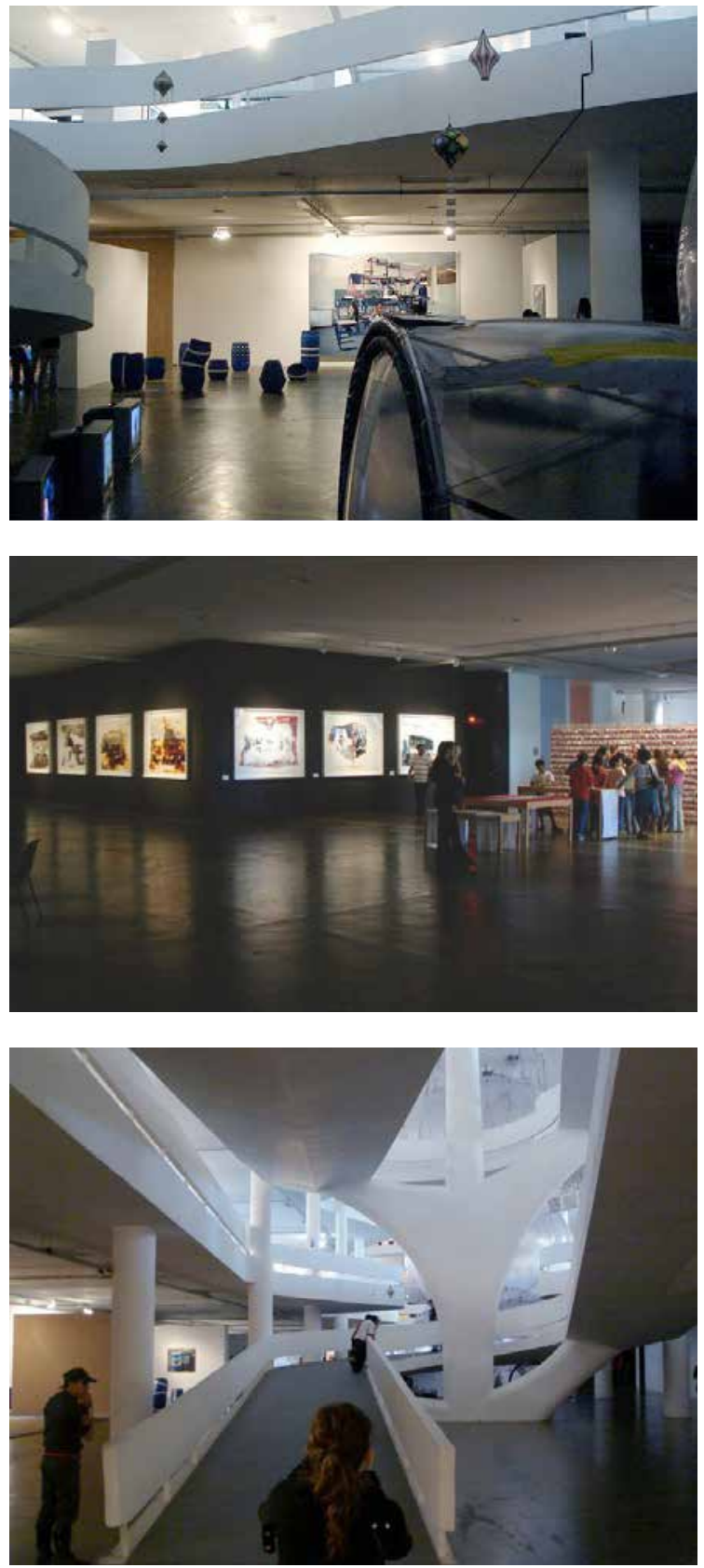

[no topo] Vista do espaço com luz controlada do primeiro pavimento. No primeiro plano o acesso para entrada na obra Comulonimbus, air-port-city [5a] de Saraceno e ao fundo o espaço de Servet Koçyigit. Fonte: flickr. Disponível em: https://flickr.com.

[ao centro] Vista do primeiro pavimento ao fundo as obras Washing de Wang Youshen e à direira Martinho Patrício. Fonte: flickr. Disponível em: https://flickr.com.

[embaixo] Vista da tomada da rampa no primeiro pavimento onde se

observa a diferença de luminosidade em relação aos pavimentos

superiores. Fonte: flickr. Disponível

em: https://flickr.com. 

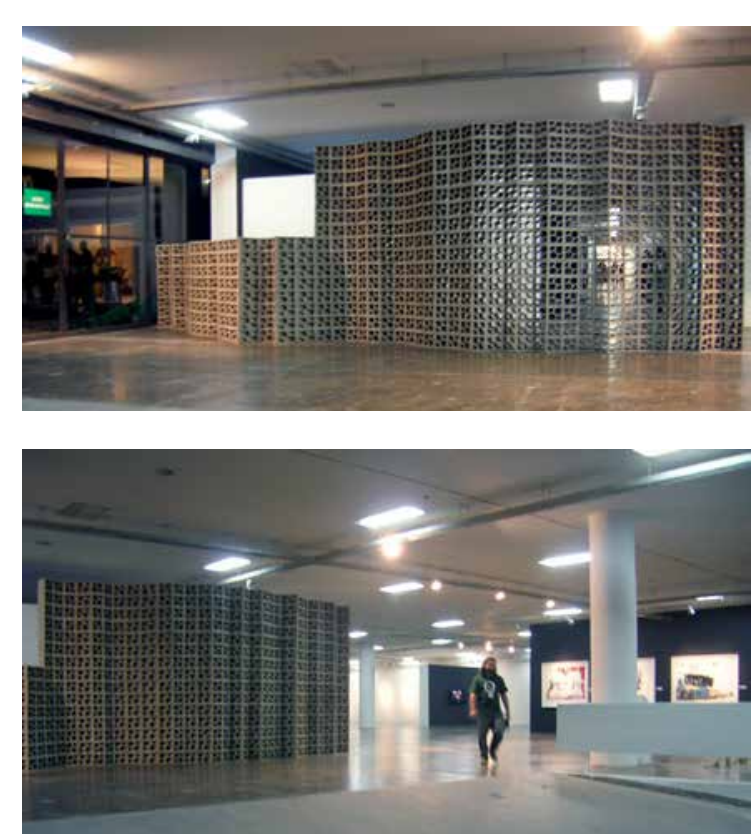

[no topo e ao centro]

Vistas a partir da rampa do térreo a instalação Uma boa ordem de Lúcia Koch e Hector Zamora [1].

Fonte: acervo da autora. Foto: Maria Julia Herklotz.

[ao centro] Vista da obra de Lislegaard a partir do centro do pavimento. No primeiro plano a obra de Martinho Patricio Brincar com Lygia. Fonte: flickr. Disponível em: https://flickr.com.

[embaixo] Videoinstalação Cristal World de Ann Lislegaard [2a].

Fonte: site Ann Lislegaard. Disponível em: https://theartstack. com/artist/ann-lislegaard/crystalworld-after-j-g-ballard-2.
Cidade do México, México). Os artistas criaram um anteparo cuja permeabilidade visual dependia do posicionamento do observador: de alguns pontos a parede ficava totalmente cega de outros permitia visuais editadas pelo elemento. A obra dialogou com a expografia, sinalizando a grande mudança de atmosfera e luz entre os pavimentos.

A videoinstalação Cristal World (2006) [2a], ${ }^{24}$ de Ann Lislegaard (1962, Tonsberg, Noruega), adere à proposta de diálogo visual entre as obras a partir do vão de forma notável. O trabalho é uma animação $3 \mathrm{D}$ em dupla projeção, uma ficção sobre um percurso em um hotel na selva abandonado que vai lentamente se mineralizando, tornando-se cristal, como se fosse uma caverna. As animações caminham por espaços arquitetônicos construídos com elementos da Casa de Vidro de Lina Bo Bardi e dos caixilhos do Pavilhão Ciccillo Matarazzo. Os caixilhos reproduzidos no filme são os dos andares superiores do pavilhão, com montantes horizontais intercalados. Como a projeção ficou aberta no espaço, é possível se estabelecer uma relação direta entre o vídeo e o real a partir das visuais do segundo pavimento pelo vão central.

24 Cristal World é um romance de ficção cientifica de J.G. Ballard (I966) que fo utilizado com referência por Robert Smithson para fazer suas estruturas espelhadas, e cuja a história é utilizada como roteiro da animação de Lislegaard. 
As grandes projeções e instalações nesse espaço tiveram destaque e puderam ser vistas por grande parte do público, seja na passagem pelo pavimento, seja pela vista da rampa ou através do vão.

Dentre as obras, se destacaram no espaço trabalhos de dois artistas: Terra primitiva (2006) [3a], um grande painel pintado por Minerva Cuevas (1975, Cidade do México, México), que criou um fundo infinito no final do pavimento com um desenho que trazia uma linguagem de cartoon e contava a história de um acidente de avião com um sobrevivente em uma selva exótica. O sobrevivente é Chico Mendes, ativista ambientalista da Amazônia, pintado em um pilar do edifício, dando um jogo de profundidade ao painel $2 \mathrm{D}$. Havia também no painel uma referência ao plano piloto de Brasília e o logotipo da Varig, extinta companhia aérea brasileira. Outras obras marcantes foram Wall Drawing (2006) [4a] e Birth of Love (2006) [4b], de Adel Abdessemed (I97I, Constantine, Argélia). A primeira era um painel constituído por nove círculos com a altura do artista (I,72m) construídos com arames farpados similares aos utilizados na prisão americana de Guantanamo (Cuba) e em áreas de fronteira; a segunda, uma grande projeção de um vídeo gravado a partir do chão em que um gato come um rato, impactante pela brutalidade e crueza das imagens.

O vão central do pavilhão e sua rampa sinuosa criam um eixo vertical que conferia amplitude ao primeiro pavimento,
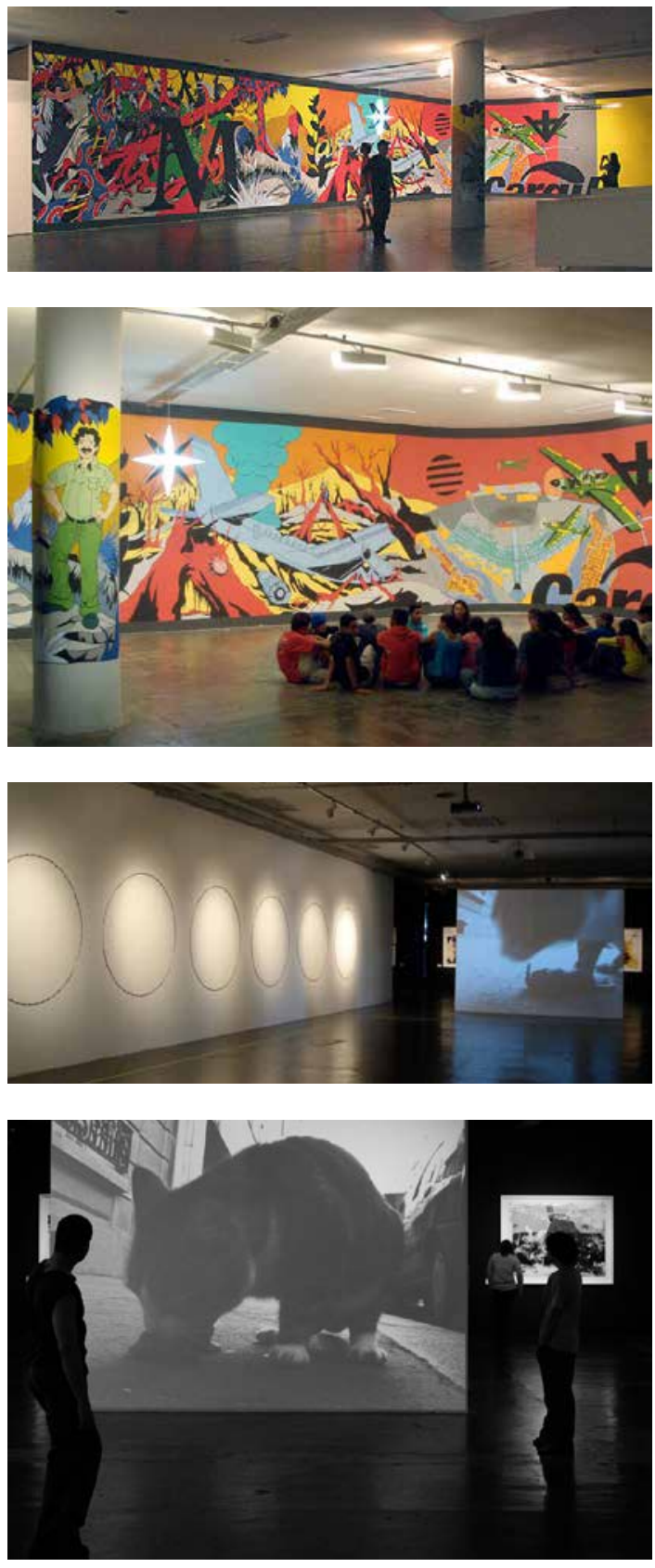

[no topo] Vistas da obra Terra primitiva um grande painel que fez um fundo infinito no pavimento, pintado por Minerva Cuevas [3]. Fonte: flickr. Disponível em: https://flickr.com. [ao centro] Vista das obras Wall Drawing [4a] e Birth of Love [4b], de Adel Abdessemed. Fonte: flickr. Disponível em: https://flickr.com.

[embaixo] Vista de Birth of Love [4b], de Adel Abdessemed e ao fundo a obra Washing de Wang Youshen. Fonte: flickr. Disponível em: https:// flickr.com. 

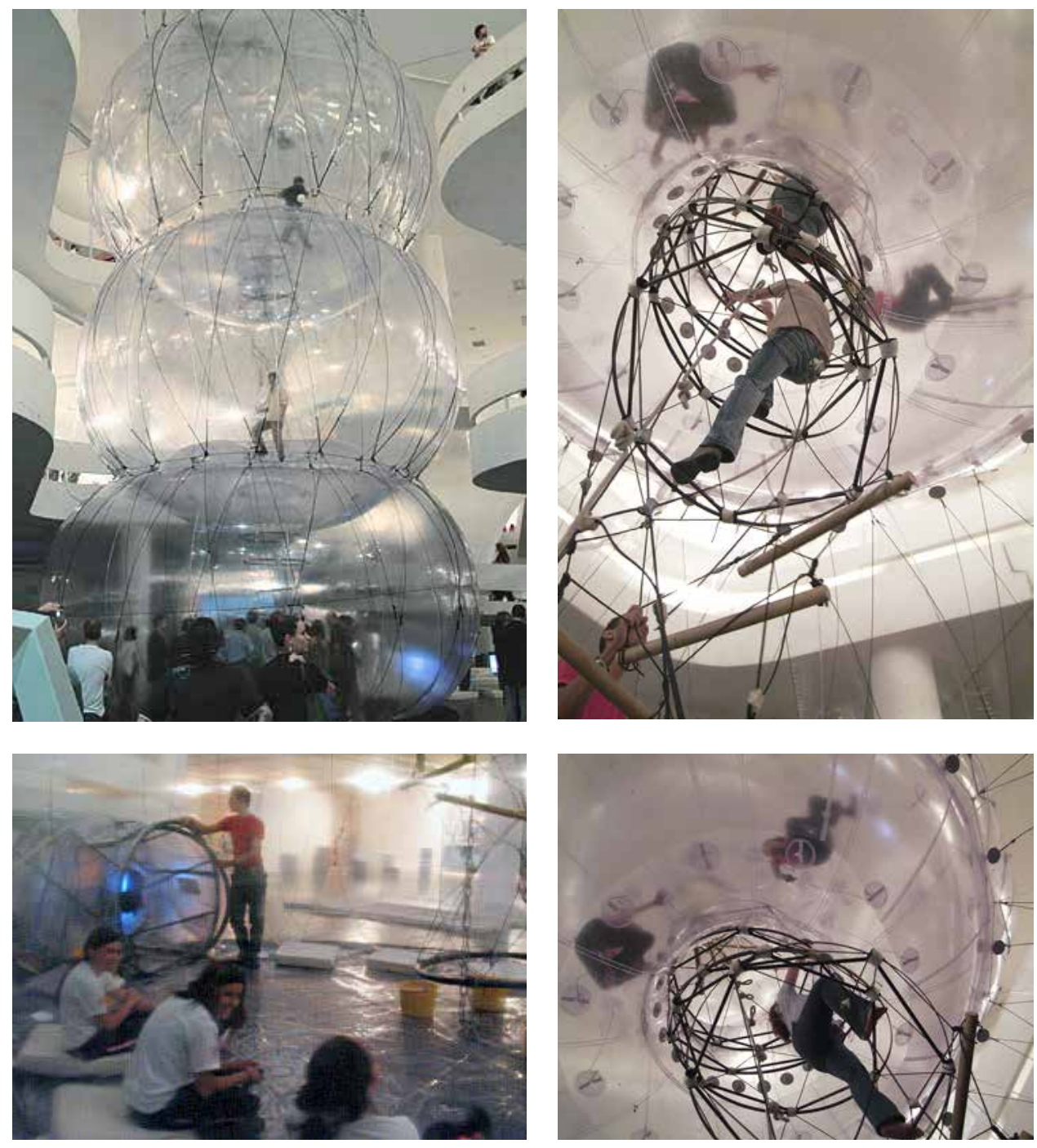

[no topo à esq.] Público passeia dentro da obra da obra Comulonimbus, airport-city [5a]. Fonte: flickr. Disponível em: https://flickr.com.

[embaixo à esq.] Vista interna no acesso da obra Comulonimbus, air-port-city de Tomas Saraceno [5a]. Fonte: flickr. Disponível em: https://flickr.com.

[à dir.] Vistas internas da obra Comulonimbus, air-port-city [5a] Fonte: Arquivo Wanda Svevo. Fotos: Juan Guerra. efeito que foi evidenciado pelo enclausuramento dos caixilhos. O espaço do vão foi compartilhado por duas obras: Comulonimbus, air-port-city(2006) [5a] de Tomas Saraceno (I973, San Miguel de Tucoman, Argentina), composta por três bolhas translúcidas infláveis gigantes, na qual se podia entrar e subir até o terceiro pavimento da Bienal — um penetrável, na leitura de Lagnado (2006c). A proposta faz parte da pesquisa do artista que trabalha com a ideia de cidades utópicas voadoras (Air-port-city): plataformas ou células habitáveis que formam cidades que flutuam no céu, como nuvens sem fronteiras geográficas ou políticas. A obra estabeleceu um diálogo intenso com o pavilhão. A vista a partir do segundo e terceiro andares era de pessoas caminhando dentro de uma superfície insólita. O percurso dentro das bolhas permitiu ao público pontos de vista inusitados do pavilhão e a dificuldade de locomoção, que se dava por uma escada estreita de corda, fez com que o público estabelecesse um convívio, porque tornava necessário a comunicação para utilizar a escada. A outra obra que ocupou o vão foi Racine du mal (2006) [6a], de Didier Faustino (1968, Paris, França), cujo título faz referência ao romance futurista distópico do francês Maurice Dantec Raízes do mal (1998), considerado pela crítica o último grande romance de ficção cientifica do final de século 20 e o primeiro das redes informáticas. Uma das questões abordadas é a proibição de reuniões em espaços públicos. O artista propôs um conjunto de mobiliário 
urbano que, com seu desenho transformado, constituiu um espaço de sociabilidade, ou, segundo a descrição do artista, um microespaço urbano (FAUSTINO, 2006, p.62). Assim, o poste de luz teve seu apoio ramificado, como raízes de árvores futurísticas, criando novas possibilidades de interação e qualificando um microespaço. A inserção da obra dentro do pavilhão afere um caráter público ao espaço do edifício. Os dois trabalhos dialogam conceitualmente por trabalharem com problemáticas urbanas e novas possibilidades de convívios em sociedade. No entanto, a aproximação de cada artista ao tema é muito específica e a decisão curatorial de implantar no vão duas obras com características formais tão distintas (volumétrica e material) criou um desequilíbrio que fragilizou a ocupação do vão. A proposta prejudicou especialmente a leitura da obra de Faustino ao se encontrar diante da forte presença das bolhas de Saraceno. Por outro lado, a escolha da obra de Saraceno para o vão, naquele momento ainda um jovem artista pouco conhecido, revelou a coragem e sensibilidade de Lagnado ao sustentar esse projeto. Logo depois da 27a. Bienal, o artista assumiu um lugar de destaque no circuito internacional de artes.

Segundo Lagnado (2006c), os curadores construíram as vizinhanças de obras sem categorizar, com mais liberdade, seguindo os preceitos de Oiticica. Portanto, não foram constituídos núcleos contendo exclusivamente obras ligadas às temáticas Projetos para vida ou Projetos construtivos, o objetivo
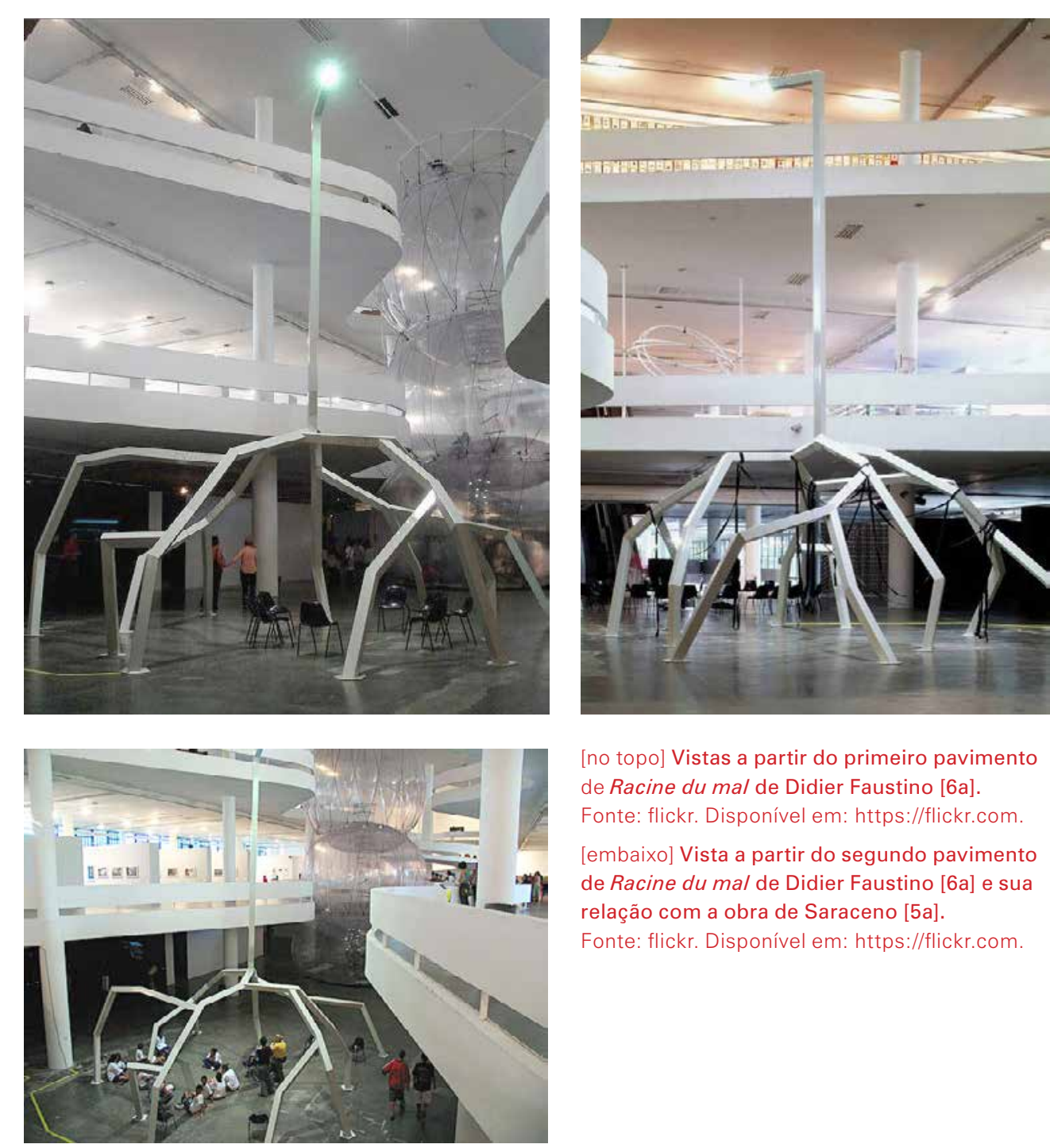

[no topo] Vistas a partir do primeiro pavimento de Racine du mal de Didier Faustino [6a].

Fonte: flickr. Disponível em: https://flickr.com.

[embaixo] Vista a partir do segundo pavimento de Racine du mal de Didier Faustino [6a] e sua relação com a obra de Saraceno [5a]. Fonte: flickr. Disponível em: https://flickr.com. 
[no topo] Ateliê Eloisa Cartonera, de Javier Barilaro e Washington Cucurto [7]. Arquivo Wanda Svevo. Foto: Juan Guerra. [embaixo] Ateliê Eloisa Cartonera, de Javier Barilaro e Washington Cucurto [7]. Fonte: flickr. Disponível em: https://flickr.com.
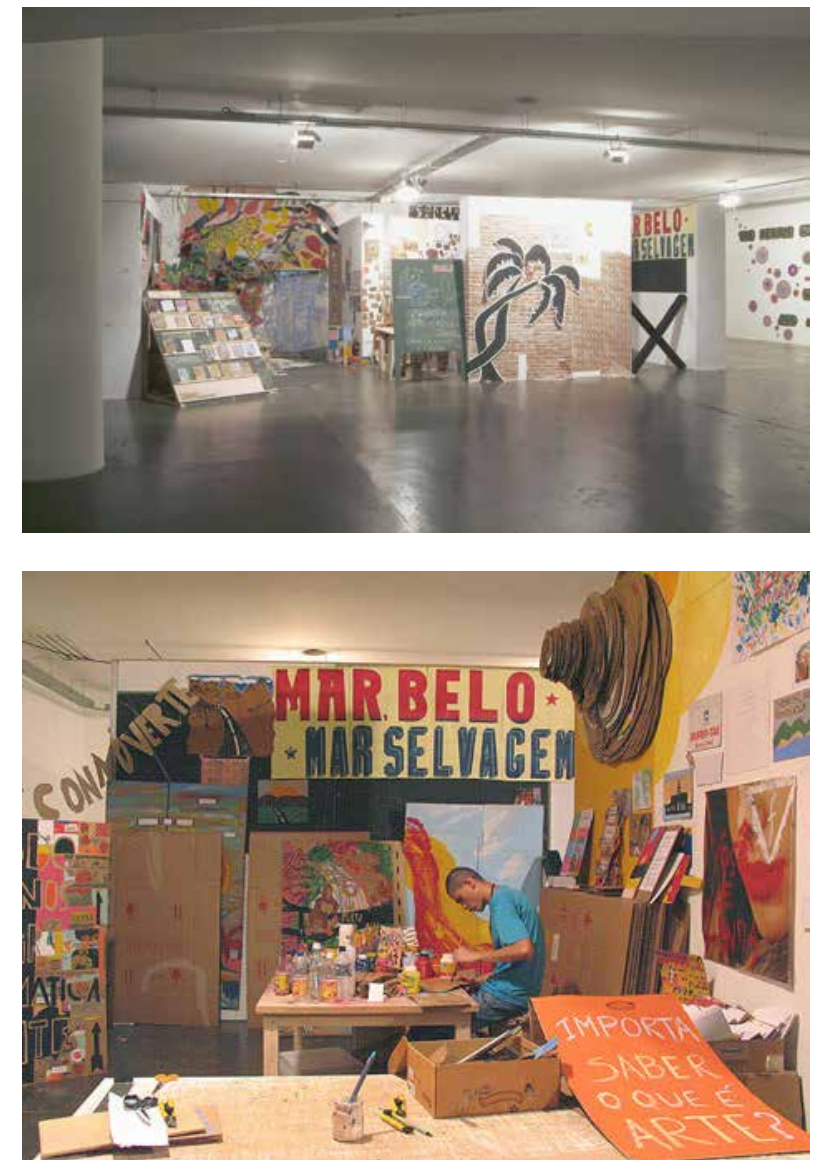

foi criar respiros e não aproximar artistas que abordassem a mesma questão, para garantir autonomia às obras. Dentro dessa proposta, o primeiro pavimento discutia o habitat. Algumas obras, como as de Lislegaard, Cuevas e as duas do vão central de Saraceno e Faustino, traziam uma abordagem utópica ou distópica ${ }^{25}$ sobre o espaço urbano. Havia também obras que tratavam de questões urbanas com uma abordagem social, como o pequeno ateliê Eloisa Cartonera, dos artistas Javier Barilaro e Washington Cucurto [7] (Buenos Aires, Argentina), que produzia livros a partir do material coletados por catadores de lixo recicláveis, com participação desta comunidade.

25 Distopia é qualquer representação ou descrição ficcional de uma organização social cujo valor representa a antítese da utopia ou promove a vivência em uma "utopia negativa". O termo também pode referir-se a um lugar ou estado imaginário em que se vive sob condições de extrema opressão, desespero ou privação. As distopias são geralmente caracterizadas pelo totalitarismo, autoritarismo, pelo controle opressivo sobre toda a sociedade. A tecnologia é usada como ferramenta de controle, seja por parte do estado, seja de instituições ou mesmo de corporações. Definição disponível em: <https://pt.wikipedia.org/wiki/Distopia>. Acesso em: I2 jan. 2019. 


\subsection{SEGUNDO PAVIMENTO: A PRESENÇA DO PROJETO EXPOGRÁFICO}

O segundo pavimento é o que apresenta o maior desafio para o projeto expográfico por ser o único espaço do edifício onde se apresenta de forma continua toda a extensão do pavilhão. Cabe a expografia fazer a edição dos espaços. Portanto, é aqui que se revela a força do projeto. Uma das principais ações foi a construção da praça Broodthaers, que, a partir da inserção de um piso elevado neste pavimento, criou uma topografia na laje continua do pavimento e uma possiblidade de edição do espaço sem construir paredes ou barreiras visuais.

O partido do projeto da 27a. Bienal buscou valorizar as características do pavilhão ao deixar clara a distinção entre arquitetura e expografia. Foi determinada uma única altura ${ }^{26}$ tanto para as salas quanto para os painéis, que foram construídos afastados dos caixilhos. Assim, configurou-se uma circulação ao longo das fachadas norte e sul que permitiu a leitura da continuidade do edifício em toda a sua extensão.

O partido original da expografia era trabalhar apenas com painéis transversais ao pavilhão, que configuravam

26 Há uma exceção sala do Jaroslaw Kozlowski, cuja instalação Gravity Room 2, uma sala domiciliar construída de ponta cabeça, precisava do pé direto de 4,95 metros e utilizou paredes e forro existente.

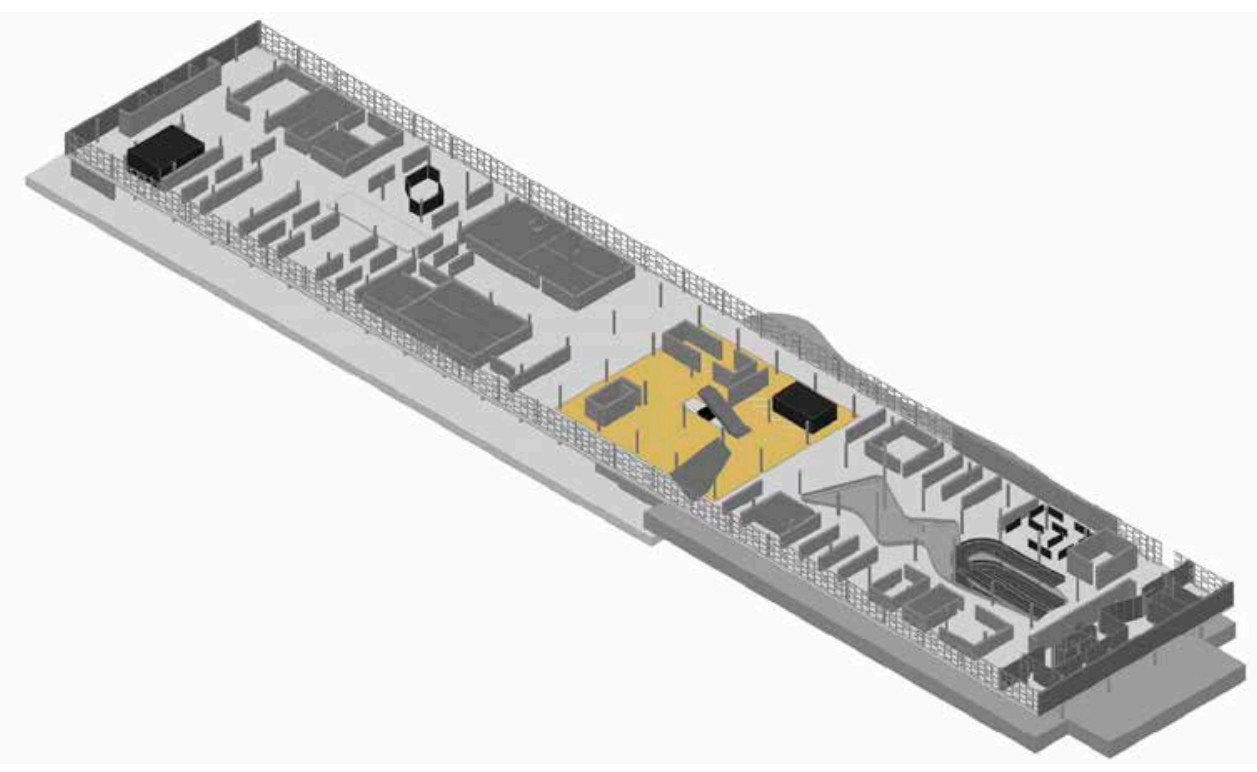

Isométrica com o sistema expositivo do segundo pavimento. Fonte: acervo da autora. 


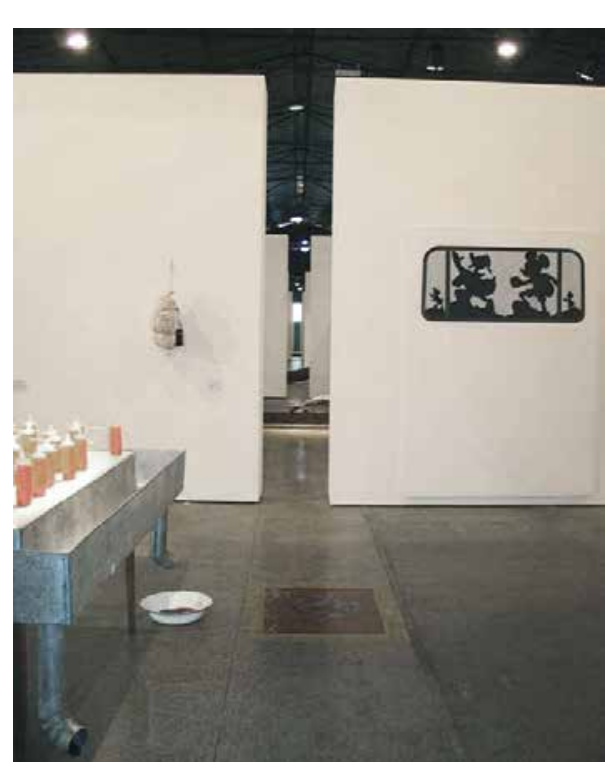

Vista da mostra Paralela 2004 com painéis paralelos em sequência. Mostra desenvolvida pela Base7, projeto expográfico de Marta Bogéa. Fonte: acervo Marta Bogéa. espaços de seis por dez metros, seguindo a modulação do vão entre pilares ${ }^{27}$. A proposta de usar apenas painéis paralelos, já havia sido utilizada por Bogéa para a mostra Paralela 2004 (São Paulo-SP) ${ }^{28}$, uma exposição de arte contemporânea patrocinada por galerias de arte que ocorria concomitantemente a Bienal. A proposta para a Paralela 2004 havia sido instalada em um galpão de forma bem sucedida ${ }^{29}$. No entanto havia uma diferença significativa na adoção desse sistema em um edifício monumental como o pavilhão. Deixar as fachadas envidraçadas e a paisagem interior e exterior presentes, representou para grande parte dos artistas uma interferência indesejável. Além disso a seleção de obras da Bienal contemplava muitos vídeos que precisavam de salas fechadas.

O sistema expositivo da 27a. Bienal teve que ser ajustado a essa demanda por salas fechadas e foram adotados dois princípios: as linhas que eram painéis transversais ao pavilhão e que tinham como proposta editar o espaço de cada artista mantendo a transparência com o pavilhão e com o parque; e os volumes que eram as salas, com ou sem forro, que criavam espaços herméticos. Apesar da cor escolhida para os painéis

27 O vão entre pilares do Pavilhão no sentido longitudinal é de dez metros e no sentido transversal é de doze metros.

28 Disponível em: < http://www.base7.com.br/portfolio/ver/36>. Acesso em: 2I de jan. 20I9.

29 Informação fornecida por Marta Bogéa em entrevista realizada em 2018. Ver anexo I. 
ter sido branca, assim como as alvenarias do pavilhão, a construção deste sistema expositivo autoportante em uma única altura permitiu que a expografia fosse identificada como um novo elemento inserido. A vista elevada a partir da rampa revelava linhas e volumes soltos construídos dentro de um perímetro demarcado que configura claramente a circulação pelas fachadas e o centro livre.

O espaço da praça Broodthaers, com seu piso elevado, era construído por obras (em sua maioria instalações), e não por painéis. A inserção da praça surge como um rompimento da lógica do padrão estabelecido pelo sistema expositivo e foi essencial para a edição do espaço continuo do segundo pavimento e a configuração de núcleos curatoriais.

Para a análise proposta neste trabalho, o segundo pavimento da 27a. Bienal foi dividido em três partes: primeiro setor — espaço ao redor do vão; segundo setor — da praça Broodthaers até o final do pavilhão — ; e a praça Broodthaers entre eles. O primeiro compreendia um núcleo com caráter político. A expografia nesse trecho conseguiu manter parcialmente a transparência da proposta inicial e pôde criar relações com o parque e o pavilhão. O segundo trecho compreendia três núcleos: Arquitetura, Acre e Reconstrução. Foi realizado sem setorização, conforme a proposta curatorial. A ocupação desse grande trecho do pavilhão, logo após a praça, se deu de forma labiríntica, com exceção do núcleo Acre, que se configurou como uma clareira arejada. No restante dos espaços havia um excesso de salas, por um lado pelas demandas dos artistas, e por outro pelo desejo dos curadores por abrigar mais obras na exposição. Estas questões interferiram substancialmente na essência do partido expográfico, comprometendo sua qualidade espacial e transformando a exposição, em muitos momentos, em percursos exaustivos para o público e comprometendo, por consequência, a leitura das obras e até do projeto curatorial.

A praça Broodthaers constituiu uma micronarrativa dentro da mostra, cuja diferenciação foi marcada pela expografia, conforme colocado acima. A praça foi dividida verticalmente e estava presente no segundo e terceiro pavimentos e, por isso, será analisada em sua relação com a área climatizada no final do capítulo, após o terceiro pavimento. [no topo à esq.] Vista do segundo setor do 2o.pavimento em montagem com o centro livre. Ao fundo a escada rolante e a praça Broodthaers. Fonte: acervo Marta Bogéa. Foto: Juan Guerra. [no topo à dir.] Vista do vão a partir da rampa, onde pode-se ver a montagem da expografia do 10. setor. Fonte: acervo Marta Bogéa. Foto: Juan Guerra. [embaixo] Vistas a partir da praça Broodthaers em montagem e a sua relação com o 20 . setor. Fonte: acervo Marta Bogéa. Foto: Juan Guerra. 

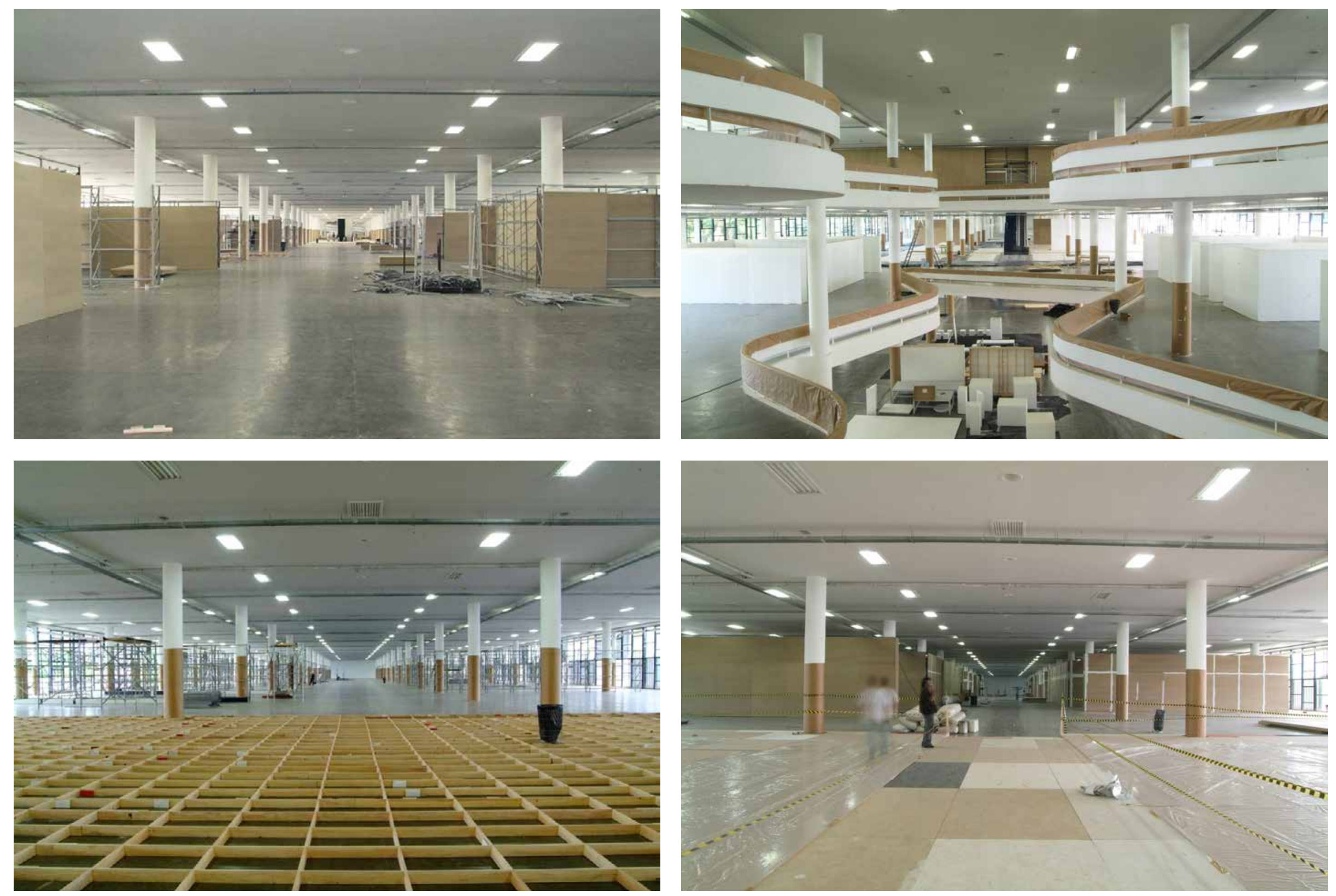

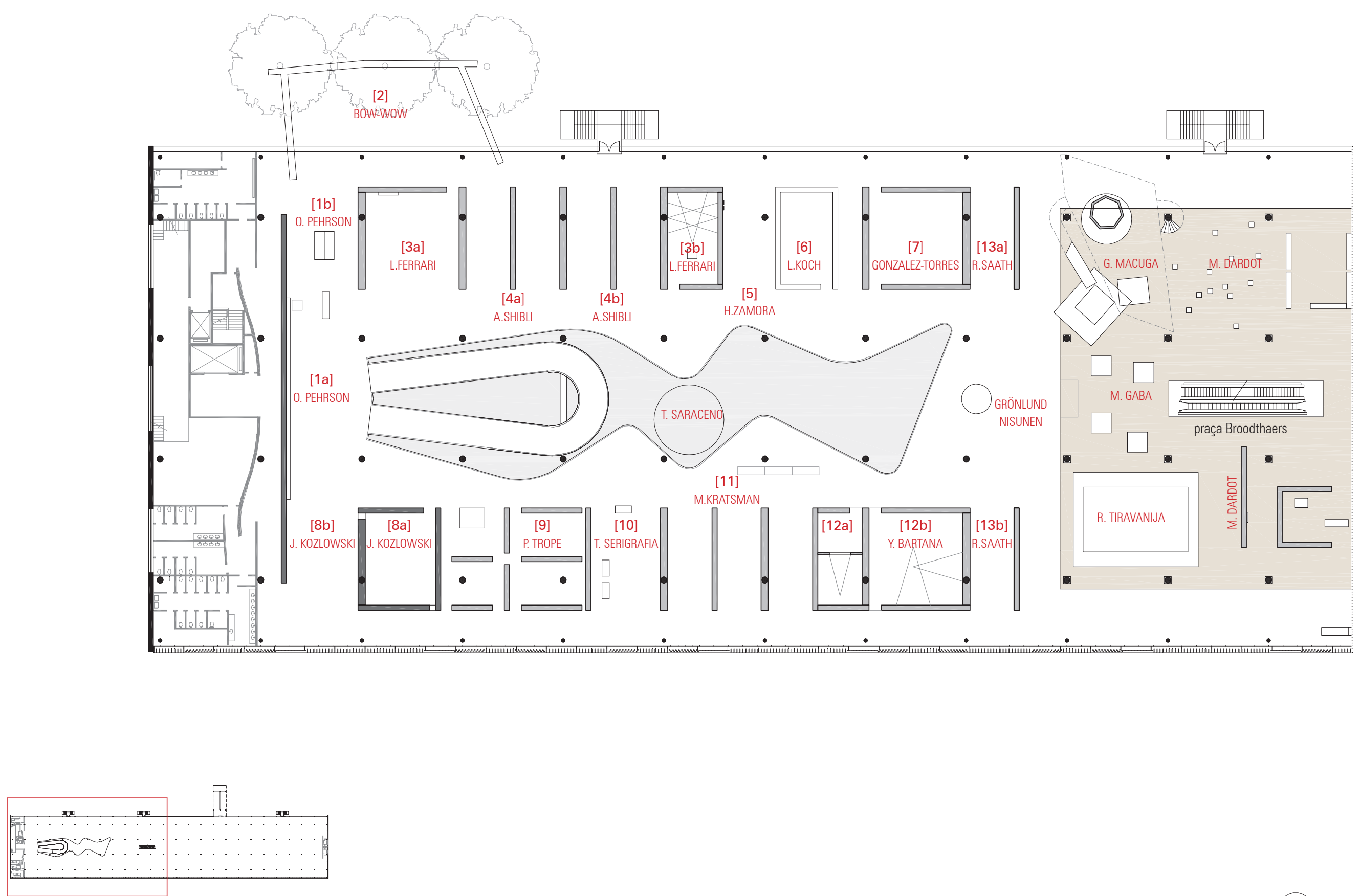

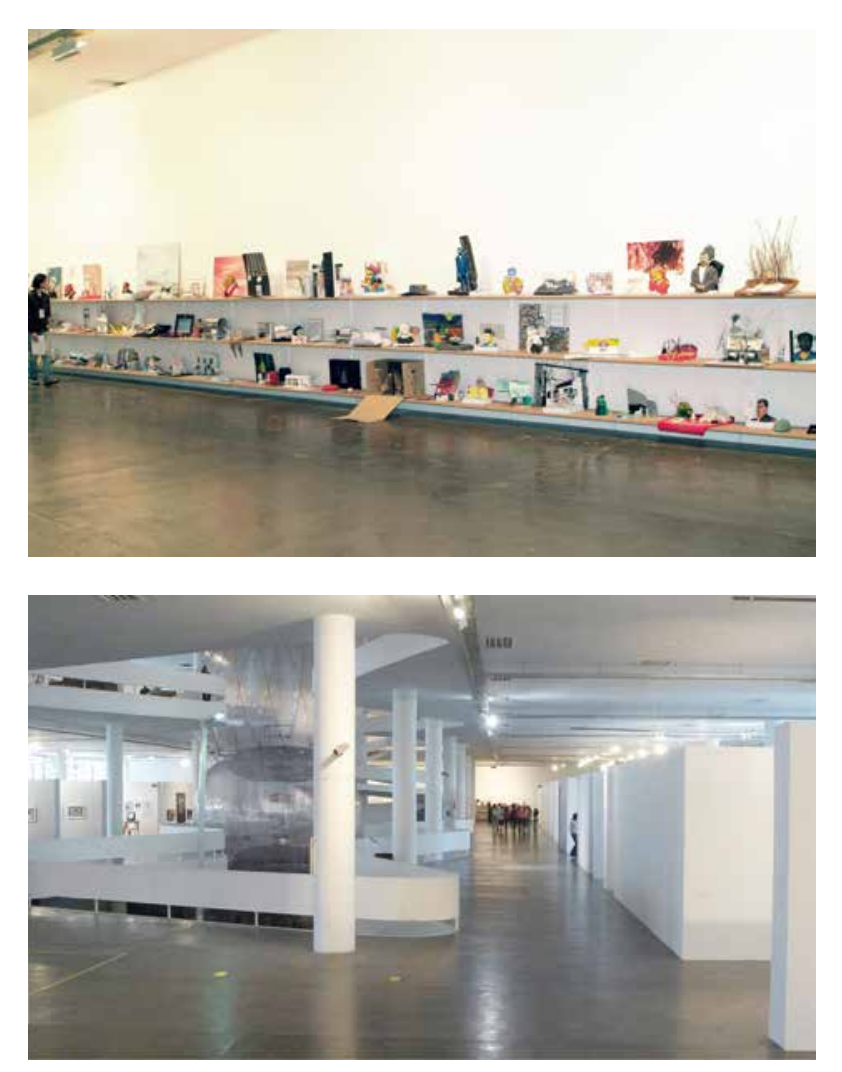

[no topo] A obra Hunt for unabomber de Ola Pehrson [1a]. Fonte: Arquivo Wanda Svevo.

[ao centro] Vista da circulação ao redor do vão central. Pode-se ver os volumes e linhas do núcleo político. Fonte: flickr. Disponível em: https://flickr.com.

[embaixo] Vista a partir do terceiro pavimento. Pode-se ver no segundo pavimento a sala de Leon Ferrari [3a] e de Ahlam Shibli [4a]. Fonte: flickr.

Disponível em: https://flickr.com.

\subsubsection{O primeiro setor}

No núcleo que margeia o vão central, nomeado inicialmente como político, apesar de ter perdido a força do partido inicial do projeto, conseguiu-se manter um equilíbrio entre linhas e volumes. Este setor da exposição manteve trechos de permeabilidade e fluidez, possibilitando que a paisagem do parque e a arquitetura do pavilhão dialogassem com as obras. O público que circulava em volta do vão ou na rampa podia ver os trabalhos desses artistas em uma condição muito distinta do espaço museológico. Desta forma, os trabalhos se confrontavam e criavam outras possibilidades de diálogo que não apenas pela sequência do percurso proposto, mas por um convívio visual. A narrativa curatorial abordou com diversas aproximações o tema da fronteira, que passou pela geopolítica, por questões identitárias e pela relação interior-exterior.

No patamar da rampa, foi implantado um imenso painel com mais de trinta metros desde o piso do primeiro pavimento ao forro do terceiro, o que criou uma importante área expositiva no eixo visual do vão e isolou visualmente toda a parte de serviços que ficava na cabeceira do pavilhão, oposta ao acesso principal. $\mathrm{O}$ artista escolhido para ocupar essa área de destaque foi Ola Pehrson ${ }^{30}$ (1964, Estocolmo, Suécia),

$30 \mathrm{O}$ artista morreu tragicamente em um acidente de carro durante o processo da 27a. Bienal e não pode finalizar seu trabalho comissionado. 
cuja obra Hunt for the Unabomber (2005) [1a] "investiga nosso relacionamento com as formas e expressões da tecnologia da comunicação" ${ }^{11} \mathrm{O}$ trabalho é uma a reconstrução de um documentário sobre o americano Theodore John Kaczynski, conhecido com "the unabomber". ${ }^{2}$ Kaczynski foi um terrorista que realizou uma campanha de bombardeio contra pessoas que estavam ligadas à tecnologia, sobretudo cientistas e engenheiros de computação das universidades norte americanas (1978 a 1995). Pehrson utilizou sucata para remontar o documentário e fez uma reconstrução caseira do filme original, mantendo apenas a trilha sonora. As peças utilizadas no vídeo foram dispostas em estantes que ocuparam a parte central do painel.

No alinhamento do patamar da rampa, junto ao caixilho da fachada sul, estava a obra Caminho do macaco (2006) [2], do Atelier Bow-Wow (Tóquio, Japão), uma ponte de madeira que levava o público para fora do pavilhão em um passeio pela copa das árvores do Parque Ibirapuera. Os artistas do coletivo ficaram impressionados com as árvores gigantescas que circundam o edifício. A estrutura e o guarda-corpos de madeira bruta que criaram formavam uma construção de caráter vernacular, que se contrapunha à estética modernista vista ao redor. A proposta buscou discutir o comportamento

3I Texto com uma breve apresentação do artista que constava na parede da mostra. 32 Codinome dado pelo FBI ao terrorista.

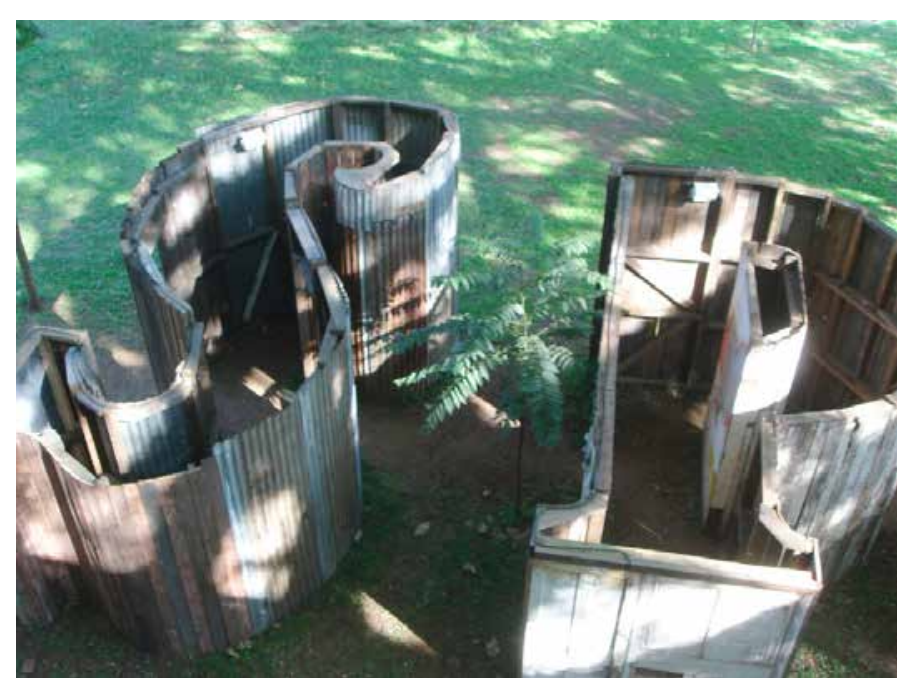

[no topo] Vista da obra Spirit and Matter de Damián Ortega. Fonte: flickr. Disponível em: https://flickr.com.

[ao centro à esq.] Acesso para obra Caminho do macaco do Atelier Bow-Wow [2]. Fonte: atelier Bow-wow.

[embaixo à esq.] Chegada no Pavilhão da obra Caminho do macaco. Fonte: atelier Bow-wow.

[embaixo à dir.] Vista a partir da obra Caminho do macaco do Atelier Bow-Wow [2].

Fonte: atelier Bow-wow.
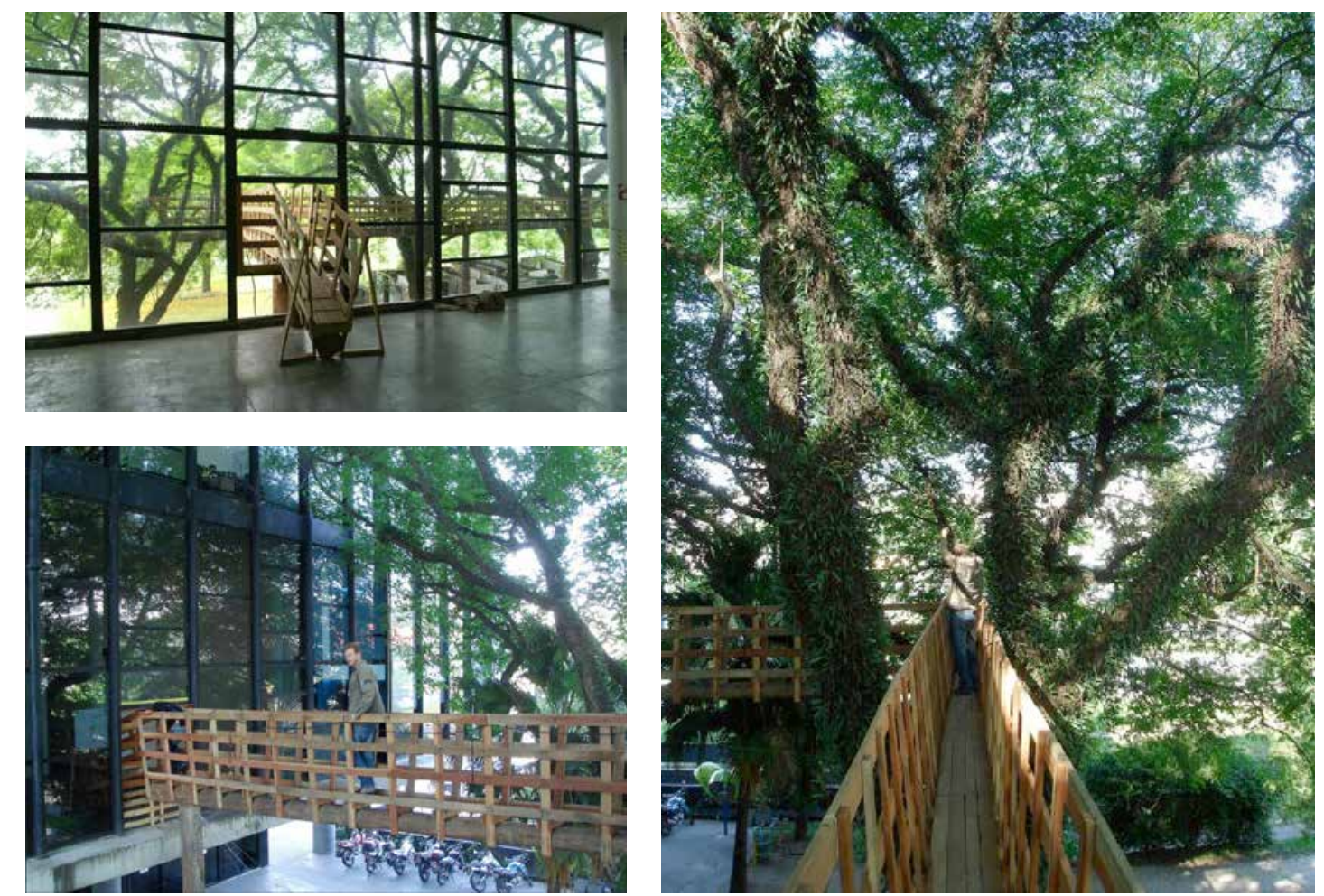

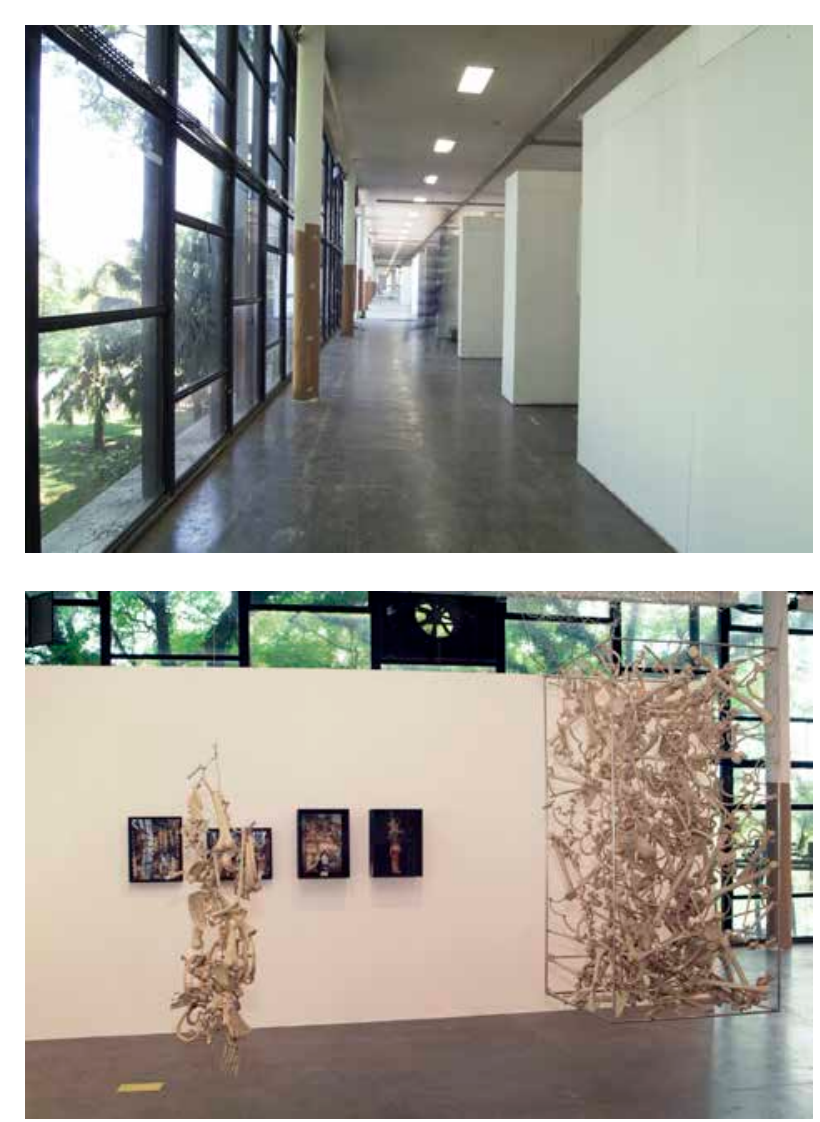

[no topo] Vista da circulação contínua pelos caixilhos. Fonte: Arquivo Wanda Svevo, Foto: Juan Guerra.

[ao centro] Vista da sala de Leon Ferrari [3a]. Fonte: Arquivo Wanda Svevo. Foto: Juan Guerra.

[embaixo] Vista do Painel que fechava os caixilhos na sala de Leon Ferrari [3a]. Fonte: site Bienal. Foto: Juan Guerra. no espaço público e, com a instalação, tirou os visitantes de dentro da exposição e os levou para um passeio pela natureza. A obra criava, desta forma, a possibilidade de interagir diretamente com o parque e vivenciar outra atmosfera e sensação temporal. A perspectiva que se dá sempre do interior do pavilhão para o exterior, foi subvertida, possibilitando avistar o edifício e a exposição a partir das árvores. A remoção de uma janela do pavilhão permitiu a passagem de dentro para fora. As pessoas tinham que se agachar para passar e depois caminhar com cuidado por uma ponte muito estreita, sendo expostas a uma situação pouco usual. Além disso, é a partir da ponte que se tinha o melhor ponto de vista para ver a obra Spirit and Matter (2004), de Damián Ortega (1967, Cidade do México, México), uma montagem precária de restos de material de construção que construía a palavra spirit, que só podia ser lida a partir dos andares superiores do pavilhão. $\mathrm{O}$ fechamento de salas nesse setor fez com que a circulação contínua pelos caixilhos se tornasse secundária e pouco utilizada. Entretanto, a obra do Atelier Bow-wow corroborou com o projeto expográfico, dando sentido à proposta da expografia ao chamar o fluxo de público para fachada.

Seguindo o percurso, ao lado do acesso à ponte, a primeira sala era a de León Ferrari (I920, Buenos Aires, Argentina) [3a], que solicitou um espaço mais amplo (dez por doze metros) configurando uma sala com painéis em " $u$ ” que se abria para o interior do pavilhão ao mesmo tempo em que 
se fechava para o parque, quebrando com a permeabilidade visual. Conhecido por sua arte política com ataque direto ao catolicismo, Ferrari era um dos artistas que possuía uma interlocução de longa data com Lagnado. As obras selecionadas para a mostra foram esculturas de arame, mapas geopolíticos com intervenções, e a série Infierno (2000).

$\mathrm{Na}$ sequência narrativa estava a série de fotografias intitulada Eastern LGBT n.l-40 (2006) [4a], da artista palestina Ahlam Shibli (ı970, Arab al-Shibli, Palestina), que aborda a casa/lar como o corpo, no contexto dos transexuais palestinos que migram para Israel por ser um país mais tolerante às opções de gênero. Segundo a artista, o corpo é o lar para esta comunidade à margem da sociedade (LAGNADO, 2007). As fotografias ficavam em painéis transversais que mantinham o diálogo pavilhão-parque-obra, conforme o partido expográfico.

Na sequência estava a obra Sala de exposição (2006) [6], de Lucia Koch, uma sala com dimensões e proporções idênticas à sala de projeção de Ferrari [3b], que estava ao seu lado. No lugar de paredes opacas que dão suporte aos trabalhos, Koch utilizou uma parede de madeira perfurada nas duas faces, criando, através da luz filtrada, novas percepções e sensações, desmanchando a solidez da expografia num claro diálogo com o projeto expográfico. As paredes permeáveis de Koch, que deixavam a luz e o som vazarem, também abordavam o tema da fronteira. O curador Moacir do Anjos faz uma análise desta obra em um livro dedicado à artista:
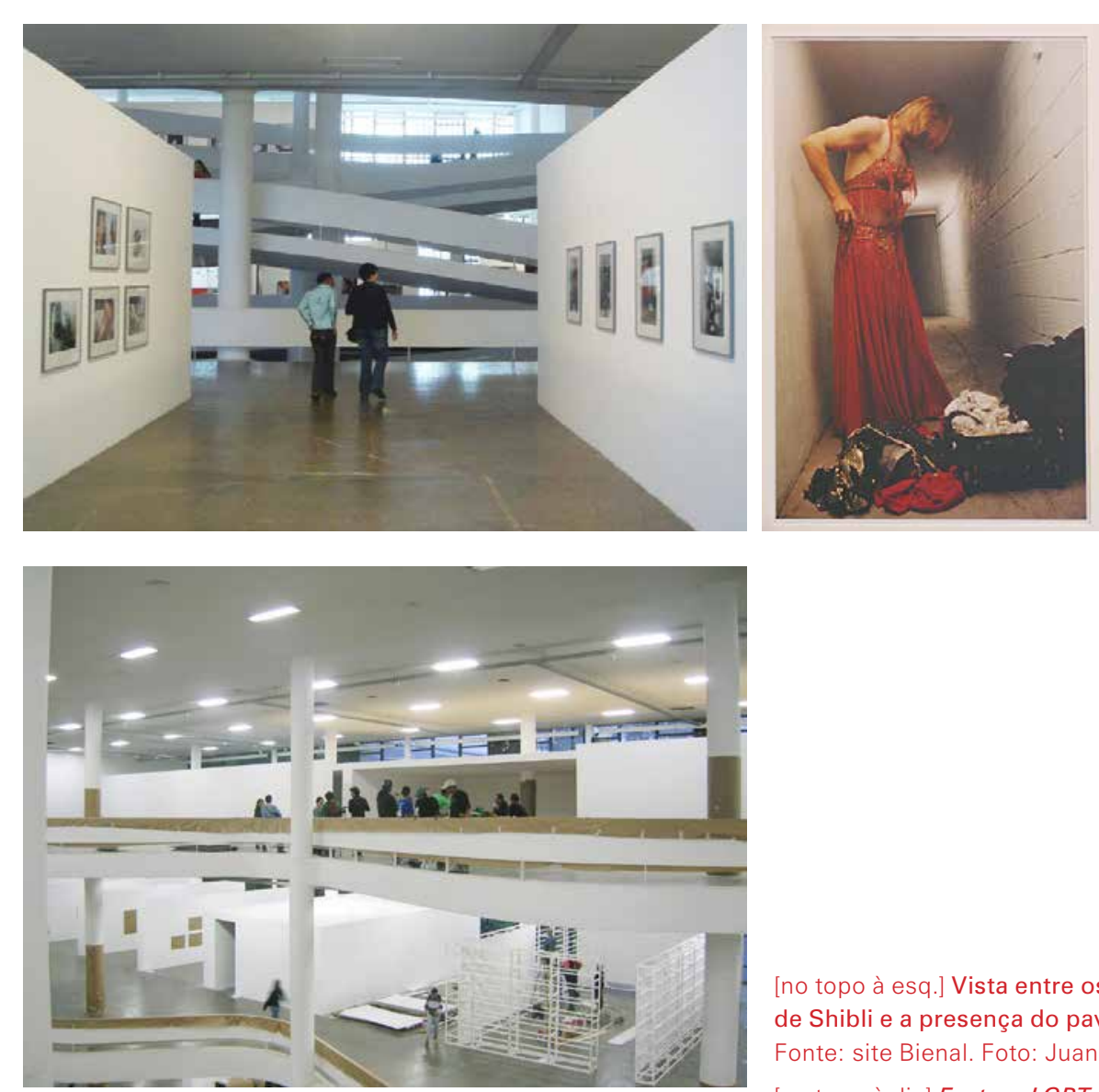

[no topo à esq.] Vista entre os painés de Shibli e a presença do pavilhão. Fonte: site Bienal. Foto: Juan Guerra.

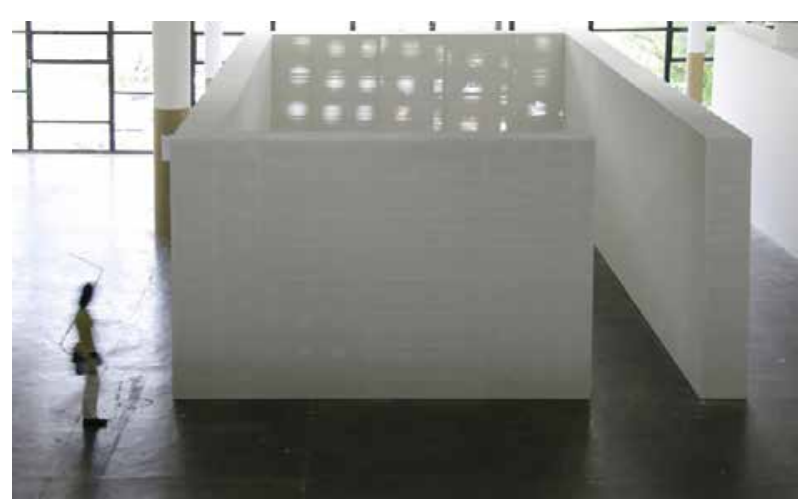
[no topo à dir.] Eastern LGBT n.1-40 de Ahlam Shibli [4a]. Fonte: site Ahlam Shibli. Disponível em: http:// www.ahlamshibli.com/essay/lisette lagnado_home_and_homland.htm. [ao centro] Vista a partir do 30. pavimento da montagem da obra Sala de exposição [6] de Lucia Koch e sua relação com a sala de Léon Ferrari [3b]. Fonte: Arquivo Wanda Svevo. Foto: Juan Guerra.

[embaixo] Vista externa da obra Sala de exposição [6] de Lucia Koch. Fonte: Anjos, 2009 
Em vez de ser abrigo de algo, sua Sala de exposição (2006) não continha nada que não fosse a luz filtrada por furos, quase toda vinda dos largos panos de vidro que ladeiam o pavilhão onde a Bienal regularmente se instala, projetado pelo arquiteto brasileiro Oscar Niemeyer. A depender da hora em que se visitava a exposição e das múltiplas posições de onde se podia experimentar o trabalho — de dentro ou de fora da sala, tendo ao fundo a obra de outro artista ou o verde das árvores que existem no exterior do prédio- - padrões geométricos eram feitos e desfeitos diante dos olhos, e relações variadas eram estabelecidas entre o ato de ver e aquilo que é visto, como se a intervenção de Lucia Koch lembrasse a todo o instante a natureza frágil e contingente das coisas (ANJOS, 2009, p.49).

Ao lado da obra de Koch estava a sala dedicada ao artista cubano Felix Gonzalez-Torres33 (I957-1996, Guaiamo, Cuba) [7],

[no topo] Untitled (Passport) e Untitled (Couple) de Felix Gonzalez-Torres [7]. Fonte: Arquivo Wanda Svevo. Foto: Juan Guerra.

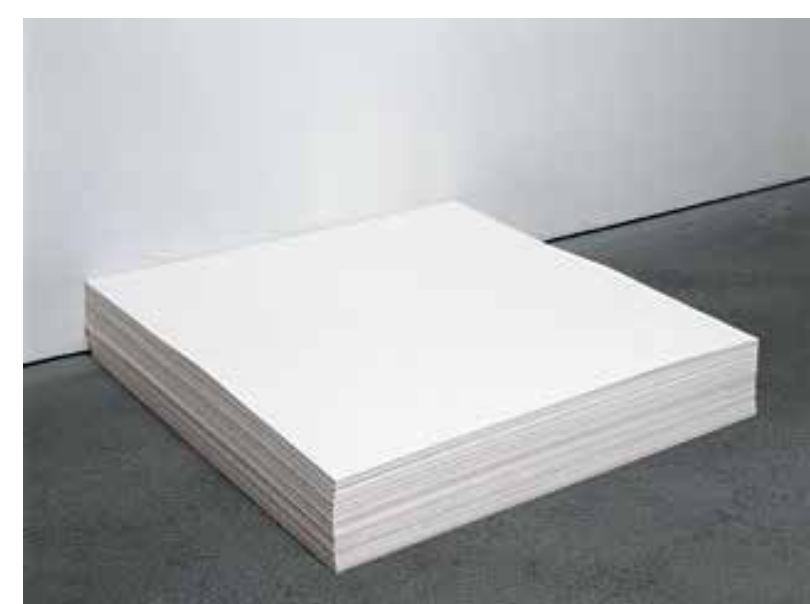

33 "Gonzalez-Torres foi um dos artistas mais influentes de sua geração, exemplificando tanto o surgimento do chamado neo-conceitualismo quanto a busca de uma exploração política e ética do cotidiano. Seus trabalhos em uma variedade de mídias abrangem temas como identidade, desejo, intimidade, mortalidade, metamorfose, contaminação, perda ou renovação pública ou social e privada. Trabalhando em série, ele produziu formas de escultura e instalação escultórica que envolvem a participação do curador, do espectador, ou de ambos, incluindo pilhas, vazamentos de doces, cordas de luz e retratos. Ele é talvez o mais proeminente artista emigrante cubano". Disponível em: $<$ https://www.tate.org.uk/art/artworks/gonzalez-torres-untitled-double-portrait-t13309 >. Acesso em: I2 jan. 2019. 
que fez parte do grupo de artistas históricos-contemporâneos. As obras de Gonzalez-Torres foram implantadas, por decisão da curadoria, em uma sala fechada sem relação visual com espaço exterior. Estavam presentes na mostra: Untitled (Couple) (I993), instalação feita com lâmpadas incandescentes em soquetes com dois fios entrelaçados — sem uma forma correta de instalação, deveria ser definida por quem faria a montagem - ; e Untitled (Passport) (I99I), uma pilha de papel branco quadrado como um passaporte em branco capaz levar seu detentor a todos os lugares, sem controle de fronteiras — pilha se reduziria conforme o público pegasse seu passaporte. ${ }^{34}$ GonzalezTorres é um dos artistas chave que compõe este núcleo político e aborda em sua obra questões centrais na mostra, tais como a relação arte-vida, fronteiras, e autoria:

Felix Gonzalez-Torres vale-se da estética não-representacional minimalista. Ao identificar o objeto minimalista como portador de sentidos multidisciplinares, o artista reivindica um texto político às questões ligadas à forma. A política de Gonzalez-Torres está situada na construção de um corpo de trabalho que pode ser replicado indefinidamente mas que será

34 Na recepção do pavilhão, da área administrativa da fundação Bienal, ficava a obra Untitled (Perfect Lovers) feita com relógios de parede à pilha que em princípio estavam exatamente na mesma hora, mas que com o passar do tempo vão perdendo a sincronia e se desencontrando. sempre original, graças ao conteúdo pessoal e intransferível que lhe é concedido pelo interlocutor. Na obra de Gonzalez-Torres, sobrepõem-se as noções de original e cópia, volatilidade e transitoriedade. No estado escultórico de “pilhas” de cópias, a obra tende a desaparecer completamente do espaço expositivo, quando os impressos são levados pelos visitantes. ${ }^{35}$

Do outro lado do vão, próximo da fachada norte e protegida pelos brises soleil, a primeira sala é Gravity Room (1995) [8a], de Jarosław Kozłowski (1945, Srem, Polônia). Era a única com painéis até o forro do pavilhão. $O$ artista propôs uma instalação com móveis residenciais em uma configuração que ocupava todas as superfícies da sala: paredes, piso e teto. O lustre estava no chão, a sala de jantar no teto, uma televisão com poltrona na parede etc. Ao lado, está Morrinho (2004-2005), [9] de Paula Trope (1962, Rio de Janeiro, RJ), uma obra importante na mostra por trabalhar no limiar entre arte/não arte e ativismo social. A artista desenvolveu seu trabalho fotográfico com meninos de comunidades pobres do Rio de Janeiro. O díptico consistia em um retrato de um menino feito pela artista ao lado de uma fotografia das maquetes de morros, tirada pelo retratado. Segundo o curador

35 Texto com uma breve apresentação do artista produzido por Lagnado e Pedrosa para informar o público da mostra. 


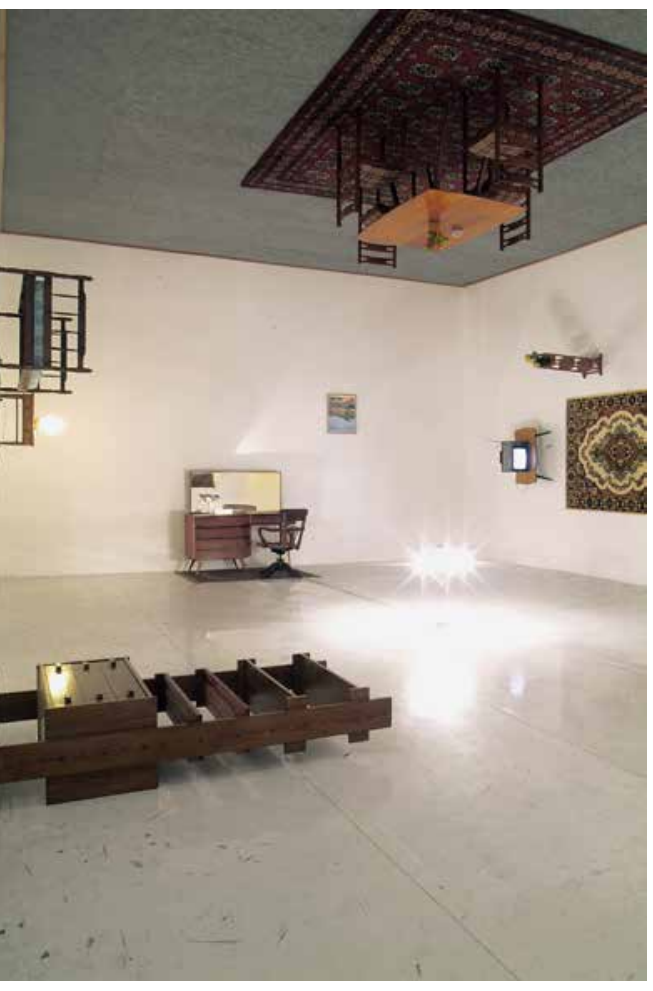
Paula Trope [9]. Fonte: Arquivo Wanda Svevo. Foto: Juan Guerra.

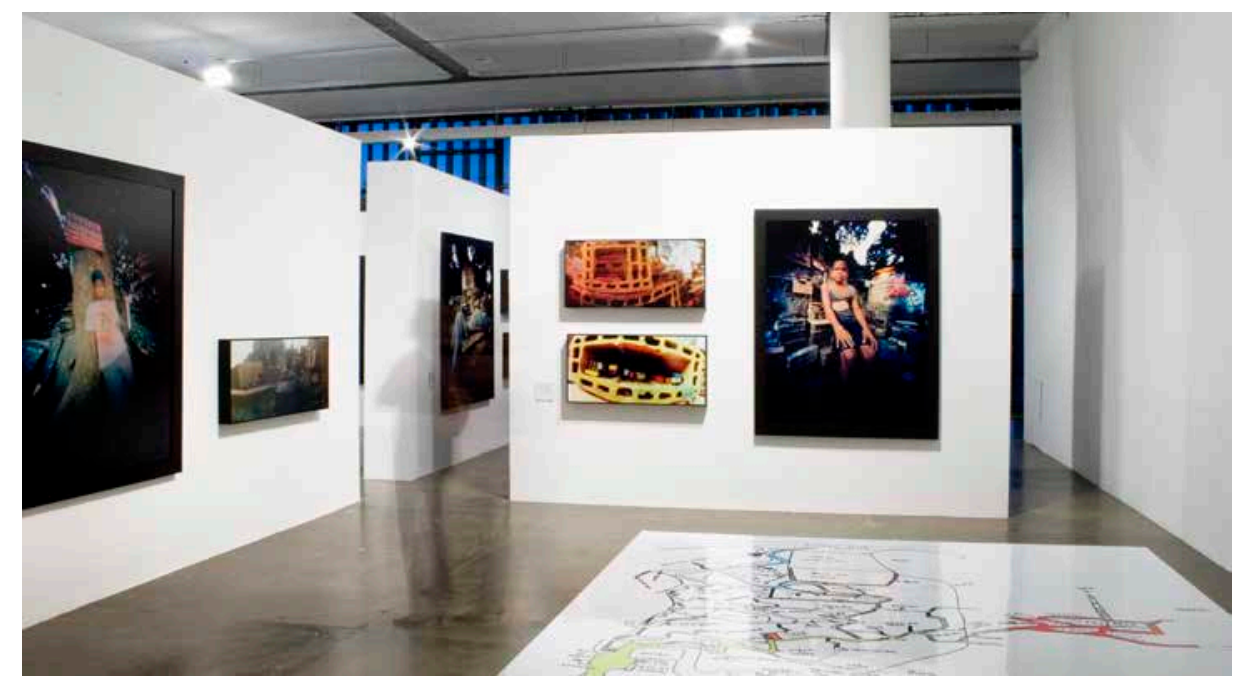

Paulo Herkenhoff (2008b), “a operação política de Trope converte os meninos - o objeto da imagem - em sujeito da fotografia..$^{36} \mathrm{~A}$ artista baniu o olho experiente de fotógrafa quando adotou o uso de pinholes, ou câmeras sem lentes. Bishop cita o trabalho de Trope como um exemplo bem-sucedido na mostra:

Minha impressão da 27a. Bienal é a de que não se trata de uma exposição moralista. E isso porque a maioria dos projetos opera de forma bem-sucedida no interior do espaço expositivo e possui uma lógica estética que é íntegra em relação à especificidade do projeto.

Por exemplo, Paula Trope usa uma câmera "pinhole" [câmeras de orifício feitas a partir de latas recicladas] em seu trabalho colaborativo com garotos de rua no Rio, e os efeitos formais dessa fotografia são um fator importante na recepção das imagens.

A câmera "pinhole" confere um efeito sobrenatural, distorcido, que é apropriado à representação de seu mundo de fantasia do Morrinho; ela também frustra nosso desejo por uma visão clara e "objetiva" desse mundo (com todas as conotações de poder que esse olhar poderia trazer) e, assim, espelha nosso desejo

36 A artista que dividiu o valor recebido pela produção e os meninos receberam crédito das obras como colaboradores. 
voyeurístico de ter acesso a esses conflituosos e, quem sabe, perigosos adolescentes (BISHOP, 2006a, s.p.).

O espaço de Trope deveria, a princípio, ter um caráter de instalação, diferente do sistema expositivo utilizado. Mas acabou sendo constituído pelos painéis expográficos padrão, utilizados, porém, de forma diferente, configurando mais uma exceção ao sistema expositivo.

$\mathrm{Na}$ sequência do espaço estava o Taller Popular de Serigrafia (2002, Buenos Aires, Argentina) [10], um grupo ativista de esquerda que atua em manifestações políticas, sindicatos e movimentos estudantis produzindo cartazes de serigrafia e bandeiras. Segundo os artistas: "O atelier é uma experiência coletiva de arte e mobilização. Como forma de rebelião"(JATRIK, SACAFATI,POSADAS; 2006, p.234).

Seguindo o percurso estavam as fotografias jornalísticas de Miki Kratsman (1959, Buenos Aires, Argentina) [11] do muro Palestina-Israel, que faziam vizinhança com o vídeo $A$ declaration [12c], de Yael Bartana (1976, Afula- Israel), obra que mostrava um homem tirando a bandeira de Israel e plantado uma oliveira no lugar — o ato substitui um símbolo nacional por outro.

As fotografias urbanas de coberturas e calçadas do Cairo de Randa Shaath (1963, Filadélfia, Estados Unidos) [13] fechavam o núcleo nas fachadas norte e sul para dar início à praça Broodthaers. A disposição dos painéis que deram suporte à essas obras, assim como as demais fotografias expostas neste núcleo, seguiram o padrão original do projeto expográfico. O uso de painéis no sentindo transversal permitiram manter a presença do pavilhão e os visuais da cidade e do parque que, por sua vez, puderam dialogar com as imagens urbanas de Saath.

As obras de Kratsman, Taller Popular de Serigrafia e Shibli, também instaladas nos painéis transversais, dialogavam visualmente com a obras de Saraceno no vão, com o público circulando dentro de suas bolhas, e criaram espaços de permeabilidade visual no qual se podia ver de uma fachada à outra do pavilhão. [no topo à esq.] Vista a partir do outro lado do vão do espaço Taller Popular de Serigrafia [10] e Morrinhos de Paula Trope [9]. Fonte: acervo Marta Bogéa. Foto: Juan Guerra. [no topo à dir.] Vista do espaço do Taller Popular de Serigrafia [10]. Fonte: site Bienal. Foto: Juan Guerra.

[embaixo à esq.] Vista do vão a partir do terceiro pavimento, onde pode-se no segundo pavimento ver as salas de vídeo de Yael Bartana à esquerda [12] e os painéis de Miki Kratsman [11]. No terceiro pavimento vista das obras de Pieter Hugo. Fonte: acervo Marta Bogéa. Foto: Juan Guerra.

[embaixo à dir.] Vista da Praça Broodthaers a partir do primeiro setor. Fonte: flickr. Disponível em: https://flickr.com. 

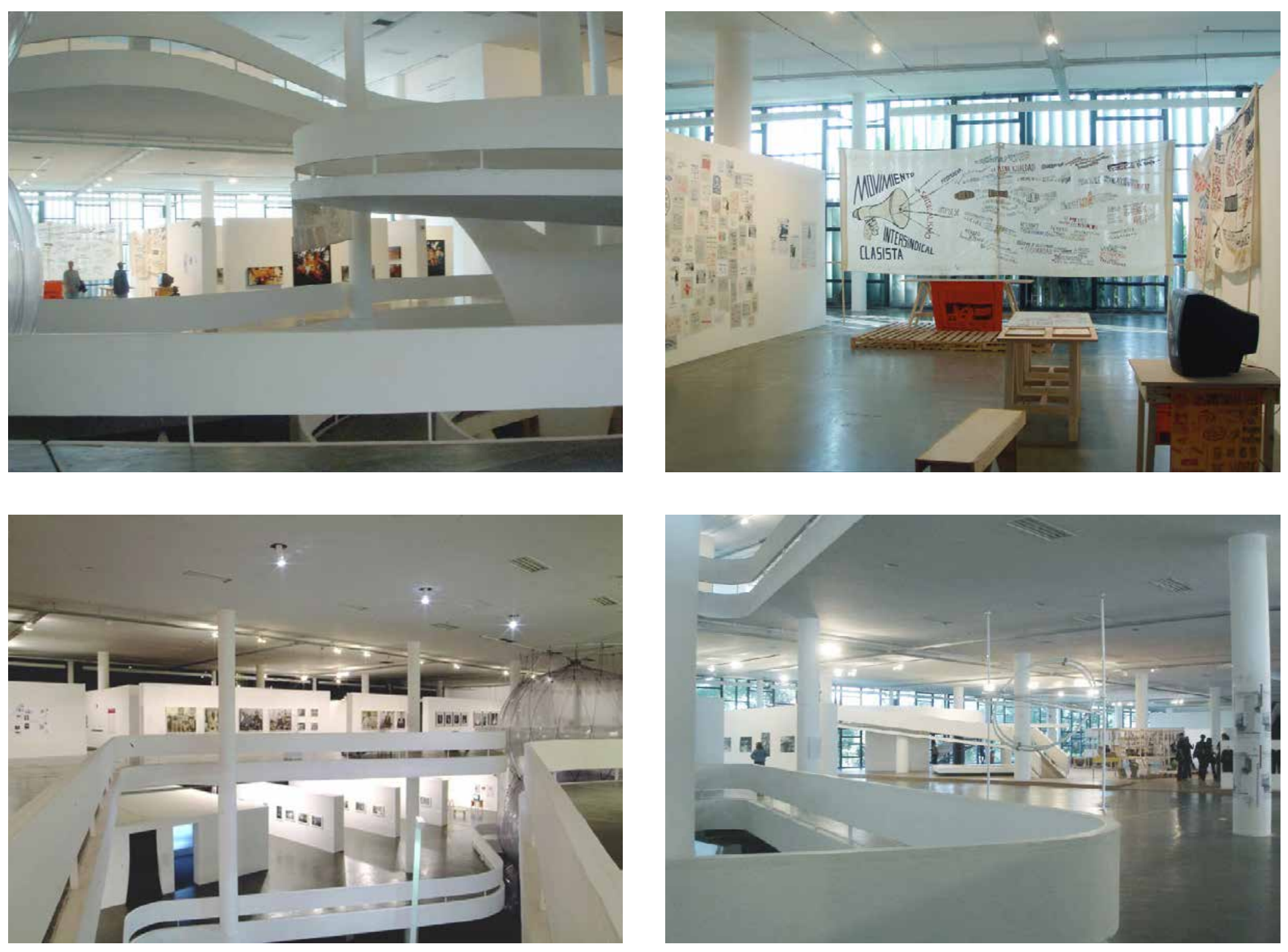

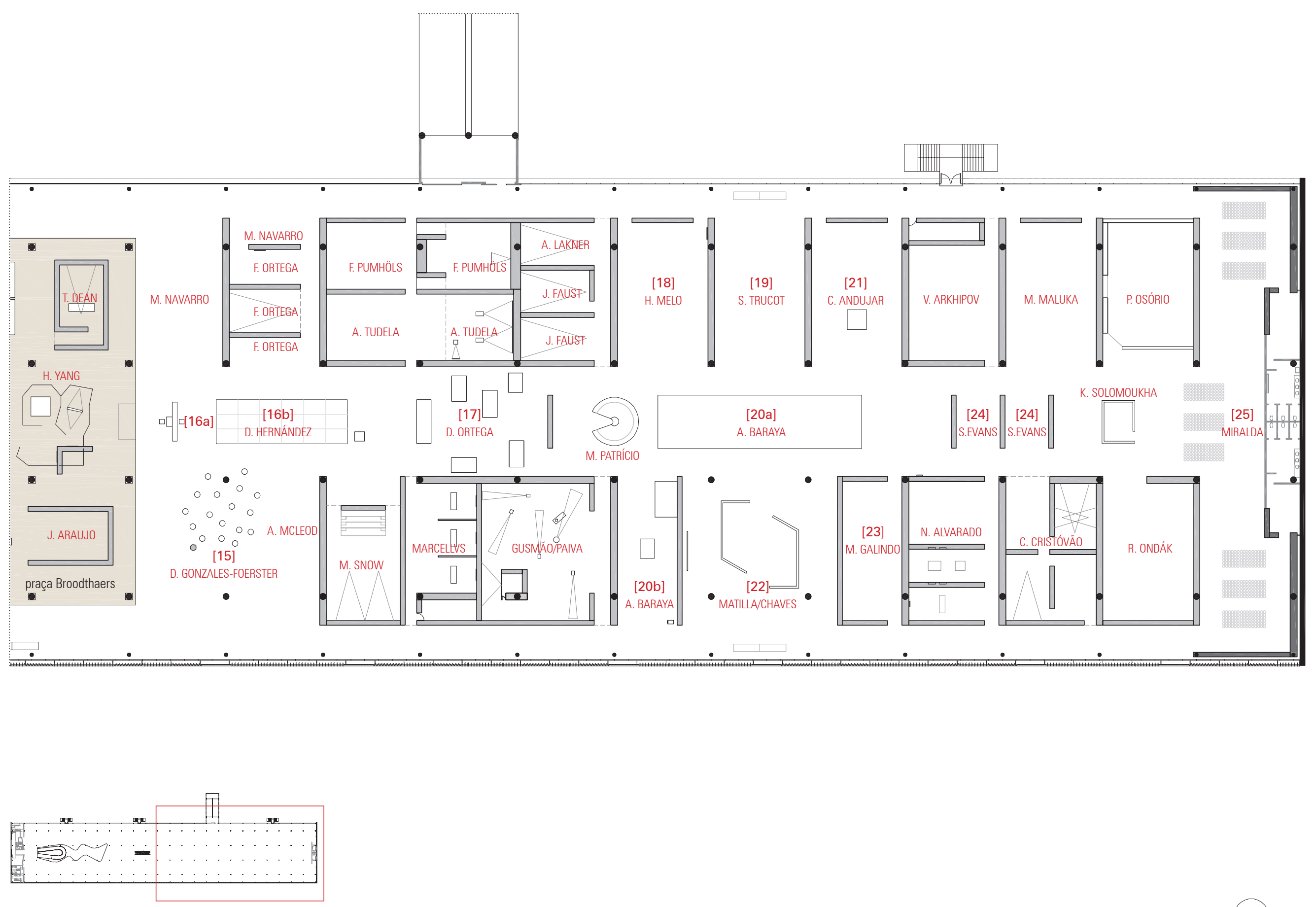

MAPA DO $2^{\circ}$ PAVIMENTO

PLANTA DO SEGUNDO SETOR DO 20PAVIMENTO - EXPOGRAFIA NA 27 BIENAL 

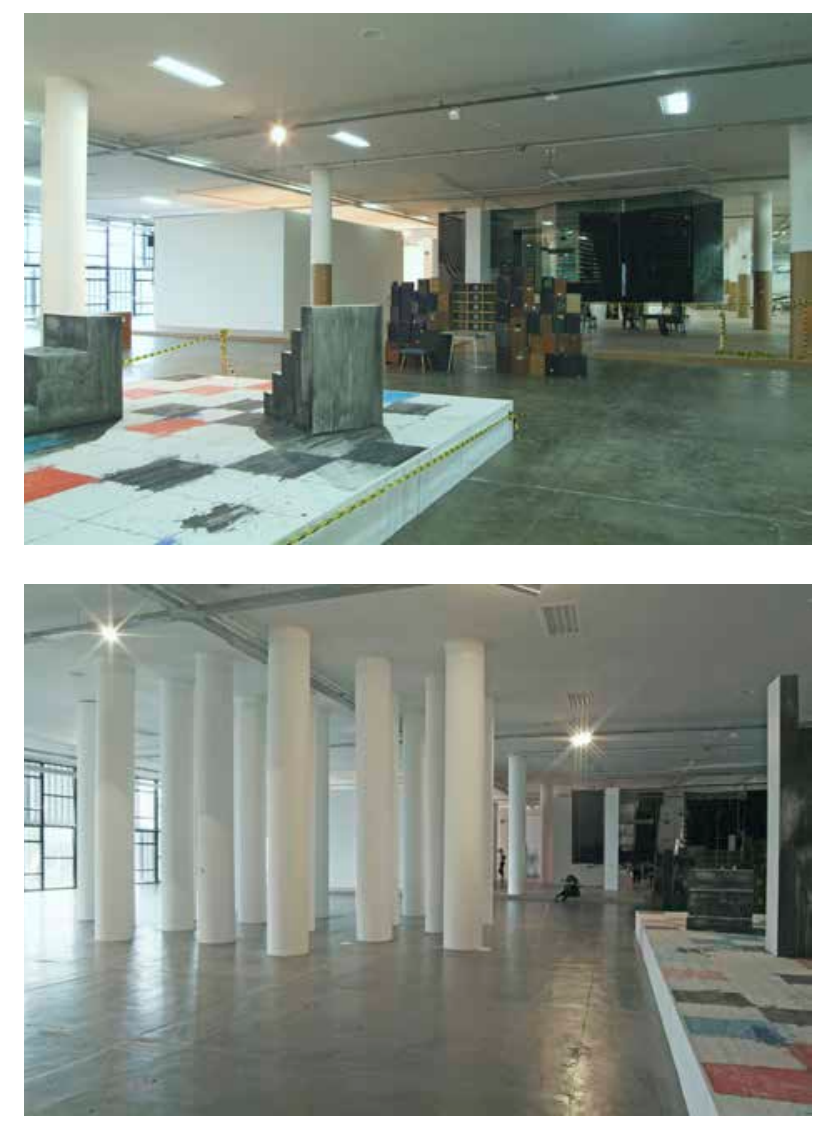

[no topo] Vista da obra We are unfinished drawings [16b] de Diango Hernández e ao fundo a praça Broodthaers. Fonte: Arquivo Wanda Svevo. Foto: Juan Guerra.

[no centro] Vista da obra Double terrain de jeu [15], de Dominique Gonzalez-Foerster. À direita a obra We are unfinished drawings [16b] de Diango Hernández e ao fundo a praça Broodthaers. Fonte: Arquivo Wanda Svevo. Foto: Juan Guerra.

[embaixo] Vista da montagem da obra de Dominique GonzalezFoerster. Fonte: acervo Marta Bogéa. Foto: Juan Guerra.

\subsubsection{O segundo setor}

Conforme descrito anteriormente, o projeto expográfico era um só para todo o pavimento, mesmo que a praça Broodthaers configurasse uma exceção e uma quebra de ritmo. O segundo setor tinha como proposta um centro livre e continuo que mantivesse a lógica do vazio expográfico do vão (embora tivesse uma dimensão menor) e a circulação pelos caixilhos, construindo, desta forma, diferentes possibilidades de percursos sem impor uma sequência rígida na narrativa. Entretanto, o excessivo adensamento de salas e a construção de anteparos no centro, para fazer a edição entre artistas que, segundo os curadores ou eles próprios, não podiam conviver visualmente, bloqueou a permeabilidade visual e dificultou o percurso do público até o fim do pavilhão. As premissas expográficas mantidas nesse setor foram a circulação continua pelos caixilhos e o sistema expositivo (painéis autoportantes com altura 4,IO metros).

O núcleo de artistas que inicia este trecho dialogava com as obras da praça e com a obra Double terrain de jeu (2006) [15], de Dominique Gonzalez-Foerster, que realizou instalações similares na marquise e no pavilhão. Pela natureza do trabalho, que estabelecia um diálogo direto com a arquitetura, lhe foi dada a liberdade de escolher o local ideal para implantação de sua obra para que houvesse a conexão visual entre as suas duas partes, ou seja, um lugar dentro do pavilhão que visualizasse a marquise (BOGÉA, 2006). 
Quinze colunas falsas idênticas às do pavilhão foram instaladas próximas a uma coluna real, subvertendo visualmente a lógica ortogonal e ritmada da estrutura do edifício. A obra foi replicada na marquise, seguindo a lógica dessa Bienal de se espalhar pelo parque. Em cada grupo de colunas apenas uma possuía rodízios na base. Uma coluna móvel que, quando descoberta, poderia ser empurrada pelo público causando estranheza e a sensação de instabilidade na solidez do edifício - a obra silenciosa passou desapercebida por parte público, pois mimetizava as construções. A instalação de Gonzalez-Foerster dialogava com as demais obras com abordagem arquitetônica em seu núcleo e na praça Broodthaers, especificamente com os trabalhos de Juan Araujo e Rirkrit Tiravanija.

Este trecho da mostra possuía treze salas de vídeo em sequência, apenas no espaço central havia instalações de Diango Hernández (1970 Sancti Spiritus, Cuba) [16], e Damian Ortega (1967, Cidade do México) [17]. Essa configuração bloqueou a relação com o espaço do pavilhão e o excesso de salas de vídeo fechadas foi pouco convidativa ao público.

No centro deste grande setor, após as salas fechadas, estava o núcleo Acre, onde o espaço voltou a ganhar mais qualidade, com permeabilidade e uma lógica de projeto clara.

No contexto da 27a. Bienal, cujos principais temas incluem a possibilidade de convivência pacífica, em um mesmo território, de sociedades com "ritmos internos" diferentes, o Acre pode ser considerado o lócus de preocupações tais como a busca de formas alternativas de comunidade e a construção de um espaço comum; justiça ambiental; estratégias de sobrevivência; inclusão do não-artista e do forasteiro como exemplos vitais do processo criativo; a questão das populações indígenas do Brasil; fronteiras políticas; isolamento e a tradição do pensamento; novas formas de coletividade; viagem e deslocamento como formas de conhecimento; a floresta e seus produtos como insumos do fazer artístico; autodidatismo e outros assuntos relacionados (ROCA, 2008, p.344).

A obra de Hélio Melo (ı26, Vila Antinari, AC) [18], acreano e seringueiro, pintor autodidata que desenvolveu sua própria técnica de extração de pigmentos da floresta, foi o eixo inicial a partir do qual se construiu o núcleo. Os artistas contemporâneos estabeleceram diálogo com Melo a partir de obras que abordavam a noção de território, fronteiras e justiça ambiental (Roca, 2006, p.134). O agrupamento contou com obras de artistas que fizeram residência no Acre: Susan Turcot (ig66, Montreal, Canadá) [19], Alberto Baraya (i968, Bogotá, Colômbia) [20] e Marjetica Potrč (I953, Ljubljana, Eslovênia) e artistas com trabalhos que abordavam as questões discutidas pelo núcleo como a série Marcados (1983/2006) [21], de 

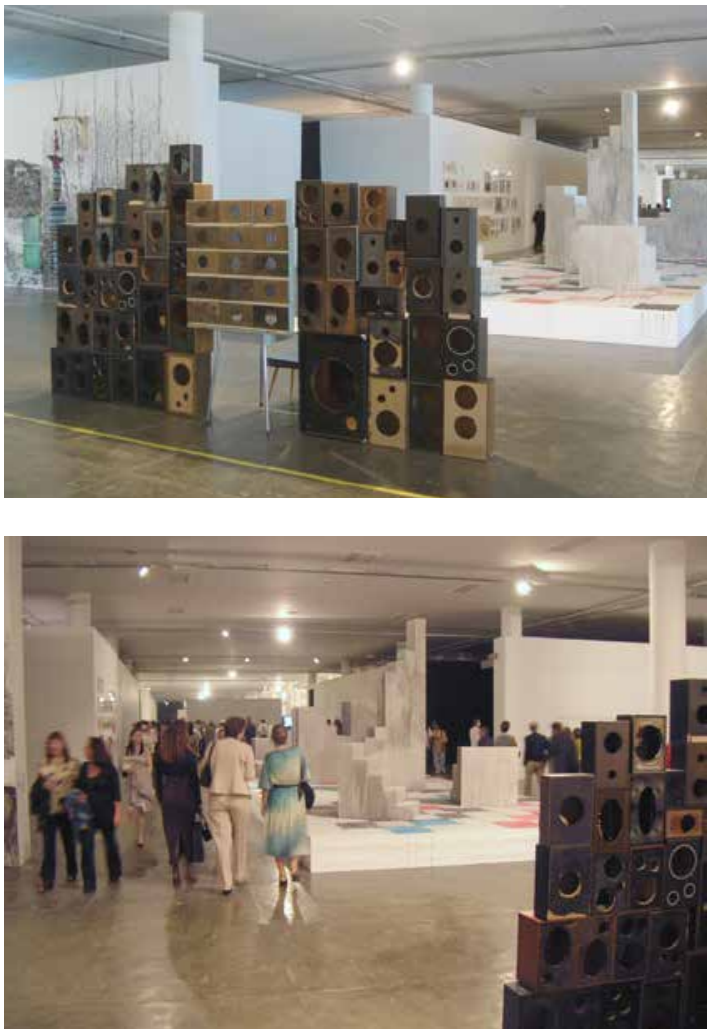

[no topo] Vista do espaço central do segundo setor. No plano da frente Drawing (my Bird don't want me back) de Diango Hernández [16]. Fonte: flickr. Disponível em: https://flickr.com.

[embaixo] Vista do espaço central do segundo seto na inauguração da mostra, com a obra de Diango Hernández [16]. Fonte: acervo da autora. Foto: Maria Julia Herklotz.
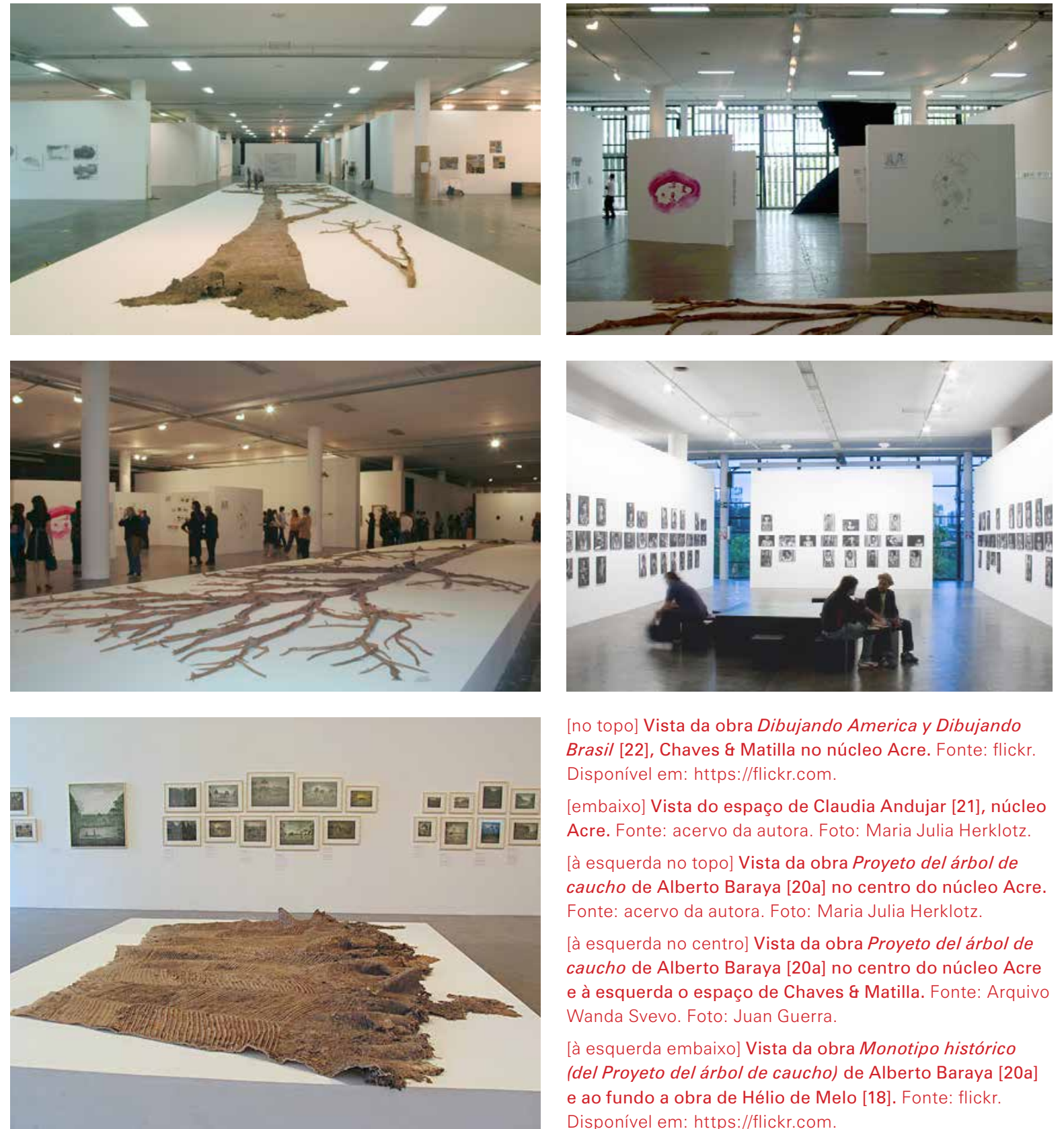

[no topo] Vista da obra Dibujando America y Dibujando Brasil [22], Chaves \& Matilla no núcleo Acre. Fonte: flickr. Disponível em: https://flickr.com.

[embaixo] Vista do espaço de Claudia Andujar [21], núcleo Acre. Fonte: acervo da autora. Foto: Maria Julia Herklotz.

[à esquerda no topo] Vista da obra Proyeto del árbol de caucho de Alberto Baraya [20a] no centro do núcleo Acre. Fonte: acervo da autora. Foto: Maria Julia Herklotz.

[à esquerda no centro] Vista da obra Proyeto del árbol de caucho de Alberto Baraya [20a] no centro do núcleo Acre e à esquerda o espaço de Chaves \& Matilla. Fonte: Arquivo Wanda Svevo. Foto: Juan Guerra.

[à esquerda embaixo] Vista da obra Monotipo histórico (del Proyeto del árbol de caucho) de Alberto Baraya [20a] e ao fundo a obra de Hélio de Melo [18]. Fonte: flickr. Disponivel em: https://flickr.com. 
Claudia Andujar (193I, Neuchatel, Suiça); Dibujando America y Dibujando Brasil (2005) [22], de Raimond Chaves (1963, Bogotá, Colômbia) \& Gilda Chaves (1967, Los Angeles, Estados Unidos); e a obra de Maria Galindo (1964, La Paz, Bolívia) [23], que tratava da relação com a Bolívia e Amazônia. Dois artistas que compõem esse núcleo, Potrč e o coletivo Superflex, foram instalados no terceiro pavimento na área climatizada, mesmo que suas obras não tivessem diretrizes de conservação. A presença dessas instalações que compõem a narrativa do núcleo climatizado será abordada a seguir.

Espacialmente, a centralidade do núcleo Acre foi estabelecida por uma imensa árvore, sobre uma base baixa, de Alberto Baraya [20a], feita em colaboração com comunidades de seringueiros nas quais o artista desenvolveu uma técnica de moldar plantas com o látex extraído das seringueiras.

A obra de Chaves \& Matilla rompeu a regularidade dos painéis em uma sala de grandes proporções e revelou a fachada norte do pavilhão. A dupla de artistas forma uma versão moderna do pintor viajante. A obra Dibujando America y Dibujando Brasil são projetos que compartilham do mesmo método de trabalho: viagens pela América do Sul nas quais os desenhos produzidos durante as viagens serviram como ferramentas de conhecimento de um contexto determinado. Neste trecho da mostra foi possível recuperar a permeabilidade visual e o diálogo com a obras de Baraya no centro e com o espaço de Turcot, composto apenas de painéis transversais.
O núcleo final do segundo pavimento foi constituído por obras relacionadas ao tema da reconstrução, mais uma vez com um adensamento de salas de vídeo e instalações que conflitam com as premissas expográficas. No centro, que se pretendia vazio, foi instalada uma sequência de pequenos painéis para atender ao grande volume de obras [24].

O trabalho escolhido para fechar o percurso do pavilhão foi Sabores y Lenguas: São Paulo (2002-2006) [25], de Antoni Miralda (1942, Barcelona, Espanha), que funcionou como atrativo para que o público chegasse até o final do percurso, percorrendo toda a extensão do pavilhão. O projeto itinerante do artista catalão buscava investigar a diversidade gastronômica e seus vínculos culturais. Era também uma obra interativa, na qual o público podia desenhar em louças brancas que estavam dispostas no chão. A instalação ocupou toda a extensão transversal do pavilhão e retomou a relação com a arquitetura e o parque. Para Bishop (2006a), a obra de Miralda foi decepcionante, por parecer fruto de uma fórmula, uma vez que o artista aplicou a mesma proposta para diversos países. 

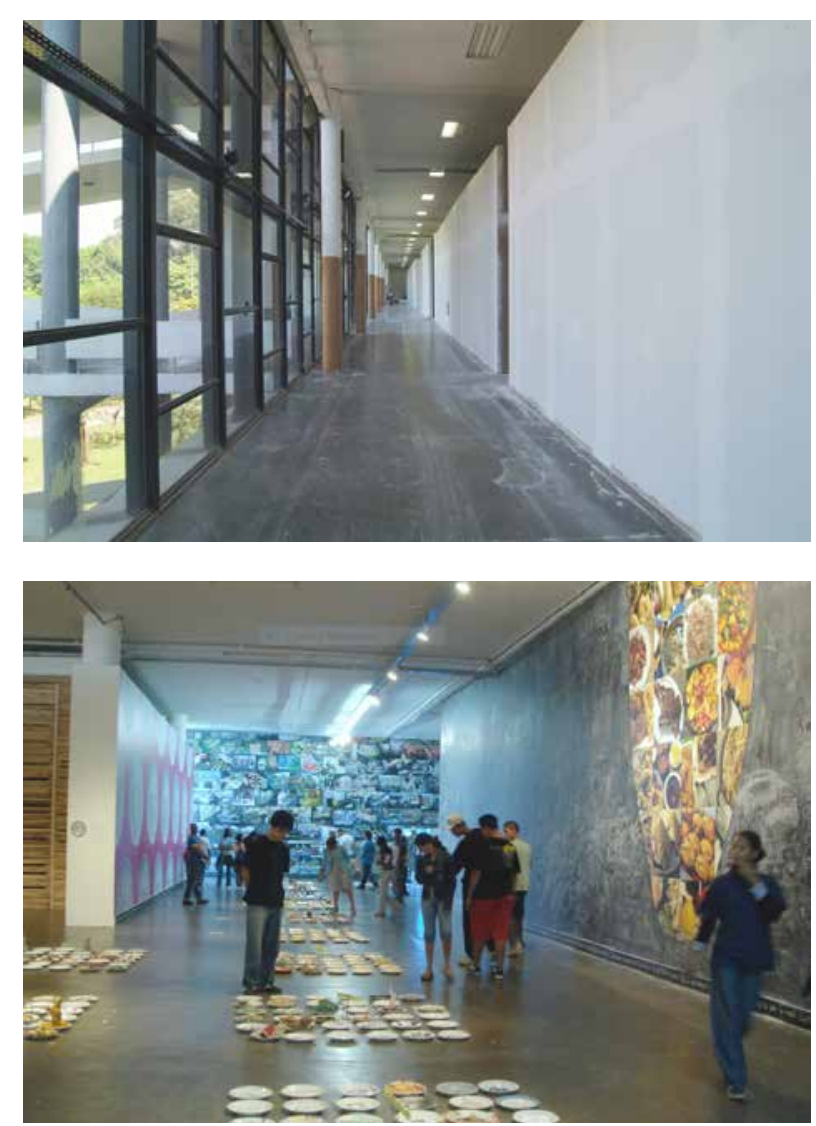

[no topo] Vista da circulação junto à fachada com as salas fechadas. Fonte: Arquivo Wanda Svevo. Foto: Juan Guerra.

[ao centro] Vistas da obra Sabores y Lenguas: São Paulo [25], de Antoni Miralda que fechava o pavilhão. Fonte: flickr. Disponível em https://flickr.com

[embaixo] Vista da montagem da obra de Kristina Solomouka e os painéis de Simon Evans no centro

do espaço do segundo setor. Fonte: acervo Marta Bogéa. Foto: Juan Guerra.

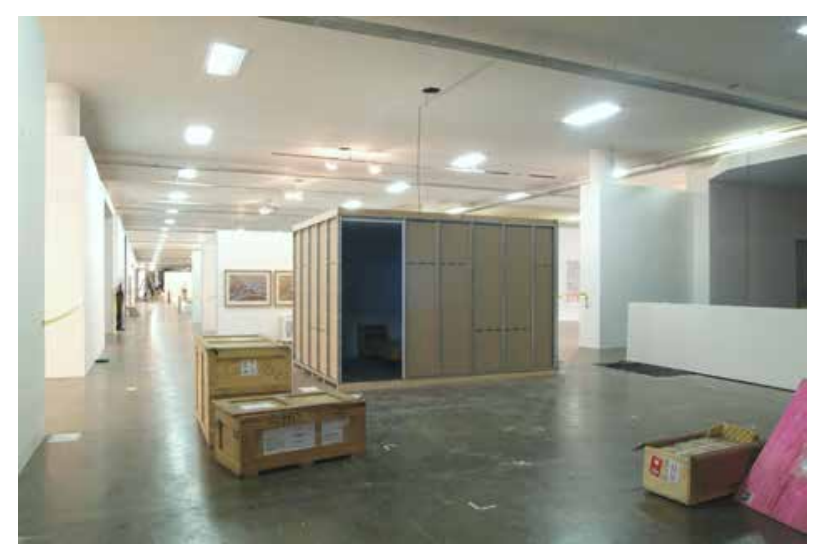

O que se percebe nesse setor é que não havia mais um projeto que conferisse unidade à expografia. O grande número de salas fechadas fez com que a circulação pelas fachadas perdesse o sentido. Houve uma cisão entre o projeto expográfico e o curatorial. Diferentemente da situação do térreo onde os curadores criaram situações de conflito com o projeto expográfico, a partir da inserção de instalações que geraram tensões no espaço, no segundo pavimento as interferências no projeto expográfico não contribuíram para intensificar a narrativa curatorial. O resultado foi um grande espaço setorizado, que remetia as divisões por salas das representações nacionais, contradizendo a essência da proposta curatorial. $\mathrm{O}$ convívio entre obras, contaminações, porosidade e a inserção no pavilhão e relação com Parque foram deixados de lado e a leitura individualizada de cada sala de artistas se sobrepôs ao partido curatorial. 

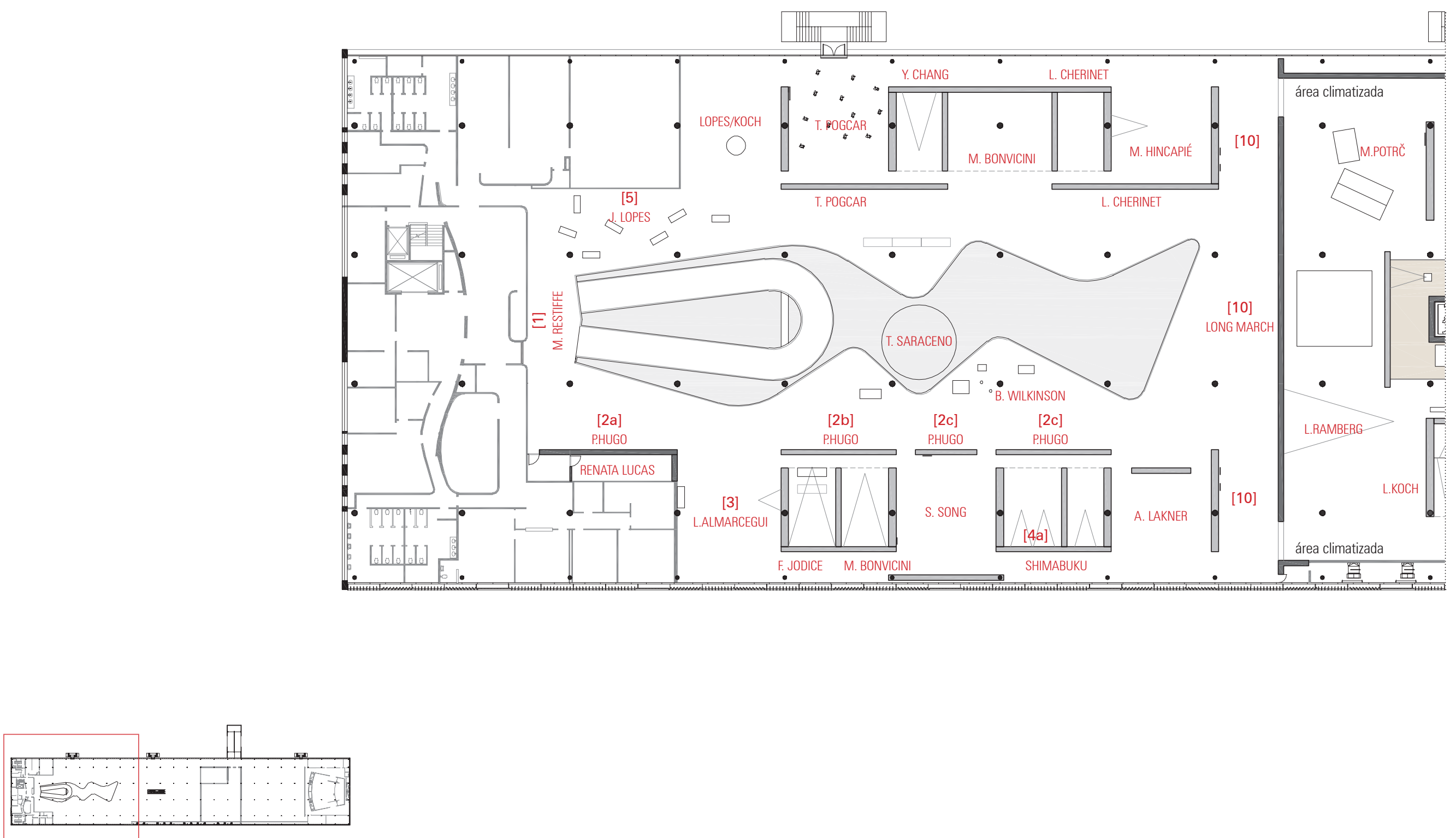


\subsection{TERCEIRO PAVIMENTO: COMO VIVER JUNTO}

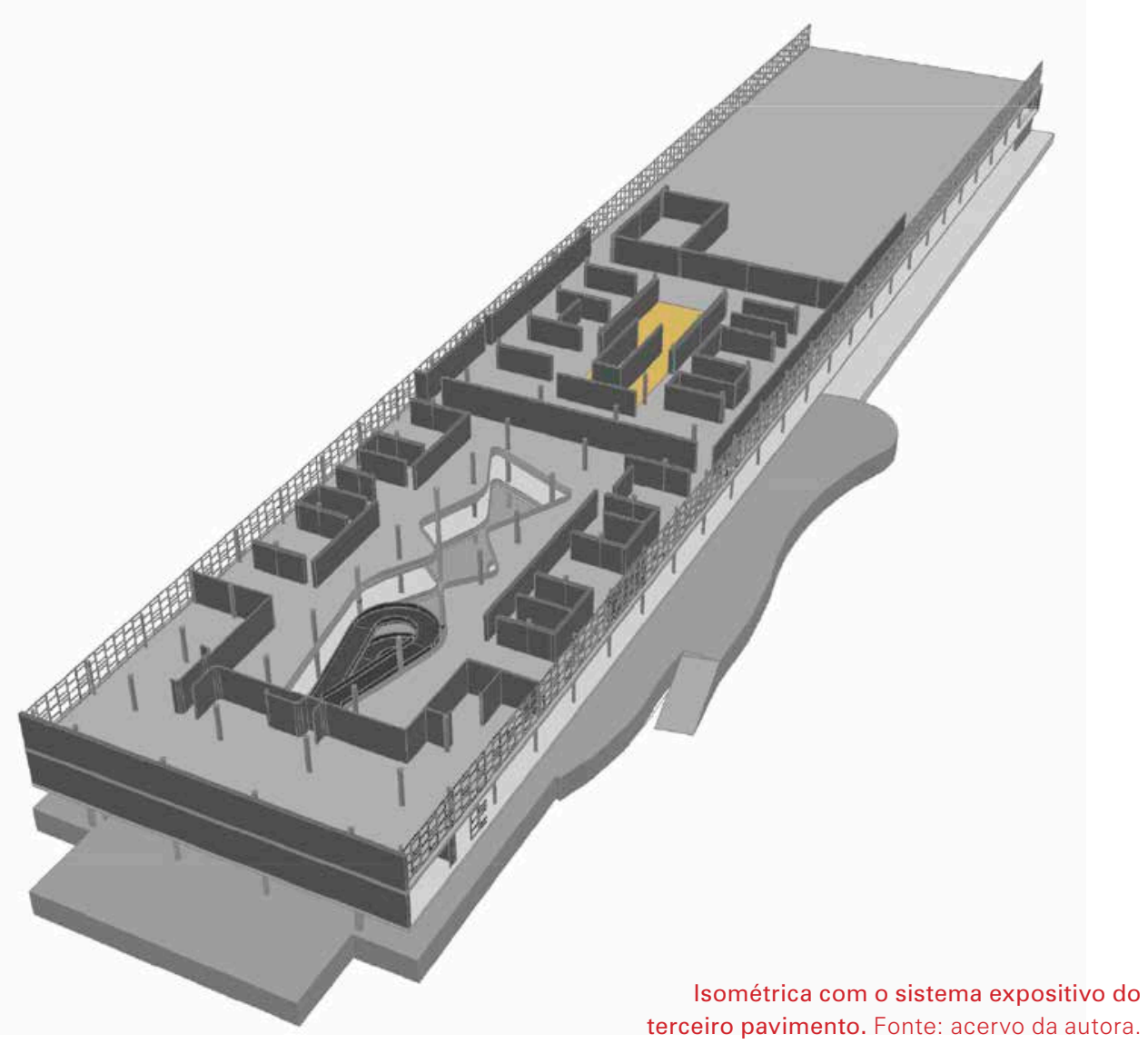

O terceiro pavimento do pavilhão tem uma configuração espacial muito distinta da do segundo. Esta área vem sendo ocupada progressivamente pelo programa administrativo da Fundação Bienal. A área mais nobre do pavilhão, ao redor do vão, foi fechada por divisórias que invadem mais de um módulo de estrutura em cada fachada, prejudicando a transparência e relação vão-parque. Esse pavimento se divide em duas partes pela área climatizada, resultando em dois espaços com dimensões mais controladas.

De acordo com o percurso narrativo, é no terceiro pavimento, depois de percorrer toda a exposição, que o público iria encontrar as obras que trazem a ideia do Como viver junto ou o Éden e Crelazer, de Oiticica. Segundo Lagnado, essa era uma parte mais otimista da exposição, que trabalhava com possibilidades de convívio e ritmos próprios. ${ }^{37}$ O Crelazer foi transposto para o ano 2000 como uma crítica à sociedade do espetáculo e ao lazer ativo. O filósofo Celso Favaretto, na palestra proferida no seminário Vida Coletiva, aborda a leitura atual dada à teoria de Oiticica e sua relação com Barthes:

37 Verbete "Idiorritmia" de Barthes (apud LAGNDO; PEDROSA, 2006a, p.78) 
No Éden, campo experimental construído em 1969 em Londres, Oiticica condensou a ideia geradora e redefinição da arte que vinha efetuando desde os inícios dos anos ig 60, tendo em vista uma concepção de estar no mundo, sugerindo, com a proposição visionária do Crelazer, um ambiente total comunitário. Nessas proposições ambientais, Oiticica configurou a sua poética de instante e do gesto, consignando a concepção de arte como estado de mudanças de comportamento teorizada em sua proposição Suprassensorial..$^{38}$

38 "Os desdobramentos do Programa de Hélio Oiticica que se seguiram à Tropicália apontam para o reconhecimento de um forte elemento autorreferencial nesse ambiente e para a simultânea vontade do artista de destituir sua produção de tal característica, dessa maneira atenuando a mitificação de sua vivência urbana. $\mathrm{O}$ amadurecimento dessa mudança de posição face à obra levou à elaboração, ainda em 1967, do conceito de Suprassensorial, em que o artista abranda, no âmbito de seu programa, a importância da 'estruturação' de um ambiente dado, passando a privilegiar os 'comportamentos' que suas proposições poderiam ativar naqueles que viessem a interagir com elas. $\mathrm{O}$ Suprassensorial seria 'a tentativa de criar, por proposições cada vez mais abertas, exercícios criativos [...] dirigidos aos sentidos, para através deles, da 'percepção total', levar o indivíduo a uma 'suprassensação', ao dilatamento de suas capacidades sensoriais habituais, para a descoberta do seu centro criativo interior, da sua espontaneidade expressiva adormecida, condicionada ao cotidiano'. (ANJOS, 2012) Disponível em: <http://www.scielo.br/scielo.php?scrip$\mathrm{t}=$ sci_arttext\&pid=SI678-53202012000200022 >. Acesso em: 12 jan. 2019 . "Com Suprassensorial a diferenciação produzida é a busca da dilatação das capacidades sensoriais habituais do sujeito, em direção ao que chamou 'supra-sensação'. Prescindindo muitas vezes do objeto, propõe exercícios criativos em que o que conta é a simultaneidade da vivência com a percepção do viver. Tal processo visa a descoberta do comportamento individual, movendo o sujeito do condicionamento inconsciente. Sujeito e ação suprassensorial
Vista geral do terceiro pavimento a partir do patamar da rampa. Fonte: flickr. Disponível em: https://flickr.com.

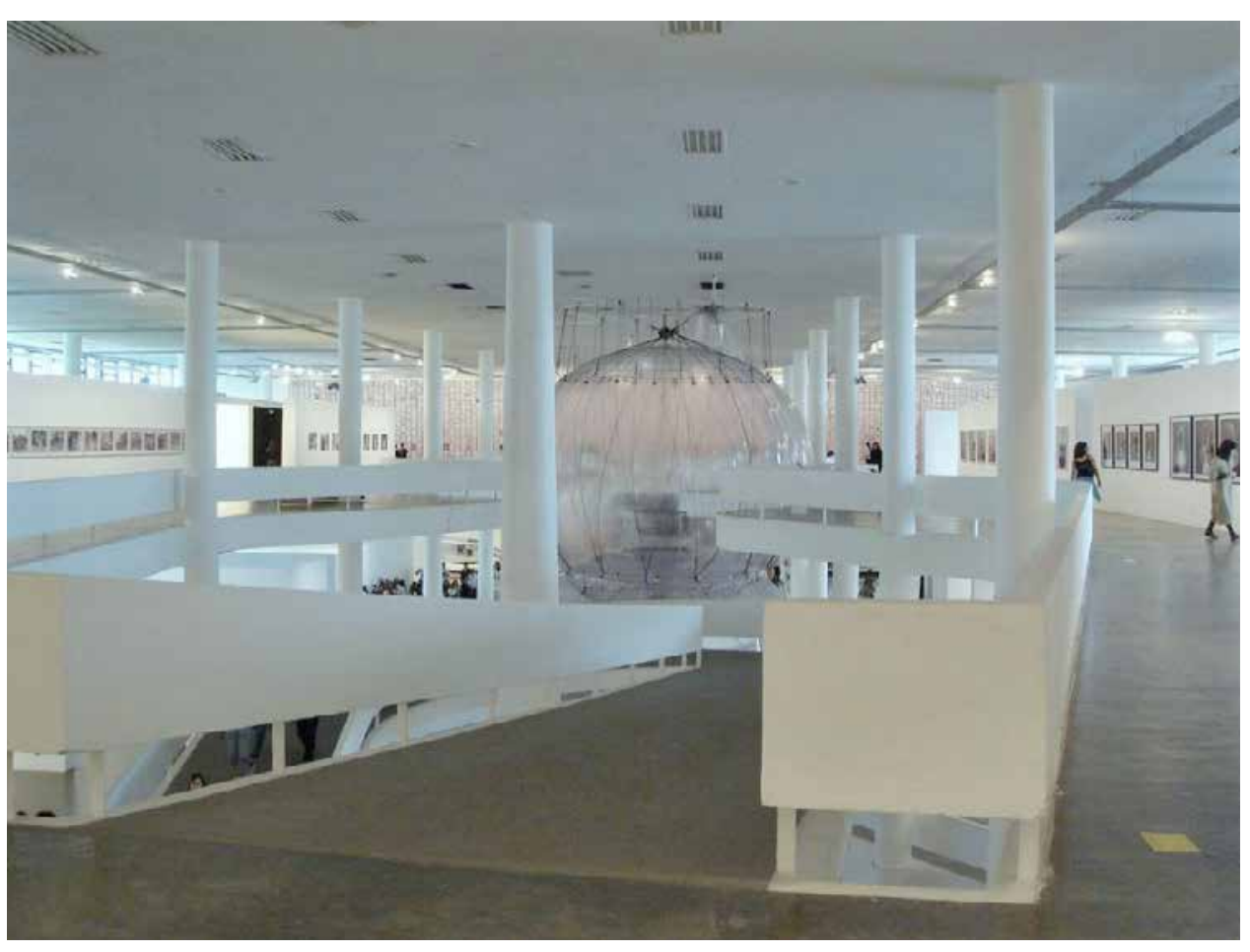


[no topo] Vista da Série Mirante \#3 de Mauro Restiffe [1] na chegada da rampa. Fonte: Arquivo Wanda Svevo. Foto: Juan Guerra. [embaixo] Mirante \#3 de Mauro Restiffe [1]. Fonte: acervo da autora.
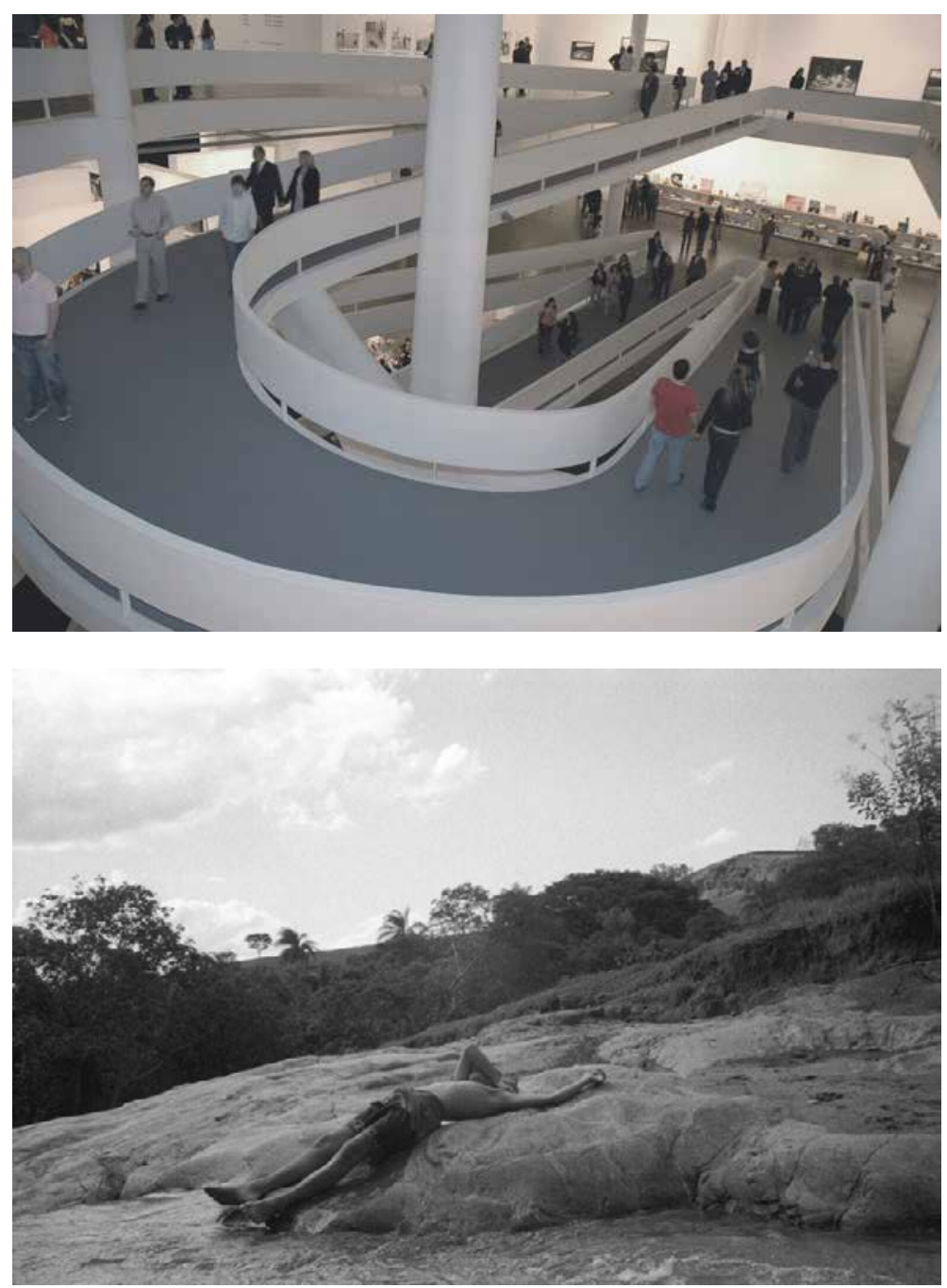

Esta poética do instante e do gesto não visa aos simbolismos da arte mas à simbólica dos estados de transformação. Assim entendidas, as ideias e proposições de Oiticica encontrariam, nas décadas seguintes plena atualidade e inúmeras atualizações.

Pode-se fazer uma analogia entre poética do instante e do gesto de Oiticica com aquilo que Roland Barthes considera o espaço de viver-junto. Nos Ninhos (I969), em todas as suas ambientações, Oiticica queria gerar espaços de proximidade, marcados pelo tato, pelo toque, constituindo o Barthes denomina como microterritório [...]. Reterritorializante, o viver-junto é, para Barthes, um fator espacial mas é também temporal, já que as mutações de temporalidade moderna são indissociáveis das transformações do espaço moderno. [...] Portanto esse espaço em que a vida se reinventa é, para ambos, o Éden, circunscrição ideal da comunidade, do viver junto (FAVORETTO, 2008, p.245-246)

A primeira obra que se via no patamar da rampa era a série Mirante (2003) [1], de Mauro Restiffe, fotografias que

processam uma meta-vivência, 'objeto’ da proposição artística”. David Sperling, "Corpo + Arte $=$ Arquitetura. As proposições de Hélio Oiticica e Lygia Clark”. In: Paula Braga (Org.), Seguindo fios soltos: caminhos na pesquisa sobre Hélio Oiticica. Edição especial da Revista do Fórum Permanente (www.forumpermanente.org), editada por Martin Grossmann. 
mostram a paisagem do lugar onde cresceu. Os personagens são a sua família em relação com a natureza. São retratos não posados que revelavam a intimidade do artista e a espontaneidade do momento de lazer.

Seguindo o fluxo em direção à fachada norte estavam as fotografias de Pieter Hugo da série The Hyena Men of Nigeria (2005) [2a], que retrata um grupo de artistas itinerantes com hienas, macacos, cães e cobras domesticados. A paisagem nas imagens são as favelas de Lagos, com uma realidade próxima à brasileira. Ao mesmo tempo, a presença dos animais selvagens no cotidiano causa um grande estranhamento.

[...] há uma incômoda proximidade entre homens e animais enfatizada pela aridez dos ambientes e pelo tratamento quase monocromático aplicado às imagens. Como se fizessem parte de uma mesma natureza, os homens, os animais e a vegetação apresentam quase uma única tonalidade sépia. Suas roupas, estrangeiras ou tipicamente locais, têm um colorido opaco, mas, ainda assim, se destacam nas cenas. Os homens olham com firmeza para a câmera enquanto os animais parecem alheios (ESPADA, 2006, s.p.).

A próxima série de Hugo era Judges, Botsuana (2005) [2b], que, segundo Espada, lembravam retratos renascentistas. As imagens enfatizavam um olhar inquiridor que enfrentava $o$
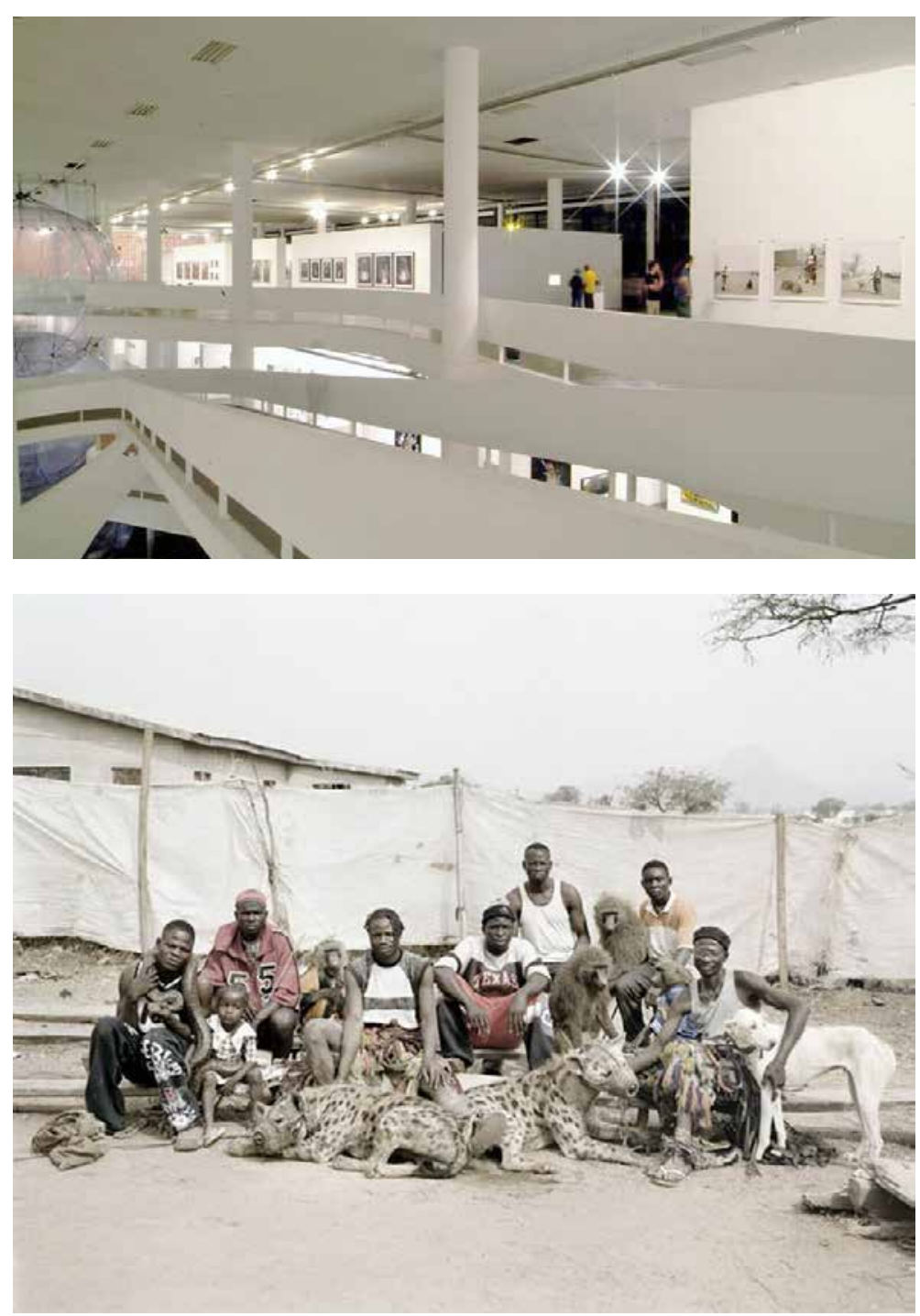

[no topo] Vista das séries fotográficas de Pieter Hugo The Hyena Men of Nigeria [2a], Judges, Botsuana [2b] e Musina 2c]. Fonte: acervo Marta Foto: Juan Guerra.

[embaixo] The Hyena Men of Abuja, Nigeria 2005, II, de Pieter Hugo [2a]. Fonte: site public delivery. Disponível em: https:// publicdelivery.org/pieter-hugo-thehyena-and-other-men/. 

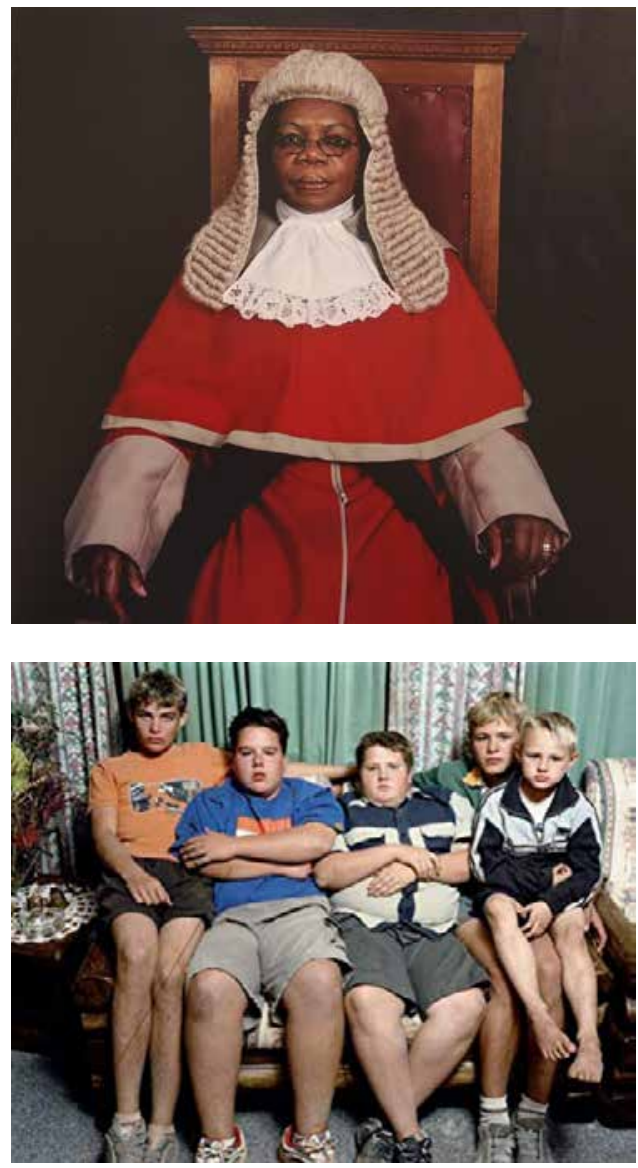
Sakardie-Mensah, da série Judges, Botsuana (2005) de Pieter Hugo [2b] Fonte: archive Stevenson. Disponíve em: http://archive.stevenson.info/ exhibitions/hugo.

[no centro] School friends in the Viljoen family's living room: Barend van den Berg, Werner Vos, Bartie Kotze, Armand Viljoen, Deon Viljoen da série Messina/Musina (2006) de Pieter Hugo [2c]. Fonte: archive stevenson. Disponível em: http:// archive.stevenson.info/exhibitions/ hugo/musina14.htm

[embaixo] Materiais de construçâo de São Paulo de Lara Almarcegui [3]

Fonte: Site Lara Almarcegui. espectador. Os adereços dos juízes que utilizavam perucas e togas remetiam ao colonialismo inglês, tradições que foram mantidas após a independência do país em i966. E para finalizar a participação de Hugo na mostra, sua nova série Musina (2006) [2c], que retrata famílias de uma pequena cidade da África do Sul. As fotografias, em contraste com as da primeira série citada, são sempre em ambientes internos, dentro das casas e com animais domésticos. Enquanto os artistas mambembes têm uma postura sempre altiva, as famílias brancas parecem submissas à câmera fazendo poses pouco naturais (ESPADA, 2006).

No percurso, inserida entre as séries de Hugo, estava a instalação da Lara Almarcegui [3], artista que fez residência artística em São Paulo. Ela levantou o peso de todas as construções na metrópole e produziu um guia dos terrenos baldios de São Paulo. No guia, a artista defende o não lugar e a não arquitetura como espaços de respiro dentro da cidade, atribuindo valor ao acaso e à natureza que surge do abandono desses terrenos. Sua inserção na narrativa da exposição traz uma leitura desses locais como espaços para uma convivência em um ritmo apartado da cidade. A obra de Almarcegui dialoga com a de Matta-Clark, mais especificamente com Fake Estates (1973), uma crítica à urbanização. O trabalho desse artista consistia em uma fotomontagem com as escrituras, mapas de localização e dimensões de terrenos que comprou na cidade de Nova York - pequenos 
ou mínimos, inacessíveis ou parcelas mortas, frutos de um loteamento descuidado.

Shimabuko foi considerado por Lagando a melhor experiência de residência artística da $27 \mathrm{a}$. Bienal. O artista japonês se considera um viajante ou um estrangeiro que se aproxima do cotidiano das pessoas. Uma das obras apresentadas foi Asking to "remix" my works about octopus to the repentistas Peneira $\mathcal{E}$ Sonhador [Pedi aos repentistas Peneira \& Sonhador para remixar meus trabalhos de polvo] [4a], composta por dois vídeos projetados simultaneamente: Then, I decided to give a tour of Tokyo to the octopus from Akashi [Então, decidi mostrar Tóquio ao polvo de Akashi] (2000) foi a base para que repentistas fizessem uma composição, que, por sua vez, foi apresentada ao lado do registro videográfico realizado pelo artista durante a composição. Segundo Lagnado, Shimabuku fez uma descoberta em sua residência: "ele é alguém que não fala português, e repentista é pura fala, quer dizer, ele descobriu que isso é a linguagem ancestral do rap" (LAGNADO, 2006f, s.p.).

$\mathrm{Na}$ fachada sul, após o patamar da rampa, estavam as bicicletas revestidas de vime de Jarbas Lopes. Cicloviaaérea (2006) [5], que originalmente incluía uma performance e um passeio com as bicicletas na mostra, se restringiu aos objetos e desenhos. A obra se relacionava à valorização do artesanal como uma resistência ao capitalismo e sua massificação intrínseca. No entanto a presença dos objetos sem a performance ou o registro dela, esvaziou o sentido da obra. [no topo] Video instalação de Shimabuku Asking to "remix" my works about octopus to the repentistas Peneira \& Sonhador [Pedi aos repentistas Peneira \& Sonhador para remixar meus trabalhos de polvo] [4a]. Fonte: univers-in-universe. Disponível em: http:// universes-in-universe.de/car/sao-paulo/eng/2006/tour/img-39.htm.

[embaixo] Vista geral do terceiro pavimento com as obras de Jarbas Lopes à esquerda. Fonte: acervo Marta Bogéa. Foto: Juan Guerra.
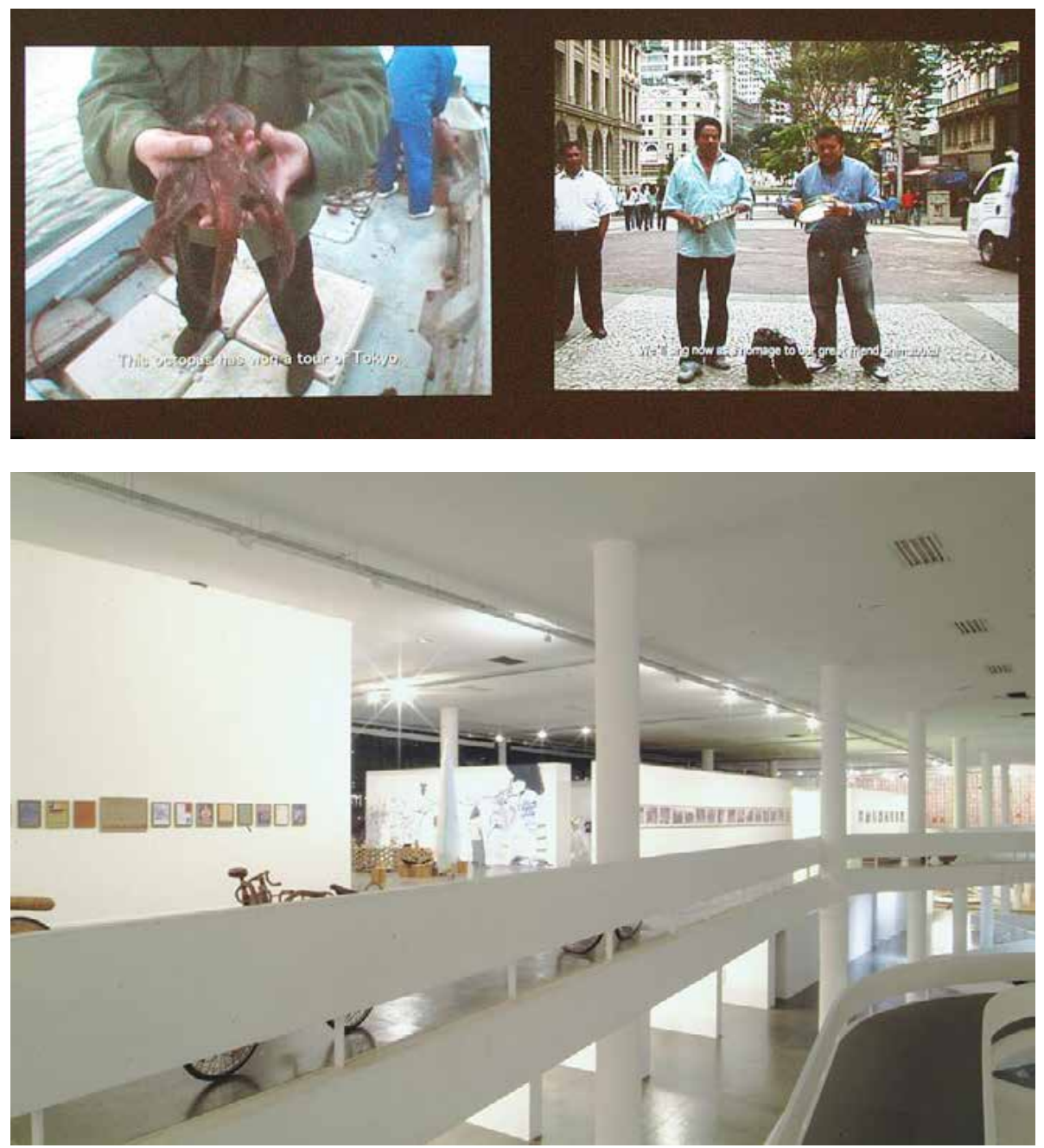
[no topo] Vista da Cicloviaaérea [5] de Jarbas Lopes e ao fundo o imenso painel de Long March project.

Fonte: acervo Marta Bogéa. Foto: Juan Guerra.

[embaixo] Vista da montagem da instalação Long March project que ocupou o painel que fazia a divisão com a área climatizada [10]. Fonte: acervo da autora. Foto: Maria Julia Herklotz.
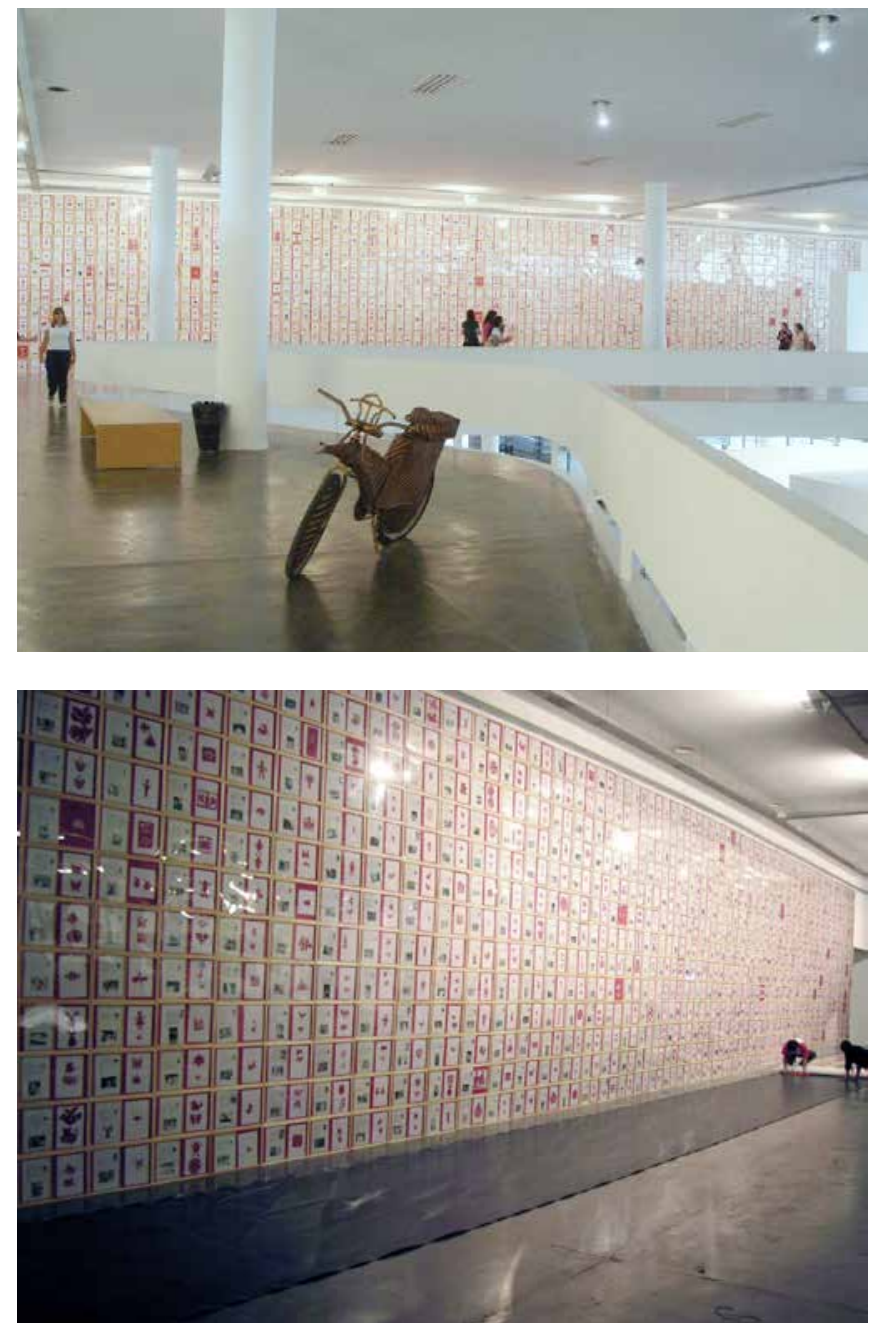

A expografia respeitou as premissas de manter as circulações pelos caixilhos e ao lado do vão. No entanto, a maioria dos espaços foi composto de salas fechadas, configurando dois blocos bem definidos: um na parte sul e outro na norte, e um grande painel que fazia a separação da área climatizada. A relação visual com o parque nesse pavimento foi bastante prejudicada.

O grande painel que fez a divisão com a área climatizada recebeu a instalação de recortes de papel, uma arte tradicional da China, do grupo Long March Project em parceria com moradores de um vilarejo [6]. O projeto envolveu populações rurais e urbanas e tinha o caráter de resistência das tradições da arte popular diante da velocidade das transformações capitalistas pelas quais o país tem passado (BISHOP, 2006a). 


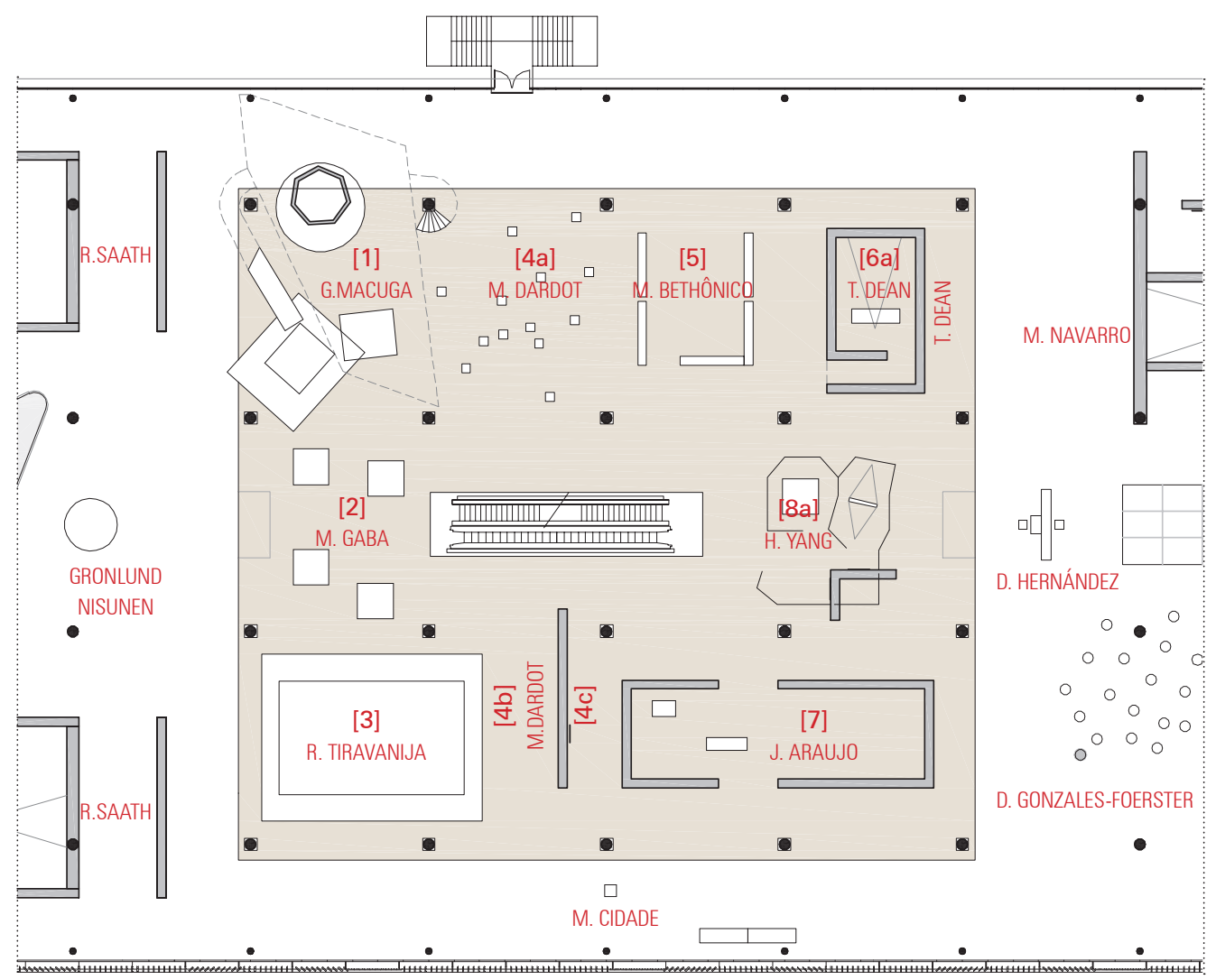

PLANTA DA PRAÇA BROODTHAERS 2PAVIMENTO - EXPOGRAFIA NA 27ª BIENAL

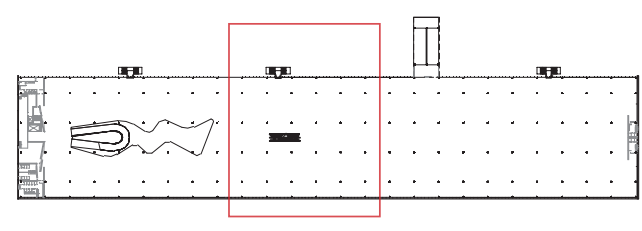

MAPA DO $2^{\circ}$ PAVIMENTO

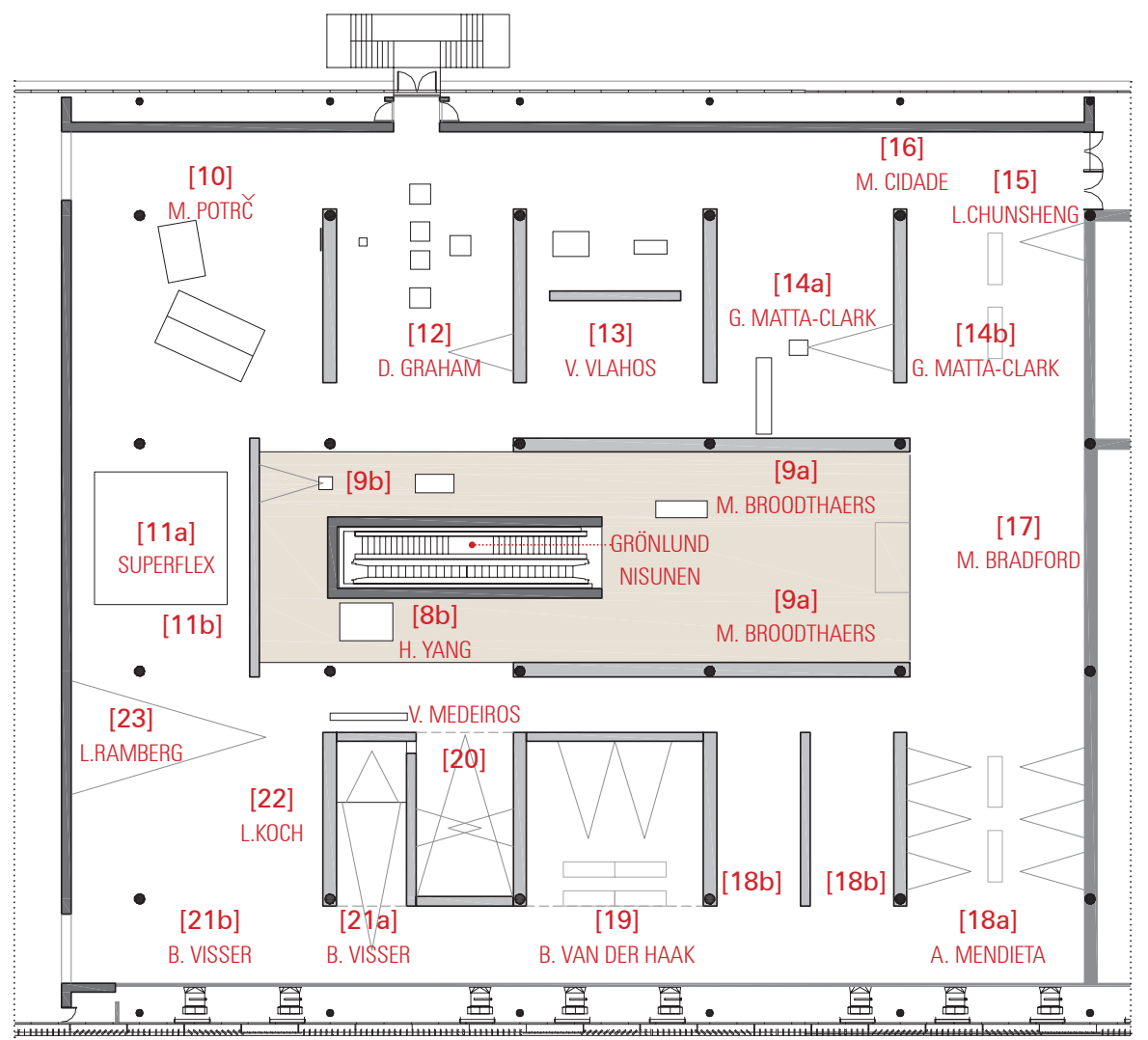

PLANTA DA PRAÇA BROODTHAERS E ÁREA CLIMATIZADA 3'PAVIMENTO

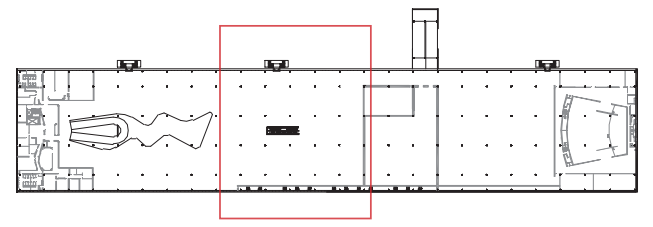

MAPA DO $3^{\circ}$ PAVIMENTO

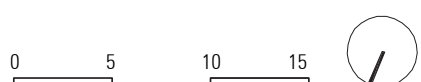




\subsection{PRAÇA BROODTHAERS E ÁREA CLIMATIZADA: UM DIÁLOGO VERTICAL E HORIZONTAL}

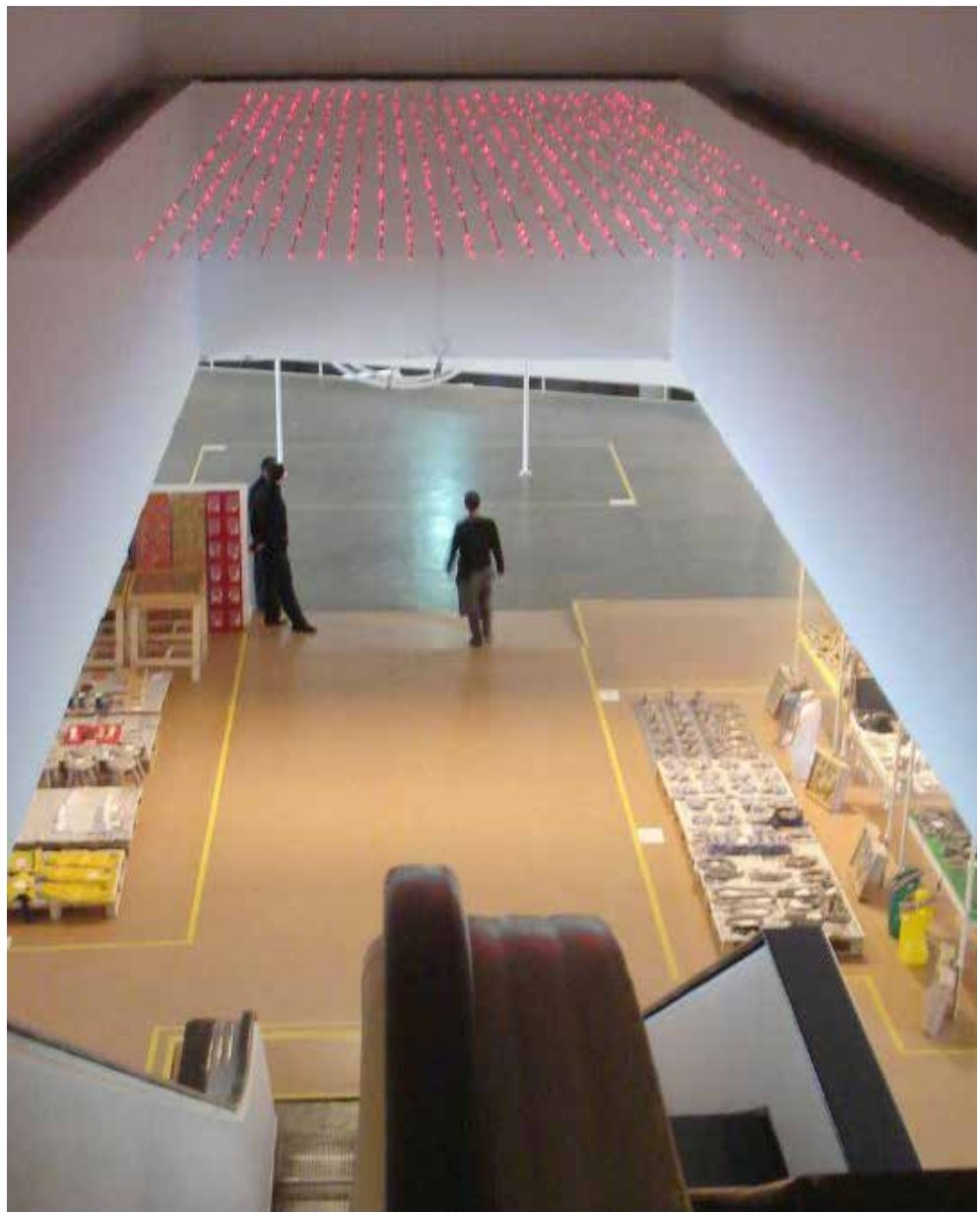

Vista da praça Broodthaers a partir da escada rolante. Sobre a escada fo instalada a obra Pattern recognition setup in a staircase de Gronlund e Nisunen. Fonte: acervo Marta Bogéa. Foto: Juan Guerra.
O núcleo Broodthaers ficou a cargo de Jochen Volz, curador convidado por Lagnado numa categoria distinta dos demais cocuradores que compunham a curadoria coletiva. O escopo de Volz se restringiu à obra de Broodthaers e de artistas selecionados cujas obras dialogavam diretamente com ele. Desta forma, criou-se uma micronarrativa dentro da narrativa curatorial.

Constituído por nove artistas, incluindo o próprio Marcel Broodthaers, o núcleo tinha uma identidade que deveria ser evidenciada, mas não poderia ser pensado de maneira isolada, já que precisava ser ativado pela vizinhança de outras obras. O desafio colocado à arquiteta pelos curadores foi o de sinalizar uma separação espacial deste grupo de obras sem criar fronteiras. A sua particularidade fez com que essa seção fosse uma ação inicial para o projeto expográfico.

Bogéa propôs a construção de um piso elevado, uma grande área quadrada que deveria ocupar o sentido transversal do pavilhão. A localização se deu a partir da conexão vertical pela escada rolante com a área climatizada, onde deveriam estar as obras de Broodthaers. O uso do mesmo piso em madeira na praça e na área climatizada criou a conexão visual. 
Esta praça foi elemento importante da expografia porque configurou, a partir do piso elevado de madeira, um espaço com outra qualidade e criou uma referência dentro do pavilhão. Também conferiu uma unidade para as obras, que se relacionaram sem que houvesse qualquer indicação de sequência entre elas - conforme o desejo da curadoria.

$\mathrm{Na}$ área climatizada, Broodthaers foi uma presença fundamental, estabelecendo diálogo com o trabalho de dois artistas essenciais para construção do statement curatorial: Ana Mendieta e Gordon Matta-Clark, denominados histórico-contemporâneos pelos curadores.

\subsubsection{A Praça Broodthaers}

Marcel Broodthaers é um dos artistas centrais para a elaboração do partido curatorial da 27a. Bienal. Lagnado construiu uma relação conceitual entre as obras de Oiticica e de Broodthaers. Embora nunca tenham se encontrado, possuem trabalhos que, para ela, compartilharam uma zona de atuação. Para estabelecer a relação entre os artistas, a curadora usou como argumento as aulas de Barthes no Collège de France, De quem sou contemporâneo?, segundo a qual o viver junto independe do fato de partilhar o mesmo lugar e de viver ao mesmo tempo (LAGNADO, 2008a). [no topo] Un coup de dés jamais n'abolira le hasard [Um jogo de dados jamais abolirá o acaso] (1969) Marcel Broodthaers. Fonte: MoMA. Disponível em: https://www.moma.org/collection/works/146983.

[embaixo] Construção da praça Broodthaers no segundo pavimento. Fonte: acervo Marta Bogéa. Foto: Juan Guerra.
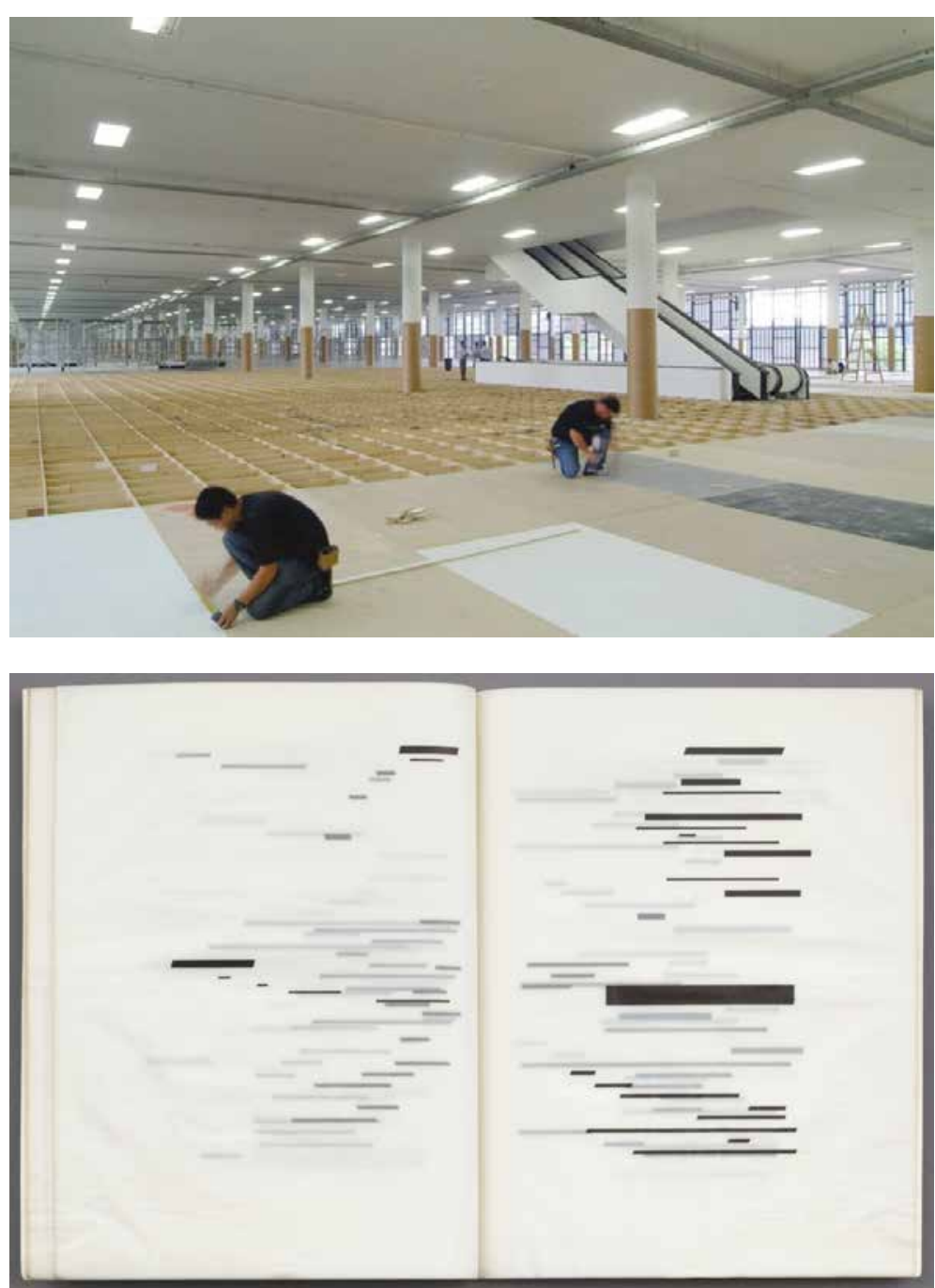
Broodthaers nasceu em Bruxelas (Bélgica) em I924, iniciou sua carreira como poeta entre os anos I940 e I950, publicou diversos artigos, resenhas e dois volumes de poemas. "O terceiro volume intitulado Pense-bête se transformou, em I963, em um objeto de arte, que lhe deu fama e marcou o início de sua carreira como artista visual, aos 40 anos de idade" (VOLZ, 2008, p.22). Após três anos, inaugurou uma retrospectiva entre 1968 e I972, criou seu museu fictício, o Musée d'Art Moderne, Departement des Aigles, um museu iniciado em sua residência, sem acervo permanente e nem sede fixa. ${ }^{39} \mathrm{O}$ artista assumiu o papel de diretor da instituição e utilizou a águia como símbolo que representa, de forma irônica, o triunfo da arte conceitual (idem).

Assim ao transformar o próprio trabalho no centro do poder administrativo ideológico, Broodthaers se posicionou dentro desses parâmetros, anteriormente excluídos de que se considerava ser a concepção e recepção da obra de arte. Desta forma foi simultaneamente capaz de articular a crítica (FOSTER apud VOLZ, 2006, p.I83).

Nos anos I970, Broodthaers produziu uma série de exposições retrospectivas que receberam o título de Decor. Após

39 O museu foi exibido em etapas na casa do artista em Kassel. sua morte prematura, aos 52 anos, foram realizadas várias retrospectivas de sua obra em museus e galerias. O artista tornou-se uma importante referência para artistas e teóricos, mas sua obra continuou desconhecida de um público mais amplo (VOLZ, 2008).

Lagnado construiu uma relação de contemporaneidade entre Marcel Broodthaers e Hélio Oiticica por referências compartilhadas entre os artistas e pela aproximação de conceitos ou críticas propostas por suas obras. Havia por ambos uma devoção ao poeta Mallarmé, ${ }^{40}$ que segundo Broodthaers foi o inventor do espaço moderno para poesia visual, graças ao seu poema Um coup de dés jamais n'abolira le hasard [Um jogo de dados jamais abolirá o acaso], de i897. O artista fez uma obra a partir deste poema, sobrepôs retângulos pretos no texto, criando um poema ilegível. O mesmo poema está por trás das obras Newyorkaises, ${ }^{41}$ de Oiticica, que pretendia ser um livro sem ordem linear, que contasse com o acaso; Merzbau, ${ }^{42}$

40 “Étienne Mallarmé, (1842-1898) foi um poeta e crítico literário francês. Autor de uma obra poética ambiciosa Mallarmé promoveu uma renovação da poesia na segunda metade do século I9. Mallarmé desempenhou um papel fundamental na evolução da literatura no século XX, especialmente nas tendências futuristas e dadaístas. Um jogo de dados (Un coup de dés) (I897) é um longo poema de versos livres e tipografia revolucionária que constitui a declaração trágica da impossibilidade de atingir o estabelecido no livro”. Disponível em: $<$ https://pt.wikipedia.org/wiki/St\% $\mathrm{C}_{3} \%$ A9phane_Mallarm\% $\mathrm{C}_{3} \% \mathrm{~A}_{9}>$. Acessado em: I2 jan. 20I9.

4I Livro inacabado de Oiticica produzido na sua temporada em Nova York.

42 "Kurt Schwitters por volta de 1923 até I937 produziu o seu primeiro grande 
de Kurt Schwitters, é outra referência importante para os artistas. O primeiro filme de Broodthaers foi dedicado a ele e, para Oiticica, o Merz̧au é a única referência da história da arte para compreender o Parangolé. No campo das proposições, as relações são mais conceituais, uma vez que os repertórios são muito distintos. Broodthaers é um dos pioneiros do cinema experimental, realizando sua primeira projeção de slides em 1966, trabalho que passa integrar o Musée d'Art Moderne, Departement des Aigles em i97I, com o nome Section Cinema. A ideia chave dos filmes de Broodthaers era criar um outro sistema de leitura. Em 1973, Oiticica e Neville d'Almeida fizeram a experiência Cosmococa, com projeção de slides, trilha sonora, ambientação e instruções ao participante. Para Oiticica, os slides são o advento do conceito quase-cine$m a,{ }^{43}$ cuja estrutura é a não narração, uma crítica à linearidade do discurso e à indústria cultural (LAGNADO, 2008a). Na

trabalho de ocupação espacial, que posteriormente chamou de 'Merzbau' (Casa Merz), considerada a primeira instalação artística, que ocupava toda a residência do artista em Hannover. Com o passar dos anos, Merzbau se transformou em uma espécie de colagem abstrata composta de grutas e colunas e objetos encontrados, sempre mutáveis e em constante expansão. Era mais do que apenas um estúdio; foi em si uma obra de arte. Esta obra foi destruída, durante um ataque aéreo aliado em 1943 ou pela Gestapo após a fuga do artista da Alemanha”. Disponível em: <https://www.moma.org/explore/ inside_out/2012/07/09/in-search-of-lost-art-kurt-schwitterss-merzbau/>. Acessado em: I2 jan. 20I9.

43 Quase cinema faz parte do um programa ambiental que é a possibilidade de valorização do indivíduo na coletividade (LAGNADO, 2008). instalação Un jardin d'hiver (1974) ${ }^{44}$ de Broodthaers, designada Décor, o artista faz uma composição cênica com I6 cadeiras de jardim e 30 palmeiras plantadas em vasos de plástico, o uso da palmeira um símbolo do exotismo tropical inserido no contexto da instalação evidenciou a ironia do artista. A obra revela o sarcasmo de Broodthears em relação ao display expositivo e à função decorativa que as obras de arte adquirem ao serem inseridas no ambiente doméstico. Em tropicália Oiticica persegue o instante, ou em suas palavras o momento vivido (OITICICA apud LAGNADO, 2008a, p.I0o), em contraposição à representação e sua obra se transformou quando ele incorporou a dança. Em outras palavras, ambos compartilhavam uma busca pelo rompimento dos paradigmas da representação (LAGNADO, 2008a). "A pergunta que une MB e HO é: como romper com a expectativa de um visitante de museus, galeria ou mesmo de bienal, expondo algo que não seja uma 'obra de arte'?” (LAGNADO, 2008a, p.IOI). Enquanto Broodthaers fez da sua assinatura uma estratégia crítica, ilustrando a passagem do objeto para a condição de mercadoria e posteriormente da de mercadoria a de fetiche, Oiticica apostou em parcerias e colaborações, e na participação do espectador, deixando instruções para que cada um construísse o seu parangolé-capa (LAGNADO, 2008b).

44 Instalação para exposição coletiva realizada no Museu de Belas-Artes de Bruxelas em 1974 . 
[no topo] Vista da instalação, 'Marcel Broodthaers. Un Jardin d'Hiver', Hauser \& Wirth Londres, 2017. Fonte: the Estate and Hauser \& Wirth. Foto: Alex Delfanne. Disponivel em: http://artresearchmap. com/exhibitions/marcel-broodthaers-un-jardin-dhiver/ [embaixo] Untitled 2006 (Palm Pavilion) de Rirkrit Tiravanija. Fonte: Arquivo Wanda Svevo. Foto: Juan Guerra.
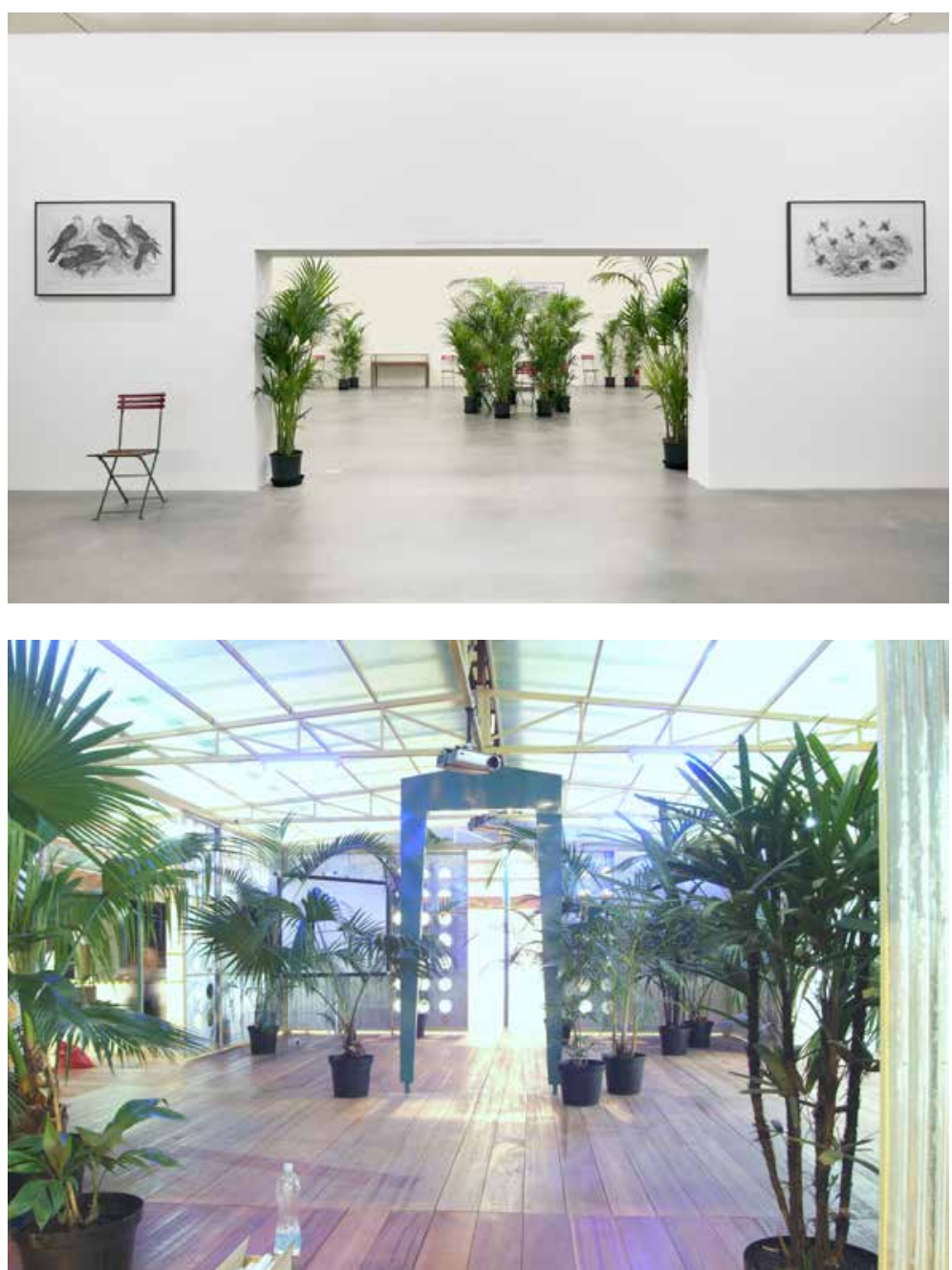

Lagnado também traça um paralelo entre o museu criado na residência de Broodthaers e o loft de Nova York de Oiticica, que recebeu o nome de babylonest. Ambos concentram ao sumo da produção de cada artista.

Segundo Volz, a proposta de trazer Broodthaers para a 27a. Bienal surge pela repercussão que sua obra teve em diversos artistas contemporâneos que ampliaram e reverberaram suas críticas e interesses. As questões centrais na sua obra são: a ficção, a antiteoria, a linguagem, a crítica institucional, a não-arte, o falso, o papel do artista, do curador entre outras. Broodthaers é descrito por Rosalind Krauss ${ }^{45}$ como uma das mais fortes influências da arte instalação que ganha força nos anos I990. Jochen Volz assumiu o núcleo Broodthaers e foi nomeado por Lagnado curador convidado, uma categoria distinta dos demais co-curadores que compunham a curadoria coletiva.

O projeto arquitetônico do núcleo foi desenvolvido por Bogéa em um trabalho conjunto com Volz e Lagnado, ainda na etapa conceitual do projeto. Havia duas importantes questões a serem equacionadas pela expografia: a primeira era o desafio de conferir unidade ao núcleo e, ao mesmo tempo, manter as relações de vizinhanças com as demais obras, evitando criar barreiras e reiterando a proposta de uma narrativa

45 Rosalind Krauss, A Voyage on the North Sea / Art in the age of post-medium condition. Londres: Thames \& Hudson, 2000. 
dentro de outra; a segunda questão se referia à localização no pavilhão, já que o núcleo contou com as obras do próprio Marcel Broodthaers que, por exigência de conservação, deveriam ficar na área climatizada, enquanto as demais obras não tinham o mesmo requisito.

As duas questões foram trabalhadas de forma conjunta pela expografia em busca de uma resposta única. Como o espaço climatizado é restrito ao terceiro pavimento do pavilhão e são muitas as obras emprestadas por instituições com exigências de conservação, essa área teria uma grande demanda. Assim, não seria possível concentrar todo núcleo ali. Volz indicou em conversas com arquitetura que a relação entre as obras deveria ter um caráter de praça, não linear. Este dado impossibilitou a locação do núcleo no terceiro andar com parte das obras na área climatizada, parte fora. A saída foi criar, a partir da conexão vertical da escada rolante, um núcleo dividido em dois pavimentos. A obra de Broodthaers foi instalada na área climatizada, no terceiro andar, e as demais no segundo, com as escadas ao centro. A adoção de um piso elevado em mdf, ${ }^{46}$ com altura de dezessete centímetros, altura de um degrau, criou uma distinção com relação ao resto do pavilhão e atribuiu um caráter singular ao núcleo,

46 MDF é a sigla de Medium Density Fiberboard, que significa placa de fibra de média densidade. É um material de aglomerado de madeira, fabricado com resinas sintéticas. conectando visualmente as obras nos dois pavimentos. A escolha do material buscou estabelecer diálogo com a obra de Broodthaers. Optou-se, então, por algo que se aproximasse das caixas de madeira presentes em seu museu fictício que embalam obras de arte.

As obras de Broodthaers e Haegue Yang (197I, Seul, Coréia do Sul), no terceiro pavimento, foram dispostas sobre um piso de 34,20xıo,80m contido por três painéis que deram suporte às obras e configuraram uma sala ao redor da escada rolante. Estiveram presentes na 27a. Bienal três conjuntos de Broodthaers. Os conjuntos n.2, com sua primeira obra, Pense-bête (1964), Musée d'Art Moderne à vendre - pour cause de faillite (1970), e Museum-Museum (1972) entre outras; n.3, com Assinaturas M.B. entre outras obras; e n.5, com o filme $L a$ Pluie (projet pour un texte) (1969) e uma vitrine com as obras Un Coup de dés jamais n'abolira le hasard (1969) e Je hais le mouvement qui déplace les lignes de Charles Baudelaire (1973) [9a].

A instalação Storage Piece (2004) [8b], de Haegue Yang, foi implantada junto às obras de Broodthaers. Trata-se de uma sobreposição de objetos e obras de arte embrulhados e empacotados sob um estrado de madeira. Dois atores nas projeções indicam que as obras embrulhadas são parte da produção anterior da artista, como se ela não tivesse como guardá-los. Assim seu trabalho faz uma crítica às dicotomias público/privado, e obra de arte/autor. 

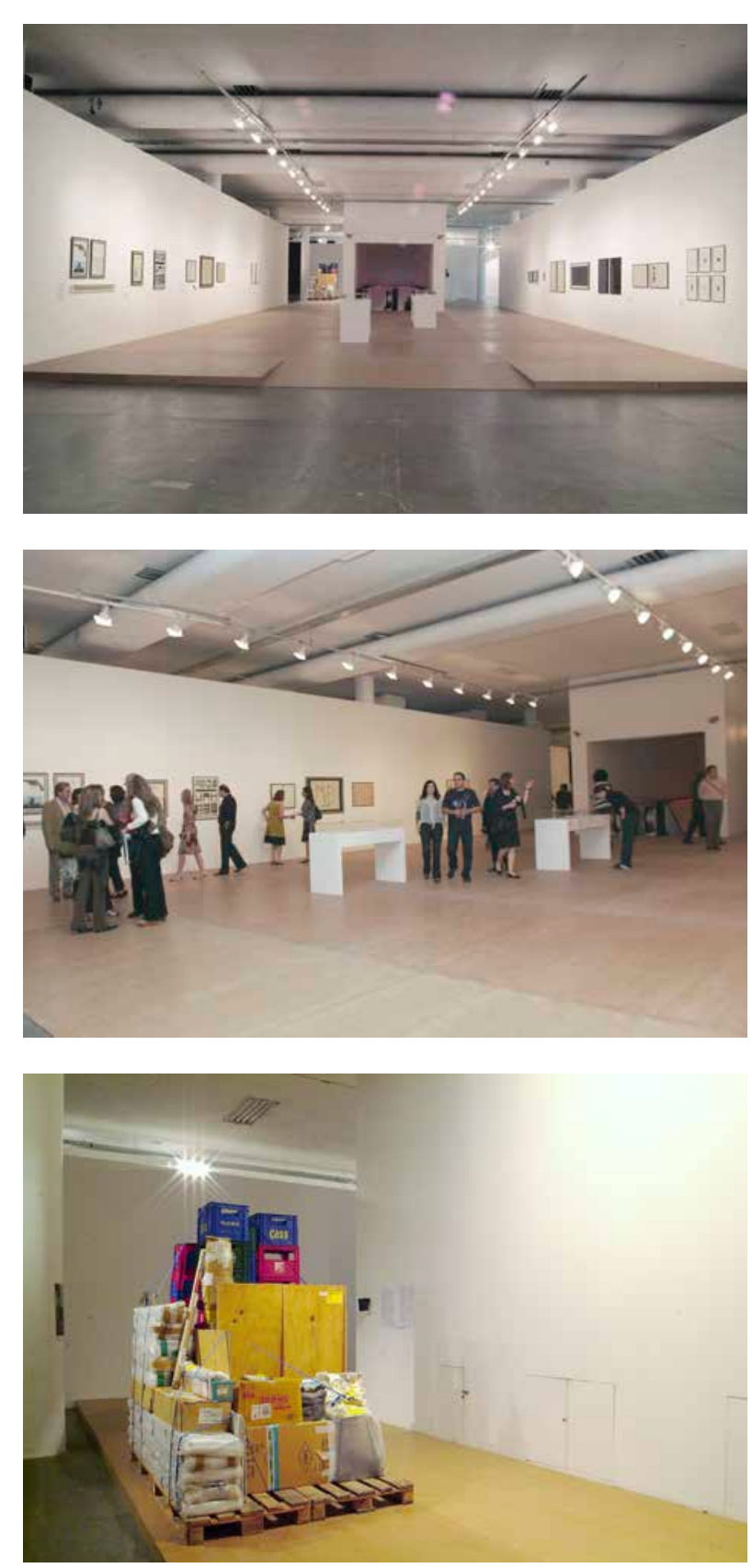

Assim como Broodthaers e Tiravanija, o Storage Piece de Haegue Yang parece cruzar a fronteira entre aparência e realidade, a brincadeira e seriedade. Mas seu trabalho, assim como o trabalho dos outros sob a perspectiva desenvolvida, sugere que se criam modelos, e que se simulam cenários que oscilam entre realidade e a ficção para pontuar, ainda com mais precisão, a diferença entre arte e a vida (VOLZ, 2006, p.190).

Obras de oito artistas foram dispostas sobre o piso do segundo pavimento, um tablado de 4I,40x37,80m, de forma a estabelecer um percurso circular com um caráter de praça no qual as obras puderam dialogar entre si e com a forte presença do pavilhão. Muitas das obras desse núcleo eram instalações, apenas a sala de projeção de Tacita Dean (1965, Canterbury, Reino Unido) [6a], Marulho (2006) [4b], de Marilá Dardot (I973, Belo Horizonte, MG); e as pinturas Juan Araujo (I97I, Caracas, Venezuela) [7] continham painéis brancos. A inserção destes painéis sobre o piso enfraqueceu o partido expográfico e curatorial rompendo em alguns trechos a qualidade espacial da praça e sua permeabilidade visual. No entanto, os obstáculos criados pelas construções não foi impedimento para que houvesse a leitura do conjunto das obras em simultaneidade e que estas estabelecessem as relações com o seu entorno. A configuração do núcleo Broodthaers, com poucos artistas, dentro da grande exposição, poderia ter viabilizado 
um diálogo mais intenso com os artistas em busca de outras formas de display que não criassem barreira visual que, seguramente, teriam dado rigor à proposta.

Um exemplo da boa qualidade espacial que se estabeleceu na praça é a obra Mula sem cabeça (2006) [1], da artista Goshka Macuga (1967, Varsóvia, Pôlonia), uma construção que explode os limites da praça inspirada no Pavilhão da Bienal com as cores e detalhes como o guarda-corpo desenhado por Niemeyer. Com uma plataforma elevada acessada por rampa curva, o trabalho possibilitava uma vista de controle do pavilhão, um panóptico da exposição. Uma escada helicoidal levava a uma sala de pesquisa, onde a artista expôs objetos e gravuras adquiridos no Brasil, todos relacionados ao passado colonial, história religiosa, heróis populares, zoologia ou arte em uma organização que remetia ao gabinete de curiosidades $^{47}$ ou ao museu do século I9, também repertório de Broodthaers. Na base desta estrutura elevada a artista plantou uma erva cuja crença popular diz afastar os maus espíritos. Segundo o crítico de arte Michael Wilson,

47 "As expressões gabinete de curiosidades e quarto das maravilhas designam os lugares onde, durante a época das grandes explorações e descobrimentos dos séculos XVI até XVIII, se colecionava uma multiplicidade de objetos raros ou estranhos dos três ramos da biologia considerados na época: animal, vegetal e mineral; além das realizações humanas". Disponível em: <https://pt.wikipedia.org/wiki/Gabinete_de_curiosidades>. Acessado em: I2 jan. 2019.
Mula sem cabeça, em suma, incorporou a tensão entre o modernismo brasileiro e as convicções espirituais do país. Essa coexistência aparentemente paradoxal do modernismo com a metafísica e das ideias de progresso com o arcaico é de particular interesse para Macuga (WILSON, 2007, s.p.).

Volz aponta que Macuga atua como artista-curadora e invade os arquivos do museu com objetivo de desenvolver narrativas alternativas baseada em associações pessoais ou ficcionais. A artista amplia a abrangência de Broodthaers, desenhando e construindo seu próprio museu temporário. A instalação permitiu uma nova leitura do espaço estabelecendo diálogo com o pavilhão e valorizou a expografia a partir da vista do mezanino, possibilitando a percepção clara da continuidade do forro e as circulações contínuas ao lado dos caixilhos, nas fachadas norte e sul.

A lado da Macuga, no centro do piso, estava a obra de Meschac Gaba, Museum Shop (2006) [2], que faz parte do Museu de Arte Contemporânea Africana, uma instituição fictícia com doze salas. O artista retoma a discussão de Broodthaers com um foco adicional nas condições pós-coloniais da cultura não ocidental. A loja de museu de Gaba pouco tem a ver com o seu modelo, com objetos de design e livros de arte. São tendas que se aproximam das estruturas provisórias de ambulantes, como expositores de camisetas, acessórios e notas 

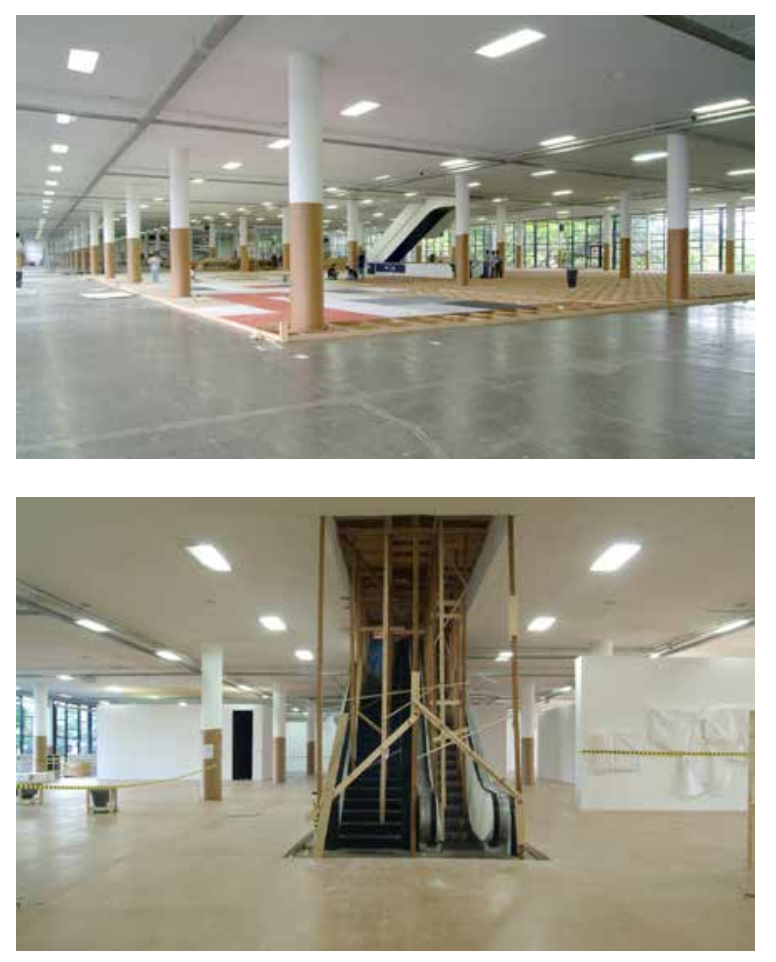

[no topo] Montagem da Praça Broodthaers e sua relação com o pavilhão. Fonte: Arquivo Wanda Svevo. Foto: Juan Guerra.

[ao centro] Vista dos painéis de Marulho [4b] construídos sobre a praça. Fonte: Arquivo Wanda Svevo. Foto: Juan Guerra.
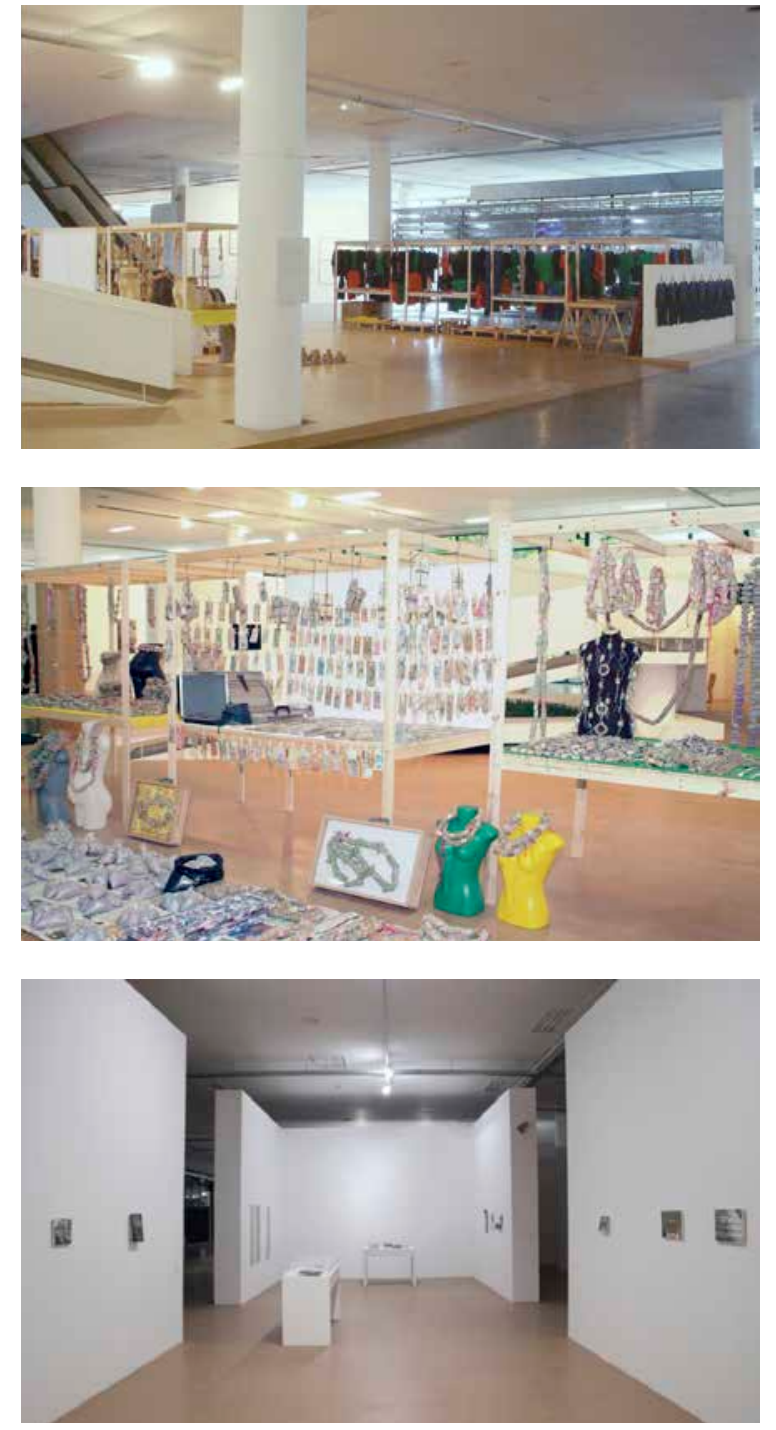

[no topo] Vista da instalação Museum shop [2] de Meshac Gaba Fonte: Arquivo Wanda Svevo. Foto: Juan Guerra. [ao centro] Museum Shop [2] de Meschac Gaba. Fonte: Arquivo Wanda Svevo. Foto: Juan Guerra.

[embaixo] Sala de Juan Araujo [7]. Fonte:Galeria Luisa Strina. Foto: Edouard Fraipont. Disponível em: http://www.galerialuisastrina.com.br.
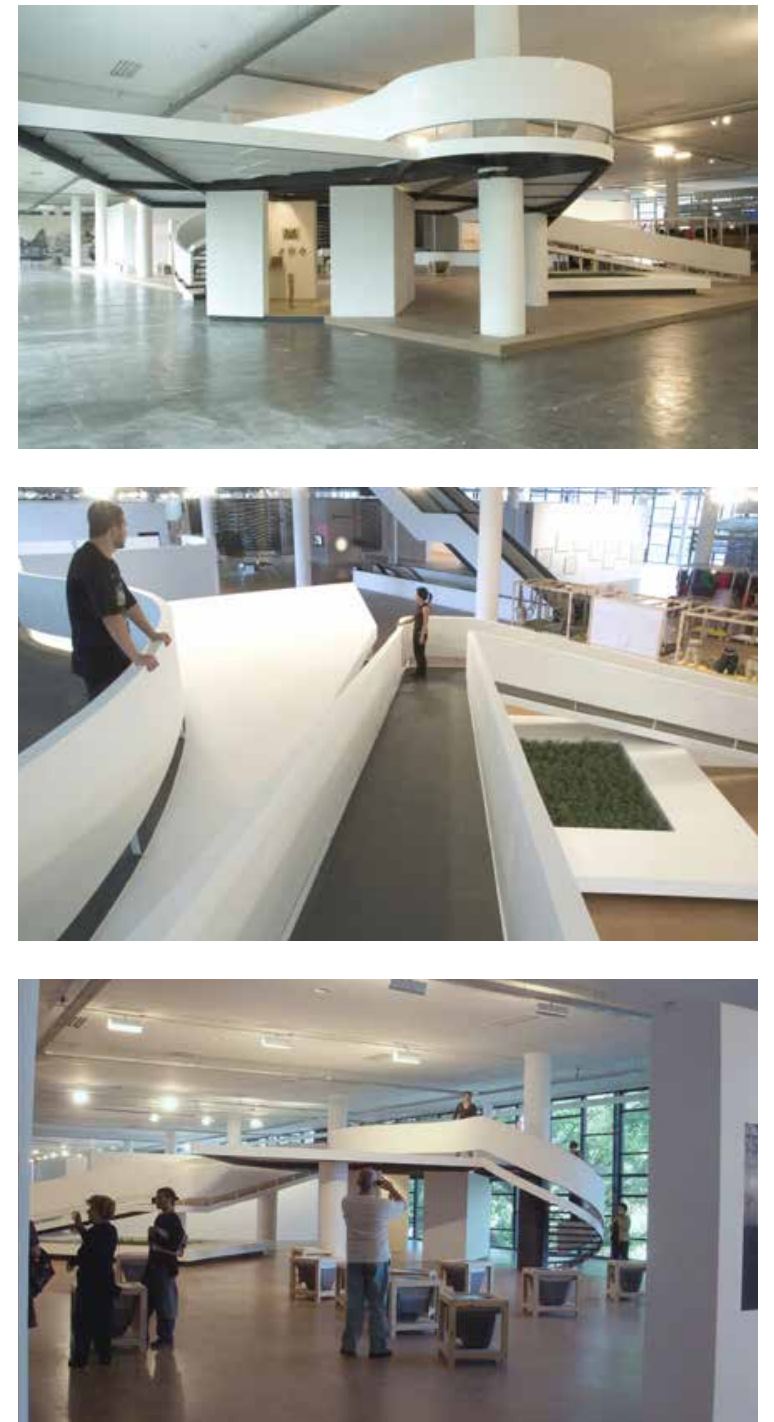

[no topo e ao centro] Vistas da instalação Mula sem cabeça [1], de Goshka Macuga. Fonte: Kate MacGarry. Disponível em: http://www.katemacgarry.com/artists/goshka-macuga/

[embaixo] Vista da obra Entre Nós [4a] de Marilá Dardot e Mula sem cabeça [1], de Goshka Macuga. Fonte: acervo Marta Bogéa. Foto: Juan Guerra. 
de dinheiro. O local onde a obra foi implantada, na tomada da escada rolante no segundo pavimento, segue a lógica das lojas de museu que são estrategicamente locadas nas circulações, tornando-se parada obrigatória do público.

Museumuseu [4], de Mabe Bethônico (I966, Belo Horizonte, $M G$ ), era também um museu fictício que se apropriava dos tradicionais sistemas de organização museólogicas. ${ }^{4^{8}} \mathrm{~A}$ instalação, na 27a. Bienal, trouxe uma pesquisa da artista sobre as Bienais de São Paulo, cujos catálogos e arquivos de edições anteriores organizou segundo seu próprio critério.

Nos trabalhos de Bethônico, Macuga e Gaba, assim como na obra Musée d'Arte Moderne, Département des Aigles, de Broodthaers, o uso do museu como modelo tem um peso muito maior hoje em dia, já que o museu como tal é uma abstração da cultura e da sociedade, com objetivo de representação. Ele tem como intenção resguardar o patrimônio cultural e natural, sendo, portanto, uma imagem, ou, até certo ponto, um modelo para sociedade (VOLZ, 2006, p.I89).

Rirkrit Tiravanija (I961, Buenos Aires, Argentina) é um dos artistas chave da mostra, seus trabalhos têm como

48 Desde 2000, museumuseu tem aparecido em websites, exposições temporárias, ações e intervenções (VOLZ2006, p.188).
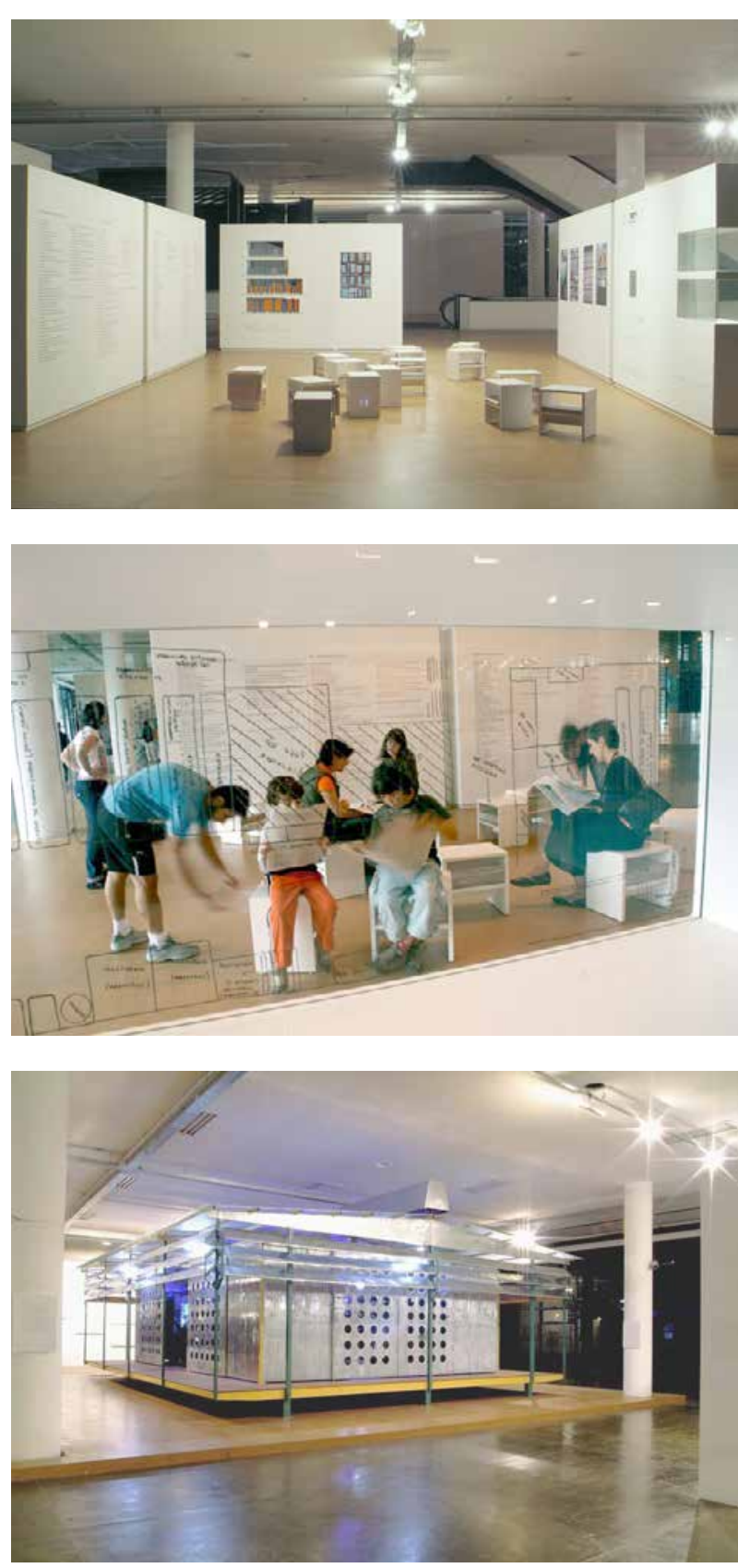

[no topo e ao centro] Museumuseu [4], de Mabe Bethônico. Fonte: arquivo Wanda Svevo. Foto: Juan Guerra.

[embaixo] Untitled 2006 (Palm Pavilion) de Rirkrit Tiravanija. Fonte: arquivo Wanda

Svevo. Foto: Juan Guerra. 
fundamento colocar as pessoas em uma ação coletiva. Suas instalações não constroem separação entre artista e público, subvertendo o espaço expositivo e questionando o valor da autoria. Portanto, sua obra se relaciona com os Projetos para Vida de Oiticica, com o Como viver junto de Barthes e com a obra de Broodthaers. A obra concebida para a 27a. Bienal foi Untitled 2006 (Palm Pavilion) (2006) [3], uma réplica da Maison Tropicale do arquiteto modernista Jean Prouvé $\left(\right.$ I9OI-I984) ${ }^{49}$ - moradia pré-fabricada desenvolvida para abrigar franceses residentes nas colônias africanas e que era transportada por cargueiros. No interior do pavilhão, assim como na obra Décor de Broodthaers, há várias espécies de palmeiras, além de vídeos e objetos relacionados à planta símbolo do exotismo tropical.

Os vídeos contidos na obra documentam testes nucleares no pacífico sul com um grupo de palmeiras filmadas no primeiro plano e uma série de imagens que têm a palmeira como referência cultural_-incluindo ilustrações científicas, cédulas de dinheiro e selos..$^{\circ}$

49 Jean Prouvé (190I-1984) foi um trabalhador metalúrgico francês, arquiteto e designer autodidata. Sua principal conquista foi transferir a tecnologia de manufatura da indústria para a arquitetura, sem perder as qualidades estéticas.

50 Disponível em: http://inhotim.org.br/inhotim/arte-contemporanea/obras/ palm-pavilion/. Acessado em: I2 jan. 2019.
A instalação do pavilhão modernista ícone da arquitetura industrializada à serviço da colonização europeia dentro do Pavilhão da Bienal revela a ironia do artista que também é adotada por Broodthaers como discurso para dissolver as hierarquias institucionais.

Volz propõe uma leitura do trabalho de Broodthaers a partir do conceito de modelo, no qual defende que o museu serviu como modelo para o artista e entende que talvez esta seja a explicação da influência de seu trabalho no momento atual.

Um modelo é uma representação abstrata de um sistema, a partir do ponto de vista do modelador. Ajuda a simular a realidade, questioná-la compreendê-la e tornou-se uma ferramenta central da teoria científica, na matemática e em todas as ciências naturais e sociais durante a segunda metade do século 20. Todos os modelos implicam em reduções e abstrações, suposições falsas e erros. São, portanto, claramente fictícios, porém modelos fictícios ajudam a desvendar a realidade (VOLZ, 2006, p.I87).

Segundo Volz, a obra de Tiravanija incorpora o conceito de modelo em uma dimensão desconhecida. O artista trabalha através da apropriação de ícones da arquitetura usando a ideia de modelo em vários níveis de abstração. E suas obras 
provocam a interação do público levando-o a uma experiência entre vida e ficção (VOLZ, 2006).

A obra de Marilá Dardot (I973, Belo Horizonte, BH) estabelece outro tipo de diálogo com a obra de Broodthaers: Entre Nós (2006) [4a] é uma série de filmes curtos, montados com monitores horizontais como pequenas mesas. O filme trata de um jogo de dados com letras em que os participantes usam as letras de forma aleatória para construir palavras. $\mathrm{O}$ acaso torna-se uma conversa remetendo a obra Untitled Poem (I966-1969), de Broodthaers, e ao poema de Mallarmé:

Um coup de dés jamis n'abolira le hasard

( 1 'alphabet est um dé à 26 faces)

Um dé a 26 faces, Modèle: L'alphabet

ABCDEFGHIJKLMNOPQRSTUVXYZ...

(Marcel Broodthaers)

O filme de Tacita Dean (1965, Canterbury, Inglaterra), Section Cinèma (2002) [6a], que constitui a única sala fechada do núcleo, foi realizado no estúdio de Broodthaers, no qual aparecem os escritos nas paredes utilizados pelo artista.

As pinturas de Juan Araujo (I97I, Caracas, Venezuela) [7], por sua vez, analisam as reproduções das obras de arte. O artista utilizou a tradicional pintura a óleo para questionar a noção de originalidade e de autoria na arte, questões centrais na obra de Broodthaers.
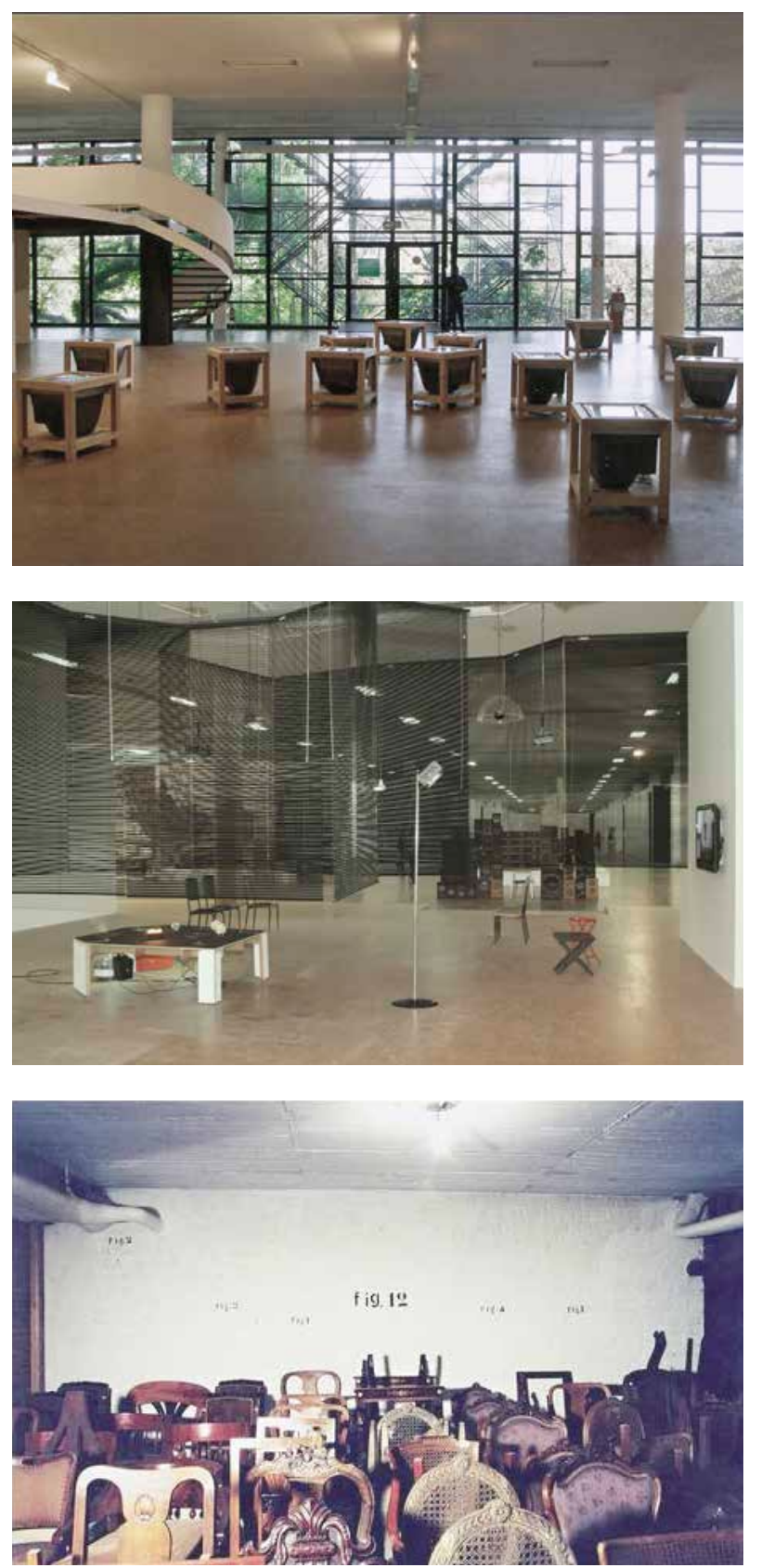

[no topo] Vista da obra Entre Nós [4a] de Marilá Dardot e sua relação aberta com a paisagem exterior. Fonte: acervo Marta Bogéa. Foto: Juan Guerra.

[ao centro] Blind Room [8a] de Haegue Yang. Fonte: Arquivo Wanda Svevo. Foto: Juan Guerra.

[embaixo] Section Cinèma [6a] de Tacita Dean. Fonte: Marim Goodman Gallery. Disponível em: http://archive.mariangoodman.com/ exhibitions/2003-01-10 _ tacita-dean/. 
A disposição sobre o piso elevado de madeira no segundo e terceiro pavimentos criou uma identidade que possibilitou ao público uma rápida associação entre as obras em ambos os andares. Este é um trecho da exposição em que o projeto curatorial pode ser lido com clareza e as obras estabeleceram ricos diálogos entre si e com a arquitetura. A obra Entre nós, de Dardot, ganhou um novo ponto de vista a partir da obra de Macuga, e todos os monitores de vídeo puderam ser vistos simultaneamente, como dados jogados aleatoriamente. A obra Marulho [4b], também de Dardot, instalada no painel, também ganhou novas camadas ao ser vista através do pavilhão de Tiravanija. A transparência das persianas de Blind Room (2006) [8a], de Haegue Yang, possibilitou que as obras da praça e as que fizeram vizinhança fossem vistas através de sua instalação.

Portanto, as obras implantadas na praça estabeleceram uma relação direta com o pavilhão e, por consequência, com o parque. E sua leitura foi influenciada por esse contexto. Nas situações em que foram construídos painéis, como o da sala de Araujo, o fechamento foi rompido por uma grande abertura no sentido transversal do pavilhão que permitia que as obras do entorno e o pavilhão fossem vistos. Na praça Broodthaers, houve um encontro profícuo entre arquitetura, curadoria, expografia e obras de arte que resultou em uma boa qualidade espacial, evidenciando na mostra a possibilidade de se estabelecer uma relação de diálogo e equilíbrio entre as partes.

\subsection{2. Área Climatizada}

Uma das premissas da 27a. Bienal era a de que a área climatizada não deveria ter o caráter de sala especial ou histórica. No entanto, na mostra, é nesse espaço que estão artistas fundamentais para compreensão da estrutura do projeto curatorial, nomeados de histórico-contemporâneos pelos curadores: Ana Mendieta, Gordon Matta-Clark e Marcel Broodthaers. A contingência física do pavilhão e as exigências de conservação para empréstimo de obras de grandes instituições acabaram por determinar a localização destas obras. Para dissolver o caráter de espaço privilegiado dentro da exposição os curadores se apropriaram do conceito de contaminação, utilizado por Herkenhoff na 24a. Bienal. ${ }^{11}$ A proposta consistia em aproximar jovens artistas ou obras comissionadas às de artistas consagrados.

A solução expográfica foi configurar uma sala sem caixilhos, encerrada na fachada sul com painéis. A fachada norte é onde estão instalados os equipamentos de ar-condicionado, já isolados por um grande painel. Os vedos que constroem esse espaço são todos piso-teto, compondo uma nova configuração na mostra: uma grande caixa-branca de onde não se vê mais a paisagem ou mesmo o pavilhão e sua

5I Princípio desenvolvido na 24a. Bienal por Paulo Herkenhoff. Para mais informações ver tópico 2.3.2. 
continuidade. A centralidade deste espaço é dada pelo piso elevado de Broodthaers que margeia a escada rolante e que faz a conexão com a praça do segundo pavimento. As salas de artistas foram dispostas de forma a criar um circuito circular ao redor da praça.

Ao entrar na área climatizada pelo acesso próximo à fachada sul, as primeiras obras implantadas são de Potrč e do Superflex (1993, Copenhague, Dinamarca), ambos deslocados do núcleo Acre e cujas obras tem um forte caráter arquitetônico. A instalação Xapuri: rural school de Potrč [10] foi produzida após sua residência artística no Acre e concebida a partir da "análise das arquiteturas de sobrevivência e novas formas de comunidades no Acre" (ROCA, 2006, p.134). Uma escola de palafitas autossuficiente com energia solar e uma antena parabólica que cumpre o papel de conectar áreas remotas com o mundo, construindo a possibilidade de uma rede de trocas. Ao seu lado, está a instalação Direito autoral [11a], do Superflex, que substituiu a obra Guaraná Power [11b], uma performance que faria a distribuição de um refrigerante artesanal mas que foi impedida por questões jurídicas pela Fundação Bienal. A proposta era fazer uma produção artesanal de guaraná como crítica às multinacionais que exploram os pequenos produtores na Amazônia. A instalação presente na mostra foi uma plataforma cheia de réplicas da cadeira formiga modificadas manualmente, em uma versão barata da peça de design. A proposta buscava tornar cada cadeira uma [no topo] A instalação Xapuri: rural school de Marjetica Potrč [10]. Fonte: site Bienal. Foto: Juan Guerra.

[embaixo] No plano da frente a instalação Guaraná

Power [11b] de Superflex fazia referência à performance

cancelada. Atrás a instalação Direiro Autoral [11a].

Fonte: Arquivo Wanda Svevo. Foto: Juan Guerra.
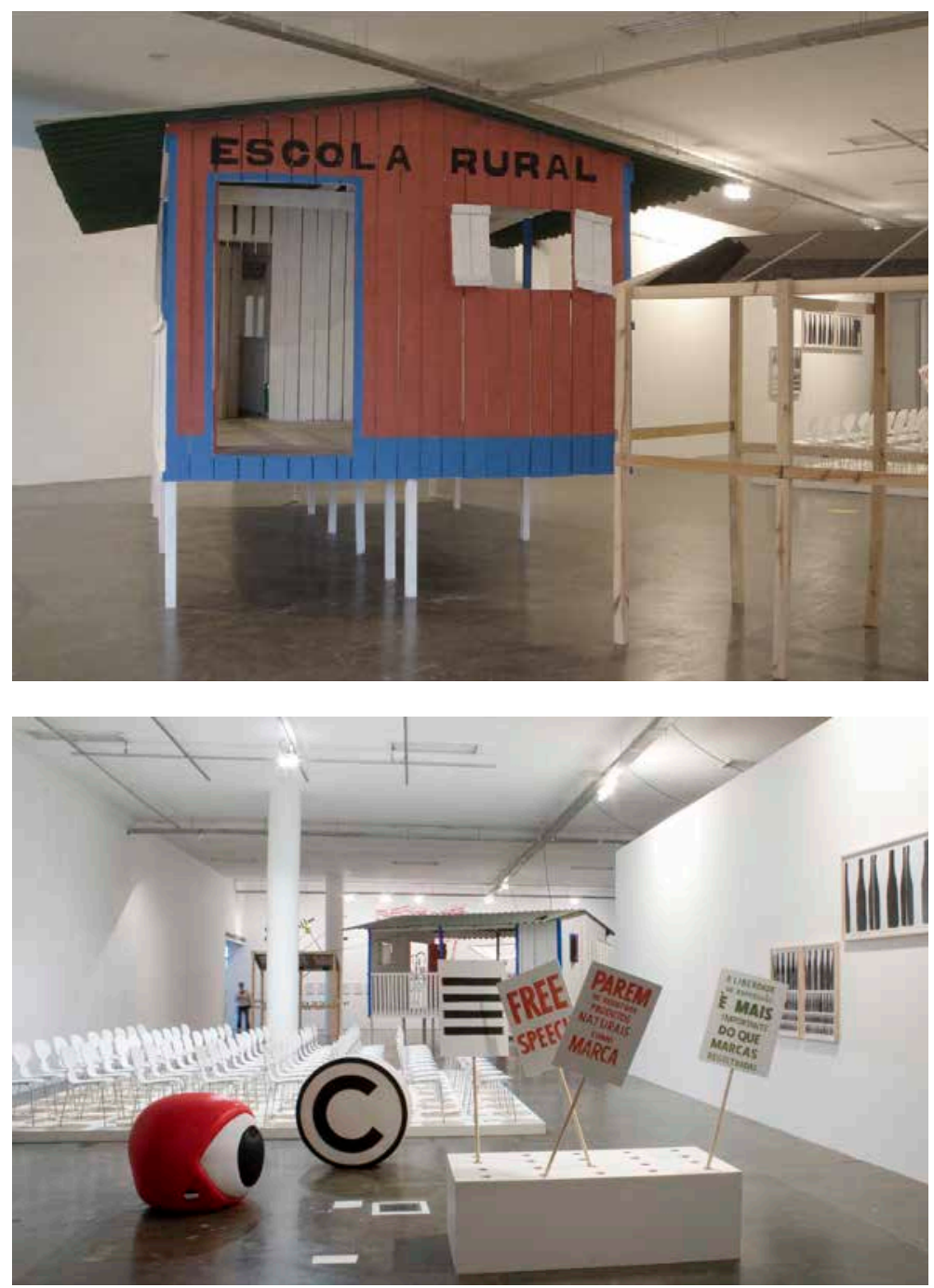
peça única, contrariando o seu projeto original feito para produção em série. O trabalho aborda os direitos da propriedade intelectual como uma resposta a censura sofrida.

Os trabalhos dos artistas posicionados junto à fachada sul apresentavam um caráter arquitetônico que dialogava com as obras de Broodthaers no centro do espaço, voltadas para a crítica institucional. Ao lado da escola de palafita de Potrč, separada por um painel, estavam as maquetes e vídeos de Dan Graham [12], que trabalha com a precisão e a reflexibilidade do vidro. Pedrosa, curador responsável pelo eixo Arquitetura, indica que a relação arte-arquitetura teve uma inflexão nos anos 1960, quando os artistas passaram a questionar os limites entre as duas disciplinas. Graham ${ }^{52}$ foi um artista essencial para essa aproximação. Suas obras se aproximavam da plataforma conceitual da 27a. Bienal seja pela investigação das casas suburbanas de Nova Jersey em Homes for America (1967), seja pelo pavilhão Homenage to Vilanova Artigas (2006), instalado no térreo.

Segundo Beatriz Colomina, a obra de Graham se desenvolve em paralelo à arquitetura moderna. Se a arquitetura do começo do século 20 era vinculada a revistas ilustradas, fotografia e cinema, a do pós-guerra é a arquitetura da televisão e do vídeo.

52 Embora seja uma referência importante e um artista consagrado não estava na lista de histórico-contemporâneo por continuar atuante.
Toda a obra de Graham é a arquitetura dos meios de comunicação, desde as primeiras elaboradas em revistas, como Homes of America, aos desenhos das casas como Alteration to a Suburban House, os pavilhões que atualmente dominam seu trabalho. Não se trata simplesmente de falar de temas arquitetônicos [...] ou de utilizar os meios tradicionalmente usados pelo arquiteto, mas aqui o próprio edifício é um meio e comunicação (COLUMINA, 2008, p.I4I).

As obras de Graham presentes na mostra foram: a projeção de slides Homes of America (I966-I967); e as maquetes dos pavilhões Skateboard Pavilion (1989), Yin/Yang Pavilion (I998) (acompanhada de um vídeo), Double Exposure / Landscape Photo Pavilion (I995) (também acompanhada de um vídeo), e Swimming Pool/Fish Pond (1997). Homes of America é considerada por muitos como a primeira obra de Graham. Publicado em ig66 na Arts Magazine, o trabalho é um artigo que junta fotografias das casas seriadas em Nova Jersey e textos que descrevem sua organização espacial. Seguindo o padrão de diagramação da revista, o trabalho se apropria do meio de comunicação. $\mathrm{O}$ artista fez, através de seu ensaio, um paralelo entre os bairros residenciais produto da indústria imobiliária e a produção artística do minimalismo (KUHNERT, 20I5). Segundo Hal Foster, a obra é "um registro das repetições modulares no desenvolvimento 
de um conjunto habitacional que reenquadra as estruturas minimalistas como objetos achados num subúrbio tecnocrático" (2017, p.175).

Entre as salas de Graham e Matta-Clark foi implantada a sala do jovem artista Vangelis Vlahos (I97I, Atenas-Grécia) [13], cujo trabalho tem como foco a simbologia identitária dos edifícios. Vlahos pesquisa a arquitetura do poder e faz uso de maquetes e espelhos. Um dos trabalhos mais contundentes do artista tem como objeto de análise a Embaixada Americana em Atenas, edifício projetado no final dos anos I950 pelo arquiteto modernista Walter Gropius. Vlahos documenta a transformação do edifício de símbolo utópico da democracia para símbolo da política americana, alvo de ataques terroristas. Após o ataque sofrido em 1996, o edifico que possuía uma estrutura aberta, se transforma em uma fortaleza.

Gordon Matta-Clark se formou em arquitetura e decidiu romper com as tradições de sua profissão. Se dedicou a fazer recortes (building-cuts) em edifícios abandonados dos subúrbios de Nova York. Com essa ação, o artista trouxe a land art $\mathrm{e}$ o site specific para o espaço urbano. Segundo Pedrosa, MattaClark levou a arquitetura e a escultura tradicionais ao colapso ao cortar e fazer incisões violentas em casas e edifícios. O curador faz um paralelo do ato radical de Matta-Clark ao de Lucio Fontana que, ao cortar a tela, levou o entendimento da pintura tradicional ao colapso (PEDROSA, 2008). Segundo
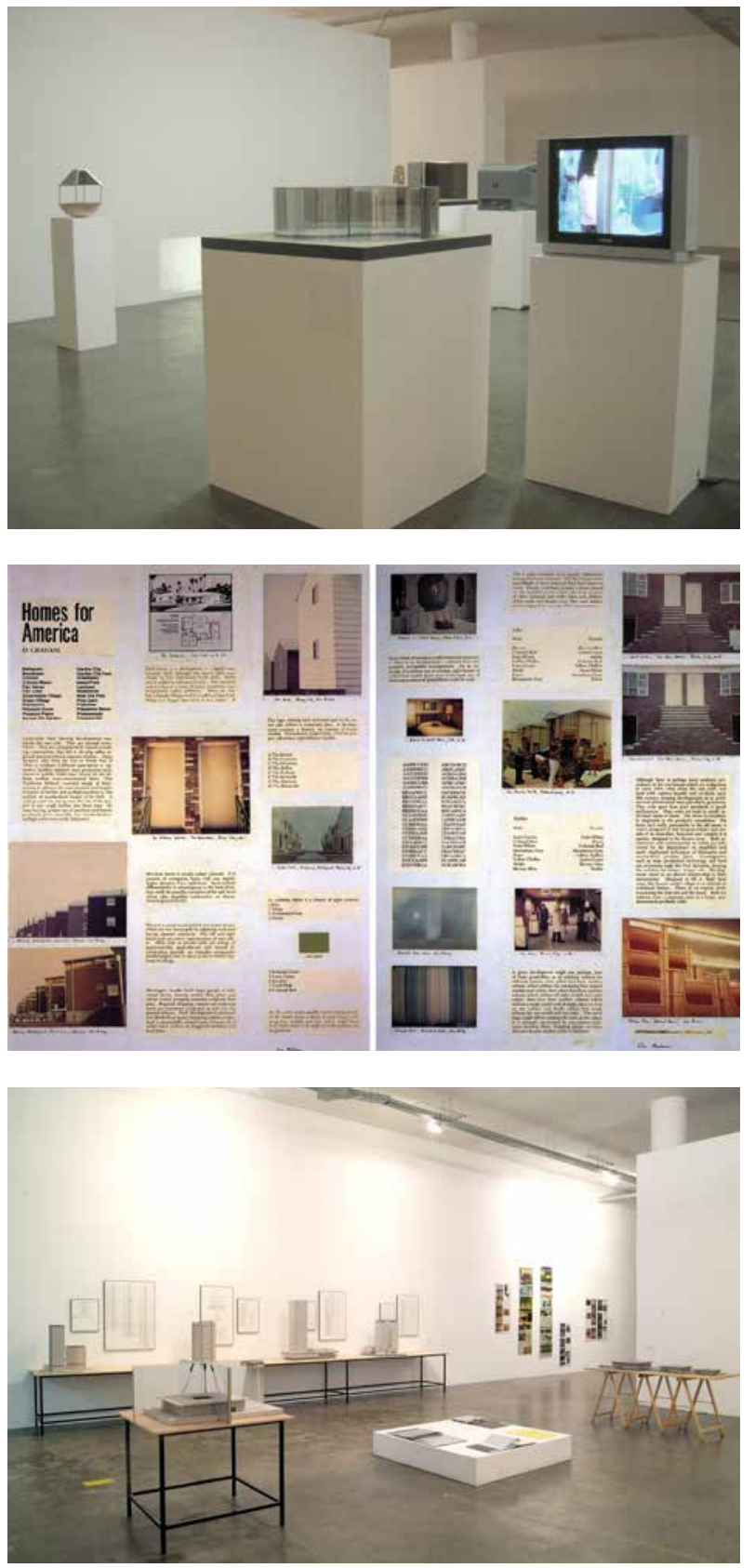

[no topo] Vista da obra Yin/Yang Pavillion na sala de Dan Graham [12]. Fonte: acervo da autora. Foto: Maria Julia Herklotz.

[ao centro] Homes of America de Dan Graham. Fonte: medium.

[embaixo] Sala de Vangelis Vlahos [13]. Fonte: Arquivo Wanda Svevo.

Foto: Juan Guerra. 

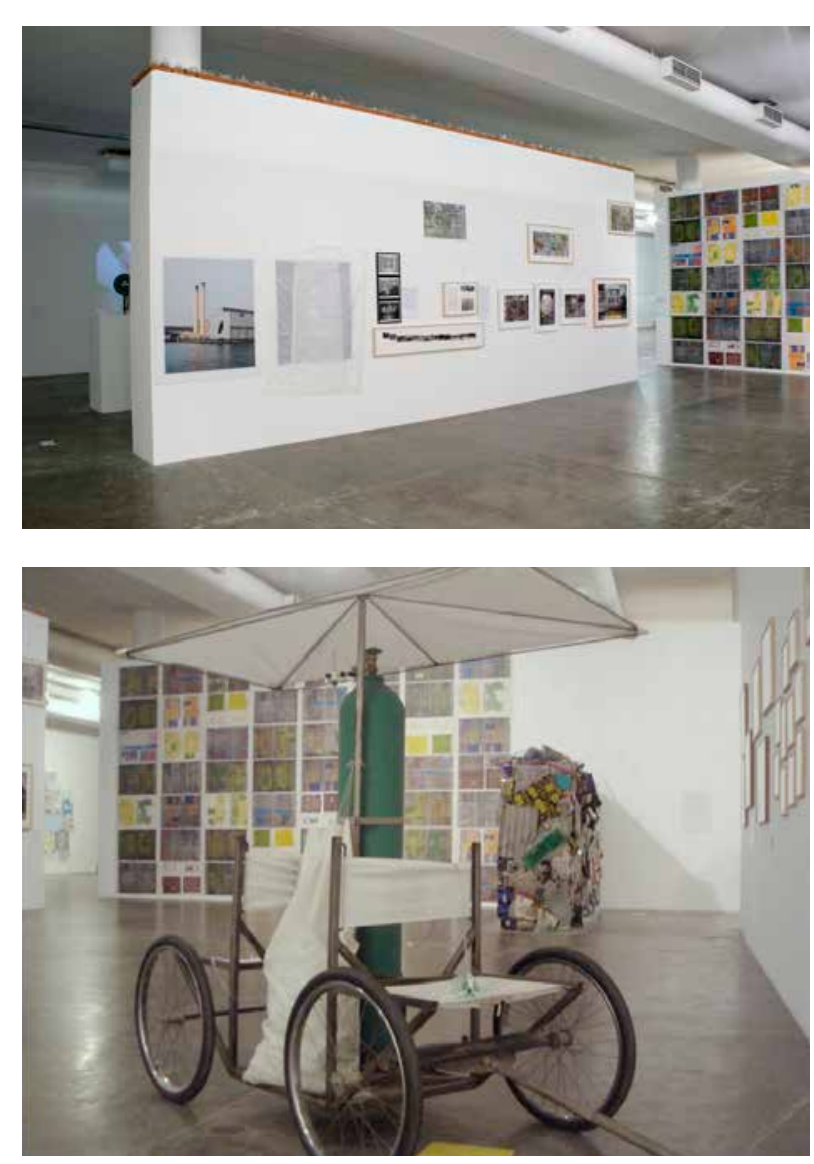

[no topo] Vista da sala de Matta-Clark. Fonte: Arquivo Wanda Svevo. Foto: Juan Guerra. [ao centro] Fresh Air Cart de Matta-Clark [14a], Fonte: site Bienal. Foto: Juan Guerra.

[embaixo] Splitting 1974, wall paper instalation, garbage wall de Gordon Matta-Clark [14a]. Sobre o painel a obra Intramuros de Marcelo Cidade e ao fundo a obra de Mark Bradford. Fonte: site Bienal. Foto: Juan Guerra.
Guilherme Wisnik, “o seu ataque à arquitetura diz respeito à ilusão de perenidade e eficiência que nela se materializa, tornando-a uma poderosa metáfora do status quo social" (WISNIK, 2008, p.I57). Ao mutilar edifícios, Matta-Clark revelou o caráter efêmero e inútil da arquitetura. $\mathrm{O}$ artista fez parte da cena underground e de contracultura dos anos I960 e I970 em Nova York, assim como Oiticica, e suas obras tinham um forte caráter de crítica social e institucional.

As obras de Matta Clark presentes na mostra foram os desenhos e fotografias Sky Hook (Study for a Balloon Building) (1978), Sous-sols de Paris (1977), Splitting (1974), Conical Intersect (1978) e Bingo (Bingone) (1974); e as instalações Fresh Air Cart (1973), que tem sua origem numa performance do artista problematizando a qualidade do ar de Nova York, e Garbage Wall (I970) [14a], concebida originalmente no bairro nova-iorquino East Village e reconstruída para 27a. Bienal. A mostra contou também com uma seleção de filmes feitos por Matta-Clark entre I97I e 1976 registrando suas intervenções [14b], cujo espaço era compartilhado com o filme The Third Space in the Fourth World (2002) de Lu Chunsheng (i968, Changchun, China) [15] que tratava da paralisia diante da especulação imobiliária na China (HARUM, 2009, s.p.).

Um exemplo da contaminação de artistas novos e consagrados, de maneira mais incisiva, ocorreu na sala de MattaClark. Marcelo Cidade instalou no topo do painel de do artista 
americano a obra Intramuros (2005) [16], um pedaço de muro cheios de cacos de vidro colados, recurso utilizado para proteger terrenos privados nas cidades. Esse trabalho parasita de Cidade, que a priori aconteceria em diversos painéis, exigiu negociações para que fosse implantado e revelou a dificuldade de se estabelecer contaminações entre obras. Cidade questionava a reivindicação dos artistas por salas individuais em bienais. Segundo ele, há uma busca por proteção do espaço privado ${ }^{\varsigma 3}$ para dar destaque às obras que acabam replicando a lógica da propriedade privada. A instituição que representava Matta-Clark não queria permitir a interferência, mas sua viúva, em visita ao pavilhão, autorizou a implantação da instalação por entender que a obra de Cidade dialogava com a de Matta-Clark.

Entre as salas de Matta-Clark e Ana Mendieta e em frente ao núcleo Broodthaers estava a obra Ridin'Dirty (2006) de Mark Bradford [17]. Sua presença neste entroncamento criava uma conexão entre uma produção atual e a de três artistas históricos-contemporâneos. O trabalho de Bradford era feito a partir de colagem de cartazes de publicidade e sinalização coletados em Los Angeles. Segundo o artista: “Minha prática é de decollage e colagem ao mesmo tempo. Decollage: eu levo embora; colagem: eu imediatamente adiciono de volta. É quase como um ritmo. Eu sou um construtor e

53 Depoimento dado pelo artista para tv uol em 24/08/2006.Disponível em: $<$ https://tvuol.uol.com.br/video/27-bienal-de-sao-paulo--marcelo-cidade-04029B $316 \mathrm{AC}_{4} \mathrm{CI}_{43} 66>$. Acessado em: 13 jan. 20I9.
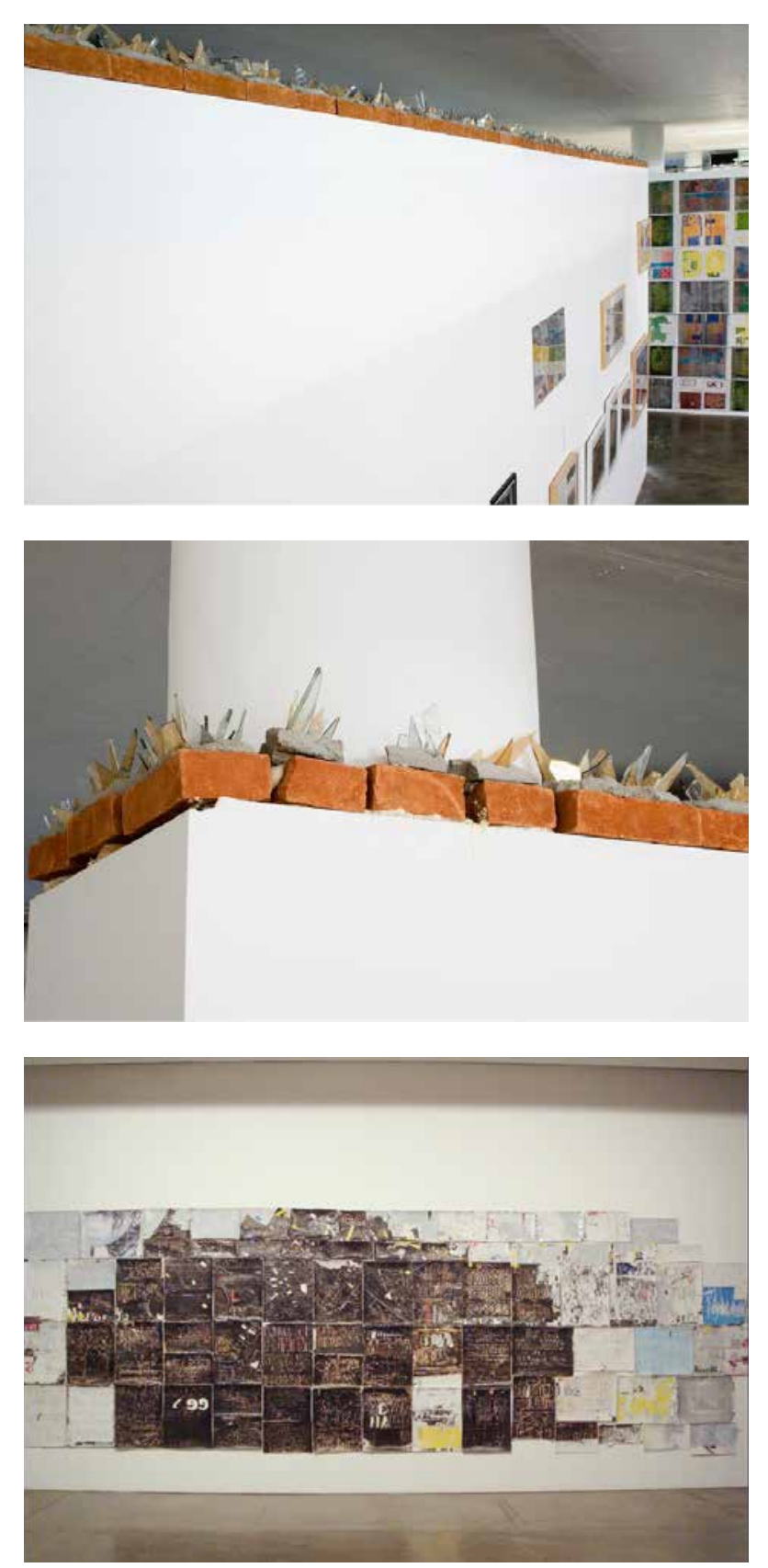

[no topo] Vistas da obra Intramuros de Marcelo Cidade sobre o painel de Gordon Matta-Clark. Fonte: galeria Vermelho. Disponível em: https:// galeriavermelho.com.br/pt/artista/40/ marcelo-cidade. Foto: Juan Guerra. [embaixo] Ridin'Dirty de Mark Bradford [17]. Fonte: acervo da autora. Foto: Maria Julia Herklotz. 
um demolidor. Eu coloquei para que eu possa derrubar" (BREDFORD, 2007, s.p.).

Ana Mendieta (1948, Havana, Cuba-1985, Nova York, Estados Unidos), segundo Lagnado, é uma das principais contribuições que esta Bienal trouxe para o público. A artista, muito pouco conhecida no Brasil, foi exilada de Cuba na adolescência ${ }^{54}$ e sua obra trabalha com conceitos de identidade, gênero e exílio. Sua poética cria um diálogo intenso com a narrativa da 27a. Bienal, na qual a abordagem do território é um dos principais eixos.

Mendieta produz uma "dialética do exílio" onde se evidencia que a estabilidade do conceito de nação é intrínseca à noção de exílio — para existir, depende de um "outro" como elemento constituinte das narrativas nacionais e binárias que estabilizam a cultura moderna ocidental. Neste sentido, Mendieta trabalha em favor e contra sua posição de exilada,

54 "Mendieta nasceu em Havana, Cuba, em uma família de políticos proeminentes. Aos I2 anos de idade, a fim de escapar do regime de Fidel Castro, Ana e sua irmã, Raquelin, de I 4 anos foram enviadas aos Estados Unidos por seus pais para viver em Iowa, fazendo parte de um programa patrocinado pelo governo para remover e realocar crianças cubanas, sob o regime de Castro. Através da Operação Peter Pan, um programa colaborativo do governo americano com a organização Catholic Charities, Mendieta e sua irmã passaram suas primeiras semanas em campos de refugiados antes de passarem por várias instituições e em casas de famílias adotivas em Iowa”. Disponível em: $<$ https://pt.wikipedia.org/wiki/Ana_Mendieta>. Acesso em: I3 jan. 2019. associando-a com sua posição feminina: “A mulher é um estrangeiro familiar, um outro irreconciliável” (SHUCK; GARCIA, 20I7, p.4).

As obras de Mendieta presentes na mostra eram fotografias de 1972, seus primeiros trabalhos [18b]: Untitled (Glass on Body Imprints Glass) (1972) e Untitled (Facial Hair Transplants) (1972), em que a artista utiliza seu próprio corpo para abordar, questionar e ressignificar a noção de gênero e identidade. Na série Siluetas (1973), feita em Iowa, Estados Unidos, e no México, a artista cobre seu corpo com terra ou flores e delineia a sua silhueta com pedras, capim, pólvora, velas e outros elementos naturais. Mendieta cria um diálogo entre a paisagem e o corpo feminino, uma combinação de land art, escultura e performance nomeado por Mendieta de earth-body [corpo-terra]. Também foram exibidos filmes das performances [18a]: Sweating Blood (1973), que foca no rosto de Mendieta, com os olhos fechados, enquanto sague escorre de sua testa; Untitled (Body Tracks) (I974), na qual a artista executa um desenho com suas mãos e braços cheios de sangue; Corazón de Roca con Sangre (1975); Alma Silueta en Fuego (Silueta de Cenizas) (1975); Burial Pyramid, Yagul, Mexico (1974) e Untitled (Flower Person \#, \#2) (1975).

Mendieta fez parte de um coletivo de artistas feministas até 1982 que denunciava a violência contra a mulher. O sangue, que é muito presente em sua obra, no entanto, tem 

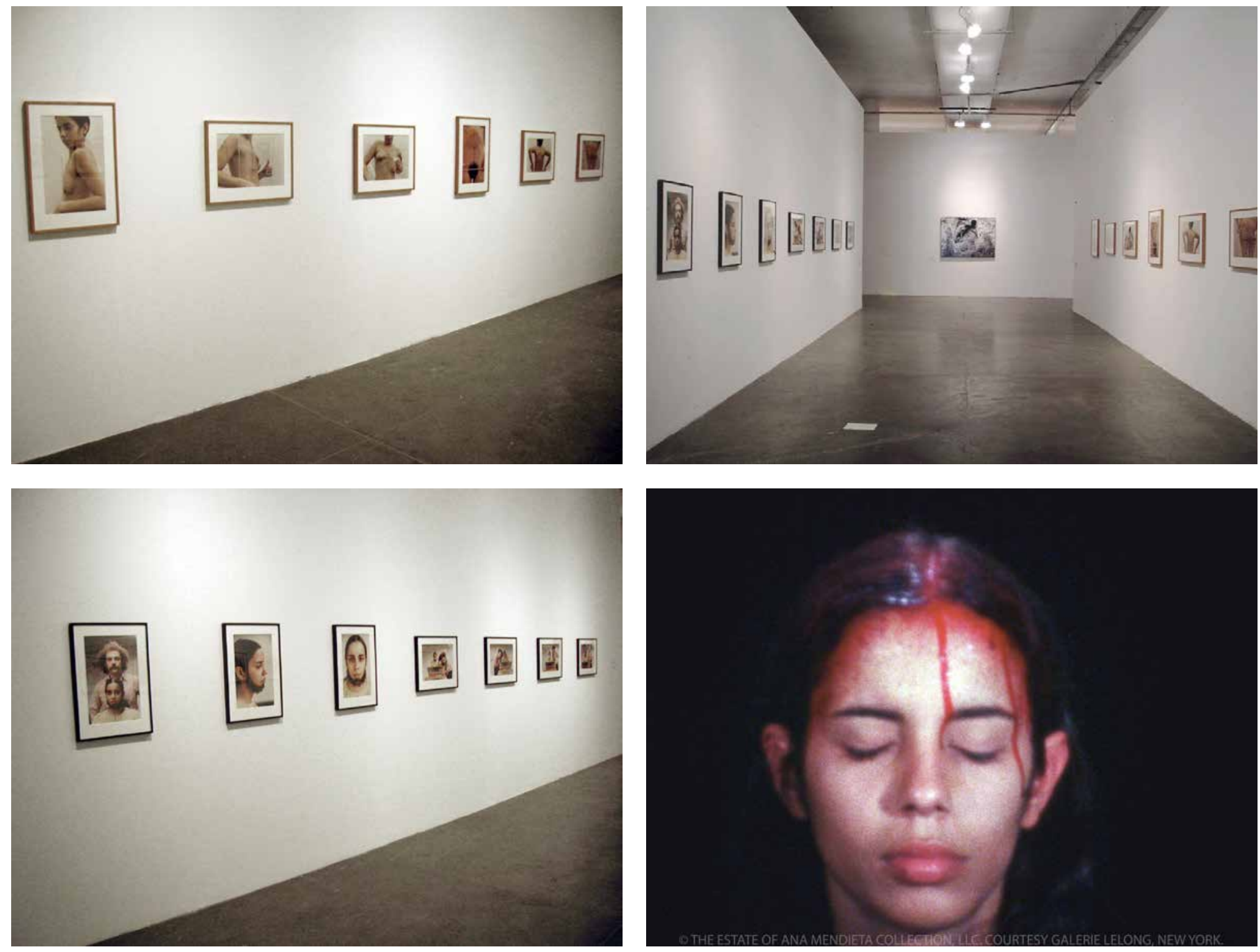

[no topo à esq.] Untitled Glass on Body Imprints Glass) de Ana Mendieta. Fonte: acervo da autora. Foto: Maria Julia Herklotz. [embaixo à esq.] Untitled (Facial Hair Transplants) de Ana Mendieta. Fonte: acervo da autora. Foto: Maria Julia Herklotz.

[no topo à dir.] Vista da sala com séries fotográficas de Ana Mendieta [18b]

Fonte: acervo Marta Bogéa.

Foto: Juan Guerra.

[embaixo à dir.] Sweating Blood filme $8 \mathrm{~mm}$ de Ana Mendieta

[18a]. Fonte: The estate of Ana Mendieta collection. 
mais um caráter ligado à visceralidade e ao ritualístico.5 Ela trabalha com o conceito de identidade, questionando as noções convencionais. Para Mendieta, a identidade só pode ser encontrada a partir da rejeição da individualidade, sem que haja uma definição estática. Suas obras evocam temas como feminilidade e morte e trazem caráter ritualístico e ancestral como busca por origem. Nas palavras da artista:

Minha arte é baseada na crença em uma Energia Universal que atravessa tudo, de inseto a homem, de homem a espectro, de espectro a planta, de planta a galáxia. Minhas obras são as veias de irrigação do fluido Universal. Através deles ascendem a seiva ancestral, as crenças originais, as acumulações primordiais, os pensamentos inconscientes que animam o mundo..$^{56}$

55 Com exceção da obra Untitled, Rape Scene (1973) na qual Mendieta fez uso do sangue para mostrar a violência contra a mulher e simulou uma cena de estupro. Nas outras obras o sangue aparece com um caráter ritualístico e ancestral, Mendieta estava ligada a religião cubana Santeria que adotava a prática de sacrifícios como uma conexão com o Orisha.

56 Tradução da autora. "My art is grounded in the belief of one universal energy which runs through everything: from insect to man, from man to spectre, from spectre to plant from plant to galaxy. My works are the irrigation veins of this universal fluid. Through them ascend the ancestral sap, the original beliefs, the primordial accumulations, the unconscious thoughts that animate the world". Mendieta, Ana. "A Selection of Statements and Notes", Sulfur, v.22, 1988, p.70.
Mendieta, de forma inovadora, desfez fronteiras entre performance, escultura, land art, vídeo e fotografia, e explorou em suas obras a relação entre arte, vida, corpo, memória e espiritualidade.

As três salas de projeção que dão continuidade ao percurso eram dedicadas a artistas mulheres. Duas delas apresentavam obras em diálogo direto com Medieta por lidar com questões identitárias, feministas e queer, a de Virginia de Medeiros (I973, Feira de Santana, BA) e a de Bregtje van der Haak (I966, Utrecht, Holanda). A outra sala era a de Barbara Visser (I966, Haarlem, Holanda), cujo trabalho de crítica institucional tratava da influência do design modernista. O bloco foi fechado pela fotografia Açúcar orgânico (2006), de Lucia Koch.

Medeiros mergulhou no universo das travestis de Salvador, Bahia, onde alugou uma sala comercial que se transformou em um estúdio para recebê-las. A obra Studio Butterfly (2006) [20] foi construída a partir dos depoimentos colhidos e do papel da artista como mediadora, que acabou por imergir nas histórias com suas próprias paixões e fantasias.

Lagos: Wide \& Close (2005) [19], de Van der Haak, faz uma transição entre a abordagem de Mendieta e o caráter arquitetônico das obras que se seguem no espaço expositivo. O vídeo foi baseado na pesquisa dos arquitetos Rem Koolhass e Philip Johnson ${ }^{57}$ sobre a metrópole periférica, mas traz em paralelo

57 Rem Koolhas (I944, Roterdã, Holanda) é arquiteto, urbanista e escritor e 
uma abordagem sociológica pela nova configuração das famílias a partir da inserção das mulheres no mercado de trabalho.

A instalação Wallpaper [21b], de Visser, é um recorte da série de cartões-postais Detitled (2000/2006), que traz fotos de móveis de design modernista desgastados e quebrados. Já a videoinstalação Two Projections (2005) [21a] traz uma entrevista sobre a decoração modernista de um apartamento projetado por Le Corbusier. Ambas as obras debatem "aquilo que existe de efêmero no fato de se conviver com um mobiliário futurista". ${ }^{8}$

Para a crítica Juliana Monachesi (2006), houve uma redundância ao abordar o esfacelamento das utopias na aproximação das obras de Visser, Superflex e a videoinstalação de Lars Ramberg [23], que documenta a construção de um novo edifício onde antes estava a sede da República Democrática Alemã.

A área climatizada do pavilhão é o espaço onde, muitas vezes, se conclui o percurso na mostra. A narrativa dessa área passou pelo site specific antropológico-arquitetônico de Potr č, pelo colapso da arquitetura de Matta-Clark, o uso da arquitetura como meio de comunicação de Graham, a presença

crítico de arquitetura. Um dos principais nomes da arquitetura contemporânea. Vencedor dos prêmios: Prêmio Pritzker, Prêmio de Arquitetura Contemporânea Mies van der Rohe, Medalha de Ouro do RIBA.Philip Johnson (I906, Cleveland, Estados Unidos) um dos principais nomes da arquitetura moderna americana. O primeiro arquiteto a vencer o prêmio Pritzker.

58 Texto com uma breve apresentação dos artistas produzido por Lagnado e Pedrosa que ficava junto às obras para informar o público da mostra.
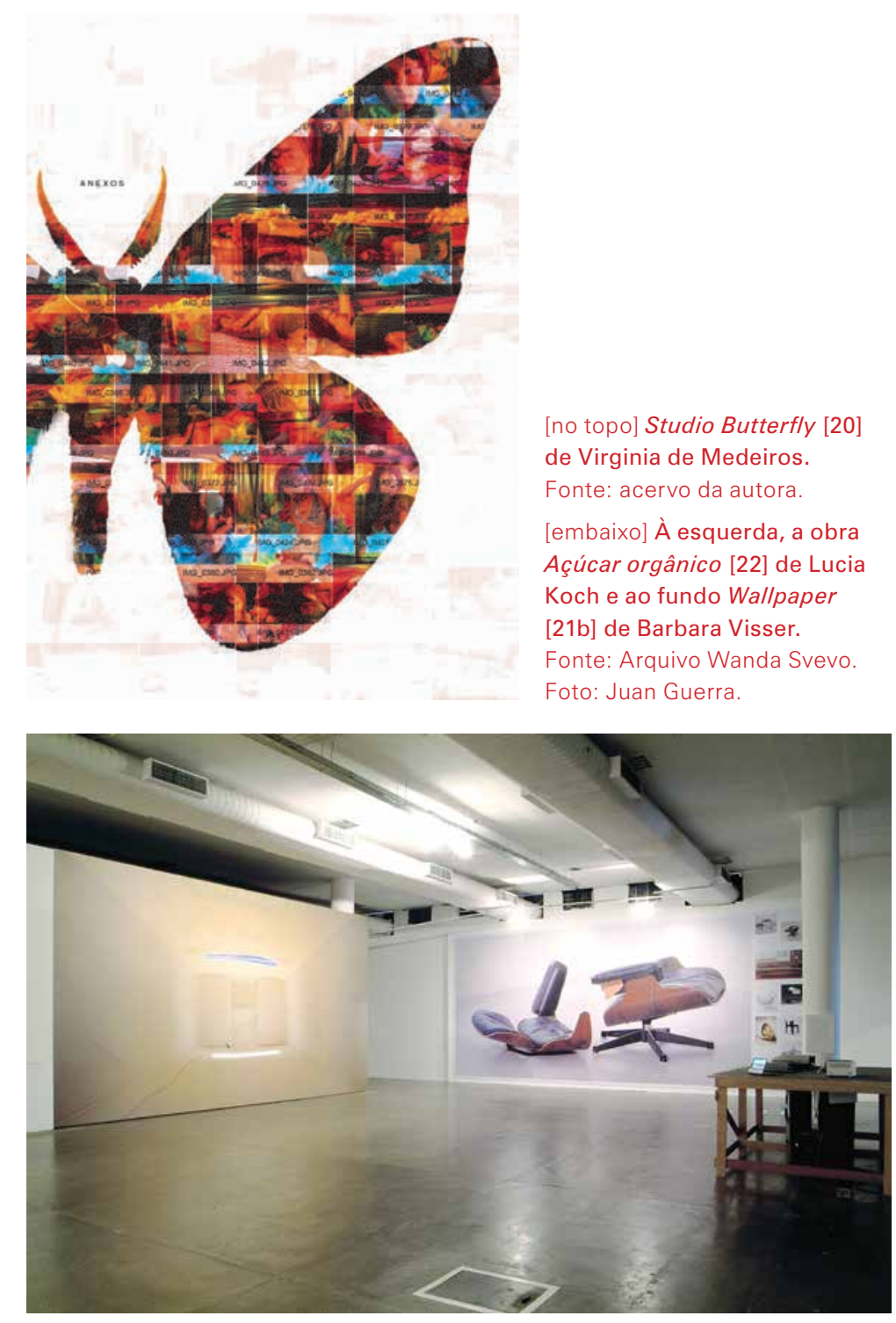
da arte feminista e o questionamento das fronteiras da identidade e o fim da utopia da arquitetura moderna. Foram estabelecidas relações entre artistas jovens e consagrados, mas, na maioria dos casos, preservando a leitura de cada artista individualmente. ${ }^{9}$ A narrativa da área foi construída ao redor das obras de Broodthaers. Para Volz, apesar de Oiticica e Broodthaers terem compartilhado campos da crítica, suas estratégias eram opostas e o artista belga pode ser descrito como antítese da investigação da 27a. Bienal. "E é através da dicotomia Broodthaers e Oiticica que foi elaborada uma das principais questões conceituais da mostra: a relação arte e vida" (VOLZ, 2008, p.25). Com aproximações e percursos distintos, Mendieta e Matta-Clark também abordam de forma radical o estreitamento da relação arte-vida, expandindo o campo de atuação da arte contemporânea. A célebre afirmação de Oiticica "o museu é o mundo" (I966) 60 está em sintonia com a obra de seus contemporâneos Mendieta e Matta-Clark e reverberou nas obras da 27a. Bienal.

59 Nesse sentido as contaminações tiveram uma leitura mais sutil, ver capítulo 2.

60 ' $[. .$.$] inclusive pretendo estender o sentido de 'apropriação' às coisas do$ mundo com que deparo nas ruas [...] — isto seria um golpe fatal ao conceito de museu, galeria de arte etc., e ao próprio conceito de exposição — ou nós o modificamos ou continuamos na mesma. Museu é o mundo; é a experiência cotidiana” (Hélio Oiticica, I966). 
3.6. ANÁLISE GRÁFICA DA EXPOGRAFIA

3. Gordon Matta-Clark

4. Jane Alexander

5. Guy Tilim

6. Mauro Restiffe

7. Marepe

8. Meschac Gaba

9. Thomas Hirschhorn

10. Laura Lima

11. Marwan Rechmaoui

12. Marcellvs $L$.

13. Ivan Cardoso

14. Marcos Bonisson

15. Shaun Gladwell

16. Lars Ramberg

17. Nikos Charalambidis 


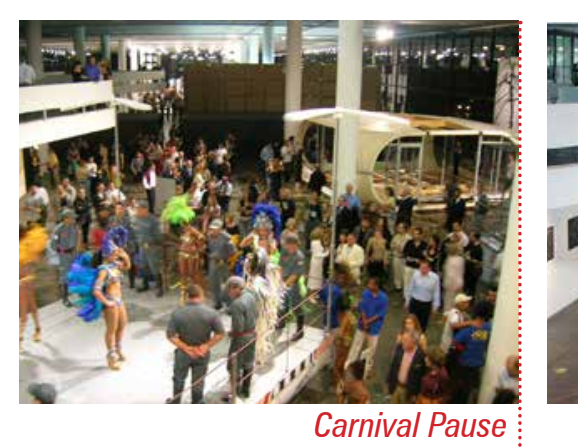

Nikos Chalarambidis

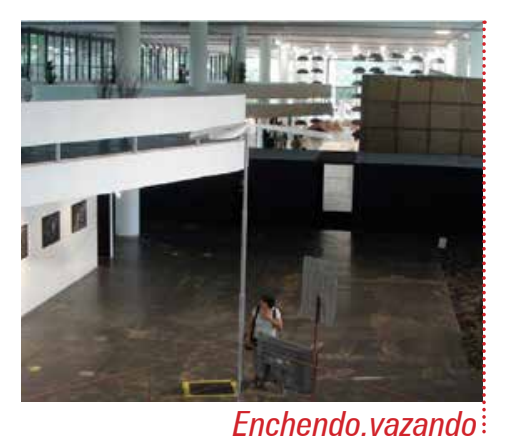

Marcellvs

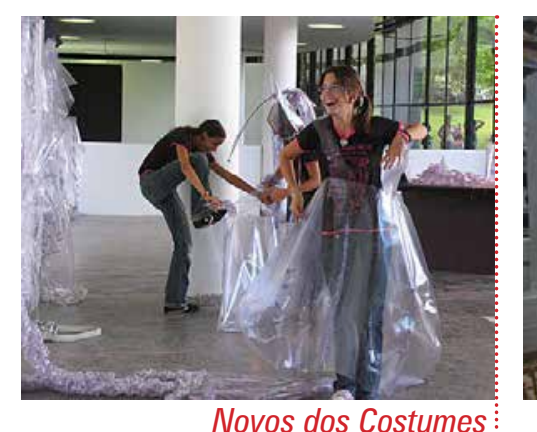

Laura Lima

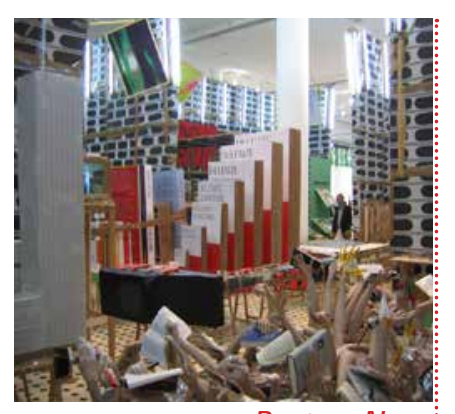

Restore Now

Thomas Hirschhorn

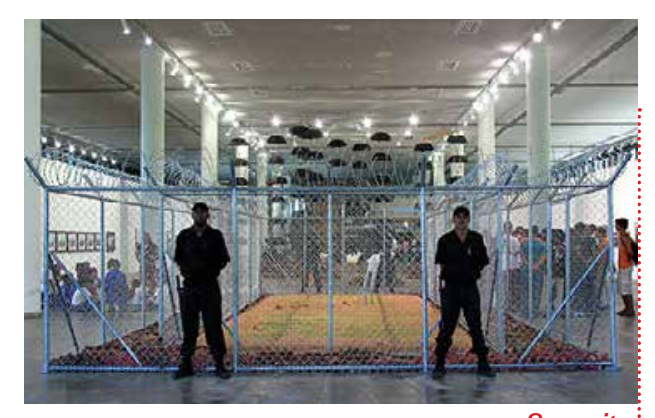

Security

Jane Alexander

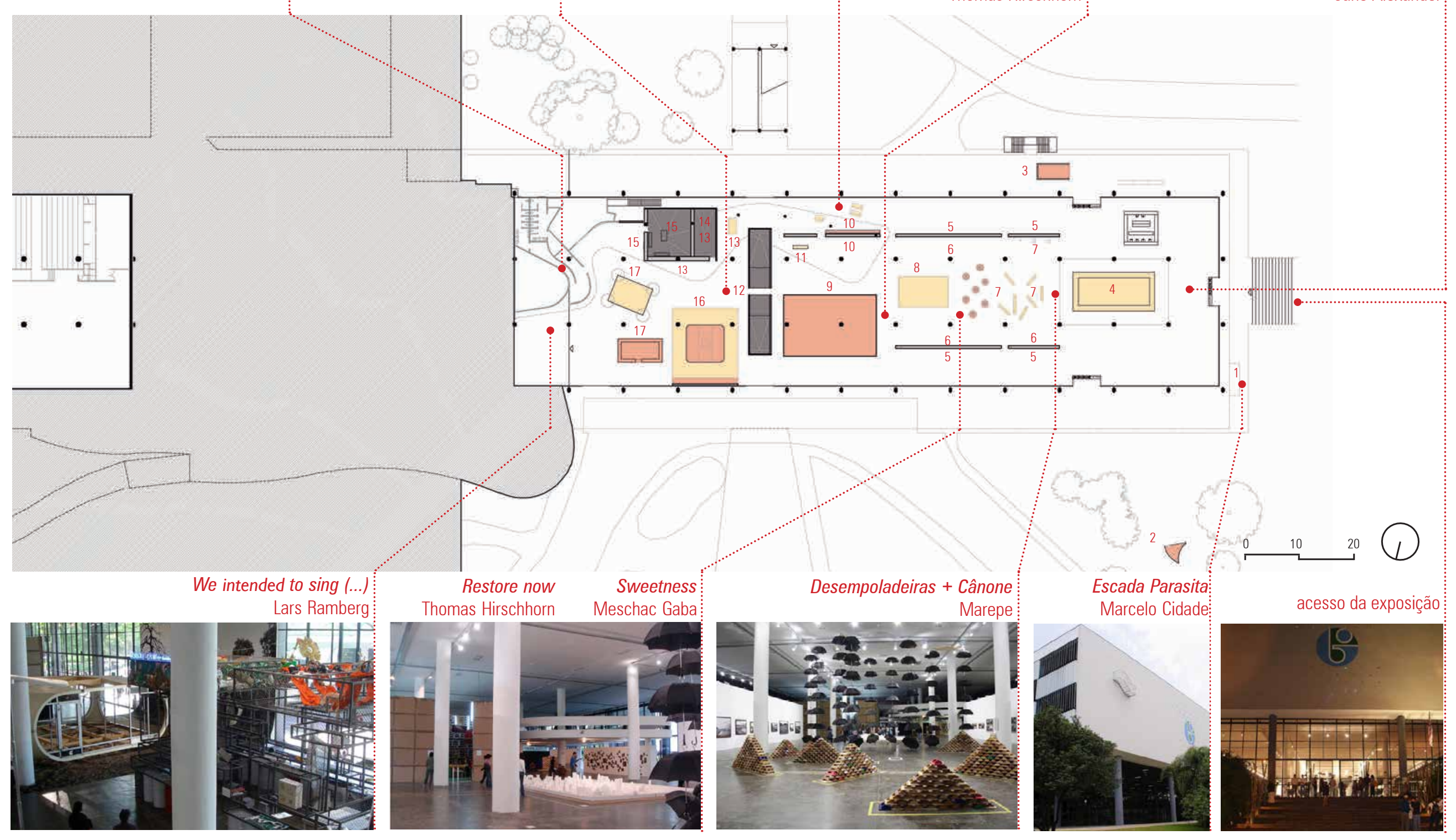




\section{LEGENDA}

instalação baixa

instalação alta

sala de projeção

sala fechada

piso elevado em MDF

ARTISTAS:

1. Lucia Koch / Hector Zamora

2. Zafos Xagoraris

3. Atelier Bow-Wow

4. Martinho Patrício

5. Wang Youshen

6. Paula Trope

7. Didier Faustino

8. Ann Lislegaard

9. Adel Abdessemed

10. Barbara Visser

11. Tomas Saraceno

12. Minerva Cuevas

13. Servet Koçyigit

14. Shaun Gladwell

15. Lida Abdul

16. Esra Ersen

17. Eloisa Cartoneira

18. Jane Alexander

19. Félix Gonzalez-Torres

20. Damián Ortega

21. JAMAC 


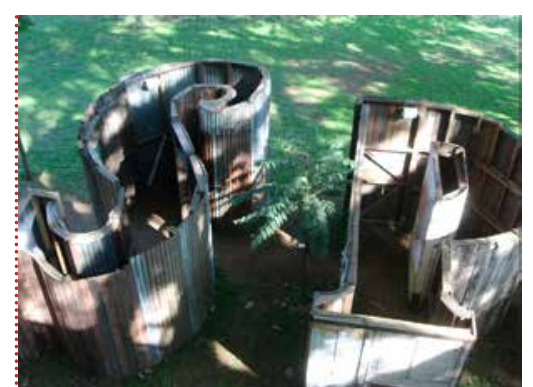

Spirit and Matter

Damián Ortega

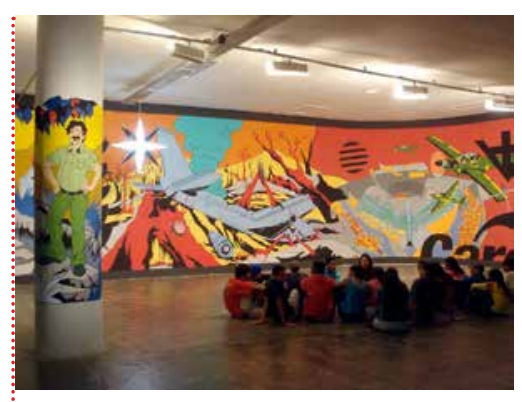

Terra primitiva

Minerva Cuevas

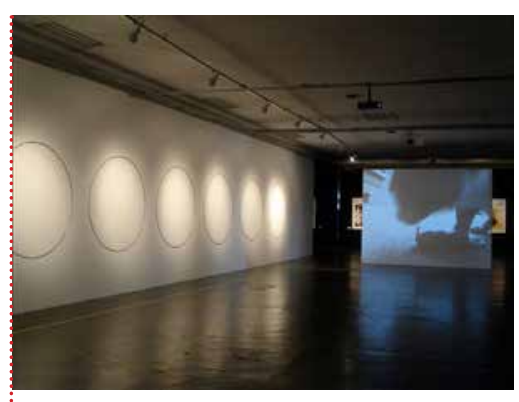

Wall drawing/ Birth of love Adel Abdessemed

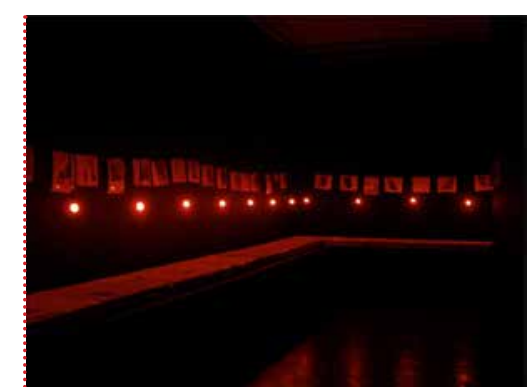

Dark room

Wang Youshen

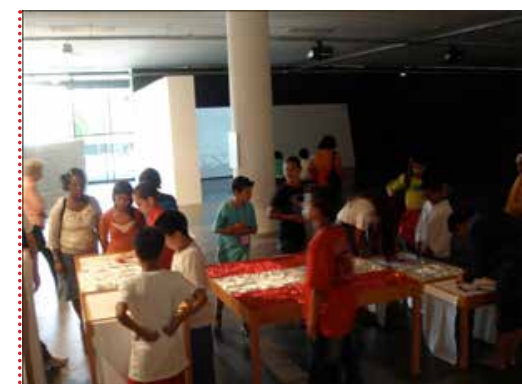

Brincar com Lygia

Martinho Patrício

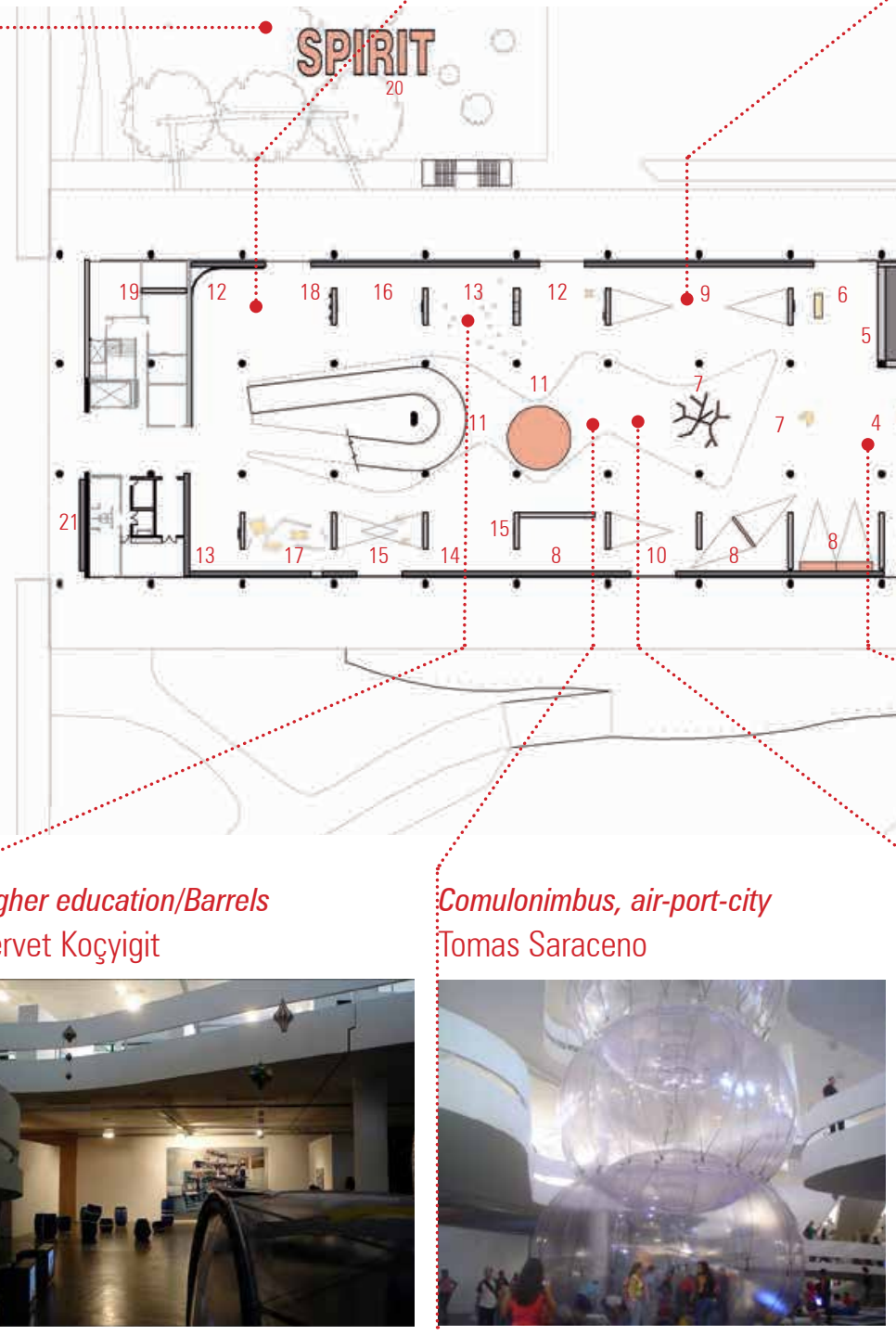

Racine du Mal

Didier Faustino

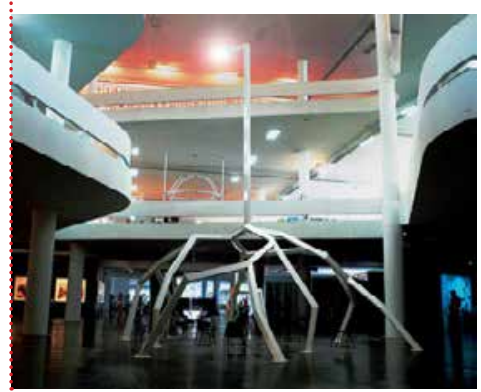

Washed photographs

Wang Youshen

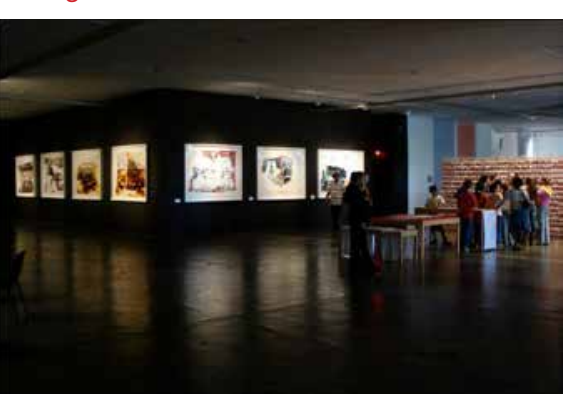

Uma boa ordem

Lucia Koch / Hector Zamora

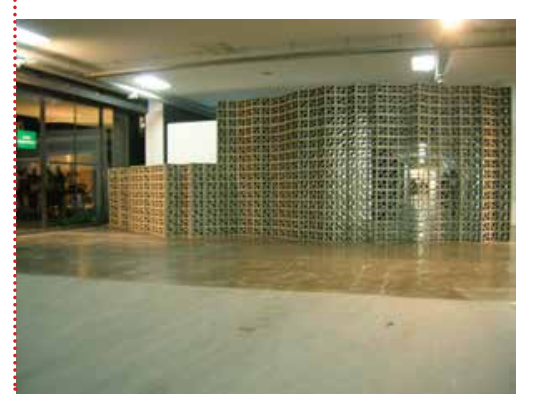


1 Ola Pehrson

15 Goshka Macuga

2 Atelier Bow-Wow

16 Marilá Dardot

3 León Ferrari

17 Mabe Bethônico

4 Ahlam Shibli

18 Tacita Dean

5 Héctor Zamora

19 Meschac Gaba

6 Lucia Koch

20 Haegue Yang

7 Felix Gonzalez-Torres

21 Rirkrit Tiravanija

8 Randa Saath

22 Juan Araujo 


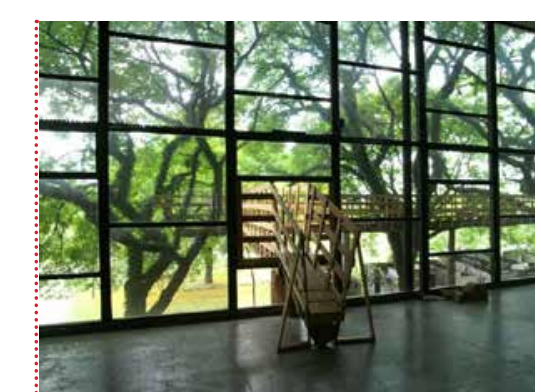

Monkey way

Atelier Bow-Wow

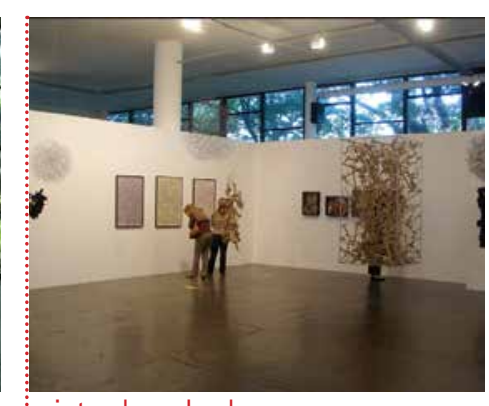

vista da sala de

León Ferrari

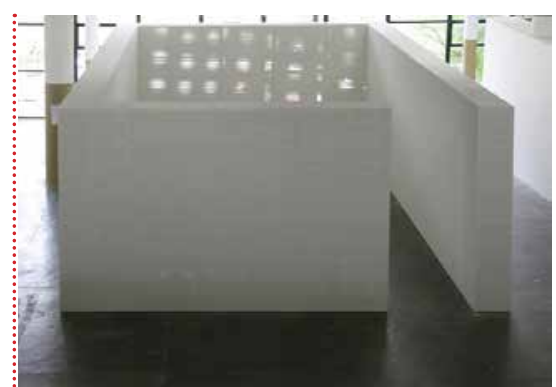

Sala de Exposição

Lucia Koch

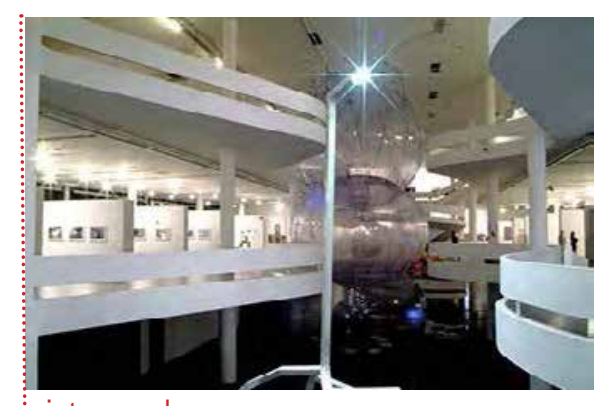

vista geral

do pavimento

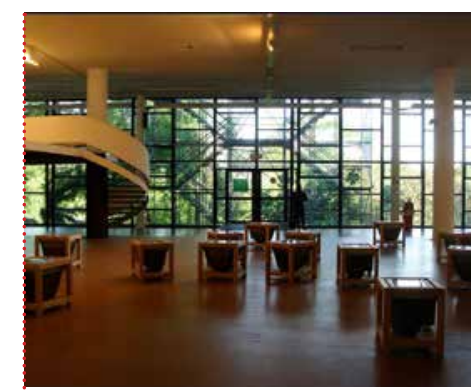

Entre nós

Marilá Dardot

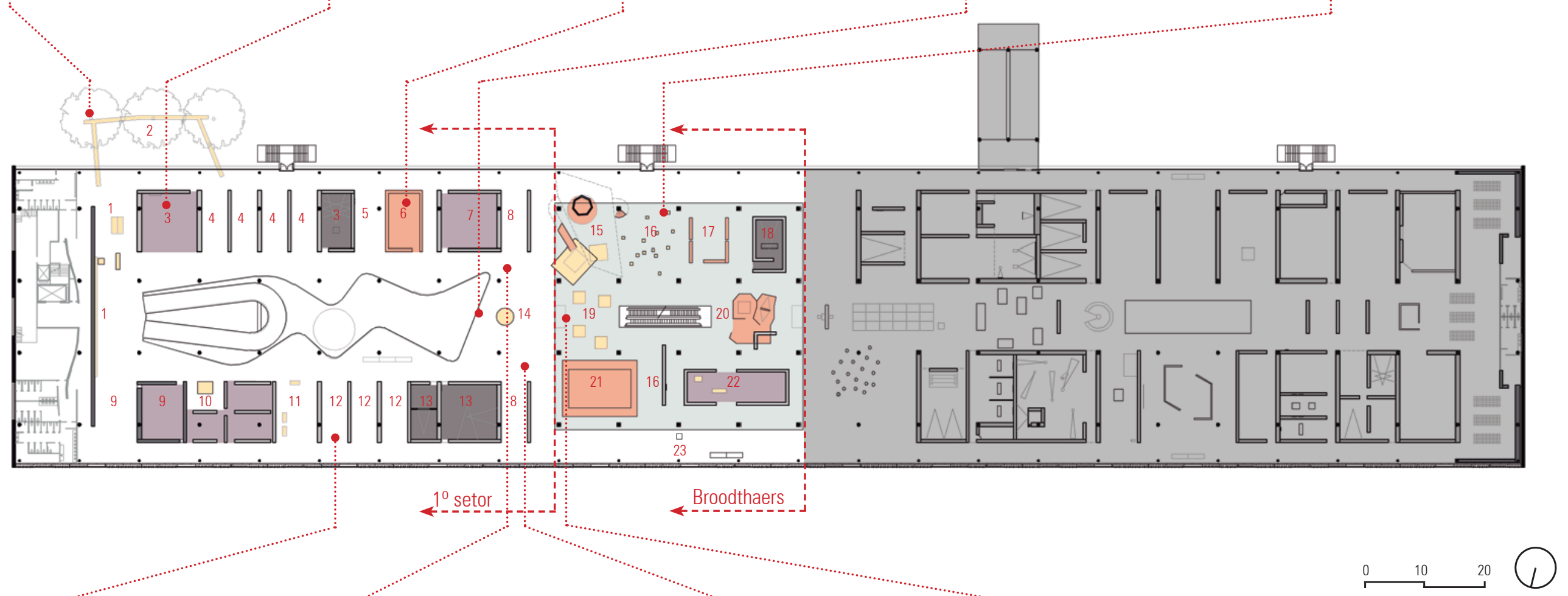

Vista do espaço de

Miki Kratsman

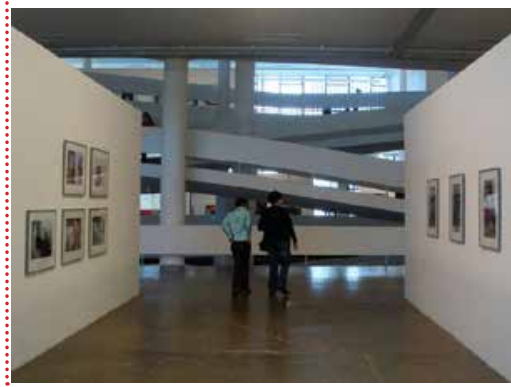

vista geral

do pavimento

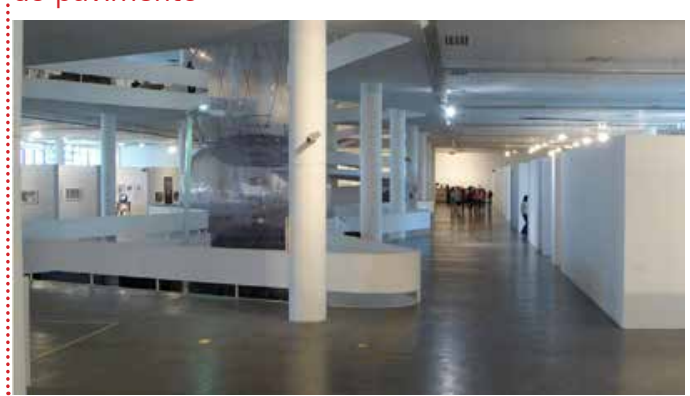

vista da

praça Broodthaers

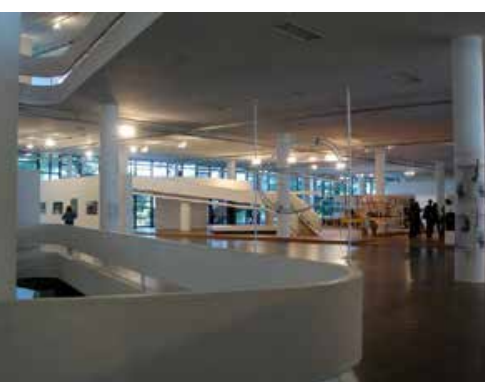

Museum Shop

Meschac Gaba

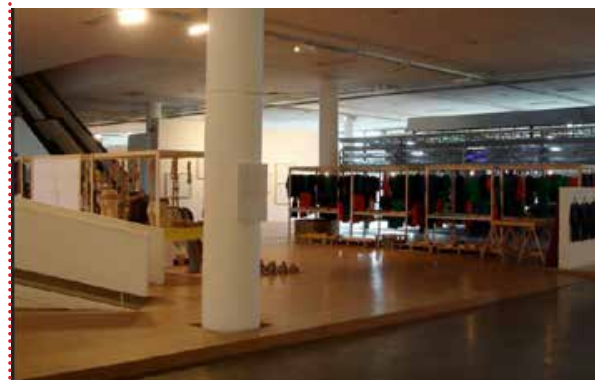


24 Mario Navarro

25 Fernando Ortega

26 Florian Pumhösl

27 Antal Lakner

28 Armando Andrade Tudela

29 Jeanne Faust

30 Diango Hernández

31 Damián Ortega

32 Martinho Patrício

33 Dominque Gonzalez-Foerster

34 Andrew McLeod

35 Michael Snow

36 Marcellvs
37 Gusmão e Paiva

38 Hélio Melo

39 Susan Turcot

40 Claudia Andujar

41 Alberto Baraya

42 Mantilla \& Chaves

43 Maria Galindo

44 Vladimir Arkhipov

45 Mustafa Maluka

46 Pepón Osório

47 Simons Evans

48 Kristina Solomoukha

49 Antoni Miralda 


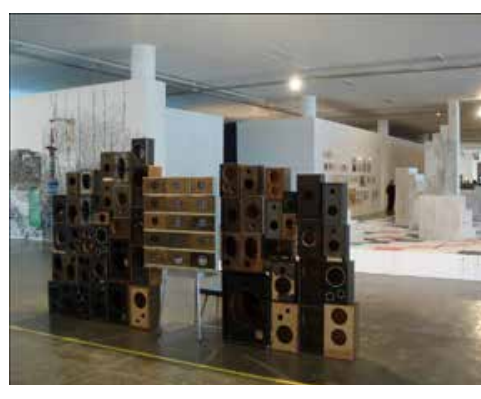

My birds don't want to come back Diango Hernández

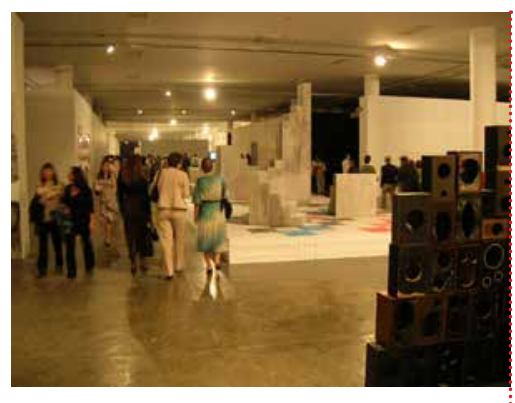

We are unfinished drawings Diango Hernández:

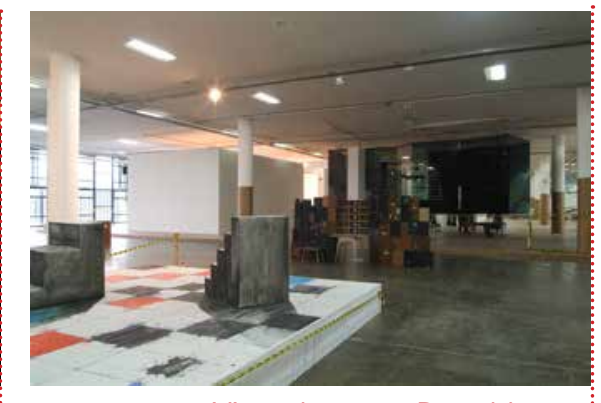

Vista da praça Broodthaers a partir do $2^{0}$ setor

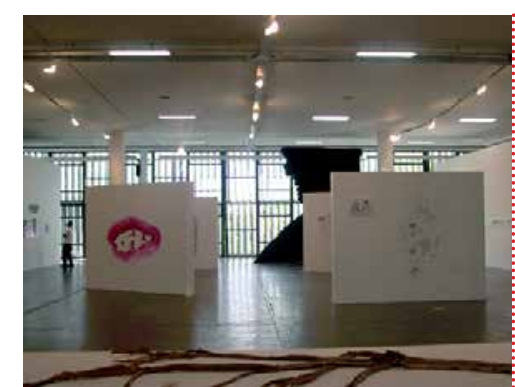

Dibujando América y (...) Brasil

Mantilla \& Chaves.

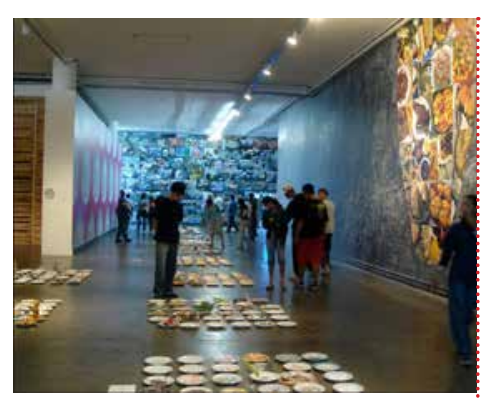

Sabores y Lenguas: Antoni Miralda

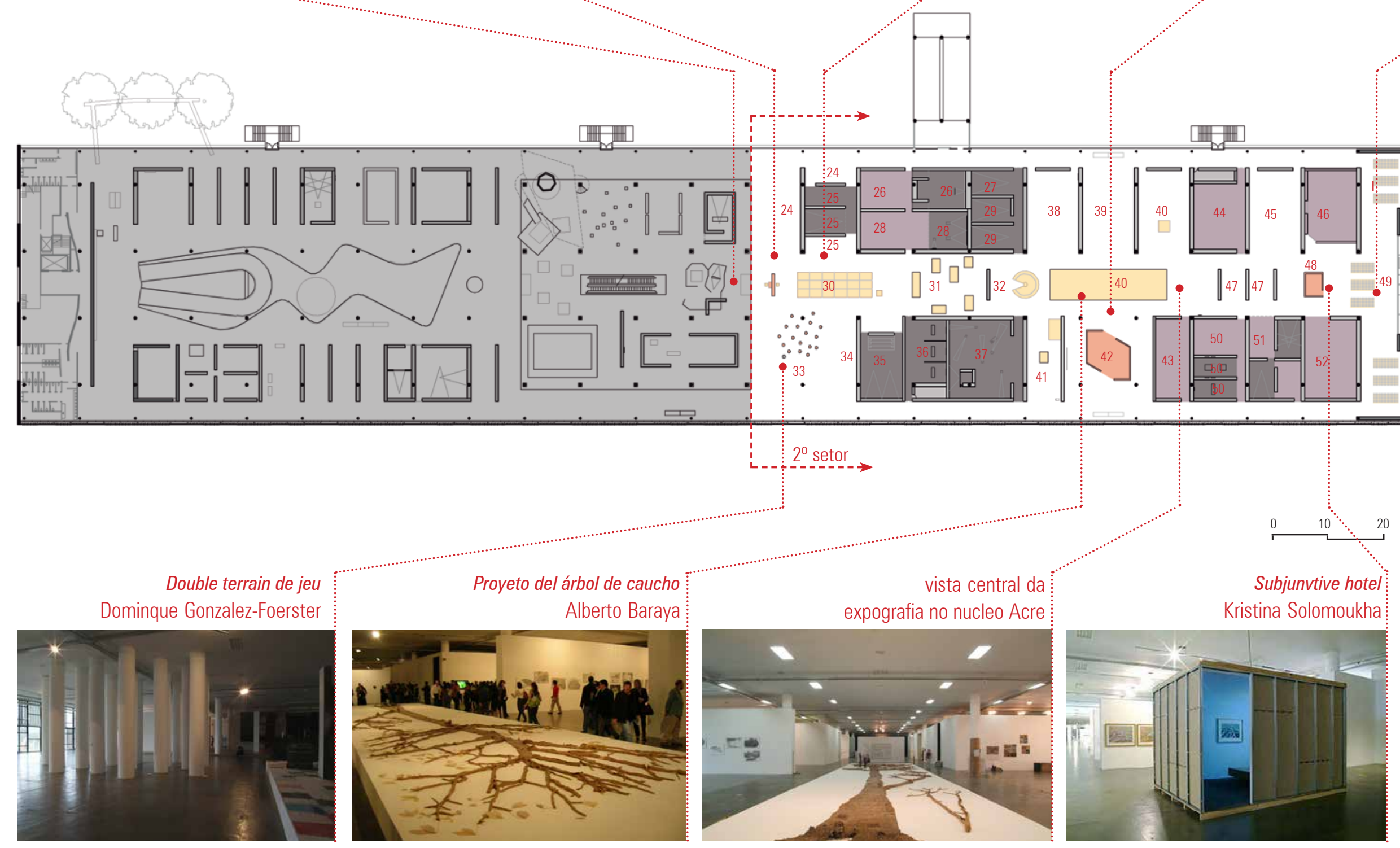


instalação baixa

instalação alta

sala de projeção

sala fechada

piso elevado em MDF

ARTISTAS ÉDEN:

1 Mauro Restiffe

2 Jarbas Lopes

3 Jarbas Lopes e Lucia Koch

4 Tadej Pogcar

5 Young-Hae Chang

6 Monica Bonvicini

7 Loulou Cherinet

8 María Terese Hincapié

9 Long March Foundation

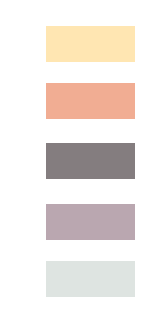

10 Pieter Hugo

11 Lara Almarcegui

12 Francesco Jodice

13 Sanghee Song

14 Shimabuku

15 Antal Lakner

16 Renata Lucas

17 Brendon Wlkinson

ARTISTAS CLIMATIZADO

18 Marjetica Potrč

19 Dan Graham

20 Vangelis Vlahos

21 Gordon Matta-Clark

22 Lu Chunsheng

23 Haegue Yang

24 Marcel Broodthaers

25 Mark Bradford

26 SuperFlex

27 Lucia Koch

28 Barbara Visser

29 Virginia de Medeiros

30 Bregtje van der Haak

31 Ana Mendieta

32 Lars Ramberg

33 Grönlund \& Nisunen

34 Marcelo Cidade 


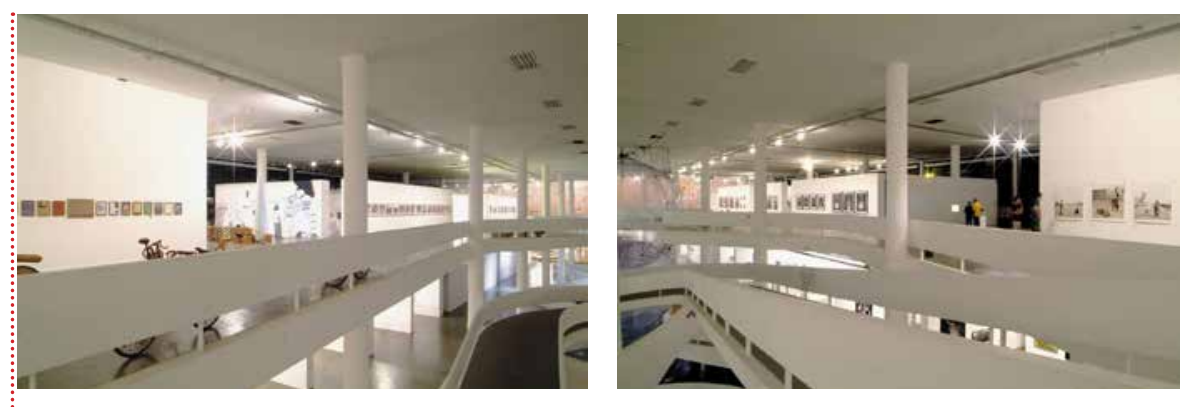

vista geral do $3^{0}$ pavimento

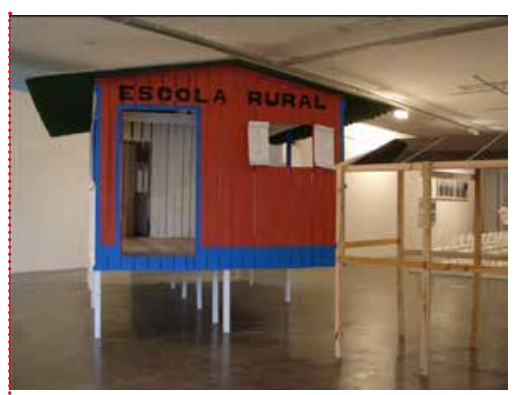

Xapuri: Rural school

Marjetica Potrč

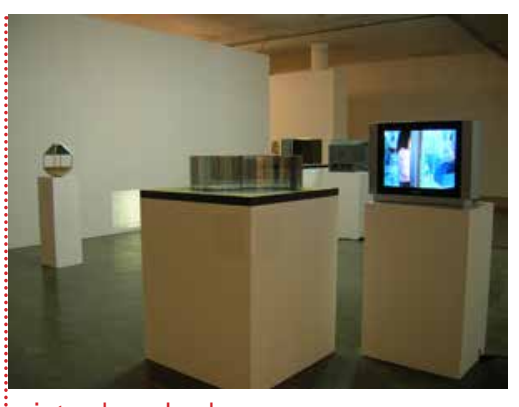

vista da sala de

Dan Graham

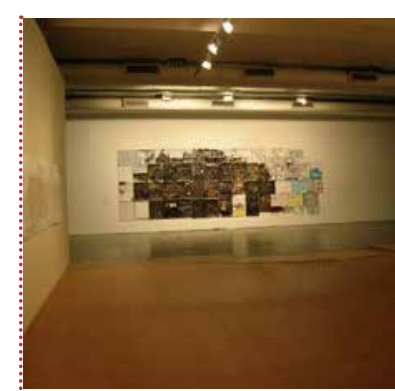

Rindin' Dirty

Mark Bradford

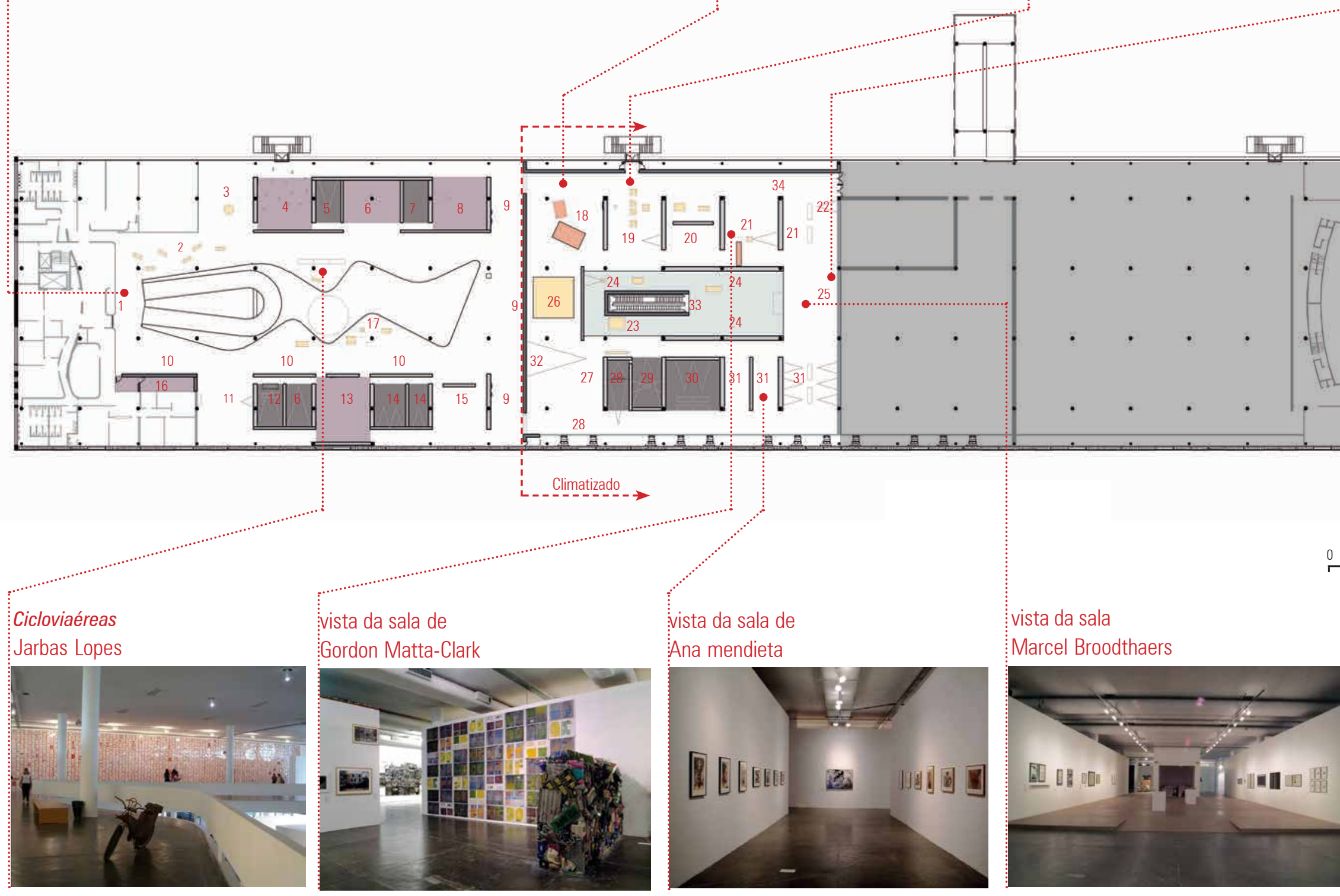


A intenção dessa dissertação foi entender como as relações interdisciplinares entre arte, curadoria, expografia e arquitetura se deram no espaço do Pavilhão Ciccillo Matarazzo na 27a. Bienal de São Paulo. A análise da mostra se deu a partir da reconstituição de um percurso pelo espaço expositivo evidenciando os vínculos criados entre as partes.

Atualmente, projetar expografias de bienais é uma atividade que se desenvolve na interface arte-arquitetura e se insere nas exposições em diálogo direto com o projeto curatorial e com as obras de arte. O histórico sobre as Bienais de São Paulo revelou que a expografia ganhou força como projeto de arquitetura após o surgimento da figura do curador geral na I6a. Bienal, em i98I, que passa a construir uma narrativa que se sobrepõe às representações nacionais. Nesse momento, há uma mudança no papel do arquiteto, que deixa de ser responsável pela setorização do edifício e começa a conceber uma espacialização da narrativa curatorial. Mais do que isso, o projeto expográfico pode ser agente para a construção de críticas contundentes à arte, como aconteceu na Grande Tela da I8a. Bienal de Sheila Leirner ou nas contaminações da 24a. Bienal de Paulo Herkenhoff. Após 2006, com o fim das representações nacionais e a adoção do modelo de curadoria discursiva, as expografias das Bienais que se sucederam consolidaram o caráter interdisciplinar e propositivo.

A 27a. Bienal foi uma mostra que transformou a estrutura da Bienal de São Paulo. Lisette Lagnado retomou e deu continuidade às propostas da 24a. Bienal, que aproximavam a exposição do modelo discursivo de Kassel. As inovações implementadas vinham no sentido de desfazer o caráter espetacular da Bienal e de ampliar a abrangência das discussões através dos seminários e do projeto educativo. No entanto, se por um lado as medidas tenham sido um avanço no sentido de democratizar o acesso ao evento, por outro aproximou a Bienal de São Paulo do sistema global das artes, que mantém a hierarquia ditada pelo ocidente, no qual o poder econômico impõe regras.

No que diz respeito à expografia da 27a. Bienal, a análise das características do Pavilhão da Bienal feita pela arquiteta Marta Bogéa foi essencial para propor uma arquitetura temporária que se evidenciasse como tal e estabelecesse diálogos com o espaço, reiterando suas qualidades. Assim, o novo acesso proposto no térreo reforçou o caráter longitudinal do edifício, evitando a cisão que o usual acesso pela marquise gerava. No primeiro pavimento, o projeto valorizou a interioridade, fechando os caixilhos e criando um ambiente sem luz natural. No segundo pavimento, a expografia buscou valorizar a grande dimensão da laje em planta livre e as relações de transparência com o parque e o pavilhão por meio da inserção de painéis transversais. A praça Broodthaers, com um piso elevado em madeira, deu um caráter singular a um núcleo que se organizou em dois pavimentos com conexão pelas escadas rolantes, sem romper com a espacialidade do segundo pavimento — único lugar de onde se podia visualizar a 
extensão total do edifício sem interferências visuais. O terceiro pavimento se dividiu em dois espaços com características muitos distintas: a área próxima ao vão, que seguiu o padrão de ocupação do segundo pavimento, e a área climatizada, onde a presença do pavilhão foi eliminada e se construiu uma grande sala hermética, cujo centro era a sala Broodthaers. $\mathrm{O}$ caráter simbólico e monumental do pavilhão teve uma forte presença na 27a. Bienal e reverberou em diversas obras de arte que dialogaram com o edifício.

Buscou-se aqui uma imersão na mostra dando ênfase às relações interdisciplinares. Nessa análise, verifica-se que os espaços em que o encontro interdisciplinar se deu de forma fértil e que, portanto, espacializaram de maneira bem-sucedida a narrativa curatorial foram o acesso, o primeiro pavimento e a praça Broodthears.

No acesso, a proposta da expografia convidava o público a entrar na exposição de forma fluida através da abertura de três portas, configurando uma praça de acolhimento. Os curadores inseriram no centro dessa praça a obra Security, de Alexander, que introduziu ao visitante o forte viés político do statement curatorial ao abordar questões em torno da segregação racial, das fronteiras e da colonização. A implantação da obra que criava um bloqueio com seguranças uniformizados e arame farpado revelou-se uma estratégia da curadoria que, a partir da inserção de instalações artísticas em certos locais, evidenciou espacialmente as tensões do viver junto.
A configuração do acesso na 27a. Bienal se deu também pela implantação de trabalhos na área externa, no Parque Ibirapuera. As obras selecionadas para fazer a introdução e estruturar o conceito da mostra foram três: Dumpster Duplex, de Matta-Clark,__uma caçamba de lixo onde o artista morou e na qual realizou diversas performances — foi um trabalho fundamental para a compreensão da aproximação da proposta de Lagnado com a obra de Hélio Oiticica; Homenagem a Vilanova Artigas, de Dan Graham, por sua vez, evocou o caráter lúdico de Crelazer de Oiticica assim como o eixo construtivo e arquitetônico da mostra; e Escada parasita, de Marcelo Cidade,__ que configurou uma contaminação de um jovem artista entre artistas consagrados — criticou o funcionalismo da arquitetura e questionou o Pavilhão da Bienal.

O projeto expográfico do primeiro pavimento trouxe uma proposta inovadora que valorizou o edifício e solucionou o problema das muitas salas de vídeo presentes neste núcleo. Ao vedar as fachadas, a verticalidade do vão foi acentuada e o espaço de luz controlada resultante possibilitou que os vídeos fossem dispostos em um grande espaço aberto - a proposta demandou um trabalho de articulação entre arquiteta, curadores e artistas. O projeto resultante possibilitou um percurso mais fluido, um diálogo mais claro entre obras que constituíam a narrativa curatorial, e uma relação das obras com o ambiente interior do pavilhão. 
A praça Broodthaers configurou uma micronarrativa dentro da mostra. A proposta expográfica respondeu às demandas dos curadores de forma efetiva. O uso do piso elevado em madeira conferiu singularidade e identidade ao núcleo, deixando manifesta a relação entre as suas duas partes no segundo e terceiro pavimentos. As demais obras da praça, em sua maioria instalações, construíram diálogos com as obras de Broodthaers, entre si e com o pavilhão. No segundo pavimento, a praça foi um elemento fundamental para a edição da grande laje e criou uma referência na continuidade do espaço sem configurar barreiras físicas. A praça quebrou o padrão regular dos painéis expográficos e do vazio central. Essa exceção valorizou o partido expográfico desse pavimento. $\mathrm{Na}$ escala do pavilhão seria insustentável a repetição de um mesmo sistema expositivo de forma modulada continuamente.

$\mathrm{Na}$ relação entre expografia e curadoria na 27a. Bienal houve tanto momentos de consonância entre partidos quanto de opsição, que se revelaram com clareza no espaço. A praça Broodthaers, a área climatizada e o primeiro pavimento são exemplos de uma proposta afinada entre os diferentes interlocutores, em que a narrativa curatorial se confirmou. As áreas de embate resultaram, em alguns casos, em espaços complexos que ratificaram o conceito curatorial, como ocorreu no térreo, onde a inserção de instalações contradizia a lógica espacial de fluxo contínuo. As obras se transformaram em barreiras que estabeleciam intencionalmente zonas de tensão. Além da obra de Alexander no acolhimento, a obra Restore Now, de Hirshhorn, foi inserida no final das duas linhas paralelas de painéis que evidenciavam o fluxo longitudinal, interrompendo a continuidade do espaço com uma imensa obra imersiva. Em outros casos, os conflitos tiveram resultado negativo para o projeto e dificultaram a leitura da narrativa e das obras, como no caso do segundo trecho do segundo pavimento cuja compreensão foi comprometida pelo excesso de salas.

Lagnado defendeu a diretriz curatorial do viver junto como manter a justa distância, a partir da leitura de Jacques Rancière e Roland Barthes: "Uma partilha do sensível fixa portanto, ao mesmo tempo, um comum compartilhado e parte exclusivas" (RANCIÈRE apud LAGNADO, 2006a, p.59). No entanto, essa proposta não se resolveu de forma plena no espaço. Havia uma contradição entre os conceitos defendidos pela curadoria de porosidade/contaminação e a seleção de obras que exigia muitas salas de vídeos e pequenas retrospectivas de todos os artistas. A exposição do percurso individual de cada artista favoreceu a defesa da construção de espaços isolados, salientando a relação entre as obras de um mesmo autor. Em muitas situações as narrativas individuais, em grande parte setorizadas, dificultaram a leitura das relações entre as obras e a grande narrativa da mostra. Nesses casos, as partes exclusivas ofuscaram o comum compartilhado. O excesso de salas de vídeos, apesar da mostra de filmes que ocorreu em um cinema, também foi um problema para a 
expografia, gerando um loteamento do espaço e, por consequência, prejudicando o acesso do público.

Nesse sentido, Herkenhoff fez uma leitura apurada ao reivindicar na $24 \mathrm{a}$. Bienal o fim da prática de reservar uma sala a cada artista (ou país), usual no modelo das representações nacionais. A partir desse controle do espaço, foi possível construir uma mostra na qual os trabalhos criaram diálogos entre si, o pavilhão foi evidenciado e a narrativa curatorial pôde ser apreendida com nitidez.

Apesar de possuir um projeto curatorial e expográfico consistentes, a construção da narrativa curatorial na 27 a. Bienal foi muitas vezes prejudicada por uma falta de articulação e objetividade na materialização do discurso no espaço. A proposta de curadoria coletiva, uma experiência do viver junto, contribuiu para a dificuldade de se alcançar o consenso, o que na mostra se apresentou como falta de compreensibilidade. Acrescente-se a isso a imprevisibilidade que há em uma mostra com grande volume de obras site specific. Para uma construção narrativa potente é necessária uma afinação profunda na relação arquitetura e curadoria, que ocorreu em setores da mostra conforme descrevemos nessa investigação.

Buscamos, com essa pesquisa, demonstrar que a conformação da 27a. Bienal no espaço explicitou as relações entre arquitetura, expografia, curadoria e arte contemporânea - inclusive seus conflitos e contradições. Relação que se iniciou no momento em que o partido do projeto expográfico foi concebido junto com o desenvolvimento do próprio projeto curatorial. Essa decisão possibilitou uma consonância de elementos chave como fluxo, acesso, configuração de núcleos, e diálogo como o pavilhão.

Apesar da expografia ter sido um amparo sereno às obras, conforme a proposta de Marta Bogéa de não conflitar espacialmente com os trabalhos de arte, ela pode ser lida e apreendida como um projeto autoral de arquitetura. Ao mesmo tempo, foi, e continua sendo, de grande relevância para a Bienal de São Paulo ao contribuir com um projeto de intervenção pensado a partir de uma leitura rigorosa do Pavilhão Ciccillo Matarazzo e ao apresentar soluções espaciais que evidenciaram a narrativa curatorial e os trabalhos exibidos. A leitura das expografias das Bienais que se sucederam à 27 a. Bienal demonstrou que houve uma transformação nos projetos, principalmente no que diz respeito à relação expografia-arquitetura, já que dali em diante as propostas passaram a buscar realizar leituras do pavilhão e se integrar ao parque.

Em muitos casos, uma suposta neutralidade da expografia faz com que sua autoria como projeto de arquitetura seja minimizada. Mas o discurso construído no espaço expositivo é parte fundamental das exposições de arte contemporânea. Embora seja na maioria dos casos negligenciada, a análise expográfica é um recurso fundamental para compreensão aprofundada de narrativa curatorial, sem a qual não é possível fazer a leitura crítica de uma exposição. 


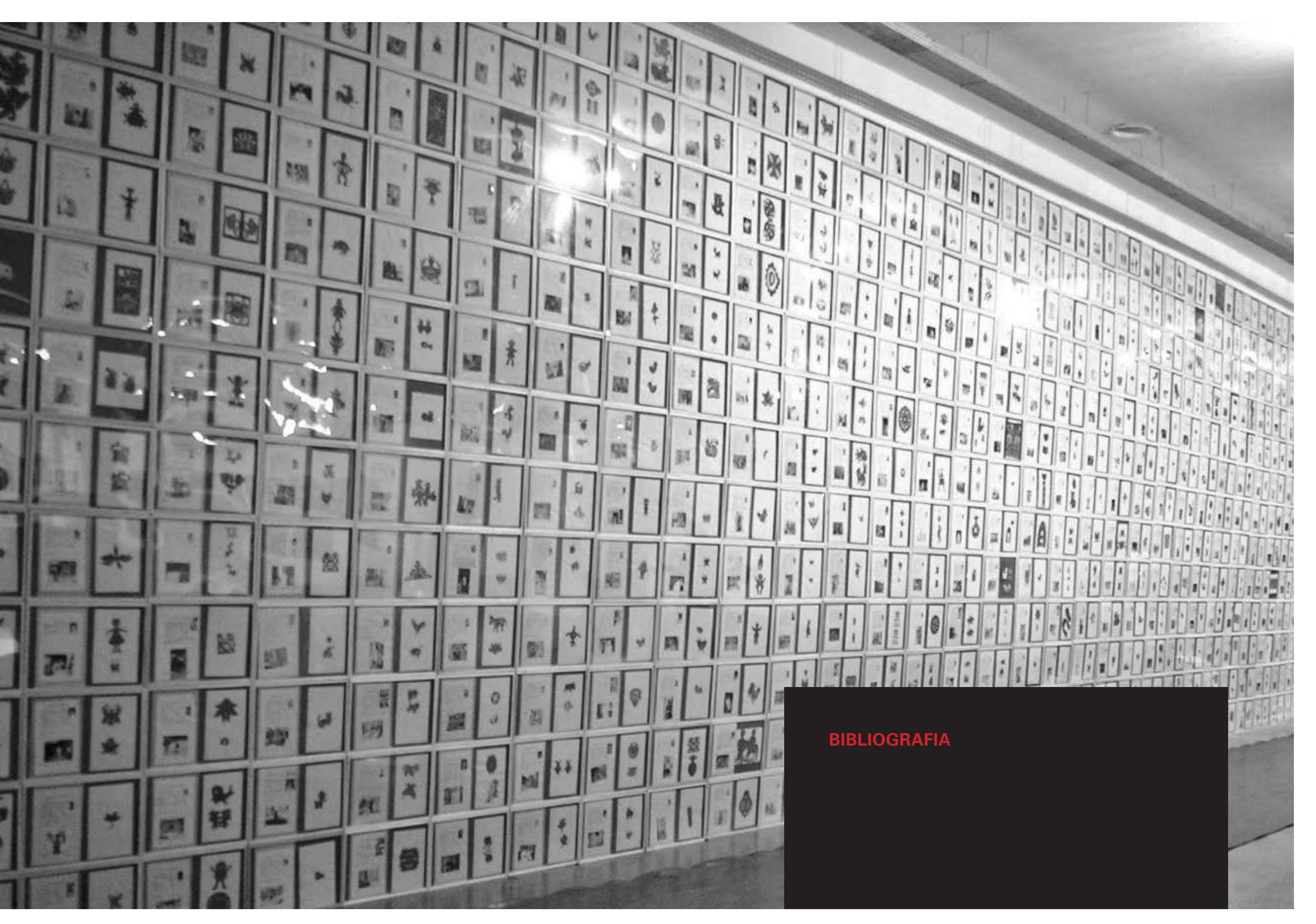


Acrópole, ano I6, n.I85, I954.

Acrópole, ano I6, n.193, I954.

ALAMBERT, Francisco; CANHETE, Polyana. As Bienais de São Paulo: da era dos museus à era dos curadores (2951-2002). São Paulo: Boi tempo,2004.

ALTSHULER, Bruce. Biennials and Beyond. Exhibitions That made Art History: 1962-2002. Phaidon Press, 2013.

AMARANTE, Leonor. As bienais de São Paulo 2952 a 2987 . São Paulo: Projeto, I989.

ANJOS, Moacir dos. As ruas e as bobagens: anotações sobre odelirium ambulatorium de Hélio Oiticica. ARS (São Paulo), São Paulo, v. Io, n. 20, p.22-45, Dec. 20I2. Disponível em: <http://www.scielo.br/scielo.php?script=sci_ arttext\&pid=SI678-532020I $2000200022 \& \operatorname{lng}=$ en\&nrm $=$ iso $>$. Acesso em 8/07/2017.

Lucia Koch. Rio de Janeiro: Aeroplano, 2009.

BARONE, Ana C. C. Ibirapuera: parque metropolitano (2926-1954). Tese de Doutorado, São Paulo, FAUUSP, 2007.

BARTHES, Roland. Como viver junto. Aulas e seminários no College de France (I976-I977). São Paulo, Martins Fontes, 2003.

BENEDETTI, Liliane; SPRICIGO, Vinicius. Relato sobre os quatro primeiros seminários. Disponível em: http://www. forumpermanente.org/event_pres/simp_sem/semin-bienal/ relato-dos-seminarios-da-27a-bienal. Acesso em: 03/I2/20I8.

BIRNBAUM, Daniel. Running on Empty: Daniel Birnbaum on the Art of Dominique Gonzalez-Foerster. Artforum International. nov, 2003. Disponível em: https://www.artforum.com/ inprint $/$ issue $=200309 \&$ id $=5684$. Acesso em 29/12/2017.
BISHOP, Claire. (2006a) Altos e baixos da Bienal. Entrevista concedida à Juliana Monachesi. Folha de São Paulo, ro de dezembro de 2006. Disponível em: <http://wwwi.folha.uol. com.br/fsp/mais/fsior 22006Io.htm>. Acesso em: 20/02/2018.

- (2006b) Social turn: collaboration and its discontents.

Artforum, fev-2006, p. I78-183.

. Antagonism and Relational Aesthetics. October, n. I Io, fall 2004 , p. $5 \mathrm{I}-80$.

- Antagonismo e estética relacional. Revista Tatuí I2, ano 20I2. p.Io9-I32. Disponível em: <https://issuu.com/tatui/ docs/tatui $2 / 7>$. Data de acesso: or/o8/2018.

BOGÉA, Marta. Deslocamentos acerca do cubo branco. Arquitexto vitruvius. Fev de 2007. Disponível em: < http://www. vitruvius.com.br/revistas/read/arquitextos/07.08I/272>. Acesso em: io de mar. 2018.

Entrevista: O território e a paisagem passam a fazer parte do interior do prédio. Uol entretenimento. Disponível em: <http:// entretenimento.uol.com.br/27bienal/ entrevistas/textos/ ult4026u8.jhtm>. 2006. Acesso em: OI/07/2017.

Sobre a construção de um arquipélogo. In: FARIAS, Agnaldo; ANJOS, Moacir dos. (org). Catálogo da 29a. Bienal de São Paulo: Há sempre um copo de mar para um homem navegar. São Paulo: Fundação Bienal de São Paulo, 20Io, p.4I2-42I.

Entrevista concedida à autora realizada dia 07/02/2018. Ver anexo I.

BONOMI, Maria. 50 anos Bienal, Bienal sempre. REVISTA USP, São Paulo, n.52, p.26-37, dezembro/fevereiro 200I-2002.

BOURRIAUD, Nicolas. Estética Relacional. Ia.edição. Buenos Aires: Adriana Hidalgo, editora, 2008. 
BRAGA, Paula. Relato da Palestra de Lisette Lagnado no seminário internacional Marcel, 30: A instituição sob suspeita. Data da conferência: 27/or/2006. Disponível em: <http:// forumpermanente.tangrama.com.br/event_pres/simp_sem/ semin-bienal/bienal-marcel/marcel $30-\mathrm{doc} / \mathrm{marcel}_{30}$ confo2 $>$. Acesso em: $02 / 10 / 2018$.

. Relato da Palestra de Marjetica Potrc no seminário internacional Arquitetura: Strategy of transition. Data da conferência: or/o4/2006. Disponível em: <http://www. forumpermanente.org/event_pres/simp_sem/semin-bienal/ bienal-arquitetura/arq-doc/arq-confo6a>. Acesso: 03/I2/20I8.

BRASIL, Ivi. Sob o mesmo teto. Cartaz. São Paulo. 26/I2/2006, p.34.

BREDFORD, Mark. Politics, Process and Postmodernism. Entrevista para art22. Setembro de 2007. Disponível em: $<$ https://art2 I.org/read/mark-bradford-politics-process-andpostmodernism/>. Acesso: $10 / 10 / 2018$.

BUCHHOLZ, Lara; WUGGENIG, Ulf. Cultural Globalization Between Myth and Reality: The Case of the Contemporary Visual Arts. ART-E-FACT, no.4. Disponível em: <http:// artefact.miz.hr/_ao4/lang_en/theory_buchholz_en.htm $>$. Acesso em: 17/Io/20I8.

CARRIER, David. Art museum as narrative. In: Museum skepticism: a history of the display of art in public galleries. Duke University Press Books, 2006, pp.9I-Io9.

CARrilho, Marcos. Problemas de conservação do conjunto arquitetônico do Parque Ibirapuera. Disponível em: <https:// periodicos.sbu.unicamp.br/ojs/index.php/parc/article/ viewFile/8634558/2479. Acesso em or/08/2017>. Acesso em: 05/05/2018. DOI: http://dx.doi.org/I0.11606/issn.21780447.ars.20I 2.644I8.
CARVALHO, Bernando. Arte, terceiro Setor. Folha de São Paulo, São Paulo, 24/10/2006, Ilustrada, Eıo.

CAUQUELIN, Anne. Arte contemporânea. Uma introdução. São Paulo: Martins Fontes, 2005.

CHIARELLI, TADEU. Mauro Restiffe e a desejada mas improvável eternidade da obra. 9 de março de 20I3. Disponível em:

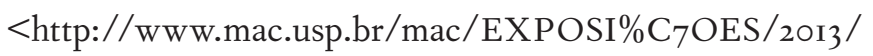
obra/home.htm>. Acesso em: OI/I2/2018.

COLI, Jorge. Vanguarda do tédio. Folha de São Paulo, São Paulo, I5/II/2006, Mais.

COLOMINA, Beatriz. Dupla Exposição: Alteração de uma casa suburbana (1978). In: LAGNADO, Lisette; PEDROSA, Adriano (orgs.). (2008a). 2Ja. Bienal de São Paulo: Seminários. Cobogó. Rio de Janeiro, 2008.

CORRULLON, Martin. Arquitetura, sociedade e arte. Bienais de Veneza e São Paulo. Vitruvius. Disponível em: http://www. vitruvius.com.br/revistas/read/arquitextos/07.077/308. Acesso em oI/07/2017.

CRAWFORD, Jane. Gordon Matta-Clark e a vida coletiva no SoHo durante os anos I970. In: LAGNADO, Lisette; PEDROSA, Adriano (orgs.). (2008a). 2Ja. Bienal de São Paulo: Seminários. Cobogó. Rio de Janeiro, 2008.

CYPRIANO, Fabio. (2005a). Curadores prometem crítica e política na Bienal o6. Folha de São Paulo, São Paulo, 29/07/2005, ilustrada, Eo4.

- (2005b). Bienal enxuga blocos e questiona a arte. Folha de São Paulo, São Paulo, I9/I2/2005, ilustrada.

. Bienal começa hoje com elogio de curadores. Folha de São Paulo, São Paulo, o7/ı/2006, ilustrada, Eı。. 
Bienal enxuga blocos e questiona arte. Folha de São Paulo, São Paulo, I6/I2/2006, ilustrada, E04.

Como viver junto: a bienal que reconfigurou a instituição. In: CYPRIANO, Fabio; OLIVEIRA, Mirtes Marins de (orgs) História das exposições. Casos exemplares. São Paulo: EDUC, 20I6, p.I5I-176. 176 p.

CYPRIANO, Fabio; OLIVEIRA, Mirtes Marins de (orgs). História das exposições. Casos exemplares. São Paulo: EDUC, $2016.176 \mathrm{p}$.

ESCHE, Charles. Making art Global. p.8-I3. In AFTER ALL: Making Art Global (Part 2): The Third Havana Biennial 1989. Bard College. Londres, 20 I.

FARIAS, Agnaldo (org). 5o anos Bienal de São Paulo: 1951-200z. Fundação Bienal de São Paulo. São Paulo, 200ı.

FARIAS, Agnaldo; ANJOS, Moacir dos. (org). Catálogo da $29 a$. Bienal de São Paulo: Há sempre um copo de mar para um homem navegar. São Paulo: Fundação Bienal de São Paulo, 20 ı.

FAVARETTO, Celso. 60/70: Viver a arte, inventar a vida. In: LAGNADO, Lisette; PEDROSA, Adriano (orgs.). (2008a). 2Ja. Bienal de São Paulo: Seminários. Cobogó. Rio de Janeiro, 2008.

Leituras de Hélio Oiticica. Entrevista grupo de pesquisa HO (FASM). Marcelina. Revista do mestrado em Artes Visuais da Faculdade Santa Marcelina. Ano 2, V.3 (2 sem. 2009) São Paulo, 2009.

FIALHO, Ana Letícia. Relato da palestra de Nicolas Bourriaud, Seminário Internacional Trocas, io de outubro de 2006. Fórum permanente. Disponível em: http://forumpermanente.tangrama. com.br/event_pres/simp_sem/semin-bienal/bienal-trocas/ trocas-doc/copy_of_confi. Acesso em: I5/Io/20I8.
FILIPOVIC, Elena. The Global white cube. Issue 22. Abril, 2014, p45-63. Disponível em:http://www.on-curating.org/ issue-22-43/the-global-white-cube.html\#.WW Eu6ojyvIU. Acesso em $08 / 07 / 2017$.

FOSTER, Hal. O Retorno do real. São Paulo: Cosac Naify, 20I 4.

FOWLE, Kate. Who cares? Understanding the role of the curator today. In: RAND, Steven e KOURIS, Heather (ed.). Cautionary tales: critical curating. New York: Apexart, 2007, pp.26-35.

FREIRE, Cristina. Contexturas: Sobre artistas e/ou antropólogos. In: LAGNADO, Lisette; PEDROSA, Adriano (orgs.). (2006a). 2Ja. Bienal de São Paulo: Como viver junto. Catálogo. Fundação Bienal. São Paulo, 2006, I07-II5.

Reconstrução: introdução. In: LAGNADO, Lisette; PEDROSA, Adriano (orgs.). 2Ja. Bienal de São Paulo: Seminários. Cobogó. Rio de Janeiro, 2008, p.I75-I8I.

GARCES, Paulo. Anais do Museu Paulista. São Paulo. N. Sér. v. 6/7. p.9-36 (I998-1999). Editado em 2003.

GIL, Gilberto. Apresentação. In: (2006a). 2Ja. Bienal de São Paulo: Como viver junto. Catálogo. Fundação Bienal. São Paulo, 2006, p.II.

GOIA, Mario. Modelo da Bienal vive crise. Folha de São Paulo, São Paulo, I6/I2/2006, ilustrada, Eo4

GRAHAM, Dan. Entrevista. In: LAGNADO, Lisette; PEDROSA, Adriano (orgs.). (2006b). 2Ja. Bienal de São Paulo: Como viver junto. Guia. Fundação Bienal. São Paulo, 2006, p.56.

GREENBERG, Reesa; FERGUNSON, Bruce; NAIRNE, Sandy. Think about Exhibition. USA, 1997.

GURIAN, Eduardo Pereira. Marquise do Ibirapuera: suporte ao uso indeterminado. Dissertação de Mestrado. São Paulo, FAUUSP, 2014 
Habitat, ano III, n.I I, Jun, I953.

Habitat, ano IV, n.I6, mai jun, I954.

HARUM, Marcio. O cavalheiro do cine Shanghai. Revista trópico. Publicado em I 4.02.2009. Disponível em: <http://www. revistatropico.com.br/tropico/html/textos/3058, I.shl> acesso em o8 de fev de 2019.

HERKENHOFF, Paulo; PEDROSA, Adriano. (orgs). XXIV Bienal de São Paulo: Arte Contemporânea Brasileira: Um elentre Outro/s. Catálogo. São Paulo: Fundação Bienal, 1998.

XXIV Bienal de São Paulo: Núcleo Histórico: Antropofagia e Histórias de Canibalismos. Catálogo. São Paulo: Fundação Bienal, I998.

. Bienal de São Paulo: Representações Nacionais. Catálogo. São Paulo: Fundação Bienal, I998.

XXIV Bienal de São Paulo: Roteiros. Roteiros. Roteiros. Roteiros. Roteiros. Roteiros. Roteiros. Catálogo. São Paulo: Fundação Bienal, I998.

HERKENHOFF, Paulo. (2008a) Bienal I998: princípios e processos. p.20-36. Marcelina. Revista do Mestrado em Artes Visuais da Faculdade Santa Marcelina. Ano i, V.I (I sem. 2008). São Paulo, 2008.

. (2008b) Fluxos desiguais. In: LAGNADO, Lisette; PEDROSA, Adriano (orgs.). 2Ja. Bienal de São Paulo: Seminários. Cobogó. Rio de Janeiro, 2008.

HINOJOSA, Lola. Open House. Disponível em: <http://www. museoreinasofia.es/en/collection/artwork/open-house. 2007>. Acesso em: 13/08/2018.
HIRSZMAN, Maria. Em Bienal bem morna, artistas vivem juntos, mas falam sozinhos. O Estado de São Paulo, 28/10/2006.

Caderno 2, D6.

JATRIK, SACAFATI, POSADAS. Entrevista. In: LAGNADO, Lisette; PEDROSA, Adriano (orgs.). (2006b). 2Ja. Bienal de São Paulo: Como viver junto. Guia. Fundação Bienal. São Paulo, 2006, p.234.

KRAUSS, Rosalind. A Voyage on The North Sea. Art in the Age of the Post-Medium Condition. Thames \& Hudson Inc. Nova Iorque-NY. Estados Unidos da America, 2000.

KUHNERT, Duda. Os subúrbios norte americanos de Dam Graham. Medium. Setembro de 2015. Disponível em: $<$ https://medium.com/revista-beira/os-sub\%C3\%BArbiosnorte-americanos-de-dan-graham-3be7163607b4 >. Acesso em: $15 / 10 / 2018$.

LAFUENTE, Pablo, LAGNADO, Lisette (orgs.). Cultural Anthropophagy: The 24th Bienal de São Paulo i998. Afterall, Bard College. Londres, 2015.

LAGNADO, Lisette(2005). Anteprojeto para a 27a. Bienal de artes de São Paulo. São Paulo, 2005. In: SEABRA, Jessica. Práticas curatoriais na 2Ja. Bienal de São Paulo: crítica institucional e discursividade. Orientador: Ruy Sardinha Lopes. São Carlos, 20I8. Dissertação de Mestrado Instituto de Arquitetura e Urbanismo, Universidade de São Paulo, 2018. . (2006a). No amor e na diversidade. In: LAGNADO, Lisette; PEDROSA, Adriano (orgs.). (2006). 2Ja. Bienal de São Paulo: Como viver junto. Catálogo. Fundação Bienal. São Paulo, 2006, p.53-60. 
(2006b). Entrevista ao fórum permanente por Fernando Oliva e Marcelo Rezende. Setembro de 2006. Disponível em: http://www.forumpermanente.org/revista/edicao-o/ entrevistas/lisette-lagnado-2 Acesso: I9/I2/20I8.

. (2006c). Lisette Lagnado: Para curadora, Bienal deve formar um espírito do tempo. Entrevista para UOL. São Paulo, 22/o9/2006. Disponível em: https://entretenimento. uol.com.br/27bienal/entrevistas/textos/ult4026u6.jhtm Acesso: 21/02/2017.

(2006d). Toda arte é política - Entrevistada a Fabio Cypriano. Folha de São Paulo, ilustrada, о / 1o/2006.

Disponível em: http://wwwi.folha.uol.com.br/fsp/ilustrad/ fqoII02006II.htm. Acesso oI/IO/2017.

(2006e). Folder do seminário Vida Coletiva. 04.08.2006.

Publicação: Fundação Bienal. São Paulo, 2006.

. (2007). Home and Homeland. About Ahalm Shibli's photo

series Eastern LGBT. Disponível em: http://www.ahlamshibli. com/essay/lisette_lagnado_home_and_homland.htm. Acesso em: 20/10/2018.

(2008a). De quem eu sou contemporâneo? In:

LAGNADO, Lisette; PEDROSA, Adriano (orgs.). (2008). 2Ja. Bienal de São Paulo: Seminários. Cobogó. Rio de Janeiro, 2008, p.97-105.

. (2008b). Vida Coletiva: introdução. In: LAGNADO, Lisette; PEDROSA, Adriano (orgs.). (2008a). 2Ja. Bienal de São Paulo: Seminários. Cobogó. Rio de Janeiro, 2008, p.227-23I.

(2008c). As tarefas do curador. Marcelina. Revista do mestrado em Artes Visuais da Faculdade Santa Marcelina. Ano I, V.I (I sem. 2008) São Paulo, 2008. p.8-I9.
(2015). Antropophagy as cultural Strategy: The 24th bienal de São Paulo. In: LAFUENTE, Pablo, LAGNADO, Lisette (orgs.). Cultural Anthropophagy: The 24th Bienal de São Paulo 2998. Afterall, Bard College. Londres, out de 2015, p.58-64.

LAGNADO, Lisette; PEDROSA, Adriano (orgs.). (2006a). $27 a$. Bienal de São Paulo: Como viver junto. Catálogo. Fundação Bienal. São Paulo, 2006.

. (2006b). 2Ja. Bienal de São Paulo: Como viver junto. Guia. Fundação Bienal. São Paulo, 2006.

. (2006g). Texto com uma breve apresentação dos artistas produzido por Lagnado e Pedrosa que ficava junto às obras para informar o público da mostra.

. (2008a). 2Ja. Bienal de São Paulo: Seminários. Cobogó. Rio de Janeiro, 2008.

MATOS, Diego Moreira. Curadores e arquitetos em diálogo: O Caso das Bienais Internacionais de 2981 a 2985. Dissertação de mestrado FAUUSP. Orientador Agnaldo Farias. São Paulo, 2009 .

MAYO, Nuria; Esche, Charles (orgs.) zıa. Bienal de São Paulo: Como (...) Coisas Que Não Existem. Catálogo. Fundação Bienal. São Paulo, 20I 4 .

MCCUTCHEON, Erin L. Incorporados: the Arts of Ana Mendieta. p.17-23. Elements: spring - 2005.

MEREWETHER, Charles. From Inscription to Dissolution: An Essay on Expenditure in the Work of Ana Mendieta. In: Ana Mendieta. MOURE, Gloria (Ed,). Número da edição. Local de Centra Galego de Arte Contemporanea, Barcelona: Ediciones Poligrafa, 1996. 
MESQUITA, Ivo; COHEN, Ana Paula. Guia da exposição $28 a$.

Bienal de São Paulo - Em vivo contato. Fundação Bienal. São Paulo, 2008.

MINDlin, Henrique E. Arquitetura Moderna no Brasil. Colibris. Rio de Janeiro, 1956.

Módulo, ano I, n.I, I955.

MONACHESI, Juliana. Altos e baixos da Bienal. Entrevista a Claire Bishop. Folha de São Paulo, Io de dezembro de 2006. Disponível em: <http://wwwi.folha.uol.com.br/fsp/mais/ fSIOI2 2006IO.htm>. Acesso: 20/02/2018. Acesso: 02/07/2018.

- Laura Lima costura relações sociais com obras para vestir. Folha de São Paulo, 17 de maio de 2003. Disponível em: <https://wwwi.folha.uol.com.br/fsp/acontece/ aci705200301.htm>. Acesso: 29/II/2018.

. Na mostra, ética eclipsou a estética. Folha de São Paulo, 2 de dezembro de 2006. Disponível em: <https://wwwi.folha.uol. com.br/fsp/ilustrad/fq02I22006I5.htm>. Acesso: 20/02/20I8.

NASCIMENTO, Ana Paula. Pesquisa de pós doutorado apresentada em aula ministrada no MAC-USP: Masp e $M A M(s)$. 04/05/2017.

O'DOHERTY, Brian. No interior do cubo branco: a ideologia do Espaço da Arte. São Paulo, Martins Fontes, 2002.

O’NEILL, Paul. Biennial culture and the emergence of a globalized curatorial discourse: curating in the context of biennials and large-scale exhibitions since I989. In: O'NEILL, Paul. The culture of curating and the curating of culture(s). Cambridge: MIT Press, 20I2, p.5I-85.

OKSMAN, Silvio. Contradições na Preservação da Arquitetura Moderna, Tese de Doutorado, São Paulo, FAUUSP, 2017.
OLIVEIRA, Mirtes Marins. Apropriação e montagem: melancolia e utopia. Revista Porto arte. Porto Alegre, V.I7, n.29, nov. 2010.

- Palestra: Arte e Histório: inflitrações em narrativas sobre a Bienal de São Paulo. Realizada na fundação Ema Klabin em 26 de Agosto de 2017.

PEDROSA, Adriano. Arquitetura: Introdução. In: LAGNADO, Lisette; PEDROSA, Adriano (orgs.). 2Ja. Bienal de São Paulo: Seminários. Cobogó. Rio de Janeiro, 2008.

. Como curar junto. In: LAGNADO, Lisette; PEDROSA, Adriano (orgs.). 2Ja. Bienal de São Paulo: Como viver junto. Catálogo. Fundação Bienal. São Paulo, 2006, p.8I-96.

QUEIROZ, Rodrigo (org.). Coleção Niemeyer: Os Desenhos Originais de Oscar Niemeyer. São Paulo. FAU USP/MAC USP. 2007.

RESTIFFE, Mauro. Mauro Restiffe: Quis criar uma tensão entre Brasília e Istambul. Entrevista para UOL. São Paulo, II/08/2006. Disponível em: https://entretenimento.uol.com. br/27bienal/entrevistas/textos/ult4026ur 2.jhtm Acesso: $2 \mathrm{I} / \mathrm{II} / 20 \mathrm{I} 8$.

REZENDE, Marcelo. Bienal ETC.: As coisas vistas todos os dias, 2006. Canal contemporâneo. Disponível em: <http:// www.canalcontemporaneo.art.br/arteemcirculacao/ archives/ooIoII.html> Acesso em 27/I2/2017.

ROCA, José. Acre: introdução. In: LAGNADO, Lisette; PEDROSA, Adriano (orgs.). (2008a). 2Ja. Bienal de São Paulo: Seminários. Cobogó. Rio de Janeiro, 2008, p.343-349.

. O Acre cabe todo em uma só árvore. In: LAGNADO, Lisette; PEDROSA, Adriano (orgs.). 2Ja. Bienal de São Paulo: Como viver junto. Catálogo. Fundação Bienal. São Paulo, 2006, p.I29-I37. 
ROCHA. Rafael Campos. Bienong - Ou como viver junto do jeito que eu quero. I 4 de novembro de 2006. Canal contemporâneo. Disponível em: http://www.canalcontemporaneo.art.br/ arteemcirculacao/archives/week_2006_II_I2.html. Acesso: 20/II/20I8.

SAGIV, OREN. Arquitetura. In: MAYO, Nuria; Esche, Charles (orgs.) 3za. Bienal de São Paulo: Como (...) Coisas Que Não Existem. Catálogo. Fundação Bienal. São Paulo, 20I4, p.215-225.

SALOMÃO, Wally. Hélio Oiticica qual é o parangolé e outros escritos. Rio de Janeiro: Rocco, 2003.

SCHUCK, Elena de Oliveira; GARCIA, Carolina Gallo. O feminismo de Ana Mendieta no campo das artes visuais. Anais do Seminário Internacional Fazendo Gênero 21 E 13 th Women's Worlds Congress (Anais Eletrônicos). Florianópolis, 2017, ISSN 2179-5IOX.

SEABRA, Jessica. Práticas curatoriais na 2Ja. Bienal de São Paulo: crítica institucional e discursividade. Orientador: Ruy Sardinha Lopes. São Carlos, 20ı8. Dissertação de mestrado Instituto de Arquitetura e Urbanismo, Universidade de São Paulo, 2018.

SPERLING, David. Corpo + Arte = Arquitetura. As proposições de Hélio Oiticica e Lygia Clark. In: BRAGA,Paula (org.). Seguindo fios soltos: caminhos na pesquisa sobre Hélio Oiticica. Edição especial da Revista do Fórum Permanente. editada por Martin Grossmann.

SPRICIGO, Vinicius. Relato de outra Modernidade: contribuições para uma reflexão crítica sobre a mediação da arte no contexto da globalização cultural. Tese doutorado, São Paulo, ECA-USP, 2009.

STANISZEWSKI, Mary Anne. A History of Exhibition Instalations at the Museum of Modern Art. Cambridge, Massachusetts/ Londres: The MIT Press, I998.
SUBIRÓ, Pep. Security (Surveys from the Cape of Good Hope). Exhibition at La Centrale Électrique, Brussels. Maio de 20I I. Disponível em: https://universes.art/en/magazine/ articles/20II/jane-alexander/. Acesso: ०8/o9/20I8.

VOLZ, Jochen. Marcel 3o: Introdução. In: LAGNADO, Lisette; PEDROSA, Adriano (orgs.). (2008a). 2Ja. Bienal de São Paulo: Seminários. Cobogó. Rio de Janeiro, 2008.

. Vida e ficção, realidade e arte. In: LAGNADO, Lisette; PEDROSA, Adriano (orgs.). 2Ja. Bienal de São Paulo: Como viver junto. Catálogo. Fundação Bienal. São Paulo, 2006.

W ILSON, Michael. Goshka Maguga. Artforum 2007. Disponível em: http://www.michaeljwilson.com/2007ArtforumMacuga. htm. A. Acesso: 27/12/2017.

WISNIK, Guilherme. A anarquitetura de Matta-Clark. Folha de São Paulo, 23 de outubro de 2006 . Ilustrada. Disponível em: https://wwwi.folha.uol.com.br/fsp/ilustrad/fq23I02006I I. htm. Data de acesso: 08/I2/20I8.

. O informe e a ponte truncada entre arte e arquitetura. In: LAGNADO, Lisette; PEDROSA, Adriano (orgs.). $27 a$. Bienal de São Paulo: Seminários. Cobogó. Rio de Janeiro, 2008, P.I55-I65. 


\section{ACESSOS NA INTERNET:}

http://bienal.org.br

http://biennialfoundation.org

http://cargocollective.com/didierfaustino/2006_Les-racines-du-mal

http://enciclopedia.itaucultural.org.br/

http://escoladacidade.org/bau/rubens-mano-o-espaco-enquanto-imagem-projetada-2/

http://g-n.fi

http://inhotim.org.br/inhotim/arte-contemporanea/obras/restore-now/

http://lislegaard.com/

http://oncurating-journal.de/

http://universes-in-universe.de/

http://www.artnexus.com

http://www.bow-wow.jp/

http://www.bv33.org/schede/22_vangelis/e-vangelis.html

http://www.dgf5.com/

http://www.forumpermanente.org/

https://tvuol.uol.com.br/video/27-bienal-de-sao-paulo--marcelo-cidade-04029 B316AC 4 CI $_{43} 66$

https://www.artgallery.nsw.gov.au/collection/works/I20.20I4/

https://www.e-flux.com/announcements/4I260/letter-from-former-curators-of-manifesta-6/

https://www.flickr.com/photos/mediachef/I39273236I/in/album-72157602047468467/

https://www.macba.cat/es/miralda

https://www.moma.org/

https://www.nunoramos.com.br

\section{PESQUISA:}

Arquivo Histórico Wanda Svevo / Fundação Bienal de São Paulo. 



\section{ANEXO 1: ENTREVISTA COM MARTA BOGÉA}

Entrevista concedida à autora pessoalmente no dia 07 de fevereiro de 2018

\section{Breve currículo da entrevistada}

Marta Bogéa é Arquiteta e Urbanista pela Universidade Federal do Espírito Santo (1987), mestre em Comunicação e Semiótica pela Pontifícia Universidade Católica de São Paulo (I993) doutora em Arquitetura e Urbanismo pela Universidade de São Paulo (2006), tese publicada sob título Cidade Errante: Arquitetura em movimento pela Editora Senac (2009); Livre docente, com tese entitulada Corpode-prova (FAUUSP, 20I8). Professora na Faculdade de Arquitetura e Urbanismo da Universidade de São Paulo, do Departamento de Projeto. É autora de diversos projetos expográficos dentre os quais se destacam: Arte/Cidade 3 (1997), Paralela (2004) 27a. Bienal de Artes de São Paulo (2006), 29a. Bienal de Artes de São Paulo (2010), 320. Panorama da Arte Brasileira (20II), Território de contato (20I2); Poder Provisório(20I4), Adornos do Brasil Indígena (SESC/MAE-USP, 20I6); Visões da Arte no Acervo do MAC USP I900-2000 (MAC-USP, 20I6, longa duração); Papéis Efêmeros: memórias gráficas do cotidiano (SESC/ Museu Paulista-USP, 2018).

\section{Entrevista: A expografia da 27a. Bienal de São Paulo}

MARTA BOGÉA: Vou informalmente começar contando que para mim, é importante o reconhecimento dessa cabeceira do pavilhão, isso está dito em várias situações. Essa decisão de projeto teve início quando nós (a equipe inicial do projeto - Marta Bogéa, Anna Helena Villela e Maju Herklotz), visitando todo o edifício, e ainda sem nenhum processo de curadoria iniciado ou uma lista de obra, reconhecíamos o que seria o melhor modo de acesso, vislumbramos essa cabeceira. A hipótese se confirmou quando, em uma conversa com André Vainer e Guilherme Paolielo sobre seus projetos para exposições, eles me perguntaram: "Você está fazendo Bienal, como anda o projeto?". Revelei que estava intrigada com o acesso, pois me parecia que o acesso, tido como habitual, guardava uma contradição: a marquise incide sobre o flanco lateral transversal do edifício, mas não é a melhor visada, certamente não é a visão em perspectiva projetada por Niemeyer, quando se sobe a escadaria. Diante disso, eles me disseram: “Muito bem, você então está retomando um aspecto proposto nos primeiros estudos para esse edifício, onde todo o trecho 
logo após a marquise era sem fechamento, aberto como uma praça coberta”, buscam o livro do Mindlin e me mostram o desenho. O desenho revelado, confirma a hipótese adotada por nós no projeto para 27a. Bienal e que depois vai sendo reiterado por outras edições da Bienal, até o limite, quando na 28a., a praça em semelhança do que vimos nos estudos da equipe do Ibirapuera em 1954 , era re-apresentada.

Mas, antes ainda de qualquer arquitetura ter trabalhado esse acesso, Quem me chamou a atenção para essa porta "de fundos", na verdade, foi um trabalho de Rubens Mano, Vazadores (1998). Na 24a. Bienal, com curadoria adjunta de Agnaldo, naquele espaço que, como em geral, estava tratado como "fundos", Rubens Mano configura uma passagem camuflada.

As pessoas se perguntam: "quem fez primeiro isso?", para mim pouco importa, importa que os arquitetos, entre nós, e juntos aos artistas, vêm ensaiando um modo de chegar ao edifício e já fizemos de várias formas: na praça lateral superior, onde ficam as bandeiras; pela rampa do MAC; pelo acesso voltado para avenida. Então, entrar no edifício para mim sempre pareceu uma das questões fundamentais, assim como se dá em qualquer outra arquitetura, é relevante saber qual é o primeiro modo de se acercar da paisagem, como atravessar o umbral da paisagem exterior para a paisagem interior.

ANNA HELENA VILLELA: Isso ocorre porque a circulação em uma exposição é um dado fundamental.
MB: E esse é um aspecto muito importante. Por exemplo, se você me perguntasse se na 29a. Bienal se poderia entrar pela marquise, eu diria que sim. Eu teria menos resistência em relação a esse acesso. A minha questão na 29a. Bienal, o que me fez manter o acesso por aquela porta, é que eu acho aquelas portas laterais com a marquise eram mais amplas, mais protegidas. Aquilo que é típico de foyer de situações culturais como, por exemplo, no Municipal de São Paulo, o grande plano elevado que te permite ao chegar ou sair poder ficar ainda um pouco por ali na paisagem exterior antes de entrar no edifício.

Mas na 29a. Bienal, seguindo esse raciocínio de circulação, eu poderia entrar pela marquise porque não há narrativa linear. Na 27a. Bienal, era fundamental a entrada por aqui, porque nas primeiras reuniões, Lisette me dizia: "Não tem núcleo anexo, nem Broodthaers”. E, observava que o modo de visitar a exposição devia se dar em linearidade, um núcleo após o outro e após o outro, e, sobretudo, sem idas e voltas. Nesse sentido, é o oposto da 29a. bienal que era o jogo de amarelinha, não tinha totalidade, não tinha linearidade. Com a 27a. o modo de compreender aquela bienal tinha núcleo I, núcleo 2, núcleo 3; no qual você saia desdobrando núcleos, assegurar essa continuidade era fundamental.

Coube ao projeto de arquitetura ao definir por esse acesso, atentar para essa solicitação e, ao mesmo tempo constituir uma praça de chegada. O acesso se deu como uma praça articulada por três portas, que permitiria visões amplas e 
uma espécie de primeira chegada suave. Recebeu uma obra que originalmente não estava lá, e que é instalada ao final, "Security" de Jane Alexander, obra com arame farpado e guardas com cassetetes na mão. Este espaço revela assim uma evidente diferença no modo de entender a paisagem proposta pela curadoria e por mim.

Pois a agressividade do modo de "recepção" proposta pela obra é absolutamente contraditório com o modo de convívio, do convite de acesso fluido proposto pela arquitetura, o statement curatorial se colocou aqui. Certamente não era o modo como eu estava propondo o acesso, mas a prerrogativa de curadoria é sempre o que dá o tom da paisagem da exposição, arquitetura é só uma espécie de geografia de início, quando é trabalhado muito junto, ao final você não sabe, o que é de um e o que é de outro. No caso da 27a., em vários momentos você consegue perceber a diferença de intenções entre um pensamento da curadoria e um pensamento do projeto de arquitetura - como descrito.

Em outros momentos, ao contrário, a conexão entre curadoria e arquitetura é muito fluída. Por exemplo, o primeiro pavimento é desenho indissociável entre Lisette Lagnado, Cristina Freire e José Roca, em grande proximidade com a arquitetura. Os três curadores tinham artistas que acompanhavam e que estavam completamente coniventes com o pensamento de total transparência nos planos - um dos aspectos apontados desde o início pela curadoria, de ser um espaço poroso, em continuidade entre as obras. Adotamos nesse piso, um núcleo com muita projeção, usufruindo de um andar onde o fechamento total era oportuno, como uma única grande sala onde as projeções ocorriam em planos soltos. Houve um momento fundamental para isso, Adriano Pedrosa, por exemplo, que compreendia, junto aos artistas que estava acompanhando, como mais adequado a projeção em sala, foi para o segundo pavimento. Acho importante revelar, que durante o trabalho os núcleos vão sendo reorganizados a partir das diferentes perspectivas.

AHV: A Lisette Lagnado diz, em uma entrevista, que dentro da proposta de curadoria coletiva a arquitetura e o educativo foram chamados a participar desde as primeiras reuniões conceituais, e de como este fato surpreendeu parte da equipe de curadores. Você credita que inclusão da arquitetura nas primeiras reuniões de curadoria foi uma inovação da 27a. Bienal? Como era o trabalho de expografia naquele momento?

MB: Ela tem razão, é muito raro o curador iniciar a conversar com arquitetura, acredito, também com o educativo, antes de uma lista de obras. O que a Lisette fez, é fora do padrão, inclusive teve que defender essa posição junto a Fundação Bienal e em relação a alguns curadores, porque estávamos convidados simplesmente para ouvir o debate curatorial.

Tem uma certa peculiaridade no modo de trabalhar, muito disponível e generoso, que significa, eu não espero de vocês 
ainda nenhuma posição por que eu não tenho nada para falar com vocês sobre obras, eles estavam começando o debate e apresentar algumas questões ainda gerais, tínhamos uma posição na mesa que era sentar e ouvir e eles estavam apresentando uns aos outros, os artistas que lhes pareciam oportunos, alguns daqueles artistas já eram deslocados, não tinha a mínima convergência para seguir. Então era como se cada curador estivesse apresentando aos outros o seu statement curatorial e foi importante, do meu ponto de vista, a arquitetura estar nesse momento, porque nesse momento e naquela escala e com alguns curadores, que eu nunca tinha trabalhado junto, era um modo também de conhecê-los. Ali foi possível compreender as balizas de trabalho de Rosa Martinez, Adriano Pedrosa, Cristina Freire, Jochen Volz e de José Roca, essa relação foi fundamental. Foi em uma dessas reuniões, inclusive, que nasce a proposta do piso, que é uma das coisas fortes desse projeto. E isso está descrito algumas vezes porque foi muito relevante, antes de pensar em qualquer obra, antes de pensar em qualquer coisa, antes de pensar no Broodthaers, Lisette endereça uma pergunta livre para mim: "Se você tivesse que editar o espaço sem nenhuma parede, como você faria?”. Minha resposta foi que eu recorrerria ao piso, ao desenho do piso, esta conversa ficou no ar porque ainda não fazia sentido. Quando a gente voltou a discutir (Jochen, Lisette e eu) sobre o Broodthaers, Jochen dizia: "Não é possível ficar no terceiro pavimento instalar obras do núcleo Broodthaers, climatizada e as outras não climatizadas $^{1}$ em torno do vão porque isso não é uma linha, é uma praça" e foi nessas hora que eu recorri: "Praça eu sei desenhar, praça tem que ter uma conformação de fluxo mais articulado com alguma centralidade e eu iria para outra estratégia de pavimento, qual seria a conexão possível”. Lisette lembra que caminha muito rapidamente, na experiência de Bienais, usando a escada rolante, e juntos, os três, flagramos essa oportunidade, a relação vai ser vertical e não horizontal, uma coisa que depois outras bienais vão usar como uma base de reconhecimento do próprio edifício.

\section{AHV: Como foram feitos os diálogos entre arquitetura e} curadores na fase conceitual?

MB: Era uma escuta e, por outro lado, tinha uma coisa muito bonita, para a gente que é arquiteto, que é o endereçamento de perguntas ainda sem objetivo claro. Uma pergunta aberta, do ponto de vista de como você entende o desenho dos lugares. Também era estar em diálogo, já antes de ter alguma funcionalidade a cumprir. Por isso, era muito proveitoso, era um solo muito fértil, que apesar das dificuldades, na hora que a Bienal começa a atravessar velocidade, esse solo foi

I Por exigência do museu que cedeu as obras de Marcel Broodthaers suas obras deveriam ficar climatizadas mas os outros artistas do núcleo não precisavam de climatização. Como no Pavilhão a área climatizada se restringe a um trecho do terceiro pavimento surgiu este problema sobre como implantar o núcleo Broothaers de forma articulada. 
fundamental para poder criar uma espécie de premissa anterior que a gente recorria para poder tratar. $O$ primeiro pavimento, por exemplo, foi uma recorrência dessas, quando falei para Lisette: “Lembra que você disse, que por você, não teria paredes, então por que teríamos que ter salas? Vamos trabalhar com planos de projeção".

AHV: $O$ projeto curatorial da 27a. Bienal a princípio era constituído de seis blocos que foram substituídos por dois grandes blocos, como você vê a organização do discurso narrativo no espaço?

MB: Na nossa experiência, quando existem blocos, a gente procura dar unidades, por exemplo na paralela 2004, aquelas balizas transversais tinham a ver com esses núcleos de aproximação, são salas abertas, mas são recintos, muito comum que se trabalhe com blocos. O que eu percebi do movimento deles é que, de fato inicialmente, esses seis itens eram quase um modo de convergência entre eles, pelo modo de traba1ho. Cada um assumiu uma frente e, sobretudo os outros, contribuíam para aquele raciocínio, acho que foi mais um processo de trabalho que de fato uma definição de desenho de exposição. Quando eles conseguiram pactuar os artistas, eles começam a trabalhar com essa chave que estava clara desde o início, imaginavam poder caminhar em um atravessamento continuo e permeável todo espaço, eles passam a fazer quase como se fossem dois campos de narrativas, mas eles não distinguem essa narrativa.
Os grupos de artistas são apresentados em : "Projetos para Vida" e "Projeto Construtivo", mas se você prestar atenção na lista, eles estão justapostos na paisagem, é muito mais um fluxo de pensamento dos curadores do que uma organização do espaço. A organização do espaço amadureceu para outra coisa, no diálogo entre as obras de fato, a arquitetura e a orquestração curatorial. Por exemplo, Se a entrada do térreo é sempre o statement curatorial e a decisão sobre quais os artistas e obras que recebem o público e criam uma espécie de prólogo de toda exposição. Então, aqui tem mais do que uma temática, é mais uma espécie de primeira convergência, que dá já de início visibilidade da variedade de geração e de nacionalidade em convívio (importante lembrar que nessa edição a curadoria não trabalha, pela primeira vez, com as salas por nacionalidade): Hirshhorn, que é um dos grandes artistas dessa Bienal, está ao lado de Marcellvs, que hoje é uma artista que já tem um reconhecimento forte, mas naquele momento era um jovem artista mineiro indo para Berlim.

Tem uma coragem de convivência de estatutos que tem a ver com a grande revolução que a Lisette faz, que é acabar com o cerceamento nacionais e hierárquicos no sentido das climatizações. Quando ela bota, para dentro do território climatizado, que é o território onde estarão todas as fundações, junto com Dan Graham, Ana Mendieta, Matta-Clark, um jovem artista como Marcelo Cidade dentre outros. Eu lembro de Marcelo Cidade por que teve uma negociação com 
a instalação dos cacos de vidro (obra Entremuros) sobre os painéis da obra de Matta-Clark, a fundação Matta Clark resistir e a detentora das decisões de montagem, que é a viúva, autorizar ao dizer que essa obra agradaria à Gordon.

Ali tem uma revolução muito singular, Lisette dissolve não só o território de nacionalidades, ela dissolve o território hierárquico no sentido do estatuto dos artistas no sistema da arte. Ela aproxima por obras e não por nome de artistas, ela é de fato, nesse sentido, uma curadora muito consistente e muito convicta no que isso significa como política. Muitos curadores fazem isso, mas não exatamente com a mesma convicção, de que este gesto é parte da ideologia da exposição, o que está na Lisette é essa clareza.

AHV: Você cita em entrevista de 2006 para uol que a mudança do acesso para o extremo do pavilhão foi uma das principais ações da arquitetura na 27a. Bienal. Esta proposta foi incorporada na maioria das bienais subsequentes, qual foi a sua leitura do pavilhão ao fazer o projeto?

MB: Na verdade, a leitura do pavilhão tem a ver com a contradição no projeto do conjunto do Ibirapuera. Quando você olha o edifício em relação ao conjunto edificado em que ele está endereçado pela marquise é um acesso lateral e o edifício, ignorando a marquise, tem um endereçamento típico de um acesso prioritário frontal, inclusive com o logotipo da fundação bienal na testeira do edifício e uma escadaria que guarda uma certa mudança de paisagem. Se você olhar, independentemente de qualquer outra coisa, a proposta da arquitetura, é como se aqui Niemeyer se contradissesse.

A força da marquise, que talvez ele nem considerasse naquele momento, que agrega as pessoas para cá; a contradição do fluxo de carro, que foi se tornando cada vez mais intenso, atrapalhando essa área sombreada de chegada; e a porta de fato muito estreita fazem esse acesso ser sempre conturbado. Todas as vezes que as exposições adotaram esse acesso direto com toda a clareza do endereçamento pela marquise, elas tropeçam nessa dificuldade de tráfego, do conflito de pedestre e carro. O que me levou prestar atenção nisso foi essa contradição dos termos que eu, particularmente, acho muito bonito, porque fico pensando que, em i954, dificilmente com aquela equipe, com toda convicção que todo arquiteto pode ter quando gera um gesto inédito, poderia prever que a marquise seria um elemento agregador tão poderoso do parque inteiro. Tem um texto lindo do Igor Guatelli que analisa a marquise. $\mathrm{E}$, sabemos todos os arquitetos que passam pelo Brasil, podem até não entrar em edifício nenhum do conjunto, mas a marquise precisam visitar. A marquise é citada pelo SANAA no pavilhão Serpentine, como uma espécie de homenagem que amplia e replica a hipótese. Desdobra a marquise da Casa de Baile, em Pampulha, quando Niemeyer soltou esse elemento que estava sempre derivado do edifício, e o transformou em um elemento que encaminha novos endereçamentos e o transforma em um grande recinto. Toda vez que se pode, independente se está 
chovendo, no Parque do Ibirapuera se caminha pela marquise, a contradição era portanto, menos clara no início, no momento do projeto e ela vai se constituindo à medida que os usos reinventam a potência das paisagens do parque.

A marquise chega de frente para a cortina de vidro do Pavilhão, uma contradição mesmo, porque já no projeto original, a praça estava desconectada da marquise, esse desenho merece ser refeito. O que eu acho importante que quando você se coloca nesse ponto (no extremo oeste), no levantamento que fizemos do edifício no início do projeto, verificamos que este é o ponto de vista prioritário da pavilhão, em que se vê toda a sua monumentalidade longitudinal. Quando se entra pela marquise eu topo com um edifício curto estreito e com o mezanino na minha frente, quando eu entro do outro lado eu vejo o convite a esse atravessamento continuo que me levara a uma surpresa imensa do vazio "central”, que é na verdade, descentrado.

AHV: A proposta expográfica para o pavimento térreo foi criar dois eixos de painéis no sentido da perspectiva, encaminhando o olhar do público e seu fluxo. A proposta era que o espaço fosse constituído também pelas grandes instalações artísticas. Como você avalia a qualidade deste espaço após a inserção das obras?

MB: É o conflito, que vale a pena tratar como uma evidência de que por mais que seja um trabalho comum, existem autorias. Essas autorias, e isso faz parte da riqueza das exposições, entre arquitetura, curadoria, iluminação. A arquitetura delineia um convite ao acesso, que se pode chegar distraidamente, a curadoria põe uma obra de statement de parada. É um indicador claro de conflito e de pausa, não adentra. Então, tem uma espécie de contradição em termos, as três portas dizem "entre e fique à vontade" e a obra diz, "é melhor parar onde você está" — arame farpado e homem armado.

AHV: Ao começar a trabalhar com as plantas e imagens da mostra, puder observar que há uma contradição entre a planta do pavimento térreo e sua concretização. A obras de Thomas Hirshhorn transforma completamente o projeto para o pavimento e acesso, com um volume de cinco metros que obstrui completamente a visibilidade. Você acredita que esta imprevisibilidade é inerente a uma mostra com grande volume de site specific? Seria possível em um processo de projeto, nessas condições onde as obras não estão prontas, buscar uma representação mais próxima do que será construído?

MB: Eu acho que não dá para fazer uma antecedência, mas eu acredito, e todas as vezes que eu trabalhei em situações mais convergentes, a medida mesmo que essas situações vão se apresentando, se vai redesenhando processualmente a arquitetura. Nesse caso se evidencia a leitura de Lisette que acredita que para viver junto, sobretudo prevalece o conflito e o com o conflito alimenta o convívio. Essa relação faz parte desse modo de trato no trabalho. 
Assim como a Lisette afastou alguns curadores para conseguir concluir o trabalho curatorial, do modo que ela entendia e nesse caso os beneficiados fomos nós, em relação ao primeiro pavimento, no térreo ela faz a mesma coisa em relação a arquitetura. A partir de agora a arquitetura não se envolve e simplesmente instala o que está determinado. Para mim o curador é o maestro e eu sou um dos instrumentistas e é inevitável que as vezes uma hora um instrumentista queira tocar de outro modo e o maestro dirá não, não será assim.

E a gente, porquê de fato também acredita na importância desse território autoral muito claro, de uma curadoria que está construindo com o maior esforço um diálogo infinito com um número imenso de pessoas, esforce-se por manter uma coerência própria, que seja justo e que é de direito, que a curadoria tenha a prerrogativa da palavra no final. Eu falo isso por que fica a sensação que "então faltou a idealização da relação”, isso é bobagem. Por mais que subjetivamente seja desconfortável para mim, eu consigo compreender e se me perguntarem se faria de outro jeito, eu direi que não. Posso compreender que para a curadoria da $27 \mathrm{a}$. Bienal tenha sido fundamental que o primeiro recado fosse esse: "vai devagar que aqui não tem facilidade”, que é o oposto do meu desejo de como viver juntos.

Esse foi modo de trabalho da Lisette, talvez até pela dificuldade desse convívio compartilhado, em alguns momentos, ela se cercou daqueles que foram os interlocutores fundamentais para que pudesse levar a cabo o que estava buscando. No nosso caso, custou o térreo, do ponto de vista da 27 a. eu acho um grande acerto esse térreo rude, inclusive com essa imensa sala do Hirchhorn, por que é a contradição típica da Lisette, ela quer o espaço poroso, mas ela constrói catapultas e armadilhas e tropeçar no Hirchhorn significava também não ir a diante. Todas as obras que eu tinha estudado do Hirchhorn, me parecia que o lugar onde ele deveria estar era debaixo do mezanino para transbordar, o Hirchhorn é alguém que gosta de obstáculos para poder transbordar, aqui o obstáculo ocorreu no atravessamento do térreo, como uma segunda pausa, dada pela dimensão da sala construída pelo artista como parte da obra.

AHV: As Bienais contemporâneas têm uma demanda grande por salas escuras de vídeo, no caso da 27a. Bienal não foi diferente. A proposta expográfica do primeiro pavimento foi fechar os caixilhos e criar um grande espaço unificado de luz controlada, onde as projeções poderiam ficar abertas e vistas em simultaneidade, esta solução evitou a construção de muitas salas. Esta proposta parece resolver, em parte, o problema que se coloca em uma exposição deste porte, onde o excesso de pequenas salas torna o percurso do público exaustivo. Como foi o processo junto a curadoria e artistas para viabilizar esta proposta?

MB: Já conversamos sobre isso, tem um momento em que para conseguir isso a Lisette afasta os curadores que eram 
contra a excessiva contaminação entre as obras e todo artista que declarou que a obra deveria estar instalada em uma sala não estava neste andar. Por outro lado, na contramão disso, todo artista que gosta ou usufrui da contaminação, comemorou. Eu me lembro de Ann Lislegaard, que quando esteve no pavilhão, comemorou todos os inusitados pontos de vista do segundo pavimento e do terceiro pavimento, com que a obra dela estava contaminando e sendo contaminada, também, pela obra desses outros andares, e aí viva Niemeyer!

A forma orgânica do vão, vazio que não é prismático, mas que tem direções múltiplas, ricocheteia e amplia muito os pontos de vista entre andares. É importante entender que essa transparência é também uma transparência que usufrui do vão, é uma leitura criteriosa do vão. O vão é sobretudo um lugar de verticalidade, mas também de visuais entre verticalidades. Aquela cena típica de bienal, que é ficar encostado no parapeito do vão, olhar tudo, que passa, significa olhar também as obras que estavam lá embaixo; e essas eram obras, muitas delas, muito potentes. Porque o grande desafio deste tipo de situação é que a obra tem que se segurar, apesar do ruído de borda. Tem que ser obras de grande convicção sobretudo, porque o vão era muito saturado. O vão, do meu ponto de vista, também guardava duas obras muito distintas, do Didier Faustino e do Tomas Saraceno. Enquanto arquiteta, se eu tivesse essa prerrogativa, eu teria uma das obras apenas e não as duas. O jogo do vão bipartido, desse jeito, ficou um vão confuso, espacialmente falando, posso entender que tivessem ali dois princípios muito distintos. O Saraceno ganhou o espaço pela necessidade de altura, do meu ponto de vista o argumento é frágil, porque todo artista quer estar no vão e não é aquele artista que define a maior dimensão vertical que vai estar no vão, obrigatoriamente. Ele poderia estar tranquilamente no pé direito de 7,5 metros do térreo, relacionado com a marquise se ele quisesse, pois é de certo modo uma obra de sítio específico.

Acho isso bonito do site specific, os artistas irem se adaptando, como o atelier Bow-wow, eles escolhem as três arvores porque elas são quase paralelas e alinhadas ao edifício para fazer a saída no segundo pavimento. Então aquela obra não tem como sair daquele lugar, porque eu não tenho como reconhecer outras árvores daquele jeito. Mas algumas outras obras que são sítio especifico, como por exemplo a Dominique Gonçalez- Foerster precisava de uma clareira entorno dela, a gente ajustou este desenho e para ela tanto fazia, importava que ela tivesse área e que ela ainda estivesse na região que se pudesse ver a influência da marquise. Se Bow-wow não saia do lugar, Dominique foi ajustada e poderia ter sido ajustada ainda um pouco mais.

AHV: Em entrevista você diz que o projeto expográfico buscou valorizar a relação com o parque, soltando os painéis dos caixilhos, criando um espaço com características distintas de um museu, em minha análise observo que 
esta transparência se evidencia no primeiro trecho do 20 pavimento e na praça Broodthears, e que a segunda parte do segundo pavimento, após a escadas rolantes, o projeto mantinha o mesmo partido mas em uma versão adensada com salas e esta relação entre obras e o parque se perdeu, a transparência do centro em continuidade ao vão também não se realizou, constituindo um espaço mais próximo ao museográfico ou isolado de se contexto. Você acha que a qualidade da primeira parte fica garantida pela transparência do vão e a que segunda se apresenta como um grande desafio pela arquitetura do pavilhão? Como você entende estas diferenças de qualidade espaciais?

MB: Não. Eu acho que isso tem a ver com tratar de decisões, e se por um lado havia muito claramente, do ponto de vista da curadoria, um desejo de espaço poroso e transparente, a realidade de contato com os artistas muitas vezes foi outra. No esforço típico de artista de grandes exposições, de garantir uma certa autonomia de visada da própria obra, muitos deles andaram pleiteando salas e os curadores, de algum modo, ao invés de sustentar o princípio da contaminação que presidia as primeiras conversar, acabam, talvez até na velocidade e no cansaço, cedendo e a gente foi fechando. Eu entendo esse segundo pavimento um desastre nesse sentido, por que o território livre é de fato o Broodthears, mas mesmo na primeira parte, ele já está em mais salas que ele teria, esse trabalho inteiro da Paula Trope era aberto em planos e ele foi ficando defensivo.
As salas aqui me incomodam, nessa exposição, porque todo o princípio da arquitetura se baseou na ideia de transparência, continuidade e porosidade, é como se eu tivesse traído o partido, no momento em que eu não tenho mais como construir uma baliza de projeto. Por isso é que para qualquer um que lê a arquitetura com uma certa habilidade, fica nítido que algum nó aqui aconteceu, ou esse arquiteto desistiu e abandonou este princípio, ou de fato ele foi submetido a uma voz com mais prerrogativa que exigiu o fechamento progressivo.

O segundo pavimento foi um território de bastante desgaste, porque evidente que é justamente o segundo pavimento é o mais exaustivo no sentido da visitação, me parecia um erro sobreposto e que de fato eu não consegui contornar. O que de fato eu consegui fazer foi assegurar que a rua central não perdesse sua prerrogativa, não admitindo nenhum tipo de fechamento aqui. Teve um momento com tendência a isso que faria um zigue-zague. Outra coisa que implicou esforço de negociação foi manter a circulação periférica, nas muitas vezes em que foi preciso resistir ao "desenho" de curadores mostrando salas completadas até o vidro, "para que está desperdiçando esse corredor? ". Curadores que depois, em outros momentos, vão enaltecer a maneira arejada que no Sagiv $^{2}$, com uma circulação periférica como elemento bastante relevante. Mas essa é uma estratégia que é uma convicção

2 Oren Sagiv Curador e arquiteto da 3ra. Bienal (2OI 4) 
dos arquitetos, quase que na sua hegemonia, que sobretudo em edifícios modernos em que a paisagem exterior está convidada a proximidade muito intensa com a arquitetura. Liberar as bordas é reconhecer também a arquitetura que está lá. é a paisagem visitante querendo se colocar como narrativa própria, mas em diálogo com a arquitetura existente, que é a arquitetura residente, mais estável, mais duradoura, deixando-a em visibilidade. O esforço de não conectar parede em vidro e não subir sala até o teto, obliterando a leitura do espaço, tem mais a ver com meu dialogo com Niemeyer, ou com o pavilhão que está lá, do que pode ser compreendido pela própria curadoria. Foi uma queda de braço, descer as alturas de sala, os desenhos vinham com altura de sala completa porque estava "perdendo" cinquenta centímetros de pé direito. Repare que em exposição não tem absoluto. Por exemplo a sala Pierre Huyghe, uma das salas mais bonitas expositivas da 32a. bienal que é desenhada pelo Álvaro Razuk', é uma sala que vai até o teto, mas ali a construção é toda mais acidental, então tudo bem. Ela vai construindo outros parâmetros, ela explode a sala inteira, o teto vai até a parede, naquela defesa da variedade, uma espécie de valor que se coloca como um princípio, aqui era de máxima proximidade, que é o oposto. Então tem sim uma contradição. Por outro lado, nesse mesmo piso, tiveram momentos de grande proximidade e atenção

3 Arquiteto da 32a. Bienal (2016) entre obras e arquitetura por artistas que estavam também um tanto disponíveis e atentos para arquitetura. Como por exemplo, o trabalho da Lucia Koch, "sala de exposição", ao lado do Felix Gonzalez Torres, "untitled (couple)" é maravilhoso. Lucia realiza o diálogo mais sofisticado com a arquitetura, como ela lê bem arquitetura, incide na paisagem da arquitetura. O desenho corresponde ao desenho geral das salas, Lucia Koch não usa nada além da geometria dada e a substituição dos painéis opacos por chapas perfuradas. ela constrói nessa sala uma profundidade que existe como princípio na arquitetura, mas o faz de modo a transformar a sala corriqueira, o princípio geral, em uma sala singular que irradia uma paisagem ótica a partir do movimento.

AHV: Há muitas obras arte dessa Bienal que dialogam com a expografia e pavilhão: Escada parasita de Marcelo Cidade; as obras do vão: Tomas Saraceno e Didier Faustino; Monkeyway do atelier Bow-wow; Sala de Exposição de Lucia Koch; Mula sem cabeça de Goshka Macuga e Double Terrain de jeu de Domenique Gonzales-Foester. Você acredita que o projeto expográfico contribuiu para que os artistas pudessem trazer uma leitura do pavilhão em suas obras?

MB: Eu acho que não, nesse caso é sempre o contrário. Tem os artistas que estão comissionados e que vão fazer intervenção, eles em geral estão com essa disponibilidade. Eu acho que, por exemplo, uma figura como Ann Lislegaard foi 
beneficamente surpreendida em uma arquitetura que põe a obra dela, que é disponível para contaminação e para visibilidade múltipla, com uma potência que ela não podia imaginar, que habitualmente ela não tinha visível. Ou a Barbara Visser que é uma figura que entende muito de arquitetura assim como muitos desses artistas nesta Bienal, e o Adriano Pedrosa era um dos grandes defensores desse perfil de artista, tinham essa vocação desse núcleo que ele chamava construtivo, que era arquitetônico com uma curiosidade de intervenção em paisagem.

O que eu sinto em alguns artistas, e isso até tem a ver com a documentação das obras nas peças gráficas das obras que estavam fora do pavilhão tiveram pouca visibilidade. A obra principal da Renata Lucas, a que ela fez na Lapa, a gente não ficou nem com vestígio daquela obra, podia ser um filme, podia ser documentação fotográfica, ela ficou alijada da exposição. Teve alguma coisa que desconectou as obras que realmente estavam resultando em intervenção urbana. Nem se ouviu muito a respeito, a não ser no catálogo como consulta, mas eu me lembro que foi uma abertura muito tímida, com poucas pessoas, quase como se fosse uma outra exposição, como se aquela obra fosse paralela a Bienal e não parte da Bienal. Do mesmo modo, as bicicletas do Jarbas Lopes que deveriam de alguma maneira irrigar a discussão, e teve situação em que o Jarbas Lopes foi para o parque, com outras exposições posteriores. Aqui a bicicleta era objeto escultórico, ela estava apoiada no chão e não com contaminação do parque em um lugar em que muitas pessoas se deslocam tão somente para andar de bicicleta como ocorre habitualmente no Parque Ibirapuera. Tinha algumas coisas que eu acho que eram mais retóricas e menos factual do modo como a curadoria tratou determinada disposição para o convívio externo. Se você pegar o mesmo curador, em várias outras exposições, provavelmente eles apresentaram menos contradição do que eles apresentam na bienal. Eu acho que isso tem a ver com o volume de obras e com o território de negociação. Ele é muito intenso, a visibilidade é muito alta e tanto artistas quanto curadores, o time inteiro está pressionado por um campo de negociação que a medida que vai chegando perto, vai acelerando e aumentando.

Curiosamente, para natureza de pensamento, pela maneira de desenho, os momentos de saturação são vistos com uma certa particularidade, mas na 29a., que foi um território bem mais contínuo de trabalho, ainda assim as praças, as clareiras, foram solapadas. Na conversa com Agnaldo, com Moacir e comigo no Capacete ${ }^{4}$ o Agnaldo aponta para isso, reconhece que ao final na urgência e diante de um volume imenso de artistas o que era um statement curatorial muito importante, que eram as clareias, essas pausas, as ocupações "informais" foram vindo e comendo território, elas foram comidas pela borda, o campo circundante e arejado não se manteve até o final.

4 Espaço de debates de arte contemporânea. http://capacete.org/ 
Acho que em Bienal é muito comum que os curadores tenham como um dos maiores desafio a negociação, que ocorre até o final, e que com a chegada dos artistas amplia, é muita gente querendo coisas diferentes. É uma polifonia, parece um pouco a cidade, por mais que você atue, o vizinho vai surgir de algum jeito. Então tem alguma coisa que o plano é quase um norte de um pensamento, mas ele não guarda a totalidade. Ele vai ter fratura, essa fratura é curiosa e interessante, as vezes é benéfica. Por exemplo no trabalho do Bow-wow foi super benéfica, a posição deles arejou a sala do Léon Ferrari, uma sala mais fechada, então a hora que você escapa tem surpresas. A Lucia Koch foi um presente para arquitetura, tem situações que vão se estabelecendo, que são muito singulares, no núcleo do Broodthaers, essa obra (se refere à Mula sem Cabeça da Goshka Makuga) que permitia que se subisse e visse de outra posição o conjunto foi maravilhoso, quem me deu essa visada foi a artista, quem permitiu enxergar a praça de cima foi a artista, então tem umas surpresas fortes.

AHV: Este espaço tinha uma qualidade muito boa de relação entre obras e de relação com o parque.

MB: Tinha um controle, foi uma exposição dentro de uma exposição porque aqui tinha uma autonomia dessa curadoria, era apenas o Jochen falando com a Lisette, os outros falavam todos ao mesmo tempo. É uma contradição da Lisette, se ela não aceita umbral, nem de nacionalidade, nem de curadoria, por que existiu essa prerrogativa de um curador fora da curadoria? No sentido da exposição foi um alento porque criou uma variação de tom dentro, porque era um outro matiz, quase uma outra luminosidade na paisagem.

AHV: $O$ sistema expositivo proposto para a 27a.BSP é bastante tradicional com painéis autoportantes brancos. Você acredita que a expografia em uma bienal tem que se manter "neutra"? Em todas as edições recentes, com uma única exceção da 28a. Bienal onde houve uma experimentação nesse sentido, o que se vê é a reprodução de um mesmo sistema expositivo com pequenas variações.

MB: Eu acho que não tem a ver com o sistema, escrevi sobre isso no "Deslocamento acerca de um cubo branco", os artistas contemporâneos, não apenas os artistas modernos, continuam trabalhando com uma espécie de endereçamento para o que se configurou como o espaço habitual dos museus, que são as salas brancas de exposição. A obra está vista dentro dessa perspectiva, em uma exposição dessa escala, a variação acaba sendo uma variação de tudo sobre o mesmo tom, por exemplo, eu pintei de branco quente, branco frio, mas é tudo branco, eu mudei a altura. Eu acho que a coisa mais intensa no sentido da perturbação, tinha a ver com aquelas formas esconsas da 29a. Bienal, mas se você prestar atenção naquele desenho que eu fazia becos ruelas e os ângulos, estavam muito claros, muitos artistas exigiram retificação da sala mesmo quando era projeção, porque estabiliza o corpo, por que os ângulos criam vórtices. Eu acho que em grandes exposições, 
como essa, como a arquitetura precisa dar conta de uma variedade muito grande, acho difícil pensar que ela vibre também. As vezes em que fiz paisagens mais singulares, experimentações mais intensas do ponto da expografia, foram em exposições de menor escala, com um número menor de variáveis de artistas com a condição do trato. Mudar a materialidade dos suportes tem o risco de empastelar completamente com as obras porque os artistas usam muito essa chave, tem que ser um trabalho de parceria do artista e do arquiteto, não dá para ser feito só do ponto de vista da arquitetura. Eu acho, por isso, que para fazer uma bienal é quase inviável, por que você tem que lidar com 500 artistas que chegam cada um com uma expectativa, assim, como todas as outras grandes exposições constuma-se usar a mesma chave, são princípios para serenar o espaço.

\section{AHV: Qual é a sua leitura deste projeto hoje?}

MB: Quando olho retrospectivamente, esse olhar é um pouco narcísico, porque a gente se olha querendo ver aquilo que gostaria de ter visto e se defrontando com o que foi possível. É uma visão mais tendenciosa do que de quem olha a produção do outro, mas eu guardo com alegria alguns acertos: a aposta da transparência; poder reconhecer a verticalidade do edifício foi lindo; poder abrir completamente uma exposição com artistas tão diferentes no primeiro pavimento, com projeções daquele jeito pulsando (não tem periférico, que está cego, o parque não interessa, a paisagem é toda interior) e a posição de abrir as três portas, o parque inteiro entrar no edifício. Acho que essa exposição, teve momentos, do ponto de vista da construção da paisagem muito fortes que eu comemoro. Por outro lado, ele guarda essa trava de uma exposição que, a partir de um determinado momento, o projeto foi sendo solapado, então o segundo pavimento é um desastre completo do meu ponto de vista, por que ele é exaustivo, é uma sequência de salas, é tudo aquilo que eu não queria que tivesse acontecido, que eu lutei para que não acontecesse. Eu me esforcei para construir em outros termos, até porque, eu de fato não vejo o menor sentido nessas salas. As balizas que eu fiz na paralela (2004) mostram com evidência outra alternativa às salas fechadas, pois se você tem elementos transversos à circulação principal para sair dos recintos é necessário que você mude a posição de corpo; e se a baliza é longa o suficiente para você estar contido em duas paredes paralelas não há necessidade de fechamento posterior e anterior, não tem porque desenhar esta dobra. Seria, na minha compreensão, absolutamente possível se fossem em outros termos, se a coisa tivesse caminhado de outro jeito, se partindo daqui a gente tivesse então só fazendo o desenho final da exposição.

Tem coisas muito acertadas que são confirmadas por arquitetos que vem depois, e eu prezo esse diálogo, porque interessa que dentre nós, se alguma coisa é confirmada, significa que nós estamos podendo pactuar alguns gestos. É a beleza do Instituto 
Moreira Salles, na Paulista, convocar e lançar luz e dar continuidade do piso do térreo do MASP, que hoje está ofendido pelo modo de ocupação, e o Conjunto Nacional, é diálogo de arquitetura. Não é porque ele veio depois, que a importância dele é outra, ao contrário, ao vir depois e mostra que aquilo é valoroso, ele está lançando luz e se alinhando com uma conversa anterior. É assim que eu senti a retomada deste acesso, iniciada por mim e retomada por outros, que se alinham numa comemoração comigo, de que esta contradição merece luz, que podemos usufruir melhor desta entrada de outro jeito.

Teria feito de outro jeito? Acho que não; Os conflitos que aparecem no espaço me levam a ter menos interesse por esta exposição? também não, porque tem uma coisa que me interessa, que é bonito, que o conflito do espaço seja flagrado, talvez tenha a ver com a nossa formação de urbanista. Para mim isso é bom, porque é tão nítido o que a arquitetura buscava e o que a curadoria compreende, que é possível se pôr em divergência. 
ANEXO 2: DOCUMENTO DA FUNDAÇÃO BIENAL

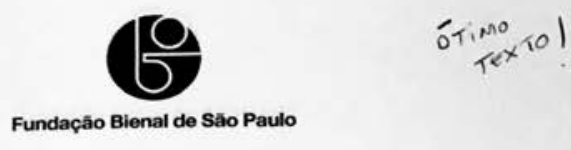

27. BIENAL DE SÃO PAULO COMO VIVER JUNTO

\section{De 7 de outubro a 17 de dezembro de 2006}

Curadoria geral: Lisette Lagnado

Rosa Martinez, José Roca e Adriano Pedrosa

Cochen

Pela primeira vez em sua historia, a Bienal de São Paulo, fundada em 1951, assume um partido "sem fronteiras geopoliticas", trabahando sem as chamadas Fun

A $27^{2}$ Bienal se situa no cruzamento de duas linhas de pensamento: o sentido de "construçáo", que está na base da experiência neoconcreta brasileira, e um "adeus ao esteticismo", ambos processos que marcaram a experimentaçăo do artista Hélio Oiticica (Rio de Janeiro, 1937-1980). Na exposiçăo, estas duas linhas se traduzem em "Projetos construtivos" e "Programas para a vida".

Um mal-entendido continua cerceando o sentido de construtividade, reduzindo-o ora à geometria, ora ao formalismo. O artista "construtor, como Oiticica chamava essa vertente capaz de abarcar vários "ismos", assim como a expressão "vontade construtiva", evocam um ideário social de "caracterização cultural". O construtor é um sujeito que discute qualidade de vida. Seu sonho é poder operar na dimensåo social, dar uma resposta pública aos acontecimentos politicos.

Chega-se a um debate dificil: quando o artista coloca seu talento a serviço do ambiente, participando da configuraça da vida colidiana, qual a diferença residual entre arte e vida, representaçăo e realidade? O título desta Bienal, "Como viver junto"1, inspirado dos cursos e seminários ministrados por Roland Barthes no Collège de France, apresentou-se como desdobramento de uma reflexâo acerca da construçáo de um espaço comum, uma vez que se debruça sobre o conturbado tema da coexistência de povos, ritmos de produçăo, práticas cooperativas. A potência criativa estaria apta a construir uma liberdade? Como estabelecer verdadeiras trocas entre arte e sociedade?

'Cf. Roland Barthes, Comment vivre ensemble: cours et seminaires au Collegge de France (1976-1977),
Paris, Editions du Sevil, novembre 2002.

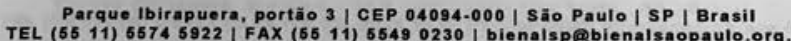

\section{(6) \\ Fundaçâo Bienal de São Paulo}

chegar no sentido ético do Viver-Junto, abordando vários tipos de lugares (de mesas para banquetes a bordeis), assim como diversas modalidades de co habilaçao (casass, grupos, familas). Barthes levanta uma questá que uma exposiça de arte náo poder margem: "De quem sou contemporáneo? Com quem estou vivendo?"

政 Bienal (titulos e subtitulos ainda provisórios)

1 - Projetos construtivos

- Arte e arquitetura: concepcōes arquitetônicas (reais ou imaginárias) no fomento de novas formas de comportamento; o que ativa um espaço $e$ o torna um lugar

- Ritmos próprios e biopotência: a relaçăo entre homem e máquina, a redefiniçăo do cinetismo a partir da "biopotência", diferentes ritmos de produção:

- Práticas de reconstruçẫo: quais os discursos que revelam a violencia das mudanças de regime politico? Como reconhecer e estudar as marcas deixadas nas manifestaçōes culturais?

II - Programas para a vida

- Homenagem a Marcel Broodthaers: o fetiche da assinatura do artista e a circulação da obra de arte; para quem o artista cria? Qual o poder da instituição?

- Trocas entre artistas e não-artistas: inclusăo do não-artista como capital no processo criativo; o trabalho imaterial: afeto e valor na base de uma nova construtividade;

- O Estado do Acre, questão de fronteiras: a tentativa de formular uma "ética coletivista"; o exemplo de "outro" padrão de produção e subsistência; a floresta e sua biodiversidade. 
ANEXO 3: LISTA DE OBRAS UTILIZADA PELA EXPOGRAFIA DA 27a. BIENAL (fonte: acervo da autora)

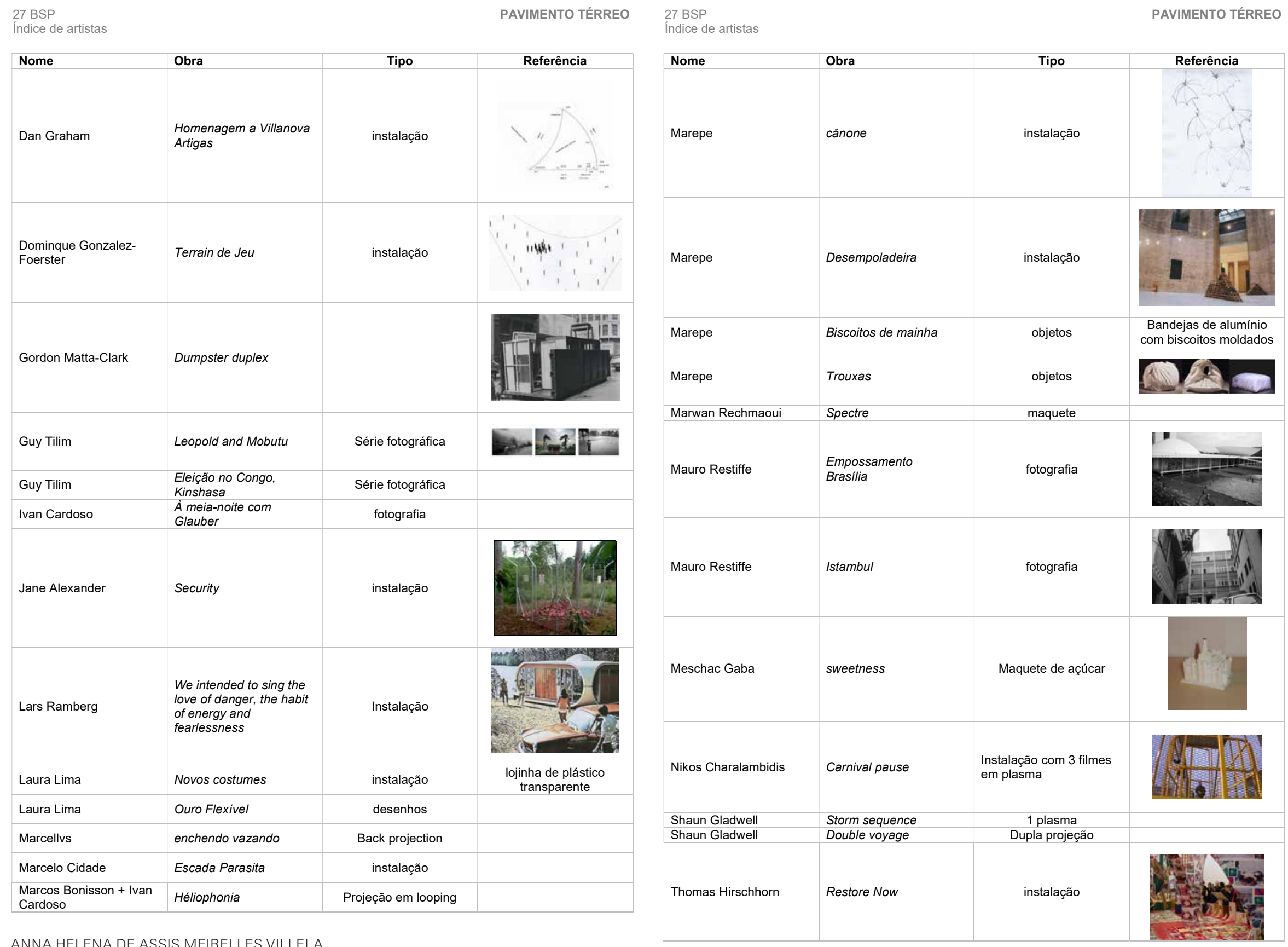




\begin{tabular}{|c|c|c|c|}
\hline Nome & Obra & Tipo & Referência \\
\hline Adel Abdessemed & Wall Drawing & objetos & \\
\hline Adel Abdessemed & Schnell [rápido] & projeção & \\
\hline Adel Abdessemed & Bith of love & projeção & \\
\hline Ann Lislegaard & Nothing but Space & $\begin{array}{c}\text { Vídeo } \\
\text { instalação } \\
\text { Dupla } \\
\text { projeção }\end{array}$ & \\
\hline Ann Lislegaard & I-You-Later-There & projeção & \\
\hline Ann Lislegaard & Cristal World (after J.G. Ballard) & $\begin{array}{l}\text { Dupla } \\
\text { projeção }\end{array}$ & \\
\hline Atelier Bow-Wow & Mangá pod & & \\
\hline Atelier Bow-Wow & Jumbo origami & & \\
\hline Barbara Visser & Transformation house & $\begin{array}{l}\text { Animação } \\
\text { projeção }\end{array}$ & \\
\hline Damián Ortega & Spirit\& Matter & instalação & \\
\hline Didier Faustino & Simpaty for the Devil & instalação & \\
\hline
\end{tabular}

\begin{tabular}{|c|c|c|c|}
\hline Nome & Obra & Tipo & Referência \\
\hline Didier Faustino & Racines du Mal & maquetes & \\
\hline Eloisa Cartonera & Lamauinade hacer paraguaytos & $\begin{array}{l}\text { Guache } \\
\text { sobre } \\
\text { papelão }\end{array}$ & \\
\hline Eloisa Cartonera & $\begin{array}{l}\text { Eloisa Carnoneira, oficina de } \\
\text { produção de livros }\end{array}$ & $\begin{array}{l}\text { Balcão com } \\
\text { mesa } \\
\text { coletiva }\end{array}$ & \\
\hline Esra Ersen & This is the Disney Word & $\begin{array}{l}\text { Filme em } \\
\text { monitor } \\
\text { embutido }\end{array}$ & \\
\hline Esra Ersen & If you could speak Swedish & $\begin{array}{l}\text { Filme em } \\
\text { monitor } \\
\text { embutido }\end{array}$ & \\
\hline Esra Ersen & Reahabilitation & instalação & \\
\hline $\begin{array}{l}\text { Felix Gonzalez - } \\
\text { Torres }\end{array}$ & Untitled (perfect lovers) & instalação & \\
\hline JAMAC & Orixás & instalação & \\
\hline Jane Alexander & $\begin{array}{l}\text { African adventure. filmes em loop: } \\
\text { Congo Honeymoon; Meal with } \\
\text { harvest grain }\end{array}$ & $\begin{array}{l}\text { Filme em } \\
\text { monitor }\end{array}$ & \\
\hline Lida Abdul & White House & $\begin{array}{l}\text { Filme em } \\
\text { monitor }\end{array}$ & \\
\hline Lida Abdul & Speaking and Remembering I II & $\begin{array}{l}\text { Filme em } \\
\text { monitor }\end{array}$ & \\
\hline Lida Abdul & Dome & $\begin{array}{l}\text { Filme em } \\
\text { monitor }\end{array}$ & \\
\hline Lida Abdul & War game (what I saw) & $\begin{array}{l}\text { Filme em } \\
\text { monitor }\end{array}$ & \\
\hline $\begin{array}{l}\text { Lucia Koch } \\
\text { e } \\
\text { Hector Zamora }\end{array}$ & Uma boa ordem & instalação & \\
\hline Martinho Partrício & Brincar com Lygia & & \\
\hline Minerva Cuevas & Terra primitiva & mural & \\
\hline Minerva Cuevas & On property & backlight & \\
\hline
\end{tabular}




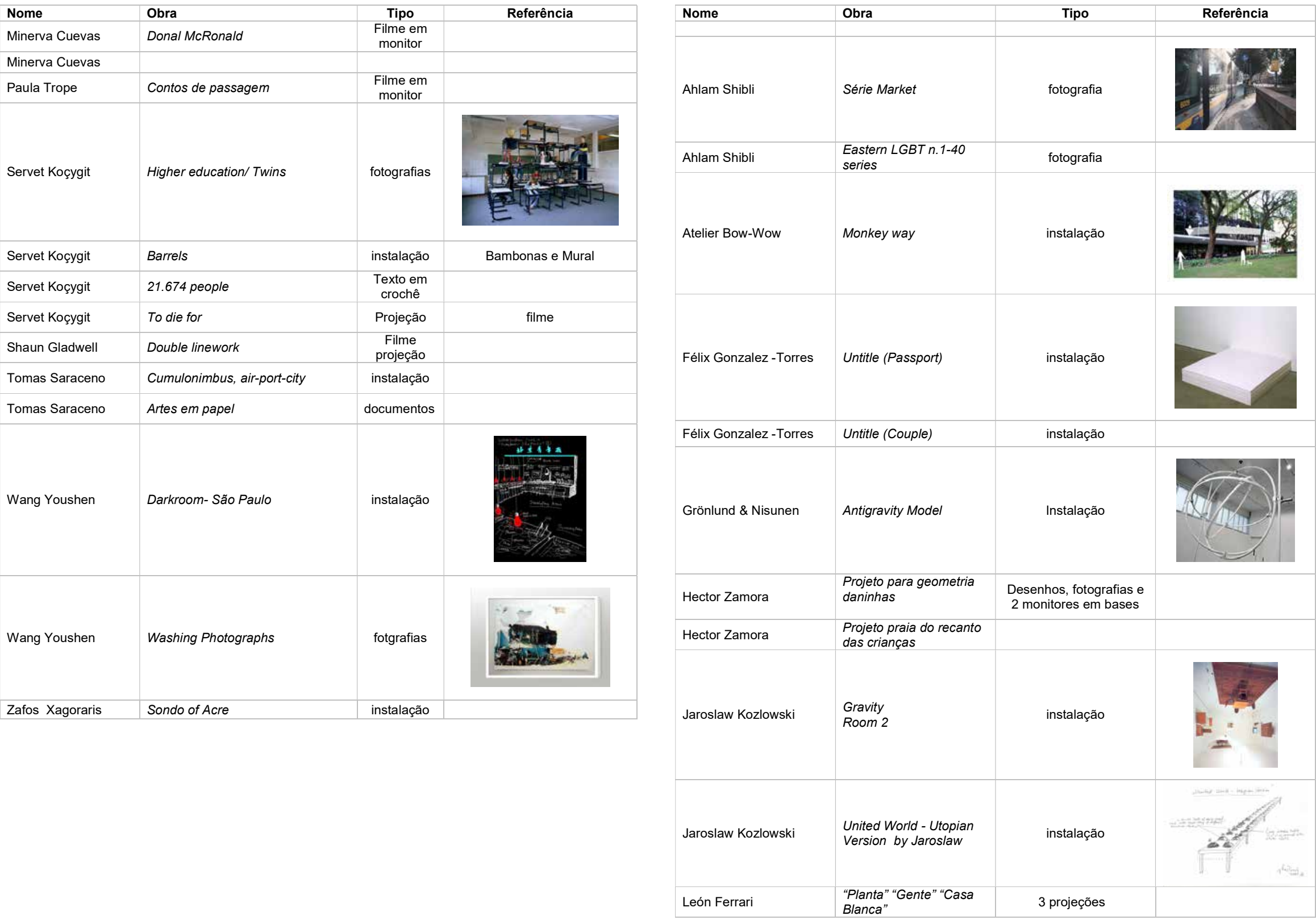




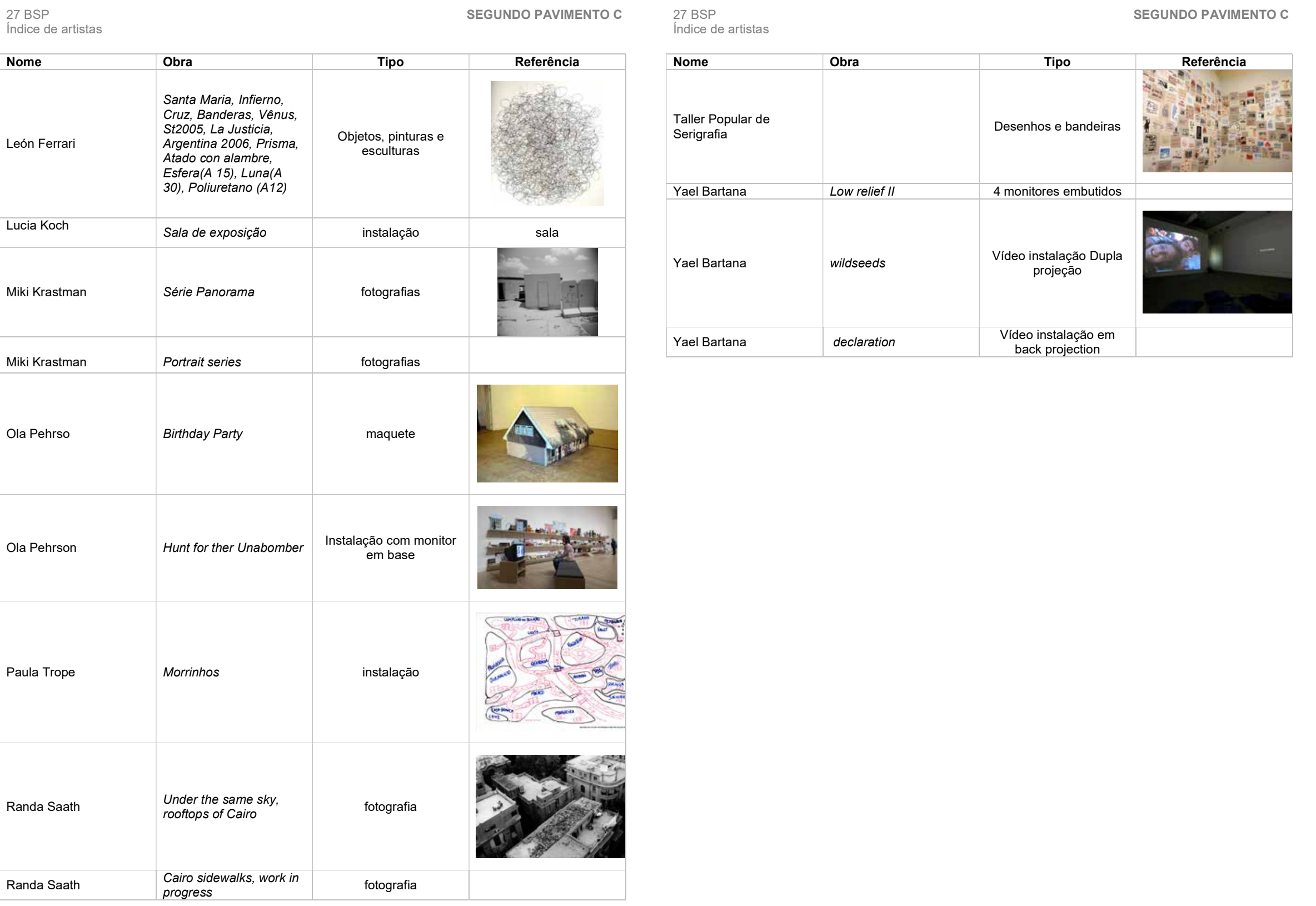




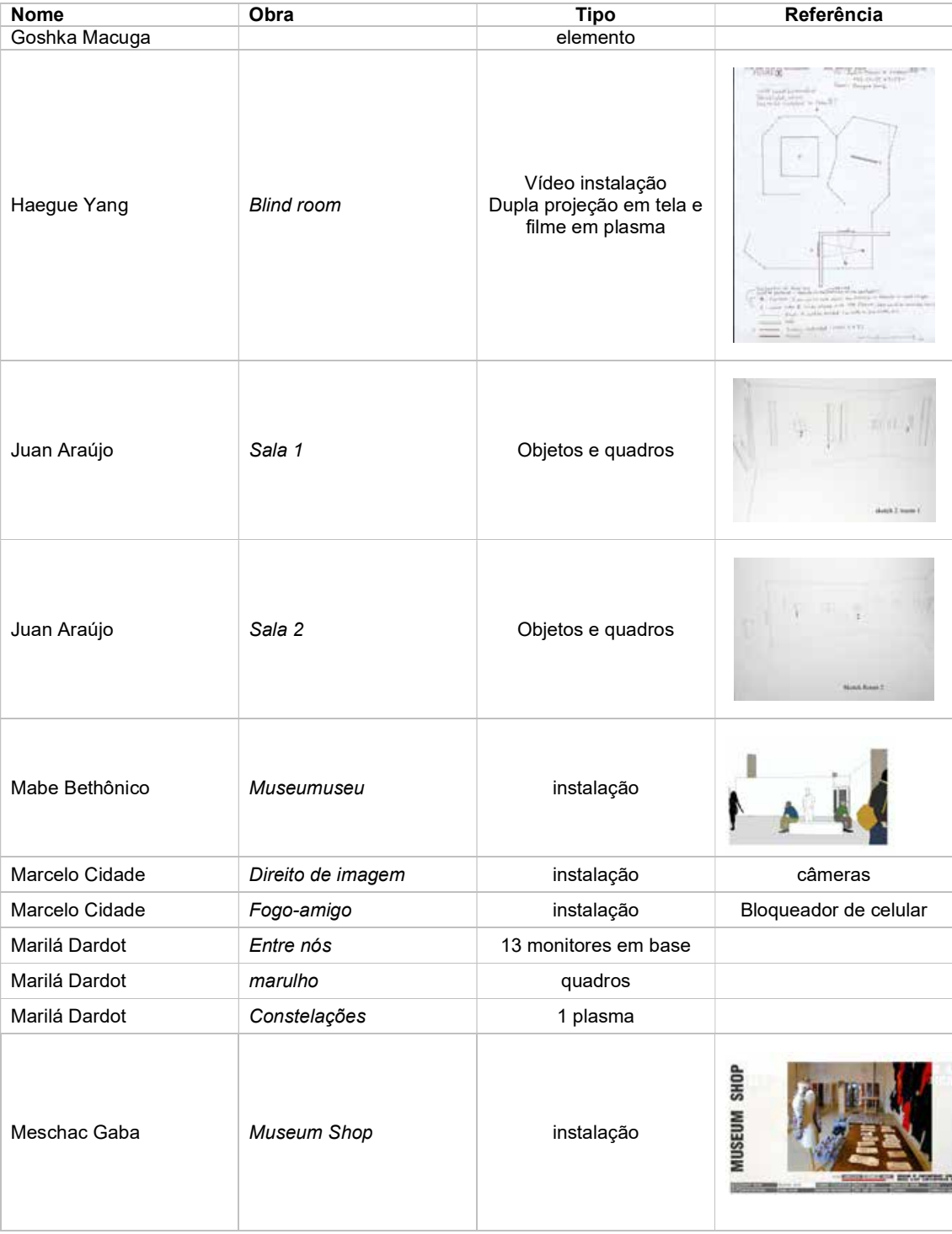

\begin{tabular}{|l|l|l|}
\hline Nome & Obra & Tipo \\
\hline Rirkrit Tiravanija & $\begin{array}{l}\text { Untitled 2006 (Palm } \\
\text { Pavillion) }\end{array}$ & instalação \\
\hline Tacita Dean & Section Cinema & Filme em projeção \\
\hline Tacita Dean & f\&l 2006 & \\
\hline
\end{tabular}




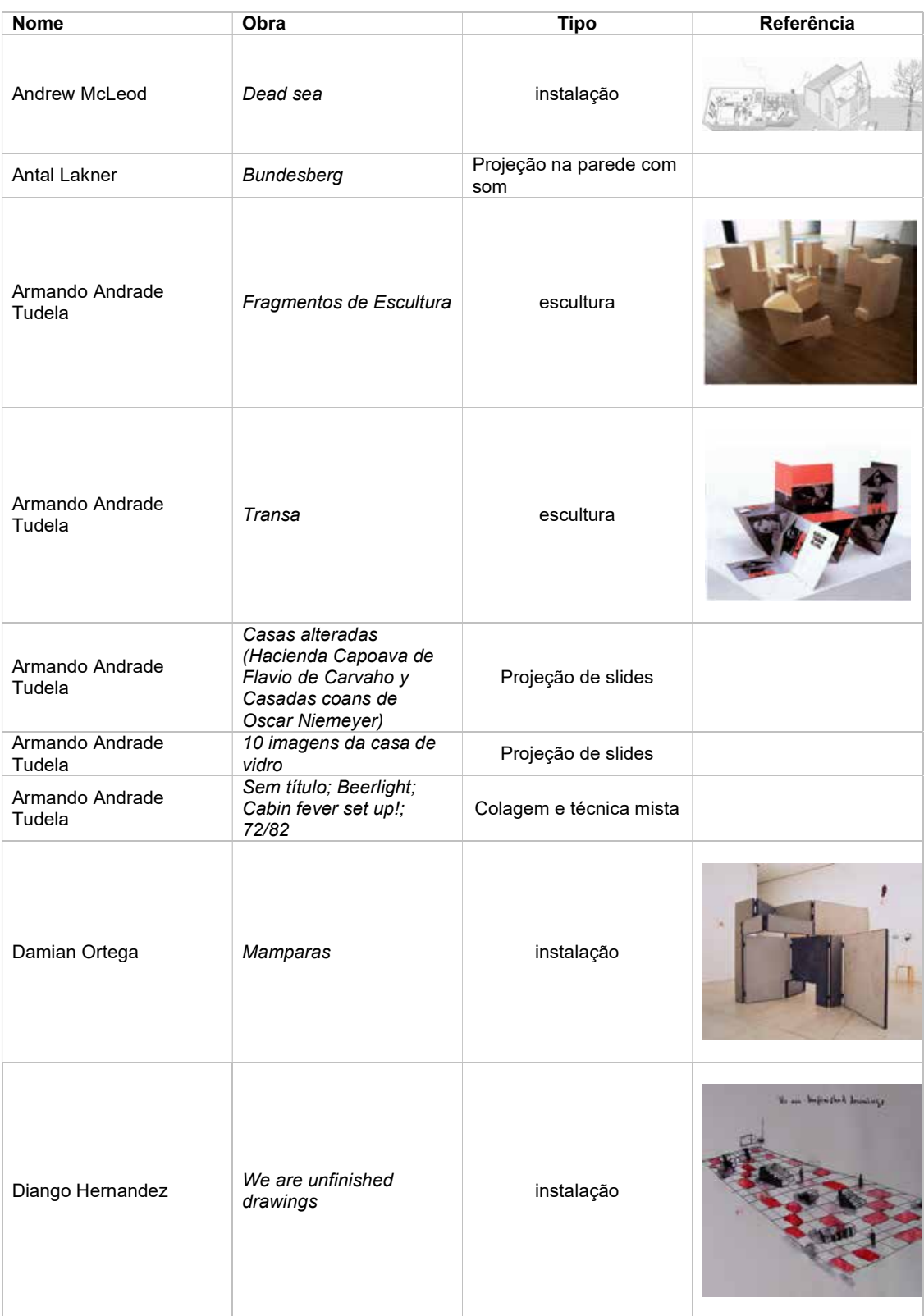

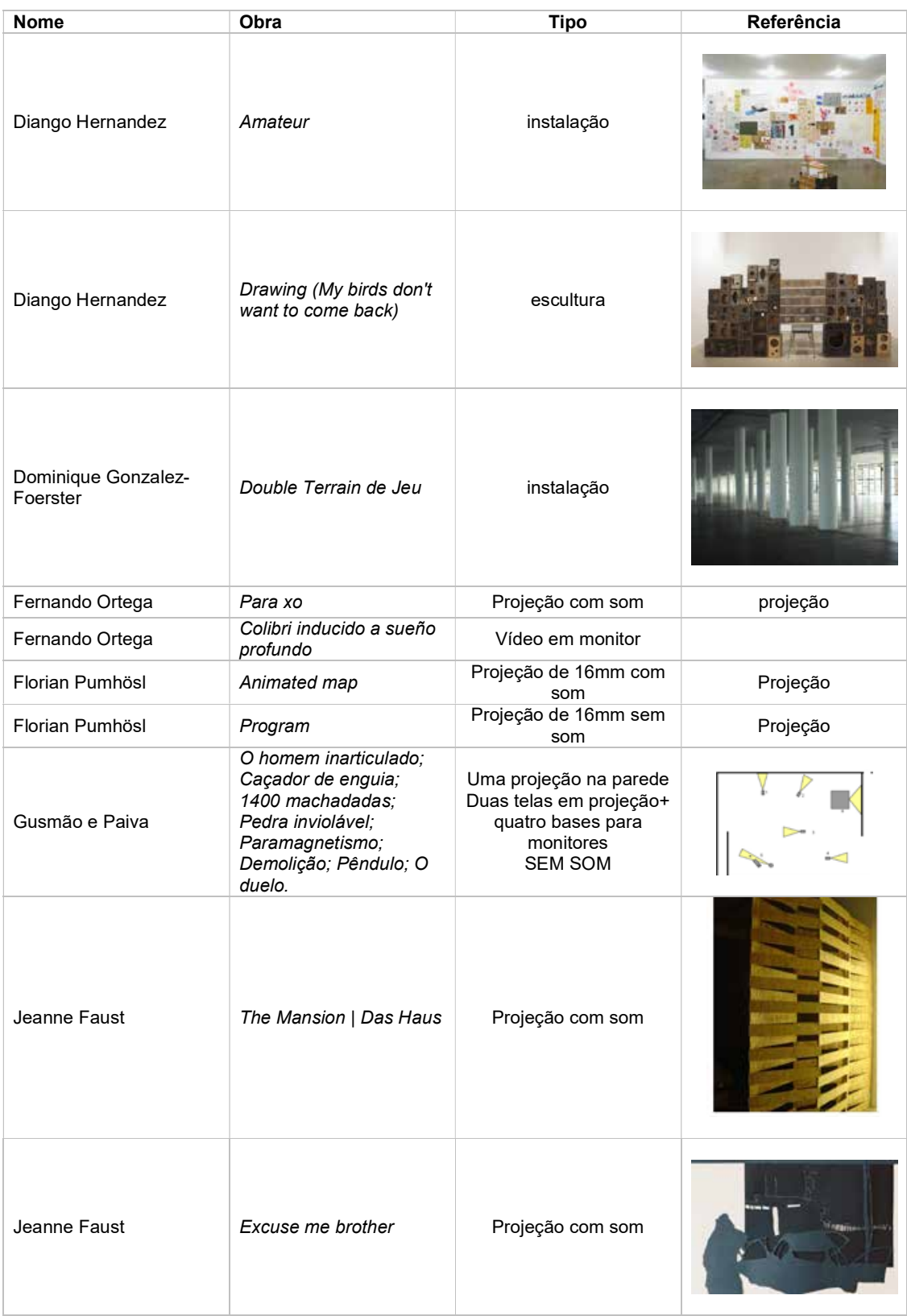




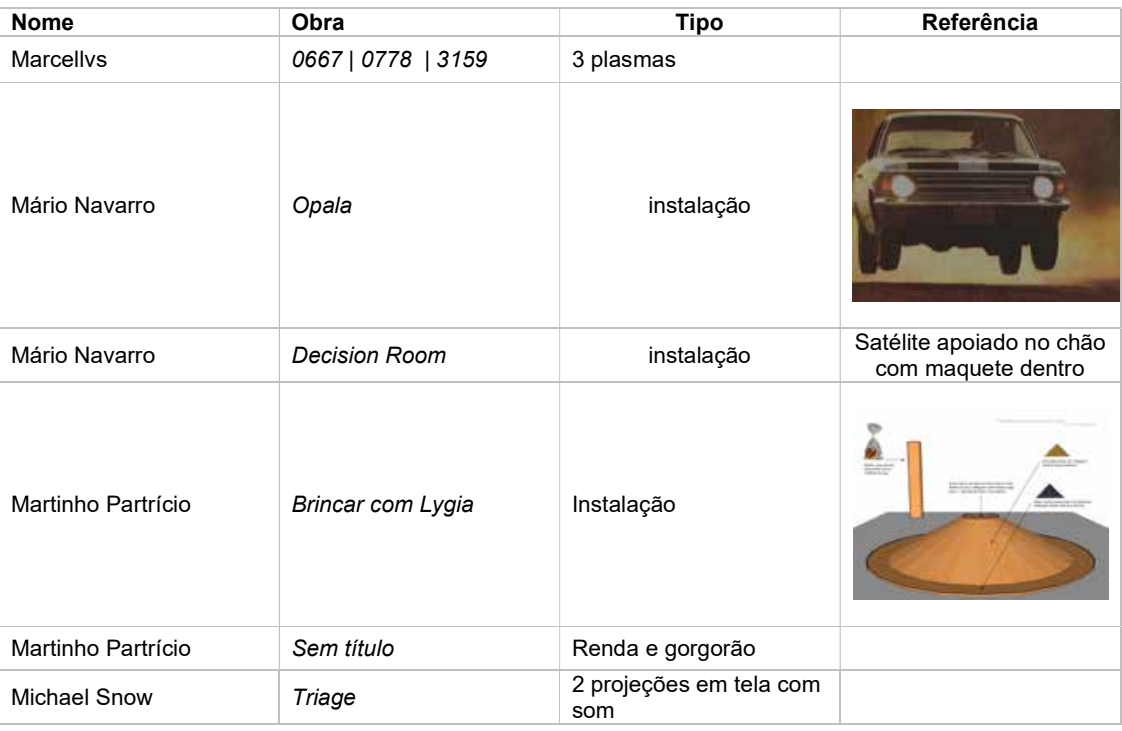

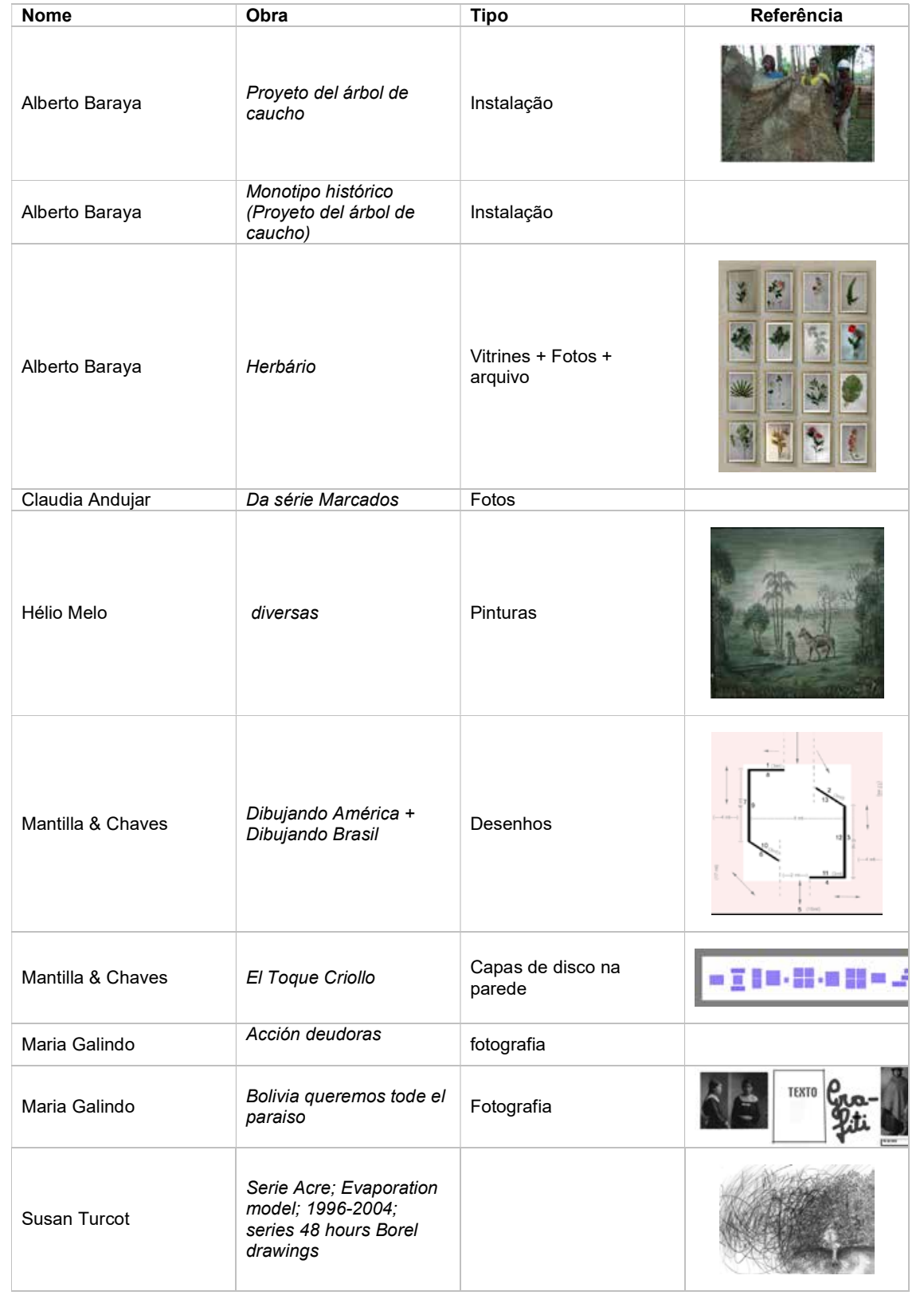




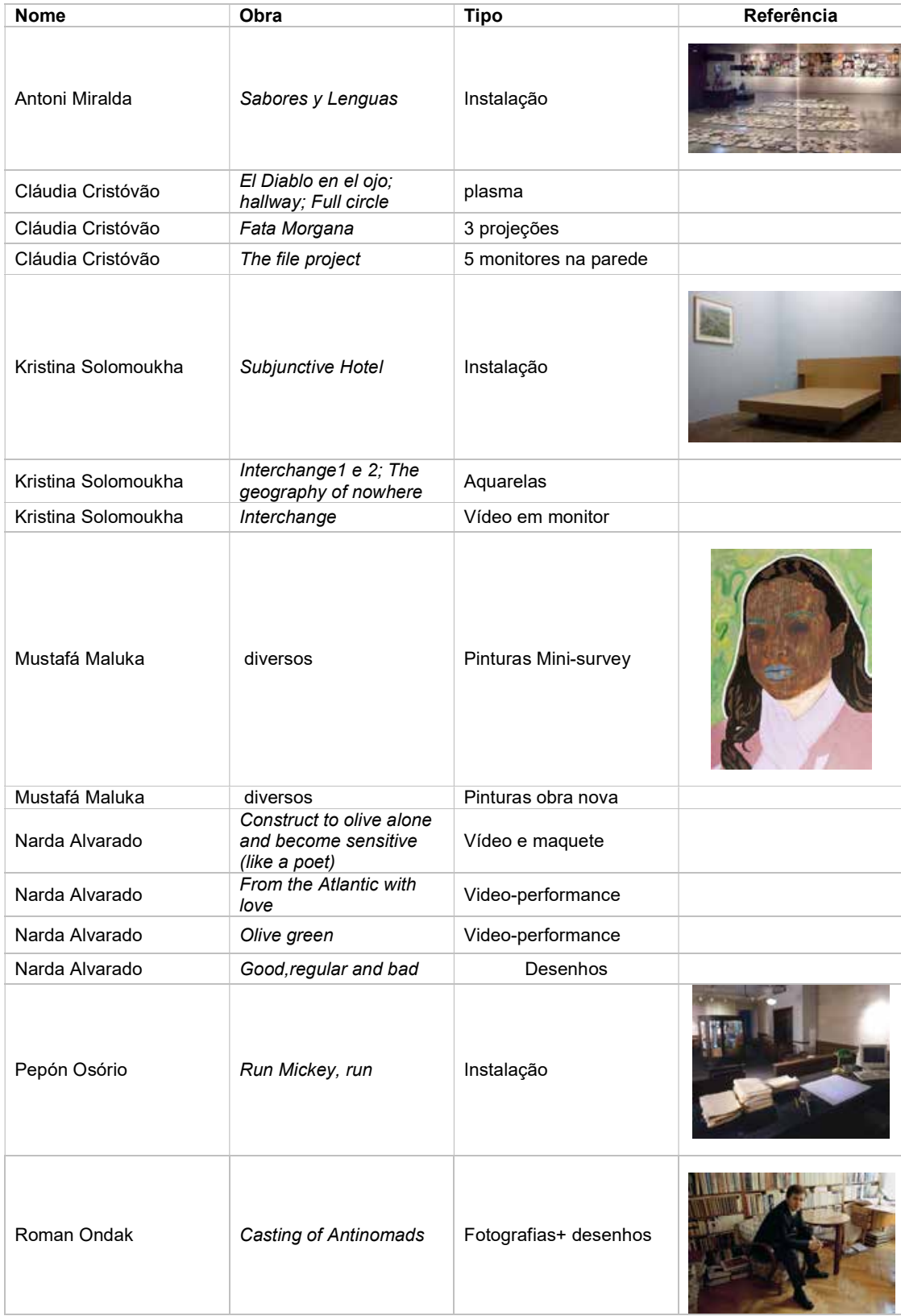

\begin{tabular}{|l|l|l|l|}
\hline Nome & Obra & Tipo & Referência \\
\hline Roman Ondak & Futuropolis & $\begin{array}{l}\text { desenhos } \\
\text { Técnica mista sobre } \\
\text { papel }\end{array}$ & \\
\hline Simons Evans & diversos & $\begin{array}{l}\text { Functioning Sculpture/ } \\
\text { Brazil }\end{array}$ & 15 monitores com som \\
\hline Vladimir Arkhipov & & \\
\hline
\end{tabular}




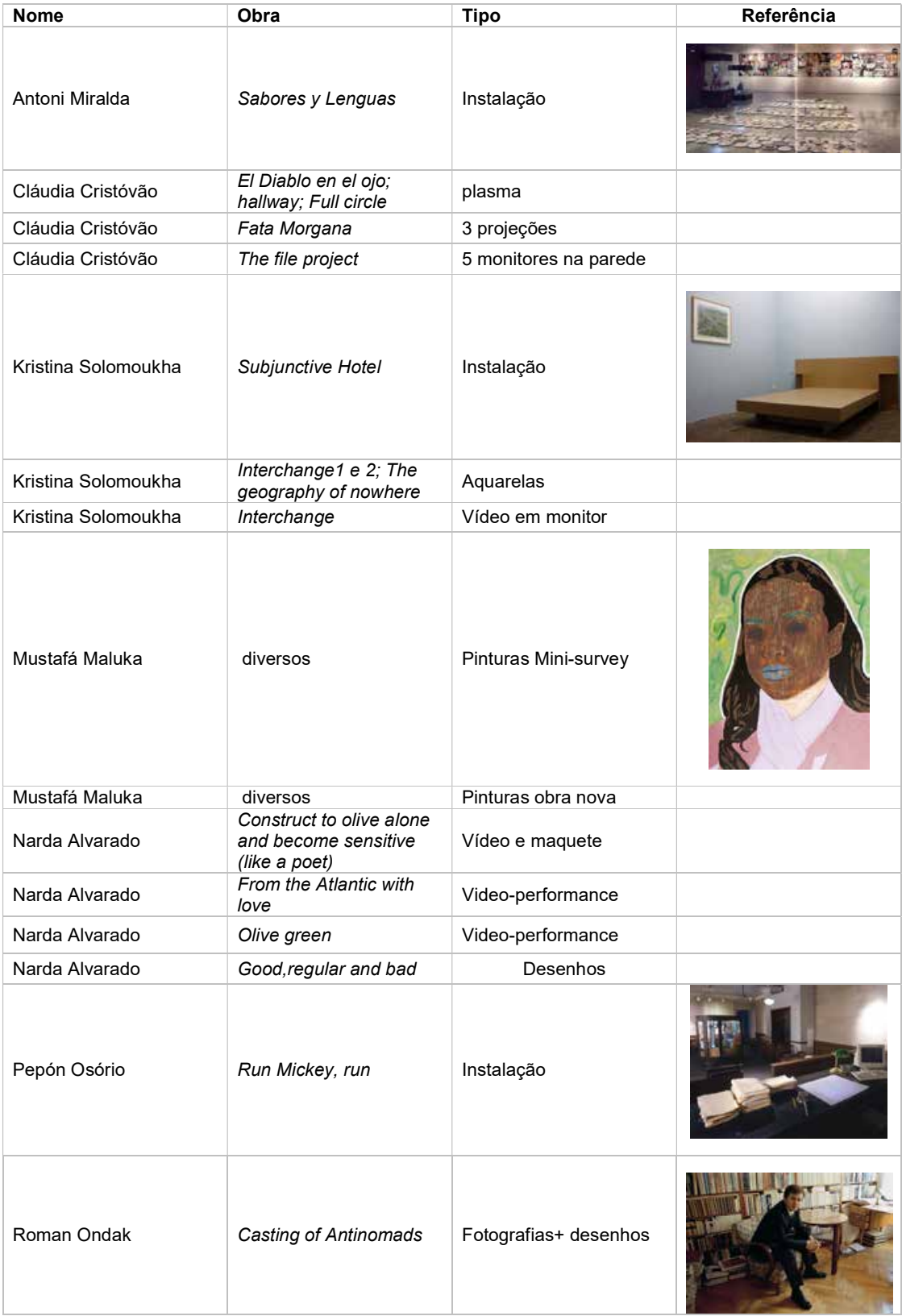

\begin{tabular}{|l|l|l|l|}
\hline Nome & Obra & Tipo & Referência \\
\hline Roman Ondak & Futuropolis & $\begin{array}{l}\text { desenhos } \\
\text { Técnica mista sobre } \\
\text { papel }\end{array}$ & \\
\hline Simons Evans & $\begin{array}{l}\text { fiversos } \\
\text { Brazil }\end{array}$ & 15 monitores com som Sculpture/ \\
\hline Vladimir Arkhipov & & \\
\hline
\end{tabular}




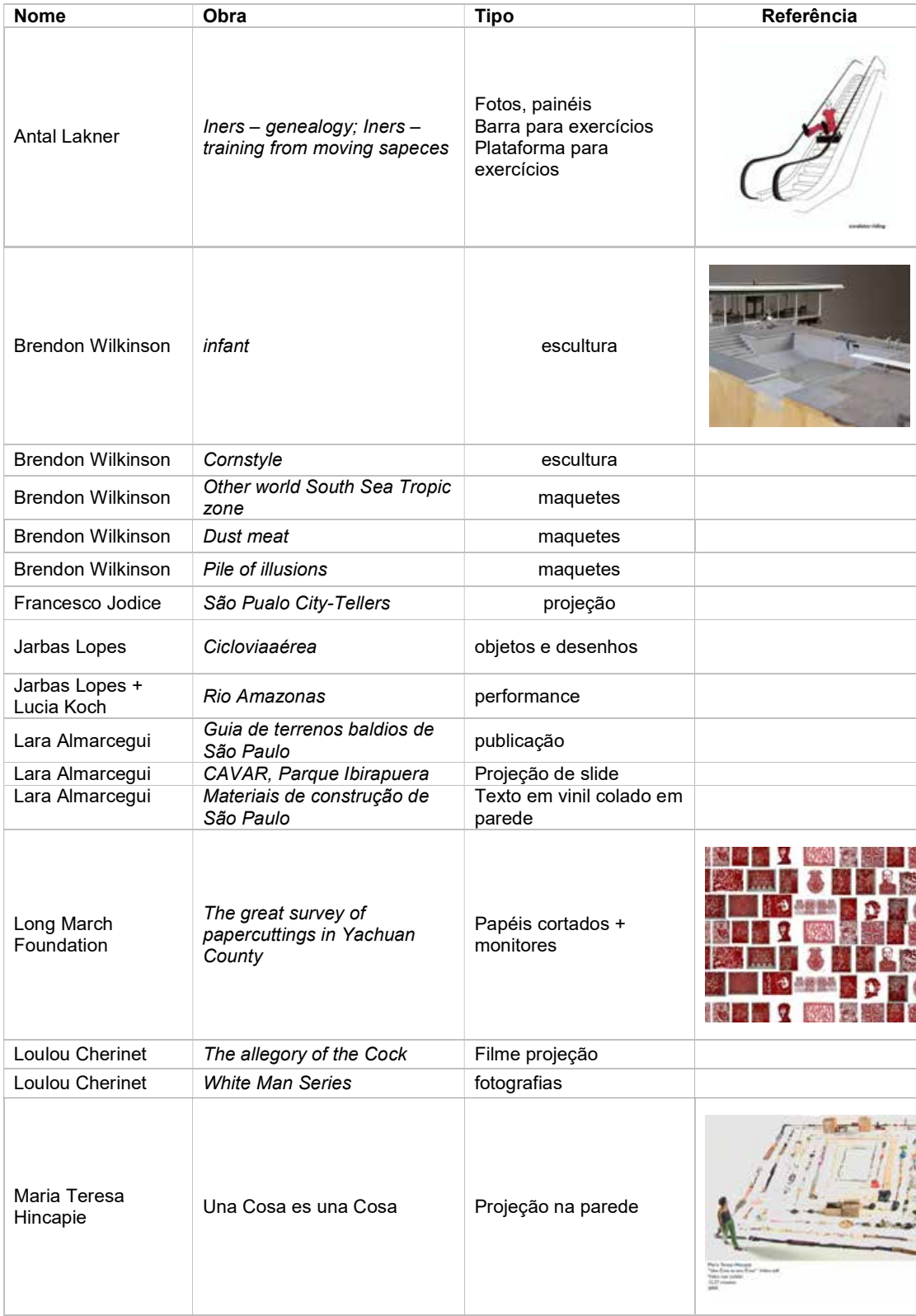

\begin{tabular}{|c|c|c|c|}
\hline $\begin{array}{l}\text { Maria Teresa } \\
\text { Hincapie }\end{array}$ & Vitrina & Fotografias & \\
\hline Mauro Restiffe & Mirante & Fotografias & \\
\hline Monica Bonvicini & Hammering out & $\begin{array}{l}\text { Projeção em DVD na } \\
\text { parede com som }\end{array}$ & \\
\hline Monica Bonvicini & No head men & Instalação- performence & \\
\hline Pieter Hugo & The Hyena men of Nigeria & Fotografias & \\
\hline Pieter Hugo & $\begin{array}{l}\text { Judges, Bostwana + } \\
\text { Barristers and Solicitors of } \\
\text { the Supreme Court of Ghama }\end{array}$ & Fotografias & \\
\hline Pieter Hugo & Mesina & Fotografias & \\
\hline Renata Lucas & Barulho de Fundo & $\begin{array}{l}\text { instalação } \\
1 \text { monitor } 34\end{array}$ & \\
\hline Sanghee Song & Her funeral & $\begin{array}{l}1 \text { monitor } 34 \text { embutido } \\
\text { na parede com som }\end{array}$ & 0 \\
\hline Sanghee Song & $\begin{array}{l}\text { Gesture to be a Good } \\
\text { Daughter }\end{array}$ & Plano elevado e objetos & \\
\hline Sanghee Song & The firstlady A & c-print & \\
\hline Sanghee Song & The national Theater & Vídeo em loop & \\
\hline Sanghee Song & Ready to die & intalação & \\
\hline Shimabuku & $\begin{array}{l}\text { Imigrantes; história das sete } \\
\text { pedras }\end{array}$ & $\begin{array}{l}\text { Projeção na parede com } \\
\text { som }\end{array}$ & \\
\hline Shimabuku & $\begin{array}{l}\text { Pedi aos repentistas } \\
\text { Peneira\&Sonhador para } \\
\text { remixar meus trabalhos de } \\
\text { polvo }\end{array}$ & $\begin{array}{l}\text { Projeção dupla em um } \\
\text { dos cantos com som }\end{array}$ & Vídeo \\
\hline Tadej Pogcar & CODE:RED Brasil, Daspu & Objetos & Manequins e roupas \\
\hline Tadej Pogcar & Street economy archive & Fotografias & 806 \\
\hline Young-H & $\begin{array}{l}\text { Orient; travelling; Declaracion } \\
\text { de artistas 45.730.944: el } \\
\text { perfecto wed site artístico; } \\
\text { what now? }\end{array}$ & $\begin{array}{l}\text { Animação } \\
\text { Projeção com som }\end{array}$ & \\
\hline
\end{tabular}




\begin{tabular}{|c|c|c|c|}
\hline Nome & Obra & Tipo & Referência \\
\hline Ana Mendieta & $\begin{array}{l}\text { Untitled (Glass on Body } \\
\text { Imprints Glass); Untitled } \\
\text { (Facial Hair } \\
\text { Transplants); Serie } \\
\text { Siluetas work in lowa; } \\
\text { Serie Siluetas work in } \\
\text { México; Untitled } \\
\text { (Varadero) }\end{array}$ & Fotografias & \\
\hline Ana Mendieta & $\begin{array}{l}\text { Sweating Blood; Untitled } \\
\text { (Body Tracks); Corazón } \\
\text { de Roca con Sangre } \\
\text { (1975); Alma Silueta en } \\
\text { Fuego (Silueta de } \\
\text { Cenizas); Corazon de } \\
\text { rca com angre; Burial } \\
\text { Pyramid, Yagul, Mexico; } \\
\text { Untitled (Flower Person } \\
\# 1, \# 2)\end{array}$ & Projeção na parede & \\
\hline Barbara Visser & Two Projections & $\begin{array}{l}\text { Projeção dupla (frente e } \\
\text { trás) com som baixo }\end{array}$ & \\
\hline Barbara Visser & Detitled & Papel de parede & \\
\hline Bregtje Van Der Haak & Lagos: Wide \& Close & $\begin{array}{l}2 \text { projeções com } \\
\text { headphones }\end{array}$ & \\
\hline Dan Graham & $\begin{array}{l}\text { Skate Board Pavillion + } \\
\text { Yin Yang Pavillion + } \\
\text { Double Exposure } \\
\text { /LandscapePhoto } \\
\text { Pavllion + Swimming } \\
\text { Pool/Fish Pond }\end{array}$ & $\begin{array}{l}\text { Maquetes + } 2 \text { monitores } \\
29 \text { " sobre base }\end{array}$ & \\
\hline Dan Graham & Homes of America & Projeção de slides & \\
\hline Gordon Matta-Clark & $\begin{array}{l}\text { Basket housing; } \\
\text { Garbage wall; Fresh air } \\
\text { cart; Wallpaper } \\
\text { installation; Untitled (tree } \\
\text { forms); Graffiti; Untitled } \\
\text { (Arrows); Splitting; } \\
\text { Conical intersect; sous- } \\
\text { sol de Paris; Reality } \\
\text { positions: Fake states } \\
\text { "Long Island City"; Sky } \\
\text { hook }\end{array}$ & $\begin{array}{l}\text { Fotos, desenhos, } \\
\text { instalações }\end{array}$ & , \\
\hline Gordon Matta-Clark & $\begin{array}{l}\text { Tree dance; fire child; } \\
\text { fresh kill; food; open } \\
\text { house; clockshower; } \\
\text { Splitting; bingo X ninths; } \\
\text { Conical intersect; Day's } \\
\text { end; City slivers }\end{array}$ & Projeção sem som & \\
\hline Grönlund\& Nisunen & $\begin{array}{l}\text { Pattern recoginition } \\
\text { setup in a staircase }\end{array}$ & Instalação & \\
\hline
\end{tabular}

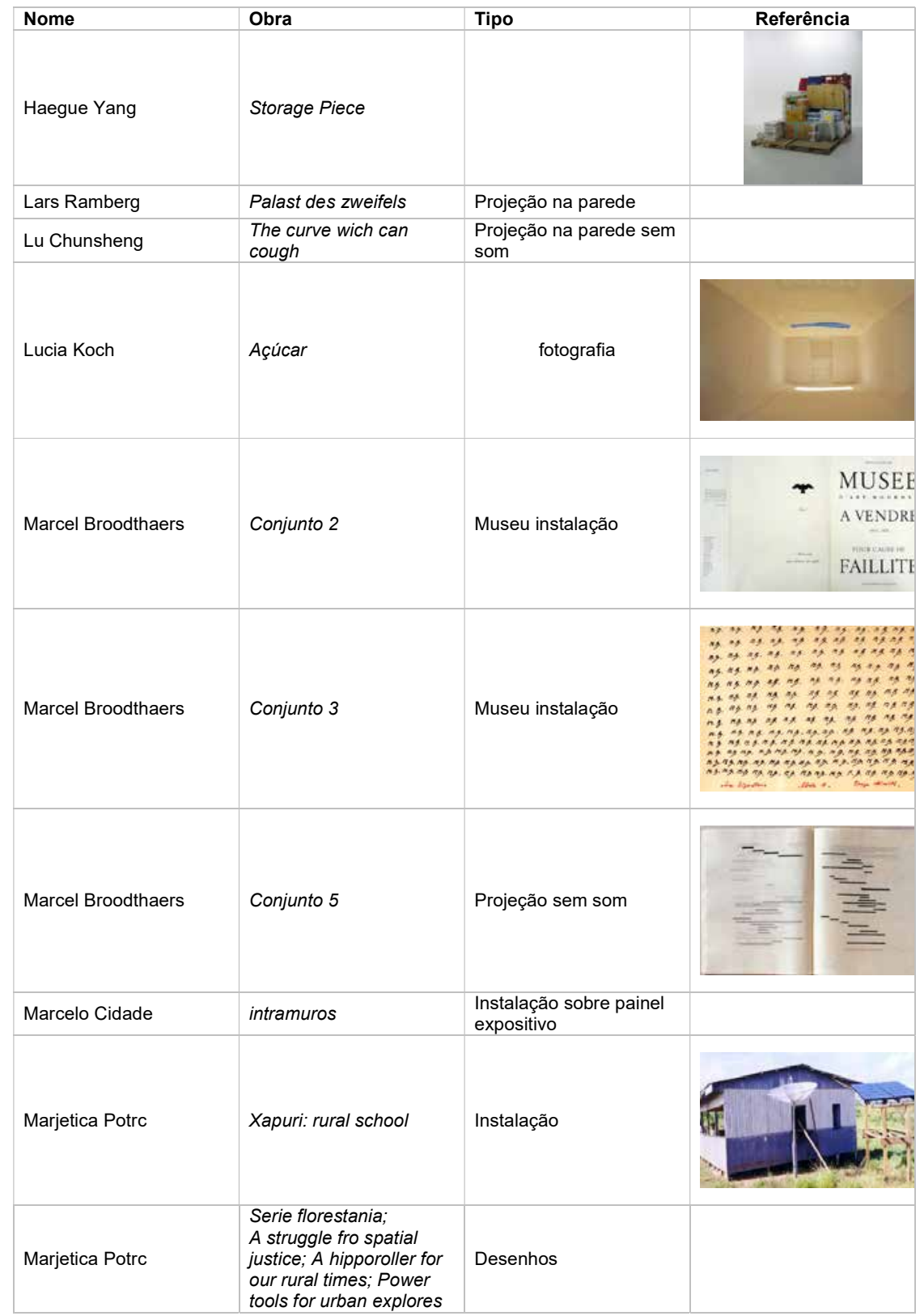




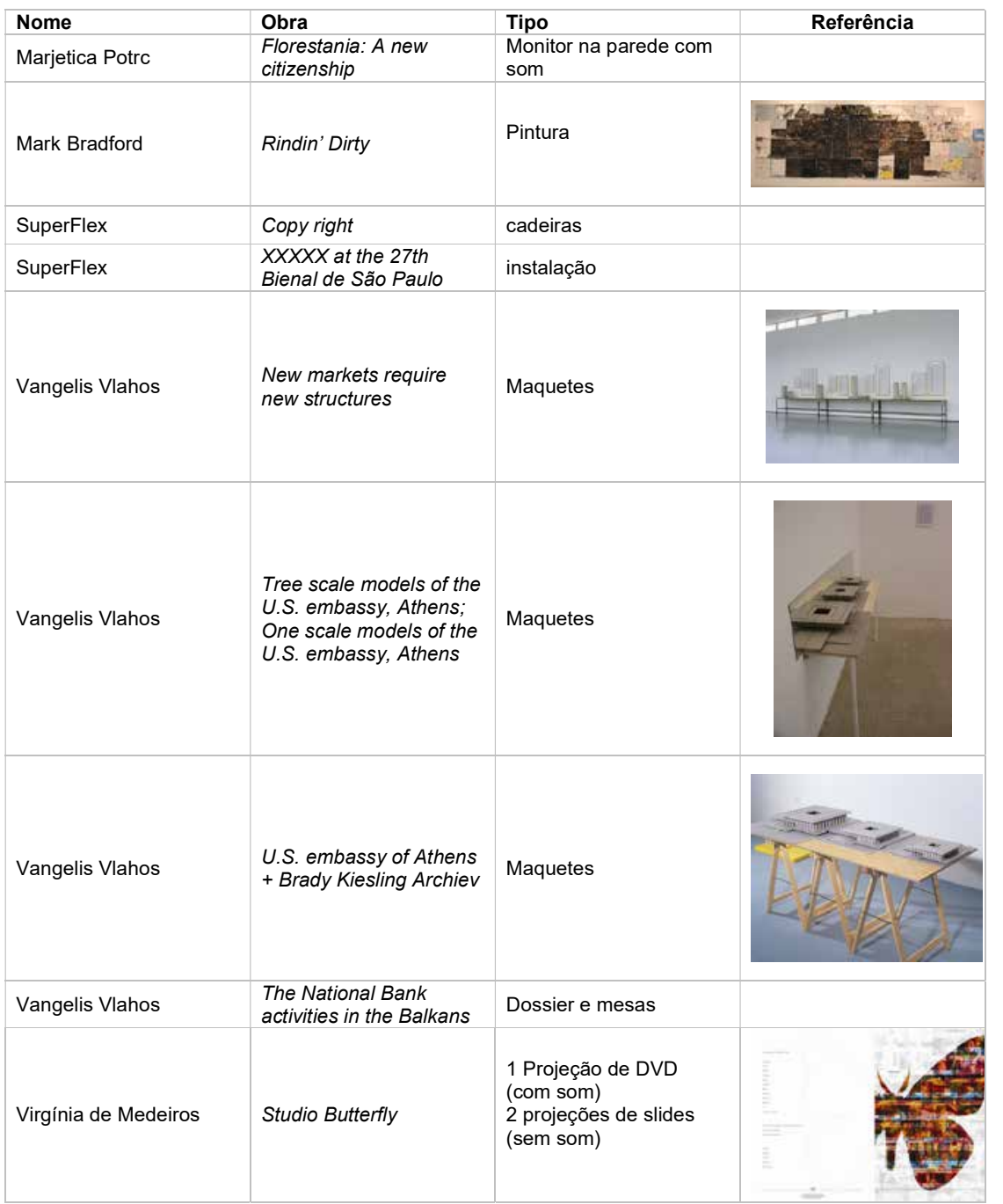


